\title{
Geochemical Characterization of Coexisting Precipitates and Waters from High-Sulfidation Epithermal Gold Deposits
}

By

Lori Manoukian

A thesis submitted to the Department of Geological Sciences and Geological Engineering In conformity with the requirements for the degree of Master of Science

Queen's University

Kingston, Ontario, Canada

February 2016

Copyright @ Lori Manoukian, 2016 


\begin{abstract}
Water management and treatment at closed mine sites have become primary concerns for mining companies due to their costly nature, potential commitment of decades of water treatment, and impact on the environment. The long-term objective of this research investigates methods of extracting metals from acid mine waste in order to minimize the environmental impact of the drainage and decrease the financial burden on mining companies. However, understanding the mechanism of element mobility in mine waste requires a comprehensive assessment of the composition of the water and co-existing minerals at studied mines El Indio, Lagunas Norte and Pierina, which is the primary goal of this thesis. No study has previously provided a detailed analysis of the secondary precipitates at these mines or their role in storing trace elements.

Water samples were analyzed by inductively coupled mass spectrometry and inductively coupled optical emission spectrometry. Coexisting mineral samples were characterized using an environmental scanning electron microscope, $\mathrm{X}$-ray diffraction and synchrotron-based microanalysis. The $\mathrm{pH}$ of waters is acidic with values of 2.24 to 4.5. Major elements in waters include $\mathrm{Ca}, \mathrm{Al}, \mathrm{Fe}$ and $\mathrm{SO}_{4}$; minor elements include $\mathrm{Cu}, \mathrm{Mg}, \mathrm{Mn}, \mathrm{Zn}, \mathrm{K}, \mathrm{Na}$ and trace elements consisted of $\mathrm{As}, \mathrm{Co}, \mathrm{Ni}, \mathrm{Sr}, \mathrm{Pb}$ and $\mathrm{Cd}$. This study has identified previously unreported phases that may be placed into 3 broad groups: 1) hydrous $\mathrm{Na}-, \mathrm{Mg}-\mathrm{Ca}$, $\mathrm{Cu}$ - and other metal-sulfates such as blodite group minerals, hexahydrite and gypsum 2) Fe-oxides, oxyhydroxides and oxyhydroxysulfates such as ferrihydrite, goethite, scorodite and jarosite 3) other metal-rich, poorly crystalline Al phases. Synchrotron microanalysis has shown that these minerals sequester $\mathrm{Cu}, \mathrm{Mn}, \mathrm{Zn}, \mathrm{Cd}, \mathrm{As}, \mathrm{Ni}$ and other trace elements.

This research has improved the understanding of the mobility of elements by identifying the trace elements associated with minerals and by characterizing the relationship between chemistry of precipitates and solution. The occurrence of secondary precipitates stands as evidence purporting that sulfide oxidation at these mine sites is ongoing. Barrick Gold Corporation can consider capturing the sulfate-rich secondary precipitates by mechanically enhanced pond-evaporation and precipitation of efflorescent salts, methods which may allow to efficiently capture elements of interest.
\end{abstract}




\section{Acknowledgements}

I would first like to thank my supervisor Dr. Heather Jamieson for her guidance and for the knowledge she has shared with me throughout this degree. I am grateful to have been able to work with such an inspiring scientist on a project that was challenging, interesting and perfectly aligned with my interests. I am appreciative of the introduction to geomicrobiology that I received from my co-supervisor Dr. Danielle Fortin.

A big thank you to all my colleagues and friends that I have crossed paths with throughout my academic tenure at Queen's. They have each made this experience truly memorable. I would like to especially acknowledge Lionel for helping me believe in myself, for always being there to patiently listen to my practice talks and for being a great teacher with a big heart. Thank you to Anezka for always having a smile on her face, even during difficult times, and for being an important source of strength, support and encouragement. I also wanted to thank her for sharing her advanced Slovakian thin section lifting technique. Bryn for sharing her knowledge with me, assisting me with my field work and for helping create memories that I will never forget.

Thank you to the team at Argonne, especially at Sector 13, who helped me understand my data and patiently answered all my questions. To Graham from ASU for his technical expertise. To Agatha for always being extremely helpful while on the SEM, particularly for taking some spectacular pictures.

Thank you to Claudio, Barrick Gold Corporation and employees, for the regular feedback and for giving me the opportunity to work with them, to travel and to learn about the mining industry. Working in Chile and Peru was an opportunity that I will never forget and I am grateful to have been a part of this adventure.

Finally and most importantly, the successful completion of this thesis would not have been achieved without the continued support of my family. Thank you for believing in me and for encouraging me every step of the way. Words are inadequate to express my gratitude for the incomparable love you gave in my trying moments. 


\section{Table of contents}

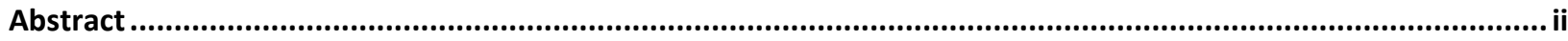

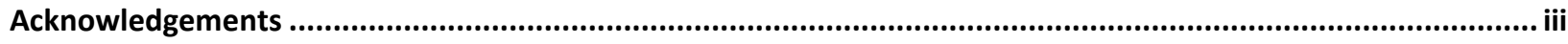

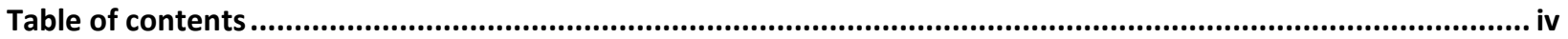

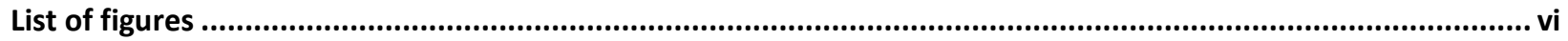

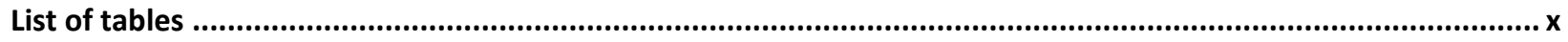

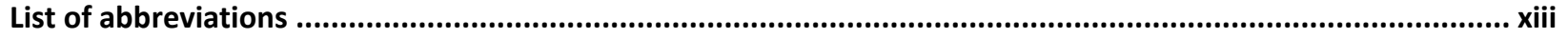

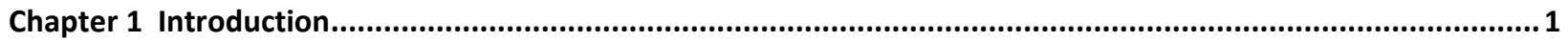

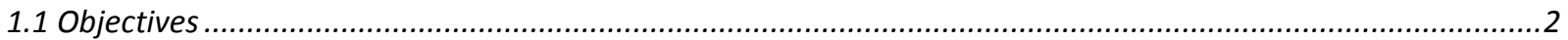

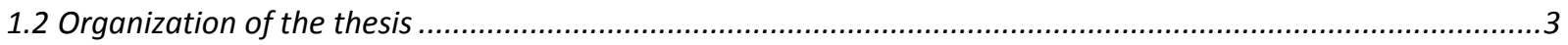

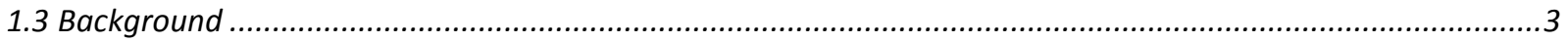

1.3.1 High-sulfidation (HS) epithermal deposits, mineralogy and associated elements ....................................

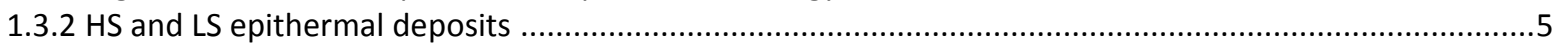

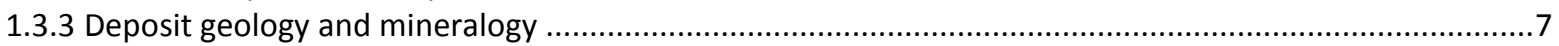

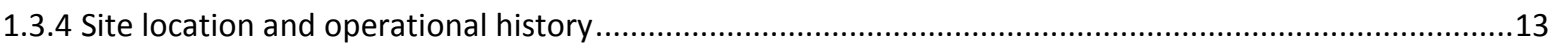

1.3.5 Mine components and water management ....................................................................................15

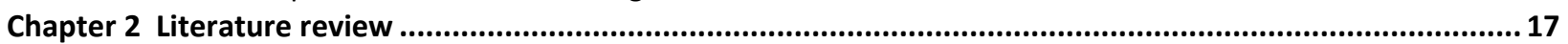

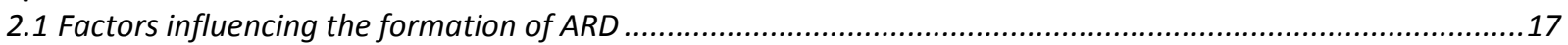

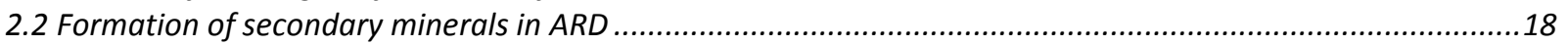

2.3 The sulfate system: Compositions of hydrated metal sulfate salts .............................................................20

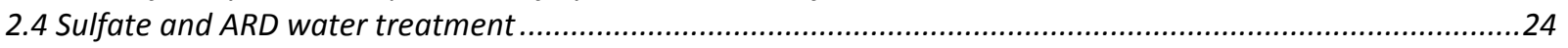

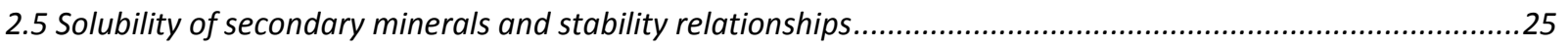

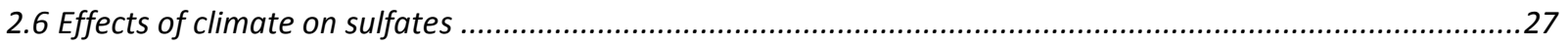

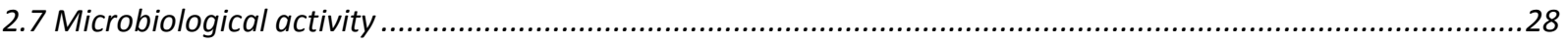

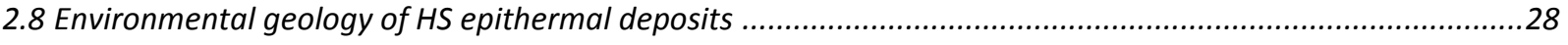

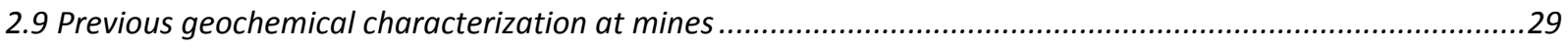

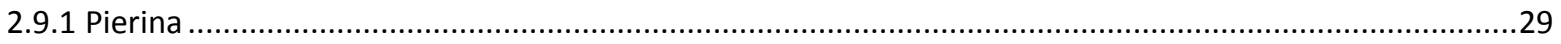

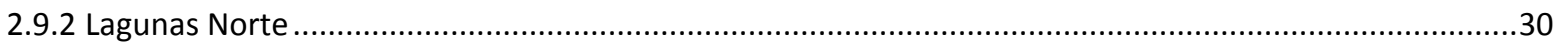

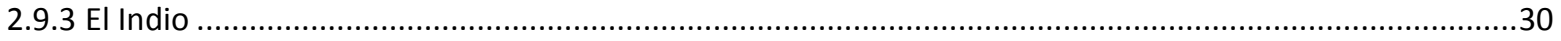

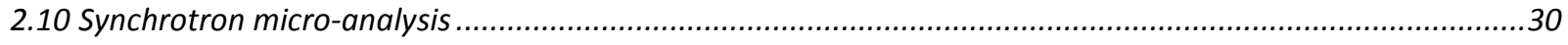

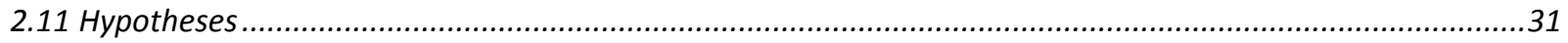

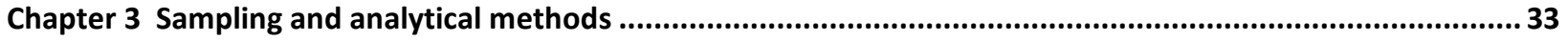

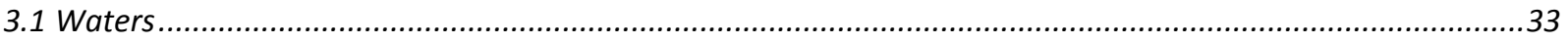

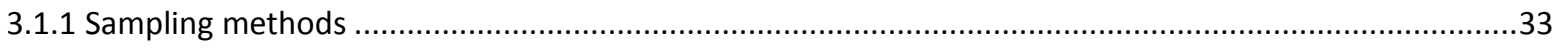

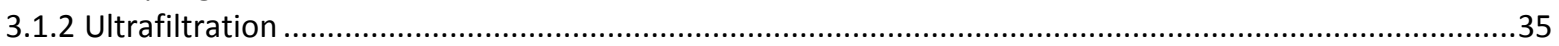

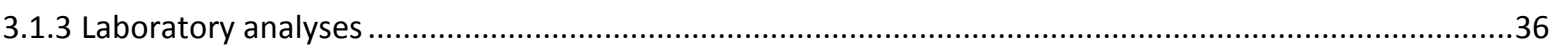

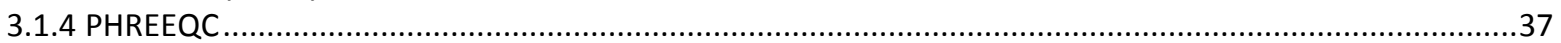

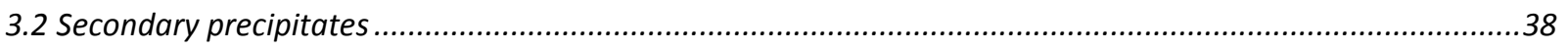

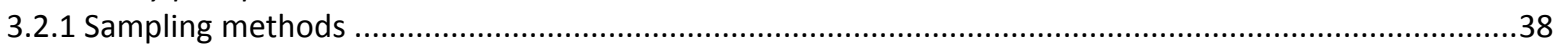

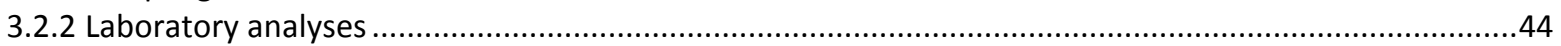

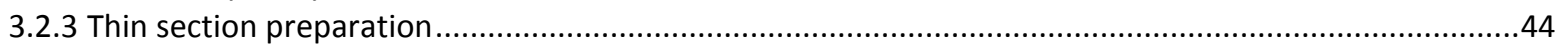

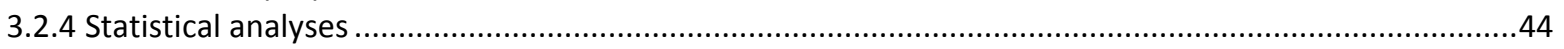

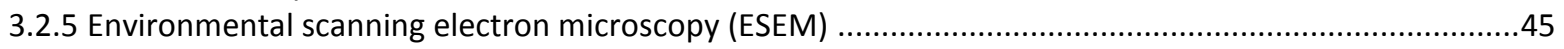

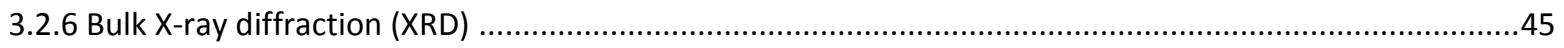

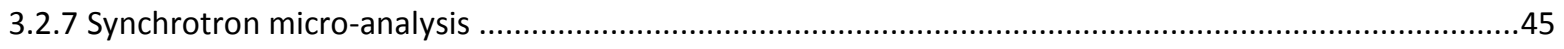

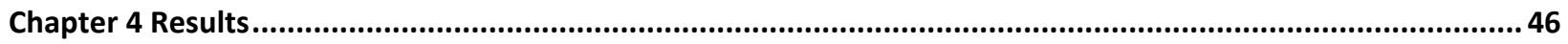

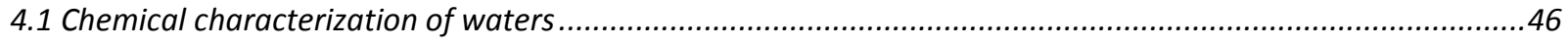

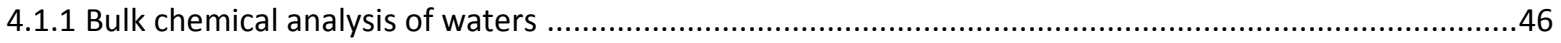

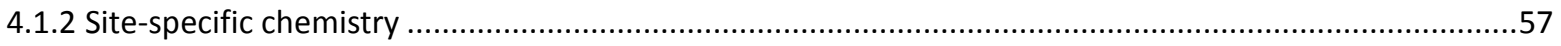

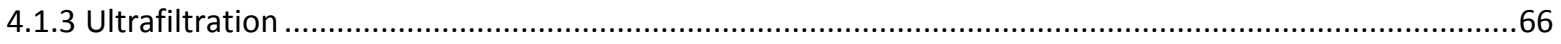




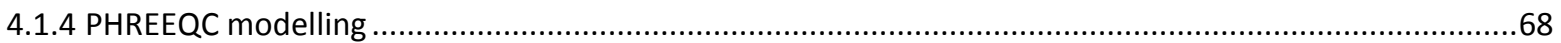

4.2 Geochemical and mineralogical characterization of secondary precipitates.................................................70

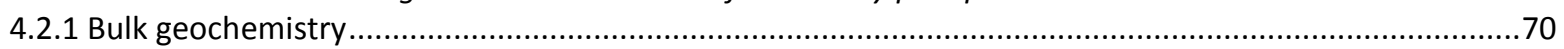

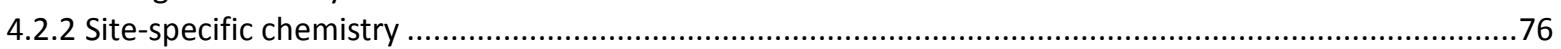

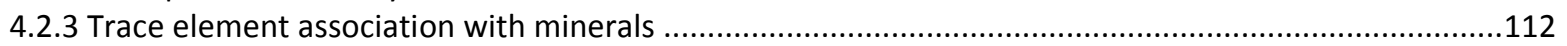

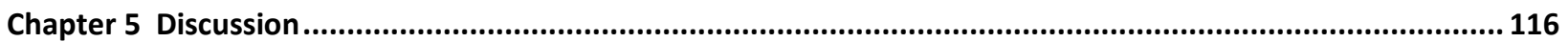

5.1 Discussion of geochemical characterization of waters ......................................................................116

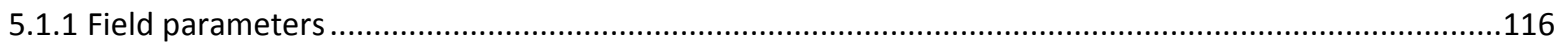

5.1 .2 Comments on ultrafiltration and colloidal stability ..............................................................118

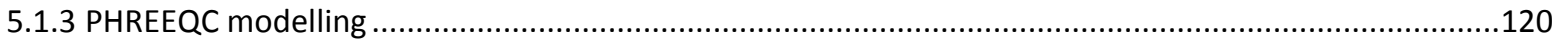

5.1.4 Bulk geochemistry and comparison to effluent regulations .......................................................124

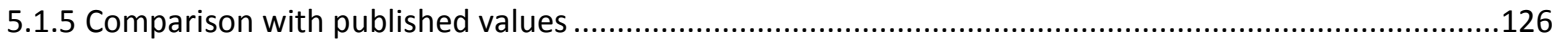

5.2 Discussion of secondary precipitate occurrences and characterization ....................................................128

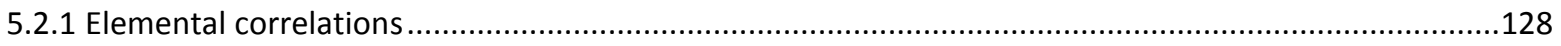

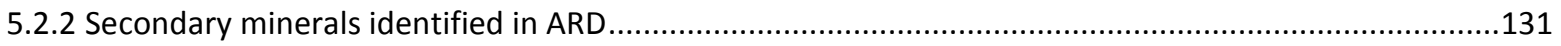

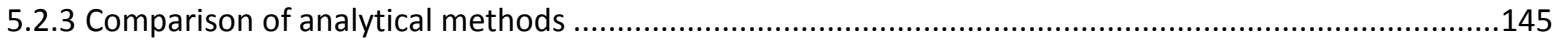

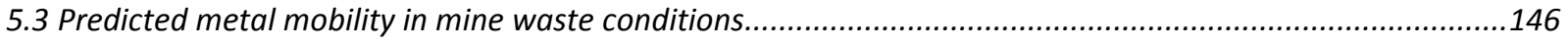

5.4 Implications of research to water treatment at sites .........................................................................147

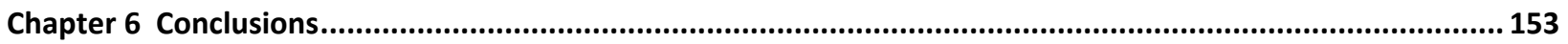

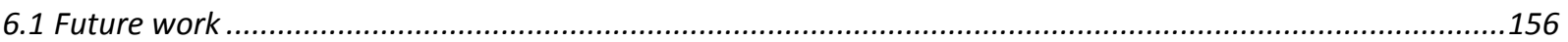

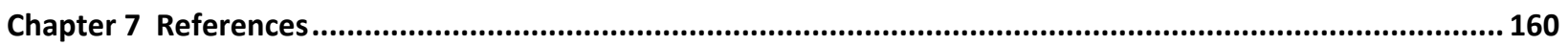

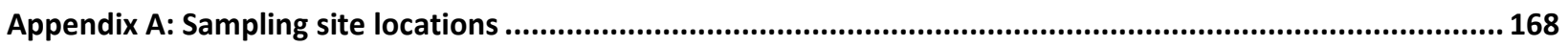

Appendix B: PHREEQC modeling minerals with $\mathrm{SI} \geq 0$....................................................................172

Appendix C: PHREEQC modeling with $\mathrm{SI} \geq 0$ in solutions concentrated 20 fold .......................................... 177

Appendix D: Comparison of methods ICP-MS \& ICP-OES ....................................................................... 180

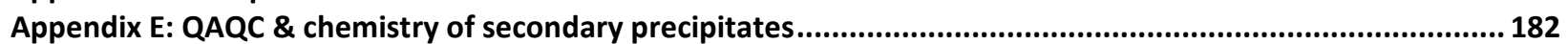

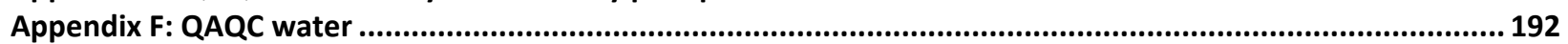

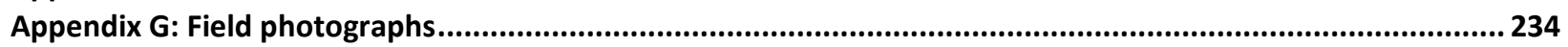




\section{List of figures}

Figure 1-1 The alteration types observed in HS deposits. ................................................................ 5

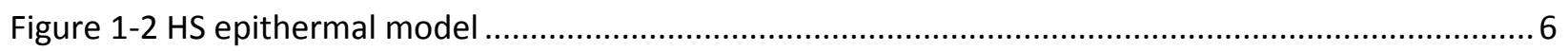

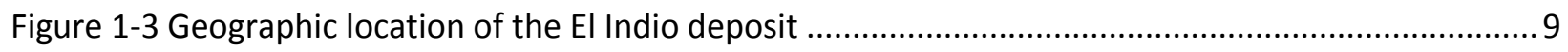

Figure 1-4 Generalized geologic setting of north-central Chile and the location of the El Indio deposit ....9

Figure 1-5 Geographic location of Pierina and Lagunas Norte deposits................................................10

Figure 1-6 Regional geological map of the Lagunas Norte Domain and the Quturvilca Domain ...............11

Figure 1-7 Regional geological map of Pierina mine.................................................................... 13

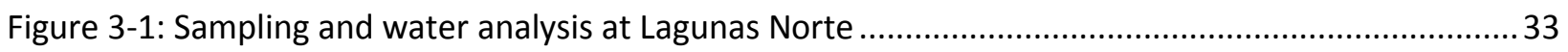

Figure 3-2 Schematic representation of ultrafiltration method. ......................................................36

Figure 3-3 Images of secondary precipitates sampled at El Indio and map (IN-28, IN-RMATR, IN-2) ........39

Figure 3-4 Images of secondary precipitates sampled at El Indio and map (IN-13, IN-2) ...................... 40

Figure 3-5 Images of secondary precipitates sampled at Lagunas Norte and map (LN-DAR-1, LN-SP-3, LN-

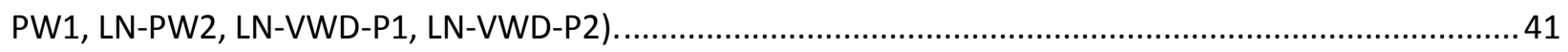

Figure 3-6 Aerial image of Lagunas Norte and solid and water sampling sites ....................................42

Figure 3-7 Images of secondary precipitates sampled at Pierina (P-WRD, P-EC, P-PW1, P-PW2) ........... 43

Figure 4-1 Major and minor element concentrations from water samples at El Indio..........................50

Figure 4-2 Minor and trace element concentrations from water samples at El Indio ............................51

Figure 4-3 Major and minor element concentrations from water samples at Lagunas Norte..................52

Figure 4-4: Minor and trace element concentrations from water samples at Lagunas Norte..................53

Figure 4-5 Minor and trace element concentrations from water samples at Pierina .............................54

Figure 4-6 : Major and minor element concentrations from water sampless at Pierina. ........................55

Figure 4-7 : Concentration of elements at IN23 on a scatterplot....................................................5 
Figure 4-8: Concentration of elements at IN28 on a scatterplot

Figure 4-9: Concentration of elements at IN-RMATR on a scatterplot...... 59

Figure 4-10: Concentration of elements at IN2 on a scatterplot .59

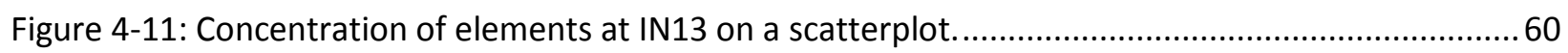

Figure 4-12: Concentration of elements at LN-SP3 on a scatterplot................................................60

Figure 4-13: Concentration of elements at LN-DW-B11 on a scatterplot. ...........................................61

Figure 4-14: Concentration of elements at LN-DAR-1 on a scatterplot............................................... 61

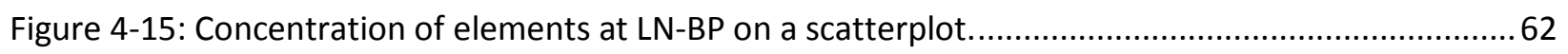

Figure 4-16: Concentration of elements at LN-PW2 on a scatterplot. .............................................62

Figure 4-17: Concentration of elements at LN-VWD on a scatterplot............................................... 63

Figure 4-18: Concentration of elements at P-ARD17 on a scatterplot. .............................................. 63

Figure 4-19: Concentration of elements at P-WRD on a scatterplot................................................ 64

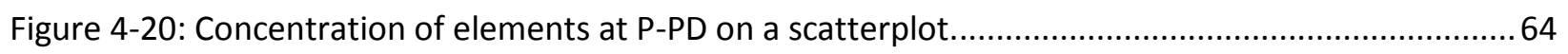

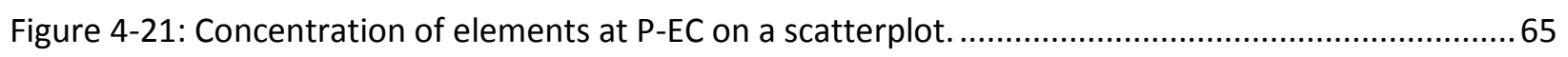

Figure 4-22 Concentration of elements at El Indio, in ppm and on a box and whisker diagram ..............75

Figure 4-23 Concentration of elements at Lagunas Norte, in ppm and on a box and whisker diagram....75

Figure 4-24 Concentration of elements at Pierina, in ppm and on a box and whisker diagram..............76

Figure 4-25 Concentrations of elements in samples IN28-P1, IN-28-P2, IN-28-P3 and IN28-P4..............78

Figure 4-26 $\mu$ XRD 2D diffraction patternof natrojarosite, quartz, alunite and magnesiocopiapite. ......... 78

Figure 4-27 $\mu$ XRD elemental maps collected on thin section IN28-P2 .............................................. 79

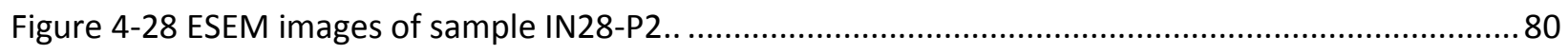

Figure 4-29 $\mu$ XRD elemental maps collected on thin section IN28-P4 ................................................ 81 
Figure 4-30 Concentrations of elements in samples RMATR-P1, RMATR-P2, RMATR-P3, RMATR-P4 and

RMATR-P5 . .83

Figure 4-31 Concentration of elements in solid samples IN2-P1, IN2-P2, and IN2-P3. .84

Figure 4-32 Concentration of elements in solid samples IN13-P1, IN13-P2, IN13-P3, IN13-P4 and IN13-P5.

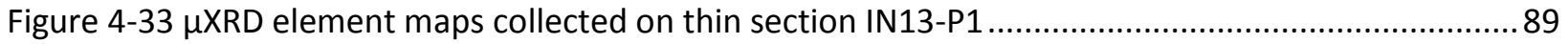

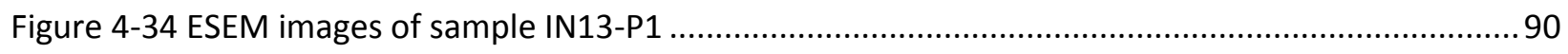

Figure 4-35 $\mu$ XRD elemental maps collected on thin section IN13-P2 ..............................................91

Figure 4-36 $\mu$ XRD 2D diffraction pattern of natrojarosite and associated 1D diffraction pattern .............91

Figure 4-37 $\mu$ XRD elemental maps collected on thin section IN13-P3................................................92

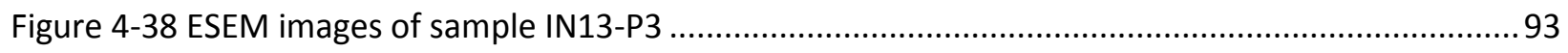

Figure 4-39 $\mu$ XRD elemental maps collected on thin section IN13-P4 ..............................................95

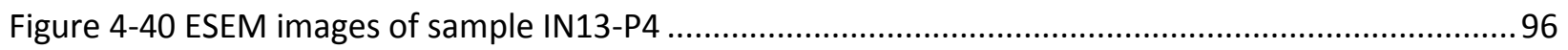

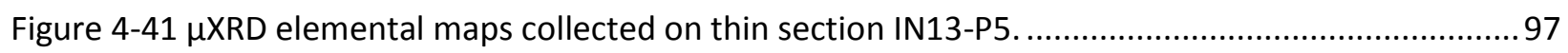

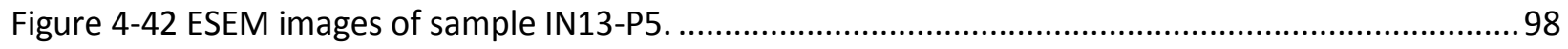

Figure 4-43 Concentration of elements in $\mathrm{mg} / \mathrm{kg}$ in the solid sample LN-DAR01.................................99

Figure 4-44 Concentration of elements in $\mathrm{mg} / \mathrm{kg}$ in the solid sample LN-SP3 ..................................100

Figure 4-45 Concentration of elements in $\mathrm{mg} / \mathrm{kg}$ in the solid sample LN-PW1-P1 and LN-PW1-P2........101

Figure 4-46 $\mu$ XRF elemental maps from the thin section made of sample LN-PW1-P1........................102

Figure 4-47 $\mu$ XRD 2D diffraction pattern of antlerite and associated 1D diffraction pattern.................102

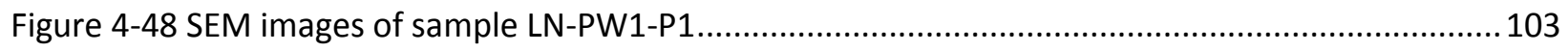

Figure 4-49 Concentration of elements in solid samples LN-VWD-P1 and LN-VWD-P2 ........................ 104

Figure 4-50 Concentration of elements in the solid sample P-WRD-P1 ............................................. 106 
Figure 4-51 Concentration of elements in the solid sample P-EC

Figure 4-52 Concentration of elements solid samples P-PW-Pb and P-PW-Pc 109

Figure 4-53 ESEM images of sample P-PW1-Pc 109

Figure 4-54 ESEM images of sample P-PW1-Pb. .110

Figure 5-1 $\mu$ XRD spectra collected from sample IN28-P4. 121

Figure 5-2 Comparison of data collected from El Indio, Lagunas Norte and Pierina, compared to HS deposits studied by Plumlee et al. (1999).

Figure 5-3 Hydrogenetic grids for hydrated metal-sulfate salts kieserite, hexahydrite, and epsomite...138

Figure 5-4 Hydrogenetic grids for hydrated metal-sulfate salts bonattite and chalcanthite 140

Figure 5-5 pE-pH diagram, showing the stable solid phases in Fe-S-K-O-H system 141

Figure 5-6 Hydrogenetic grids for hydrated metal-sulfate salts rozenite and melanterite. .144 


\section{List of tables}

Table 1-1 Key characteristics of high- and low- sulfidation deposits.....................................................

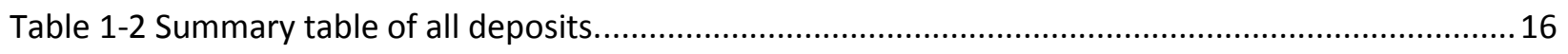

Table 2-1 A list of a few secondary precipitates and their potential trace element compositions............23

Table 2-2 Minerals whose solubilities are likely to control metal concentrations in mine waters...........27

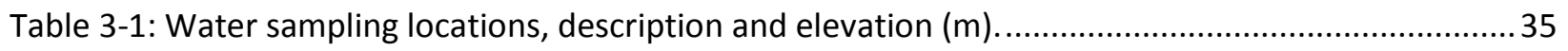

Table 4-1 Chemical analysis of filtered and acidified samples from El Indio demonstrating concentrations

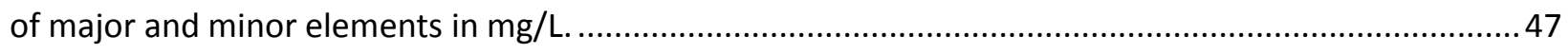

Table 4-2 Chemical analysis of filtered and acidified samples from El Indio demonstrating concentrations

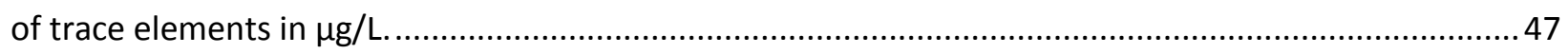

Table 4-3 Chemical analysis of filtered and acidified samples from Lagunas Norte demonstrating

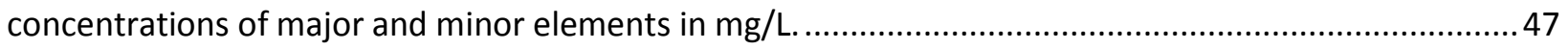

Table 4-4 Chemical analysis of filtered and acidified samples from Lagunas Norte demonstrating

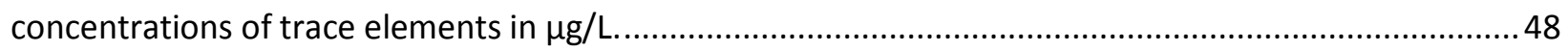

Table 4-5 Chemical analysis of filtered and acidified samples from Pierina demonstrating concentrations

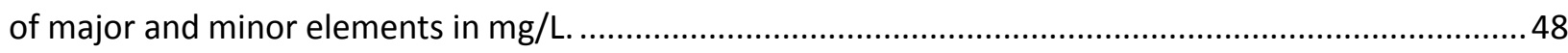

Table 4-6 Chemical analysis of filtered and acidified samples from Pierina demonstrating concentrations

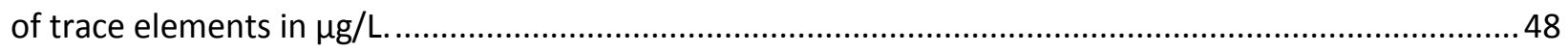

Table 4-7 Field variables measured at El Indio with YSI meter measured in May 2014..........................56

Table 4-8 Field variables measured at Lagunas Norte with YSI meter measured in May 2014. ...............56

Table 4-9 Field variables measured at Pierina with YSI meter measured in May 2014 .........................56

Table 4-10 Relative percent concentrations of $\mathrm{Al}, \mathrm{As}, \mathrm{Ca}, \mathrm{Cu}, \mathrm{Fe}, \mathrm{Mg}, \mathrm{Mn}, \mathrm{K}, \mathrm{S}, \mathrm{Zn}$ as colloids from ultrafiltration results at Pierina. 
Table 4-11 List of elements with average colloidal concentrations in ppb at sampling locations at Pierina.

Table 4-12 Relative percent concentrations of $\mathrm{Al}, \mathrm{As}, \mathrm{Ca}, \mathrm{Cu}, \mathrm{Fe}, \mathrm{Mg}, \mathrm{Mn}, \mathrm{K}, \mathrm{S}, \mathrm{Zn}$ in colloid and dissolved from ultrafiltration within Lagunas Norte. 68

Table 4-13 List of elements with average colloidal concentrations at sampling sites at Lagunas Norte...68

Table 4-14 List of minerals with SI>0 from waters collected at LN-PW2-W and minerals with SI>0 from 20-fold concentrated waters. .70

Table 4-15 Spearman correlation matrix of major, minor and trace elements of interest at El Indio.......72

Table 4-16 Spearman correlation matrix of major, minor and trace elements of interest at Lagunas

Norte. .73

Table 4-17 Spearman correlation matrix of major, minor and trace elements of interest at Pierina........74

Table 4-18 List of minerals identified at IN28-P2 with $\mu$ XRD, bulk XRD and SEM. 79

Table 4-19 List of minerals identified on thin section IN28-P4 through $\mu$ XRD bulk XRD and SEM. .81

Table 4-20 Positively identified minerals by bulk XRD fro samples collected at El Indio. .86

Table 4-21 List of minerals identified at IN13-P1 with $\mu$ XRD, XRD and SEM (MSP). 89

Table 4-22 List of minerals identified at IN13-P2 with $\mu$ XRD methods, bulk XRD and SEM. 92

Table 4-23 List of minerals identified at IN13-P3 with $\mu$ XRD methods, bulk XRD and SEM .94

Table 4-24 List of minerals identified at IN13-P4 with $\mu$ XRD methods, bulk XRD and SEM....... .95

Table 4-25 List of minerals identified at IN13-P5 with $\mu$ XRD methods, bulk XRD and SEM. 97

Table 4-26 List of minerals identified at LN-PW1-P1 with $\mu$ XRD methods, bulk XRD and SEM. 103

Table 4-27 Minerals identified with bulk XRD from samples collected at Lagunas Norte mine. 105

Table 4-28 Minerals identified with bulk XRD from samples collected at Pierina mine. 111 
Table 4-29 Elements associated to blodite, alunite, hexahydrite and goethite in decreasing order within samples from El Indio. .113

Table 4-30 Elements associated to goethite in decreasing order within samples from El Indio....... .113

Table 4-31 Trace elements determined with $\mu$ XRF (weight percent) 114

Table 4-32 Trace elements determined with $\mu$ XRF (weight percent). 115

Table 5-1 Calculated mass of colloids present at each sampling site at Pierina...... 119

Table 5-2 Calculated mass of colloids present at each sampling site at Lagunas Norte. 120

Table 5-3 List of all minerals identified at El Indio, Lagunas Norte and Pierina mines. 123

Table 5-4 Peruvian effluent guidelines for mine sites in mg/L from 2010. 126

Table 5-5 Sulfide minerals, chemical formulas and minor or trace elements that may partake in cation substitution. .130

Table 5-6 The critical ranges for sorption of divalent metal cations on hydrous Fe and Al oxides. 130

Table 5-7 Names and formulae of minerals discussed in following sections.

Table 5-8 Minerals whose solubilities are likely to control metal concentrations in mine waters .135

Table 5-9 List of economic prices of elements as per stock values on October $14^{\text {th }}, 2015$. 149

Table 5-10 Sampling sites, flow rates, and elemental concentrations ( $\mathrm{Al}, \mathrm{Cu}, \mathrm{Fe}, \mathrm{Mg}, \mathrm{Mn}, \mathrm{Ni}, \mathrm{Pb}, \mathrm{Zn}$ ) as per collection data provided by Barrick Gold Corporation between 1900-2014. 151

Table 5-11 Amounts of recoverable metals from each sampled site in $\mathrm{mg} / \mathrm{year}$ by multiplying concentration with annual flow rate. 151

Table 5-12 Amount in USD per year was calculated by multiplying mg/year values with market value.151 


\section{List of abbreviations}

\begin{tabular}{l|l} 
ARD & Acid rock drainage \\
EMPA & Electron microprobe \\
ESEM & Environmental scanning electron microscope \\
HS & High-sulfidation \\
HDS & High density sludge \\
ICP-OES & Inductively coupled plasma optical emission spectrometry \\
ICP-MS & Inductively coupled mass spectrometry \\
LS & Low-sulfidation \\
MicroPIXE & Proton induced X-ray emission \\
MSP & Mounted secondary precipitates \\
MV & Metal value \\
NMR & Nuclear magnetic resonance imaging \\
ORP & Oxidation-reduction potential \\
QA/QC & Quality assurance and quality control \\
RC & Recovery cost \\
RO & Reverse osmosis \\
SI & Saturation index \\
TDS & Total dissolved solids \\
XRD & X-ray diffraction \\
$\mu$ XRD & Micro X-ray diffraction \\
XRF & X-ray fluorescence \\
XAFS & X-ray absorption fine structure \\
WTC & Water treatment cost \\
&
\end{tabular}




\section{Chapter 1 \\ Introduction}

Acid rock drainage (ARD) is an important source of pollution in active and abandoned sulfide-rich mining areas (Carbone et al., 2013). The Rio Tinto in Spain, the Norwegian Raubekken, Iron Creek in Colorado and Iron Mountain in California are known cases of historical ARD. In a modern day setting, mining activities are known to accelerate the ARD process and are financially liable for the remediation of closed mine sites, and must meet regulations governing the quality of the effluent leaving their properties. One approach to limiting the financial burden and environmental impact of water treatment is to extract or isolate elements found in ARD that can be recovered to offset costs (Plumlee, 1999; MEND Treatment Committee, 2013; Lorax Environmental, 2003). Examples of elements of potential economic significance include $\mathrm{Cu}, \mathrm{Fe}, \mathrm{Ag}, \mathrm{Ni}, \mathrm{Zn}, \mathrm{Mn}, \mathrm{Co}, \mathrm{Mo}, \mathrm{Te}, \mathrm{Pb}$ and environmentally harmful elements include $\mathrm{Ag}, \mathrm{As}, \mathrm{Ce}$, $\mathrm{Pb}, \mathrm{Hg}, \mathrm{Te}, \mathrm{Sn}$ amongst others (Krieger et al., 2000; Smith and Huyck, 2000). This thesis aims to understand the geochemistry of waters and secondary precipitates at three gold mines: El Indio in Chile, and Lagunas Norte and Pierina in Peru, thereby providing the necessary groundwork for the improvement of water treatment methods.

These high-sulfidation epithermal Au-mines are ideal sites to study as they produce ARD resulting from sulfide oxidation leading to the high concentration of elements in solution, as well as the formation of abundant secondary minerals that host various trace elements (Evans et al., 2012; Cerpa et al., 2013; Robert et al., 2007; Rainbow et al., 2005; Montgomery, 2012; Klohn Crippen Berger, 2012b, 2012a). The first descriptions of epithermal precious and base-metal deposits are dated to the early $20^{\text {th }}$ century when

Ransome (1907) documented and described the occurrence and association of gold with alunite at Goldfield, Nevada (Rainbow et al., 2005 after Ransome, 1907). Subsequently, Lindgren (1922) defined epithermal deposits as mineralization that forms within the first kilometer of the continental crust at 
temperatures below $350^{\circ} \mathrm{C}$ (Rainbow, 2009). Plumlee et al. (1999) summarize many key geologic characteristics of mineral deposits that control their environmental signatures prior to and post mining.

Understanding the mechanisms of element mobility in mine waste requires a comprehensive assessment of the composition of the water and co-existing minerals, both primary ore and accessory minerals (source) and secondary precipitates (sink). Furthermore, understanding of trace elements and the secondary minerals that host them allows for the prediction of trace element behavior and mobility throughout a mine site (Lottermoser, 2010c, 2010b).

\subsection{Objectives}

The long-term objective of this research project is to investigate methods of extracting metals from acid mine waste in order to minimize the environmental impact of the drainage and to offset remediation costs. The primary goal of this thesis is to gain a more detailed understanding of the geochemistry of waters and secondary precipitates at El Indio, Lagunas Norte and Pierina HS gold mines and controls on metal mobility.

The objectives of this research were achieved by:

1- Characterizing the major and trace element composition of waters.

2- Characterizing secondary minerals co-existing with sampled waters.

3- Identifying the trace element content of the secondary sulfate minerals.

4- Relating the precipitates and waters by characterizing their relationship using geochemical modeling software.

5- Evaluating the importance of various techniques used to characterize secondary minerals and dissolved elements.

6- Evaluating the possibility of extracting valuable elements from effluent in order to offset water treatment costs. 


\subsection{Organization of the thesis}

This thesis is organized into six chapters. Chapter 1 introduces El Indio, Lagunas Norte and Pierina mines and the objectives of this project followed by detailed explanations of mining history, local and regional geology, geography, and a description of HS epithermal deposits. Chapter 2 presents a literature review of ARD and secondary minerals associated with these systems, metal sulfates, their solubility and stability relationship, and viable water treatment methods for sulfate waters. This section also summarizes previous geochemical work conducted at El Indio, Lagunas Norte and Pierina mines, and a list of hypotheses. Chapter 3 describes the analytical methods used for the geochemical characterization of the solids and waters. Chapter 4 reports the mineralogical and geochemical results of water and secondary precipitate analyses. This descriptive section is followed by an interpretation of results and a discussion section in chapter 5 . Finally, conclusions and recommendations for future work are included in the last chapter.

\subsection{Background}

\subsubsection{High-sulfidation (HS) epithermal deposits, mineralogy and associated elements}

HS epithermal deposits form when precious metals and gangue minerals are deposited from

hydrothermal fluids at shallow crustal levels $(<1 \mathrm{~km})$ and low temperatures $\left(<300^{\circ}\right)$ (Hedenquist et al., 2000). The metal-bearing hydrothermal fluids are magmatic and/or meteoric waters. Gold-silver epithermal deposits occur in volcano-plutonic arcs, island arcs and continental margins associated with subduction zones and convergent-plate settings (Taylor, 2007). The magmatic intrusions into volcanic arcs provide heat, which creates and drives convection of the hydrothermal fluids (Figure 1-2) (Corbett et al., 1998). At around $300^{\circ} \mathrm{C}, \mathrm{H}_{2} \mathrm{SO}_{4}$ and $\mathrm{HCl}$ dissociate, where these molecules are split into smaller molecules or ions and release $\mathrm{H}^{+}$into solution. The gradually formed hot acidic fluids then mix with meteoric waters and react with the country rock to form the deposit (Corbett et al., 1998). The host rock is extensively 
leached creating a porous silica residue that eventually hosts the ore minerals to varying degrees (Corbett and Leach, 1998; Arribas, 1995).

Global distribution of epithermal gold deposits demonstrates that they are associated with the Circum-Pacific Belt as a result of their genetic relation to magmatic centers (Hedenquist et al., 2000). Numerous epithermal deposits are associated with dome complexes and summit domes, followed by central-vent volcano setting and calderas (Hedenquist et al., 2000). The ore bodies are situated close to volcanic vents and have numerous structural conduits. In fact, hot-springs, geysers and fumaroles represent modern-day epithermal systems (Corbett and Leach, 1998; Rowland and Simmons, 2012). Epithermal precious metal deposits are significant due to their global abundance, as well as their potential of high grade and tonnage.

Boiling followed by rapid cooling lead to the formation of steam-heated waters that are responsible for advanced argillic alteration in both high- and low-sulfidation systems (Figure 1-1) (Hedenquist et al., 2000). As the hypogene acid fluids from the volcanic-hydrothermal system leach the rocks upon their ascent, a core of vuggy silica is formed (Figure 1-1). This silicic core of leached, residual silica is the main host of HS ore and is the central part of the advanced argillic halo that is formed of hypogene quartz-alunite and kaolin minerals (Figure 1-1) (Hedenquist et al., 2000). Hydrothermal alterations present in HS epithermal deposits are advanced argillic, argillic, silicic, and propyllitic (Figure 1-1)(Arribas, 1995). Kaolinite $\left(\mathrm{Al}_{2} \mathrm{Si}_{2} \mathrm{O}_{5}(\mathrm{OH})_{4}\right)$, dickite $\left(\mathrm{Al}_{2} \mathrm{Si}_{2} \mathrm{O}_{5}(\mathrm{OH})_{4}\right)$, pyrophyllite $\left(\mathrm{Al}_{2} \mathrm{Si}_{4} \mathrm{O}_{10}(\mathrm{OH})_{2}\right)$, alunite $\left(\mathrm{KAl}_{3}\left(\mathrm{SO}_{4}\right)_{2}(\mathrm{OH})_{6}\right)$ and diaspore $(\mathrm{AIO}(\mathrm{OH}))$ are minerals that are stable in acidic conditions and make up the alteration assemblages of HS epithermal type deposits (Arribas, 1995). Steam-heated overprinting from hypogene fluids may also occur and will vary vertically (Arribas, 1995). 


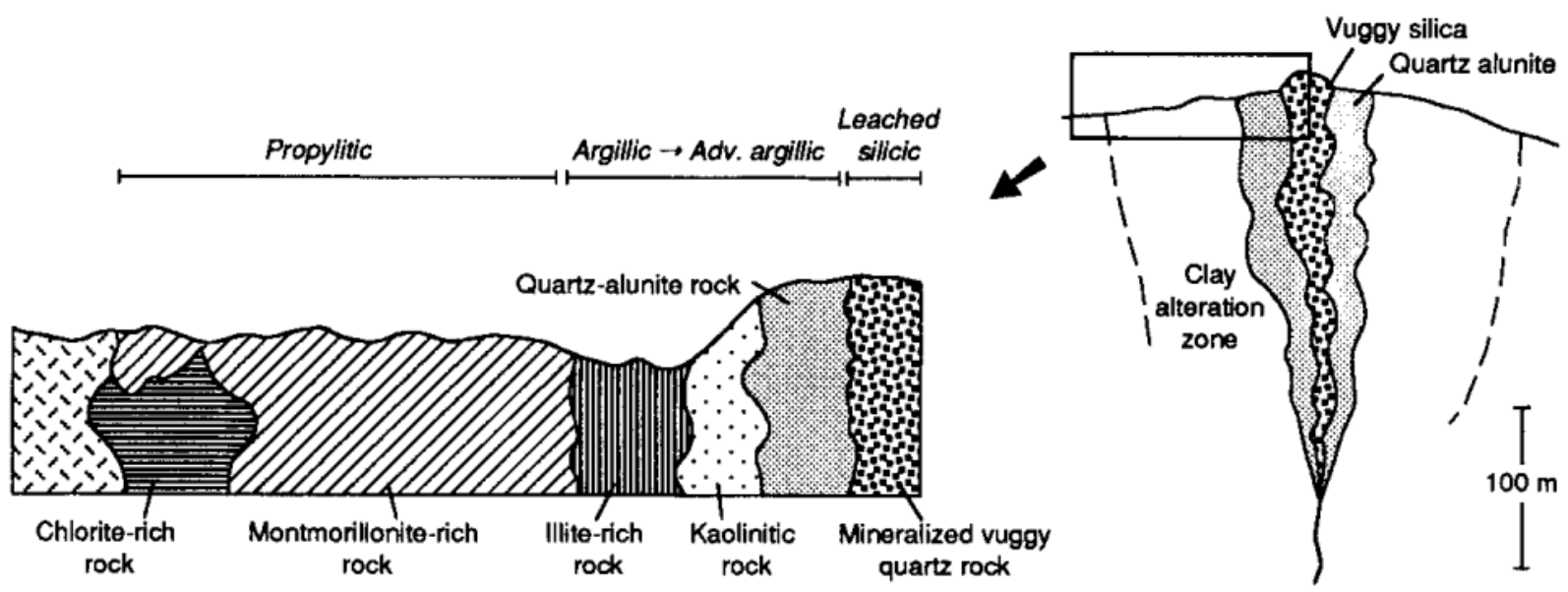

Figure 1-1 Hydrothermal alterations present in typical epithermal deposits are advanced argillic, argillic, silicic, and propyllitic (Hedenquist et al., 2000). Steam-heated acidic waters leach the country rock upon their ascent creating a core of vuggy silica. This silicic core of leached, residual silica is the main host of high-sulfidation ore and is the central part of the advanced argillic halo that is formed of hypogene quartz-alunite and kaolin minerals (Hedenquist et al., 2000). Mineral assemblages and zonation of alteration demonstrate evidence of neutralization of hydrothermal fluids by host-rock reaction further from the source.

\subsubsection{HS and LS epithermal deposits}

The two end members of epithermal deposits are of the high-sulfidation (HS) and low-sulfidation

(LS) types. Although HS epithermal deposits show a clear relationship to subduction related magmatism,

LS deposits do not demonstrate this (Taylor, 2007). The term "high-sulfidation" is used to specify the occurrence of high sulfidation state minerals such as enargite and tennantite (Corbett et al., 1998) and not the abundance of sulfur. HS epithermal deposits are dominated by acidic, hot and saline magmatic fluids, whereas LS epithermal deposits are formed by cool, near neutral $\mathrm{pH}$ and dilute meteoric waters (Corbett et al., 1998). All deposits studied in this thesis are of the HS type.

As previously mentioned, HS deposits form when highly acidic fluids are channeled from magma and directed along a fault. These acidic fluids dissolve the rock creating vuggy silica. Then, metal-rich brines from the magma precipitate metals in the vuggy silica zone (Arribas, 1995). Fluids forming LS veins interact with the rock for a longer period of time, become neutralized and dissolve silica (Arribas, 1995). Boiling of the fluids produces high-grade gold and silver deposits (Hedenquist and Lowenstern, 1994). 
Boiling is a process that allows for bisulfide-complexed metal such as gold to precipitate (Hedenquist and Lowenstern, 1994). Experimental studies have demonstrated that metals and ligands could be completely mobilized by associated magmas (Hedenquist and Lowenstern, 1994). Magmas obtain metals from mass transfer from subducting oceanic lithosphere, mantle melting, which are subsequently concentrated beneath volcanic arcs (Hedenquist and Lowenstern, 1994).

Common host rocks of gold mineralization in epithermal deposits are volcanic or volcanoclastic rocks of calc-alkaline series or basement rocks (Hedenquist et al., 2000). These felsic volcanic rocks have a low buffering capacity. The effects of volatiles and metals are not as clear for LS deposits as it is for HS deposits. Furthermore, the origin of the heat source may vary for low-sulfidation deposits (Kerrich et al., 2005). Typically, the highest content of sulfides is associated with the silicified and leached zones in HS epithermal deposits.

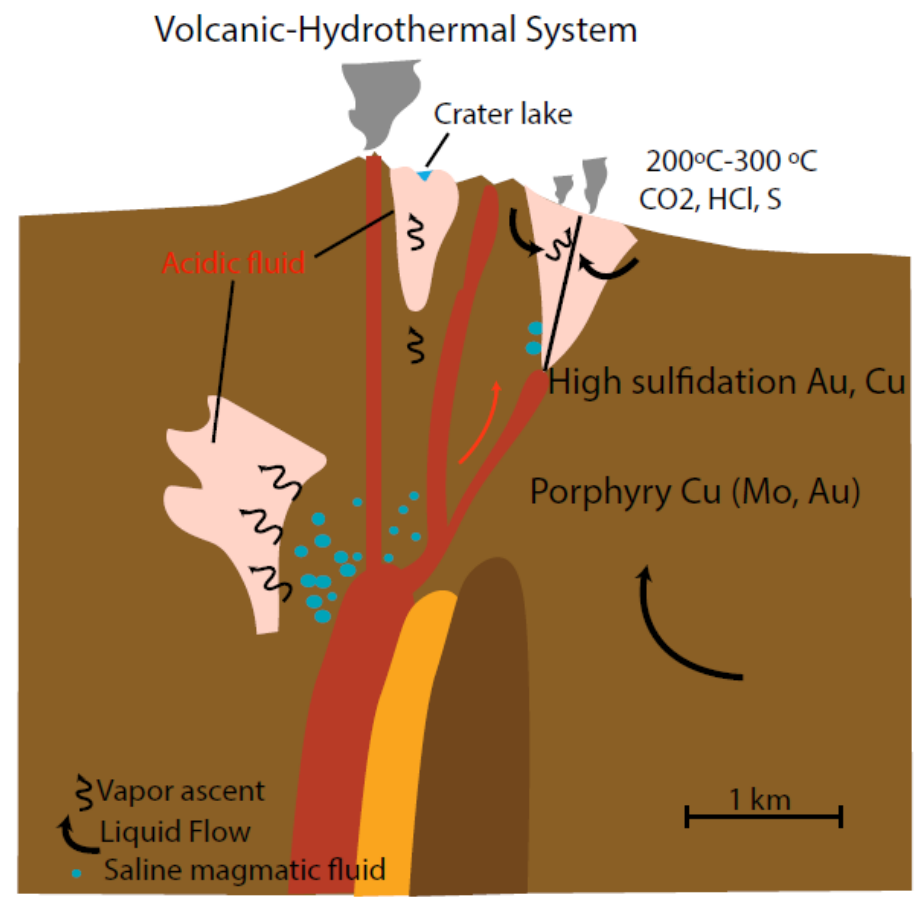

Figure 1-2 Schematic cross-section of sub-volcanic intrusions and the environments deduced for the formation of porphyry $\mathrm{Cu}$ and $\mathrm{HS}$ epithermal deposits (modified from Hedenquist and Lowenstern, 1994). Boiling followed by rapid cooling lead to the formation of magmatic-sourced, steam-heated and acidic vapor that leaches the country rock (pink). Active volcanic-hydrothermal system extend from degassing magma to fumaroles and acidic springs (Hedenquist and Lowenstern, 1994). The different coloured magma chambers represent multiple intrusions. 
Table 1-1 describes the main differences between high-sulfidation and low-sulfidation epithermal deposits:

Table 1-1 Key characteristics of HS and LS deposits (Hedenquist et al., 1994; White et al., 1995; Bowell et al., 2000).

\begin{tabular}{|c|c|c|}
\hline & Low Sulfidation & High Sulfidation \\
\hline & \multicolumn{2}{|c|}{$160-270^{\circ} \mathrm{C}$ depth of $\leq 1.0 \mathrm{~km}$} \\
\hline Ore minerals & $\begin{array}{l}\text { pyrite, sphalerite, maracasite, galena, } \\
\text { electrum, gold (arsenopyrite, argentite, } \\
\text { chalchopyrite, tetrahedrite) }\end{array}$ & $\begin{array}{c}\text { pyrite, enargite-luzonite, } \\
\text { chalcopyrite, covellite, tetrahedrite- } \\
\text { tennanite, gold (sphalerite, galena, } \\
\text { tellurides) }\end{array}$ \\
\hline Gangue minerals & $\begin{array}{l}\text { quartz, chalcedony, calcite, rhodocrosite, } \\
\text { adularia, barite, illite }\end{array}$ & quartz, kaolinite, alunite, barite \\
\hline Dominant metals & $\mathrm{Au}, \mathrm{Cu}, \mathrm{As}, \mathrm{Hg}$ & $\mathrm{Au}, \mathrm{Ag}, \mathrm{Cu}, \mathrm{As}, \mathrm{Fe}, \mathrm{Mn}$ \\
\hline Minor metals & $\mathrm{Zn}, \mathrm{Pb}, \mathrm{Sb}, \mathrm{Se}$ & $\mathrm{Pb}, \mathrm{Hg}, \mathrm{Sb}, \mathrm{Te}, \mathrm{Sn}, \mathrm{Mo}$ \\
\hline Metals enriched in rocks & $\mathrm{Cu}, \mathrm{Zn}, \mathrm{As}, \mathrm{Se}, \mathrm{Ag}, \mathrm{Cd}, \mathrm{Te}, \mathrm{Au}, \mathrm{Hg}$ & $\begin{array}{l}\mathrm{Fe}, \mathrm{Mn}, \mathrm{Co}, \mathrm{Ni}, \mathrm{Cu}, \mathrm{Zn}, \mathrm{As}, \mathrm{Se}, \mathrm{Mo} \\
\mathrm{Ag}, \mathrm{Cd}, \mathrm{Sn}, \mathrm{Sb}, \mathrm{Te}, \mathrm{Au}, \mathrm{Hg}, \mathrm{Tl}, \mathrm{Pb}, \mathrm{Bi}\end{array}$ \\
\hline Alteration & $\begin{array}{c}\text { (Neutral alteration) Sericitic/illitic } \\
\text { clays } \rightarrow \text { propyllitic veins dominated by } \\
\text { quartz, carbonate adularia }\end{array}$ & $\begin{array}{l}\text { (Zoned pervasive acidic alteration): } \\
\text { residual } \\
\text { quartz } \rightarrow \text { alunite } \rightarrow \text { kaolinite } \rightarrow \text { illite } \rightarrow \\
\text { propyllitic }\end{array}$ \\
\hline \%Sulfide & $<0.1-6.3$ & $3.4-31$ \\
\hline Final pH & $2.82-6.54$ & $0.78-4.56$ \\
\hline Conditions & Reduced, alkaline & Oxidized, acidic \\
\hline
\end{tabular}

HS deposits are enriched in $\mathrm{Fe}, \mathrm{Mn}, \mathrm{Co}, \mathrm{Ni}, \mathrm{Cu}, \mathrm{Zn}, \mathrm{As}, \mathrm{Se}, \mathrm{Mo}, \mathrm{Cd}, \mathrm{Sn}, \mathrm{Sb}, \mathrm{Hg}, \mathrm{Pb}$, and $\mathrm{Bi}$, whereas LS deposits are enriched in As, Se, Cd, and Pb (Bowell et al., 2000). Typically, up to 50\% of the ore zone of HS deposits can be composed of sulfides (Bowell et al., 2000). HS deposits also contain ore minerals such as pyrite $\left(\mathrm{FeS}_{2}\right)$, enargite-luzonite $\left(\mathrm{Cu}_{3} \mathrm{AsS}_{4}\right)$, chalcopyrite $\left(\mathrm{CuFeS}_{2}\right)$, covellite (CuS), tetrahedrite-tennanite $\left((\mathrm{Cu}, \mathrm{Fe})_{12} \mathrm{Sb}_{4} \mathrm{~S}_{13}\right)$, sphalerite ((Zn,Fe)S), galena $(\mathrm{PbS})$ and tellurides (Bowell et al., 2000).

\subsubsection{Deposit geology and mineralogy}

\subsubsection{El Indio}

The El Indio Belt is a district of epithermal deposits containing four significant economic deposits:

El Indio, Veladero, Tambo and Pascua-Lama. The El Indio belt is part of the Main Cordillera that was formed as a result of plate convergence and intermittent periods of regional extension (Chouinard et al., 
2005). The El Indio belt extends from Pascua-Lama-Veladero in the north to Coipita in the south (Charchaflié et al., 2007) and between latitudes $29^{\circ} 20^{\prime}$ and $30^{\circ} 30^{\prime}$ (Figure 1-3) (Bissig et al., 2003). The Nazca Plate was subjected to subduction beneath South America during the Miocene. A change in subduction angle from $35^{\circ}$ to nearly horizontal has been observed (Pilger, 1984) and this flattening is assumed to be caused by the consumption of Juan Fernandez Ridge beneath the South American Plate (Bissig et al., 2003). Volcanic activity leading to the major economically viable deposits occurred prior to flattening of Nazca plate. The Au-rich deposits in the belt are directly associated with Miocene magmatic rocks between the Baños del Toro fault in the west and Colangul fault in the east (Chouinard et al., 2005), both reverse faults with opposite dips. As a direct result of periods of crustal shortening and subsequent relaxation, northerly trending high-angle reverse and normal faults and folds were formed in the El Indio belt (Kay et al., 1999). This deposit can be described in terms of the magmatic and plate tectonic evolution of the Nazca plate and South America margin from the Oligocene and Miocene (Oyarzun et al., 2007). The El Indio belt presently lies in an amagmatic sequence of the Chilean Andes (Chouinard et al., 2005).

The alteration zones at El Indio are advanced argillic alteration mineral assemblages with kaolinite, alunite, and silica jaspers (Oyarzun et al., 2007), as well as sericitic and solfataric alterations (Jannas et al., 1990). The host rocks of El Indio are largely composed of felsic volcanic units (Bissig et al., 2003). The Au-Cu-Ag mineralization is hosted by ignimbrites and volcanic tuffs (Jannas et al., 1990). The hydrothermal fluids of the El Indio deposit were rich in sulfur and metal as a result of change in magmatism, leading to $\mathrm{Cu}-\mathrm{Au}-\mathrm{As}-\mathrm{S}$ ore. The main ore minerals are enargite $\left(\mathrm{Cu}_{3} \mathrm{AsS}_{4}\right)$, tennantite $\left(\mathrm{Cu}_{12} \mathrm{As}_{4} \mathrm{~S}_{13}\right)$ and native gold. Other minerals present include alunite $\left(\mathrm{KAl}_{3}\left(\mathrm{SO}_{4}\right)_{2}(\mathrm{OH})_{6}\right)$, chalcocite $\left(\mathrm{Cu}_{2} \mathrm{~S}\right)$, chalcopyrite $\left(\mathrm{CuFeS}_{2}\right)$, galena $(\mathrm{PbS})$, jarosite $\left(\mathrm{KFe}^{3+}{ }_{3}(\mathrm{OH})_{6}\left(\mathrm{SO}_{4}\right)_{2}\right)$, pyrite $\left(\mathrm{FeS}_{2}\right)$, sphalerite $((\mathrm{Zn}, \mathrm{Fe}) \mathrm{S})$ and tellurium, hubernite $\left(\mathrm{MnWO}_{4}\right)$, bornite $\left(\mathrm{Cu}_{5} \mathrm{FeS}_{4}\right)$, digenite $\left(\mathrm{Cu}_{9} \mathrm{~S}_{5}\right)$, emplectite $\left(\mathrm{CuBiS}_{2}\right)$, marcasite $\left(\mathrm{FeS}_{2}\right)$, and barite $\left(\mathrm{BaSO}_{4}\right)$ (Jannas et al., 1990; Arribas, 1995). 


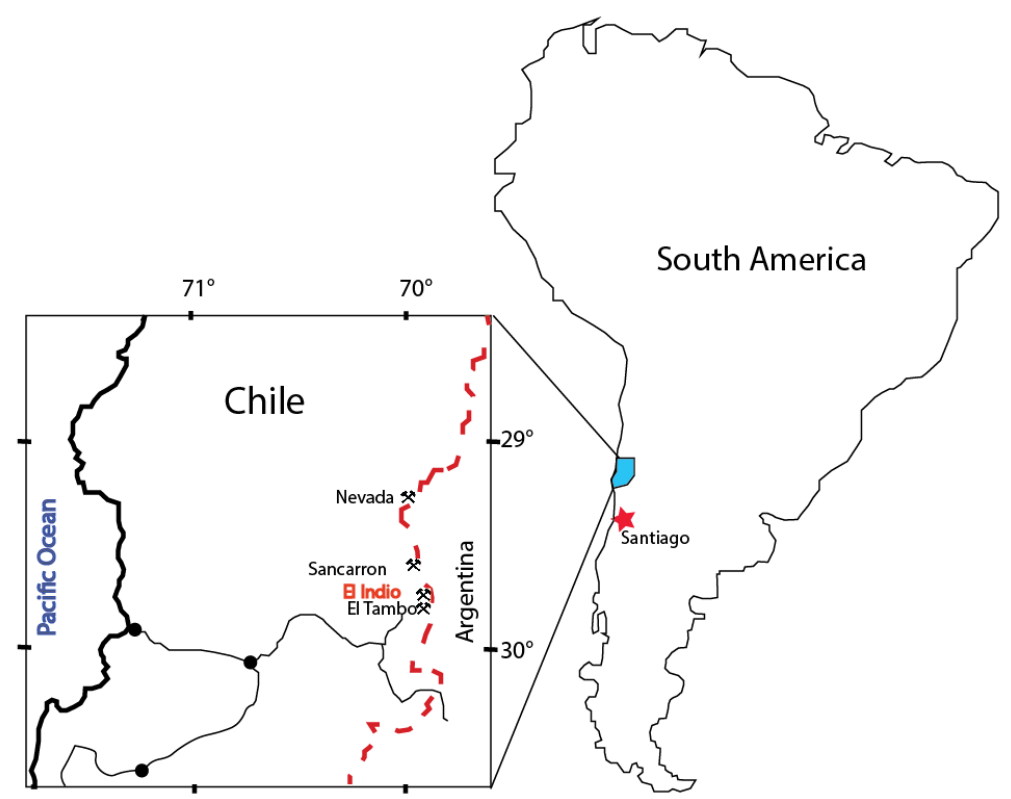

Figure 1-3 Geographic location of the El Indio deposit (Modified from Jannas et al., 1990).

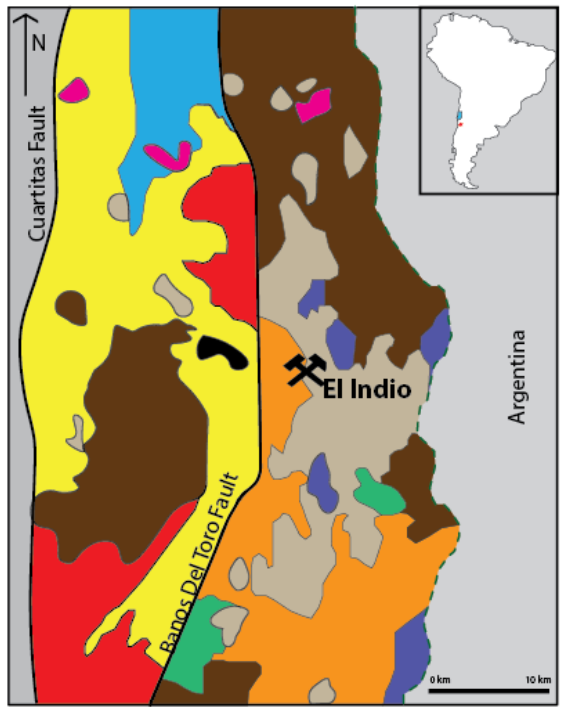

Sedimentary and Extrusive Rocks

Lacustrine sediments and rhyolites Andesite

Ignimbrites and basaltic andesites

TERTIARY

Ignimbrites and basaltic andesite

CRETACEOUS

Andesitic lavas and breccias

TRIASSIC-JURASSIC

Rhyolitic lavas

PERMIAN-TRIASSIC

Intrusive Rocks

Granodiorite

TERTIARY

Granitic basement

PALEOZOIC

Hydrothermal alteration

Symbols

2. Mine

International border

Figure 1-4 Generalized geologic setting of north-central Chile and the location of the El Indio deposit (Modified from Jannas et al., 1990).

\subsubsection{Lagunas Norte}

The Lagunas Norte ore deposit is a Miocene HS epithermal Au-Ag deposit with a resource of $~ 14$

M oz Au. The local geology is defined by folded and thrusted Upper Jurassic - Lower Cretaceous marine sedimentary strata that are unconformably overlain by lower Oligocene to Middle Miocene subaerial Calipuy Supergroup volcanic rocks (Montgomery, 2012). Mineralization is hosted in the highly-deformed 
Valanginian Chimú Formation quartz arenite and in weakly-deformed, Lower Miocene dacitic volcaniclastic rocks (Montgomery, 2012).

There are six stages of mineralization at Lagunas Norte. Stage I represents quartzose replacement of sedimentary units with minor gold mineralization association (Montgomery, 2012). Stage II shows quartz arenite units associated with minor pyrite $\left(\mathrm{FeS}_{2}\right)$, enargite $\left(\mathrm{Cu}_{3} \mathrm{AsS}_{4}\right)$ and gold. Stage III, the main mineralization event, is representative of the formation of vuggy silica (Montgomery, 2012). High-grade gold mineralization is associated with pyrite-enargite assemblages where pyrite is the main host for Au and is representative of Stage IV. Native sulfur and barite $\left(\mathrm{BaSO}_{4}\right)$ fill the remaining vugs in Stage V. Finally, Stage $\mathrm{VI}$ is the oxidation and release of $\mathrm{Au}$ from pyrite into goethite $(\mathrm{FeO}(\mathrm{OH}))$.

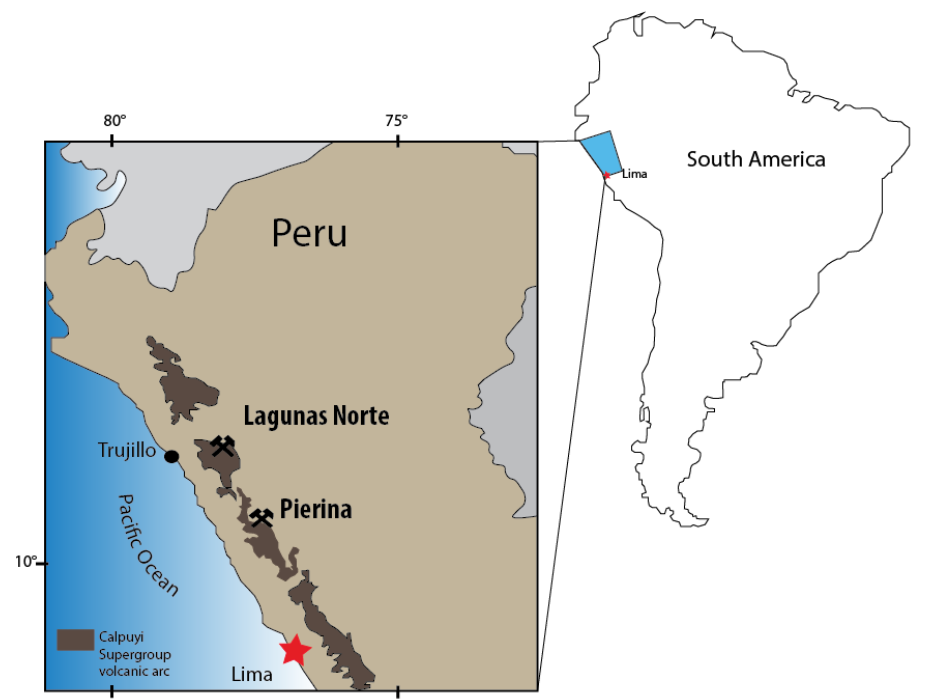

Figure 1-5 Geographic location of Pierina and Lagunas Norte deposits. 


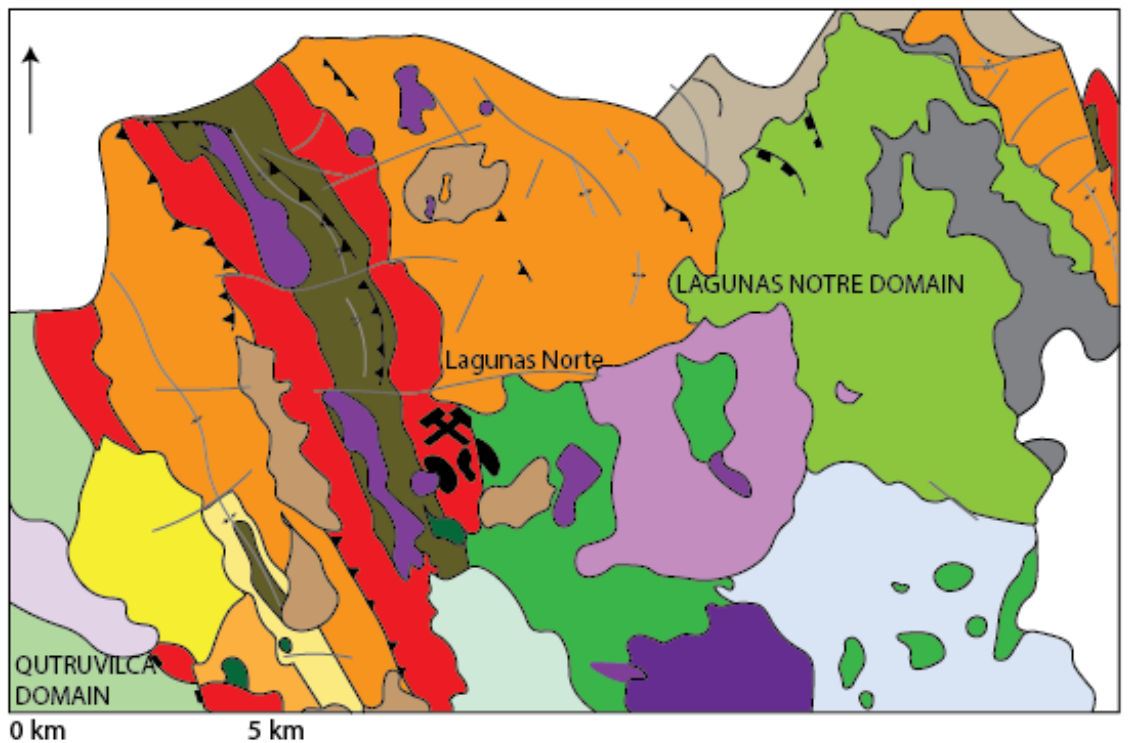

\section{PILO-QUATERNARY}

Pllo-glacial deposits

Undivided fluvioglacial deposits

Cenozoic Calipuy Supergroup (Huaraz Croup)

Undivided andesitic volcanics

Las Princesas Volcanic Complex

Las Princesas ignimbrite and dacitic to rhyolitic intrusions

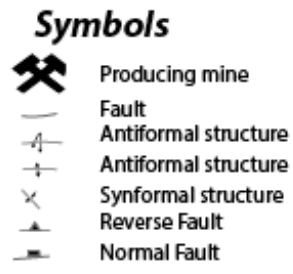

Syn-minerallzation Lagunas Norte Formation

Syn-mineralization dacitic domes and flows

Lagunas Norte mine sequence; undivided, altered, andesitic to rhyolitic

volcaniclastic deposits, Dafne diatreme breccia, fossiliferous dacitic

crystal-lapilli tuff and andesitic flows

Pre- to syn-minerallzation Sauco Volcanic Complex

Andesitic to dacitic domes

Andesitic to dacitic flows

Andesitic to dacitic flows

Andesitic block-ash flow, debris flows, ash, tuff, and breccia

Andesitic tuff breccia, lapilli and air-fall tuff and debris flows

Early andesitic domes, minor flows and breccias

Millagros Formation

$\square$ Undifferentiated, altered dacitic domes and volcaniclastic deposits

MESOZOIC

Tithonlan-Alblan sedlmentary unlts

$\square$ Farrat Formation

Santa/Carhuaz Formations

Chimu Formation

Chicama Formation

Figure 1-6 Regional geological map of the Lagunas Norte Domain and the Quturvilca Domain (Modified from Montgomery, 2012). 


\subsubsection{Pierina}

The Pierina ore deposit is an Au-Ag HS epithermal type deposit located $5 \mathrm{~km}$ north of the intermediate-sulfidation Santo Toribio Ag-base-metal epithermal deposit in the Cordillera Negra at elevations of 3800-4200 meters (McNulty and Farber, 1998). Pierina has a pre-mining resource of $~ 8 M$ oz $\mathrm{Au}-(\mathrm{Ag})$. The regional geology is primarily Jurassic and Cretaceous marl, shale, limestone and clastics overlain by Eocene to Miocene volcanics (Rainbow et al., 2005). This deposit is typical of HS epithermal deposits and the alteration types include vuggy silica, silicic, quartz alunite, and argillic alterations(Rainbow et al., 2005). Paragenetic minerals that are of importance for ARD include alunite $\left(\mathrm{KAl}_{3}\left(\mathrm{SO}_{4}\right)_{2}(\mathrm{OH})_{6}\right)$, pyrite $\left(\mathrm{FeS}_{2}\right)$, sphalerite $((\mathrm{Zn}, \mathrm{Fe}) \mathrm{S})$, bismuthinite-stibnite $\left(\mathrm{Bi}_{2} \mathrm{~S}_{3}, \mathrm{Sb}_{2} \mathrm{~S}_{3}\right)$, enargite $\left(\mathrm{Cu}_{3} \mathrm{AsS}_{4}\right)$, galena (PbS), tennantite $\left(\mathrm{Cu}_{6}\left[\mathrm{Cu}_{4}(\mathrm{Fe}, \mathrm{Zn})_{2}\right] \mathrm{As}_{4} \mathrm{~S}_{13}\right)$, covellite (CuS), native sulfur (S), schwertmannite $\left(\mathrm{Fe}_{8} \mathrm{O}_{8}(\mathrm{OH})_{6}\left(\mathrm{SO}_{4}\right) \cdot \mathrm{nH}_{2} \mathrm{O}\right)$, lepidocrocite $(\mathrm{FeOOH})$, goethite $(\mathrm{FeOOH})$, barite $\left(\mathrm{BaSO}_{4}\right)$, and acanthite $\left(\mathrm{Ag}_{2} \mathrm{~S}\right)$ (Rainbow et al., 2005).

The following is sourced from Klohn Crippen Berger (2012) unless stated otherwise. Mineralization at Pierina is confined in a zone of $450 \mathrm{~m}$ by $1200 \mathrm{~m}$ and controlled by a north, northeast and northwest trending fault system. The local geology of Pierina is composed primarily of units belonging to the Huaraz Group (29.3-14.8 Ma). These rocks include pyroclastics that overlay a dacitic flow-dome complex, as well as andesitic lavas. Tertiary rocks belong to the Calipuy Supergroup (Rainbow et al., 2005). Basement rocks include moderately folded Cretaceous Carhuaz and Santa formation hornfelsic sedimentary rocks. The deposit found at Pierina is representative of the last volcanic stage during the evolution of the Huaraz Group (Rainbow et al., 2005). 


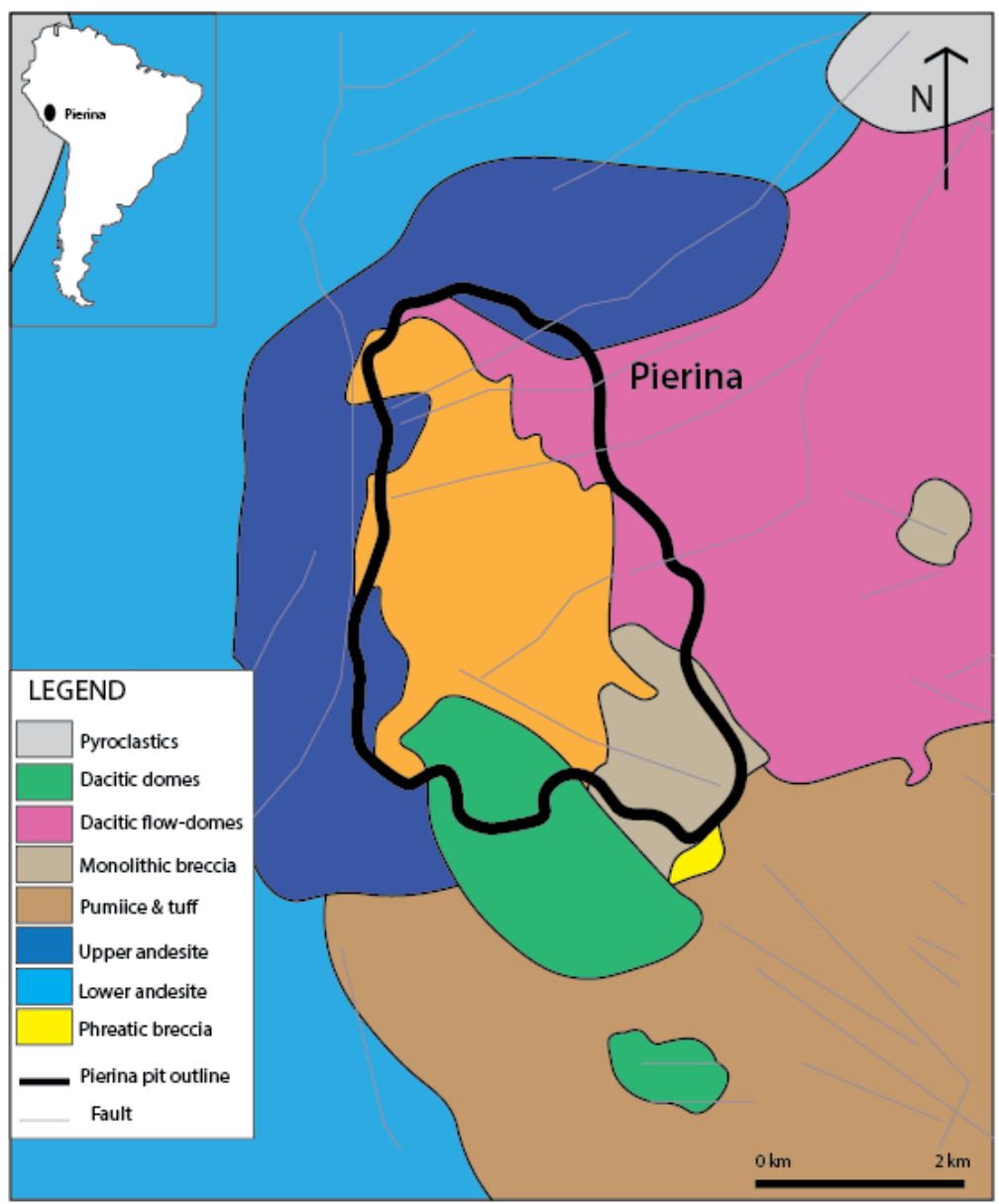

Figure 1-7 Regional geological map of Pierina mine with the outline of the Pierina pit highlighted (Modified from Rainbow et al., 2005).

\subsubsection{Site location and operational history}

Lagunas Norte and Pierina are located in Peru, and El Indio is located in Chile. Specifically, the Lagunas Norte open pit mine $\left(7^{\circ} 56^{\prime} 30^{\prime \prime} \mathrm{S} ; 7^{\circ} 56^{\prime} 30^{\prime \prime} \mathrm{S}\right)$ is located $140 \mathrm{~km}$ east of the city of Trujillo and 175 $\mathrm{km}$ north of the Pierina open pit operation $\left(9^{\circ} 26.5^{\prime} \mathrm{S} ; 77^{\circ} 35^{\prime} \mathrm{W}\right)$ in the Peruvian Andes at an elevation of 4,000-4,260 meters above sea level (Lacroix, 2012). Pierina is in the Ancash Department in close proximity to the city of Huaraz in north-central Peru, at an altitude of 4,100 meters. The El Indio underground mine, in Chile, is found $480 \mathrm{~km}$ north of Santiago, $160 \mathrm{~km}$ east of La Serena in the High Andes of north-central Chile and at an elevation of approximately 3,960 meters. 
At Lagunas Norte and Pierina, the annual temperatures range from greater than $25^{\circ} \mathrm{C}$ to less than $-10^{\circ} \mathrm{C}$ (Lacroix, 2012). Periods of extreme precipitation are not uncommon and the rainy season is from October to April. Temperatures at El Indio are similar, ranging from a high of $25^{\circ} \mathrm{C}$ in January to $-10^{\circ} \mathrm{C}$ in August (Belanger, 2003). The wet season at these sites is from October to April and dry season from May to September. The average annual rainfall at Pierina is 1.16 meters (George et al., 2009). The month of March experiences the greatest amount of precipitation, whereas the month of August experiences the greatest amount of evaporation (George et al., 2009).

The Lagunas Norte deposit was discovered in the year 2002 and operations by Barrick Gold Corporation began in 2005 (Barradas, 2014; Thomaz, 2006). The Lagunas Norte mine is an open pit operation with major on site processes such as a two-stage crushers and a cyanide heap leach (Barradas, 2014; Thomaz, 2006).

The El Indio mine operations began in 1981 under owners such as St. Joe Minerals, Fluor Minerals, Bond Gold and Lac Minerals before Barrick Gold Corporation acquired it in 1994 (Jannas et al., 1990; Belanger, 2003). El Indio was an open pit and mineral processes included flotation, concentration, roasting and cyanide in pulp leaching (BGC personal communication, 2015). Depletion of reserves occurred in the year 2002 and a closure plan with the goal of minimizing the environmental impact of the mine was inaugurated (Pouiller, 2011). During its years of production, El Indio produced 5.5 million ounces of Au, 24 million ounces of $\mathrm{Ag}$ and 500 thousand tonnes of $\mathrm{Cu}$ (Pouiller, 2011).

Pierina is an open-pit mine, heap leach operation where ore is crushed and transported to the leach pad area (Craze, 2001). Closure activities were initiated at Pierina in August, 2013 (BGC, 2015). Nineteen Mt of mine materials are scheduled for extraction from 2012 to 2019. Barrick Gold Corporation acquired Pierina in 1996 when it was at the advances exploration stage, and operations began in 1998 (Craze, 2001). 


\subsubsection{Mine components and water management}

The sampling locations of interest include pit walls, sedimentation ponds, dewatering stations, seepage collection ponds, water monitoring stations and water treatment plants. The water quality of the three mine sites, each with different water treatment methods, will be compared. There is no active water treatment at El Indio, whereas $\mathrm{pH}$ adjustment via lime addition and sedimentation are practiced at Pierina and high density sludge (HDS) and reverse osmosis (RO) plants currently being built (Thomaz, 2006; BGC, 2014b). Active treatment via lime neutralization and HDS generation is done at Lagunas Norte (Thomaz, 2006; BGC, 2014b). In addition, water treatment facilities at Lagunas Norte include cyanide destruction for barren process solutions, various solution storage ponds and associated water management infrastructure (Thomaz, 2006). Secondary water treatment plants are designed for ferric sulfate precipitation, which removes metals, and reverse osmosis to remove ammonia (Evans et al., 2012). At El Indio, there is only passive water treatment via the Pastos Largos sedimentation pond (BGC, 2014b).

El Indio is closed with mitigation measures near completion composed of waste rock dump covers, permeable underground portal plug, open pit backfilling, water diversions and monitoring. Pierina is at the late stages of operations and into the stage of progressive closure, and Lagunas Norte is in mid-life operations (BGC, 2014b, 2014a). Contact water is collected, monitored and mitigated by various strategies at all sites (BGC, 2014b, 2014a). 
Table 1-2 Summary table of all deposits comparing information about the mine types, mineral reserves, average gold recovery, stage of mines, host rocks, tectonic setting, system emplacement, sulfidation state, associated economic metals, mineralogy, climate, precipitation, and present water treatment.

\begin{tabular}{|c|c|c|c|}
\hline & \\
\hline & El Indio & Lagunas Norte & Pierina \\
\hline Mine type & Underground & Open pit & Open pit \\
\hline Mineral reserves & $10 \mathrm{Moz} \mathrm{Au}$ & $\sim 13.1 \mathrm{Moz} \mathrm{Au}$ & $\sim 8 \mathrm{Moz}$ \\
\hline Recovery Au (average) & - & 75\% & $\sim 85 \%$ \\
\hline Stage of mine & Closure & Operating & $\begin{array}{l}\text { Operating, near } \\
\text { closure }\end{array}$ \\
\hline Host rocks & $\begin{array}{l}\text { Miocene andesite, dacite, } \\
\text { rhyolite tuffs. } \\
\text { Volcaniclastic rocks of } \\
\text { Tilito Member of Dona } \\
\text { Ana Formation }\end{array}$ & $\begin{array}{l}\text { Valaginian quartz } \\
\text { arenite and Lower } \\
\text { Miocene dacitic } \\
\text { volcanics }\end{array}$ & $\begin{array}{l}\text { Middle Miocene } \\
\text { hypabyssal-to- } \\
\text { extrusive pumice tuff } \\
\text { and older dacitic flow- } \\
\text { dome complex }\end{array}$ \\
\hline Tectonic setting & \multicolumn{3}{|c|}{ Convergent margin } \\
\hline $\begin{array}{l}\text { Hydrothermal system } \\
\text { emplacement }\end{array}$ & 6.2-9.5 Ma & 16.7-17.1 Ma & $\sim 14.4 \mathrm{Ma}$ \\
\hline Sulfidation & High and intermediate & High & High \\
\hline Associated economic metals & Au-Cu-As & $A u-A g$ & $\mathrm{Au}-\mathrm{Ag}$ \\
\hline Mineralogy & $\begin{array}{l}\text { Enargite-pyrite } \pm \\
\text { chalcopyrite, quartz-gold } \\
\pm \text { calaverite-enargite }\end{array}$ & $\begin{array}{l}\text { Pyrite-enargite, } \\
\text { goethite-hematite }\end{array}$ & $\begin{array}{l}\text { Pyrite, bismuthinite- } \\
\text { stibnite, enargite and } \\
\text { barite, galena and } \\
\text { sphalerite, hematite- } \\
\text { goethite }\end{array}$ \\
\hline Climate at site & \multicolumn{3}{|c|}{ From greater than $25^{\circ} \mathrm{C}$ to less than $-10^{\circ} \mathrm{C}$} \\
\hline Precipitation & $1 \mathrm{~m}$ (average/year) & - & $1.16 \mathrm{~m}$ (average/year) \\
\hline Present water treatment & $\begin{array}{l}\text { Passive treatment } \\
\text { (current:sedimentation) } \\
\text { (future:neutralisation, } \\
\text { HDS, RO) }\end{array}$ & $\begin{array}{l}\text { Lime addition and } \\
\text { sedimentation, } \\
\text { HDS (future:RO) }\end{array}$ & $\begin{array}{l}\text { Cyanide destruction } \\
\text { plant, ARD pond, } \\
\text { sedimentation and } \\
\text { secondary treatment } \\
\text { plant }\end{array}$ \\
\hline References & $\begin{array}{l}\text { (Jannas et al., 1990), } \\
\text { (Oyarzun et al., 2007) }\end{array}$ & $\begin{array}{l}\text { (Cerpa et al., } \\
\text { 2013), (Evans et } \\
\text { al., 2012), } \\
\text { (Montgomery, } \\
\text { 2012) }\end{array}$ & $\begin{array}{l}\text { (George et al., 2009), } \\
\text { (Rainbow et al., 2005) }\end{array}$ \\
\hline
\end{tabular}




\section{Chapter 2 \\ Literature review}

\subsection{Factors influencing the formation of ARD}

The formation of ARD has been extensively studied and described previously (Nicholson, 1994; Lottermoser, 2010b; Jönsson et al., 2006; Romero et al., 2011; Buckby et al., 2003; Jambor et al., 2000). The mineralogy and chemical nature of HS epithermal Au-Ag-Cu deposits enable the production of ARD and the release of elevated metal concentrations. Commonly occurring sulfides such as pyrite and pyrrhotite that are present at these types of deposits oxidize and produce $\mathrm{H}^{+}$ions, lowering the $\mathrm{pH}$ of the solution. The weathering of minerals can be classified as acid producing (generating $\mathrm{H}^{+}$), acid buffering (consuming $\mathrm{H}^{+}$), or neither. The weathering reaction of pyrite is acid producing, whereas the weathering of calcite is acid buffering (Lottermoser, 2010c). However, carbonate minerals are nonexistent at the studied mines, therefore acid buffering does not influence the chemistry of the waters. Furthermore, the sulfide mineral grains tend to be quite small, with high surface area, thereby increasing reactivity (Bowell et al., 2000).

Pyrite is the most abundant sulfide mineral, it commonly occurs with ore deposits and is only stable under strongly reducing conditions (Lottermoser, 2010c; Frau, 2000; Romero et al., 2006; Carbone et al., 2013; Jambor et al., 2000; Nordstrom et al., 1999). Pyrite oxidation mechanisms occur by: 1) oxidation by oxygen, 2) oxidation by oxygen in the presence of microorganisms, 3) oxidation by oxygen and iron, 4) oxidation by oxygen and iron in the presence of microorganisms (Lottermoser, 2010c). The indirect oxidation of pyrite, an exothermic process, occurs in 3 steps (Equations 2.1, 2.2, 2.3) and involves the oxidation of pyrite by both oxygen and ferric iron. Stoichiometric chemical reactions are used to describe the four oxidation mechanisms described. In abiotic and biotic direct oxidation processes, oxygen directly oxidizes pyrite (Equation 2.1). 
Oxidation of pyrite by oxygen:

$\mathrm{FeS}_{2}+{ }^{7} / 2 \mathrm{O}_{2}+\mathrm{H}_{2} \mathrm{O} \rightarrow \mathrm{Fe}^{2+}+2 \mathrm{SO}_{4}^{2-}+2 \mathrm{H}^{+}$

Equation 2.1

Oxidation of ferrous iron to ferric iron:

$\mathrm{Fe}^{2+}+1 / 2 \mathrm{O}_{2}+2 \mathrm{H}^{+} \rightarrow \mathrm{Fe}^{3+}+\mathrm{H}_{2} \mathrm{O}$

Equation 2.2

Oxidation of pyrite by ferric iron:

$\mathrm{FeS}_{2}+14 \mathrm{Fe}^{3+}+8 \mathrm{H}_{2} \mathrm{O} \rightarrow 15 \mathrm{Fe}^{2+}+2 \mathrm{SO}_{4}^{2-}+16 \mathrm{H}^{+}$

Equation 2.3

The three steps demonstrate how oxidized pyrite produces dissolved ferrous iron, sulfate and hydrogen ions. Subsequently, the dissolved iron sulfate ions increase the total dissolved solids of water and the release of hydrogen produces acid (Lottermoser, 2010c). The oxidation of ferrous iron to ferric iron by oxidation occurs during the second step at low $\mathrm{pH}$ conditions. The third step demonstrates ferrous iron as the oxidizing agent. Some aerobic bacteria and Archea may speed up the chemical oxidation rate of ferrous iron and sulfur when oxygen is present (Lottermoser, 2010a). Other sulfides (i.e. galena, pyrrhotite) demonstrate different stabilities, acid production potentials and reaction rates (Alpers et al, 1992; Nordstrom et al., 1992; Jambor et al., 2000; Lottermoser, 2010c).

\subsection{Formation of secondary minerals in ARD}

A consequence of ARD is the precipitation of secondary minerals. Secondary minerals form as a result of weathering of sulfides before, during or after mining activities which releases sulfate, metals and metalloids into coexisting solution thereby increasing the ionic content of the water (Lottermoser, 2010c). Ions may be absorbed by minerals such as chlorite, talc and illite or Fe or Mn oxyhydroxides (Lottermoser, 2010c). The remainder of the ions in the weathering solution eventually reach saturation levels and precipitate as secondary minerals. Evaporation is a mechanism conducive to forming these secondary precipitates (Lottermoser, 2010c). Surficial secondary minerals are known as efflorescences and may be 
found in waste piles, stream beds, seepage areas and pit walls (Lottermoser, 2010c). These can also form by capillary migration of water to the surface of tailings or waste-rock piles (Romero et al., 2006).

The characteristics of the secondary precipitates formed in these environments are dependent on variations in conditions such as pH, Eh and T (Carbone et al., 2013). Efflorescence minerals are highly soluble, and may disappear with the arrival of the first rains and precipitate during dry periods (Romero et al., 2006; Keith et al., 2001). Oxidation, dehydration and neutralization reactions control the precipitation of efflorescent sulfates (Romero et al., 2006; Jambor et al., 2000). As such, changes in redox potential, humidity and temperature will cause changes in mineralogy (Romero et al., 2011; Frau, 2000; Jamieson et al., 2005).

Mechanisms of adsorption or coprecipitation significantly decrease the mobility of the elements in acid mine waters thereby temporarily naturally attenuating aqueous concentrations in mine effluent (Lottermoser, 2010c). Simple hydrous metal sulfates are generally soluble and easily release stored metals into mine waters when dissolved (Lottermoser, 2010c).

Various studies have analyzed and described the types of secondary precipitates formed at ARD settings(Nordstrom and Alpers, 1999; Lottermoser, 2010d; Buckby et al., 2003; Frau, 2000; Jönsson et al., 2006; Buurman, 1975). Lottermoser (2010a) describes the general mechanisms of the formation of secondary minerals in ARD environments. Carbone et al. (2013) describe minerals that can form in ARD settings and classify them into three broad groups:

1. Fe-oxides, -oxyhdroxides, and -oxyhydroxysulfates, and other low crystallinity Fe phases including ferrihydrites, goethite, hematite, schwertmannite, and jarosite

2. Hydrous $\mathrm{Ca}-\mathrm{Fe}, \mathrm{Al}-$ and other metal-sulfates including gypsum, melanterite, copiapite, halotrichite, chalcanthite, epsomite

3. Other metal-rich phases 
These minerals all have specific Eh and $\mathrm{pH}$ stability fields that occur in ARD environments (Carbone et al., 2013). Fe-sulfate-rich evaporative minerals from a specific deposit in Spain were analyzed by Buckby et al. (2003). Melanterite $\left(\mathrm{Fe}\left(\mathrm{SO}_{4}\right) \cdot 7\left(\mathrm{H}_{2} \mathrm{O}\right)\right)$, rozenite $\left(\mathrm{Fe}\left(\mathrm{SO}_{4}\right) \cdot 4\left(\mathrm{H}_{2} \mathrm{O}\right)\right)$, rhomboclase $\left(\mathrm{HFe}\left(\mathrm{SO}_{4}\right)_{2} \cdot 4\left(\mathrm{H}_{2} \mathrm{O}\right)\right)$, szomolnokite $\left(\mathrm{FeSO}_{4} \cdot\left(\mathrm{H}_{2} \mathrm{O}\right)\right)$, copiapite $\left(\mathrm{Fe}^{2+} \mathrm{Fe}^{3+}{ }_{4}\left(\mathrm{SO}_{4}\right)_{6}(\mathrm{OH})_{2} \cdot 2 \mathrm{O}\left(\mathrm{H}_{2} \mathrm{O}\right)\right)$, coquimbite $\left(\mathrm{Fe}^{3+}{ }_{2}\left(\mathrm{SO}_{4}\right)_{3} \cdot 9\left(\mathrm{H}_{2} \mathrm{O}\right)\right)$, hexahydrite $\left(\mathrm{Mg}\left(\mathrm{SO}_{4}\right) \cdot 6\left(\mathrm{H}_{2} \mathrm{O}\right)\right)$, halotrichite $\left(\mathrm{FeAl}_{2}\left(\mathrm{SO}_{4}\right)_{4} \cdot 22\left(\mathrm{H}_{2} \mathrm{O}\right)\right)$ and gypsum $\left(\mathrm{Ca}\left(\mathrm{SO}_{4}\right) \cdot 2\left(\mathrm{H}_{2} \mathrm{O}\right)\right)$ were identified on the banks of the Rio Tinto for the first time in the study by Buckby et al.(2003). The formation-dissolution and precipitation cycle of melanterite from the Genna Lucas mine in Italy was analyzed by Frau (2000). The paragenetic sequence of ARD minerals formed in laboratory experiments by evaporating acid mine waters is also observed, alongside field observations (Frau, 2000; Buurman, 1975).

\subsection{The sulfate system: Compositions of hydrated metal sulfate salts}

Sulfate is formed by the oxidation of sulfide minerals. Sulfate concentrations in mine drainage are generally higher than concentrations of Fe and other metals since few natural processes remove dissolved sulfate from ground and surficial waters (Jambor et al., 2000). Sulfate minerals in tailings and around mine sites are typically dominated by Fe since oxidation of Fe-sulfide releases both Fe and $\mathrm{SO}_{4}$. Magnesiumdominant sulfates form where gangue minerals contain dolomite or other relatively soluble Mg-bearing minerals (Jambor et al., 2000). Hydrated sulfate minerals with divalent cations, trivalent cations and those salts that contain both divalent and trivalent cations have been studied by Jambor et al. (2000). Gypsum most likely formed from the reactions between sulfuric acid and Ca-rich minerals (Deer et al., 1992).

Simple hydrated salts with divalent cations have the chemical formula $\mathrm{Me}^{2+}\left(\mathrm{SO}_{4}\right) \cdot n\left(\mathrm{H}_{2} \mathrm{O}\right)$. Experiments show that " $n$ " decreases with relative humidity and water activity, and increases with temperature and acidity of the solution (Jambor et al., 2000). Hydrated metal sulfate salt groups with divalent cations include: Melanterite group, epsomite group, hexahydrite group, chalcanthite group, 
rozenite group, kieserite group (Jambor et al., 2000). As noted by Nordstrom and Alpers(1999), at metal concentrations of $10^{-6}$ molar, metal hydroxides are likely to precipitate in the following sequence with increasing $\mathrm{pH}: \mathrm{Fe}^{3+}, \mathrm{Pb}, \mathrm{Al}, \mathrm{Cu}, \mathrm{Zn}, \mathrm{Fe}^{2+}$, and $\mathrm{Cd}$. Hydrated metal sulfate salts with trivalent cations include minerals such as: Lausenite $\left(\mathrm{Fe}^{3+}{ }_{2}\left(\mathrm{SO}_{4}\right)_{3} \cdot 6\left(\mathrm{H}_{2} \mathrm{O}\right)\right)$, kornelite $\left(\mathrm{Fe}^{3+}{ }_{2}\left(\mathrm{SO}_{4}\right)_{3} \cdot 7\left(\mathrm{H}_{2} \mathrm{O}\right)\right)$, coquimbite $\left(\mathrm{Fe}^{3+}{ }_{2}\left(\mathrm{SO}_{4}\right)_{3} \cdot 9\left(\mathrm{H}_{2} \mathrm{O}\right)\right)$, paracoquimbite $\left(\mathrm{Fe}^{3+}{ }_{2}\left(\mathrm{SO}_{4}\right)_{3} \cdot 9\left(\mathrm{H}_{2} \mathrm{O}\right)\right)$, quenstedtite $\quad\left(\mathrm{Fe}^{3+}{ }_{2}\left(\mathrm{SO}_{4}\right)_{3} \cdot 11\left(\mathrm{H}_{2} \mathrm{O}\right)\right)$, alunogen $\left(\mathrm{Al}_{2}\left(\mathrm{SO}_{4}\right)_{3} \cdot 17\left(\mathrm{H}_{2} \mathrm{O}\right)\right)$ and meta-alunogen $\left(\mathrm{Al}_{4}\left(\mathrm{SO}_{4}\right)_{6} \cdot 27\left(\mathrm{H}_{2} \mathrm{O}\right)\right)$ (Jambor et al., 2000). Hydrated metal sulfate salt groups with divalent and trivalent cations include: Halotrichite group, and copiapite group (Jambor et al., 2000).

Secondary precipitates such as chalcanthite $\left(\mathrm{Cu}\left(\mathrm{SO}_{4}\right) \cdot 5\left(\mathrm{H}_{2} \mathrm{O}\right)\right)$, jarosite $\left(\mathrm{KFe}^{3+}{ }_{3}(\mathrm{OH})_{6}\left(\mathrm{SO}_{4}\right)_{2}\right)$, scorodite $\left(\mathrm{Fe}\left(\mathrm{AsO}_{4}\right) \cdot 2\left(\mathrm{H}_{2} \mathrm{O}\right)\right)$, and Fe-sulfate salts have been observed at other $\mathrm{HS}$ epithermal deposits (Bowell et al., 2000). Halotrichite, melanterite and szomolnokite have also been documented at this type of deposits (Bowell et al., 2000). A wide array of secondary precipitates have been identified at tailing impoundments in arid climates including several Fe and $\mathrm{Mg}$ salts of the $\mathrm{Me}^{2+} \mathrm{SO}_{4} \cdot n \mathrm{H}_{2} \mathrm{O}$. Some rare minerals such as blodite $\left(\mathrm{Na}_{2} \mathrm{Mg}\left(\mathrm{SO}_{4}\right)_{2} \cdot 4\left(\mathrm{H}_{2} \mathrm{O}\right)\right)$ and hydrobasaluminite $\left(\mathrm{Al}_{4}\left(\mathrm{SO}_{4}\right)(\mathrm{OH})_{10} \cdot 15\left(\mathrm{H}_{2} \mathrm{O}\right)\right)$ have been identified in Australia (Jambor et al., 2000).

The incorporation of trace elements in sulfate salts has been presented in various studies (Buckby et al., 2003; Romero et al., 2006, 2011; Jamieson et al., 2005). Buckby et al. (2003) have studied secondary minerals along the margins of the acidic Rio Tinto during 3 field seasons. Minerals were identified using XRD, SEM and ICP-AES, and melanterite displays high $\mathrm{Cu}(1.6 \mathrm{wt} \%)$ and $\mathrm{Zn}(1.0 \mathrm{wt} \%)$ concentrations. Frau (2000) Jambor et al. (2000), Hammarstrom et al. (2005), Peterson (2003) and Peterson et al. (2006) have discussed the ability of melanterite to sequester $\mathrm{Cu}$ and $\mathrm{Zn}$. Melanterite has a structure that comprises a flexible array of metal-containing octahedra that are held together by hydrogen bonds and can incorporate divalent transition metals (Peterson, 2003). The results of chemical analyses conducted by 
Peterson (2003) including electron microprobe (EMPA) work and ICP-MS on natural and synthetic samples, demonstrate that the composition of melanterite ranges from Fe end-member to some samples with equal amounts of $\mathrm{Fe}, \mathrm{Cu}, \mathrm{Zn}$. Jamieson et al. (1999) identified maximum Zn concentrations of 22 wt\% in melanterite, $17.4 \mathrm{wt} \%$ in szomolnokite, $7.6 \mathrm{wt} \%$ in voltaite and $1.0 \mathrm{wt} \%$ in romerite from samples collected at Iron Mountain and analyzed with the EMPA and microPIXE. In general terms, the substitutions of elements into the hexahydrite lattice are comparable to melanterite because of the similarity in crystal structures; however little is known about the limits of solid solution in hexahydrate (Buckby et al., 2003; Jambor et al., 2000). Romero et al. (2006) studied mineralogy and geochemistry of efflorescent sulfates that had precipitated along the acidic streams draining from the abandoned Pena del Hierro mine in Southwestern Spain. Samples were analyzed by XRD, SEM and XRF (X-ray fluorescence), and their results demonstrate that there is a replacement of $\mathrm{Mg}$ by $\mathrm{Fe}(0.68-1.74 \mathrm{wt} \%$ ) and $\mathrm{Mn}$ (up to $0.62 \mathrm{wt} \%$ ) in hexahydrite.

Studies by Manceau et al. (2000), have analyzed the crystal chemistry of trace elements in natural and synthetic goethite with the use of X-ray absorption fine structure spectroscopy (EXAFS) at the European Synchrotron Radiation Facility. These researchers have found $\mathrm{Cr}(0.73 \mathrm{wt} \%), \mathrm{Mn}(0.88 \mathrm{wt} \%)$, Co (0.166 wt\%), Ni (0.898 wt\%), Cu (0.263 wt\%) and Zn (0.026 wt\%) in goethite. Jamieson et al. (2005) studied major and trace element compositions of copiapite-group minerals from Richmond mine in Iron Mountain, California using analytical techniques such as SEM, EMPA, microPIXE, and XRD. Copiapite-group minerals, which generally occur in the oxidation zone of sulfidic iron ore and massive sulfide deposits, may store $\mathrm{Zn}(0.142 \mathrm{wt} \%), \mathrm{Cu}(0.027 \mathrm{wt} \%)$ and As (0.0064 wt\%) (Jamieson et al., 2005). Arsenic has been assumed to substitute for $\mathrm{SO}_{4}{ }^{2}$ - as $\mathrm{AsO}_{4}{ }^{3-}$ in copiapite, but has also been suggested for jarosite (Dutrizac et al., 1987; Savage et al., 2005). Hydronium and Na substitution for $\mathrm{K}$ (15-25 mol\%) in jarosite has also been noted by (Alpers and Brimhall, 1989; Dutrizac and Jambor, 2000; Robinson, 2000; Stoffregen et al., 
2000) with the use of NMR techniques. Furthermore, $\mathrm{Cu}, \mathrm{Zn}$ and $\mathrm{Pb}$ can substitute for $\mathrm{Fe}^{3+}$ in the jarosite structure (Dutrizac et al., 1987). Solid solution in the alunite group exists between $\mathrm{Fe}^{3+}$ and $\mathrm{Al}^{3+}$ (Dutrizac et al., 1987). Stoffregen et al. (2000) have determined that the most significant substitution in alunite is that of $\mathrm{Na}^{+}$for $\mathrm{K}^{+}$. These authors also state that alunite from Goldfield samples contain up to $0.2 \mathrm{wt} \% \mathrm{BaO}$ and $0.05 \mathrm{wt} \% \mathrm{P}_{2} \mathrm{O}_{5}$. It is not specified whether alunite in question is of primary or secondary nature.

Experimental neutralization of waters by Munk et al. (2006) shows that $\mathrm{Pb}, \mathrm{Cu}, \mathrm{Zn}, \mathrm{Ni}$ are sorbed onto Al-hydroxysulfate minerals with increasing $\mathrm{pH}$. They added a saturated solution of $\mathrm{NaOH}$ obtaining final $\mathrm{pH}$ values of $4.2,4.8,5.7,6.0,6.4$ and 6.7 . These solutions were stirred and measured daily until pH had stabilized. The increase in $\mathrm{pH}$ caused precipitates to form, and their experiments demonstrate that the sorption sequence is as follows, with a steady increase in $\mathrm{pH}: \mathrm{Pb}, \mathrm{Cu}, \mathrm{Zn}$, Ni. Finally, studies by Sracek et al. (2010) have previously identified small amounts of Co (2.28 wt\%) and Mn in blodite based on energydispersive spectra.

Table 2-1 A list of a few secondary precipitates and their potential trace element compositions. The methods used to identify the compositions as well as references are included. Where there are no concentrations, the presence of the trace elements have been identified but the concentrations have not.

\begin{tabular}{|c|c|c|c|}
\hline $\begin{array}{c}\text { Secondary minerals } \\
\text { precipitated from ARD }\end{array}$ & Measured trace element compositions & Methods & Reference \\
\hline Melanterite & $\begin{array}{c}\mathrm{Cu}(1.6 \mathrm{wt} \%), \mathrm{Zn}(1.0 \mathrm{wt} \%), \mathrm{Ni}, \mathrm{Mg} \\
(7.45 \mathrm{wt} \%)\end{array}$ & XRD, SEM, XRD and ICP-AES & $\begin{array}{l}\text { Buckby et al., 2003; Peterson, } \\
2003\end{array}$ \\
\hline Hexahydrite & $\mathrm{Ni}$, Fe (0.68-1.74wt\%), Mn (<0.62wt\%) & XRD, SEM, XRF & Janijic et al., 1980 \\
\hline Copiapite & $\begin{array}{c}\mathrm{Zn}(0.142 w t \%), \mathrm{Cu}(0.027 w t \%), \text { As } \\
(0.064 w t \%)\end{array}$ & $\begin{array}{l}\text { SEM, electron microprobe, } \\
\text { micro-PIXE, XRD }\end{array}$ & $\begin{array}{c}\text { Jamieson et al., 2005; Jamieson } \\
\text { et al., } 1999\end{array}$ \\
\hline Goethite & $\begin{array}{c}\mathrm{Cr}(0.73 w t \%), \mathrm{Mn}(0.88 w t \%), \mathrm{Co} \\
(0.166 w t \%), \mathrm{Ni}(0.898 w t \%) \\
\mathrm{Cu}(0.263 w t \%) \text { and } \mathrm{Zn}(0.026 w t \%)\end{array}$ & XAFS & Manceau et al., 2000 \\
\hline Jarosite & $\begin{array}{c}\mathrm{AsO}_{4}{ }^{3-}, \mathrm{H}_{3} \mathrm{O}^{+}, \mathrm{Cu}(2 \mathrm{wt} \%), \mathrm{Zn}(2.1 w t \%), \\
\mathrm{Pb}(6.3 w t \%)\end{array}$ & NMR & $\begin{array}{c}\text { Dutrizac et al., 1987; Savage et } \\
\text { al., } 2005\end{array}$ \\
\hline Coquimbite & Al (0.56wt\%-0.74wt\%) & XRD, SEM, XRD & $\begin{array}{c}\text { Romero et al., 2006; Jambor et } \\
\text { al., } 2000\end{array}$ \\
\hline Al-hydroxysulfates & $\mathrm{Pb}, \mathrm{Cu}, \mathrm{Zn}, \mathrm{Ni}$ & ICP-MS, ICP-OES & Munk et al. 2006 \\
\hline
\end{tabular}

The thermodynamic conditions of minerals allow the researcher to know if the minerals are likely to occur at the given sample site, they are also necessary to evaluate the role of the given minerals in 
acidic waters and to model reaction pathways. Although Majzlan et al. (2006) have studied the thermodynamic properties and crystal structures of ferricopiapite, coquimbite and rhomboclase, significant gaps persist in literature with regards to our understanding of the thermodynamic description of sulfate mineral assemblages in ARD environments. Furthermore, very little thermodynamic data exists for $\mathrm{Fe}^{3+}$ and mixed $\mathrm{Fe}^{2+}-\mathrm{Fe}^{3+}$ sulfates, as well as $\mathrm{Na}-\mathrm{Mg}$ oxyhydroxide sulfates.

\subsection{Sulfate and ARD water treatment}

Regulations concerning the maximum allowable sulfate in drinking water varies worldwide (92 countries) from 250 to $500 \mathrm{mg} / \mathrm{L}$ (Philippe and Kirk, 2015). It is well-known that drinking water containing sulfate concentrations greater than $600 \mathrm{mg} / \mathrm{L}$ result in laxative effects, especially in infants. The World Health Organization recommends concentrations of sulfate to be less than $500 \mathrm{mg} / \mathrm{L}$ in drinking water (Philippe and Kirk, 2015). The Canadian standards for drinking water are at $500 \mathrm{mg} / \mathrm{L}$ (Health Canada, 2011). The Peruvian standards for irrigation and drinking water standards are $300 \mathrm{mg} / \mathrm{L}$ and $500 \mathrm{mg} / \mathrm{L}$ respectively (DIGE-SA, 1998). These are values that Barrick Gold Corporation must meet in its waste water effluent. Presently, ARD from mine waste is not strictly regulated for sulfate in Chile and these values are highly dependent on environmental authorities.

Rigorous regulatory standards for sulfate in mine effluent waters in South America amplify the necessity of sulfate treatment at the Barrick Gold Corporation mines in this study. The current treatment processes that are used to reduce sulfate in mine effluent waters include: (1) chemical treatment with mineral precipitation (i.e. lime or limestone addition, barium salt addition, (2) membrane exclusion technology (i.e. reverse osmosis, electrical dialysis reversal), (3) ion exchange, and (4) biological sulfate removal (i.e bioreactors, wetlands, alkalinity producing systems (Dupon and Figueroa, 2015).In many case, a combination of these processes is applied for maximal results. These processes are selected for discussion based on their applicability for sulfate removal, and availability of data from pilot plants or larger field-trials. 
lon exchange (IX) is a process that uses the adsorption of ions of a specific charge in a solution onto the surface of a solid material, the ion exchange resin (MEND, 2014). The resin used is insoluble in water but it is hydrated and may be a salt, acid or even a base (MEND, 2014). Resins are typically designed to selectively remove one or few parameters and are selected based on their affinity for certain metals. As such, numerous ion exchange steps and different types of resins are necessary to achieve the removal of a large number of parameters.

Neutralization using hydrated lime $\left(\mathrm{Ca}(\mathrm{OH})_{2}\right)$ is the most common technology used for acid neutralization and removal of metals from effluent as a result of its low cost. Lime neutralization produces sludge that contains metal contaminants as metal hydroxides and can precipitate many species (MEND Treatment Committee, 2013). In the HDS process, hydroxide minerals are formed with the metals as large and dense particles that can readily settle (Aube, 2004). In a conventional treatment plant, the slurry is sent to a clarifier for physical solid and liquid separation (Aube, 2004).

Membrane exclusion technology such as nanofiltration removes dissolved parameters (i.e. Al, As, $\mathrm{Fe}, \mathrm{Pb}, \mathrm{Mn}, \mathrm{Ni}, \mathrm{Zn}, \mathrm{SO}_{4}$, etc.) from solutions with a pressurized application of the effluent to a charged and selectively permeable membrane. Nanofiltration has been described to remove $95 \%$ of targeted ions or molecules in effluent. Efficiency of membrane exclusion technologies depend on effluent quality and the concentration and types of parameters found in the feed.

\subsection{Solubility of secondary minerals and stability relationships}

The type of secondary minerals formed at mine sites is controlled by the composition of the waste, creating a range in solubilities between minerals formed where some are susceptible to dissolution more readily than others (Lottermoser, 2010c; Frau, 2000). HS epithermal deposits are most likely to contain $\mathrm{Fe}, \mathrm{Al}$ and metal-rich sulfate salts. Research by Lottermoser (2010) states that simple hydrous metal sulfates are soluble in water; however, Fe and Al hydroxysulfates are relatively insoluble. Poor solubility 
minerals are sinks and their precipitation may be effective control on the amount of $\mathrm{SO}_{4}, \mathrm{Ba}, \mathrm{Sr}$ and $\mathrm{Pb}$ in acidic solutions (Lottermoser, 2010c).

The most common secondary minerals are water soluble hydrous metal sulfates with divalent cations $\left(\mathrm{Me}^{2+} \mathrm{SO}_{4} \cdot n \mathrm{H}_{2} \mathrm{O}\right)$, where $\mathrm{Me}$ can be $\mathrm{Ca}, \mathrm{Mg}, \mathrm{Fe}, \mathrm{Mn}, \mathrm{Co}, \mathrm{Ni}, \mathrm{Cu}$ or $\mathrm{Zn}$ and $\mathrm{n}=1$ to 7 . Furthermore, these hydrous sulfates may dehydrate to less hydrous compositions which tend to be more stable with an increased resistance to dissolution (Lottermoser, 2010). A common example observed in the field is melanterite precipitating $\left(\mathrm{Fe}\left(\mathrm{SO}_{4}\right) \cdot 7\left(\mathrm{H}_{2} \mathrm{O}\right)\right)$ to be subsequently dehydrated to rozenite $\left(\mathrm{Fe}\left(\mathrm{SO}_{4}\right) \cdot 4\left(\mathrm{H}_{2} \mathrm{O}\right)\right)$ or szomolnokite $\left(\mathrm{Fe}\left(\mathrm{SO}_{4}\right) \cdot\left(\mathrm{H}_{2} \mathrm{O}\right)\right)$ (Lottermoser, 2010). Furthermore, $\mathrm{Fe}^{2+}$ sulfates will oxidize to $\mathrm{Fe}^{2+}-\mathrm{Fe}^{3+}$ sulfate salts and then $\mathrm{Fe}^{3+}$ sulfate salts (Lottermoser, 2010c; Jambor et al., 2000).

Elements that form oxy-anions in water such as $\mathrm{As}, \mathrm{Se}, \mathrm{Sb}, \mathrm{Mo}, \mathrm{V}, \mathrm{W}$, are relatively mobile under neutral pH conditions (Lottermoser, 2010b). This implies that lime addition may not be enough to control the mobility of certain elements. Minerals whose solubilities are likely to control metal concentrations in mine waters are listed in Table 2-2. The list is created from Nordstrom and Alpers (1999) out of modeling experience and is meant as a guide. 
Table 2-2 Minerals whose solubilities are likely to control metal concentrations in mine waters (Nordstrom and Alpers, 1999).

\begin{tabular}{ll}
\hline Solubility equilibrium likely & Solubility equilibrium possible \\
\hline alunogen & alunite \\
anglesite & ankerite \\
basaluminite & antlerite \\
calcite & atacamite, paratacamite \\
cerussite & azurite \\
chalcanthite & bronchantite \\
epsomite & chrysocolla \\
ferrihydrite & goethite \\
gibbsite & hemimorphite \\
goslarite & hematite \\
gypsum & hydrozincite \\
halotrichite & jarosite \\
manganese oxides & kaolinite \\
melanterite & kutnohorite \\
otavite & malachite \\
rhodochrosite & natroalunite \\
schwertmannite & natrojarosite \\
scorodite & plumbojarosite \\
siderite & \\
silica & \\
smithsonite & \\
witherite & \\
\hline
\end{tabular}

\subsection{Effects of climate on sulfates}

The presence of soluble secondary minerals is directly influenced by climate (Jambor et al., 2000). For example, in humid conditions, soluble sulfate minerals may not accumulate. Dissolution of formed sulfates increases significantly during storm runoff, thereby increasing the concentrations of dissolved metals and sulfate (Jambor et al., 2000). The dissolutions of sulfates give a rapid geochemical response following the first storm of the wet season (Jambor et al., 2000; Keith et al., 1998; Keith et al., 1999). Moreover, (Dagenhart, 1980) and (Alpers et al., 1992) attribute changes in metal and sulfate concentrations, as well as $\mathrm{Zn} / \mathrm{Cu}$ ratios through seasonal wet and dry cycles to the dissolution and reprecipitation of metal-sulfate salts. Nordstrom (2009) has studied the influence of climate change on 
ARD based on data collected from mines in the United States and internationally. In his research, the dynamic changes in concentrations are highlighted and are related to the dissolution of soluble salts and flushing out of waters that were previously concentrated by evaporation. A large increase in concentrations is during the first flush, the discharge following dry spells. An increased amount of droughts are associated with climate change, Hence, flushing of mine sites will cause larger sudden increase in concentrations that can deem deadly for the surrounding biosphere.

\subsection{Microbiological activity}

Although this project does not directly deal with microbial characterization, biogeochemical processes are of equal importance to ARD waters as they directly or indirectly impact the chemistry of ARD waters. Such processes can occur in surface and underground waters (Lottermoser, 2010). ARD waters cannot support normal aquatic biota and the diversity of plants is limited; however, these waters display ubiquitous microorganisms (Archaea, Bacteria, Eukarya).

Specifically, extremophiles thrive in these acidic conditions. A case study by Ariza (1998) identifies over 1300 microorganisms in the acidic waters of the Rio Tinto in Spain. These microorganisms are able to survive and thrive because they can tolerate high concentrations of dissolved metals and metalloids, and they use the energy from chemical oxidation reactions for growth (Lottermoser, 2010). These microbes can remove metals and metalloids through adsorption and precipitation processes. The bacterium Acidithiobacillus ferrooxidans oxidizes $\mathrm{Fe}^{2+}$, which allows the precipitation of iron as iron oxides and hydroxides (Lottermoser, 2010; Ferris et al., 1989).

\subsection{Environmental geology of HS epithermal deposits}

Hs epithermal deposits are acid generating and contains a high potential for the release of potentially toxic elements. Pathfinder elements associated with this type of deposit include $\mathrm{As}, \mathrm{Sb}, \mathrm{Bi}, \mathrm{Hg}$, $\mathrm{Te}, \mathrm{Sn}, \mathrm{Pb}, \mathrm{Mo}$ and $\mathrm{Se}$, which are all considered potentially hazardous as dissolved elements in mine 
drainage (Hedenquist et al., 1994). The geological, mineralogical and geochemical characteristics described in the previous chapter influence the environmental behavior of elements and altered rocks. Secondary precipitates such as chalcanthite, jarosite, scorodite, Fe-sulfate salts, halotrichite, melanterite and szomolnokite have also been documented at this type of deposits (Bowell et al., 2000).

The high acid generating capacity of this type of deposit is a reflection of its high sulfide content and low amount of carbonates. The minimal amount of neutralizing potential is only observed in the peripheral zones of the deposit, where propylitic alteration, or where post-deposit carbonate overprint has been created (Bowell et al., 2000).

\subsection{Previous geochemical characterization at mines}

\subsubsection{Pierina}

Previous geochemical characterization work at this mine site was conducted by Klohn Crippen Berger in 2012. It has been noted that contact waters pre-treatment are described as a Ca-Fe-Al-H-SO system and most parameters are above Peruvian water quality guidelines. Studies of temporal variations demonstrate that acidity at monitoring stations are increased during the wet season as a result of dissolution and flushing of secondary acidic minerals. Secondary minerals identified in this study include alunite $\left(\mathrm{KAl}_{3}\left(\mathrm{SO}_{4}\right)_{2}(\mathrm{OH})_{6}\right)$, calcite $\left(\mathrm{Ca}\left(\mathrm{CO}_{3}\right)\right)$, gypsum $\left(\mathrm{Ca}\left(\mathrm{SO}_{4}\right)\right)$, chalcanthite $\left(\mathrm{Cu}\left(\mathrm{SO}_{4}\right) \cdot 5\left(\mathrm{H}_{2} \mathrm{O}\right)\right)$, paracoquimbite $\quad\left(\mathrm{Fe}_{2}^{3+}\left(\mathrm{SO}_{4}\right)_{3} \cdot 9\left(\mathrm{H}_{2} \mathrm{O}\right)\right), \quad$ coquimbite $\quad\left(\mathrm{Fe}^{3+}{ }_{2}\left(\mathrm{SO}_{4}\right)_{3} \cdot 9\left(\mathrm{H}_{2} \mathrm{O}\right)\right)$, zincocopiapite $\left(\mathrm{ZnFe}_{4}\left(\mathrm{SO}_{4}\right)_{6}(\mathrm{OH})_{2} \cdot 18\left(\mathrm{H}_{2} \mathrm{O}\right)\right)$, brochantite $\left(\mathrm{Cu}_{4}\left(\mathrm{SO}_{4}\right)(\mathrm{OH})_{6}\right)$, antlerite $\left(\mathrm{Cu}_{3}\left(\mathrm{SO}_{4}\right)(\mathrm{OH})_{4}\right)$ and posnjakite $\left(\mathrm{Cu}_{4}\left(\mathrm{SO}_{4}\right)(\mathrm{OH})_{6} \cdot\left(\mathrm{H}_{2} \mathrm{O}\right)\right)$. With the identification of these minerals, assuming ideal mineral lattice, it was shown that $\mathrm{K}, \mathrm{Al}, \mathrm{SO}_{4}, \mathrm{Ca}, \mathrm{C}, \mathrm{Cu}, \mathrm{Fe}$ and $\mathrm{Zn}$ are attenuated by secondary mineral precipitation. Authors claim that $\mathrm{Cu}, \mathrm{Co}, \mathrm{Mn}, \mathrm{S}, \mathrm{Al}, \mathrm{Si}, \mathrm{Na}, \mathrm{Pb}$ and $\mathrm{Mn}$ can also become attenuated as a result of substitution or sorption. 


\subsubsection{Lagunas Norte}

Roscoe Postle Associates Inc. has conducted extensive geological research on the Lagunas Norte Mine (Evans et al., 2012). The main goal of the report was to support public disclosure of the mineral resource and mineral estimates at the Lagunas Norte project. This document also touches on the environmental considerations taken at the mine site, stating that "the environmental and social practices at Lagunas Norte appear to be very effective"(Evans et al., 2012). Water monitoring is conducted at 31 points throughout the mine. Although geochemical characterization of primary minerals has been conducted (Cerpa et al., 2013; Lacroix, 2012; Montgomery, 2012), no previous research is piloted on the geochemical characterization of waters or the secondary precipitates observed on site. Montgomery (2012) does state that approximately $85 \%$ of this deposit has been oxidized, and that the Au is hosted in goethite, hematite, and jarosite.

\subsubsection{El Indio}

The geology, genesis and tectonic settings of the El Indio belt and deposit have been extensively studied (Back and Walford, 1996; Oyarzun et al., 2007, 2004; Jannas et al., 1990; Bissig et al., 2003; Heberlein, 2008; Kerrich et al., 2005; Martin et al., 1999); however, there is a lack of research with regards to the secondary minerals that have formed and water chemistry. Szomolnokite, gypsum, anglesite $\left(\mathrm{Pb}\left(\mathrm{SO}_{4}\right)\right)$, and barite $\left(\mathrm{Ba}\left(\mathrm{SO}_{4}\right)\right)$ have been previously identified as post-ore minerals and possibly secondary mineral at localities along the El Indio mineralization belt (Chouinard et al., 2005).

\subsection{Synchrotron micro-analysis}

No samples collected from Lagunas Norte, Pierina or El Indio have previously been analyzed with synchrotron techniques. As described by Jamieson et al. (2011), synchrotron microanalysis is a powerful diagnostic tool that can be used to characterize metal-bearing particles in mine tailings, soils, and even lake sediments. Specifically, combined experiments of X-ray fluorescence and diffraction, as well as 
absorption that use a microfocused beam lead to a detailed understanding of elemental concentration, crystal structure, and oxidation state of particles (Jamieson et al., 2011). Synchrotron microanalysis is not a readily available technique, therefore, not much research focusing on secondary sulfates use this tool. The crystal chemistry of goethite from a saprolite formation has been measured and analyzed by fluorescence-yielding extended X-ray absorption fine structure (EXAFS) spectroscopy with use of the European Synchrotron Radiation Facility (ESRF) (Manceau et al., 2000). Synchrotron XRD patterns of ferric sulfates were collected by Majzlan et al. (2006) for their study on the thermodynamic properties and crystal structure refinement of minerals ferricopiapite, coquimbite, rhomboclase and $\mathrm{Fe}_{2}\left(\mathrm{SO}_{4}\right)_{3} \cdot 5\left(\mathrm{H}_{2} \mathrm{O}\right)$. This research used synthetic material for all the compounds with the exception of coquimbite, which was a natural specimen.

\subsection{Hypotheses}

The hypotheses of this research are based on the literature review:

1- Minerals common in ARD such as Fe and Al oxides and oxyhydroxides, and metal sulfates will be prevalent at these sites because they are influenced by the chemical compositions of the effluent from HS epithermal deposits which tend to be enriched in sulfate and metals.

2- Trace elements will be partly attenuated by minerals where they form a major constituent and in association with Fe and Al oxides.

3- The expected complexity of these samples may influence the ability to associate the trace elements to the secondary minerals.

4- Because the minerals and waters are not always in direct contact with one another, a relationship with regards to specific chemistry is not expected. Field observations will be used to evaluate whether the water and minerals sampled are likely to be in equilibrium and this will be tested using speciation modelling. 
5- Using various analytical techniques is expected to be important because previous studies have suggested that characterization of secondary precipitates requires techniques that provide information at various scales will be used to reconfirm the occurrences of specific minerals at various scales.

6- If Barrick Gold Corporation recovers a substantial amount of metals from the effluent, then they will be able to offset water treatment costs. Elemental concentrations, flow rates, as well as recovery and treatment costs will be considered to test this hypothesis. 


\section{Chapter 3 \\ Sampling and analytical methods}

\subsection{Waters}

\subsubsection{Sampling methods}

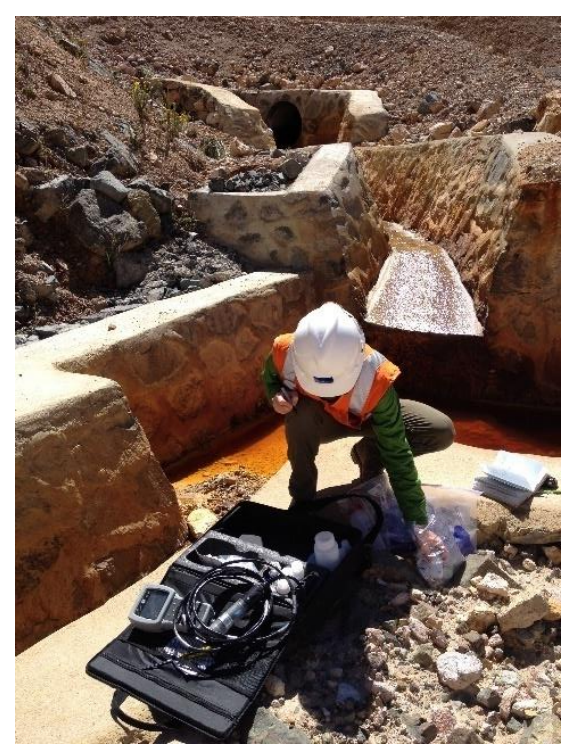

Figure 3-1: Sampling and water analysis at Lagunas Norte

Sample locations were chosen based on the availability of coexisting drainage waters, secondary precipitates and biofilm, and ease of field accessibility. With one exception, the sites were upstream of treatment points. Prior to field work and sample collection, the YSI 556 MPS Multi-Probe Field Meter was calibrated for all the field variables measured. Surface waters were collected into 1 liter bottles that were rinsed with the sample 3 times prior to collection to avoid contaminants. Temperature, $\mathrm{pH}$, Eh, dissolved oxygen (DO) and conductivity were measured immediately after collection with the YSI 556 MPS Multi-Probe Field Meter. Calculated pe used in modeling was determined from measured ORP recorded in the field. These waters were filtered with $0.45 \mu \mathrm{m}$ syringe filters in the field and then divided into aliquots for cations, anions, Fe speciation, sulfate content, and alkalinity. Additional unfiltered and acidified aliquots were collected at Pierina and Lagunas Norte to determine the amount of suspended material in the samples. Finally, two blanks were created at each mine site. The first, an acid blank, where $\mathrm{HNO}_{3}$ was added to deionized water. The second was a sample blank, where the deionized water was filtered prior to $1 \% \mathrm{HNO}_{3}$ acidification. The samples collected for the purpose of metal analyses were acidified to $1 \%$ with $8 \mathrm{~N} \mathrm{HNO}_{3}$. Fe speciation and sulfate content were determined by spectrometry with a $\mathrm{HACH} \mathrm{DR} / 2400$, within 12 hours of collecting the samples. Table 3-1lists the types of water samples that were collected from all mine sites, where UA is 
unfiltered and acidified, FA is filtered to $0.45 \mu \mathrm{m}$ and acidified, FU is filtered and unacidified and FFA is ultrafiltered to $0.01 \mu \mathrm{m}$.

\subsubsection{El Indio}

The initial sampling strategy was to target sites with low $\mathrm{pH}$ and high concentrations of dissolved metals and sites that are representative of mine drainage. Target sampling locations were primarily chosen based on field accessibility, flow of water, and anticipated orders of magnitude of exceedances of elements of concern, based on previous data. These sites were analyzed from the furthest upstream location (IN-23) to the furthest downstream location (IN-13), so as to identify change in water conditions and quality (pH, TDS, ORP) (Figure 3-3, Figure 3-4).

\subsubsection{Lagunas Norte}

Seven sites were visited for sampling and included LN-DAR-1, LN-SP-3 (twice), LN-DW-B-11, ARD water treatment plant, LN-PW-1, LN-BP, LN-PW-2 and LN-VWD. These sites were chosen because the waters are representative of mine drainage (Figure 3-5, Figure 3-6). Some of these locations have long data sets collected by Barrick Gold Corporation for comparison and most are in contact with secondary precipitates.

\subsubsection{Pierina}

The sites visited include P-WRD and P-ARD-17, the pit dewatering station (P-PD) and pit runoff in the Emilio Cocha pond (P-EC). YSI measurements were taken at various streams that provide input to these ponds with the goal of observing different properties of the waters and effects on the geochemistry of the pond. These sampling points were chosen based on being representative of mine drainage and pre-existing data sets collected from Barrick Gold Corporation, required water flow and field accessibility. A description of the samples taken at the 3 mines is provided in Table 3-1, the sampling locations are specified in Appendix A. 
Table 3-1: Water sampling locations, description and elevation (m).

\begin{tabular}{|c|c|c|c|}
\hline & Sample no. & Description & Elevation (m) \\
\hline \multirow{6}{*}{ 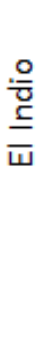 } & IN-23 & Natural ARD upstream of mine tailings/stream & 4100 \\
\hline & IN-28 & San Pablo closed tunnel downstream from tailing & 3650 \\
\hline & IN-RMATR & Upstream from settling pond & 3550 \\
\hline & IN-2 & Downstream from settling pond & 3250 \\
\hline & IN-13 & Downstream from settling pond & 2080 \\
\hline & LN-DAR-1 & $\begin{array}{l}\text { Confluence of surface and understrain acid } \\
\text { rocks }\end{array}$ & 4200 \\
\hline \multirow{7}{*}{ 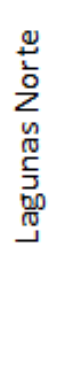 } & LN-DW-B-11 & Pit dewatering station & 3903 \\
\hline & LN-SP3-W1 & Settling pond & 4007 \\
\hline & LN-SP3-W2 & Settling pond second sample. & 4007 \\
\hline & LN-PW-1 & Pit wall (no ARD) & 3683 \\
\hline & LN-BP & Blessed pond, bottom of the open pit & 3957 \\
\hline & LN-PW2 & Pit wall (almost pH neutral) & 3926 \\
\hline & LN-VWD & $\begin{array}{l}\text { Waste rock leachate before collection pond } \\
\text { (Vizchaz pond 1) for treatment }\end{array}$ & 3951 \\
\hline \multirow{6}{*}{$\stackrel{\frac{\pi}{2}}{\frac{2}{2}}$} & P-WRD & Waste rock drainage & 4104 \\
\hline & P-ARD-17 & closed portal of old mine & 3867 \\
\hline & P-PD & Pit dewatering station & 3842 \\
\hline & P-PW1 & Pit wall 1 & 3847 \\
\hline & P-PW2 & Pit wall 2 & 3851 \\
\hline & P-EC & $\begin{array}{l}\text { Bacrock stream draining wetland going into } \\
\text { mine pit (Emilio Cocha) }\end{array}$ & 3813 \\
\hline
\end{tabular}

\subsubsection{Ultrafiltration}

Ultrafiltration to $0.01 \mu \mathrm{m}$ was conducted on all 7 samples from Lagunas Norte and all 4 samples from Pierina to determine how much colloidal material was present in the samples. The ultrafiltration technique was used to collect colloidal particles present in solution. Initially, tweezers and the ultrafiltration cell were cleaned with dilute $\mathrm{HCl}(1 \mathrm{~N})$ to get rid of any trace metals. These were then rinsed with deionized water and the filter was added, shiny side up, ensuring that no creases were created on the surface. Finally, the " $\mathrm{O}$ " ring was placed holding the polycarbonate filter to the apparatus (Figure 3-2). The top-most, tube-like piece was then screwed on by applying pressure. Once the setup was complete, deionized water was filtered through the unit. $\mathrm{N}_{2}$ gas at 30 psi was used to increase pressure and allow 
the solution to readily pass through the filter. With all the deionized water passed through, a separate receptacle was placed to capture the filtrate. Finally, filtrates from Lagunas Norte and Pierina mines were forced through a polycarbonate membrane with pore sizes of $0.01 \mu \mathrm{m}$, separating colloids from dissolved elements and solution. Ultrafiltration was not conducted at El Indio due to unavailability of $\mathrm{N}_{2}$ gas. It is assumed that $0.01 \mu \mathrm{m}$ filtrate is dissolved since these are the smallest available membranes. The full procedure can take anywhere between 1-3 hours per sample.

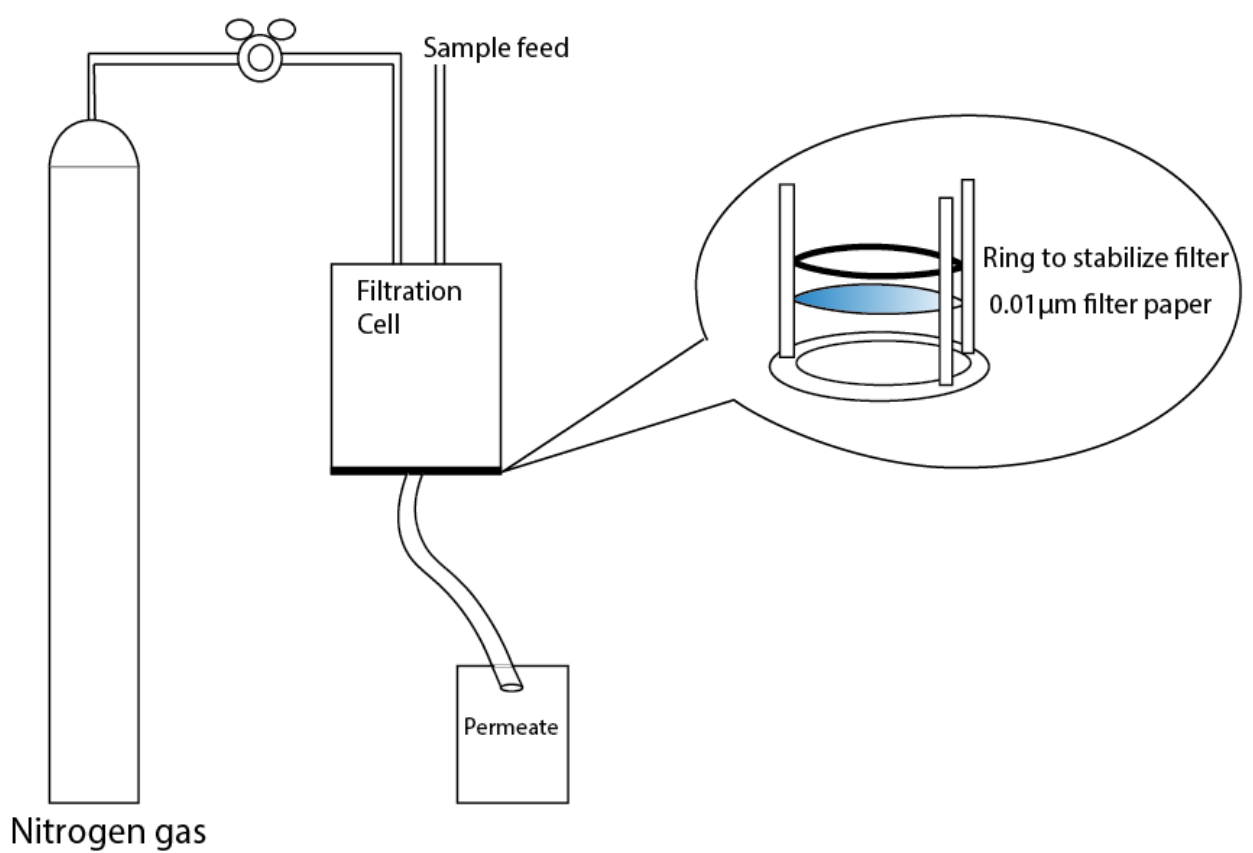

Figure 3-2 A schematic representation of the ultrafiltration method. A $0.01 \mu \mathrm{m}$ filter paper was placed in the filtration cell and was stabilized with an " $O$ " ring placed on top.

\subsubsection{Laboratory analyses}

Water analysis for dissolved metals and anions was conducted at the Analytical Services Unit of Queen's University. Metals were measured by inductively coupled plasma- mass spectrophotometry (ICPMS) for 60 elements (Al, Ag, As, B, Ba, Be, Ca, Cd, Ce, Co, Cr, Cs, Cu, Dy, Er, Eu, Fe, Ga, Gd, Ge, Hf, Ho, Ir, K, La, Li, Lu, Mg, Mn, Mo, Na, Nb, Nd, Ni, P, Pb, Pd, Pr, Pt, Rb, Rh, Re, Ru, S, Sb, Se, Sm, Sn, Sr, Ta, Tb, Te Th, Ti, Tl, U, V, W, Y, Yb, Zn, Zr) and by inductively coupled plasma optical emission spectroscopy(Varian, 
AX-Vista Pro CCD Simultaneous ICP-OES) for 30elements (Ag, Al, As, B, Ba, Be, Ca, Cd, Co, Cr, Cu, Fe, K, Mg, $\mathrm{Mn}, \mathrm{Mo}, \mathrm{Na}, \mathrm{Ni}, \mathrm{P}, \mathrm{Pb}, \mathrm{S}, \mathrm{Sb}, \mathrm{Ce}, \mathrm{Sn}, \mathrm{Sr}, \mathrm{Ti}, \mathrm{tl}, \mathrm{U}, \mathrm{V}, \mathrm{Zn})$. Determination of anions $\left(\mathrm{SO}_{4}{ }^{2-}, \mathrm{Cl}^{-}, \mathrm{F}^{-}, \mathrm{NO}_{3}{ }^{-}, \mathrm{NO}_{2}{ }^{-}\right)$ was conducted by ion chromatography.

\subsubsection{PHREEQC}

Saturation indices for minerals were calculated for these waters using PHREEQC 3 software (Parkuhurst \& Appelo, 2013). This geochemical modeling program designed and distributed by the US Geological Survey calculates saturation indices using the formula: $\mathrm{SI}=\log _{10}\left(\mathrm{IAP} / \mathrm{K}_{\mathrm{T}}\right)$ where IAP represents the activity product of the ions that are produced by the dissolution of the mineral and $\mathrm{K}_{\mathrm{T}}$ is the equilibrium constant (Wanty et al., 1999). The ICP-MS analyses for both $0.45 \mu \mathrm{m}$ and $0.01 \mu \mathrm{m}$ filtrates were entered into PHREEQC to determine the phases that are most likely supersaturated and speciation of elements. PHREEQC input included 25 elements $(\mathrm{O}, \mathrm{F}, \mathrm{Cl}, \mathrm{N}(+3), \mathrm{N}(+5), \mathrm{S}(6), \mathrm{Al}, \mathrm{As}, \mathrm{Ba}, \mathrm{B}, \mathrm{Cd}, \mathrm{Ca}, \mathrm{Cu}, \mathrm{Fe}$, $\mathrm{Pb}, \mathrm{Li}, \mathrm{Mn}, \mathrm{Ni}, \mathrm{K}, \mathrm{Rb}, \mathrm{Na}, \mathrm{Sr}, \mathrm{U}, \mathrm{Zn})$, as well as temperature, pe and $\mathrm{pH}$. Hence, 38 elements that were analyzed by ICP-MS and ion chromatography were not included in the WATEQ4F database, and therefore not considered in SI and speciation analyses. Elements exceeding a SI of 0 have likely precipitated out of solution and should be found in XRD analysis of bulk samples. Because these calculations are approximations, minerals or species $>0 \mathrm{SI}$ can be considered as potentially saturated. These values were entered in $\mathrm{mg} / \mathrm{L}$ into the program.

Evaporation simulations were also conducted to understand the paragenetic sequence of secondary minerals and were accomplished by removing water from the chemical system in PHREEQC. In order to do so, water was specified as an irreversible reactant with a negative reaction coefficient in the

"reaction" keyword input (Parkuhurst \& Appelo, 2013). Specifically, this method was used to simulate the concentration of solutions by 20 -fold by removing $95 \%$ of the water. After the composition of the collected 
sample is defined, the amount of water, in moles, to be removed from the aqueous phase is specified. In order to concentrate the solution 20 -fold, 52.73 moles of water are removed.

\subsection{Secondary precipitates}

\subsubsection{Sampling methods}

Samples of secondary precipitates were carefully collected with a clean hand trowel and spatulas, wrapped in plastic film and placed in multiple self-sealed plastic bags with a low volume of air. This storage method was designed to create a micro-environment around the sample that would limit dehydration or deliquescence (Chou et al., 2013). Mineralogy at sites were spatially heterogeneous, as such, samples were collected based on obvious visual differences such as color and texture. Samples were kept chilled and were later sub-sampled and prepared for geochemical and mineralogical characterization. Figure 3-3, Figure 3-4, Figure 3-5, Figure 3-6, Figure 3-7 show sampled locations and images of secondary precipitates at El Indio, Lagunas Norte and Pierina. 

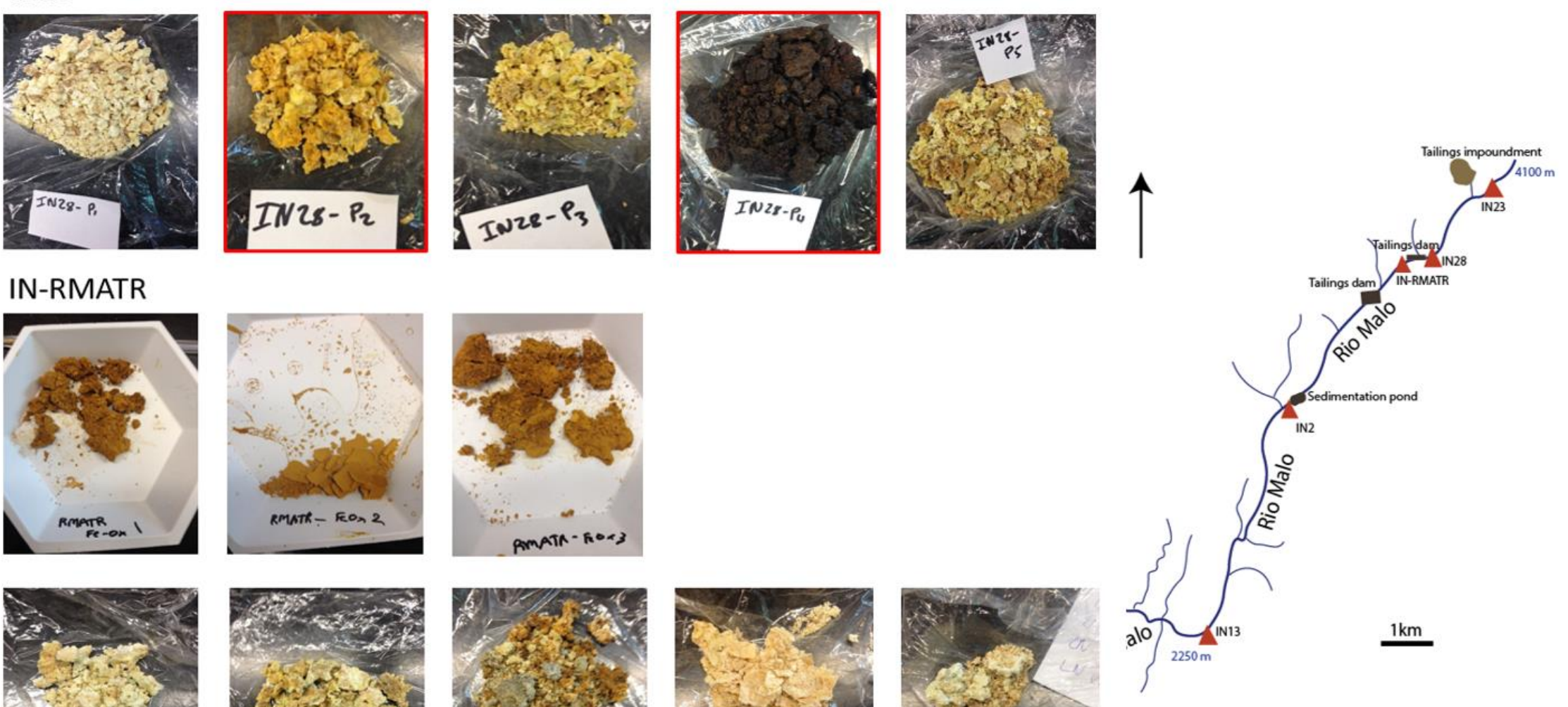

IN-RMATR
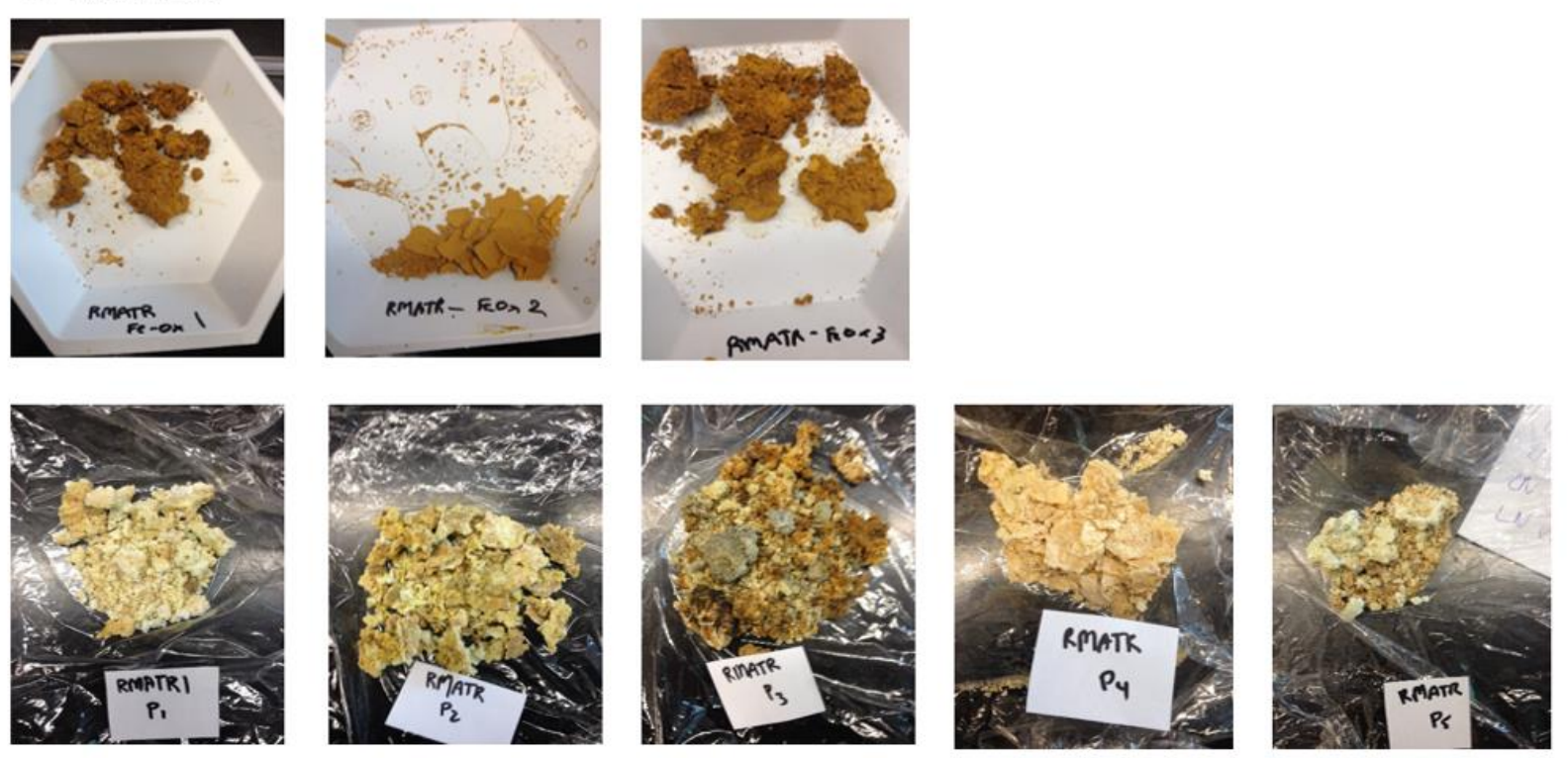

Figure 3-3 Images of secondary precipitates sampled at El Indio and map (IN-28, IN-RMATR, IN-2). IN28 is a sampling location from San Pablo, a closed tunnel downstream from tailings. IN-RMATR is found upstream from the settling pond and IN-2 is downstream from settling pond. Red boxes indicate samples that were made into thin sections. 

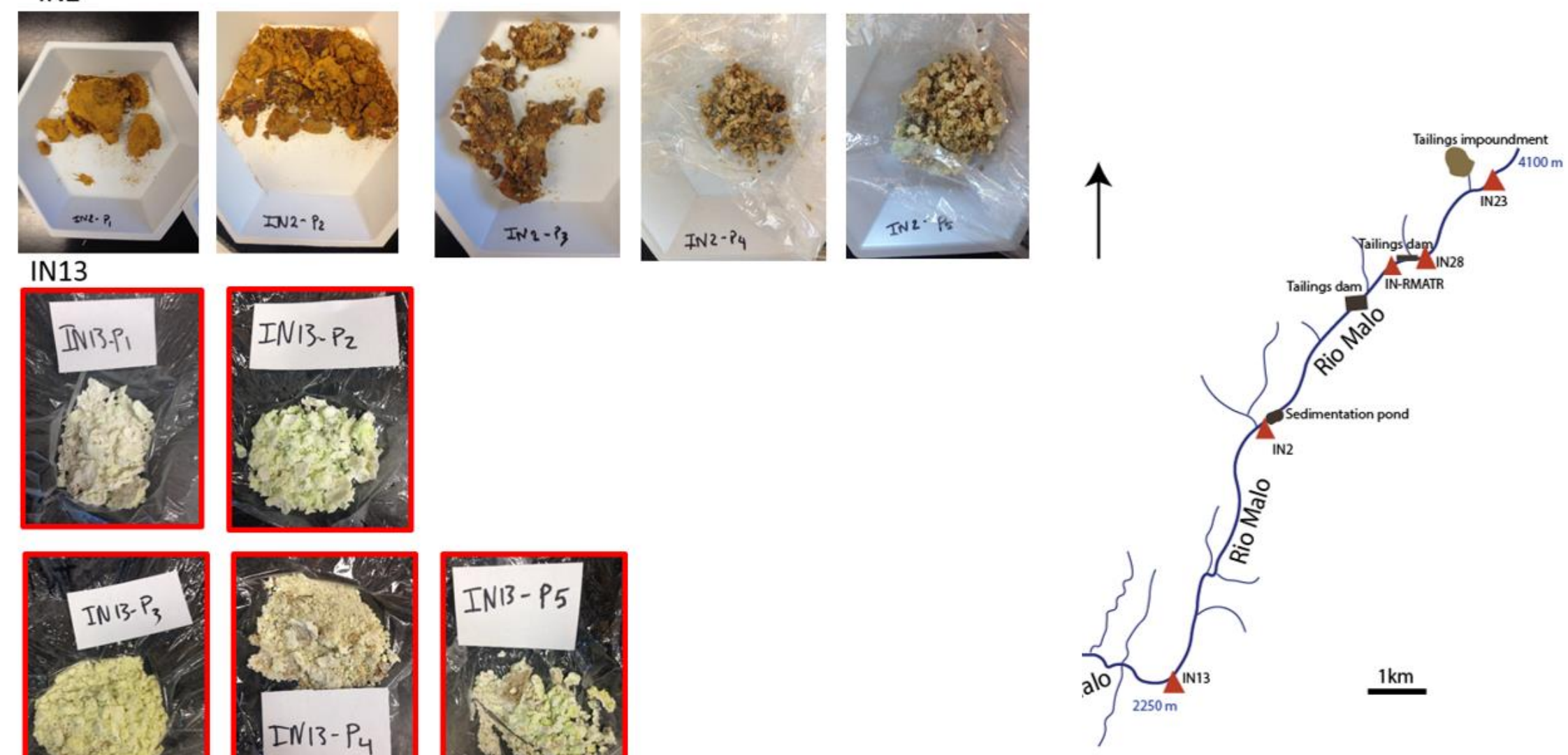

IN13
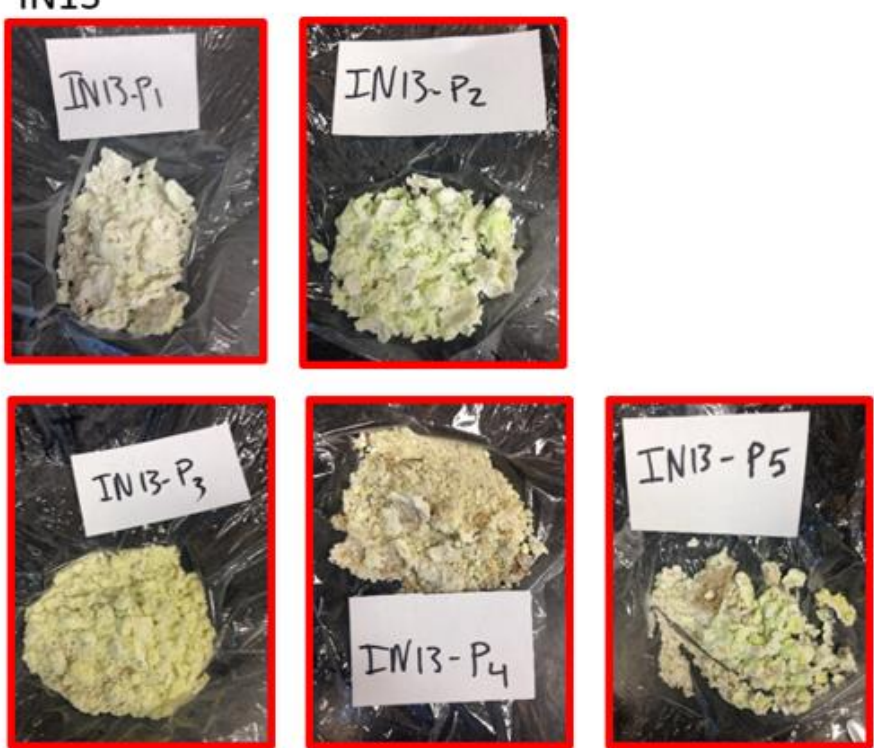

Figure 3-4 Images of secondary precipitates sampled at El Indio and map (IN-13, IN-2). Samples from IN-2 and IN-13 are collected downstream from the settling pond. Sample site IN-13 is located the furthest downstream. Red boxes indicate samples that were made into thin sections. 


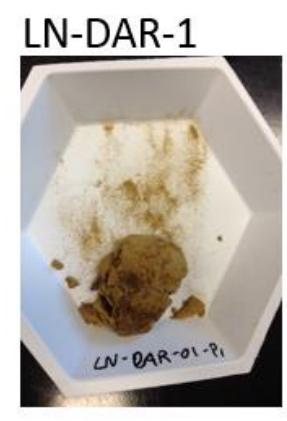

LN-PW1

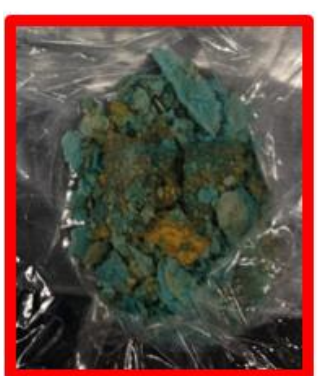

LN-VWD

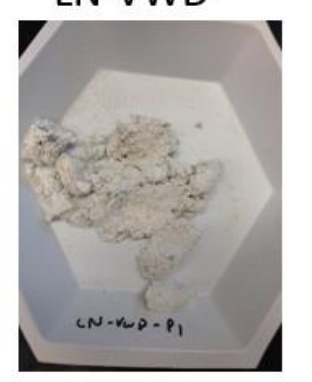

\section{LN-SP-3}

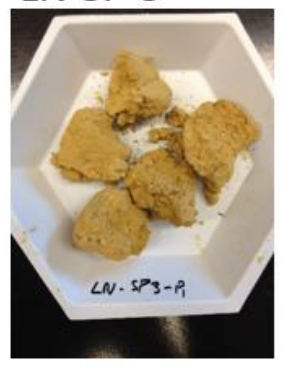

LN-PW2
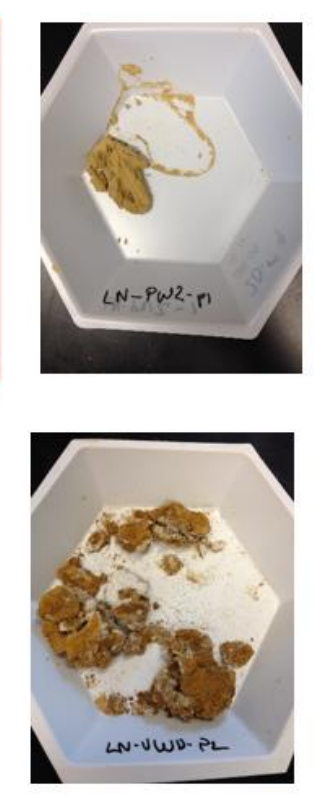

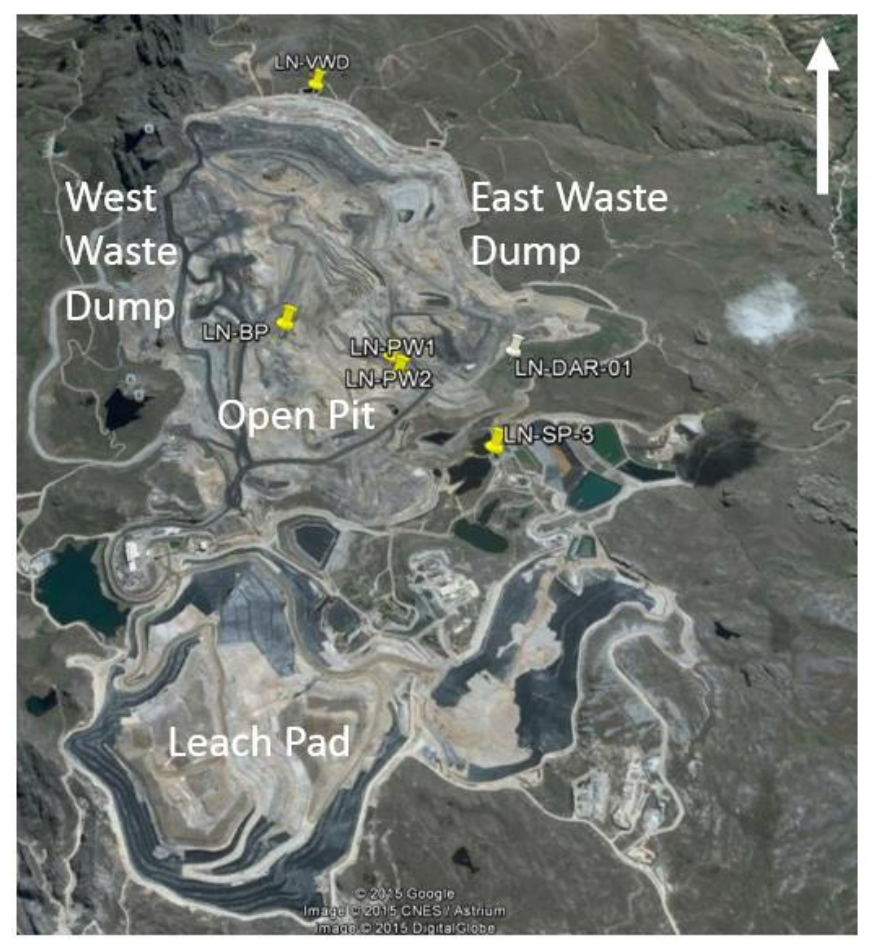

Figure 3-5 Images of secondary precipitates sampled at Lagunas Norte and map (LN-DAR-1, LN-SP-3, LN-PW1, LN-PW2, LN-VWD-P1, LN-VWD-P2).Sample site LN-DAR-1 is representative of the confluence of surface and underdrain ARD. LN-SP3 is a sampling site found at the settling pond, LN-PW1 and LN-PW2 are collected from the pit wall. LN-VWD is a sample from the waste rock leachate before the collection pond. The red box indicates samples that were made into thin sections. 


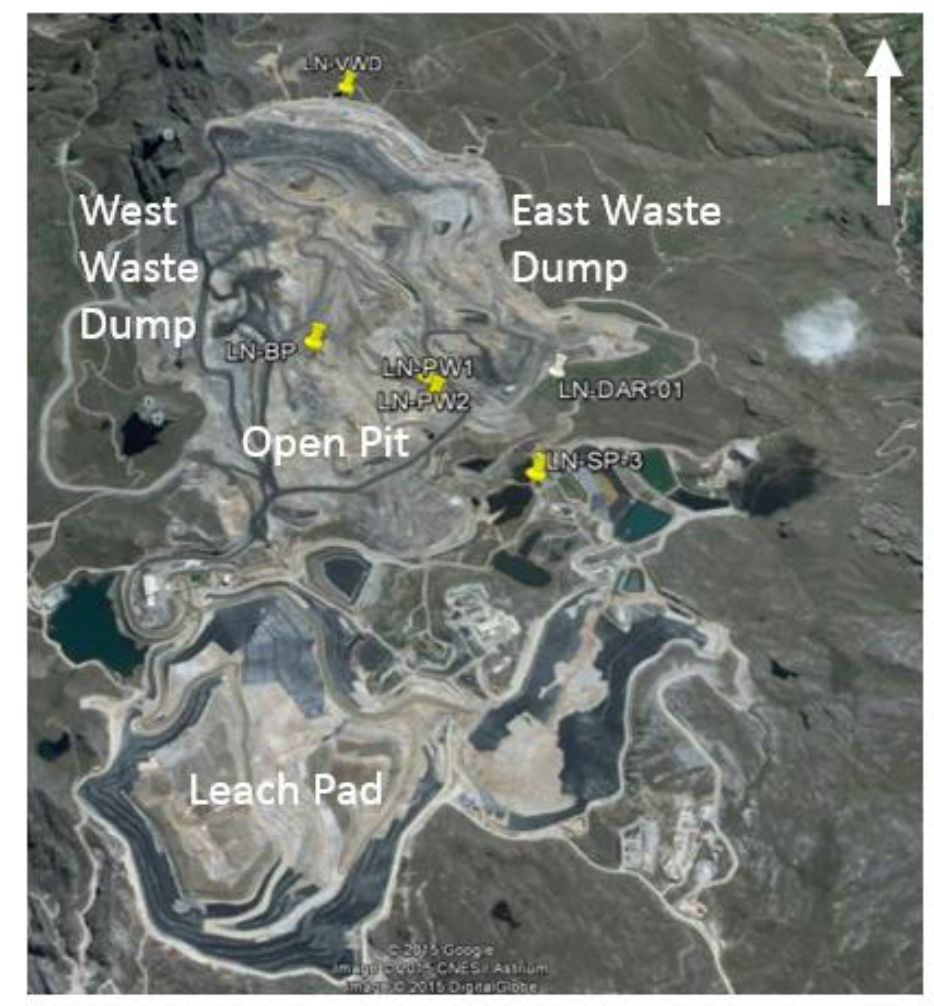

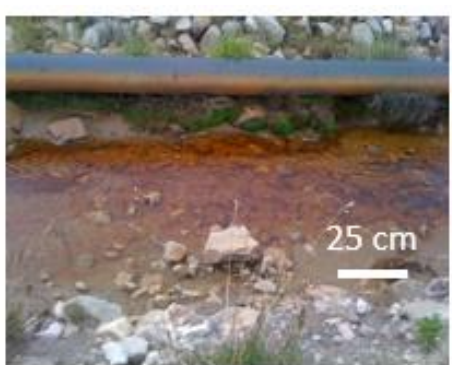

\section{LN-DAR-1}

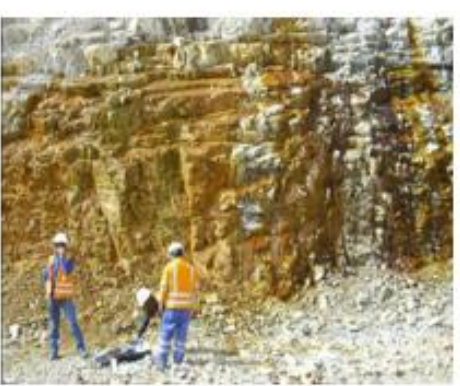

LN-PW2

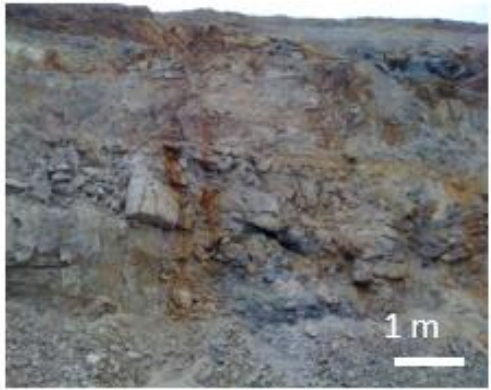

LN-PW1

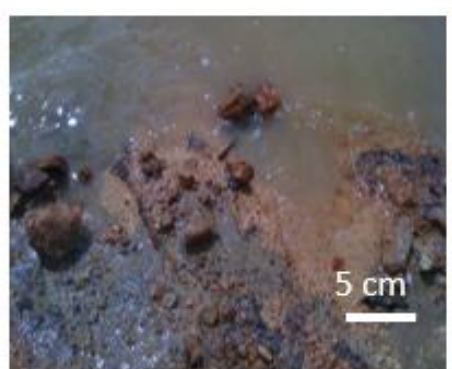

LN-SP-3

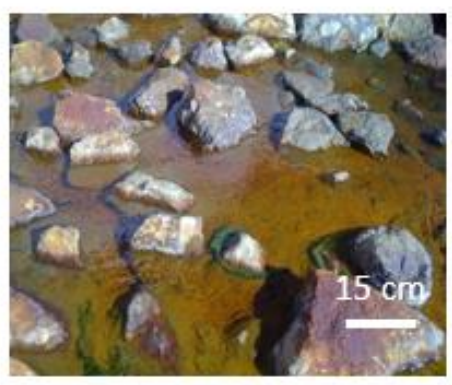

LN-VWD

Figure 3-6 Aerial image of Lagunas Norte (left) and solid and water sampling sites (right). LN-DAR-1 is representative of the confluence of surface and underdrain ARD. LN-SP3 is a sampling site found at the settling pond, LN-PW1 and LN-PW2 are collected from the pit wall. LN-VWD is a sample from the waste rock leachate before the collection pond. 


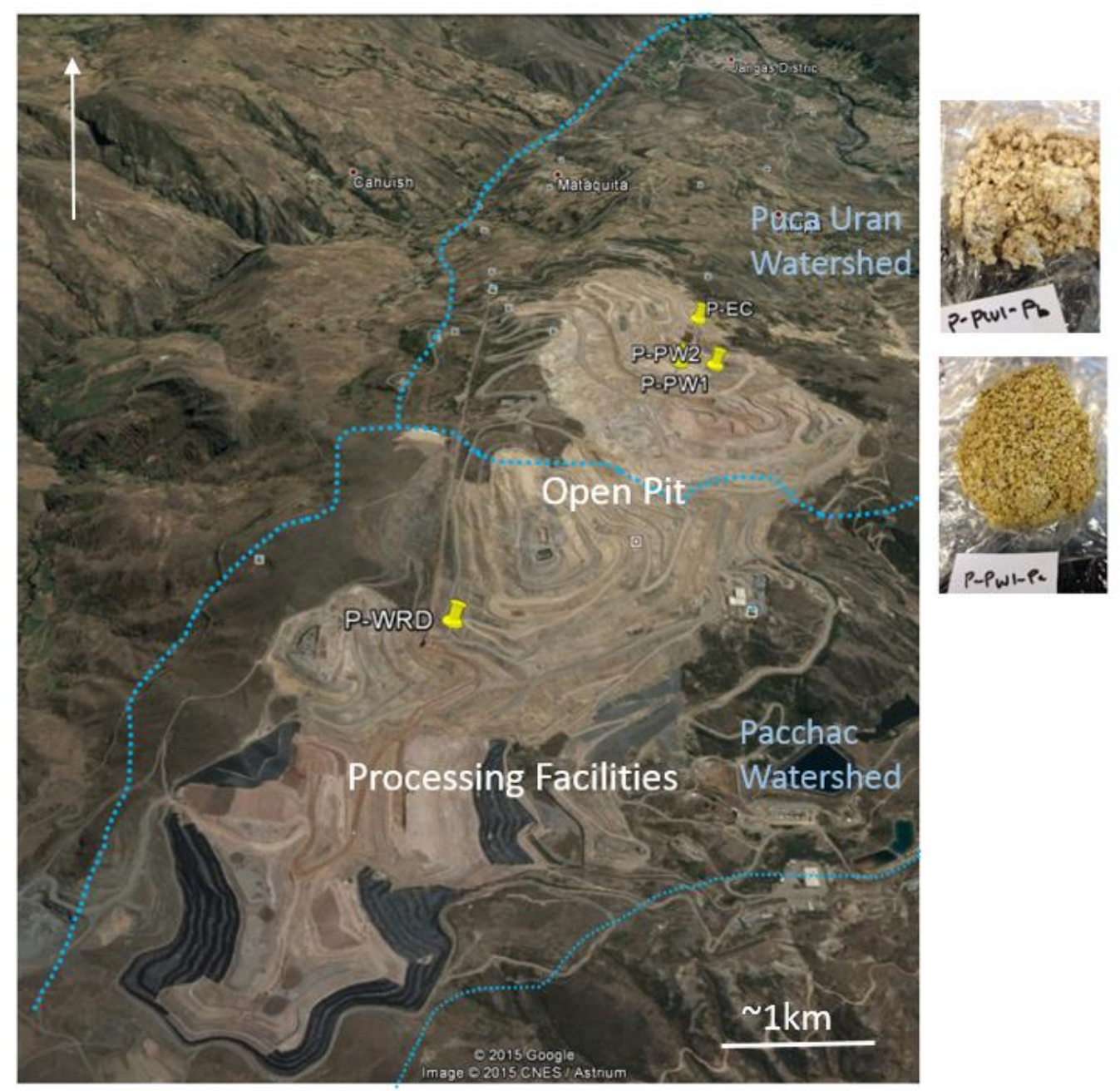

Figure 3-7 Images of secondary precipitates sampled at Pierina and map (P-WRD, P-EC, P-PW1, P-PW2). Secondary precipitates were only collected from sample site P-PW1, which is located along the pit wall. Sample site P-WRD is representative of waste rock drainage, P-EC is a sampling site along the Emilo Cocha pond, P-PD is a pit dewatering station and P-ARD-17 is located at the closed portal of the old mine. 


\subsubsection{Laboratory analyses}

Analysis of secondary precipitates for cations was conducted at the Analytical Services Unit of Queen's University. Samples were manually crushed, using a clean mortar and pestle. A total of $1.5 \mathrm{~g}$ or more of each sample was sent to Analytical Services, where $0.5 \mathrm{~g}$ were used per run, and $0.5 \mathrm{~g}$ for replicate. Metals were measured by inductively coupled plasma- mass spectrophotometry (ICP-MS) for 60 elements (Al, Ag, As, B, Ba, Be, Ca, Cd, Ce, Co, Cr, Cs, Cu, Dy, Er, Eu, Fe, Ga, Gd, Ge, Hf, Ho, Ir, K, La, Li, Lu, Mg, Mn, Mo, Na, Nb, Nd, Ni, P, Pb, Pd, Pr, Pt, Rb, Rh, Re, Ru, S, Sb, Se, Sm, Sn, Sr, Ta, Tb, Te, Th, Ti, TI, U, V, W, Y, $\mathrm{Yb}, \mathrm{Zn}, \mathrm{Zr}$ ) and by inductively coupled plasma optical emission spectroscopy(Varian, AX-Vista Pro CCD Simultaneous ICP-OES) for 31 elements (Ag, Al, As, B, Ba, Be, Ca, Cd, Co, Cr, Cu, Fe, K, Mg, Mn, Mo, Na, Ni, $\mathrm{P}, \mathrm{Pb}, \mathrm{S}, \mathrm{Sb}, \mathrm{Ce}, \mathrm{Si}, \mathrm{Sn}, \mathrm{Sr}, \mathrm{Ti}, \mathrm{Tl}, \mathrm{U}, \mathrm{V}, \mathrm{Zn}) . \mathrm{QA} / \mathrm{QC}$ of the analyzed samples is discussed in Appendix E: QAQC \& chemistry of .

\subsubsection{Thin section preparation}

A thin film of Vaseline was applied to the bottom of a $10 \mathrm{dr}$ vial. Secondary precipitates were then placed at the bottom of the vial with clean tweezers and were covered in Sealtronic epoxy made by System Three. These vials were covered and left to dry for 2 days. Vials with dried epoxy and sample were sent to Vancouver Petrographics to be made into thin sections. Thin sections were carefully separated from the glass slide using a razor blade.

\subsubsection{Statistical analyses}

Statistical analyses were performed using Spearman correlation matrices for bulk geochemistry results from ICP-OES analyses. Spearman rank correlation provides a distribution free measure of correlation between two variables (Bonett and Wright, 2000). This method is preferred over the Pearson correlation because it looks at the correlation between ranked values and not absolute values, and is therefore less influenced by outliers and non-normally distributed populations (Lehman, 2005). Elements 
that demonstrated a high percentage of values that are below their detection limit were not included in the correlation matrices since unknown values could not be correlated. These functions were conducted using Excel and ioGas ${ }^{\mathrm{TM}}$ (REFLEX $\left.{ }^{\circledR}\right)$.

\subsubsection{Environmental scanning electron microscopy (ESEM)}

Two types of samples were analyzed by ESEM: a) ultrafiltration filters b) mounted secondary precipitates (MSP). Ultrafiltration filters were mounted on carbon stubs and examined for colloids using the environmental scanning electron microscope FEI-MLA Quanta 650 FEG-ESEM at Queen's University. These stubs were carbon coated to enhance imaging quality and were examined under high vacuum conditions at $10 \mathrm{KeV}$ to image potential organic and inorganic colloids present and to prevent sample damage. Secondary precipitates were stuck on stubs using a modeling epoxy. These samples were carbon coated and examined under both high vacuum or low vacuum conditions depending on the amount of sample charging. The energy used on the secondary precipitates was $15 \mathrm{KV}$ and 10KV.

\subsubsection{Bulk X-ray diffraction (XRD)}

The major crystalline phases present in collected samples were identified by using X-ray diffraction methods (XRD) with the Philips X-Pert diffractometer at Queen's University. Samples were crushed using a clean mortar and pestle as sample preparation. Secondary precipitates from the El Indio, Lagunas Norte, and Pierina mine sites were analyzed and the mineralogical phases were identified using PANalytical X-Pert Highscore Mineral Identification software.

\subsubsection{Synchrotron micro-analysis}

Micro-scale characterization of lifted thin sections of secondary precipitates mounted on Kapton ${ }^{\circledR}$ taped slide holders was conducted at synchrotron beamline 13-IDE at the Advanced Photon Source (APS), Argonne National Laboratory in Argonne, IL. This specific beamline is an undulator-based, hard X-ray microprobe instrument that emphasizes the application of X-ray microbeam analytical techniques for 
research in geochemistry and environmental sciences (GSECARS, 2013). At the Sector 13-IDE beamline, analyses were conducted under micro-focused beam for $\mu \mathrm{XRD}$, and XRF mapping in August of 2014. This beamline has a spectral range from 2.4 to $28 \mathrm{KeV}$. The source of this beam is a $3.6 \mathrm{~cm}$ period undulator that is optimized to provide the abovementioned energy range. An X-ray energy of $17480 \mathrm{eV}$ was used, with an intensity and flux of $1572 \mathrm{e}+11 \mathrm{~Hz}$ and $0.0104 \mathrm{uA}$. The beam resolution can be smaller than $1 \mu \mathrm{m}$. This X-ray energy allows for the excitement of elements $\mathrm{K}$ - and L- edge emissions are below that of Yttrium. Beam spot size was approximately 1 by $2 \mu \mathrm{m}$, with $\mu$ XRF maps having a step (pixel) size of 3 to 25 $\mu \mathrm{m}$ and a dwell time of 20 milliseconds/pixel. Thin sections used were detached from the glass slide using a razor blade, and were mounted on Kapton ${ }^{\mathrm{TM}}$.

Micro-X-ray fluorescence mapping was performed to understand the general chemistry of the samples and hosts of metals. This mapping can analyze a large area of a sample for potential $\mu$ XRD samples. The $250 \mu$ XRD diffraction patterns were all calibrated with $\mathrm{Al}_{2} \mathrm{O}_{3}$ and lanthanum hexaboride standards, their backgrounds were corrected, and finally converted to 2-D spectra using Fit2D (Hammersley, 2004). Finally, macro-crystallinity bright spots were masked and the 1-D diffraction pattern was integrated in order to allow accurate identification of phases.

\section{Chapter 4 Results}

\subsection{Chemical characterization of waters}

\subsubsection{Bulk chemical analysis of waters}

Waters analyzed at El Indio, Lagunas Norte and Pierina are typical acid sulfate waters normally seen in acid mine drainage. Waters draining from HS deposits are highly acidic and can contain very high concentrations of a variety of elements that have been leached from alteration zones, wallrock and ore minerals (Plumlee et al., 1999). Major elements are defined in this study as $\geq 100 \mathrm{ppm}$, minor elements are $100 \mathrm{ppm}-10 \mathrm{ppm}$ and trace elements $<10 \mathrm{ppm}$. Major elements in waters sampled from El Indio include 
$\mathrm{Ca}$ and $\mathrm{SO}_{4}$, minor elements include $\mathrm{Na}>\mathrm{Mg}>\mathrm{Al}>\mathrm{Mn}>\mathrm{Cu}>\mathrm{Fe}>\mathrm{K}$, and trace elements are $\mathrm{Zn}>\mathrm{Sr}>\mathrm{Pb}>\mathrm{Co}>\mathrm{As}>\mathrm{Ni}>\mathrm{Cd}$. Differences in elemental concentrations are observed at Lagunas Norte where major elements consist of $\mathrm{SO}_{4}>\mathrm{Ca}>\mathrm{Fe}>\mathrm{Al}$, minor elements comprise $\mathrm{Mg}>\mathrm{Cu}>\mathrm{Zn}>\mathrm{Na}>\mathrm{Mn}$, and trace elements are $\mathrm{Sr}>\mathrm{K}>\mathrm{As}>\mathrm{Co}>\mathrm{Ni}>\mathrm{Pb}>\mathrm{Cd}$. Finally, $\mathrm{SO}_{4}>\mathrm{Fe}$ are the most concentrated elements at Pierina, with $\mathrm{Mn}>\mathrm{Mg}>\mathrm{Zn}>\mathrm{Cu}$ as minor elements and $\mathrm{K}>\mathrm{As}>\mathrm{Sr}>\mathrm{Co}>\mathrm{Pb}>\mathrm{Cd}>\mathrm{Ni}$ as trace elements. The concentrations of all elements are listed in Appendix F: QAQC water and site specific chemistry will be discussed in section

\subsection{2.}

Table 4-1 Chemical analysis of filtered and acidified samples from El Indio demonstrating concentrations of major and minor elements in $\mathrm{mg} / \mathrm{L}$.

\begin{tabular}{|c|c|c|c|c|c|c|c|c|c|c|}
\hline Sample & $\mathrm{pH}$ & $\mathrm{Ca}$ & $\mathrm{SO}_{4}$ & Al & $\mathrm{Cu}$ & Mg & Mn & K & $\mathrm{Fe}$ & $\mathrm{Na}$ \\
\hline Units & & $\mathrm{mg} / \mathrm{L}$ & $\mathrm{mg} / \mathrm{L}$ & $\mathrm{mg} / \mathrm{L}$ & $\mathrm{mg} / \mathrm{L}$ & $\mathrm{mg} / \mathrm{L}$ & $\mathrm{mg} / \mathrm{L}$ & $\mathrm{mg} / \mathrm{L}$ & $\mathrm{mg} / \mathrm{L}$ & $\mathrm{mg} / \mathrm{L}$ \\
\hline IN23-W & 6.7 & 80 & 870 & $<0.0050$ & $<0.0050$ & 12 & 0.0015 & 1.1 & $<0.05$ & 18 \\
\hline IN28-W & 4.4 & 160 & 67 & 15 & 28 & 32 & 3.1 & 12 & 23 & 69 \\
\hline IN-RMATR-W & 3.5 & 180 & 86 & 31 & 20 & 41 & 41 & 12 & 23 & 66 \\
\hline IN2-W & 3.4 & 200 & 1050 & 46 & 16 & 51 & 7.5 & 10 & 13 & 65 \\
\hline IN13-W & 4.3 & 250 & 995 & 24 & 8.5 & 62 & 5.2 & 15 & 3.6 & 180 \\
\hline
\end{tabular}

Table 4-2 Chemical analysis of filtered and acidified samples from El Indio demonstrating concentrations of trace elements in $\mu \mathrm{g} / \mathrm{L}$.

\begin{tabular}{ccccccccc}
\hline Sample & pH & As & Co & Ni & Sr & Pb & Cd & Zn \\
\hline Units & & $\mu \mathrm{g} / \mathrm{L}$ & $\mu \mathrm{g} / \mathrm{L}$ & $\mu \mathrm{g} / \mathrm{L}$ & $\mu \mathrm{g} / \mathrm{L}$ & $\mu \mathrm{g} / \mathrm{L}$ & $\mu \mathrm{g} / \mathrm{L}$ & $\mu \mathrm{g} / \mathrm{L}$ \\
IN23-W & 6.7 & 2.87 & $<0.050$ & $<1.0$ & 807 & $<2.0$ & $<0.030$ & $<10$ \\
IN28-W & 4.4 & 110 & 56 & 40 & 1000 & 450 & 9.1 & 1967 \\
IN-RMATR-W & 3.5 & 6.9 & 87 & 59 & 890 & 0.91 & 17 & 3800 \\
IN2-W & 3.4 & 2.4 & 110 & 77 & 843 & 1.0 & 19 & 4100 \\
IN13-W & 4.3 & 62 & 75 & 50 & 1100 & 0.33 & 11 & 2400 \\
\hline
\end{tabular}

Table 4-3 Chemical analysis of filtered and acidified samples from Lagunas Norte demonstrating concentrations of major and minor elements in $\mathrm{mg} / \mathrm{L}$.

\begin{tabular}{cccccccccc}
\hline Sample & $\mathbf{p H}$ & $\mathbf{C a}$ & $\mathbf{S O}_{\mathbf{4}}$ & $\mathbf{A l}$ & $\mathbf{C u}$ & $\mathbf{M g}$ & $\mathbf{M n}$ & $\mathbf{F e}$ & $\mathrm{Na}$ \\
\hline Units & & $\mathbf{m g} / \mathbf{L}$ & $\mathbf{m g} / \mathbf{L}$ & $\mathbf{m g} / \mathbf{L}$ & $\mathbf{m g} / \mathbf{L}$ & $\mathbf{m g} / \mathbf{L}$ & $\mathbf{m g} / \mathbf{L}$ & $\mathbf{m g} / \mathbf{L}$ & $\mathbf{m g} / \mathbf{L}$ \\
LN-SP3-W & 2.9 & 120 & 690 & 47 & 9.5 & 17 & 5.8 & 48 & 12 \\
LN-DW-B-11-W & 2.8 & 78 & 845 & 28 & 110 & 3.9 & 2.2 & 170 & 15 \\
LN-DAR-1-W & 2.6 & 400 & 5400 & 380 & 17 & 130 & 40 & 640 & 27 \\
LN-BP-W & 3 & 31 & 190 & 6.25 & 3.8 & 2.8 & 0.965 & 13 & 16 \\
LN-PW2-W & 6.2 & 150 & 310 & 0.059 & 0.0075 & 3.8 & 0.0060 & 0.050 & 27 \\
LN-VWD-W & 2.6 & 500 & 3600 & 200 & 22 & 74 & 32.5 & 495 & 49.5 \\
\hline
\end{tabular}


Table 4-4 Chemical analysis of filtered and acidified samples from Lagunas Norte demonstrating concentrations of trace elements in $\mu \mathrm{g} / \mathrm{L}$.

\begin{tabular}{cccccccccc}
\hline Sample & pH & As & Co & $\mathbf{N i}$ & $\mathbf{S r}$ & $\mathbf{P b}$ & $\mathbf{C d}$ & $\mathrm{Zn}$ & $\mathrm{K}$ \\
\hline Units & & $\mu \mathrm{g} / \mathrm{L}$ & $\boldsymbol{\mu g} / \mathrm{L}$ & $\boldsymbol{\mu g} / \mathrm{L}$ & $\mu \mathrm{g} / \mathrm{L}$ & $\mu \mathrm{g} / \mathrm{L}$ & $\mu \mathrm{g} / \mathrm{L}$ & $\mu \mathrm{g} / \mathrm{L}$ & $\mu \mathrm{g} / \mathrm{L}$ \\
LN-SP3-W & 2.9 & 10 & 150 & 140 & 610 & 30 & 34 & 2100 & 2400 \\
LN-DW-B-11-W & 2.8 & 1300 & 210 & 150 & 350 & 290 & 170 & 5100 & 1100 \\
LN-DAR-1-W & 2.6 & 920 & 933 & 870 & 2050 & 3.5 & 180 & 14000 & 1300 \\
LN-BP-W & 3 & 3.1 & 86 & 42 & 100 & 46 & 6.7 & 107 & 1700 \\
LN-PW2-W & 6.2 & 9.1 & 0.52 & 1.0 & 1000 & 0.23 & 0.16 & 10 & 377 \\
LN-VWD-W & 2.6 & 335 & 910 & 975 & 2950 & 6.8 & 130 & 7000 & 955 \\
\hline
\end{tabular}

Table 4-5 Chemical analysis of filtered and acidified samples from Pierina demonstrating concentrations of major and minor elements in $\mathrm{mg} / \mathrm{L}$.

\begin{tabular}{ccccccccccc}
\hline Sample & $\mathbf{p H}$ & $\mathrm{Ca}$ & $\mathrm{SO}_{4}$ & $\mathrm{Al}$ & $\mathrm{Cu}$ & $\mathrm{Mg}$ & $\mathrm{Mn}$ & $\mathrm{Zn}$ & $\mathrm{Fe}$ & $\mathrm{Na}$ \\
\hline Units & & $\mathrm{mg} / \mathrm{L}$ & $\mathrm{mg} / \mathrm{L}$ & $\mathrm{mg} / \mathrm{L}$ & $\mathrm{mg} / \mathrm{L}$ & $\mathrm{mg} / \mathrm{L}$ & $\mathrm{mg} / \mathrm{L}$ & $\mathrm{mg} / \mathrm{L}$ & $\mathrm{mg} / \mathrm{L}$ & $\mathrm{mg} / \mathrm{L}$ \\
P-ARD-17-W & 3.1 & 2.5 & 54 & 2.4 & 0.61 & 0.72 & 1.6 & 1.8 & 5.1 & 1.1 \\
P-WRD-W & 2.6 & 385 & 2750 & 120 & 37 & 47 & 140 & 37 & 470 & 12 \\
P-PD-W & 2.7 & 34 & 880 & 44 & 0.022 & 5.3 & 16 & 39 & 230 & 3.3 \\
P-EC-W & 2.8 & 0.36 & 1200 & 40 & 5.4 & 16 & 34 & 23 & 35 & 13 \\
\hline
\end{tabular}

Table 4-6 Chemical analysis of filtered and acidified samples from Pierina demonstrating concentrations of trace elements in $\mu \mathrm{g} / \mathrm{L}$.

\begin{tabular}{ccccccccc}
\hline Sample & $\mathrm{pH}$ & $\mathrm{As}$ & $\mathrm{Co}$ & $\mathbf{N i}$ & $\mathrm{Sr}$ & $\mathbf{P b}$ & $\mathrm{Cd}$ & $\mathrm{K}$ \\
\hline Units & & $\boldsymbol{\mu g} / \mathrm{L}$ & $\boldsymbol{\mu g} / \mathrm{L}$ & $\boldsymbol{\mu g} / \mathrm{L}$ & $\boldsymbol{\mu g} / \mathrm{L}$ & $\boldsymbol{\mu g} / \mathrm{L}$ & $\boldsymbol{\mu g} / \mathrm{L}$ & $\boldsymbol{\mu g} / \mathrm{L}$ \\
P-ARD-17-W & 3.1 & 33 & 3.4 & 2.4 & 655 & 5.0 & 2.1 & 1300 \\
P-WRD-W & 2.6 & 890 & 760 & 200 & 1300 & 16 & 310 & 1300 \\
P-PD-W & 2.7 & 1800 & 530 & 170 & 37 & 730 & 5.8 & 1300 \\
P-EC-W & 2.8 & 4.9 & 360 & 100 & 900 & 120 & 5.0 & 4800 \\
\hline
\end{tabular}

All surface waters collected were analyzed for 5 anions, $\mathrm{F}^{-}, \mathrm{Cl}^{-}, \mathrm{NO}_{2}{ }^{-}, \mathrm{NO}_{3}{ }^{-}, \mathrm{SO}_{4}{ }^{2-}$ in the $<0.45 \mu \mathrm{m}$ samples (results are shown in Appendix F: QAQC water). At El Indio, $\mathrm{NO}_{2}{ }^{-}$and $\mathrm{NO}_{3}{ }^{-}$were found to be below the instrumental detection limit of $2.0 \mathrm{mg} / \mathrm{L}$. At Lagunas Norte, $\mathrm{F}^{-}, \mathrm{Cl}^{-}$and $\mathrm{NO}_{2}{ }^{-}$are consistently found below their instrumental detection limits of $2.0 \mathrm{mg} / \mathrm{L}$. At Pierina all anions, except for $\mathrm{SO}_{4}{ }^{2-}$, are below their respective instrumental detection limits. Sulfate is consistently in greatest concentrations(followed by $\mathrm{F}, \mathrm{Cl}, \mathrm{NO}_{3}{ }^{-}$and $\mathrm{NO}_{2}{ }^{-}$respectively) and sulfate has concentrations greater than 100 times relative to the other anions $(870 \mathrm{mg} / \mathrm{L}$ to $1,100 \mathrm{mg} / \mathrm{L}$ at El Indio, $5,400 \mathrm{mg} / \mathrm{L}$ to $190 \mathrm{mg} / \mathrm{L}$ at Lagunas Norte and 3,600 $\mathrm{mg} / \mathrm{L}$ to $53 \mathrm{mg} / \mathrm{L}$ at Pierina). Pristine alpine waters are known to contain 10-20 mg/L of sulfate; however, 
the concentration in HS mine-drainage waters can be more than several thousand $\mathrm{mg} / \mathrm{L}$ (Ficklin and Mosier, 2000). Anion analysis also reveals highest $\mathrm{Cl}^{-}$and $\mathrm{F}^{-}$concentrations at El Indio and highest $\mathrm{SO}_{4}^{2-}$ and nitrate concentrations at Lagunas Norte. Low $\mathrm{pH}$ values present at all mine sites are indicative of open-system weathering of sulfide minerals and have an important effect on elemental mobility. Specifically, under these conditions, most trace elements will be mobilized rapidly.

Box and whisker diagrams were used to depict the analytical results (Figure 4-1, Figure 4-2, Figure 4-3, Figure 4-4, Figure 4-5, Figure 4-6).Water analysis diagrams demonstrate a variance in the chemical compositions of the different types of elements. 


\section{El Indio Water Analysis Results}

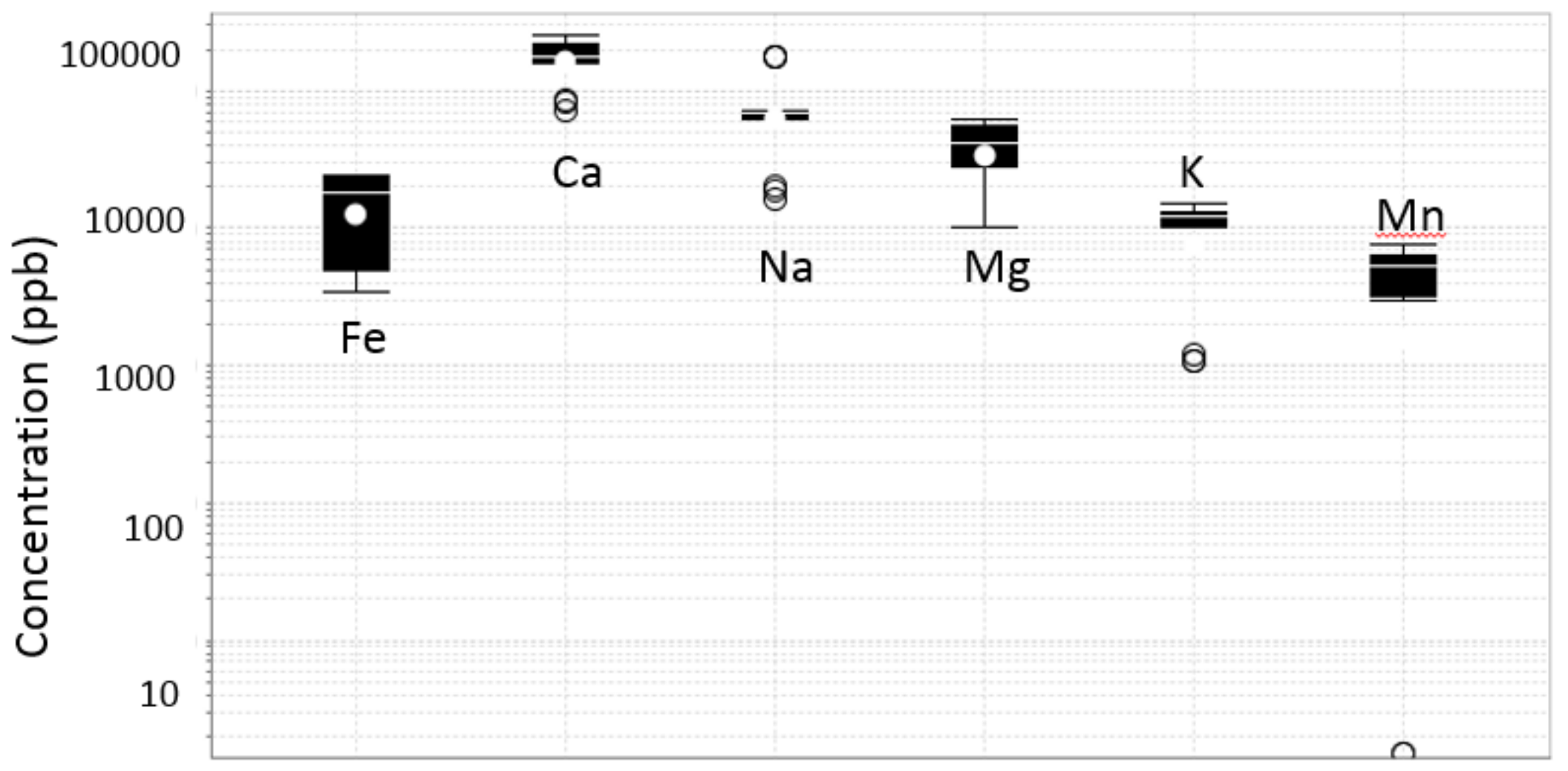

Figure 4-1 Major and minor element concentrations from all filtered and acidified sample sites at El Indio. The central box is the middle $50 \%$ of data with a highlighted median line. Circles represent outliers further than 1.5*(Q3-Q1) from the box. A triangle represents outliers that are further than 3.0*(Q3-Q1). The whiskers represent the extreme values that are not outliers. 


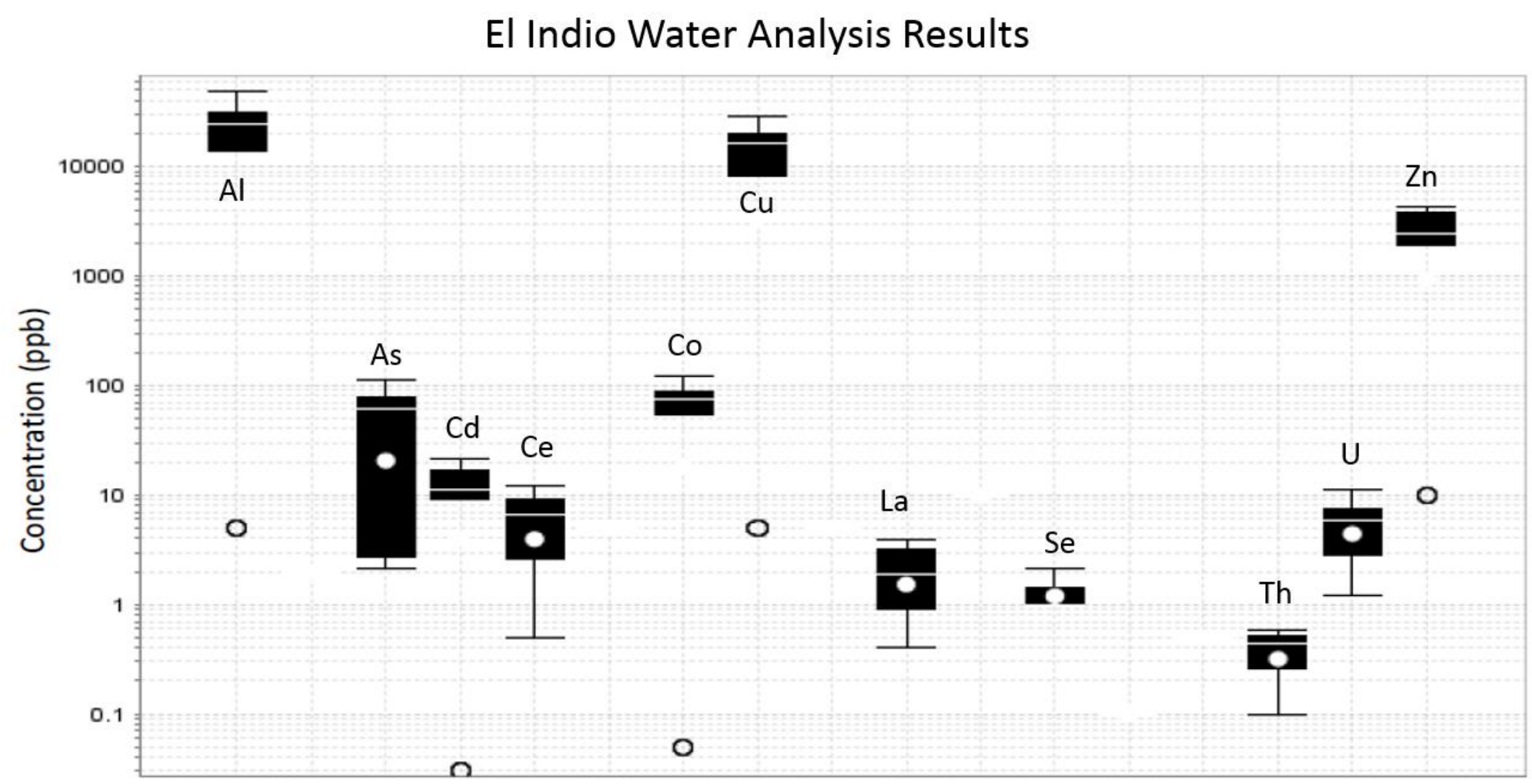

Figure 4-2 Minor and trace element concentrations from all filtered and acidified sample sites at El Indio. Circles represent outliers further than 1.5*(Q3-Q1) from the box. A triangle represents outliers that are further than 3.0*(Q3-Q1). The whiskers represent the extreme values that are not outliers. 


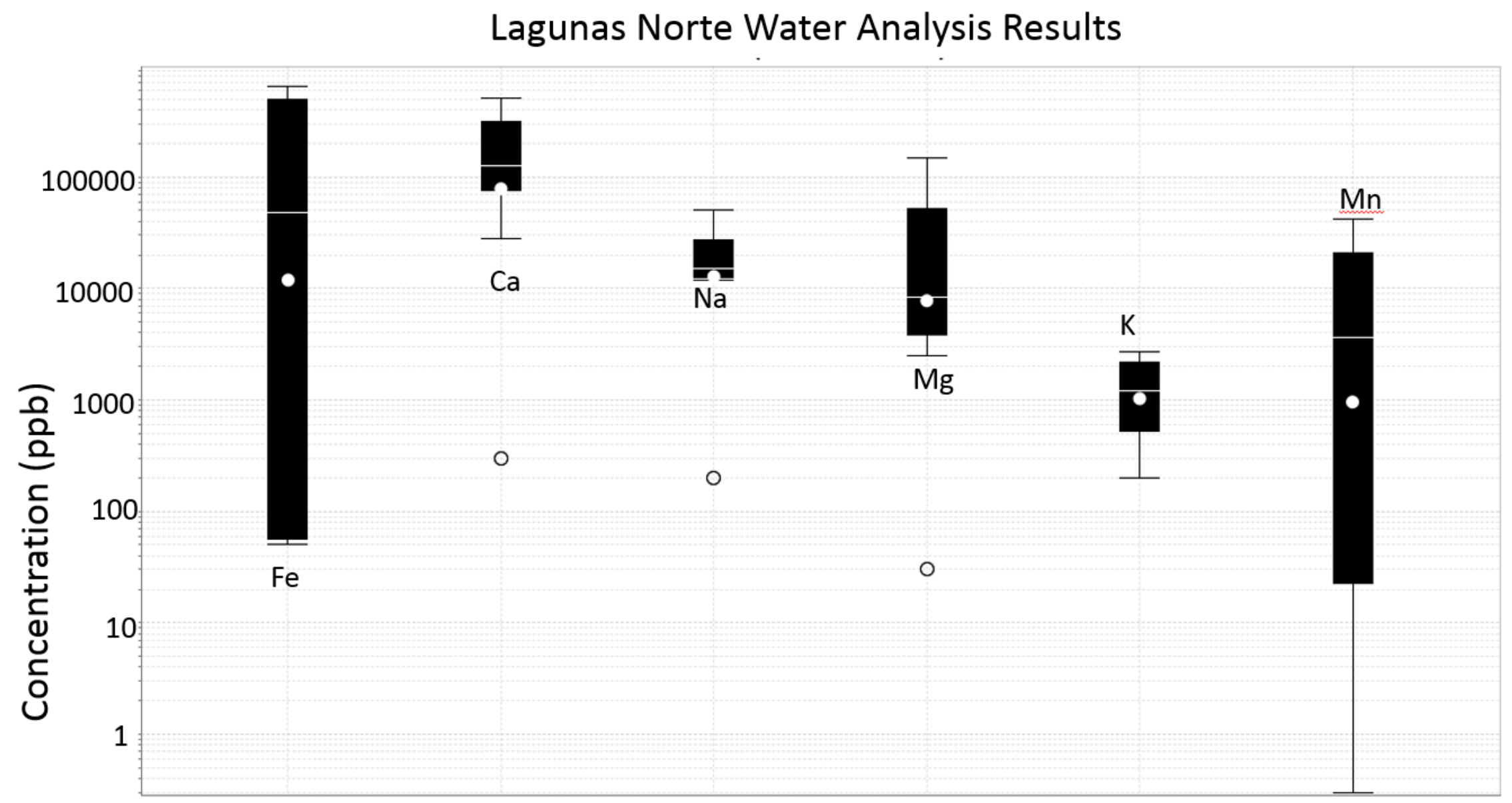

Figure 4-3 Major and minor element concentrations from all filtered and acidified sample sites at Lagunas Norte. Circles represent outliers further than 1.5*(Q3-Q1) from the box. A triangle represents outliers that are further than 3.0*(Q3-Q1). The whiskers represent the extreme values that are not outliers 


\section{Lagunas Norte Water Analysis Results}

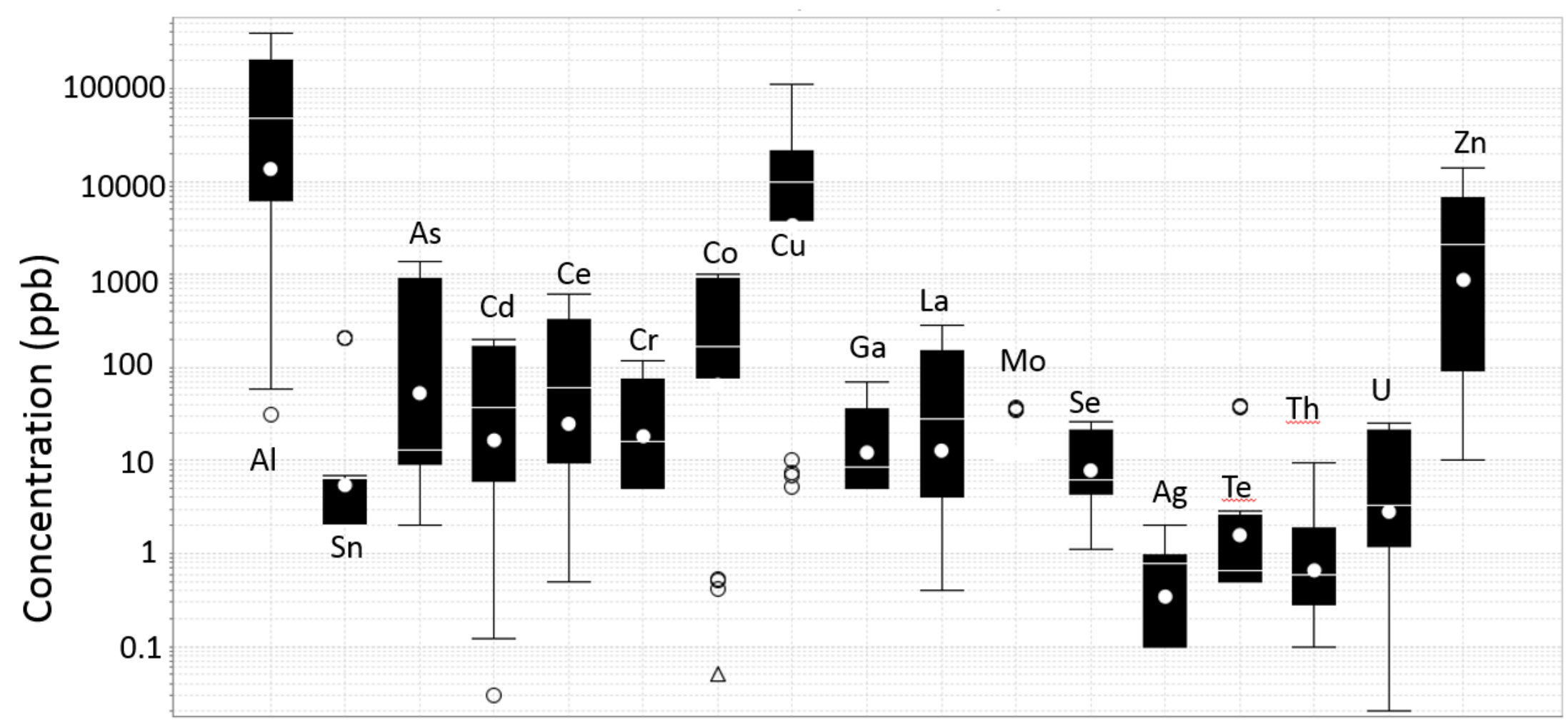

Figure 4-4 Minor and trace element concentrations from all filtered and acidified sample sites at Lagunas Norte. Circles represent outliers further than $1.5^{*}(Q 3-Q 1)$ from the box. A triangle represents outliers that are further than 3.0*(Q3-Q1). The whiskers represent the extreme values that are not outliers. 


\section{Pierina Water Analysis Results}

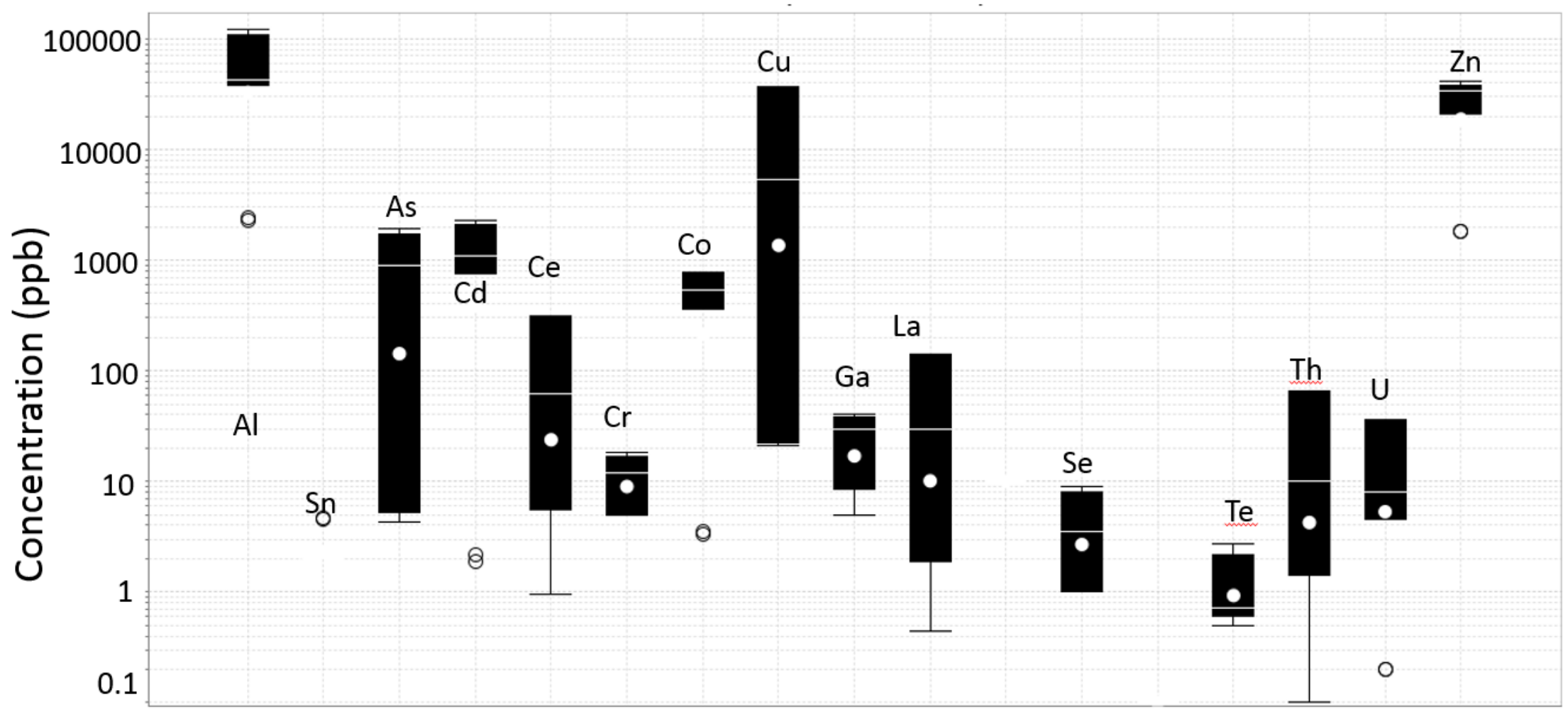

Figure 4-5 Minor and trace element concentrations from all filtered and acidified sample sites at Pierina. Circles represent outliers further than 1.5*(Q3-Q1) from the box. A triangle represents outliers that are further than 3.0*(Q3-Q1). The whiskers represent the extreme values that are not outliers. 


\section{Pierina Water Analysis Results}

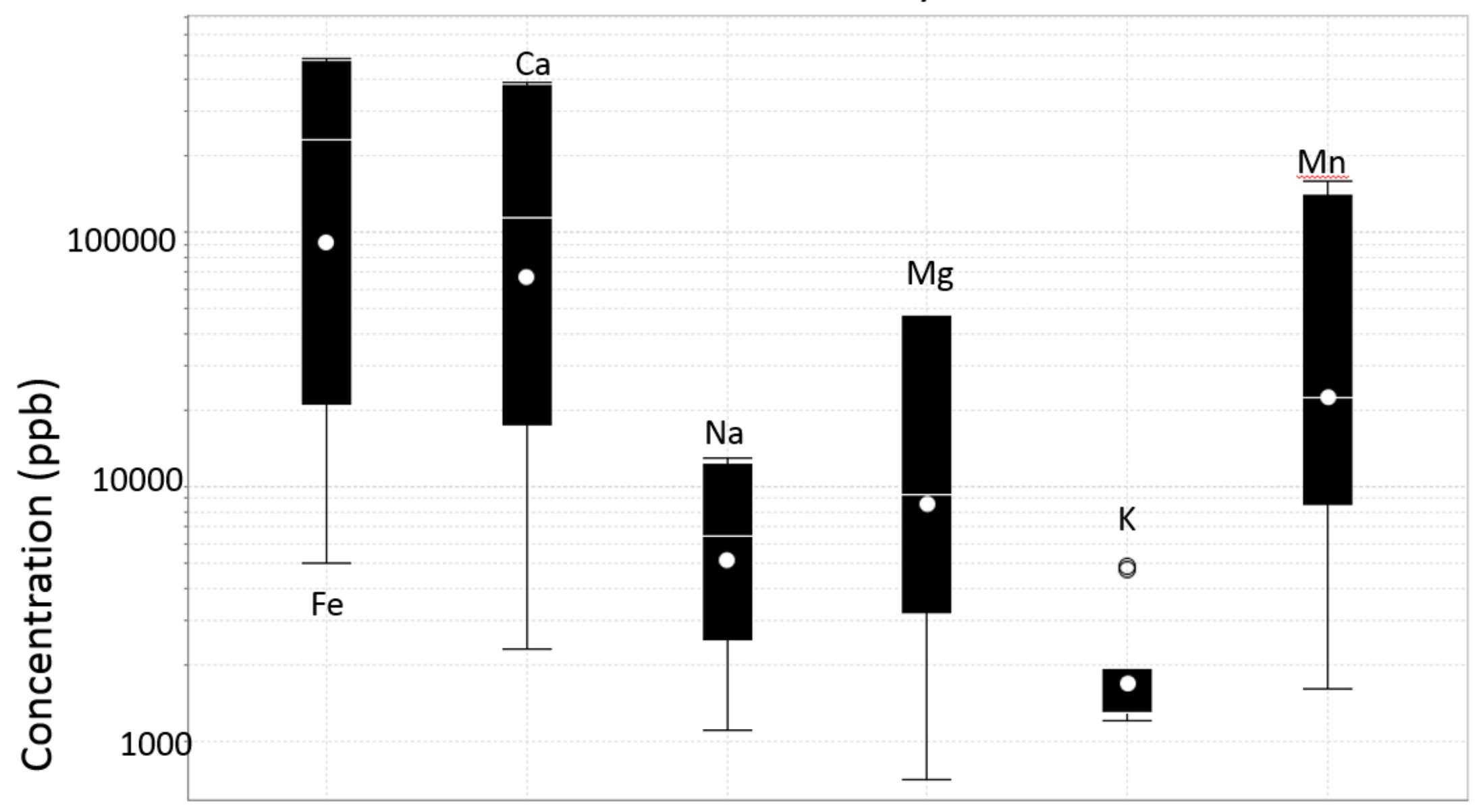

Figure 4-6 Major and minor element concentrations from all filtered and acidified sample sites at Pierina. Circles represent outliers further than 1.5*(Q3-Q1) from the box. A triangle represents outliers that are further than 3.0*(Q3-Q1). The whiskers represent the extreme values that are not outliers. 
Field parameters for surface waters collected at the 3 mines are listed in Table 4-7, Table 4-8, Table 4-9. The $\mathrm{pH}$ values ranged from 2.45 to 7.31 , with a majority below 4 . The highest pe value of 13.1 came from the waste rock leachate before the collection pond at Lagunas Norte. Dissolved oxygen was not measured at El Indio; however, results from Lagunas Norte and Pierina are fairly similar, with the highest value being $7.21 \mathrm{mg} / \mathrm{l}$ at Lagunas Norte and lowest value $2.07 \mathrm{mg} / \mathrm{L}$ at Pierina. Specific conductance demonstrated a wide range of values in each mine site. For example, a variation of 251 $\mu \mathrm{S} / \mathrm{cm}$ to $4000 \mu \mathrm{S} / \mathrm{cm}$ was observed at Pierina, values ranging from $3200 \mu \mathrm{S} / \mathrm{cm}$ to $433 \mu \mathrm{S} / \mathrm{cm}$ were observed for Lagunas Norte whereas a minimum value of $458 \mu \mathrm{S} / \mathrm{cm}$ and a maximum value of $1798 \mu \mathrm{S} / \mathrm{cm}$ was measured at El Indio.

Table 4-7 Field variables measured at El Indio with YSI meter measured in May 2014. Where there is an " $x$ ", the given variable was not measured.

\begin{tabular}{|c|c|c|c|c|c|c|c|}
\hline Site & pH & TDS & Conductivity & ORP & Temperature & DO & pe \\
\hline & & $\mathrm{g} / \mathrm{l}$ & $\mathrm{uS} / \mathrm{cm}$ & $\mathrm{mV}$ & $\mathrm{C}$ & $\mathrm{mg} / \mathrm{L}$ & \\
\hline IN-23 & 7.31 & 0.30 & 458 & 256 & 10.3 & $x$ & 8.1 \\
\hline IN-28 & 4.51 & 0.68 & 1128 & 440 & $11.2-11.4$ & $x$ & 11.3 \\
\hline IN-RMATR & $3.49-3.69$ & $0.77-0.88$ & 1180 & 300 & 9.96-9.09 & $x$ & 8.9 \\
\hline IN-2 & $2.65-3.38$ & 0.99 & 1530 & 460 & 3.46 & $x$ & 11.7 \\
\hline IN-13 & $4.68-4.53$ & 1.2 & 1798 & 259.2 & 14.8 & 8.2 & 8.1 \\
\hline
\end{tabular}

Table 4-8 Field variables measured at Lagunas Norte with YSI meter measured in May 2014.

\begin{tabular}{|c|c|c|c|c|c|c|c|}
\hline Site & pH & DO & TDS & Conductivity & ORP & Temperature & pe \\
\hline & & $\mathrm{mg} / \mathrm{l}$ & $\mathrm{g} / \mathrm{l}$ & $\mathrm{uS} / \mathrm{cm}$ & $\mathrm{mV}$ & $\mathrm{C}$ & \\
\hline LN-DAR-1 & 2.45 & 5.94 & 2.1 & 3200 & 547.8 & 14.8 & 13.1 \\
\hline LN-DW-B-11 & 2.74 & 2.03 & 0.80 & 1242 & -25.70 & 10.8 & 3.1 \\
\hline LN-SP3-W1 & 3.01 & 6.19 & 0.57 & 875 & 485.7 & 16.3 & 11.9 \\
\hline LN-SP3-W2 & 3.05 & 5.43 & 0.66 & 1020 & 488.8 & 15.2 & 12.0 \\
\hline LN-PW-1 & 5.47 & 5.20 & 0.75 & 1148 & 121.6 & 18.4 & 5.6 \\
\hline LN-BP & 3.31 & 6.10 & 0.28 & 434 & 429.0 & 14.0 & 11.0 \\
\hline LN-PW2 & 6.4 & 6.40 & 0.28 & 433 & -132.9 & 13.0 & 1.2 \\
\hline LN-VWD & 2.63 & 7.21 & 1.9 & 2882 & 566.0 & 12.7 & 13.5 \\
\hline
\end{tabular}

Table 4-9 Field variables measured at Pierina with YSI meter measured in May 2014.

\begin{tabular}{ccccccccc}
\hline Site & pH & DO & TDS & Conductivity & ORP & Temperature & pe \\
\hline & & $\mathrm{mg} / \mathrm{l}$ & $\mathrm{g} / \mathrm{l}$ & $\mathrm{uS} / \mathrm{cm}$ & $\mathrm{mV}$ & $\mathrm{C}$ & 17.3 & 1.8 \\
P-WRD & 2.8 & 5.56 & 2.6 & 4000 & 479.4 & 14.0 & 11.7 \\
P-ARD-17 & 3.0 & 5.56 & 0.163 & 251 & 468.4 & 372.3 & 17.0 & 9.94 \\
P-PD & 3.1 & 2.07 & 0.868 & 1336 & 17.3 & 10.2 \\
P-EC & 4.3 & 6.81 & 1.117 & 1719 & 387.0 & & \\
\hline
\end{tabular}




\subsubsection{Site-specific chemistry}

Comparison of metals and anions shows a significant variation of concentrations between mines and from one site to another (Figure 4-10, Figure 4-24). Iron concentrations ranged from $22 \mathrm{mg} / \mathrm{L}$ (INRMATR) to $23 \mathrm{mg} / \mathrm{L}$ (IN28) at El Indio, $50 \mu \mathrm{g} / \mathrm{L}$ (LN-PW2) to $640 \mathrm{mg} / \mathrm{L}$ (LN-DAR-1) at Lagunas Norte, and $5.1 \mathrm{mg} / \mathrm{L}$ (P-ARD17) to $473 \mathrm{mg} / \mathrm{L}(\mathrm{P}-\mathrm{WRD})$ at Pierina. The most concentrated parameter in waters, $\mathrm{SO}_{4}$, demonstrates a range of concentration from $870 \mathrm{mg} / \mathrm{L}$ (IN23) to 1,100 mg/L (IN2) at El Indio, $190 \mathrm{mg} / \mathrm{L}$ (LN-VWD-W) to 5,400 mg/L (LN-DAR-1-W) at Lagunas Norte, and $53 \mathrm{mg} / \mathrm{L}$ (P-ARD17) to 2,900 mg/L (PWRD) at Pierina. Calcium is also elevated in concentration at all mines. Specifically, the range of concentrations lie between $85 \mathrm{mg} / \mathrm{L}$ (IN23) to $250 \mathrm{mg} / \mathrm{L}$ (IN13) at El Indio, $31 \mathrm{mg} / \mathrm{L}$ (LN-BP) to $500 \mathrm{mg} / \mathrm{L}$ (LN-VWD) at Lagunas Norte, and $2.45 \mathrm{mg} / \mathrm{L}$ (P-ARD17) to $383 \mathrm{mg} / \mathrm{L}$ (P-WRD). Anion analysis reveals the highest concentration of $\mathrm{Fl}$ as $3.8 \mathrm{mg} / \mathrm{L}$ (IN-RMATR) at El Indio, and values below detection limits for Lagunas Norte and Pierina. The highest concentration of $\mathrm{Cl}$ is $140 \mathrm{mg} / \mathrm{L}$ at El Indio (IN13), $6.4 \mathrm{mg} / \mathrm{L}$ (LNPW2) at Lagunas Norte, and $0.55 \mathrm{mg} / \mathrm{L}(\mathrm{P}-\mathrm{ARD} 17)$ at Pierina. 
Figure 4-7 Concentration of elements at IN23 on a scatterplot.

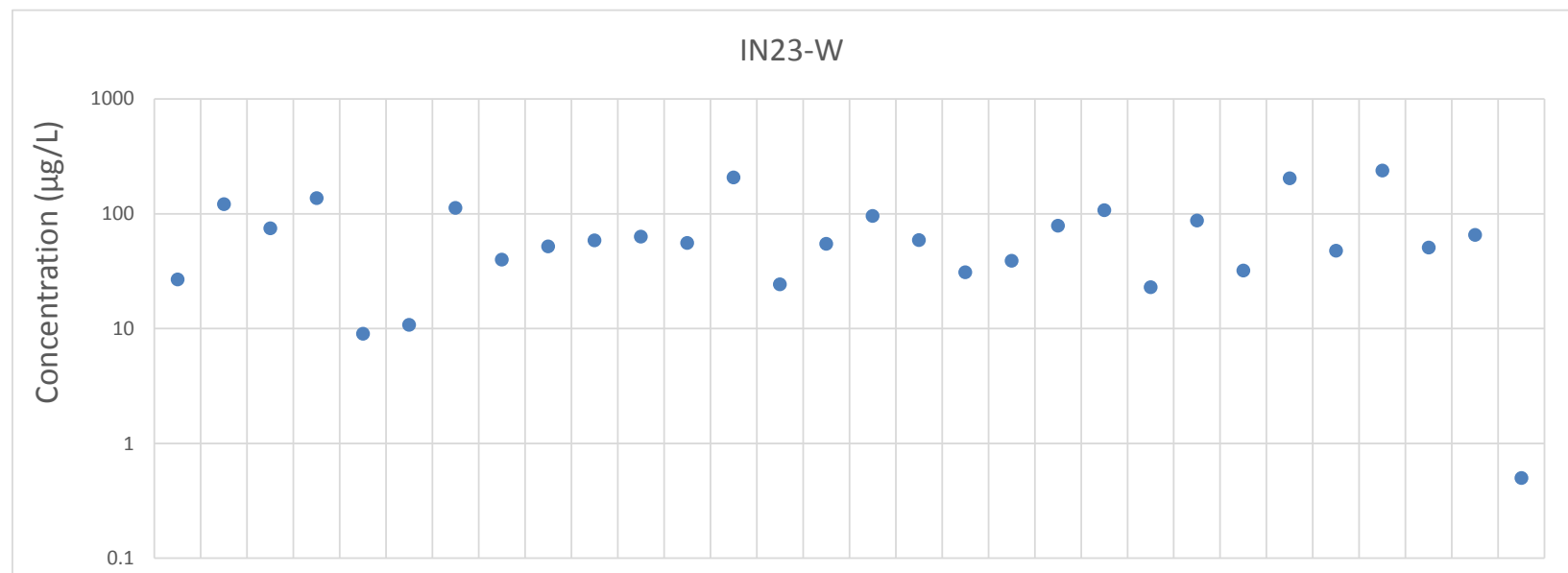

Al Sb As Ba Be B Cd Ca Cr Co Cu Fe Pb Mg Mn Mo Ni P K Se Ag Na Sr S Tl Ti U V Zn Ce

Figure 4-8 Concentration of elements at IN28 on a scatterplot.

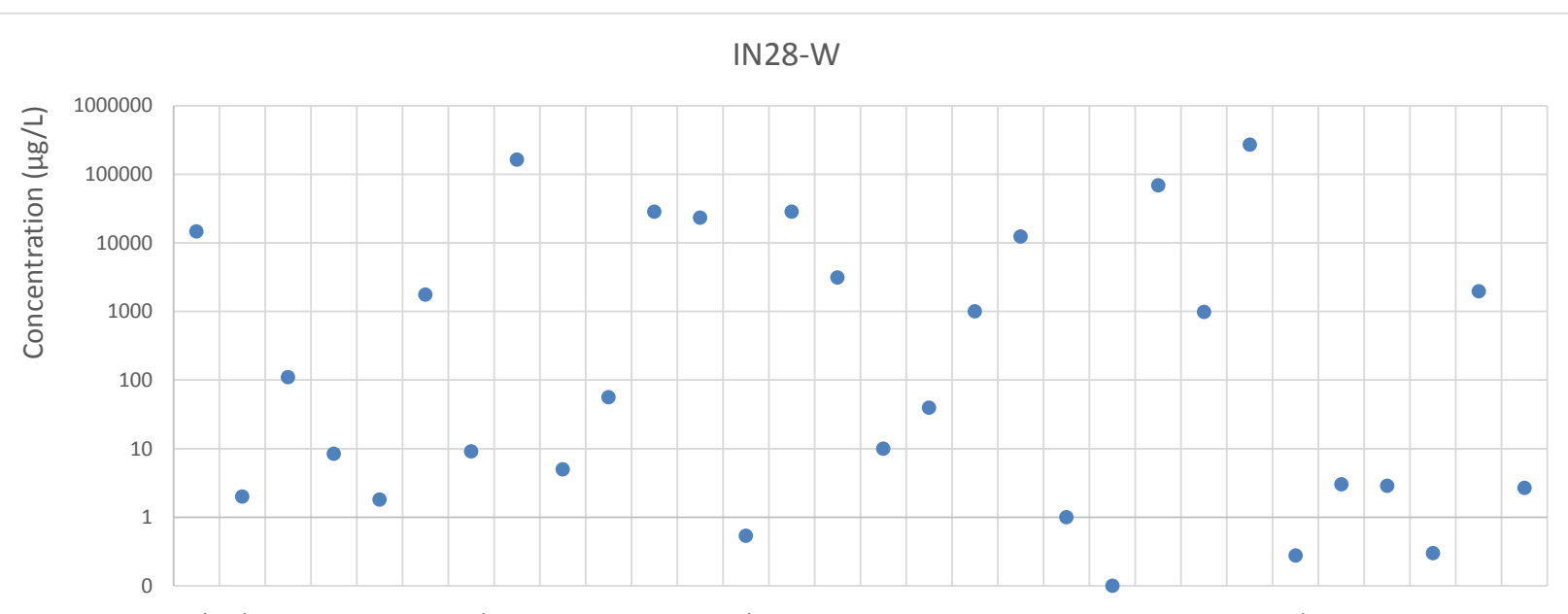

Al Sb As Ba Be B Cd Ca Cr Co Cu Fe Pb MgMnMo Ni P K Se Ag Na Sr S Tl Ti U V Zn Ce 
Figure 4-9 Concentration of elements at IN-RMATR on a scatterplot.

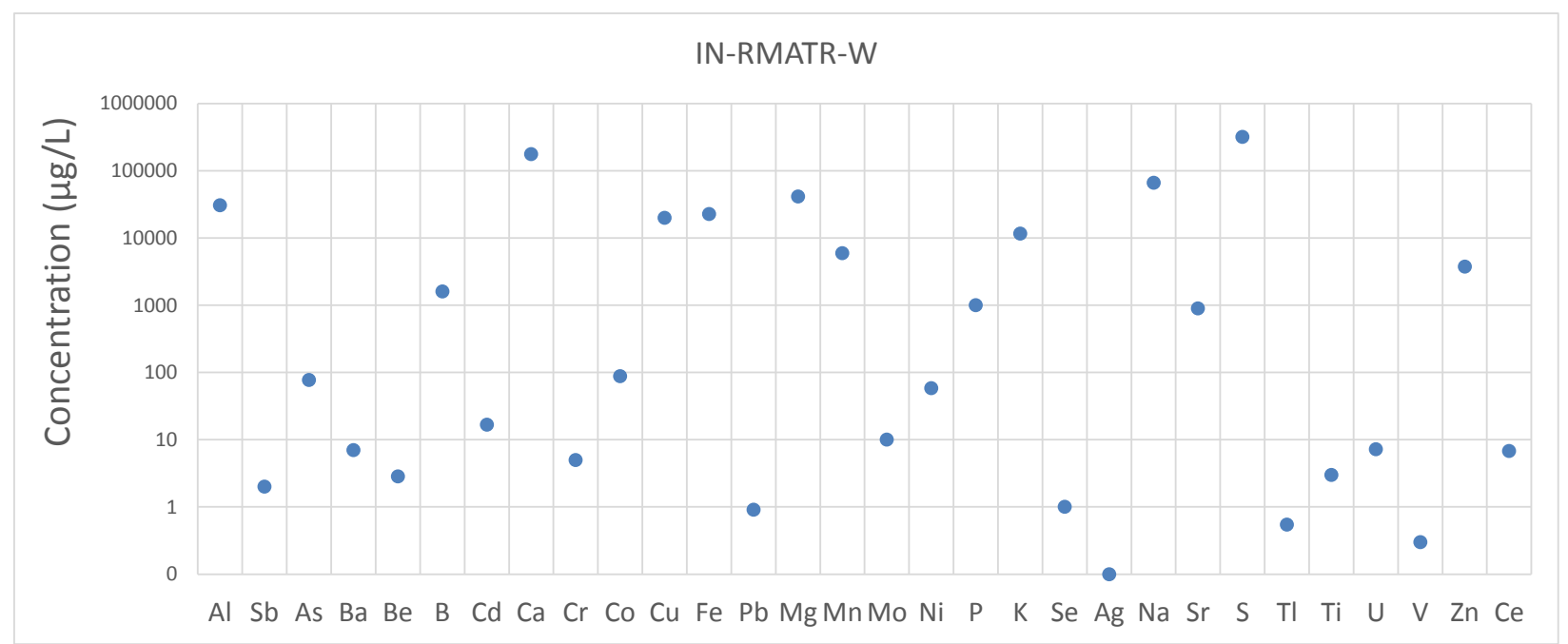

Figure 4-10 Concentration of elements at IN2 on a scatterplot.

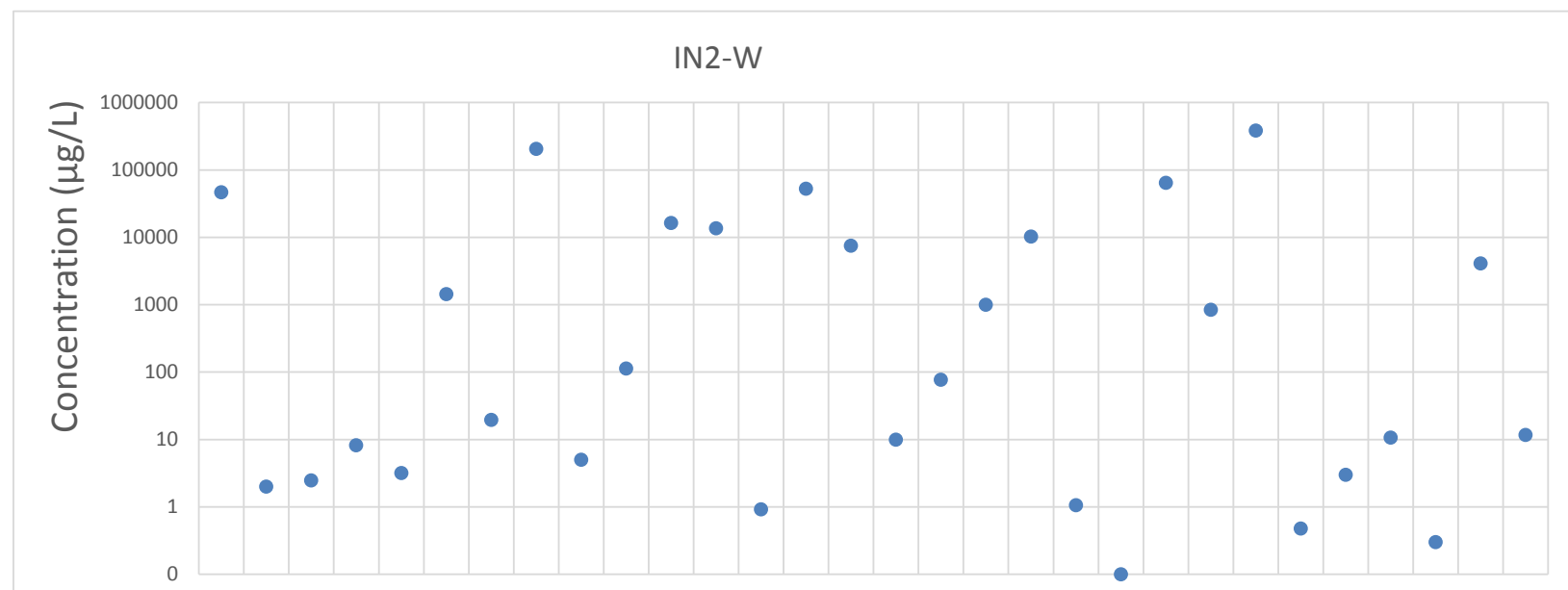

Al $\mathrm{Sb}$ As Ba Be B Cd Ca Cr Co Cu Fe Pb MgMnMo Ni P K Se Ag Na Sr S Tl Ti U V Zn Ce 
Figure 4-11 Concentration of elements at IN13 on a scatterplot.

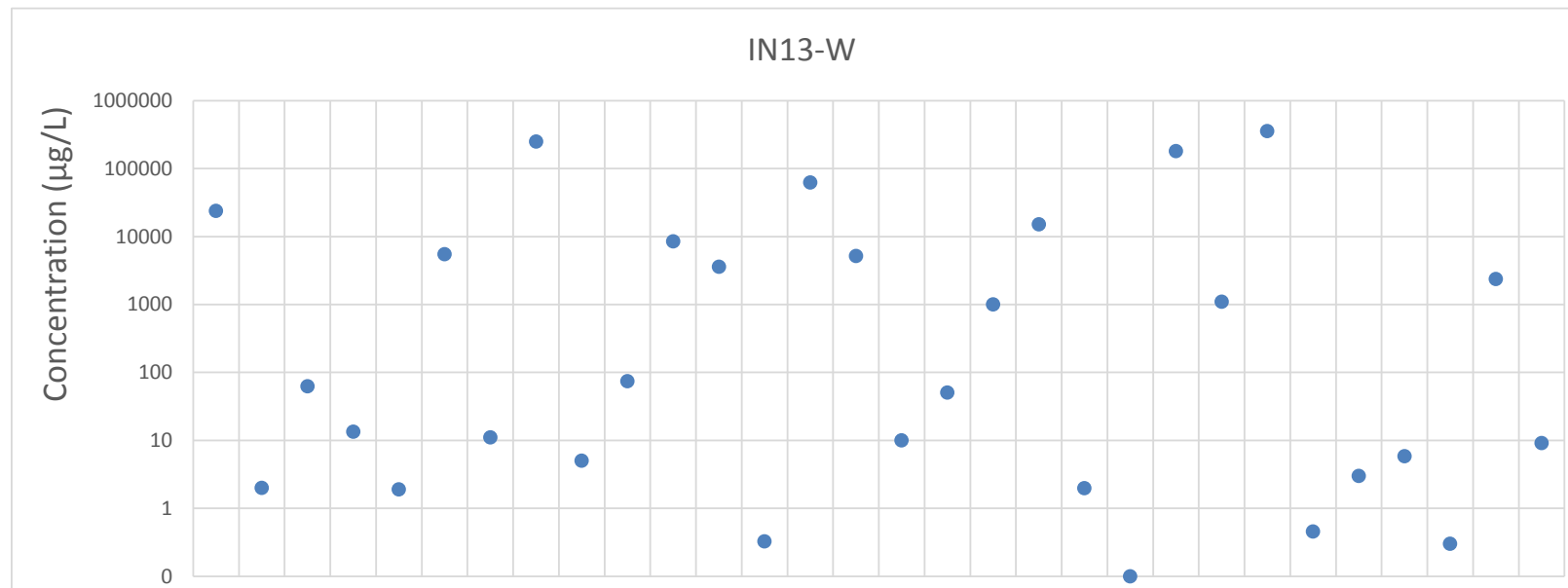

Al Sb As Ba Be B Cd Ca Cr Co Cu Fe Pb MgMnMo Ni P K Se Ag Na Sr S Tl Ti U V Zn Ce

Figure 4-12 Concentration of elements at LN-SP3 on a scatterplot.

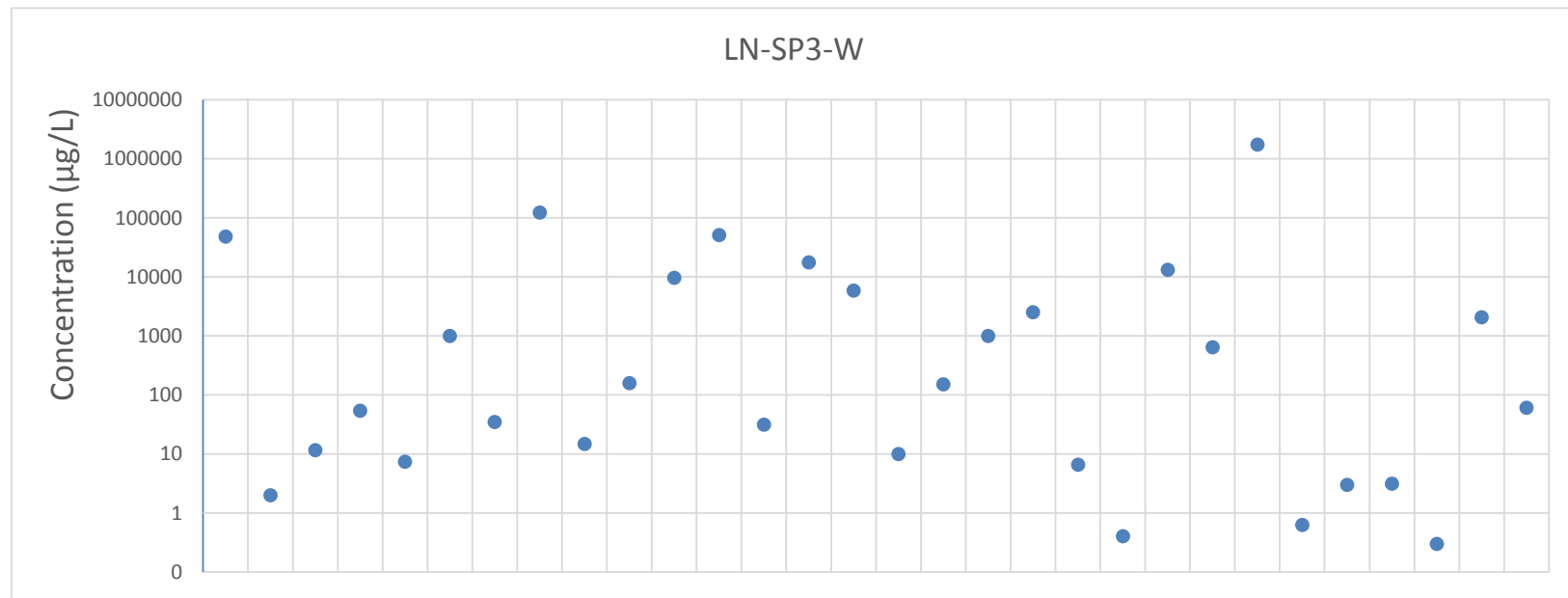

Al Sb As Ba Be B Cd Ca Cr Co Cu Fe Pb MgMnMo Ni P K Se Ag Na Sr S Tl Ti U V Zn Ce 
Figure 4-13 Concentration of elements at LN-DW-B11 on a scatterplot.

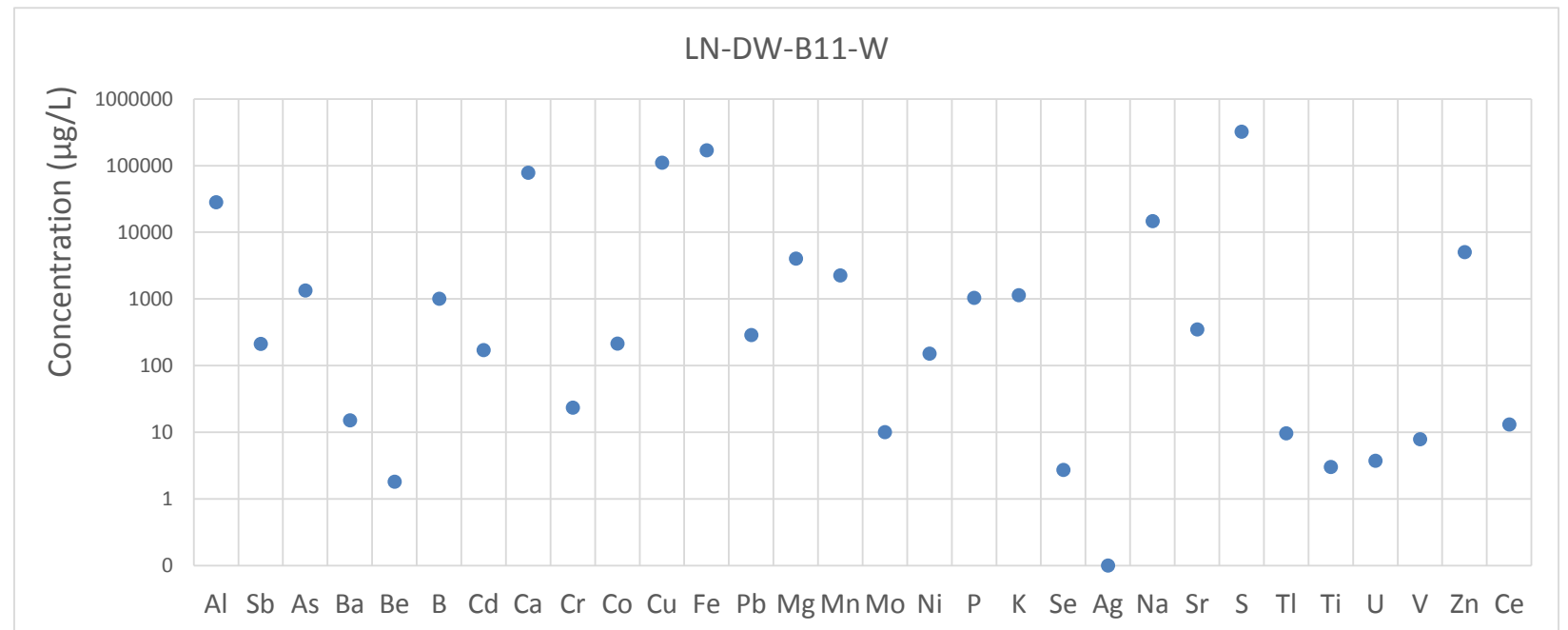

Figure 4-14 Concentration of elements at LN-DAR-1 on a scatterplot.

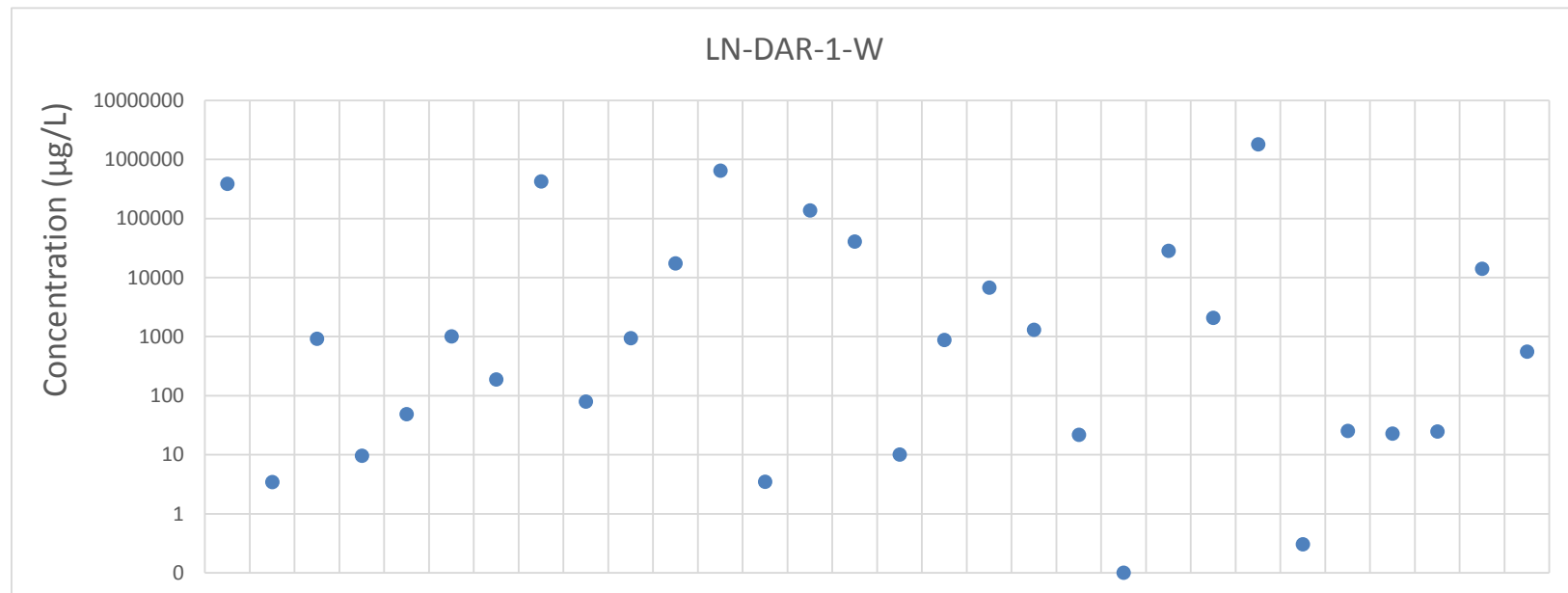

Al $\mathrm{Sb}$ As Ba Be B Cd Ca Cr Co Cu Fe Pb MgMnMo Ni P K Se Ag Na Sr S Tl Ti U V Zn Ce 
Figure 4-15 Concentration of elements at LN-BP on a scatterplot.

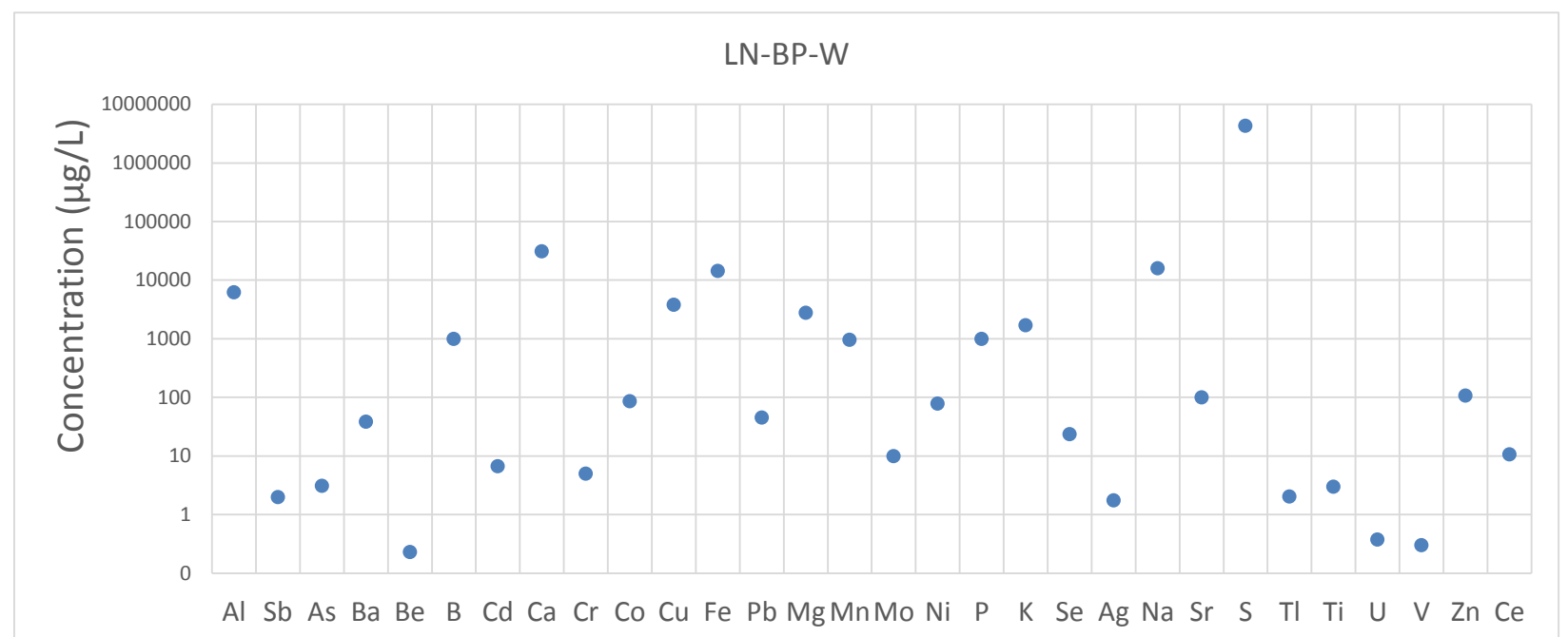

Figure 4-16 Concentration of elements at LN-PW2 on a scatterplot.

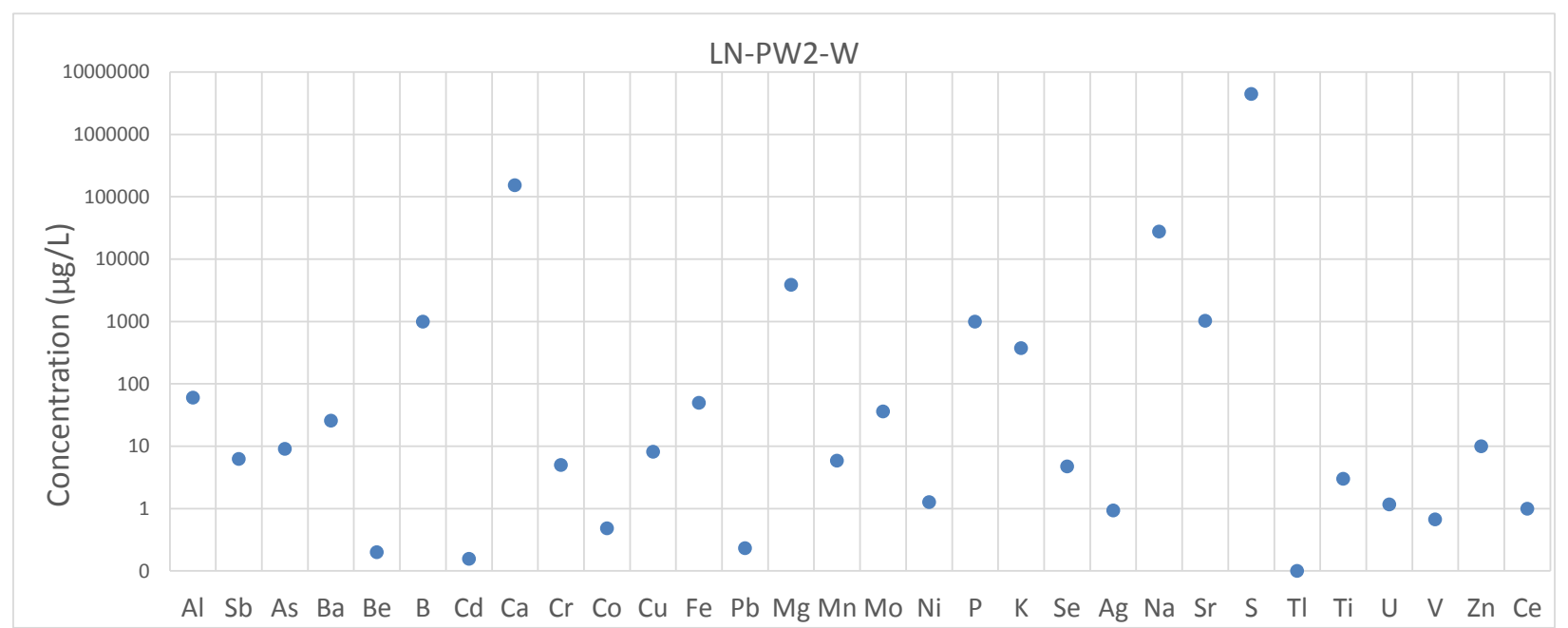


Figure 4-17 Concentration of elements at LN-VWD on a scatterplot.

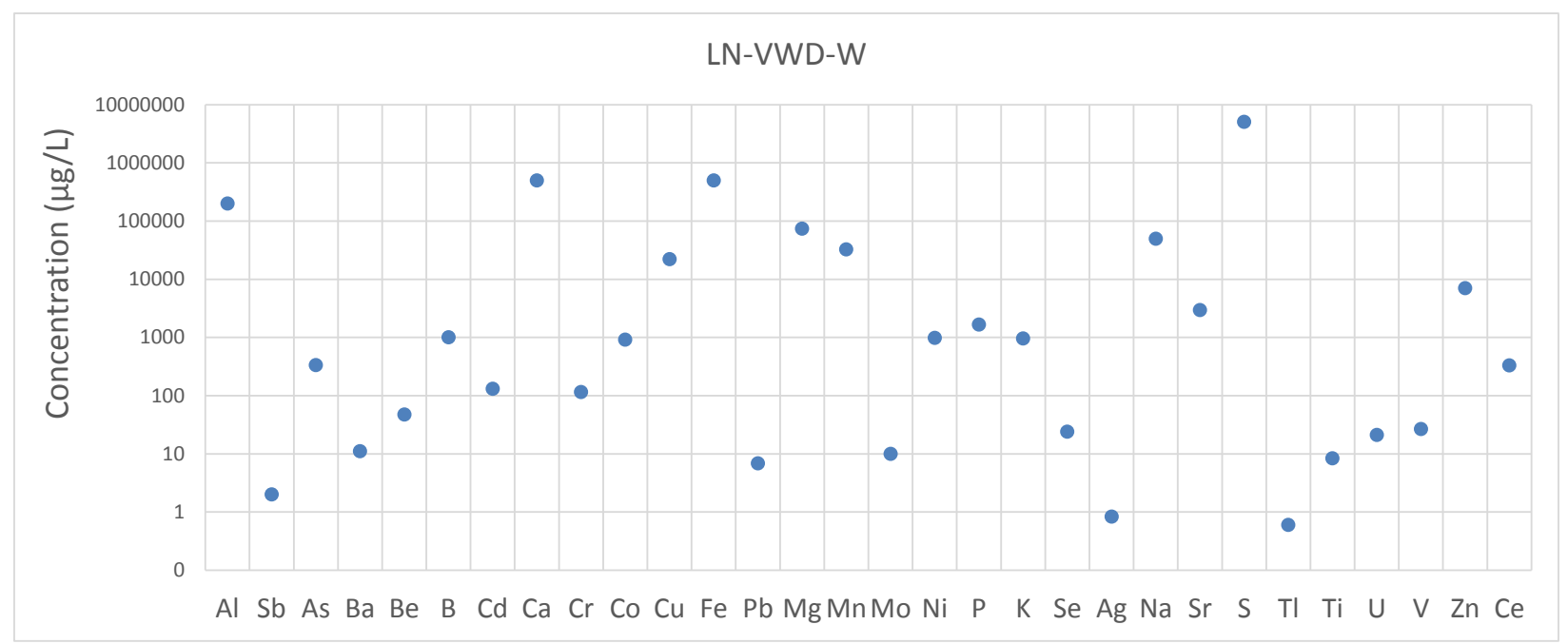

Figure 4-18 Concentration of elements at P-ARD17 on a scatterplot.

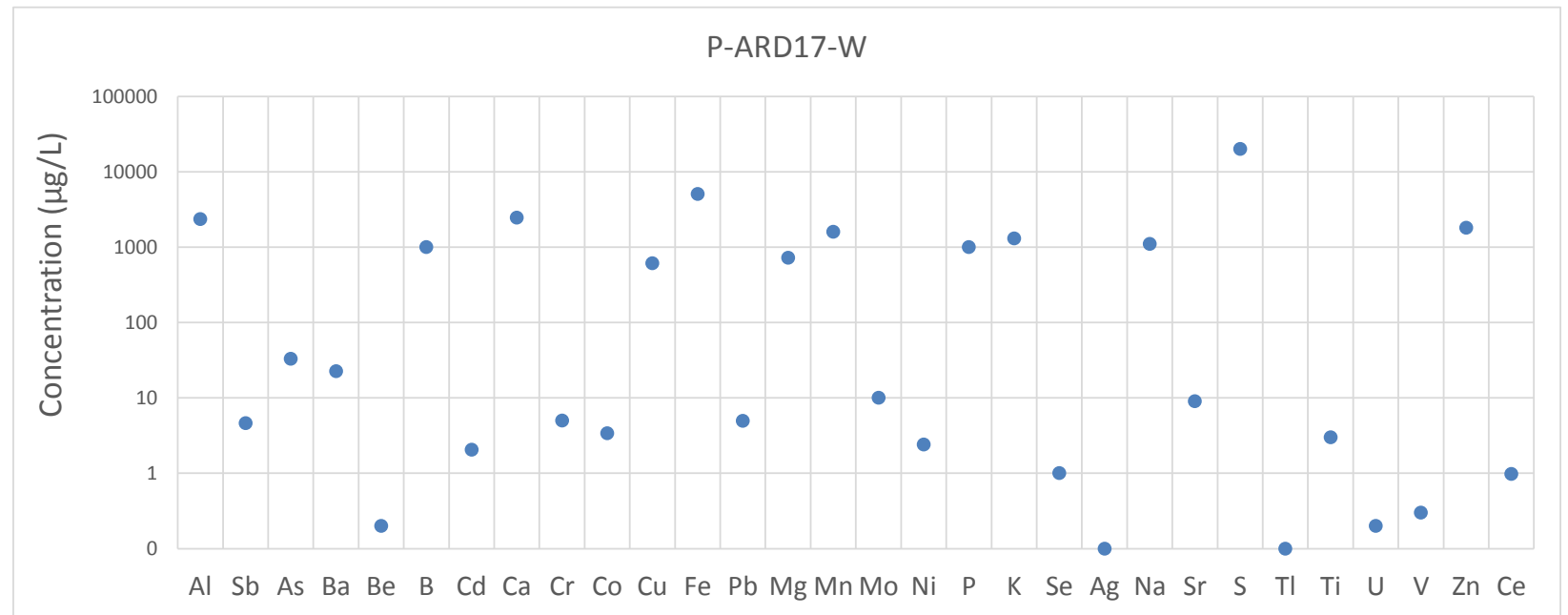


Figure 4-19 Concentration of elements at P-WRD on a scatterplot.

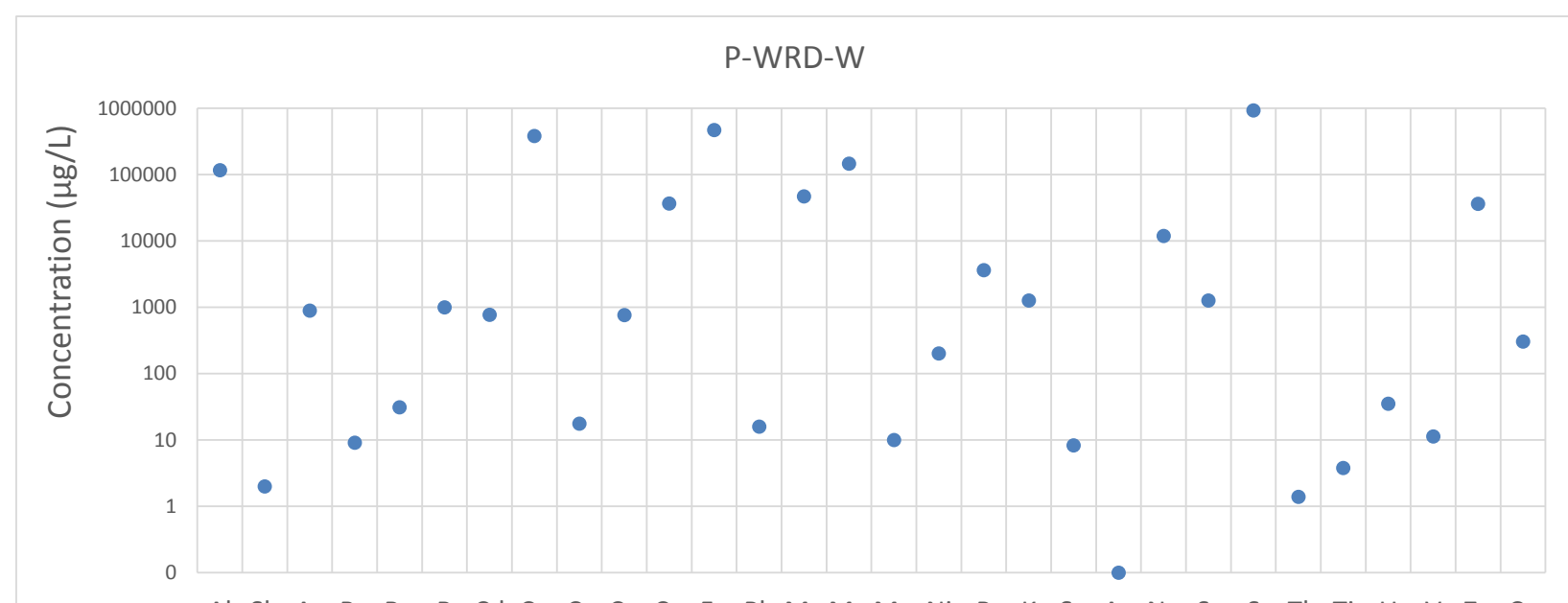

Al Sb As Ba Be B Cd Ca Cr Co Cu Fe Pb MgMnMo Ni P K Se Ag Na Sr S Tl Ti U V Zn Ce

Figure 4-20 Concentration of elements at P-PD on a scatterplot.

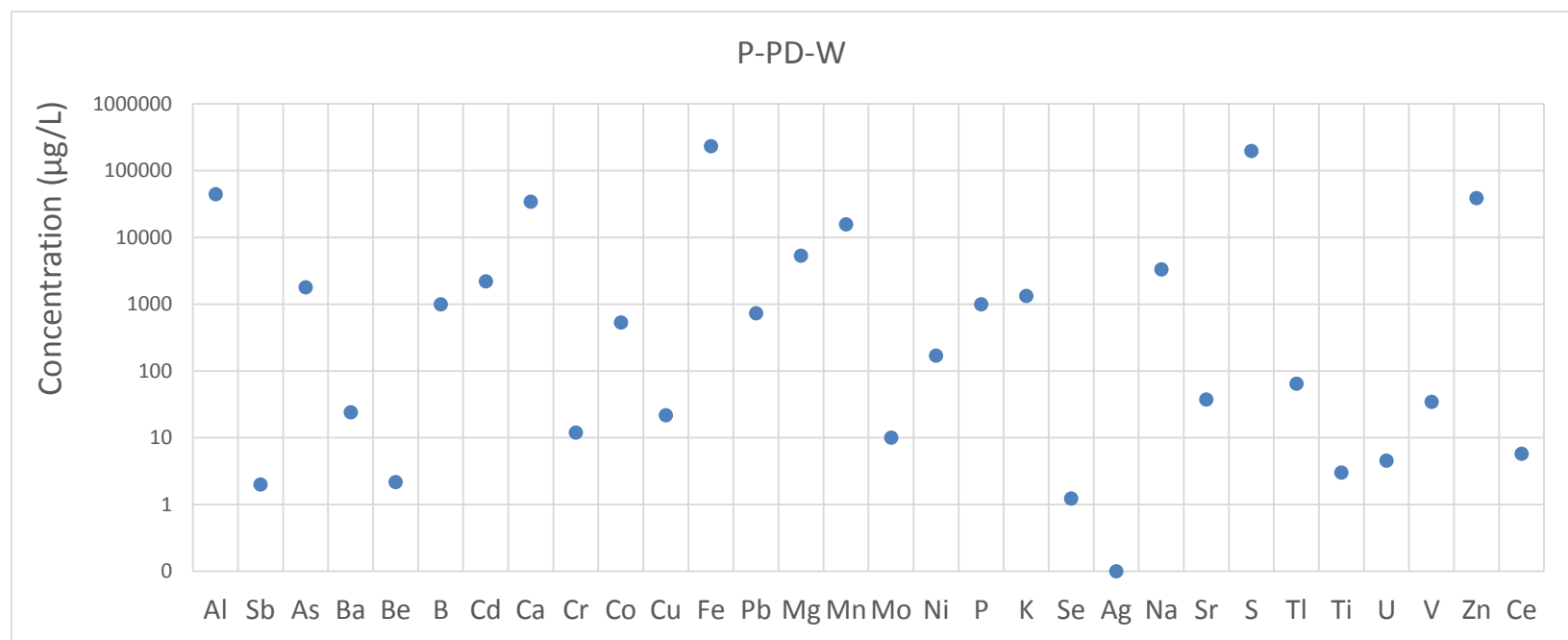


Figure 4-21 Concentration of elements at P-EC on a scatterplot.

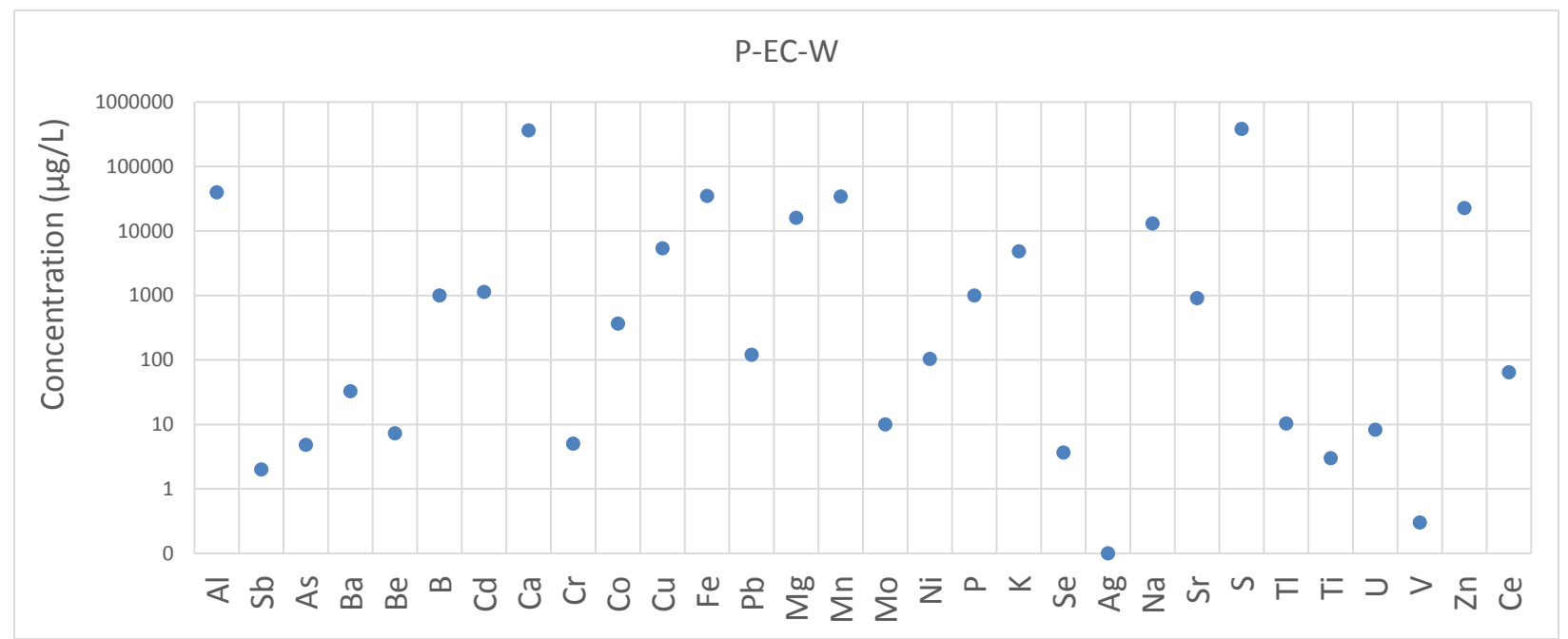

At El Indio, changes in water chemistry from upstream to downstream are noted (see Figure 3.3,

Figure 3.4). IN23-W, the most upstream site which is unaffected by mining activities, has the lowest concentrations of all elements amongst the 5 sampling sites and the highest $\mathrm{pH}$ at 6.7 . IN28-W has the highest concentration of As at $110 \mu \mathrm{g} / \mathrm{L}, \mathrm{Cu}$ at $29000 \mu \mathrm{g} / \mathrm{L}$ and $\mathrm{Fe}$ at $24000 \mu \mathrm{g} / \mathrm{L}$. IN-RMATR-W has the lowest $\mathrm{pH}$ but does not have the highest metal concentrations. IN2-W demonstrates the highest concentrations of sulfate, $\mathrm{F}, \mathrm{Al}, \mathrm{Cd}, \mathrm{Co}, \mathrm{Mn}, \mathrm{Ni}, \mathrm{Zn}$. IN13-W has the highest concentration of $\mathrm{Cl}, \mathrm{Ca}, \mathrm{Ce}, \mathrm{Mg}$, $\mathrm{K}, \mathrm{Na}, \mathrm{Sr}$. A general increase of $\mathrm{SO}_{4}$ and metals is observed in the downstream direction with the highest concentrations at sites IN2 and IN13 (Figures 3.3, Figure 3.4) (Table 4-1).

The sampling sites were not distributed along simple drainage patterns at Lagunas Norte and Pierina as they were at El Indio (Figure 3.5 and Figure 3.6 respectively) (Table 4-3). At Lagunas Norte, sampling locations with the lowest $\mathrm{pH}$ is LN-DAR-1 $(2.6 \mathrm{pH})$ and the location with the highest $\mathrm{pH}$ is $\mathrm{LN}$ PW2 (6.2 pH). Fluoride, $\mathrm{Cl}, \mathrm{NO}_{2}$ and $\mathrm{NO}_{3}$ are below detection limits at all sites, with the exception of $\mathrm{Cl}$ at LN-PW2 that is measured at $6.4 \mathrm{mg} / \mathrm{L}$. Aluminum concentrations are highest at LN-DAR-1 (380 mg/L) followed by LN-VWD (200 mg/L) and LN-SP3 $(50 \mathrm{mg} / \mathrm{L})$. Similarly, $\mathrm{SO}_{4}, \mathrm{Al}, \mathrm{Ca}, \mathrm{Ni}$ are highest at LN-DW-B11 followed by LN-VWD. Copper is also highest at DW-B-11 (110 mg/L), followed by LN-VWD (23 mg/L). 
Arsenic and Fe are highest at LN-DW-B-11 with concentrations of $1.4 \mathrm{mg} / \mathrm{L}$ and $650 \mathrm{mg} / \mathrm{L}$. respectively. DW-B-11 has the highest concentrations of $\mathrm{Pb}$ and $\mathrm{Zn}$ at $0.29 \mathrm{mg} / \mathrm{L}$ and $14 \mathrm{mg} / \mathrm{L}$ respectively. LN-VWD shows evidence of sodium concentrations $(50 \mathrm{mg} / \mathrm{L})$ greater than other sampling locations. Magnesium concentrations are highest at DAR-1-W (150 mg/L), followed by LN-VWD (75 mg/L), whereas Mn is most concentrated at LN-DAR-1 (42 mg/L). LN-PW2 generally has low metal concentrations with the exception of Mo $(0.037 \mathrm{mg} / \mathrm{L})$ which is the highest from all the sampling locations. Out of the 6 sampling locations, the water chemistry at LN-DW-B-11 and LN-VWD is the most enriched in metals and elements that may be potentially toxic or economically valuable.

At Pierina, sample sites P-PD, P-ARD-17, P-WRD, and P-EC were distributed throughout the mine and demonstrate a wide range of concentrations (Figure 3.6) Table 4-5. Sulfate and Fe are the most heavily concentrated at P-WRD $(2.75 \mathrm{mg} / \mathrm{L} \& 480 \mathrm{mg} / \mathrm{L}$ respectively). Calcium, $\mathrm{Ce}, \mathrm{Cu}, \mathrm{Mg}, \mathrm{Y}, \mathrm{Zn}$ and $\mathrm{Mn}$ amounts are greatest P-WRD followed by P-EC. Cadmium has the highest concentrations at P-PD $(2.3 \mathrm{mg} / \mathrm{L})$ followed by P-EC (1.2 mg/L). Changes in Cu concentrations at these sites depict the variation in chemistry throughout the mine, from $0.022 \mathrm{mg} / \mathrm{L}$ at P-PD to $37 \mathrm{mg} / \mathrm{L}$. Potassium and $\mathrm{Na}$ are found in their highest concentration at P-EC.

\subsubsection{Ultrafiltration}

Ultrafiltration was used to capture colloids from the water samples collected in the field at Pierina and Lagunas Norte. In this research, it is assumed that the difference between the concentrations in the 0.45 um and the 0.01 um ultrafiltered samples is equivalent to the concentration found in the colloidal phase:

$$
[M e]_{\text {colloidal }}=[M e]_{0.45 \mu m}-[M e]_{0.01 \mu m}
$$

The component of the initial concentration retained on the filter paper can be calculated by subtracting a value of 1 from the quotient of [Me] permeate and [Me] retenate.

$$
R C=1-\frac{[\text { Me }] \text { permeate }}{[\text { Me }] \text { retenate }}
$$

Equation 4.2 
The results from calculations demonstrate that $\mathrm{Al}, \mathrm{Ca}, \mathrm{Cu}, \mathrm{Fe}, \mathrm{Mg}, \mathrm{Mn}, \mathrm{K}, \mathrm{S}$ and $\mathrm{Zn}$ are present as colloids in Pierina and $\mathrm{Al}, \mathrm{Ca}, \mathrm{Cu}, \mathrm{Fe}, \mathrm{Mg}, \mathrm{Mn}, \mathrm{Na}, \mathrm{S}, \mathrm{Sr}$ and $\mathrm{Zn}$ at Lagunas Norte. The concentration of elements at Lagunas Norte and Pierina are listed in Table 4-11 and Table 4-13. The percentage of elements in colloids was also calculated and is tabulated in Table 4-10 and Table 4-12. This is done by dividing [Me $]_{\text {colloidal }}$ by the average concentration of the element in the FA sample. The negative values are assumed to be caused by sampling or analytical errors.

Table 4-10 Relative percent concentrations of $\mathrm{Al}, \mathrm{As}, \mathrm{Ca}, \mathrm{Cu}, \mathrm{Fe}, \mathrm{Mg}, \mathrm{Mn}, \mathrm{K}, \mathrm{S}, \mathrm{Zn}$ as colloids from ultrafiltration results at Pierina.

\begin{tabular}{crrrc}
\hline & P-ARD-17-W & P-WRD-W & P-PD-W & P-EC-W \\
\hline $\begin{array}{c}\text { Temperature } \\
\text { lonic strength } \\
\text { Elements }\end{array}$ & 13.95 & 17.25 & 16.98 & 17.27 \\
$\mathrm{Al}$ & $1.41 \mathrm{E}-03$ & $6.54 \mathrm{E}-02$ & $1.99 \mathrm{E}-02$ & $2.83 \mathrm{E}-02$ \\
$\mathrm{As}$ & $18 \%$ & & & \\
$\mathrm{Ca}$ & $2 \%$ & $5 \%$ & $22 \%$ & $-421 \%$ \\
$\mathrm{Cu}$ & $7 \%$ & $6 \%$ & $7 \%$ & $0 \%$ \\
$\mathrm{Fe}$ & $11 \%$ & $5 \%$ & $-20 \%$ & $5 \%$ \\
$\mathrm{Mg}$ & $6 \%$ & $6 \%$ & $6 \%$ & $5 \%$ \\
$\mathrm{Mn}$ & $6 \%$ & $25 \%$ & $17 \%$ & $21 \%$ \\
$\mathrm{~K}$ & $8 \%$ & $-3 \%$ & $2 \%$ & $2 \%$ \\
$\mathrm{Na}$ & $9 \%$ & $8 \%$ & $4 \%$ & $8 \%$ \\
$\mathrm{Sr}$ & $1 \%$ & $21 \%$ & $6 \%$ & $4 \%$ \\
$\mathrm{~S}$ & $0 \%$ & $12 \%$ & $3 \%$ & $18 \%$ \\
$\mathrm{Zn}$ & $-6 \%$ & $24 \%$ & $12 \%$ & $21 \%$ \\
\hline
\end{tabular}

Table 4-11 List of elements with average colloidal concentrations in ppb at sampling locations within Pierina.

\begin{tabular}{cccccc}
\hline & Units & P-ARD-17-W & P-WRD-W & P-PD-W & P-EC-W \\
\hline $\begin{array}{c}\text { Temperature } \\
\text { lonic strength }\end{array}$ & ${ }^{\circ} \mathrm{C}$ & 13.95 & 17.25 & 16.98 & 17.27 \\
Elements & & $1.41 \mathrm{E}-03$ & $6.54 \mathrm{E}-02$ & $1.99 \mathrm{E}-02$ & $2.83 \mathrm{E}-02$ \\
$\mathrm{Al}$ & $\mathrm{ppb}$ & 50 & 16,667 & 4,333 & 1,667 \\
$\mathrm{As}$ & $\mathrm{ppb}$ & 6 & 47 & 400 & -20 \\
$\mathrm{Ca}$ & $\mathrm{ppb}$ & 50 & 23,333 & 2,333 & 0 \\
$\mathrm{Cu}$ & $\mathrm{ppb}$ & 40 & 2,000 & -4 & 267 \\
$\mathrm{Fe}$ & $\mathrm{ppb}$ & 550 & 23,333 & 13,333 & 1,667 \\
$\mathrm{Mg}$ & $\mathrm{ppb}$ & 40 & 3,000 & 133 & 0 \\
$\mathrm{Mn}$ & $\mathrm{ppb}$ & 100 & 36,667 & 2,667 & 7,000 \\
$\mathrm{~K}$ & $\mathrm{ppb}$ & 100 & -33 & 33 & 100 \\
$\mathrm{Na}$ & $\mathrm{ppb}$ & 100 & 1,000 & 133 & 1,000 \\
$\mathrm{Sr}$ & $\mathrm{ppb}$ & 0 & 267 & 2 & 40 \\
$\mathrm{~S}$ & $\mathrm{ppb}$ & 0 & 110,000 & 6,667 & 70,000 \\
$\mathrm{Zn}$ & $\mathrm{ppb}$ & -100 & 8,667 & 4,667 & 4,667 \\
\hline
\end{tabular}


Table 4-12 Relative percent concentrations of $\mathrm{Al}, \mathrm{As}, \mathrm{Ca}, \mathrm{Cu}, \mathrm{Fe}, \mathrm{Mg}, \mathrm{Mn}, \mathrm{K}, \mathrm{S}, \mathrm{Zn}$ in colloid and dissolved from ultrafiltration at respective sampling sites within Lagunas Norte.

\begin{tabular}{cccccccc}
\hline Elements & LN-SP3-W & LN-SP3-W2 & LN-DW-B-11-W & LN-DAR-1-W & LN-BP & LN-PW2-W & LN-VWD-W \\
\hline $\mathbf{A l}$ & $5 \%$ & $7 \%$ & $7 \%$ & $3 \%$ & $7 \%$ & $1 \%$ & $5 \%$ \\
$\mathbf{A s}$ & $-79 \%$ & $-14 \%$ & $18 \%$ & $-4 \%$ & $-90 \%$ & $-32 \%$ & $4 \%$ \\
$\mathbf{C a}$ & $0 \%$ & $8 \%$ & $0 \%$ & $5 \%$ & $13 \%$ & $9 \%$ & $8 \%$ \\
$\mathbf{C u}$ & $6 \%$ & $5 \%$ & $9 \%$ & $8 \%$ & $5 \%$ & $-97 \%$ & $0 \%$ \\
$\mathbf{F e}$ & $3 \%$ & $13 \%$ & $0 \%$ & $3 \%$ & $10 \%$ & $-44 \%$ & $9 \%$ \\
$\mathbf{M g}$ & $6 \%$ & $11 \%$ & $-3 \%$ & $5 \%$ & $11 \%$ & $8 \%$ & $11 \%$ \\
$\mathbf{M n}$ & $4 \%$ & $7 \%$ & $10 \%$ & $2 \%$ & $6 \%$ & $-41 \%$ & $-2 \%$ \\
$\mathbf{K}$ & $4 \%$ & $-15 \%$ & $-6 \%$ & $0 \%$ & $6 \%$ & $7 \%$ & $-3 \%$ \\
$\mathbf{S}$ & $7 \%$ & $4 \%$ & $1 \%$ & $6 \%$ & $3 \%$ & $19 \%$ & $-3 \%$ \\
$\mathbf{Z n}$ & $8 \%$ & $5 \%$ & $9 \%$ & $0 \%$ & $10 \%$ & $0 \%$ & $7 \%$ \\
\hline
\end{tabular}

Table 4-13 List of elements with average colloidal concentrations at sampling sites within Lagunas Norte.

\begin{tabular}{|c|c|c|c|c|c|c|c|c|}
\hline & Units & LN-SP3-W & LN-SP3-W2 & LN-DW-B-11-W & LN-DAR-1-W & LN-BP & LN-PW2-W & LN-VWD-W \\
\hline Temperature & ${ }^{\circ} \mathrm{C}$ & 16.33 & 15.15 & 10.82 & 14.83 & 14.04 & 12.99 & 12.68 \\
\hline Ionic Strength & & $9.19 E-03$ & $8.27 \mathrm{E}-02$ & $1.70 \mathrm{E}-02$ & $1.12 \mathrm{E}-01$ & 4.14E-03 & $8.66 \mathrm{E}-03$ & $8.00 \mathrm{E}-02$ \\
\hline \multicolumn{9}{|l|}{ Elements } \\
\hline Al & $\mathrm{ppb}$ & 2,333 & 3,500 & 2,000 & 13,333 & 450 & 0.3 & 10,000 \\
\hline As & $\mathrm{ppb}$ & -8.0 & -2 & 233.3 & -40 & -2.8 & -2.9 & 15 \\
\hline $\mathrm{Ca}$ & ppb & 0.0 & 10,000 & 0.0 & 20,000 & 4,000 & 13,333 & 40,000 \\
\hline $\mathrm{Cu}$ & $\mathrm{ppb}$ & 600.0 & 450 & 10,000 & 1,333 & 200 & -7.9 & 0 \\
\hline $\mathrm{Fe}$ & $\mathrm{ppb}$ & 1,333 & 7,000 & 0.0 & 20,000 & 1500 & -22.0 & 45,000 \\
\hline Mg & $\mathrm{ppb}$ & 1,000 & 2,000 & -100.0 & 6,667 & 300 & 300.0 & 8,000 \\
\hline$M n$ & $\mathrm{ppb}$ & 233 & 400 & 233.3 & 667 & 55 & -2.4 & -500 \\
\hline $\mathrm{K}$ & $\mathrm{ppb}$ & 100.0 & -400 & -66.7 & 0 & 100 & 26.7 & -25 \\
\hline s & $\mathrm{ppb}$ & 20,000 & 150,000 & 3,333 & 100,000 & 150,000 & 833,333 & $-150,000$ \\
\hline $\mathrm{Zn}$ & $\mathrm{ppb}$ & 166.7 & 100 & 433.3 & 0 & 11 & 0 & 500 \\
\hline
\end{tabular}

Filters analyzed by the ESEM did not show any colloids. Only gypsum crystals were observed which had likely precipitated during the drying of the samples before carbon coating. The results are problematic and will be discussed in section 5.1.2.

\subsubsection{PHREEQC modelling}

Data collected from all water samples were modelled using PHREEQC-3, a geochemical speciation model distributed by the US Geological Survey (see section 4.1.4-PHREEQC modelling).Thermodynamic modelling of waters from El Indio, Lagunas Norte and Pierina indicates that various secondary minerals can precipitate, controlling the concentration of certain elements. Saturation indices (SI) of potential 
secondary minerals were identified through PHREEQC-3. A positive SI value is indicative of supersaturation and increased likelihood of precipitation if there are no kinetic barriers. Minerals with positive SI values are listed in Appendix B. Minerals with a simple stoichiometry, reactive nature and stability at near surface conditions, are those most likely to precipitate.

Alunite, $\mathrm{Ba}_{3}\left(\mathrm{AsO}_{4}\right)_{2}$, basaluminite, boehmite, cupric and cuprous ferrite, diaspore, $\mathrm{Fe}(\mathrm{OH})_{2.7} \mathrm{Cl}_{3}$, gibbsite, goethite, hematite, maghemite and magnetite were calculated to have $\mathrm{SI} \geq 0$ from the samples collected from El Indio. Elemental As and Cu, basaluminite, boehmite, cupric and cuprous ferrite, cuprite, diaspore, $\mathrm{Fe}(\mathrm{OH})_{2.7} \mathrm{Cl}_{3}$,goethite, hematite, magnetite, $\mathrm{U}_{4} \mathrm{O}_{9}, \mathrm{UO}_{2}$ (amorphous), and uraninite have $\mathrm{SI}>0$ in the samples collected from Lagunas Norte. Alunite, basaluminite, boehmite, cupric and cuprous ferrite, diaspore, $\mathrm{Fe}(\mathrm{OH})_{2.7} \mathrm{Cl}_{3}$, gibbsite, goethite, hematite, maghemite and magnetite were calculated to have $\mathrm{SI}>0$ from the samples collected from Pierina. The results suggest that precipitates will include phases containing $\mathrm{Fe}, \mathrm{Al}$ and $\mathrm{Cu}$. The results from PHREEQC modelling combined with the results of positively identified secondary precipitates listed in the following section can be used to inform future water treatment plant designs and closure plans.

Analytical methods (i.e XRD, $\mu \mathrm{XRD}, \mu \mathrm{XRF}$, ESEM) were used to identify precipitates, which were mostly sulfates, whereas PHREEQC predicts the precipitation of $\mathrm{Fe}, \mathrm{Cu}$, or Al oxides and oxyhydroxides. Evaporation of these waters, and forward modelling by concentrating waters 20 -fold using PHREEQC generally predict an increase in the number of $\mathrm{Fe}, \mathrm{Al}$ and $\mathrm{Mn}$ oxyhyidroxides, as well as $\mathrm{Cu}$ and $\mathrm{Fe}$ sulfates. An example of forward modeling is observed in Table 4-14 from water samples collected from LN-PW2W. Specifically for waters collected from LN-PW2-W, 17 new minerals are predicted to be oversaturated in waters concentrated 20 times. These minerals include Fe, Al and Mn oxides and oxyhydroxides, as well as Al and Ba sulfates. Only waters collected from sample sites P-WRD and LN-VWD show no oversaturation of new minerals. The list of the oversaturated minerals ( $\mathrm{S} \geq 0$ ConcX1 and ConcX20) are found in Appendix C. 
Table 4-14 List of minerals with SI>0 from waters collected at LN-PW2-W (conc $1 \mathrm{X}$ ) and minerals with SI>0 from 20-fold concentrated waters.

\begin{tabular}{|c|c|c|c|}
\hline \multicolumn{4}{|l|}{ LN-PW2-W } \\
\hline Conc.1X & \multicolumn{3}{|c|}{ Conc.20X } \\
\hline Basaluminite & $\mathrm{Al}_{4}(\mathrm{OH})_{10} \mathrm{SO}_{4}$ & $\mathrm{Al}(\mathrm{OH}) 3(\mathrm{a})$ & \\
\hline Boehmite & $\mathrm{AlOOH}$ & Alunite & $\mathrm{KAl} 3\left(\mathrm{SO}_{4}\right) 2(\mathrm{OH}) 6$ \\
\hline $\mathrm{Cu}$ & & Barite & $\mathrm{BaSO}_{4}$ \\
\hline Cuprite & $\mathrm{Cu}_{2} \mathrm{O}$ & Basaluminite & $\mathrm{Al}_{4}(\mathrm{OH})_{10} \mathrm{SO}_{4}$ \\
\hline CuprousFerrite & $\mathrm{CuFeO}_{2}$ & Boehmite & $\mathrm{AlOOH}$ \\
\hline Diaspore & $\mathrm{AlOOH}$ & Birnessite & $\mathrm{MnO} 2$ \\
\hline Gibbsite & $\mathrm{Al}(\mathrm{OH})_{3}$ & Bixbyite & $\mathrm{Mn} 2 \mathrm{O}_{3}$ \\
\hline UO2(a) & & CuprousFerrite & $\mathrm{CuFeO} 2$ \\
\hline \multirow[t]{13}{*}{ Uraninite } & $\mathrm{UO} 2$ & CupricFerrite & $\mathrm{CuFe} 2 \mathrm{O} 4$ \\
\hline & & Diaspore & $\mathrm{AlOOH}$ \\
\hline & & $\mathrm{Fe}(\mathrm{OH}) 2.7 \mathrm{Cl} .3$ & \\
\hline & & $\mathrm{Fe}(\mathrm{OH}) 3(\mathrm{a})$ & \\
\hline & & Gibbsite & $\mathrm{Al}(\mathrm{OH}) 3$ \\
\hline & & Goethite & $\mathrm{FeOOH}$ \\
\hline & & Hausmannite & $\mathrm{Mn} 3 \mathrm{O}_{4}$ \\
\hline & & Hematite & $\mathrm{Fe}_{2} \mathrm{O} 3$ \\
\hline & & Maghemite & $\mathrm{Fe}_{2} \mathrm{O}_{3}$ \\
\hline & & Magnetite & $\mathrm{Fe}_{3} \mathrm{O}_{4}$ \\
\hline & & Manganite & $\mathrm{MnOOH}$ \\
\hline & & Nsutite & $\mathrm{MnO}_{2}$ \\
\hline & & Pyrolusite & $\mathrm{MnO}_{2}$ \\
\hline
\end{tabular}

\subsection{Geochemical and mineralogical characterization of secondary precipitates}

\subsubsection{Bulk geochemistry}

Solid-phase bulk geochemistry results for major, minor and trace elements of mineral precipitates are plotted in box and whisker diagrams using ioGAS ${ }^{T M}$ (REFLEX $\left.{ }^{\oplus}\right)$ to evaluate and observe variations through sample sites and mine sites (Figure 4-22, Figure 4-24, Figure 4-25).The elements in highest concentration for the secondary precipitates from the El Indio, Lagunas Norte and Pierina mines are in Al, $\mathrm{Ca}, \mathrm{Cu}, \mathrm{Fe}, \mathrm{Mg}, \mathrm{K}, \mathrm{P}, \mathrm{Mn}, \mathrm{Na}, \mathrm{S}$, and $\mathrm{Zn}$. In general, most secondary precipitates at El Indio showed higher average concentrations in $\mathrm{Al}(1.41 \mathrm{wt} \%)$, As (1,143ppm), Fe (10.3 wt\%), Mg (2.09 wt\%), Mn (3,780 ppm), $\mathrm{K}(3,458 \mathrm{ppm}), \mathrm{Na}(4.15 \mathrm{wt} \%), \mathrm{S}(10.8 \mathrm{wt} \%)$ and $\mathrm{Zn}(2,102 \mathrm{ppm})$ than at Lagunas Norte where concentrations may be of magnitude lower for these elements: Al (8,375 ppm), As (196 ppm), Fe (3.87 wt\%), Mg (4,922 ppm), Mn (468 ppm), Na (242 ppm), S (4.72 wt\%), Zn (110 ppm). Pierina demonstrates the second highest concentrations of As (790 ppm), Mn (594 ppm), K (3,202 ppm), Na (262 ppm), S (6.06 
wt\%) and $\mathrm{Zn}(163 \mathrm{ppm})$, the highest average concentration of Fe (15.1 wt\%) and $\mathrm{Pb}(366 \mathrm{ppm})$ and the lowest in $\mathrm{Ca}(2,196 \mathrm{ppm}), \mathrm{Cu}(776 \mathrm{ppm})$ and $\mathrm{Mg}(1,256 \mathrm{ppm})$. For full analytical results, see Appendix E: QAQC solids.

Spearman correlations matrices of concentrations of trace and major metals were created. The major elements included in the matrices are $\mathrm{Al}, \mathrm{Ca}, \mathrm{Cu}, \mathrm{Fe}, \mathrm{K}, \mathrm{Mg}, \mathrm{Na}, \mathrm{P}, \mathrm{Zn}, \mathrm{Mn}$ and $\mathrm{S}$. The trace and minor metals used in the matrices include $\mathrm{Ag}, \mathrm{As}, \mathrm{Cd}, \mathrm{Pb}, \mathrm{Sb}$. Elements that had a majority of concentrations below detection limit were not included due to the lack of absolute values. At El Indio, the trace metals generally demonstrate a moderate (0.40-0.59) to strong correlations (0.60-1.0) with one another. Notably, the strongest (anti)correlations are between Fe and $\mathrm{As}(0.96), \mathrm{Zn}$ and $\mathrm{Cd}(0.92)$, Fe and $\mathrm{Na}(-0.9)$, as well as $\mathrm{Na}$ and $\mathrm{Mg}$ (0.98). Other elements show little correlation, such as $\mathrm{Cd}$ with $\mathrm{Ag}(-0.13)$ and $\mathrm{As}$, or $\mathrm{Cu}$ with $\mathrm{Ag}(-0.076)$. Sb, $\mathrm{Ca}$ and $\mathrm{Ag}$ lack significant correlations. Strong (anti)correlations are observed between $\mathrm{Mg}$ and $\mathrm{As}(-0.84), \mathrm{Na}$ and $\mathrm{As}(-0.84), \mathrm{Cu}$ and $\mathrm{Cd}(0.81), \mathrm{Mn}$ and $\mathrm{Cd}(0.87)$, Fe and $\mathrm{Mg}(-0.89), \mathrm{Pb}$ and $\mathrm{Mg}(-$ $0.81), \mathrm{Zn}$ and $\mathrm{Mn}(0.89)$.

At Lagunas Norte, trace metals demonstrate weak $(<0.39)$ to strong correlations $(>0.60)$. The strongest elemental correlations at Lagunas Norte are between $\mathrm{Zn}$ and $\mathrm{Cd}(0.96), \mathrm{S}$ and $\mathrm{Ni}(0.93)$, As with $\mathrm{Sb}$ (0.89), and $\mathrm{Na}$ with As (0.81). Trace elements at Pierina generally demonstrate moderate (0.40-0.59) to strong correlations (0.60-1.0). Various very strong correlations are observed between elements at Pierina notably between $\mathrm{Al}$ and $\mathrm{Cu}(-0.95), \mathrm{Al}$ and $\mathrm{Ag}$ (0.95), Al and S (-0.95), Cd and $\mathrm{Ca}(1), \mathrm{Cd}$ and $\mathrm{Mg}(1)$, $\mathrm{Cd}$ and $\mathrm{Mn}(1), \mathrm{Cd}$ and $\mathrm{Zn}(1), \mathrm{Ca}$ and $\mathrm{Mg}(1), \mathrm{Ca}$ and $\mathrm{Mn}(1), \mathrm{Fe}$ and $\mathrm{S}(1), \mathrm{Pb}$ and $\mathrm{Ni}(1), \mathrm{Pb}$ and $\mathrm{P}(0.95)$, $\mathrm{Mn}$ and $\mathrm{Zn}(1), \mathrm{Mg}$ and $\mathrm{Zn}(1), \mathrm{Ni}$ and $\mathrm{Ag}(-1), \mathrm{K}$ and $\mathrm{Na}(-1), \mathrm{Ag}$ and $\mathrm{S}$. The standard errors are considered in the discussion section. 
Table 4-15 Spearman correlation matrix of major, minor and trace elements of interest, from secondary precipitates digested by aqua regia and analysed by ICP-OES at El Indio. Coloured cells are indicative of correlation coefficients $\geq 0.80$ (pink) or $\geq 0.9$ (red).

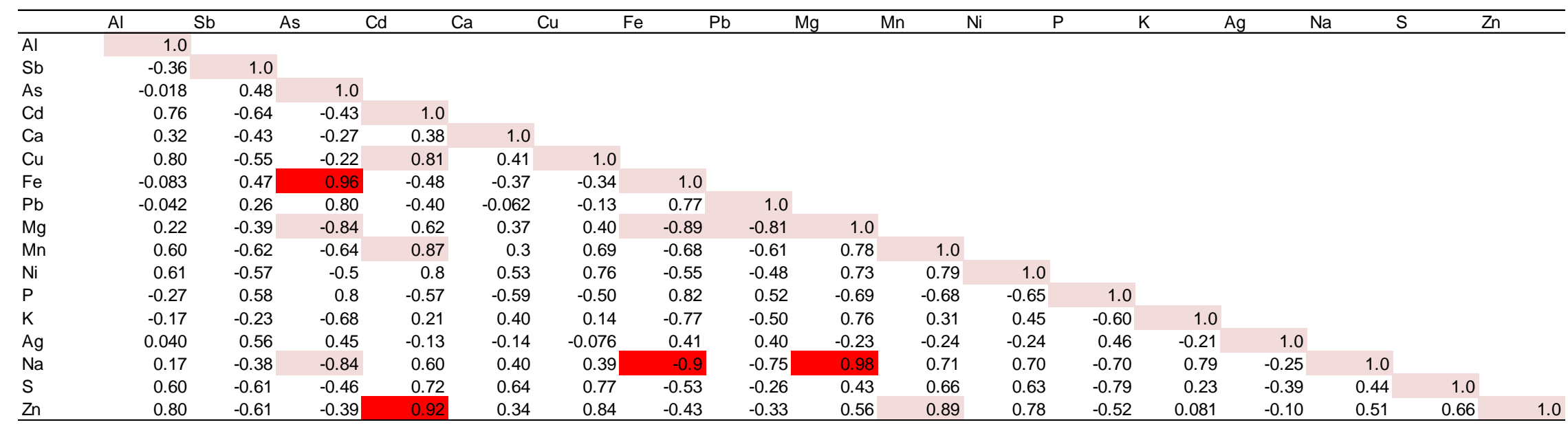


Table 4-16 Spearman correlation matrix of major, minor and trace elements of interest, from secondary precipitates digested by aqua regia and analysed by ICP-OES at Lagunas Norte. Coloured cells are indicative of correlation coefficients $\geq 0.80$ (pink) or $\geq 0.9$ (red).

\begin{tabular}{|c|c|c|c|c|c|c|c|c|c|c|c|c|c|c|c|c|c|}
\hline & $\mathrm{Al}$ & $\mathrm{Sb}$ & As & $\mathrm{Cd}$ & $\mathrm{Ca}$ & $\mathrm{Cu}$ & $\mathrm{Fe}$ & $\mathrm{Pb}$ & $\mathrm{Mg}$ & $\mathrm{Mn}$ & $\mathrm{Ni}$ & $\mathrm{P}$ & $\mathrm{K}$ & $\mathrm{Ag}$ & $\mathrm{Na}$ & $S$ & $\mathrm{Zn}$ \\
\hline $\mathrm{Al}$ & 1.0 & & & & & & & & & & & & & & & & \\
\hline $\mathrm{Sb}$ & -0.13 & 1.0 & & & & & & & & & & & & & & & \\
\hline As & -0.018 & 0.89 & 1.0 & & & & & & & & & & & & & & \\
\hline $\mathrm{Cd}$ & 0.054 & 0.21 & 0.11 & 1.0 & & & & & & & & & & & & & \\
\hline $\mathrm{Ca}$ & 0.18 & -0.36 & -0.36 & 0.36 & 1.0 & & & & & & & & & & & & \\
\hline $\mathrm{Cu}$ & -0.59 & 0.43 & 0.18 & 0.71 & 0.01 & 1.0 & & & & & & & & & & & \\
\hline $\mathrm{Fe}$ & 0.13 & 0.36 & 0.61 & 0.29 & -0.11 & 0.071 & 1.0 & & & & & & & & & & \\
\hline $\mathrm{Pb}$ & 0.23 & 0.71 & 0.68 & 0.071 & -0.39 & 0.071 & 0.64 & 1.0 & & & & & & & & & \\
\hline $\mathrm{Mg}$ & 0.67 & -0.61 & -0.5 & 0.010 & 0.75 & -0.57 & -0.21 & -0.39 & 1.0 & & & & & & & & \\
\hline $\mathrm{Mn}$ & 0.67 & -0.32 & -0.071 & 0.46 & 0.50 & -0.25 & 0.32 & -0.18 & 0.68 & 1.0 & & & & & & & \\
\hline $\mathrm{Ni}$ & -0.17 & -0.31 & -0.71 & 0.54 & 0.086 & 0.66 & -0.6 & -0.43 & -0.086 & -0.029 & 1.0 & & & & & & \\
\hline$P$ & -0.66 & -0.49 & -0.31 & -0.14 & 0.37 & -0.086 & 0.029 & -0.66 & 0.086 & 0.086 & -0.3 & 1.0 & & & & & \\
\hline $\mathrm{K}$ & 0.67 & 0.071 & 0.39 & -0.14 & 0.29 & -0.64 & 0.46 & 0.25 & 0.54 & 0.61 & -0.77 & -0.029 & 1.0 & & & & \\
\hline $\mathrm{Ag}$ & -0.31 & 0.70 & 0.30 & 0.70 & 0.80 & 0.70 & 0.10 & 0.50 & -0.20 & -0.30 & 0.40 & -0.40 & -0.10 & 1.0 & & & \\
\hline $\mathrm{Na}$ & -0.24 & 0.63 & 0.81 & 0.41 & -0.036 & 0.41 & 0.77 & 0.41 & -0.41 & 0.16 & -0.64 & 0.20 & 0.31 & 0.21 & 1.0 & & \\
\hline S & -0.56 & -0.27 & -0.45 & 0.59 & 0.40 & 0.74 & -0.20 & -0.49 & -0.09 & -0.018 & 0.93 & 0.43 & -0.67 & 0.62 & 0.018 & 1.0 & \\
\hline $\mathrm{Zn}$ & 0.13 & 0.43 & 0.32 & 0.96 & 0.32 & 0.68 & 0.36 & 0.25 & -0.036 & 0.43 & 0.31 & -0.31 & $2.40 \mathrm{E}-17$ & 0.70 & 0.52 & 0.41 & 1.0 \\
\hline
\end{tabular}


Table 4-17 Spearman correlation matrix of major, minor and trace elements of interest, from secondary precipitates digested by aqua regia and analysed by ICP-OES at Pierina. Coloured cells are indicative of correlation coefficients $\geq 0.80$ (pink) or $\geq 0.9$ (red).

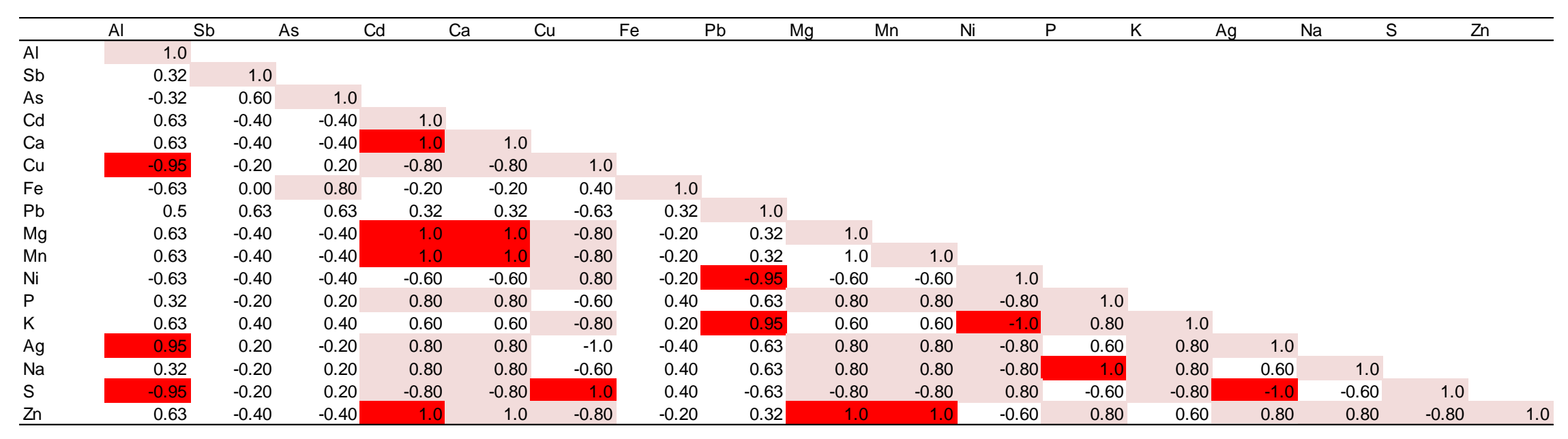




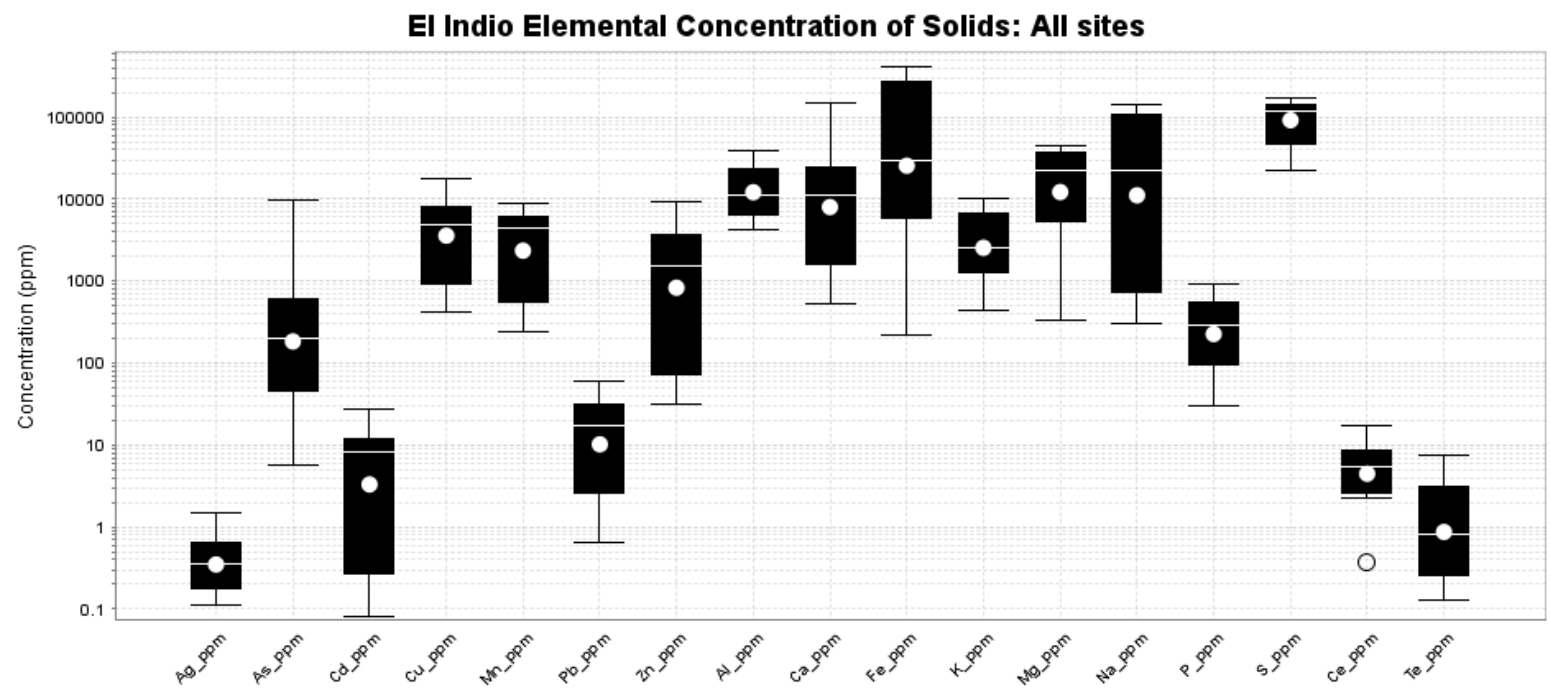

Figure 4-22 Concentration of elements $\mathrm{Ag}, \mathrm{As}, \mathrm{Cd}, \mathrm{Cu}, \mathrm{Mn}, \mathrm{Pb}, \mathrm{Zn}, \mathrm{Al}, \mathrm{Cu}, \mathrm{Fe}, \mathrm{K}, \mathrm{Mg}, \mathrm{Na}, \mathrm{P}, \mathrm{S}, \mathrm{Ca}$, Te of all sampling sites at El Indio, in ppm and on a box and whisker diagram. The highest concentrations are $\mathrm{S}, \mathrm{Fe}, \mathrm{Ca}, \mathrm{Na}$ and $\mathrm{Al}$.

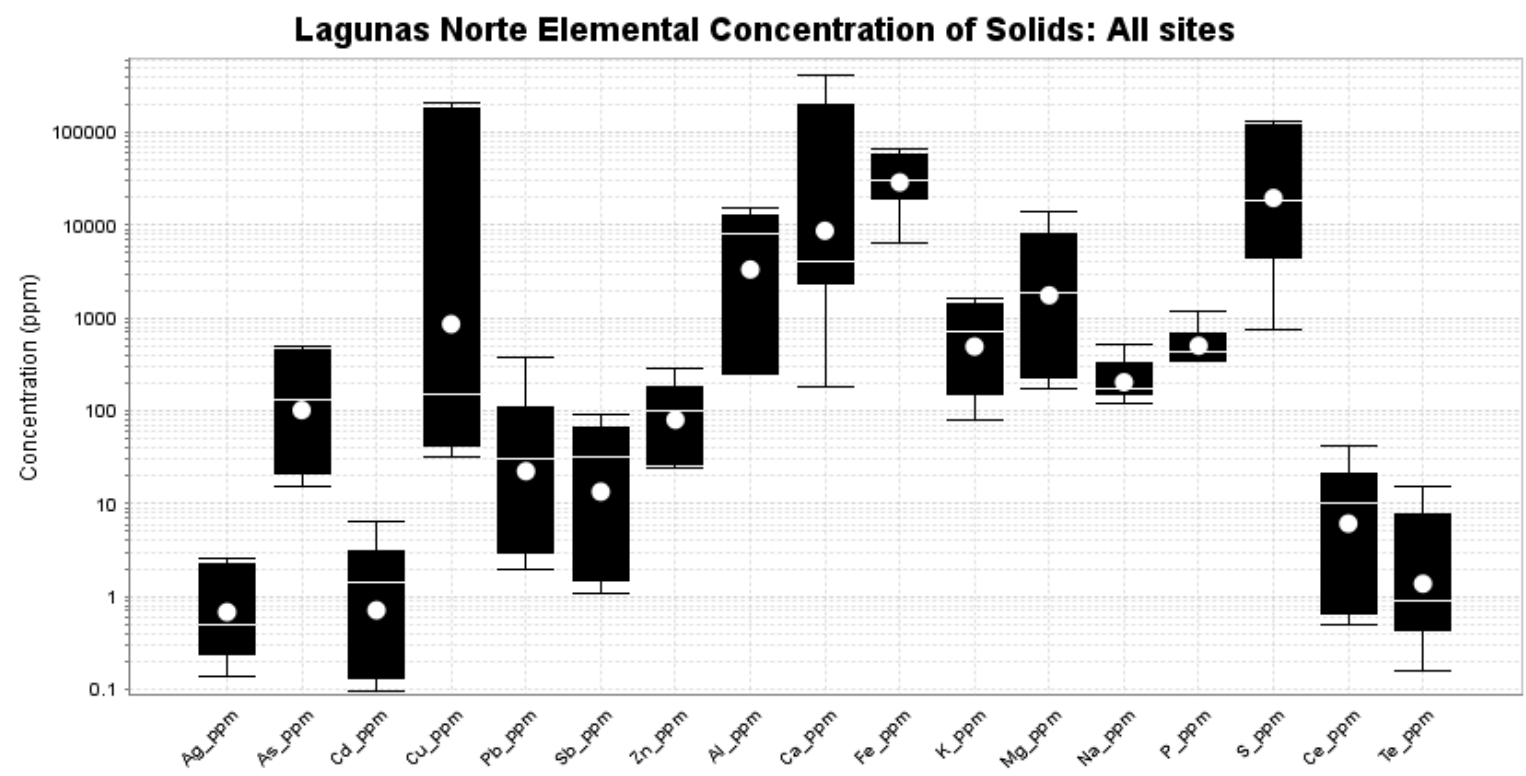

Figure 4-23 Concentration of elements $\mathrm{Ag}, \mathrm{As}, \mathrm{Cd}, \mathrm{Cu}, \mathrm{Mn}, \mathrm{Pb}, \mathrm{Zn}, \mathrm{Al}, \mathrm{Cu}, \mathrm{Fe}, \mathrm{K}, \mathrm{Mg}, \mathrm{Na}, \mathrm{P}, \mathrm{S}, \mathrm{Ca}$, Te of all sampling sites at Lagunas Norte, in ppm and on a box and whisker diagram. The highest concentrations are $\mathrm{S}, \mathrm{Fe}, \mathrm{Ca}, \mathrm{Cu}$ and Al. 


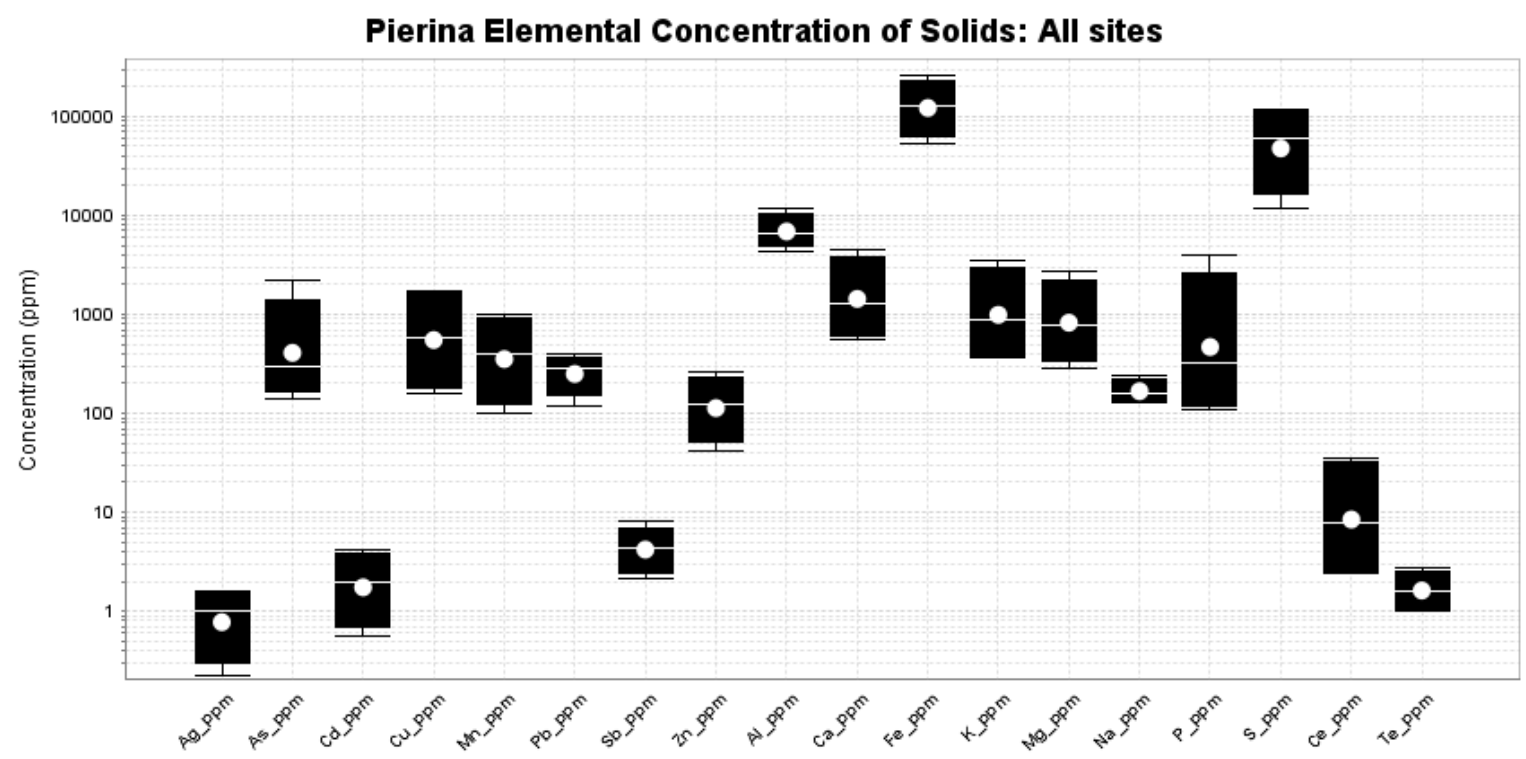

Figure 4-24 Concentration of elements $\mathrm{Ag}, \mathrm{As}, \mathrm{Cd}, \mathrm{Cu}, \mathrm{Mn}, \mathrm{Pb}, \mathrm{Zn}, \mathrm{Al}, \mathrm{Cu}, \mathrm{Fe}, \mathrm{K}, \mathrm{Mg}, \mathrm{Na}, \mathrm{P}, \mathrm{S}, \mathrm{Ca}$, Te of all sampling sites at Pierina, in ppm and on a box and whisker diagram. The highest concentrations are $\mathrm{S}, \mathrm{Fe}$, and $\mathrm{Al}$.

\subsubsection{Site-specific chemistry}

\subsubsection{El Indio}

\subsection{IN28}

These secondary precipitates were collected close to the San Pablo tunnel, a closed tunnel downstream from the tailings (Figure 3-3, Figure 3-4). Since few secondary precipitates were visible at the tunnel's entrance, samples were collected on an adjacent hill, approximately 100 meters away. Seepage waters, assumed to be similar to those emerging from the tunnel, produced abundant precipitates in this area. Several different colours of precipitate were collected in plastic wrap including white, yellow, dark yellow, and black crust.

X-ray diffraction allowed for the occurrence of a member of the halortichite group, possibly dietrichite $\left(\mathrm{ZnAl}_{2}\left(\mathrm{SO}_{4}\right)_{4} \cdot 22\left(\mathrm{H}_{2} \mathrm{O}\right)\right)$, based on the presence of $\mathrm{Zn}$, and a copiapite group mineral, likely magnesiocopiapite $\left(\mathrm{MgFe}_{4}\left(\mathrm{SO}_{4}\right)_{6}(\mathrm{OH})_{2} \cdot 20\left(\mathrm{H}_{2} \mathrm{O}\right)\right)$ because of the high $\mathrm{Mg}$ content at IN28-P2, possible dietrichite $\left(\mathrm{ZnAl}_{2}\left(\mathrm{SO}_{4}\right)_{4} \cdot 22\left(\mathrm{H}_{2} \mathrm{O}\right)\right)$, melanterite $\left(\mathrm{FeSO}_{4} \cdot 7\left(\mathrm{H}_{2} \mathrm{O}\right)\right)$ and magnesiocopiapite $\left(\mathrm{MgFe}_{4}\left(\mathrm{SO}_{4}\right)_{6}(\mathrm{OH})_{2} \cdot 20\left(\mathrm{H}_{2} \mathrm{O}\right)\right)$ at IN28-P3, finally, only quartz $\left(\mathrm{SiO}_{2}\right)$ at IN28-P4 (Table 4-20). 
The occurrences of these minerals are based on the chemistry analyzed by Analytical Services Unit at Queen's University, physical properties of the sample such as colour and XRD analyses (Figure 4-25). IN28-P2 is a bright yellow colour and its highest concentrations are $\mathrm{Al}, \mathrm{Mg}, \mathrm{Zn}$, and $\mathrm{S}$. For this sample magnesiocopiapite was identified based on colour, elemental concentration and XRD peak matching. Magnesiocopiapite is a typical secondary mineral that forms by the oxidation of pyrite (Lottermoser, 2010c; Hammarstrom et al., 2005). Based on this information, both are likely to form in this setting. IN28P3 is a lighter coloured sample and contains an additional mineral, melanterite, an Fe oxy-hydroxide. Because IN28-P4 is black, it likely contains Fe or Mn-oxides; however, these minerals may not show XRD patterns because of their amorphous nature. In fact, only quartz is identified and ICP-OES data does demonstrate elevated concentrations of $\mathrm{Fe}$, as well as $\mathrm{Cu}, \mathrm{S}$, and As.

Thin sections from samples IN28-P2 and IN28-P4 were analyzed by $\mu$ XRD (Figure 4-27, Figure 4-26) and ESEM (Figure 4-28), and MSP of sample IN28-P2 were analyzed by ESEM. The minerals identified by $\mu \mathrm{XRD}$ are compared to those identified from XRD in Table 4-18 and Table 4-19. Potassium-rich and Narich end members of the alunite group, jarosite and natrojarosite were potentially identified based on $\mu \mathrm{XRD}$ and chemistry data. At least 5 distinct phases were identified from the MSP stubs, clearly demonstrating differing morphology and chemistry: (1) desiccated mass of Al sulfate (2) platy aggregates of interpreted magnesiocopiapite (3) granules of $\mathrm{Na} \mathrm{Mg}$ sulfate (4) tabular $\mathrm{Na} \mathrm{Mg}$ sulfate (5) anhedral Fe sulfate phase. Because ESEM analysis is semi-quantitative, only general chemical formulae of minerals are known with hydration states left unknown. As such, in Table 4-18, all probable occurrences of minerals are identified in the column labelled "ESEM". Magnesiocopiapite is the only common phase between the 4 analytical methods in sample IN28-P2 and quartz the only common phase between 3 analytical methods in sample IN28-P4. Dietrichite is only potentially identified with the XRD and the presence of $\mathrm{Zn}$, and a Na Mg phase is identified on the MSP using the ESEM. 


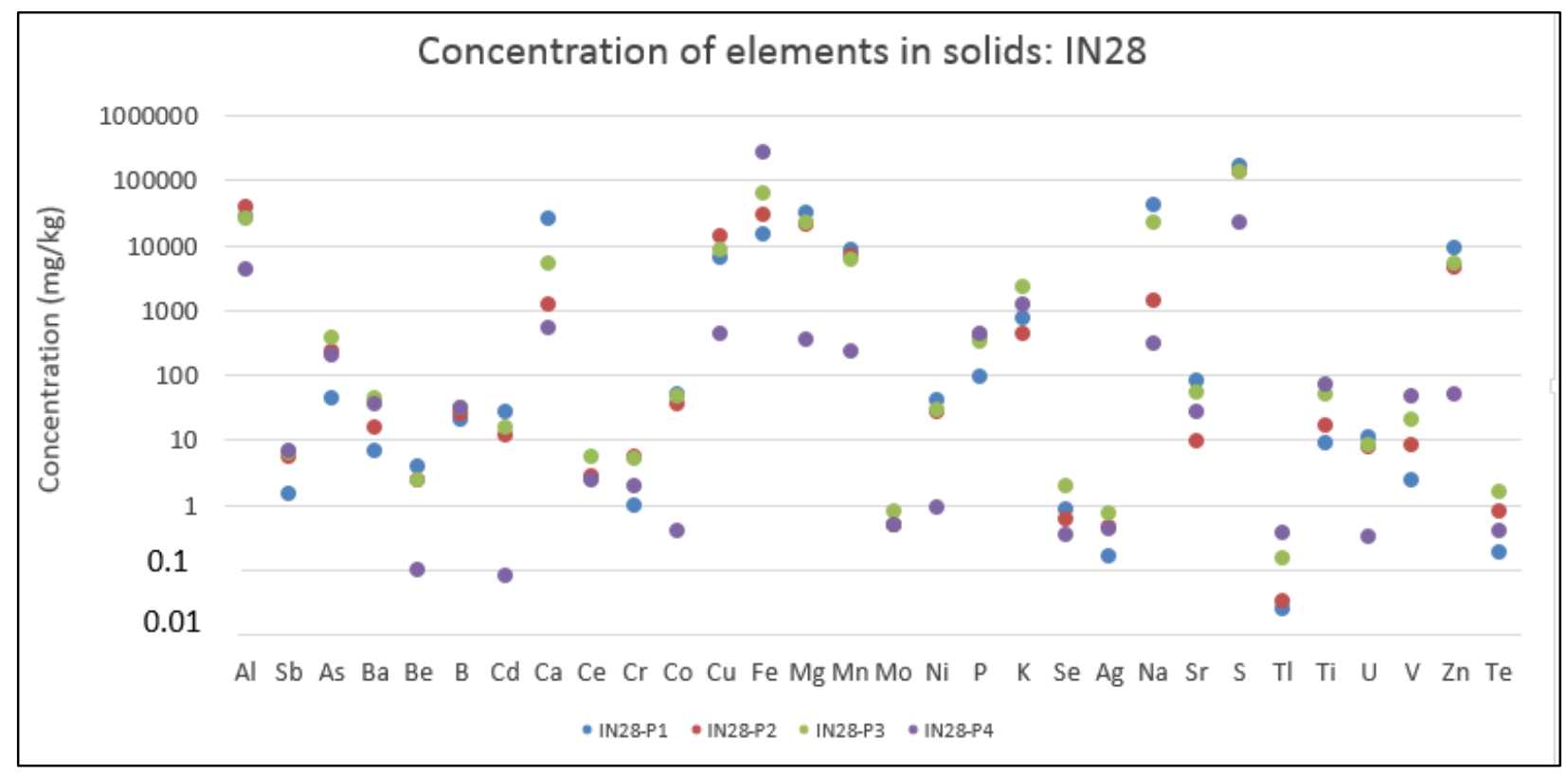

Figure 4-25 Concentrations in $\mathrm{mg} / \mathrm{kg}$ of elements in samples IN28-P1, IN-28-P2, IN-28-P3 and IN28-P4 as measured by

ICP-OES.
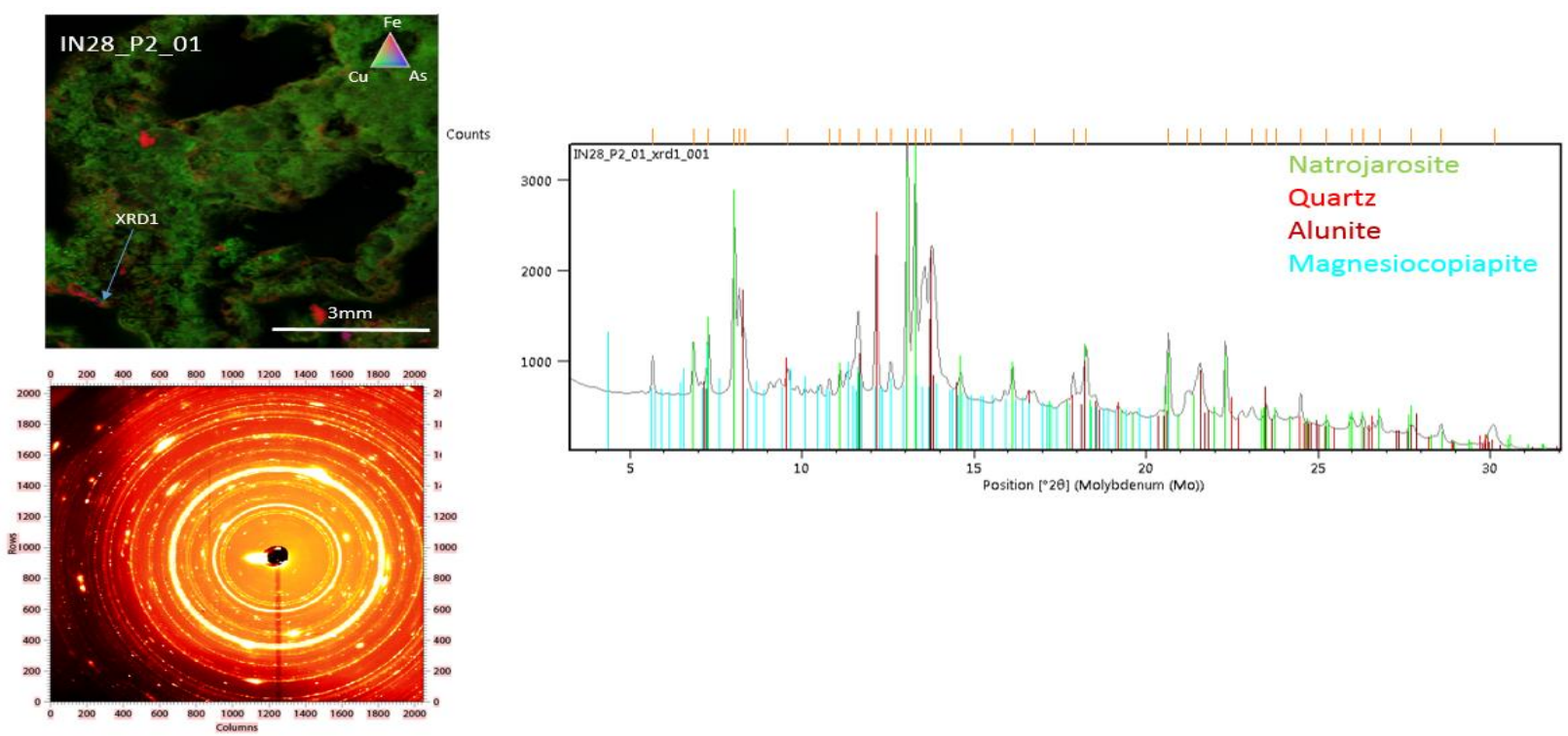

Figure 4-26 $\mu$ XRD 2D diffraction pattern (bottom left) of natrojarosite, quartz, alunite and magnesiocopiapite. The associated 1D diffraction pattern with matched mineral profiles is on the right. 

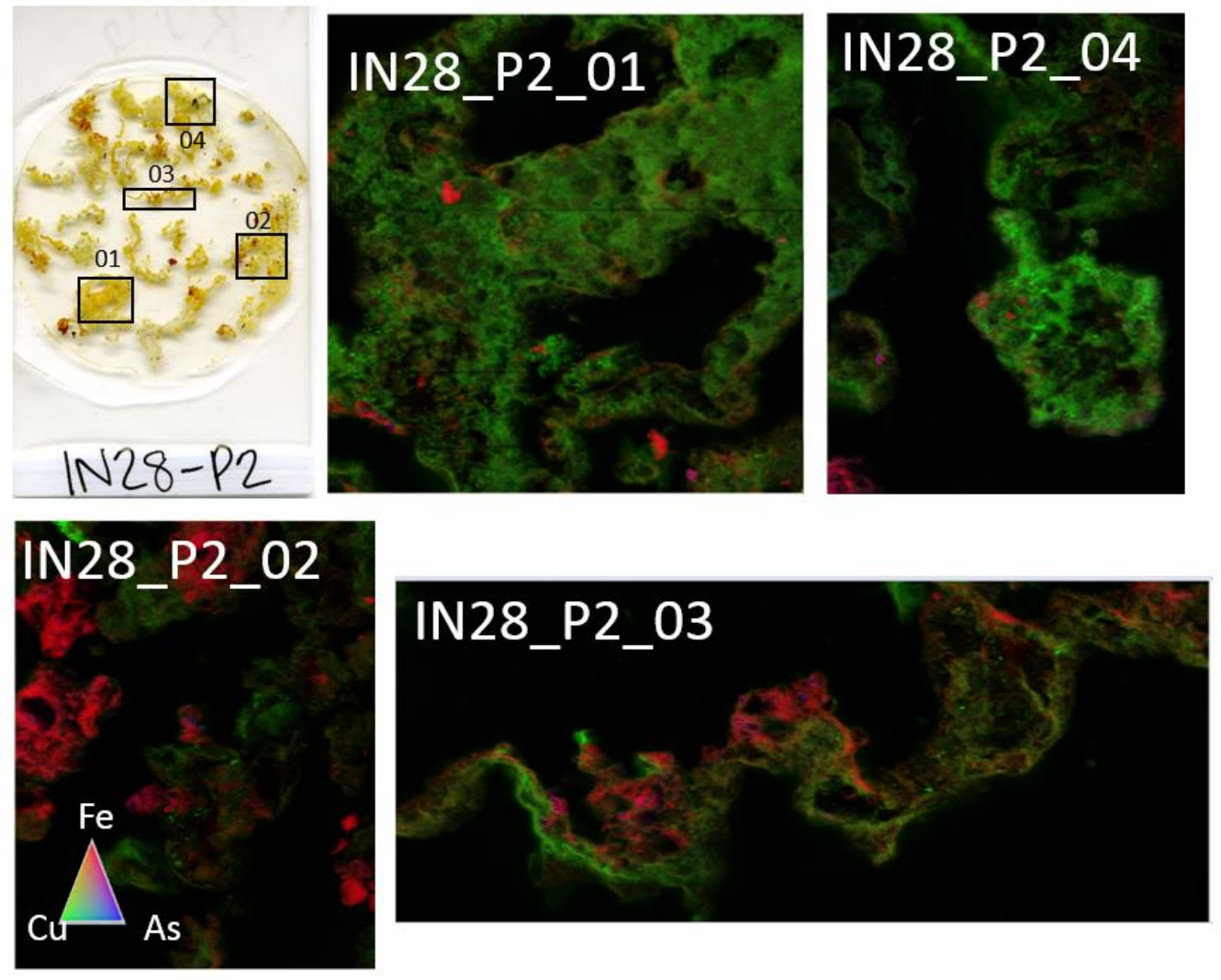

Figure 4-27 $\mu$ XRD elemental maps collected on thin section IN28-P2.

Table 4-18 List of minerals identified at IN28-P2 with $\mu$ XRD methods at the synchrotron, bulk XRD and ESEM.

\begin{tabular}{|c|c|c|c|c|}
\hline \multirow{2}{*}{$\frac{\text { IN28-P2 }}{\text { Minerals }}$} & \multicolumn{4}{|c|}{ Identification Method } \\
\hline & Formula & XRD & $\mu \mathrm{XRD}$ & ESEM \\
\hline Natrojarosite & $\mathrm{NaFe}_{3}\left(\mathrm{SO}_{4}\right)_{2}(\mathrm{OH})_{6}$ & & $x$ & $x$ \\
\hline Jarosite & $\mathrm{KFe}_{3}^{3+}(\mathrm{OH})_{6}\left(\mathrm{SO}_{4}\right)_{2}$ & & $x$ & $x$ \\
\hline Natroalunite & $\left(\mathrm{Na}_{0.75} \mathrm{~K}_{0.25}\right) \mathrm{Al}_{3}\left(\mathrm{SO}_{4}\right)_{2}(\mathrm{OH})_{6}$ & & $x$ & \\
\hline Magensiocopiapite & $\mathrm{MgFe}_{4}\left(\mathrm{SO}_{4}\right)_{6}(\mathrm{OH})_{2} \cdot 2 \mathrm{O}\left(\mathrm{H}_{2} \mathrm{O}\right)$ & $x$ & $x$ & $x$ \\
\hline Muscovite & $\mathrm{KAl}_{2} \mathrm{Si}_{3} \mathrm{AlO}_{10}(\mathrm{OH})_{2}$ & & $x$ & \\
\hline Hexahydrite & $\mathrm{Mg}\left(\mathrm{SO}_{4}\right) \cdot 6\left(\mathrm{H}_{2} \mathrm{O}\right)$ & & $x$ & \\
\hline Goethite & $\mathrm{FeO}(\mathrm{OH})$ & & $x$ & $x$ \\
\hline Alunogen & $\mathrm{Al}_{2}\left(\mathrm{SO}_{4}\right)_{3} \cdot 17\left(\mathrm{H}_{2} \mathrm{O}\right)$ & & $x$ & $x$ \\
\hline Dietrichite (?) & $\mathrm{ZnAl}_{2}\left(\mathrm{SO}_{4}\right)_{4} \cdot 22\left(\mathrm{H}_{2} \mathrm{O}\right)$ & $x$ & & \\
\hline Na Mg sulfate & & & & $x$ \\
\hline
\end{tabular}



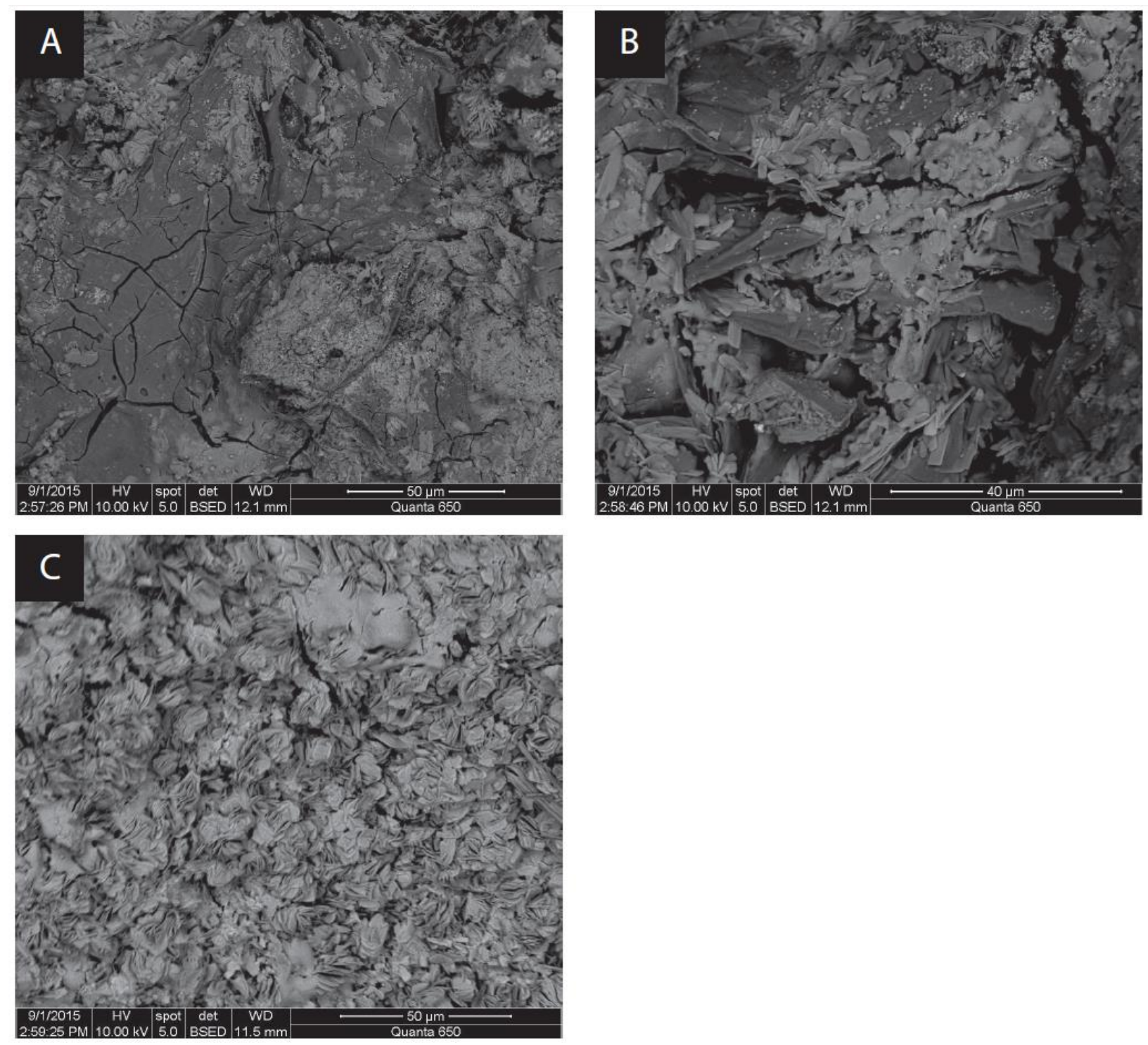

Figure 4-28 ESEM images of sample IN28-P2. (A) Desiccated mass of Al sulfate alongside platy aggregates of interpreted magnesiocopiapite and granules of $\mathrm{Na} \mathrm{Mg}$ sulfate. (B) Anhedral to subhedral tabular $\mathrm{Na} \mathrm{Mg}$ sulfate and darker anhedral Fe sulfate phase. (C) Amalgamation of platy probable magnesiocopiapite crystallites. 


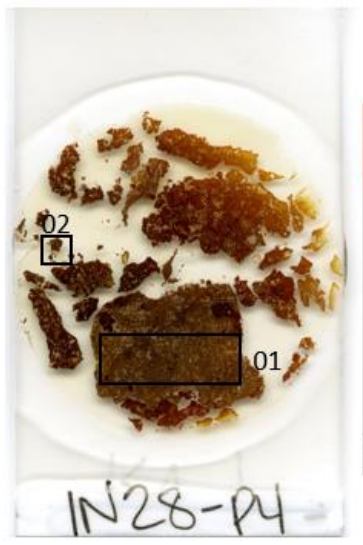

\section{IN28_P4_01}

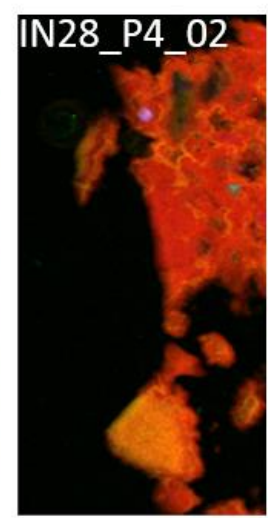

Figure 4-29 $\mu$ XRD elemental maps collected on thin section IN28-P4.

Table 4-19 List of minerals identified on thin section IN28-P4 through $\mu$ XRD bulk XRD and ESEM analyses.

\begin{tabular}{ccccc}
\hline IN28-P4 & \multicolumn{3}{c}{ Identification Method } \\
Minerals & Formula & XRD & $\mu$ XRD & ESEM \\
\hline Goethite & $\mathrm{FeO}(\mathrm{OH})$ & $\mathrm{x}$ & $\mathrm{x}$ & $\mathrm{x}$ \\
Quartz & $\mathrm{SiO}_{2}$ & $\mathrm{x}$ & $\mathrm{x}$ \\
Alunite & $\mathrm{KAl}_{3}\left(\mathrm{SO}_{4}\right)_{2}(\mathrm{OH})_{6}$ & $\mathrm{x}$ & $\mathrm{x}$ \\
Muscovite & $\mathrm{KAl}_{2} \mathrm{Si}_{3} \mathrm{AlO}_{10}(\mathrm{OH})_{2}$ & $\mathrm{x}$ & $\mathrm{x}$ \\
Anhydrite & $\mathrm{Ca}\left(\mathrm{SO}_{4}\right)$ & $\mathrm{x}$ & $\mathrm{x}$ \\
Jarosite & $\mathrm{KFe}_{3}{ }_{3}(\mathrm{OH})_{6}\left(\mathrm{SO}_{4}\right)_{2}$ & $\mathrm{x}$ & $\mathrm{x}$ \\
Scorodite & $\mathrm{Fe}\left(\mathrm{AsO}_{4}\right) \cdot 2\left(\mathrm{H}_{2} \mathrm{O}\right)$ & & &
\end{tabular}

\subsection{IN-RMATR}

Secondary precipitates were collected upstream of the settling pond (Figure 3-3). Mine waters enter the settling pond in order to remove turbidity from tunnel waters, specifically particles containing $\mathrm{Fe}, \mathrm{As}$ and $\mathrm{Cu}$. Samples collected include abundant and varied precipitates collected along the stream edge on both sides of the road including white (IN-RMATR-P1), yellow (IN-RMATR-P2), blackish (INRMATR-P3), pinkish (IN-RMATR-P4), greenish (IN-RMATR-P5) and water-saturated Fe oxides (IN-RMATRFeOx1, IN-RMATR-FeOx2).

The occurrences of these minerals are based on the bulk chemistry, physical properties of the sample such as colour and XRD analyses. Potassium and $\mathrm{Na}$ endmembers of the alum group, alum-Na 
$\left(\mathrm{NaAl}\left(\mathrm{SO}_{4}\right)_{2} \cdot 12\left(\mathrm{H}_{2} \mathrm{O}\right)\right)$, alum-K $\left(\mathrm{K}\left(\mathrm{Al}\left(\mathrm{SO}_{4}\right)_{2} \cdot 12\left(\mathrm{H}_{2} \mathrm{O}\right)\right)\right.$, as well as gypsum $\left(\mathrm{Ca}\left(\mathrm{SO}_{4}\right) \cdot 2\left(\mathrm{H}_{2} \mathrm{O}\right)\right)$, alunogen $\left(\mathrm{Al}_{2}\left(\mathrm{SO}_{4}\right)_{3} \cdot 17\left(\mathrm{H}_{2} \mathrm{O}\right)\right)$ and scorodite $\left(\mathrm{FeAsO}_{4} \cdot 2\left(\mathrm{H}_{2} \mathrm{O}\right)\right)$ are the minerals likely present in IN-RMATR-P1 (Table 4-20). A mineral from the copiapite group, likely magnesiocopiapite $\left(\mathrm{MgFe}_{4}\left(\mathrm{SO}_{4}\right)_{6}(\mathrm{OH})_{2} \cdot 2 \mathrm{O}\left(\mathrm{H}_{2} \mathrm{O}\right)\right)$, quartz $\left(\mathrm{SiO}_{2}\right)$, gypsum $\left(\mathrm{CaSO}_{4} \cdot 2\left(\mathrm{H}_{2} \mathrm{O}\right)\right)$, alunogen $\left(\mathrm{Al}_{2}\left(\mathrm{SO}_{4}\right)_{3} \cdot 17\left(\mathrm{H}_{2} \mathrm{O}\right)\right)$ and scorodite $\left(\mathrm{FeAsO}_{4} \cdot 2\left(\mathrm{H}_{2} \mathrm{O}\right)\right)$ are identified in RMATR-P2. Only quartz and gypsum are observed in RMATR-P3 and RMATR-P4 respectively (Table 420).

The most concentrated elements in RMATR-P1 and RMATR-P2 include Al, As, Ca, Mg, Fe, S (Figure 4-30). Alum is a common mineral formed at HS epithermal deposits as a result of sulfide mineral oxidation (Szakáll et al., 1997). Alunogen forms by reaction of sulfates from decomposing sulfides with aluminous minerals in pyritic deposits (Schindler et al., 2006; Keith et al., 2001; Keith, D. C., Runnells, 1998; Buckby et al., 2003). Scorodite is a common secondary mineral formed by the oxidation of arsenopyrite or other arsenic-bearing minerals (Charykova et al., 2010; Cheng et al., 2009; Camus, 1990; Bowell et al., 2000; Jamieson, 2011). RMATR-P4 is beige, and thus may contain quartz and gypsum, as suggested from the bulk XRD results; however, amorphous minerals that could not be identified with XRD may also be present. RMATR-P3 and RMATR-P5 have high concentrations of $\mathrm{Al}, \mathrm{Ca}, \mathrm{Cu}, \mathrm{Fe}, \mathrm{Mg}, \mathrm{Mn}, \mathrm{S}$, and $\mathrm{Zn}$. These minerals 
containing these elements have not been identified by XRD due to their amorphous nature.

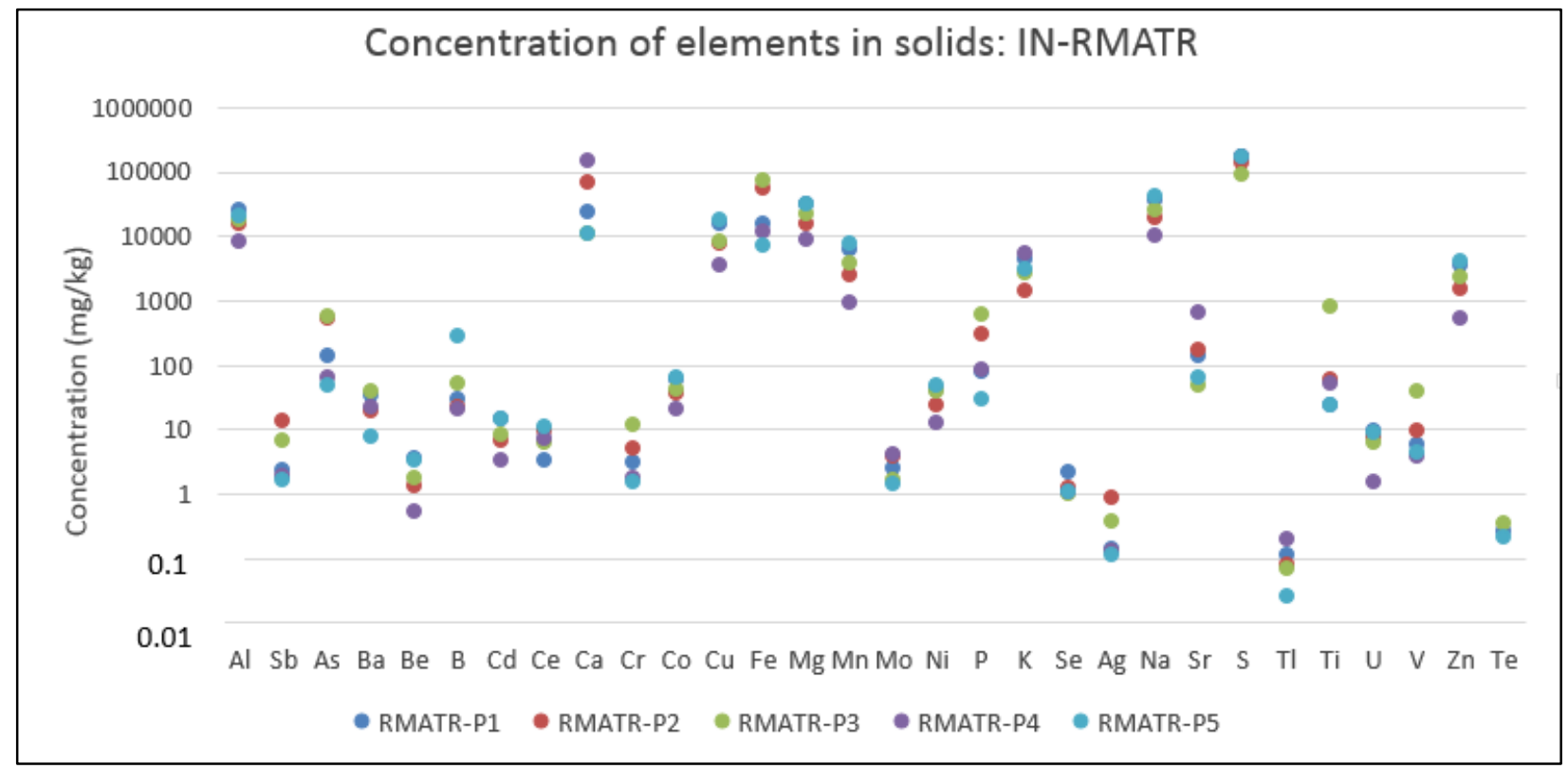

Figure 4-30 Concentrations of samples RMATR-P1, RMATR-P2, RMATR-P3, RMATR-P4 and RMATR-P5 from El Indio through ICP-OES analysis.

\subsection{IN2}

These secondary precipitates were collected from mine drainage waters downstream of the settling pond. Precipitates were not quite as abundant as the previous two sites and include black and brownish samples. Bulk XRD results have identified quartz $\left(\mathrm{SiO}_{2}\right)$ and albite $\left(\mathrm{Na}\left(\mathrm{AlSi}_{3} \mathrm{O}_{8}\right)\right)$ in IN2-P1. Quartz, albite $\left(\mathrm{Na}\left(\mathrm{AlSi}_{3} \mathrm{O}_{8}\right)\right)$ and alunite $\left(\mathrm{K}\left(\mathrm{Al}_{3}\left(\mathrm{SO}_{4}\right)_{2}(\mathrm{OH})_{6}\right)\right)$ were the main minerals in IN2-P2, and jarosite $\left(\mathrm{KFe}^{3+}{ }_{3}(\mathrm{OH})_{6}\left(\mathrm{SO}_{4}\right)_{2}\right)$, alum-Na $\left(\mathrm{NaAl}\left(\mathrm{SO}_{4}\right)_{2} \cdot 12\left(\mathrm{H}_{2} \mathrm{O}\right)\right)$, epsomite $\left(\mathrm{Mg}\left(\mathrm{SO}_{4}\right) \cdot 7\left(\mathrm{H}_{2} \mathrm{O}\right)\right)$ and gypsum $\left(\mathrm{Ca}\left(\mathrm{SO}_{4}\right) \cdot 2\left(\mathrm{H}_{2} \mathrm{O}\right)\right)$ were positively identified in IN2-P3 (Table 4-20).

IN2-P1 shows highest concentrations in Al, As, Fe, S, K, Ti (Figure 4-31). IN2-P2 and IN2-P3 demonstrate highest concentrations in $\mathrm{Al}, \mathrm{As}, \mathrm{Ca}, \mathrm{Fe}, \mathrm{Mg}, \mathrm{K}, \mathrm{S}, \mathrm{Ti}$ (Figure 4-31). Albite and quartz are common minerals found in HS epithermal deposits (Hedenquist et al., 2000). Alunite is a common alteration mineral in these types of deposits, and alum is a common mineral formed from sulfide mineral oxidation (Szakáll et al., 1997). Espomite is a secondary mineral that is often found growing on the walls of metal mines through sulfide oxidation (Jambor et al., 2000; Steiger et al., 2011; Sracek et al., 
2010; Matýsek et al., 2014; Buckby et al., 2003; Jamieson et al., 2015)

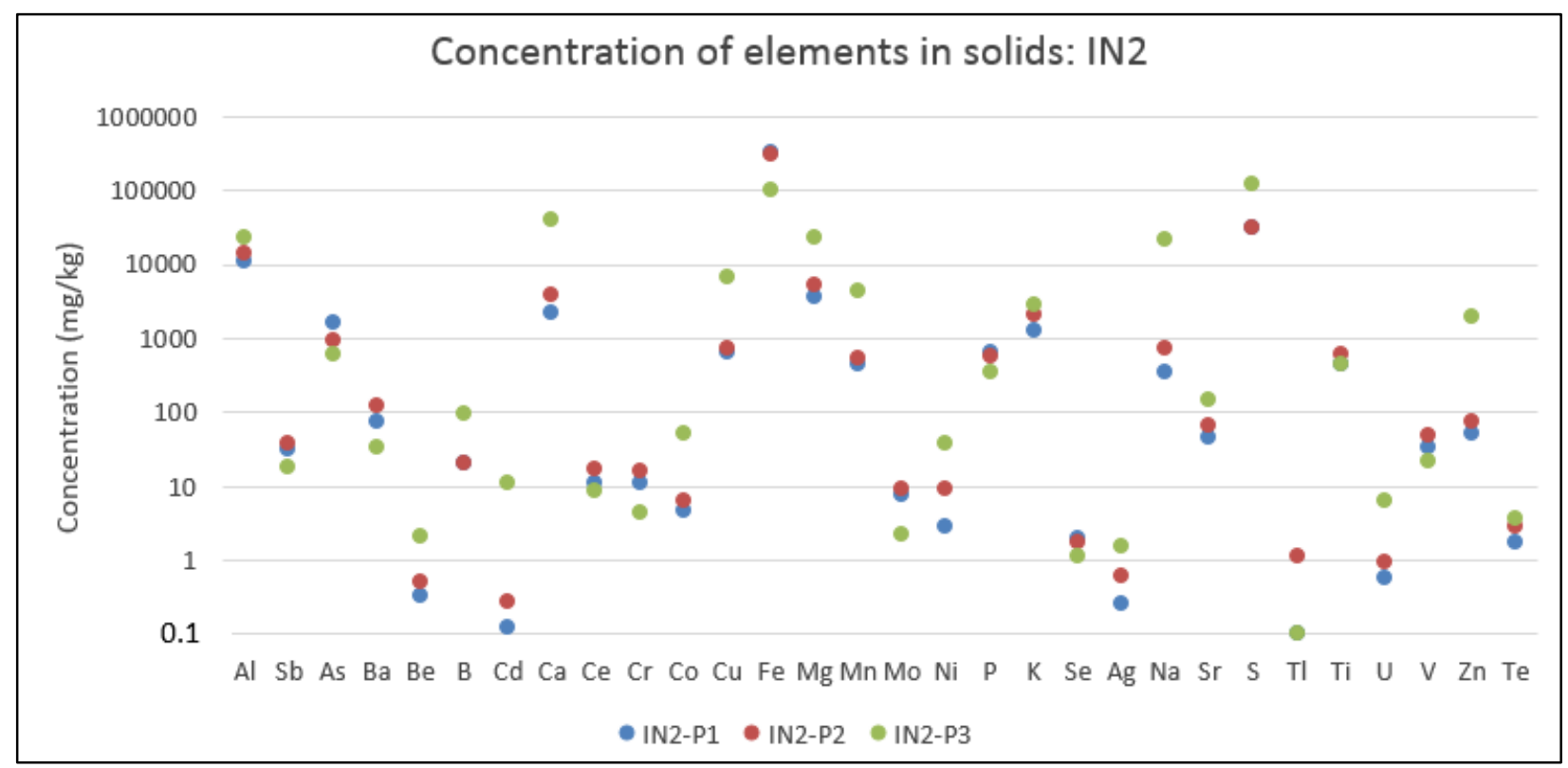

Figure 4-31 Concentration of elements in solid samples IN2-P1, IN2-P2, and IN2-P3 with ICP-OES anaylsis.

\subsection{IN13}

Secondary precipitates were collected from mine drainage waters furthest downstream from the settling pond. This site demonstrates the most variety of mineral precipitates in terms of colour. Pink/brick-red spheres/rosettes (IN13-P4), mint green smooth-surfaced crusts (IN13-P5 \& IN13-P2), yellowish crusts that turn to powder when handled (IN13-P3), and the pure white crusts were found at this location IN13-P1. Two samples of the yellow material were taken as they looked slightly different.

IN13-P1 has elevated concentrations of $\mathrm{Al}, \mathrm{Ca}, \mathrm{Cu}, \mathrm{Fe}, \mathrm{K}, \mathrm{Mg}, \mathrm{Na}, \mathrm{P}$ (Figure 4-32). IN13-P2 demonstrates high amounts of $\mathrm{Al}, \mathrm{Ca}, \mathrm{Cu}, \mathrm{K}, \mathrm{Mg}, \mathrm{Mn}, \mathrm{Na}, \mathrm{S}, \mathrm{Zn} . \mathrm{Al}, \mathrm{B}, \mathrm{Ca}, \mathrm{Cu}, \mathrm{Mn}, \mathrm{Na}, \mathrm{S}$ and $\mathrm{Zn}$ have elevated concentrations in IN13-P3 (Figure 4-32). IN13-P4 and IN13-P5 have high concentrations of Al, Ca, Cu, Fe, $\mathrm{K}, \mathrm{Mg}, \mathrm{Mn}, \mathrm{Na}, \mathrm{S}, \mathrm{Zn}$ (Figure 4-32). If the elements were not present in the identified minerals, it is presumed that they were adsorbed onto the structures or entered the crystal structure.

The occurrence of the following minerals are based on the bulk chemistry, physical properties of the sample such as colour and XRD analyses. Minerals identified in IN13-P1 include blodite 
$\left(\mathrm{Na}_{2} \mathrm{Mg}\left(\mathrm{SO}_{4}\right)_{2} \cdot 4\left(\mathrm{H}_{2} \mathrm{O}\right)\right)$ based on the occurrence of a blodite group mineral and the predominance of $\mathrm{Mg}$, alum- $\mathrm{Na}$ and gypsum $\left(\mathrm{Ca}\left(\mathrm{SO}_{4}\right) \cdot 2\left(\mathrm{H}_{2} \mathrm{O}\right)\right)$ (Table 4-20). In IN13-P2, gypsum $\left(\mathrm{Ca}\left(\mathrm{SO}_{4}\right) \cdot 2\left(\mathrm{H}_{2} \mathrm{O}\right)\right.$ ), boyleite $\left((\mathrm{Zn}, \mathrm{Mg})\left(\mathrm{SO}_{4}\right) \cdot 4\left(\mathrm{H}_{2} \mathrm{O}\right)\right)$, chrysocolla $\left(\mathrm{Cu}_{2-\mathrm{x}} \mathrm{Al} \times\left(\mathrm{H}_{2-\mathrm{S}} \mathrm{Si}_{2} \mathrm{O}_{5}\right)(\mathrm{OH})_{4} \cdot \mathrm{n}\left(\mathrm{H}_{2} \mathrm{O}\right)\right)$ and bonattite $\left(\mathrm{Cu}\left(\mathrm{SO}_{4}\right) \cdot 3\left(\mathrm{H}_{2} \mathrm{O}\right)\right)$. Minerals identified in IN13-P3 include halite $(\mathrm{NaCl})$, gypsum $\left(\mathrm{Ca}\left(\mathrm{SO}_{4}\right) \cdot 2\left(\mathrm{H}_{2} \mathrm{O}\right)\right)$, hexahydrite $\left(\mathrm{Mg}\left(\mathrm{SO}_{4}\right) \cdot 6\left(\mathrm{H}_{2} \mathrm{O}\right)\right)$ and starkeyite $\left(\mathrm{Mg}\left(\mathrm{SO}_{4}\right) \cdot 4\left(\mathrm{H}_{2} \mathrm{O}\right)\right)$. Halite $(\mathrm{NaCl})$, starkeyite $\left(\mathrm{Mg}\left(\mathrm{SO}_{4}\right) \cdot 4\left(\mathrm{H}_{2} \mathrm{O}\right)\right)$, hexahydrite $\left(\mathrm{Mg}\left(\mathrm{SO}_{4}\right) \cdot 6\left(\mathrm{H}_{2} \mathrm{O}\right)\right)$, quartz $\left(\mathrm{SiO}_{2}\right)$ and gypsum $\left(\mathrm{Ca}\left(\mathrm{SO}_{4}\right) \cdot 2\left(\mathrm{H}_{2} \mathrm{O}\right)\right)$ were identified in IN13-P4 (Table 4-20).

Hexahydrite is a monoclinic sulfate with water content and was observed as encrustations in the field and its occurrence is a result of sulfide mineral oxidation (Jambor et al., 2000). Starkeyite is a dehydrated version of hexahydrite. Quartz and halite are common minerals found in this setting, and gypsum formed on drying in the field or during sample preparation. Loweite and blodite may both occur in evaporitic environments and from sulfidic mine waste (Leduc, 2010; Stoilova and Wildner, 2004; Lottermoser, 2010c). Bonattite may form as a dehydration product of chalcanthite (Sracek et al., 2010). Boyleite, of the rozenite group, and chrysocolla are minerals of secondary origin that from in the oxidation zones of copper ore bodies (Carbone et al., 2013).

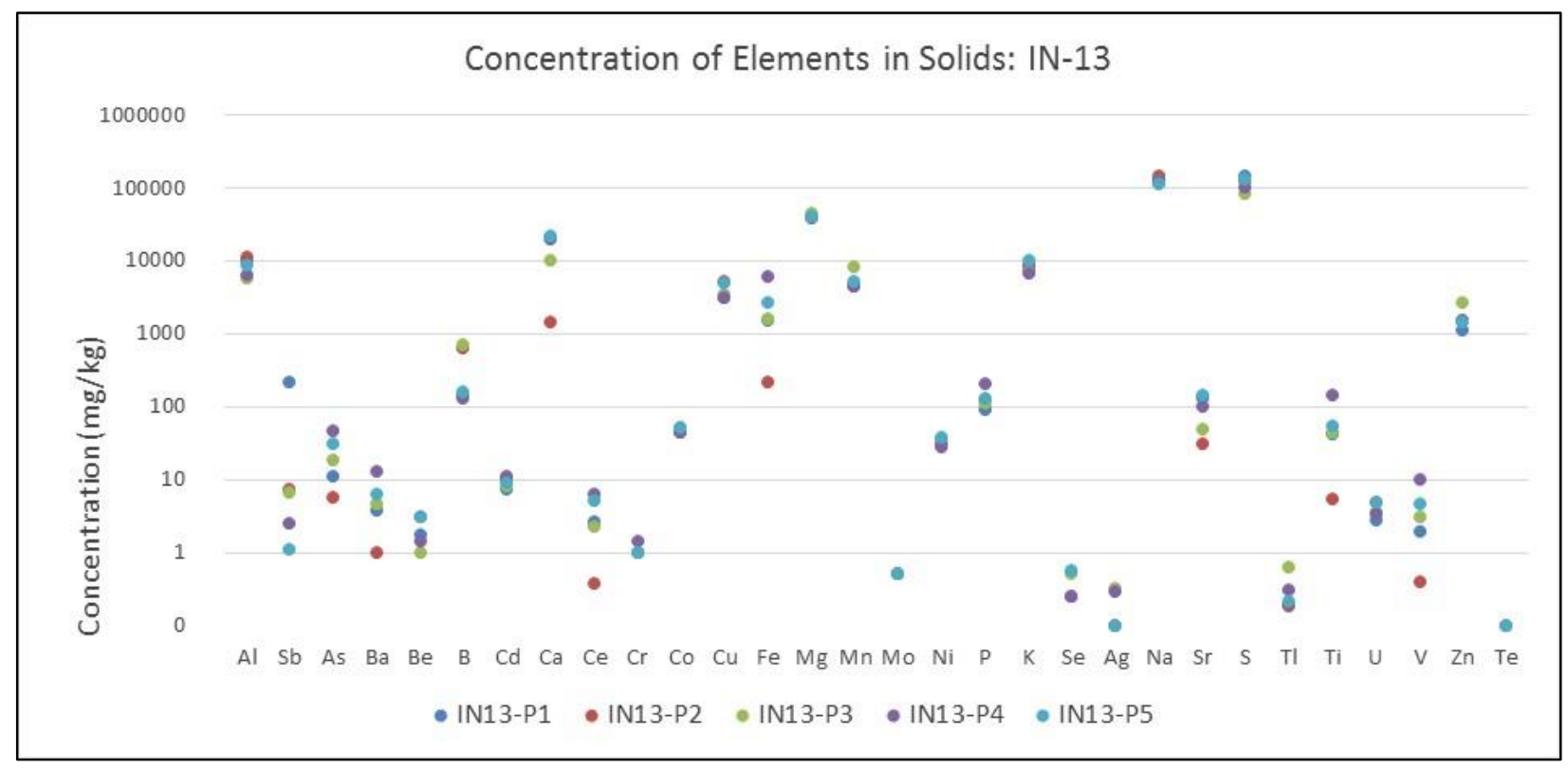

Figure 4-32 Elemental concentrations in $\mathrm{mg} / \mathrm{kg}$ in solid samples IN13-P1, IN13-P2, IN13-P3, IN13-P4 and IN13-P5 from ICP-OES measurements. 
Table 4-20 Positively identified minerals by bulk XRD from secondary precipitate samples collected at El Indio.

\begin{tabular}{|c|c|c|c|c|c|c|c|c|}
\hline Sample & Minerals & Chemical Formula & Sample & Minerals & Chemical Formula & Sample & Minerals & Chemical Formula \\
\hline \multirow[t]{2}{*}{ IN13-P1 } & Blodite & $\mathrm{Na}_{2} \mathrm{Mg}\left(\mathrm{SO}_{4}\right)_{2} \cdot 4\left(\mathrm{H}_{2} \mathrm{O}\right)$ & IN2-P1 & Quartz & $\mathrm{SiO}_{2}$ & IN28-P4 & Quartz & $\mathrm{SiO}_{2}$ \\
\hline & Gypsum & $\mathrm{Ca}\left(\mathrm{SO}_{4}\right) \cdot 2\left(\mathrm{H}_{2} \mathrm{O}\right)$ & & Albite & $\mathrm{NaAlSi}_{3} \mathrm{O}_{8}$ & RMATR-FeOx-P1 & Quartz & $\mathrm{SiO}_{2}$ \\
\hline \multirow[t]{4}{*}{ IN13-P2 } & Chrysocolla & $\mathrm{Cu}_{2-x} \mathrm{Al}_{x}\left(\mathrm{H}_{2-x} \mathrm{Si}_{2} \mathrm{O}_{5}\right)(\mathrm{OH})_{4} \cdot x\left(\mathrm{H}_{2} \mathrm{O}\right)$ & IN2-P2 & Quartz & $\mathrm{SiO}_{2}$ & RMATR-FeOx-P2 & Quartz & $\mathrm{SiO}_{2}$ \\
\hline & Boyleite & $(\mathrm{Zn}, \mathrm{Mg}) \mathrm{SO}_{4} \cdot 4\left(\mathrm{H}_{2} \mathrm{O}\right)$ & & Albite & $\mathrm{NaAlSi}_{3} \mathrm{O}_{8}$ & RMATR-FeOx-P3 & No bulk XRD & \\
\hline & Gypsum & $\mathrm{Ca}\left(\mathrm{SO}_{4}\right) \cdot 2\left(\mathrm{H}_{2} \mathrm{O}\right)$ & & Alunite & $\mathrm{K}\left(\mathrm{Al}_{3}\left(\mathrm{SO}_{4}\right)_{2}(\mathrm{OH})_{6}\right)$ & RMATR-P1 & Alum-Na & $\mathrm{NaAl}\left(\mathrm{SO}_{4}\right)_{2} \cdot 12\left(\mathrm{H}_{2} \mathrm{O}\right)$ \\
\hline & Bonattite & $\mathrm{Cu}\left(\mathrm{SO}_{4}\right) \cdot 3\left(\mathrm{H}_{2} \mathrm{O}\right)$ & IN2-P3 & Alum-Na & $\mathrm{NaAl}\left(\mathrm{SO}_{4}\right)_{2} \cdot 12\left(\mathrm{H}_{2} \mathrm{O}\right)$ & & Alum-K & $\mathrm{KAl}\left(\mathrm{SO}_{4}\right)_{2} \cdot 12\left(\mathrm{H}_{2} \mathrm{O}\right)$ \\
\hline \multirow[t]{4}{*}{ IN13-P3 } & Halite & $\mathrm{NaCl}$ & & Epsomite & $\mathrm{Mg}\left(\mathrm{SO}_{4}\right) \cdot 7\left(\mathrm{H}_{2} \mathrm{O}\right)$ & & Gypsum & $\mathrm{Ca}\left(\mathrm{SO}_{4}\right) \cdot 2\left(\mathrm{H}_{2} \mathrm{O}\right)$ \\
\hline & Gypsum & $\mathrm{Ca}\left(\mathrm{SO}_{4}\right) \cdot 2\left(\mathrm{H}_{2} \mathrm{O}\right)$ & & Gypsum & $\mathrm{Ca}\left(\mathrm{SO}_{4}\right) \cdot 2\left(\mathrm{H}_{2} \mathrm{O}\right)$ & & Alunogen & $\mathrm{Al}_{2}\left(\mathrm{SO}_{4}\right)_{3} \cdot 17 \mathrm{H}_{2} \mathrm{O}$ \\
\hline & Hexahydrite & $\mathrm{Mg}\left(\mathrm{SO}_{4}\right) \cdot 6\left(\mathrm{H}_{2} \mathrm{O}\right)$ & & Jarosite & $\mathrm{KFe}_{3}(\mathrm{OH})_{6}\left(\mathrm{SO}_{4}\right)_{2}$ & & Scorodite & $\mathrm{FeAsO}_{4} \cdot 2\left(\mathrm{H}_{2} \mathrm{O}\right)$ \\
\hline & Starkeyite & $\mathrm{Mg}\left(\mathrm{SO}_{4}\right) \cdot 4\left(\mathrm{H}_{2} \mathrm{O}\right)$ & IN2-P4 & No bulk XRD & & RMATR-P2 & Magnesiocopiapite & $\mathrm{MgFe}_{4}\left(\mathrm{SO}_{4}\right)_{6}(\mathrm{OH})_{2} \cdot 20\left(\mathrm{H}_{2} \mathrm{O}\right)$ \\
\hline \multirow[t]{5}{*}{ IN13-P4 } & Halite & $\mathrm{NaCl}$ & IN2-P5 & No bulk XRD & & & Quartz & $\mathrm{SiO}_{2}$ \\
\hline & Starkeyite & $\mathrm{Mg}\left(\mathrm{SO}_{4}\right) \cdot 4\left(\mathrm{H}_{2} \mathrm{O}\right)$ & IN28-P1 & Alum-Na & $\mathrm{NaAl}\left(\mathrm{SO}_{4}\right)_{2} \cdot 12\left(\mathrm{H}_{2} \mathrm{O}\right)$ & & Gypsum & $\mathrm{Ca}\left(\mathrm{SO}_{4}\right) \cdot 2\left(\mathrm{H}_{2} \mathrm{O}\right)$ \\
\hline & Hexahydrite & $\mathrm{Mg}\left(\mathrm{SO}_{4}\right) \cdot 6\left(\mathrm{H}_{2} \mathrm{O}\right)$ & & Alum-K & $\operatorname{KAl}\left(\mathrm{SO}_{4}\right)_{2} \cdot 12\left(\mathrm{H}_{2} \mathrm{O}\right)$ & & Alunogen & $\mathrm{Al}_{2}\left(\mathrm{SO}_{4}\right)_{3} \cdot 17\left(\mathrm{H}_{2} \mathrm{O}\right)$ \\
\hline & Quartz & $\mathrm{SiO}_{2}$ & & Magnesiocopiapite & $\mathrm{MgFe}_{4}\left(\mathrm{SO}_{4}\right)_{6}(\mathrm{OH})_{2} \cdot 2 \mathrm{O}\left(\mathrm{H}_{2} \mathrm{O}\right)$ & & Scorodite & $\mathrm{FeAsO}_{4} \cdot 2\left(\mathrm{H}_{2} \mathrm{O}\right)$ \\
\hline & Gypsum & $\mathrm{Ca}\left(\mathrm{SO}_{4}\right) \cdot 2\left(\mathrm{H}_{2} \mathrm{O}\right)$ & & Loweite & $\mathrm{Na}_{12} \mathrm{Mg}_{7}\left(\mathrm{SO}_{4}\right)_{13} \cdot 15\left(\mathrm{H}_{2} \mathrm{O}\right)$ & RMATR-P3 & Quartz & $\mathrm{SiO}_{2}$ \\
\hline \multirow[t]{5}{*}{ IN13-P5 } & Halite & $\mathrm{NaCl}$ & IN28-P2 & Dietrichite & $\mathrm{ZnAl}_{2}\left(\mathrm{SO}_{4}\right)_{4} \cdot 22\left(\mathrm{H}_{2} \mathrm{O}\right)$ & RMATR-P4 & Gypsum & $\mathrm{Ca}\left(\mathrm{SO}_{4}\right) \cdot 2\left(\mathrm{H}_{2} \mathrm{O}\right)$ \\
\hline & Gypsum & $\mathrm{Ca}\left(\mathrm{SO}_{4}\right) \cdot 2\left(\mathrm{H}_{2} \mathrm{O}\right)$ & & Magnesiocopiapite & $\mathrm{MgFe}_{4}\left(\mathrm{SO}_{4}\right)_{6}(\mathrm{OH})_{2} \cdot 2 \mathrm{O}\left(\mathrm{H}_{2} \mathrm{O}\right)$ & & & \\
\hline & Hexahydrite & $\mathrm{Mg}\left(\mathrm{SO}_{4}\right) \cdot 6\left(\mathrm{H}_{2} \mathrm{O}\right)$ & IN28-P3 & Dietrichite & $\mathrm{ZnAl}_{2}\left(\mathrm{SO}_{4}\right)_{4} \cdot 22\left(\mathrm{H}_{2} \mathrm{O}\right)$ & & & \\
\hline & Muscovite & $\mathrm{KAl}_{2} \mathrm{Si}_{3} \mathrm{AlO}_{10}(\mathrm{OH})_{2}$ & & Magnesiocopiapite & $\mathrm{MgFe}_{4}\left(\mathrm{SO}_{4}\right)_{6}(\mathrm{OH})_{2} \cdot 2 \mathrm{O}\left(\mathrm{H}_{2} \mathrm{O}\right)$ & & & \\
\hline & Starkeyite & $\mathrm{Mg}\left(\mathrm{SO}_{4}\right) \cdot 4\left(\mathrm{H}_{2} \mathrm{O}\right)$ & & Melanterite & $\mathrm{FeSO}_{4} \cdot 7\left(\mathrm{H}_{2} \mathrm{O}\right)$ & & & \\
\hline
\end{tabular}


Synchrotron micro-analysis was conducted on thin sections made from samples IN13-P1, IN13P2, IN13-P3, IN13-P4, IN13-P5 (Figure 4-33, Figure 4-35, Figure 4-36, Figure 4-37, Figure 4-39, Figure 4-41). Mounted secondary precipitates of IN13-P1, IN13-P3, IN13-P4 and IN13-P5 were analyzed by ESEM. The identified minerals from the bulk XRD were compared to those from the ESEM and $\mu$ XRD and show similar results; however, an increased amount of phases were identified by $\mu$ XRD analysis (Table 4-21, Table 4-22, Table 4-23, Table 4-24, Table 4-25). Approximately 7-15 spots were chosen for $\mu$ XRD and were based on observed elemental variation from XRF maps. Albite, loweite, alunite, hexahydrite were phases identified by $\mu$ XRD and not by XRD at IN13-P1. Out of 8 minerals identified through various methods at sample IN13-P2, only gypsum was identified through XRD analysis. Anorthite, halite and changoite, were not identified by bulk XRD within sample IN13-P3. Albite, magnetite and montmorillonite were not identified by bulk XRD analysis in sample IN13-P4. Within this same sample, probable kaolinite and atacamite minerals were identified by the ESEM of the mounted secondary precipitates. Albite, bassanite, gypsum, loweite, blodite were not identified by XRD analyses.

Morphological features and measured chemistry in samples were associated with the most likely phases already identified by XRD and $\mu$ XRD. At least 6 distinct phases were identified at IN13-P1 through ESEM analysis (Figure 4-34): (1) flat hexagonal crystallites of Ca sulfates with evidence of Cu (2) euhedral crystals of Na K sulfate phase interpreted as potentially thenardite (3) irregularly shaped halite masses (4) euhedral intergrowth of varying sizes of $\mathrm{Na} \mathrm{Mg}$ sulfates interpreted to be blodite or loweite (5) fine groundmass of probable alunite (6) intergrown nodules of alunite and quartz. Not less than 7 distinct phases were identified at IN13-P3 through ESEM analysis (Figure 4-38): (1) cubic crystals of halite (2) fine grained $\mathrm{Na}$, Mg sulfate (3) tabular to lamellar aggregates of Mg sulfate (probably starkeyite) (4) microcrystals of kaolinite (5) unknown phase of fine grained $\mathrm{Mg}$, Al sulfate (likely pickeringite) (6) micronodules of $\mathrm{Cu}$ halite (7) Euhedral cubic $\mathrm{Na} \mathrm{Mg}$ sulfate covered by crusts of halite and probably pickeringite. At the minimum 6 distinct phases were identified at IN13-P4 through ESEM analysis (Figure 
4-40): (1) Globular masses of $\mathrm{Cu}$ halite mineral presumed to be atacamite (2) anhedral mass of mixed quartz, Mg Al sulfate and probable montmorillonite (3) microcrystalline alum-K and albite (4) minor phase of probable kaolinite (5) large halite cube (6) cubic crystals of $\mathrm{Na}$ Mg sulfates. At least 10 distinct phases were identified at IN13-P5 through ESEM analysis (Figure 4-42): (1) euhedral crystals of probable blodite (2) cubic halite (3) microcrystallites of unidentified Mg sulfate (4) cubic sylvite (KCl) (5) cubic Mg Na sulfate with flattened terminations (6) aggregates of tabular Ca sulfate (gypsum or anhydrite) (7) globules of subhedral to anhedral Al sulfates (8) crusts and nodules of $\mathrm{Cu}$ halide with traces of $\mathrm{Mg}(9)$ spherical aggregates of tabular $\mathrm{Na} \mathrm{Mg} \mathrm{Cl}$ sulfate (10) anhedral globules of unidentified Mg sulfate.

A few phases identified with the ESEM were not previously observed from XRD and $\mu \mathrm{XRD}$ analyses. These include Mg-Al sulfate (likely pickeringite), Cu halides, sylvite and Na K sulfate (potentially aphtitalite). At IN13-P1, only blodite and quartz are identified with all 3 techniques, further demonstrating the importance of using various tools to understand the mineralogy of a sample (Table 4-21). Only quartz, montmorillonite and starkeyite are identified by all methods in sample IN13-P3 (Table 4-23). Potential blodite, alum-K and halite are the only minerals observed with all tools at IN13-P4 (Table 4-24). Atacamite and kaolinite were only identified from the ESEM analysis of the mounted secondary precipitates. None of the minerals are identified by all analytical methods in sample IN13-P5 (Table 4-25). 

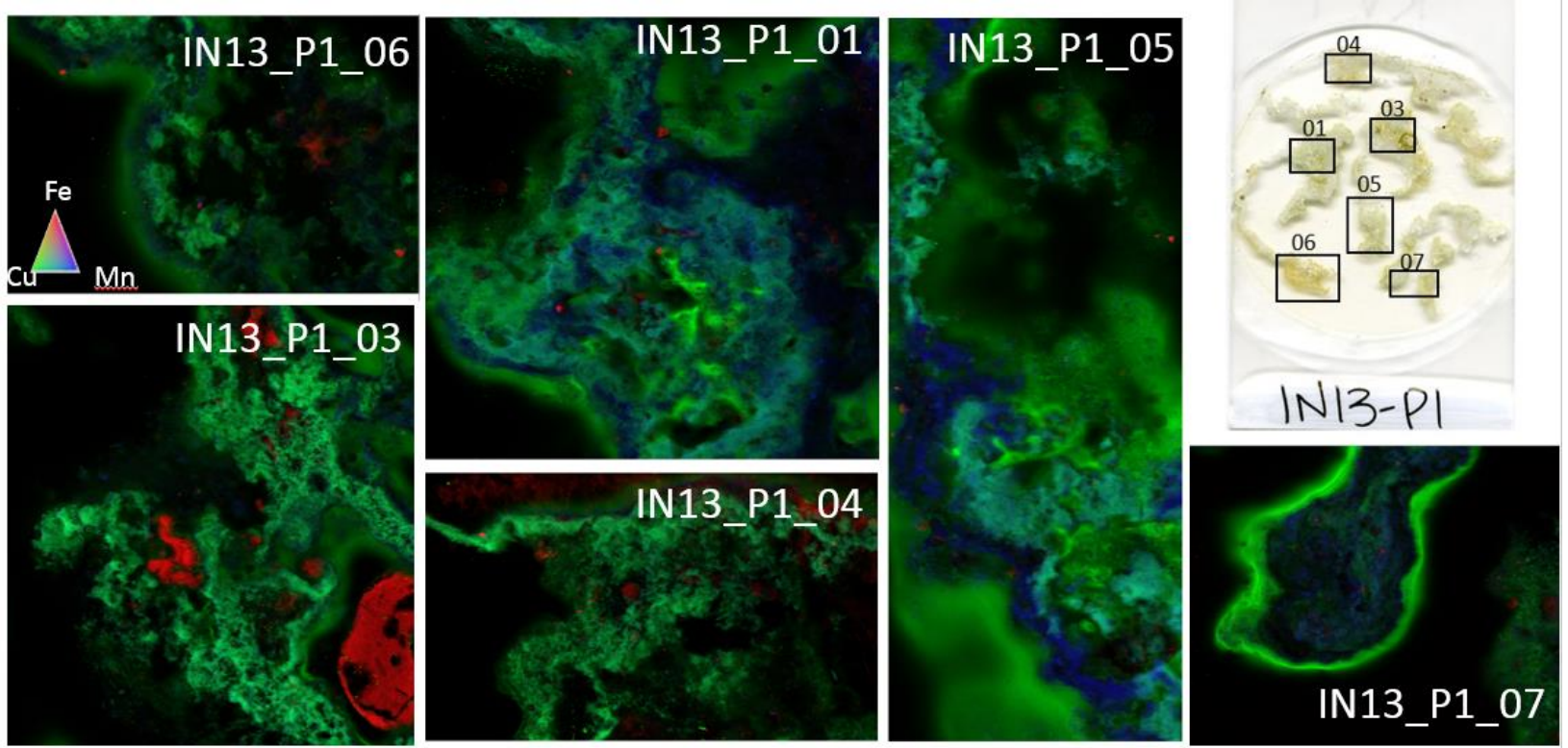

Figure 4-33 $\mu$ XRD element maps collected on thin section IN13-P1. $\mu$ XRD spots demonstrate that multiple elements are found even at the finer scale.

Table 4-21 List of minerals identified at IN13-P1 with $\mu$ XRD, XRD and ESEM (MSP).

\begin{tabular}{ccccc}
\hline IN13-P1 & \multicolumn{3}{c}{ Identification Method } \\
Minerals & Formula & XRD & $\boldsymbol{\mu}$ XRD & ESEM \\
\hline Albite & $\left(\mathrm{Na}_{0.84} \mathrm{Ca}_{0.16}\right) \mathrm{Al}_{1.16} \mathrm{Si}_{2.84} \mathrm{O}_{8}$ & & $\mathrm{x}$ & \\
Quartz & $\mathrm{SiO}_{2}$ & $\mathrm{x}$ & $\mathrm{x}$ & $\mathrm{x}$ \\
Loweite & $\mathrm{Na}_{12} \mathrm{Mg}_{7}\left(\mathrm{SO}_{4}\right)_{13} \cdot 15\left(\mathrm{H}_{2} \mathrm{O}\right)$ & & $\mathrm{x}$ & $\mathrm{x}$ \\
Blodite & $\mathrm{Na}_{2} \mathrm{Mg}\left(\mathrm{SO}_{4}\right)_{2} \cdot 4\left(\mathrm{H}_{2} \mathrm{O}\right)$ & $\mathrm{x}$ & $\mathrm{x}$ & $\mathrm{x}$ \\
Alunite & $\mathrm{KAl}\left(\mathrm{SO}_{4}\right)_{2}(\mathrm{OH})_{6}$ & & $\mathrm{x}$ & $\mathrm{x}$ \\
Hexahydrite & $\mathrm{Mg}\left(\mathrm{SO}_{4}\right) \cdot 6\left(\mathrm{H}_{2} \mathrm{O}\right)$ & & $\mathrm{x}$ & \\
Gypsum & $\mathrm{Ca}\left(\mathrm{SO}_{4}\right) \cdot 2\left(\mathrm{H}_{2} \mathrm{O}\right)$ & $\mathrm{x}$ & & $\mathrm{x}$ \\
Aphthitalite & $(\mathrm{K}, \mathrm{Na})_{3} \mathrm{Na}\left(\mathrm{SO}_{4}\right)_{2}$ & & & $\mathrm{x}$ \\
Halite & $\mathrm{NaCl}$ & & $\mathrm{x}$ \\
\hline
\end{tabular}



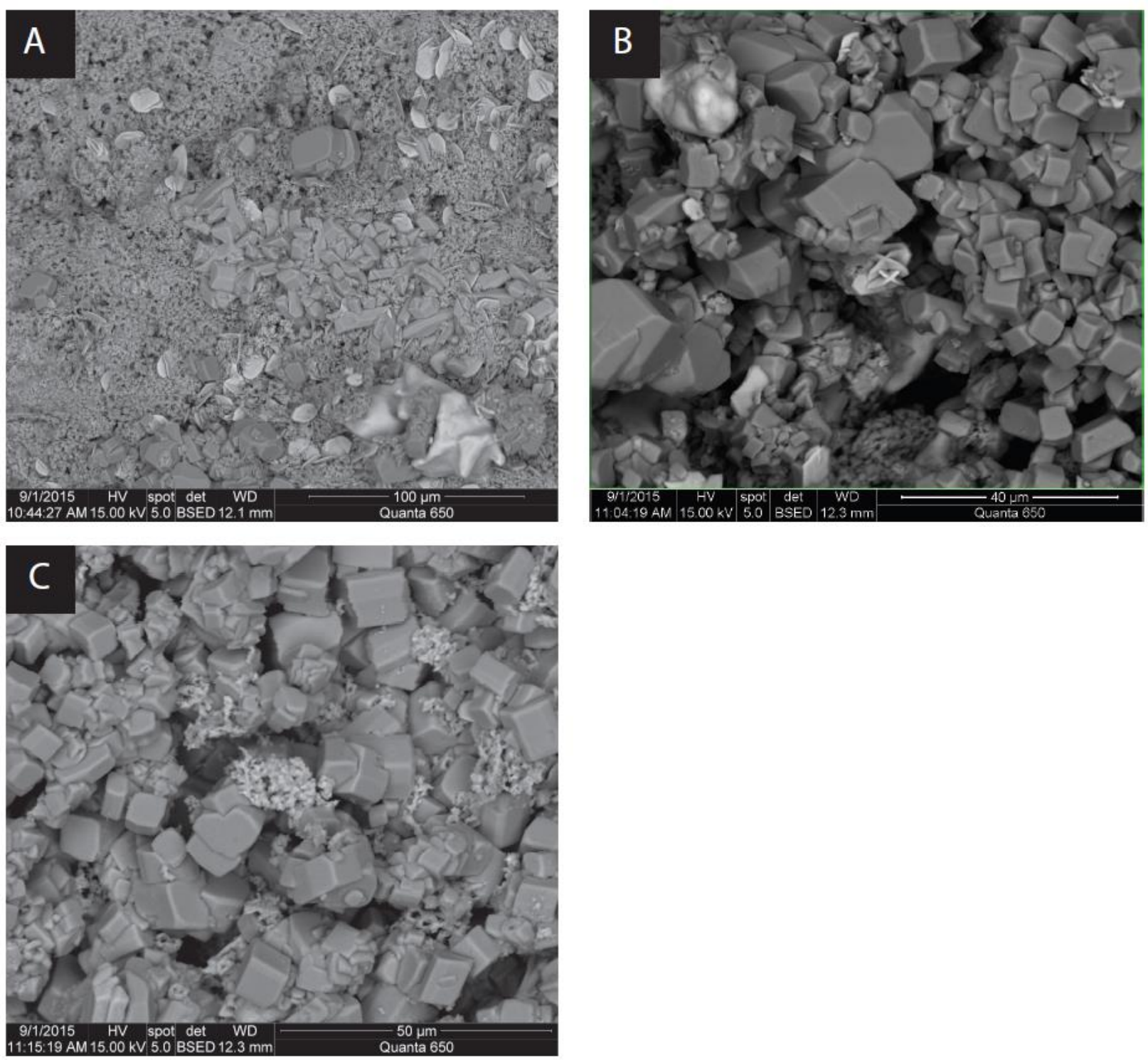

Figure 4-34 ESEM images of IN13-P1 sample measured at 15 kV. (A) Flat hexagonal crystallites of Ca sulfates with evidence of $\mathrm{Cu}$, euhedral intergrowths of $\mathrm{Na} \mathrm{K}$ sulfate phase interpreted as potentially thenardite, irregularly shaped halite mass, euhedral intergrowth of varying sizes of $\mathrm{Na} \mathrm{Mg}$ sulfate interpreted to be blodite, finer groundmass of probable alunite. (B) Irregularly shaped globular mass of halite, euhedral intergrowth of varying sizes of $\mathrm{Na} \mathrm{Mg}$ sulfate interpreted to be blodite or loweite, finer groundmass of probably alunite forming crusts on the $\mathrm{Na} \mathrm{Mg}$ sulfate phases. (C) Euhedral isometric aggregates of $\mathrm{Na} \mathrm{Mg}$ sulfates with flattened terminations and intergrown nodules of alunite and quartz. 

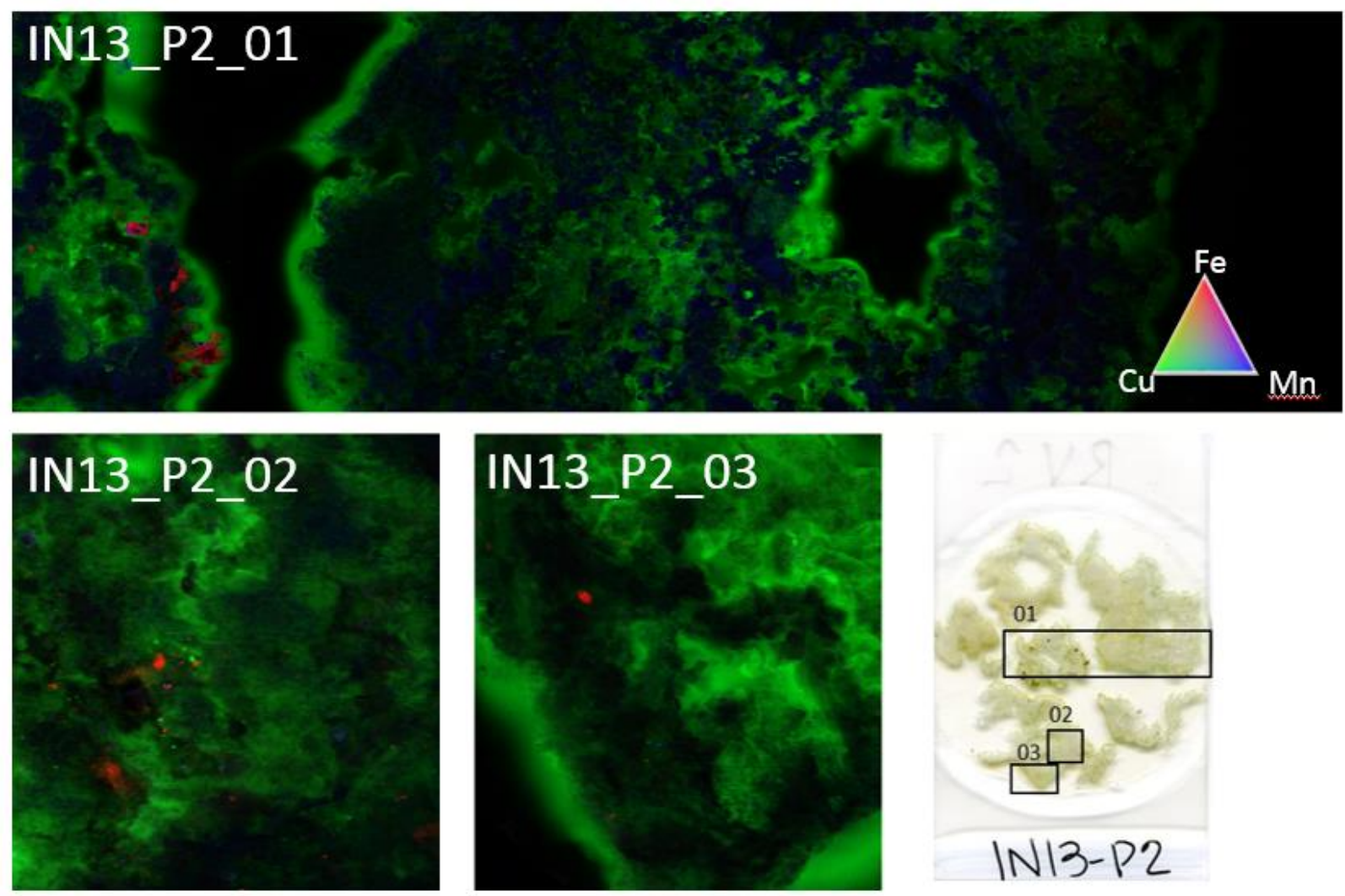

Figure 4-35 $\mu$ XRD elemental maps collected on thin section IN13-P2. Although the fluorescence map demonstrates enrichments in Cu yet no Cu minerals have been identified.

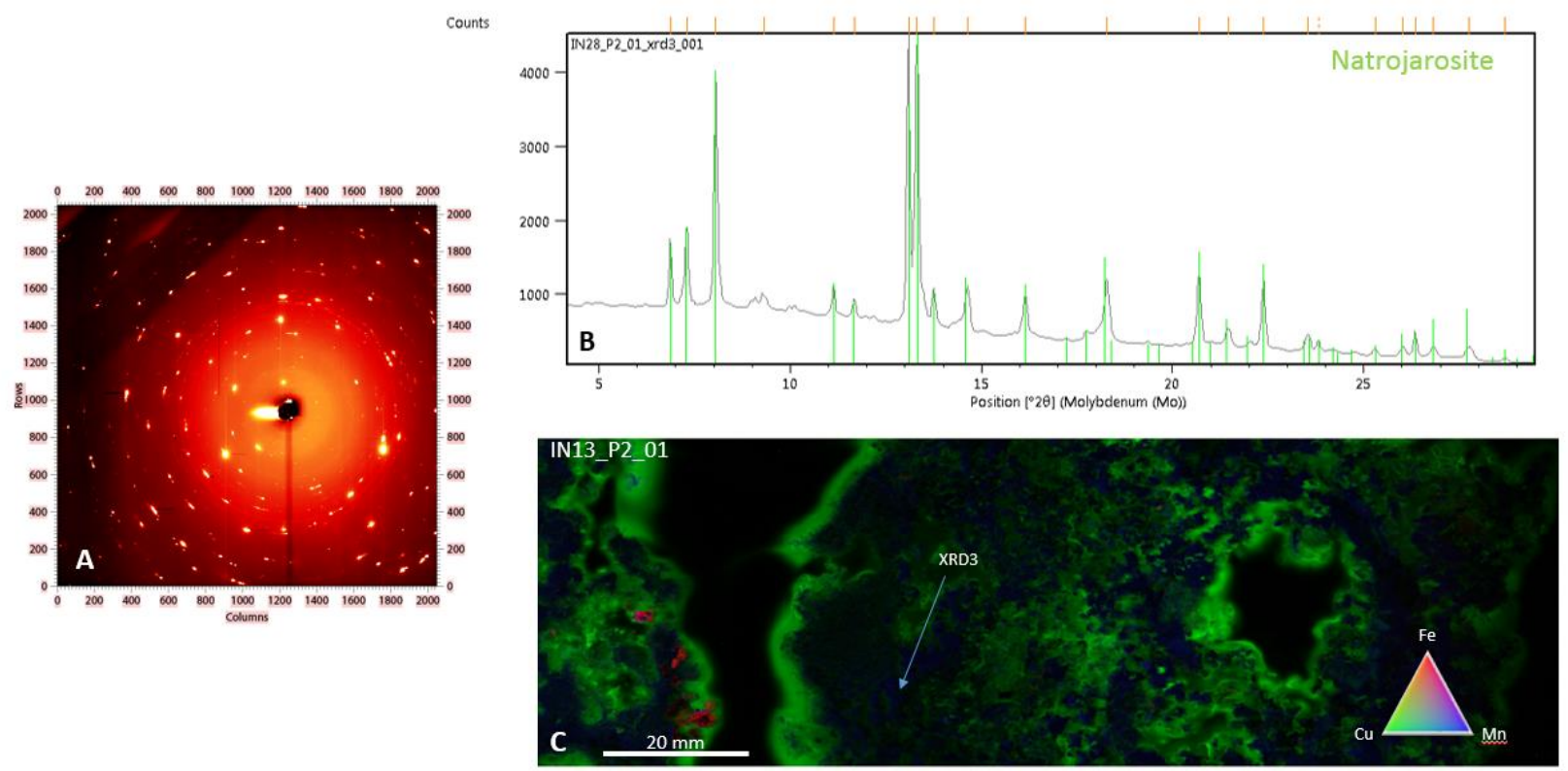

Figure 4-36 $\mu$ XRD 2D diffraction pattern of natrojarosite and associated 1D diffraction pattern with matched mineral profile (top right). 
Table 4-22 List of minerals identified at IN13-P2 with $\mu$ XRD methods at the synchrotron, bulk XRD and ESEM.

\begin{tabular}{cccc}
\hline IN13-P2 & \multicolumn{3}{c}{ Identification Method } \\
Minerals & Formula & XRD & $\boldsymbol{\mu X R D}$ \\
\hline Quartz & $\mathrm{SiO}_{2}$ & $\mathrm{NaCl}$ \\
Halite & $\mathrm{NaC}$ & $\mathrm{x}$ \\
Loweite & $\mathrm{Na}_{12} \mathrm{Mg}_{7}\left(\mathrm{SO}_{4}\right)_{13} \cdot 15\left(\mathrm{H}_{2} \mathrm{O}\right)$ & $\mathrm{x}$ \\
Blodite & $\mathrm{Na}_{2} \mathrm{Mg}\left(\mathrm{SO}_{4}\right)_{2} \cdot 4\left(\mathrm{H}_{2} \mathrm{O}\right)$ & $\mathrm{x}$ \\
Alunite & $\mathrm{KAl}_{3}\left(\mathrm{SO}_{4}\right)_{2}(\mathrm{OH})_{6}$ & $\mathrm{x}$ \\
Hematite & $\mathrm{Fe}_{2} \mathrm{O}_{3}$ & $\mathrm{x}$ \\
Hexahydrite & $\mathrm{Mg}\left(\mathrm{SO}_{4}\right) \cdot 6\left(\mathrm{H}_{2} \mathrm{O}\right)$ & & \\
Gypsum & $\mathrm{Ca}\left(\mathrm{SO}_{4}\right) \cdot 2\left(\mathrm{H}_{2} \mathrm{O}\right)$ & $\mathrm{x}$ & \\
\hline
\end{tabular}

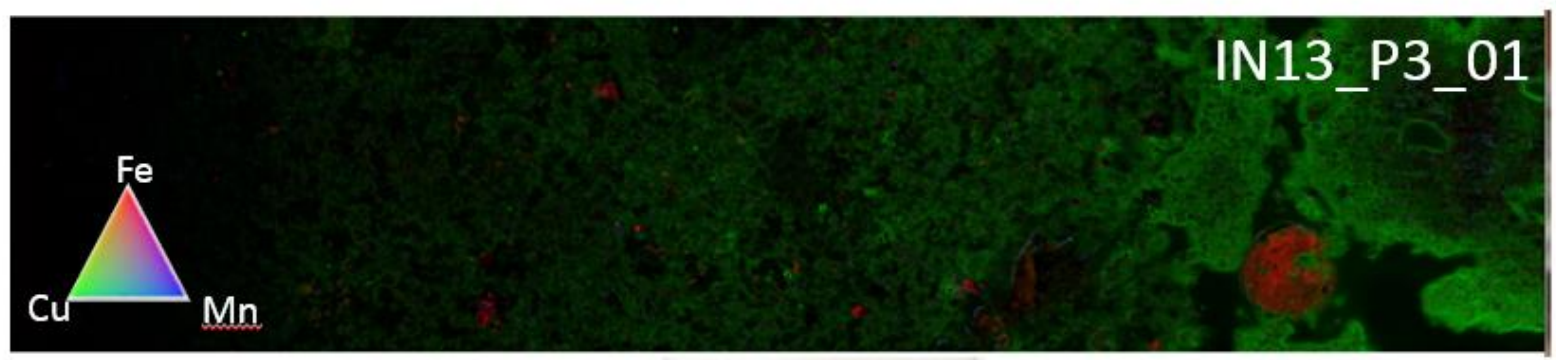

Figure 4-37 $\mu$ XRD elemental maps collected on thin section IN13-P3. 

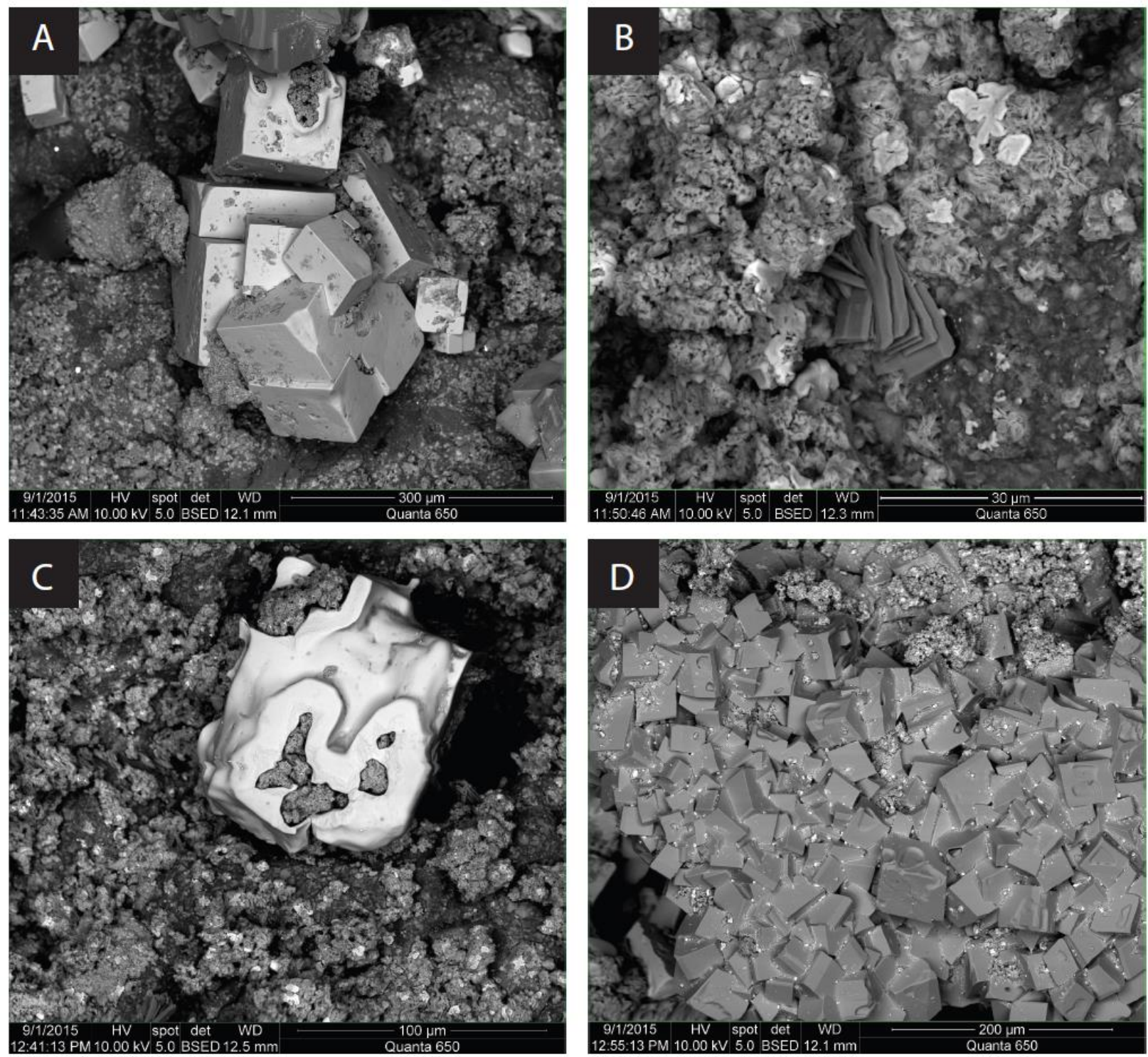

Figure 4-38 ESEM images of IN13-P3 sample measured at $10 \mathrm{kV}$. (A) Isometric euhedral grains of halite with irregularly shaped amalgamation of $\mathrm{Na}, \mathrm{Mg}$ sulfate forming within the structure. (B) Tabular to lamellar aggregate of Mg sulfate (probably starkeyite) surrounded by intergrown microcrystals of kaolinite, an unknown phase of $\mathrm{Mg}, \mathrm{Al}, \mathrm{Cl}$ sulfate (likely pickeringite), micronodules of $\mathrm{Cu}$ halite and irregularly shaped halide. (C) Isometric crystal of halite with irregular inclusion of unknown $\mathrm{Mg}, \mathrm{Al}, \mathrm{Cl}$ sulfate, surrounded by intergrown microcrystals of kaolinite, the same unknown phase of $\mathrm{Mg}$, Al sulfate and irregularly shaped halite. (D) Growth of $\mathrm{Na}, \mathrm{Mg}$ sulfate cubes covered by crusts of halite and probably pickeringite. 

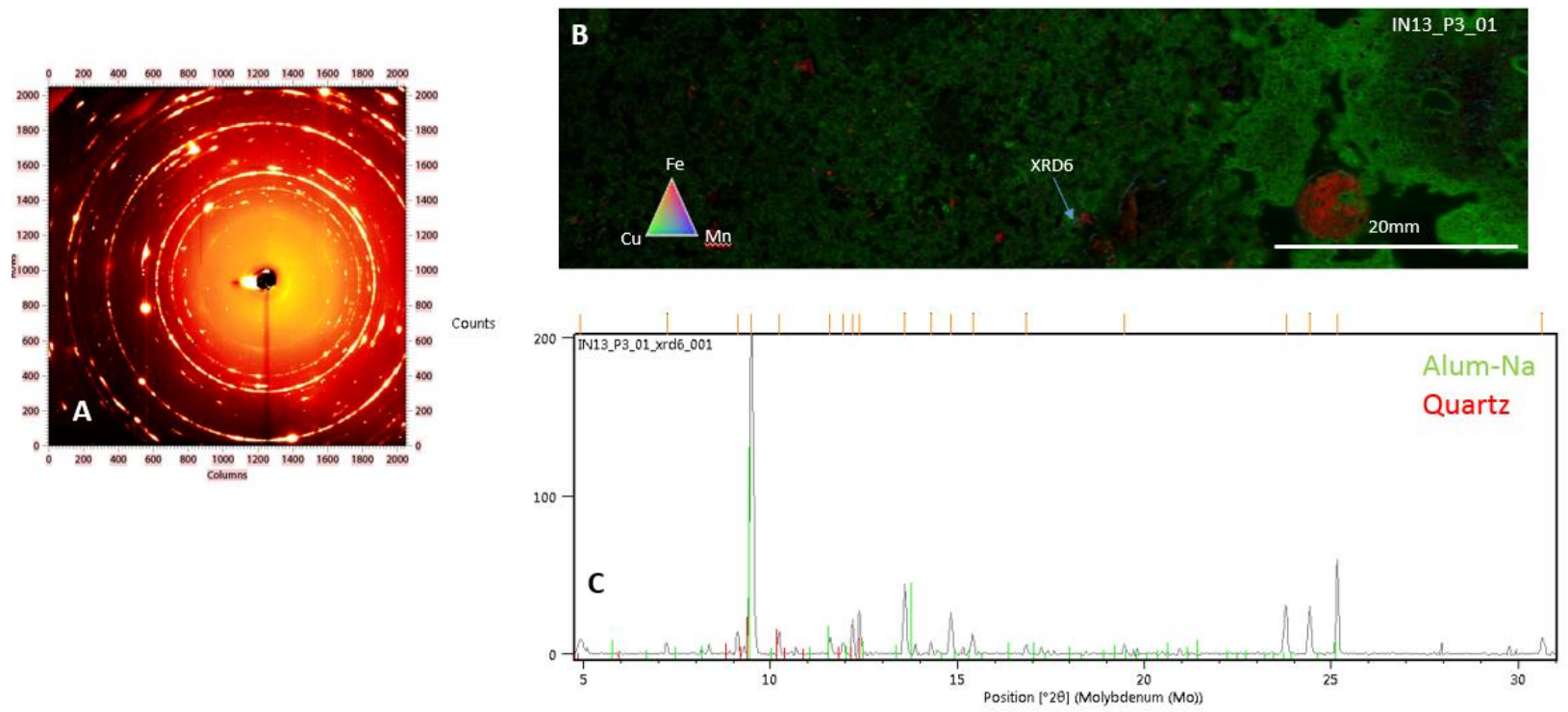

Table 4-23 List of minerals identified at IN13-P3 with $\mu$ XRD methods at the synchrotron, bulk XRD and ESEM.

\begin{tabular}{|c|c|c|c|c|}
\hline \multirow{2}{*}{$\frac{\text { IN13-P3 }}{\text { Minerals }}$} & \multicolumn{4}{|c|}{ Identification Method } \\
\hline & Formula & XRD & $\mu \mathrm{XRD}$ & ESEM \\
\hline Quartz & $\mathrm{SiO}_{2}$ & $x$ & $x$ & $x$ \\
\hline Orthoclase & $\mathrm{K}\left(\mathrm{AlSi}_{3}\right) \mathrm{O}_{8}$ & $x$ & $x$ & \\
\hline Anorthite & $\left(\mathrm{Na}_{0.45} \mathrm{Ca}_{0.55}\right)\left(\mathrm{Al}_{1.55} \mathrm{Si}_{2.45} \mathrm{O}_{8}\right)$ & & $x$ & \\
\hline Montmorillonte & $\mathrm{Na}_{0.3}(\mathrm{Al}, \mathrm{Mg})_{2} \mathrm{Si}_{4} \mathrm{O}_{10}(\mathrm{OH})_{2} \cdot \times \mathrm{H}_{2} \mathrm{O}$ & $x$ & $x$ & $x$ \\
\hline Halite & $\mathrm{NaCl}$ & & $x$ & $x$ \\
\hline Changoite & $\mathrm{Na}_{2} \mathrm{Zn}\left(\mathrm{SO}_{4}\right)_{2} \cdot 4\left(\mathrm{H}_{2} \mathrm{O}\right)$ & & $x$ & \\
\hline Anhydrite & $\mathrm{CaSO}_{4}$ & $\mathrm{x}$ & $x$ & \\
\hline Starkeyite & $\mathrm{Mg}\left(\mathrm{SO}_{4}\right) \cdot 4\left(\mathrm{H}_{2} \mathrm{O}\right)$ & $x$ & $x$ & $x$ \\
\hline Na Mg sulfate & & & & $x$ \\
\hline Kaolinite & $\mathrm{Al}_{2} \mathrm{Si}_{2} \mathrm{O}_{5}(\mathrm{OH})_{4}$ & & & $x$ \\
\hline Pickeringite & $\mathrm{MgAl}_{2}\left(\mathrm{SO}_{4}\right)_{4} \cdot 22\left(\mathrm{H}_{2} \mathrm{O}\right)$ & & & $x$ \\
\hline Atacamite & $\mathrm{Cu}_{2} \mathrm{Cl}(\mathrm{OH})_{3}$ & & & $x$ \\
\hline
\end{tabular}



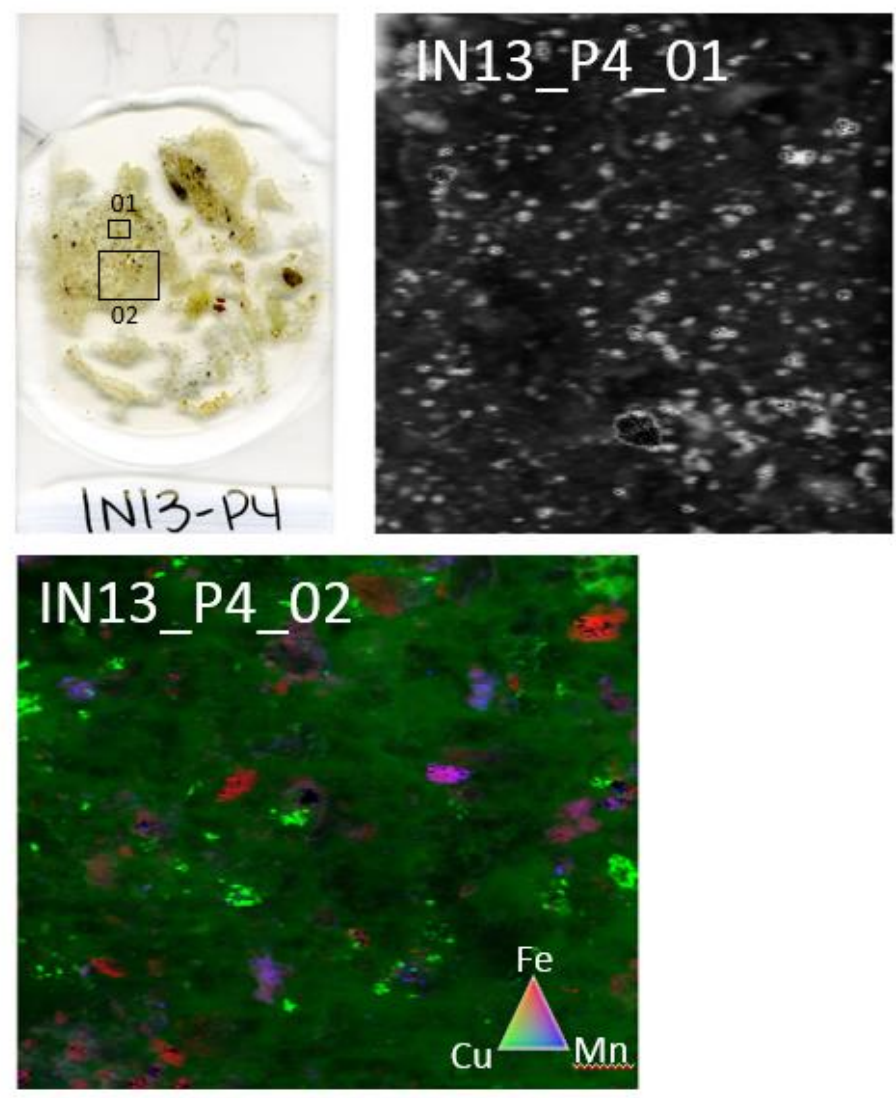

Figure 4-39 $\mu$ XRD elemental maps collected on thin section IN13-P4.

Table 4-24 List of minerals identified at IN13-P4 with $\mu$ XRD methods at the synchrotron, bulk XRD and ESEM.

\begin{tabular}{|c|c|c|c|c|}
\hline \multirow{2}{*}{$\begin{array}{l}\underline{\text { IN13-P4 }} \\
\text { Minerals }\end{array}$} & \multicolumn{4}{|c|}{ Identification Method } \\
\hline & Formula & XRD & $\mu \mathrm{XRD}$ & ESEM \\
\hline Quartz & $\mathrm{SiO}_{2}$ & $\mathrm{x}$ & $\mathrm{x}$ & $\mathrm{x}$ \\
\hline Halite & $\mathrm{NaCl}$ & $\mathrm{x}$ & $\mathrm{x}$ & $\mathrm{x}$ \\
\hline Albite & $\left(\mathrm{Na}_{0.84} \mathrm{Ca}_{0.16}\right) \mathrm{Al}_{1.16} \mathrm{Si}_{2.84} \mathrm{O}_{8}$ & & $x$ & $x$ \\
\hline Alum-K & $\mathrm{KAl}\left(\mathrm{SO}_{4}\right)_{2} \cdot 12\left(\mathrm{H}_{2} \mathrm{O}\right)$ & $\mathrm{x}$ & $x$ & $x$ \\
\hline Magnesite & $\mathrm{Mg}\left(\mathrm{CO}_{3}\right)$ & & $x$ & \\
\hline Hexahydrite & $\mathrm{Mg}\left(\mathrm{SO}_{4}\right) \cdot 6\left(\mathrm{H}_{2} \mathrm{O}\right)$ & $\mathrm{x}$ & $\mathrm{x}$ & \\
\hline Blodite & $\mathrm{Na}_{2} \mathrm{Mg}\left(\mathrm{SO}_{4}\right)_{2} \cdot 4\left(\mathrm{H}_{2} \mathrm{O}\right)$ & $x$ & $x$ & $x$ \\
\hline Montmorillonite & $\mathrm{Na}_{0.3}(\mathrm{Al}, \mathrm{Mg})_{2} \mathrm{Si}_{4} \mathrm{O}_{10}(\mathrm{OH})_{2} \cdot \mathrm{x}\left(\mathrm{H}_{2} \mathrm{O}\right)$ & & $x$ & $x$ \\
\hline Gypsum & $\mathrm{Ca}\left(\mathrm{SO}_{4}\right) \cdot 2\left(\mathrm{H}_{2} \mathrm{O}\right)$ & $x$ & & \\
\hline Atacamite & $\mathrm{Cu}_{2} \mathrm{Cl}(\mathrm{OH})_{3}$ & & & $\mathrm{x}$ \\
\hline Kaolinite & $\mathrm{Al}_{2} \mathrm{Si}_{2} \mathrm{O}_{5}(\mathrm{OH})_{4}$ & & & $\mathrm{x}$ \\
\hline
\end{tabular}



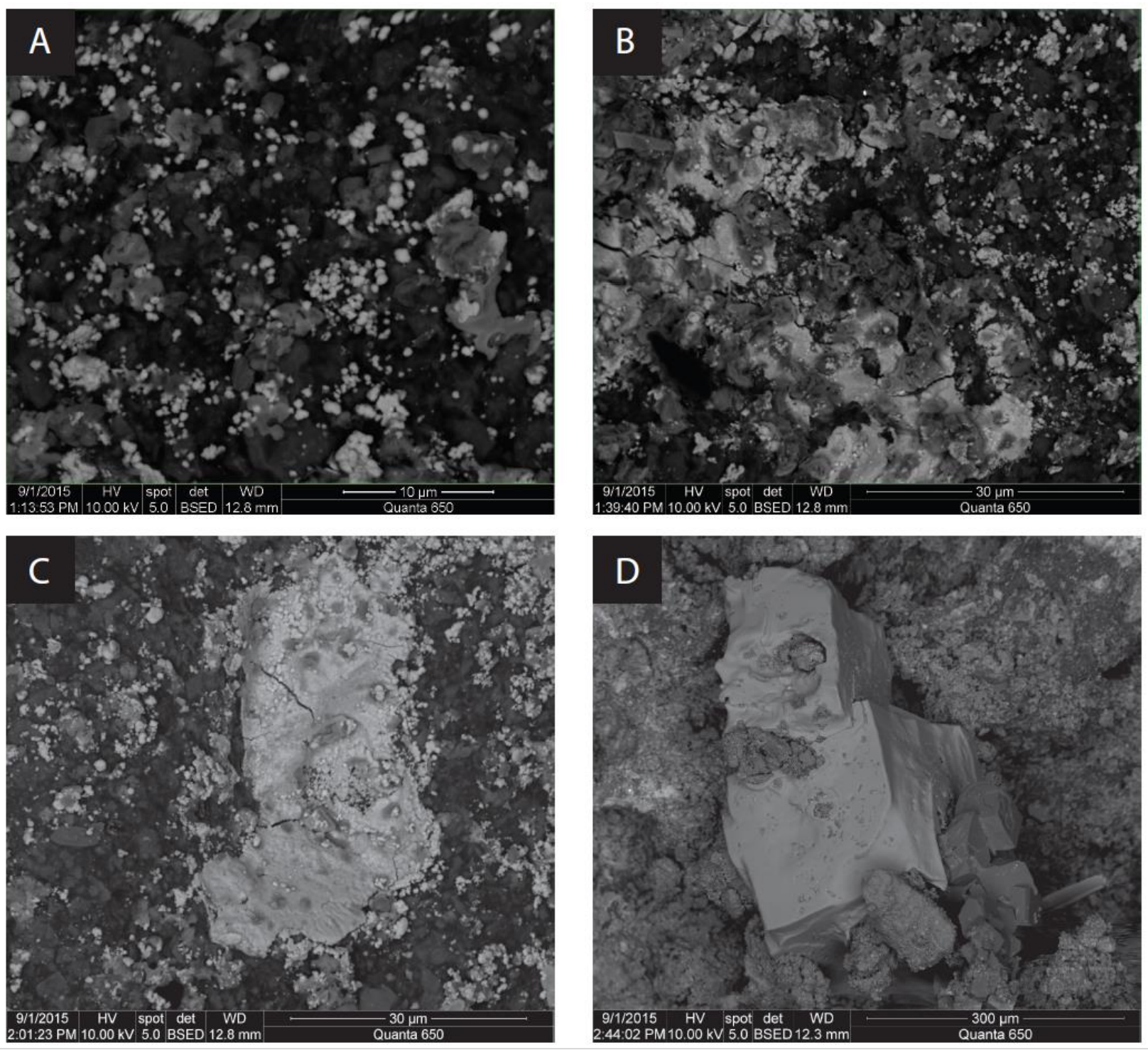

Figure 4-40 ESEM images of IN13-P4 sample measured at $10 \mathrm{kV}$. (A) Globular masses of Cu halide mineral presumed to be atacamite, surrounded by anhedral masses of quartz, $\mathrm{Mg}$ Al sulfate and probable montmorillonite. (B) Nodules of $\mathrm{Cu}$ halide mineral presumed to be atacamite, and probable microcrystalline alum$\mathrm{K}$, albite an a $\mathrm{Na} \mathrm{Mg}$ sulfate(C) Amalgamated mass of probable atacamite with minor phase of probable kaolinite (D) Larger cube of halite with possible inclusions of microcrystalline $\mathrm{Na} \mathrm{Mg}$ sulfates and kaolinite, bordering smaller cubic crystals of $\mathrm{Na} \mathrm{Mg}$ sulfates. 

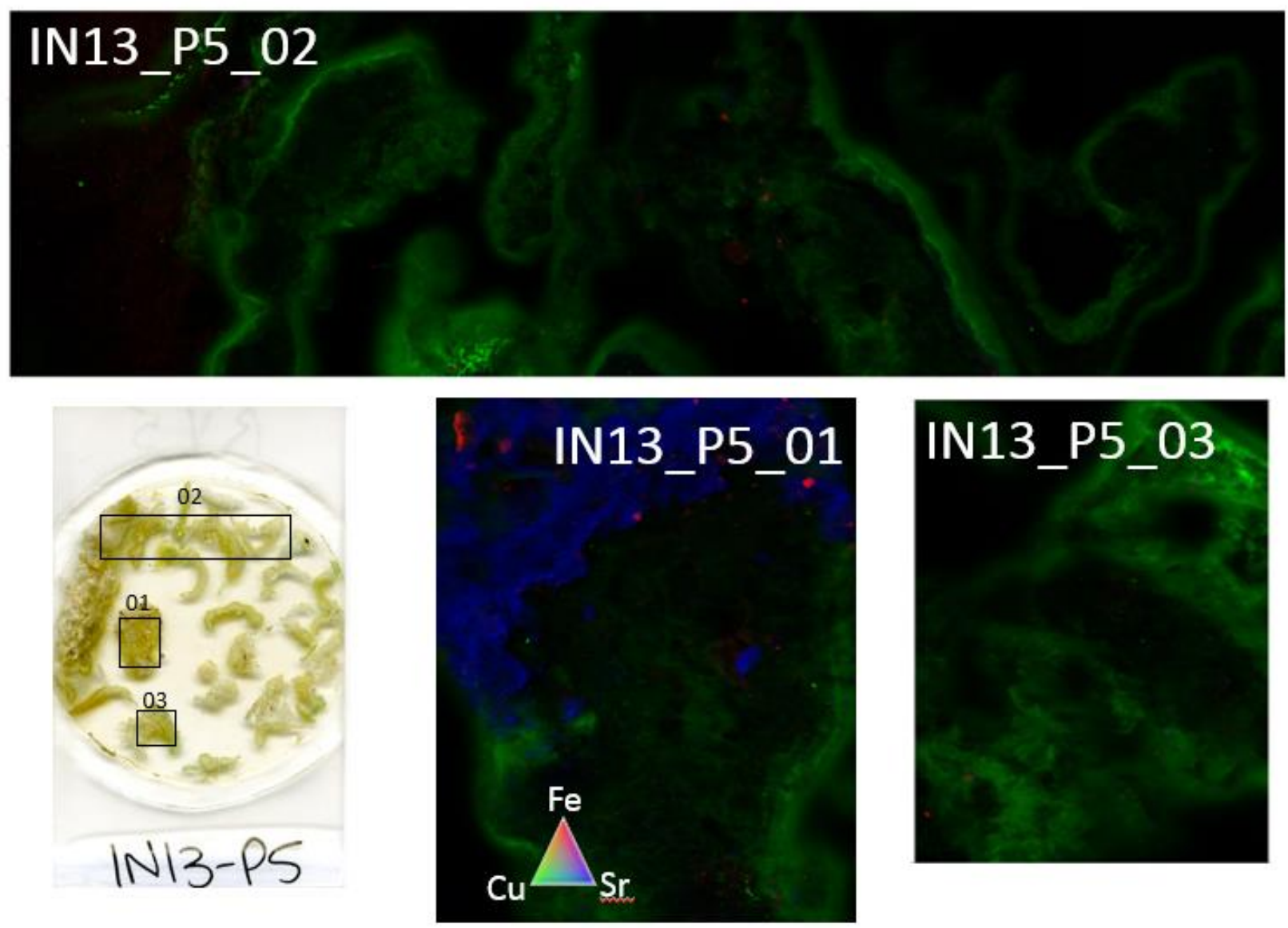

Figure 4-41 $\mu$ XRD elemental maps collected on thin section IN13-P5.

Table 4-25 List of minerals identified at IN13-P5 with $\mu$ XRD methods at the synchrotron, bulk XRD and ESEM.

\begin{tabular}{|c|c|c|c|c|}
\hline \multirow{2}{*}{$\frac{\text { IN13-P5 }}{\text { Minerals }}$} & \multicolumn{4}{|c|}{ Identification Method } \\
\hline & Formula & XRD & $\mu \mathrm{XRD}$ & ESEM \\
\hline Halite & $\mathrm{NaCl}$ & $x$ & & $x$ \\
\hline Gypsum & $\mathrm{Ca}\left(\mathrm{SO}_{4}\right) \cdot 2\left(\mathrm{H}_{2} \mathrm{O}\right)$ & $x$ & & $\mathrm{x}$ \\
\hline Hexahydrite & $\mathrm{Mg}\left(\mathrm{SO}_{4}\right) \cdot 6\left(\mathrm{H}_{2} \mathrm{O}\right)$ & $\mathrm{x}$ & $x$ & $x$ \\
\hline Muscovite & $\mathrm{KAl}_{2} \mathrm{Si}_{3} \mathrm{AlO}_{10}(\mathrm{OH})_{2}$ & $\mathrm{x}$ & $x$ & \\
\hline Starkeyite & $\mathrm{Mg}\left(\mathrm{SO}_{4}\right) \cdot 4\left(\mathrm{H}_{2} \mathrm{O}\right)$ & $\mathrm{x}$ & & $x$ \\
\hline Albite & $\left(\mathrm{Na}_{0.622} \mathrm{Ca}_{0.368}\right) \mathrm{Al}_{1.29} \mathrm{Si}_{2.7} \mathrm{O}_{8}$ & & $x$ & \\
\hline Quartz & $\mathrm{SiO}_{2}$ & $x$ & $x$ & \\
\hline Bassanite & $\mathrm{Ca}\left(\mathrm{SO}_{4}\right) \cdot 0.5\left(\mathrm{H}_{2} \mathrm{O}\right)$ & & $x$ & \\
\hline Loweite & $\mathrm{Na}_{12} \mathrm{Mg}_{7}\left(\mathrm{SO}_{4}\right)_{13} \cdot 15\left(\mathrm{H}_{2} \mathrm{O}\right)$ & & $x$ & $x$ \\
\hline Anhydrite & $\mathrm{Ca}\left(\mathrm{SO}_{4}\right)$ & & $x$ & $x$ \\
\hline Blodite & $\mathrm{Na}_{2} \mathrm{Mg}\left(\mathrm{SO}_{4}\right)_{2} \cdot 4\left(\mathrm{H}_{2} \mathrm{O}\right)$ & & $x$ & $x$ \\
\hline d'ansite & $\left(\mathrm{Zn}\left(\mathrm{SO}_{4}\right)\right)(\mathrm{NaCl})_{3}\left(\mathrm{Na}_{2}\left(\mathrm{SO}_{4}\right)\right)_{9}$ & & $x$ & \\
\hline
\end{tabular}



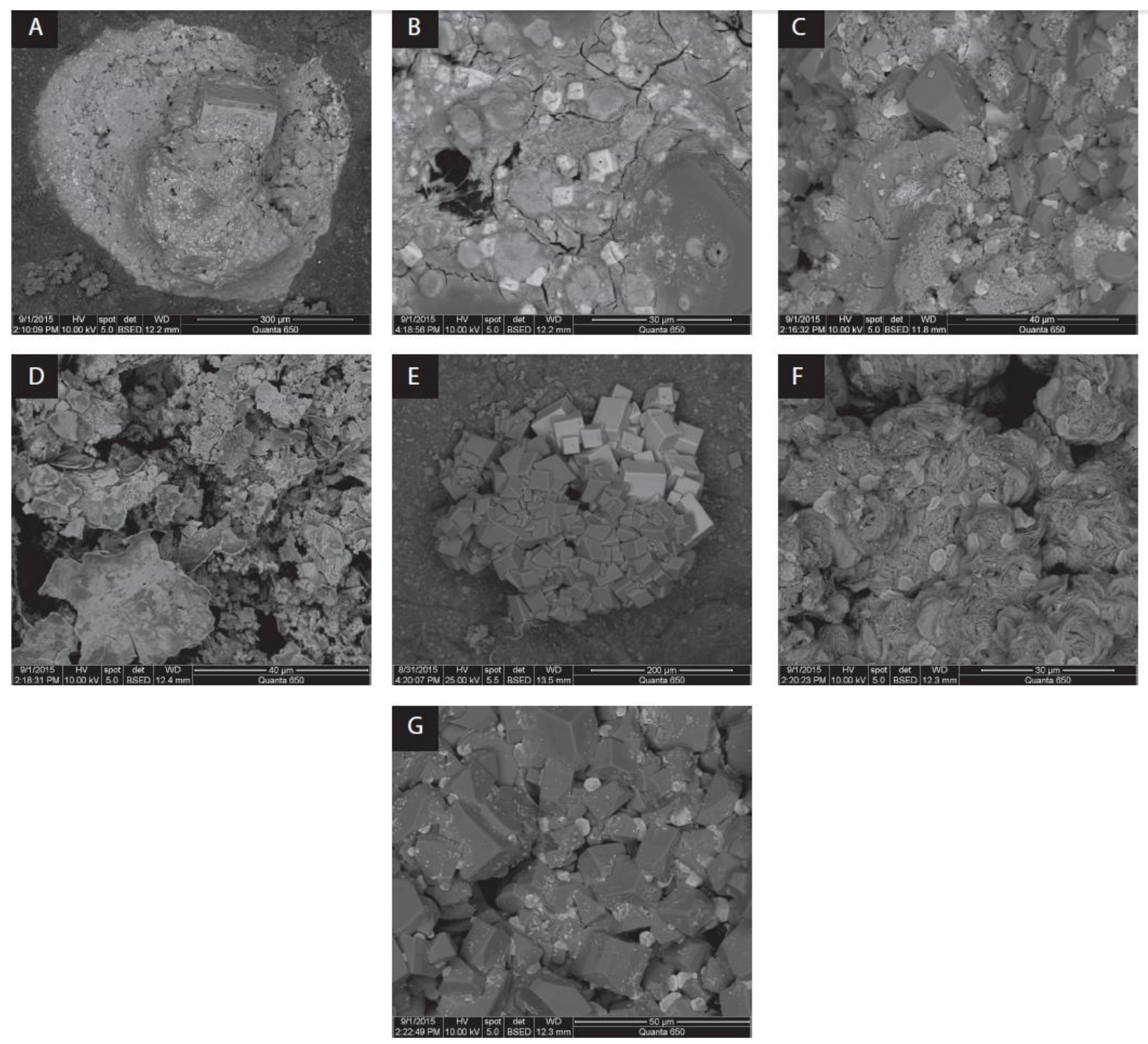

Figure 4-42 ESEM images of sample IN13-P5. (A) Euhedral crystals of probable blodite and halite enclosed in a mixture of microcrystallites of unidentified $\mathrm{Mg}$ sulfate, halite and sylvite (B) Microcrystals of cubic sylvite found alongside a larger cube of $\mathrm{Mg} \mathrm{Na}$ sulfate (C) Intergrown aggregates of tabular Ca sulfate (gypsum or anhydrite), globules of subhedral to anhedral Al sulfates and euhedral $\mathrm{Na} \mathrm{Mg}$ sulfates. (D) Crusts and nodules of Cu halide and traces of $\mathrm{Mg}$. (E) Cubic crystals of halite and isometric crystals of probable blodite. (F) Spherical aggregates of tabular $\mathrm{Na} \mathrm{Mg} \mathrm{Cl}$ sulfate and anhedral globules of unidentified $\mathrm{Mg}$ sulfate. (G) Probable euhedral crystals of blodite, covered by crusts of halite and alongside crystals of unidentified subhedral Al sulfate minerals. 


\subsubsection{Lagunas Norte}

\subsection{LN-DAR-1}

The water at DAR-1 was underdrain from waste rock pile leachate. One sample of brownish-red secondary precipitates was sampled. Hydroniumjarosite $\left(\left(\mathrm{H}_{3} \mathrm{O}\right) \mathrm{Fe}\left(\mathrm{SO}_{4}\right)_{2}(\mathrm{OH})_{6}\right)$, quartz $\left(\mathrm{SiO}_{2}\right)$ and anorthoclase (( $\left.\mathrm{Na}, \mathrm{K}) \mathrm{AlSi}_{3} \mathrm{O}_{8}\right)$ are identified (Table 4-27). Al, As, Ca, Fe, Mg, K, P and $\mathrm{S}$ are the most concentrated elements in this sample (Figure 4-43).

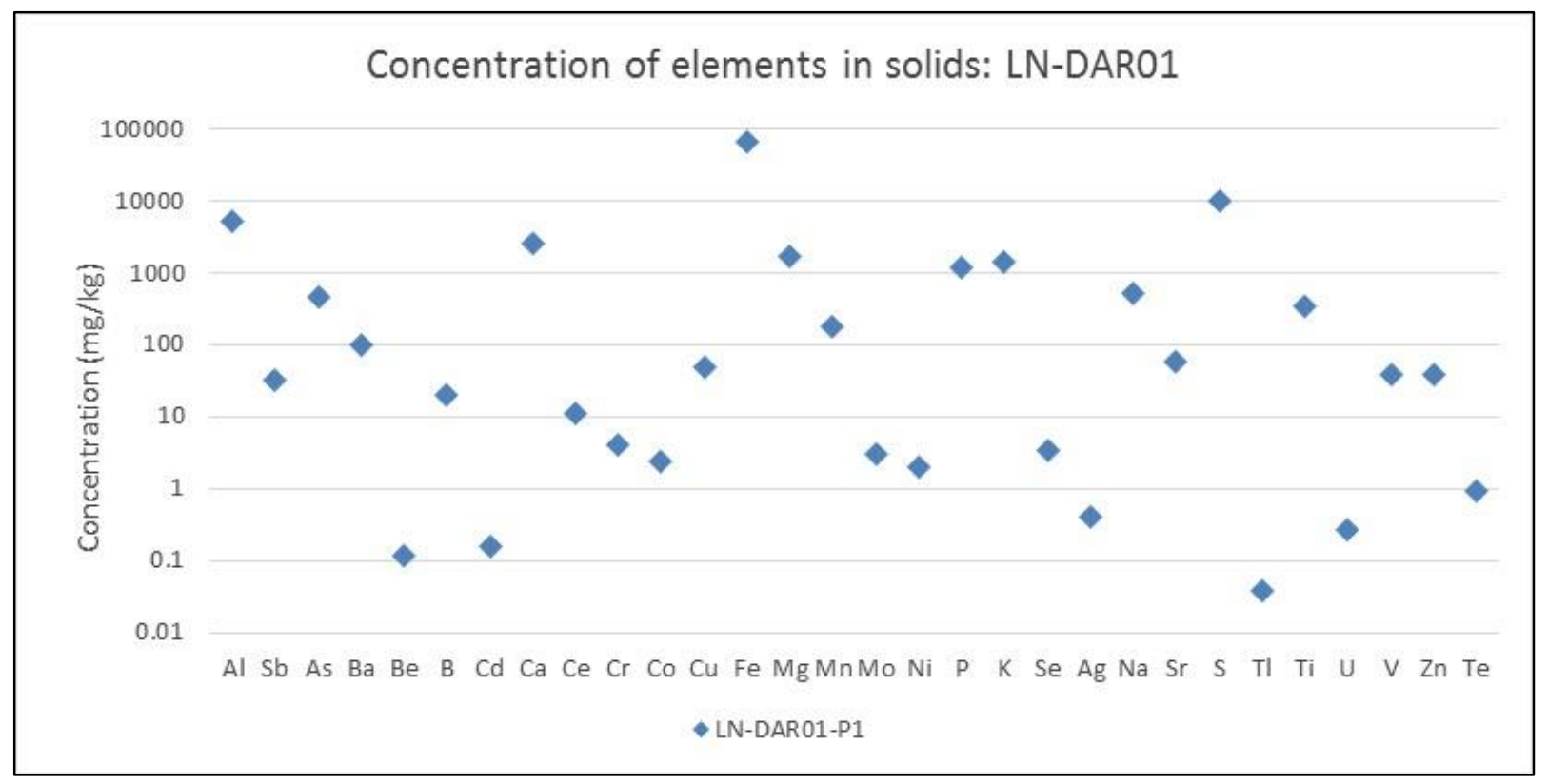

Figure 4-43 Concentration of elements in $\mathrm{mg} / \mathrm{kg}$ in the solid sample LN-DAR01 from ICP-OES analysis.

\subsection{LN-SP3}

This sampling site is the third settling pond on site. Two wet precipitate samples were collected here: Fe oxides and some creamy white material. XRD analysis demonstrates that sample LN-SP3-P1 contains mainly quartz $\left(\mathrm{SiO}_{2}\right)$ and albite $\left(\mathrm{NaAlSi}_{3} \mathrm{O}_{8}\right)$ with bulk analysis revealing highest concentrations in Al, Fe, Mg, K, S (Figure 4-44). 


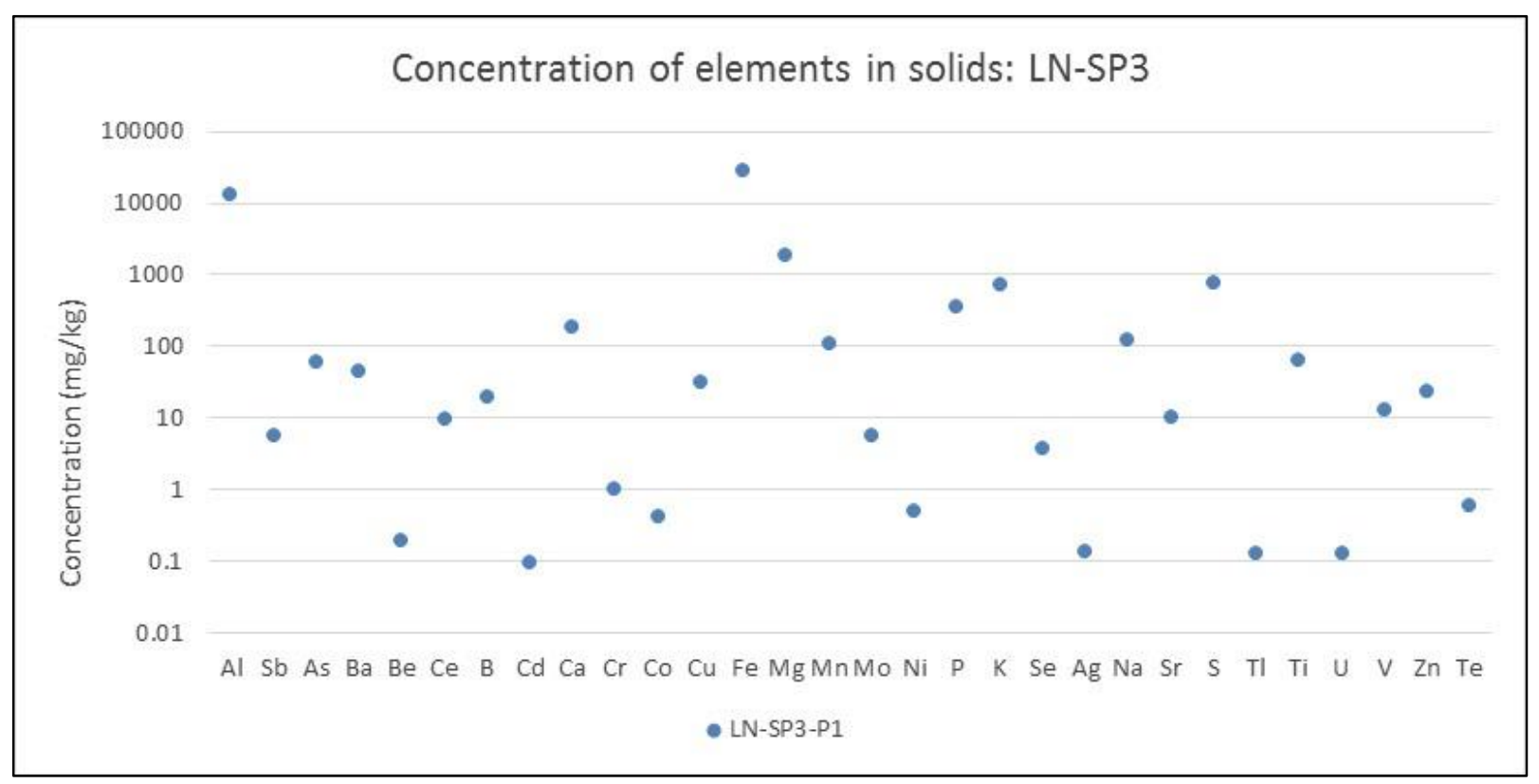

Figure 4-44 Concentration of elements in $\mathrm{mg} / \mathrm{kg}$ in the solid sample LN-SP3 from ICP-OES analysis.

\subsection{LN-PW1-P1}

Precipitates were sampled along the pit wall and can be described as blue crusts. Sample bulk chemistry data shows highest concentrations of $\mathrm{Ca}, \mathrm{Cu}, \mathrm{Fe}$ and $\mathrm{S}$ (Figure 4-45). Minerals identified for this thin section in bulk analysis include chalcanthite $\left(\mathrm{Cu}\left(\mathrm{SO}_{4}\right) \cdot 5\left(\mathrm{H}_{2} \mathrm{O}\right)\right)$ and gypsum. Thin section LN-PW1-P was made out of secondary precipitates collected from effluent mine drainage waters along the pit wall. Micro-XRD demonstrates a more diverse set of minerals present such as $\mathrm{Cu}, \mathrm{Fe}, \mathrm{Fe}-\mathrm{As}$, and $\mathrm{SO}_{4}$ rich minerals. Copper-rich minerals potentially include poitevinite $\left(\mathrm{Cu}, \mathrm{Fe}^{2+}, \mathrm{Zn}\right)\left(\mathrm{SO}_{4}\right) \cdot\left(\mathrm{H}_{2} \mathrm{O}\right)$, antlerite $\left(\mathrm{Cu}_{3}\left(\mathrm{SO}_{4}\right)(\mathrm{OH})_{4}\right)$, and chrysocolla $\left((\mathrm{Cu}, \mathrm{Mg})\left(\mathrm{SiO}_{3}\right) \cdot\left(\mathrm{H}_{2} \mathrm{O}\right)\right)$ (Table 4-26). Iron-rich minerals include fibroferrite $\left(\mathrm{Fe}(\mathrm{OH})\left(\mathrm{SO}_{4}\right) \cdot 5\left(\mathrm{H}_{2} \mathrm{O}\right)\right)$ and scorodite $\left(\mathrm{Fe}\left(\mathrm{AsO}_{4}\right) \cdot 2\left(\mathrm{H}_{2} \mathrm{O}\right)\right)(\mathrm{Table} 4-26)$. Gypsum $\left(\mathrm{Ca}\left(\mathrm{SO}_{4}\right) \cdot 2\left(\mathrm{H}_{2} \mathrm{O}\right)\right)$ was also present throughout the section. Poitevinite is a rare secondary mineral that may occur in the oxidized zone of hydrothermal mineral prospects (Schindler et al., 2006; Lottermoser, 2010c). Although potevinite is closely related to the kieserite group, it is differentiated by the presence of $\mathrm{Cu}, \mathrm{Fe}$ and $\mathrm{Zn}$. Antlerite is a secondary mineral occurring in the oxidized zone of copper deposits in arid regions (Zvereva et al., 2015). Jarosite, is a straw-yellow mineral that is common found in the weathered zone of sulfide ore deposits 
and in acid sulfate soils (Bigham et al., 2000). Chrysocolla is a commonly associated with other secondary copper minerals. Bonattite is also a common secondary mineral from a pyrite containing deposit. Scorodite is a common secondary mineral formed by the oxidation of arsenopyrite or other arsenicbearing minerals (Triantafyllidis and Skarpelis, 2006; Jamieson et al., 2011).

This sample was also mounted on a stub and carbon coated to be analyzed by ESEM. The results demonstrate great variation in morphologies and chemical composition. At least 5 phases were identified by the ESEM (Figure 4-48): (1) intergrowths of sheet-like stacks of Fe Al sulfate interpreted to be aluminocopiapite, the aluminium (2) crystals of tabular gypsum (3) anhedral to subhedral tabular crystals of Cu sulfates with rounded terminations (4) anhedral Cu sulfate crystals showing evidence of desiccation (5) microcrystalline Cu silicate (likely chrysocolla). These results demonstrate that only chalcanthite was identified by all methods, whereas the Al Fe sulfate phase likely aluminocopiapite, was only identified using the ESEM.

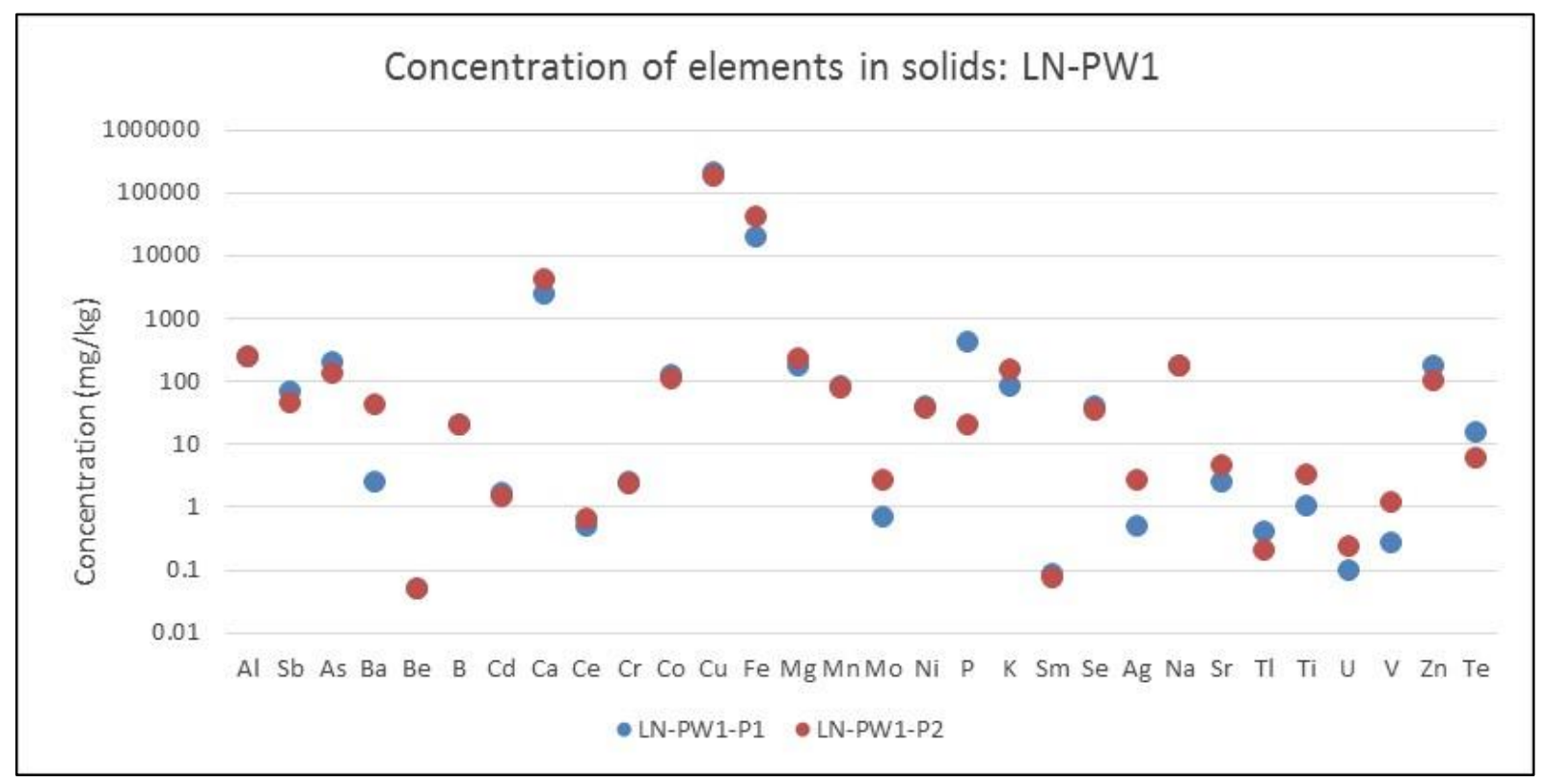

Figure 4-45 Concentration of elements in $\mathrm{mg} / \mathrm{kg}$ in the solid sample LN-PW1-P1 and LN-PW1-P2 from ICP-OES analysis.

Synchrotron microanalysis was conducted on the sample LN-PW1-P1. The results are tabulated so as to show common phases with differing analytical methods (Table 4-26). 


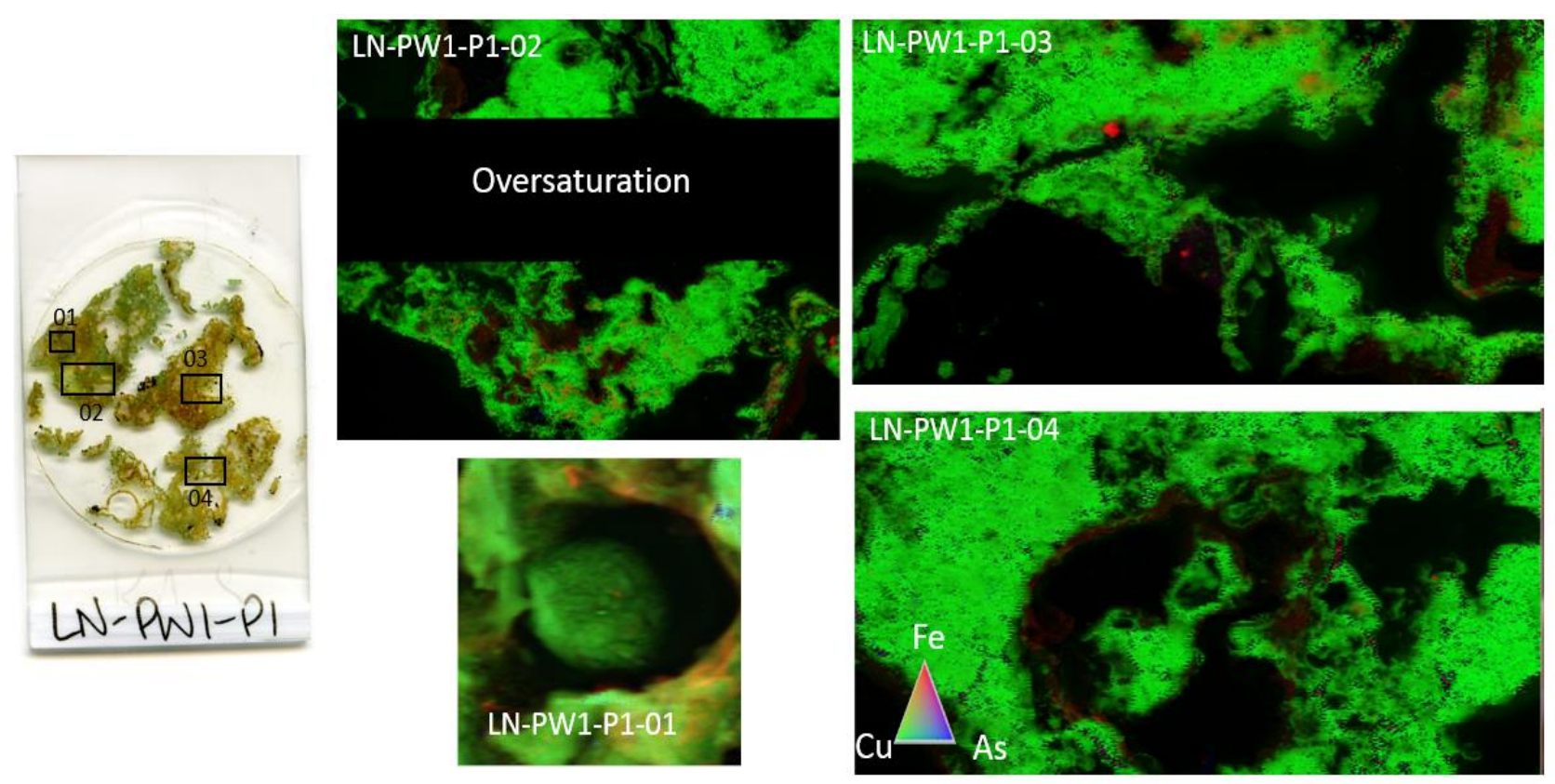

Figure 4-46 $\mu$ XRF elemental maps from the thin section made of sample LN-PW1-P1.

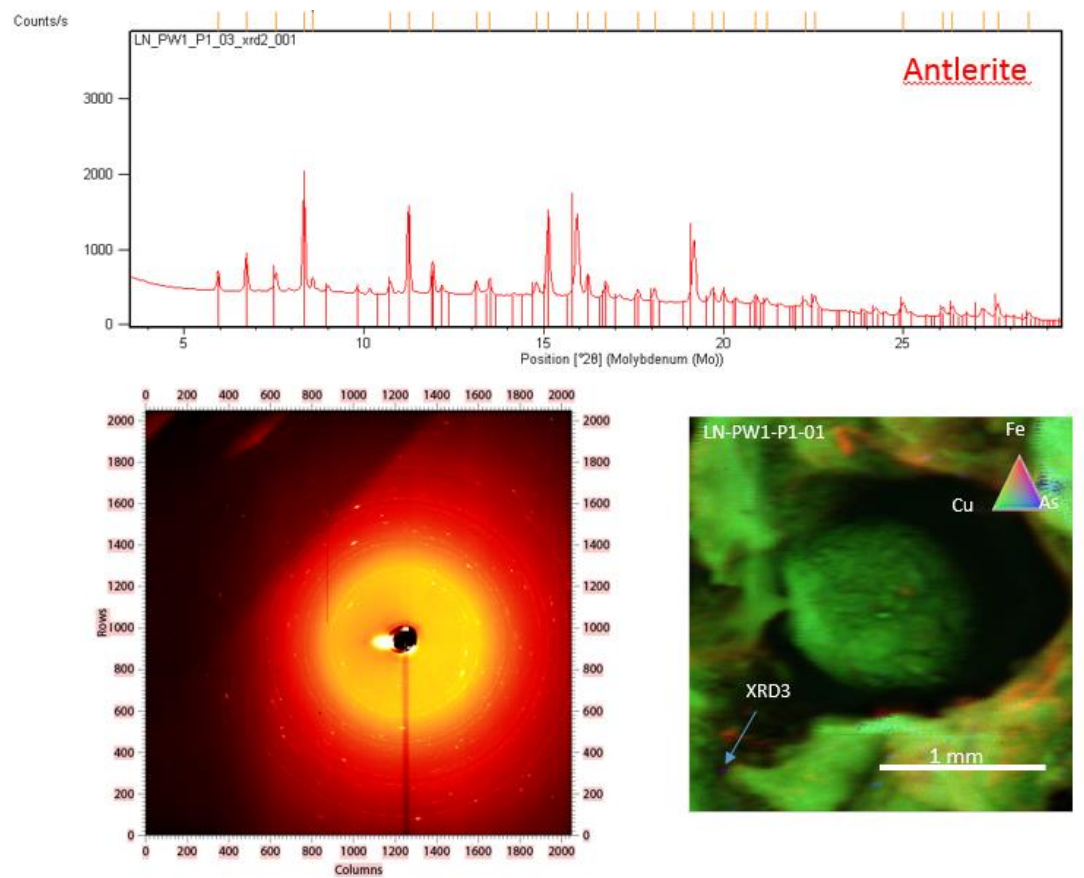

Figure 4-47 $\mu$ XRD 2D diffraction pattern (bottom left) of antlerite. The associated 1D diffraction pattern with matched mineral profiles is on the right. 

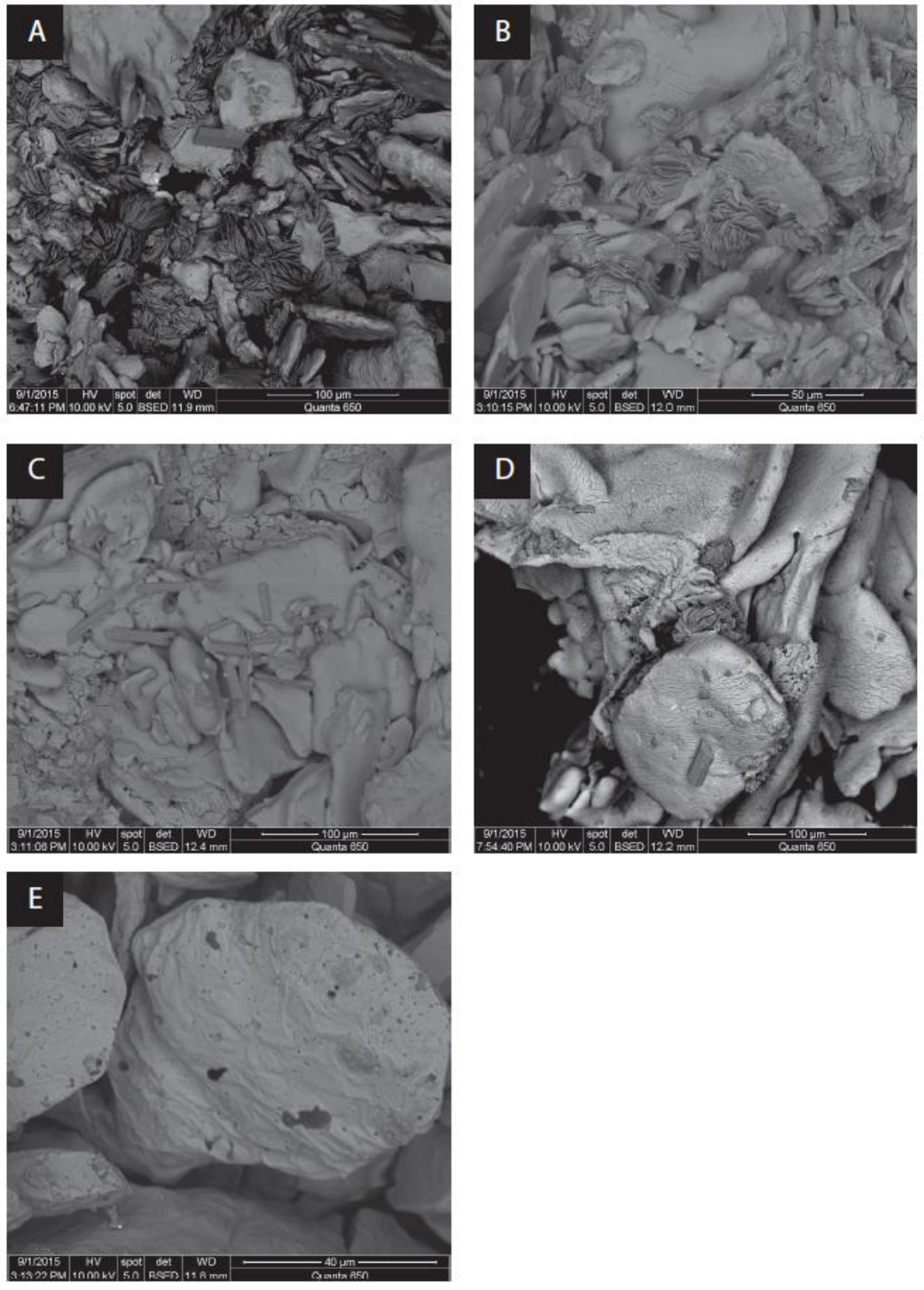

Figure 4-48 ESEM images of sample LN-PW1-P1 mounted on a stub. (A) Intergrowths of sheetlike stacks of $\mathrm{Fe} \mathrm{Al}$ sulfate interpreted to be aluminocopiapite, crystals of tabular gypsum and anhedral to subhedral tabular crystals of $\mathrm{Cu}$ sulfates with rounded terminations. (B) Sheet-like aggregates of $\mathrm{Cu}$ and Fe sulfates surrounded by tabular $\mathrm{Cu}$ sulfate minerals. (C) Tabular euhedral crystal of $\mathrm{Cu}$ sulfates, as well as anhedral, larger $\mathrm{Cu}$ sulfate crystals showing evidence of desiccation. (D) Larger tabular subhedral crystal of unidentified Cu sulfate and smaller crystal of gypsum. (E) Anhedral tabular grain of Cu sulfate.

Table 4-26 List of minerals identified at LN-PW1-P1 with $\mu$ XRD methods at the synchrotron, bulk XRD and ESEM.

\begin{tabular}{|c|c|c|c|c|}
\hline \multicolumn{2}{|l|}{ LN-PW1-P1 } & \multicolumn{3}{|c|}{ Identification Method } \\
\hline Minerals & Formula & XRD & UXRD & ESEM \\
\hline Chalcanthite & $\mathrm{CuSO}_{4} \cdot 5\left(\mathrm{H}_{2} \mathrm{O}\right)$ & $x$ & $x$ & $x$ \\
\hline Antlerite & $\left(\mathrm{Cu}_{3}(\mathrm{OH})_{4}\left(\mathrm{SO}_{4}\right)\right.$ & & $x$ & $x$ \\
\hline Chrysocolla & $(\mathrm{Cu}, \mathrm{Mg}) \mathrm{SiO}_{3} \cdot\left(\mathrm{H}_{2} \mathrm{O}\right)$ & & $x$ & $x$ \\
\hline Scorodite & $\mathrm{Fe}\left(\mathrm{AsO}_{4}\right) \cdot 2\left(\mathrm{H}_{2} \mathrm{O}\right)$ & & $x$ & \\
\hline Poitevinite & $\mathrm{Cu}\left(\mathrm{SO}_{4}\right) \cdot\left(\mathrm{H}_{2} \mathrm{O}\right)$ & & $x$ & $x$ \\
\hline Fibroferrite & $\mathrm{Fe}(\mathrm{OH})\left(\mathrm{SO}_{4}\right) \cdot 5\left(\mathrm{H}_{2} \mathrm{O}\right)$ & & $x$ & \\
\hline Aluminocopiapite & $\mathrm{Al}_{2 / 3} \mathrm{Fe}_{4}\left(\mathrm{SO}_{4}\right)_{6}(\mathrm{OH})_{2} \cdot 20\left(\mathrm{H}_{2} \mathrm{O}\right)$ & & & $x$ \\
\hline Gypsum & $\mathrm{Ca}\left(\mathrm{SO}_{4}\right) \cdot 2\left(\mathrm{H}_{2} \mathrm{O}\right)$ & & $x$ & $x$ \\
\hline
\end{tabular}




\subsection{LN-VWD}

Solid samples were collected next to the waste rock leachate before the collection in the Vizcachaz pond for treatment. Two white precipitate samples, and Fe oxide crust overlying the white material were sampled and analyzed. LN-VWD-P1 reveals high concentrations in Al, Ca, Fe, Mn, P, K, S (Figure 4-49). LNVWD-P2 reveals high concentrations in Al, $\mathrm{Ca}, \mathrm{Fe}, \mathrm{Mg}, \mathrm{Mn}, \mathrm{P}, \mathrm{K}, \mathrm{S}$ (Figure 4-49). The occurrences of the following minerals are based on bulk chemistry, physical properties of the sample such as colour and XRD analyses: Ettringite $\left(\mathrm{Ca}_{6}\left(\mathrm{Al}(\mathrm{OH})_{6}\left(\mathrm{SO}_{4}\right)_{3} \cdot 26\left(\mathrm{H}_{2} \mathrm{O}\right)\right)\right.$, calcite $\left(\mathrm{Ca}\left(\mathrm{CO}_{3}\right)\right)$, quartz and alunogen were identified in LN-VWD-P1; gypsum, quartz and ettringite were identified at LN-VWD-P2 (Table 4-27). Ettringite is assumed to have an anthropogenic origin in the sample because of the nearby lime addition. Calcite may have possibly formed as a result of lime addition near this sampling location.

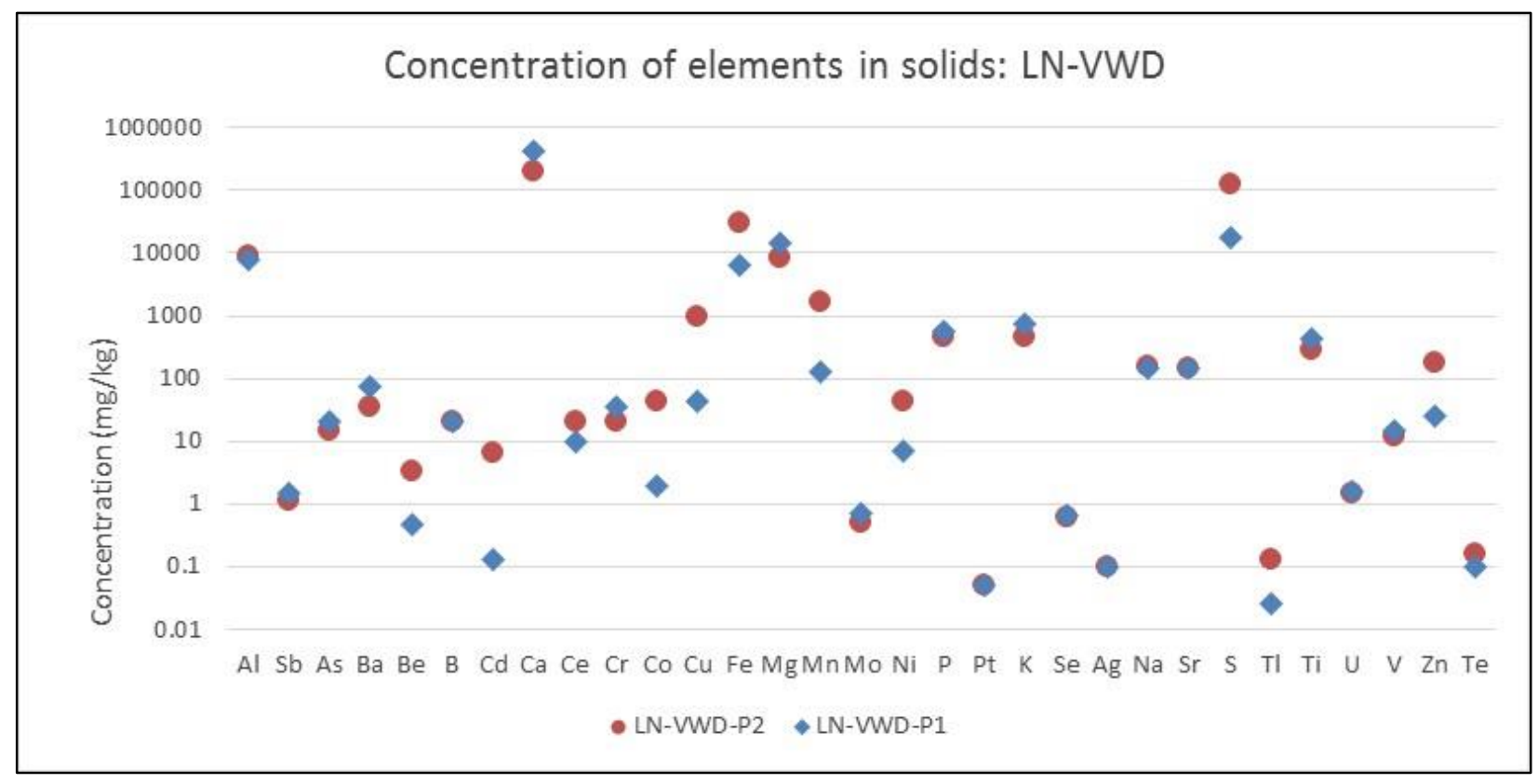

Figure 4-49 Concentration of elements in $\mathrm{mg} / \mathrm{kg}$ in the solid sample LN-VWD-P1 and LN-VWD-P2 from ICP-OES analysis. 
Table 4-27 Minerals identified with bulk XRD from samples collected at Lagunas Norte mine.

\begin{tabular}{|c|c|c|}
\hline Sample & Minerals & Chemical Formula \\
\hline \multirow[t]{3}{*}{ LN-DAR01-P1 } & Quartz & $\mathrm{SiO}_{2}$ \\
\hline & Hydroniumjarosite & $\left(\mathrm{H}_{3} \mathrm{O}\right) \mathrm{Fe}_{3}\left(\mathrm{SO}_{4}\right)_{2}(\mathrm{OH})_{6}$ \\
\hline & Anorthoclase & $\mathrm{Na}_{0.7} \mathrm{~K}_{0.29} \mathrm{AlSi}_{3} \mathrm{O}_{8}$ \\
\hline \multirow[t]{3}{*}{ LN-SP3-P1 } & Quartz & $\mathrm{SiO}_{2}$ \\
\hline & Albite & $\mathrm{NaAlSi}_{3} \mathrm{O}_{8}$ \\
\hline & Mus covite & $\mathrm{KAl}_{2} \mathrm{Si}_{3} \mathrm{AlO}_{10}(\mathrm{OH})_{2}$ \\
\hline LN-PW1-P1 & Chalcanthite & $\mathrm{Cu}\left(\mathrm{SO}_{4}\right) \cdot 5\left(\mathrm{H}_{2} \mathrm{O}\right)$ \\
\hline \multirow[t]{5}{*}{ LN-PW1-P2 } & Chalcanthite & $\mathrm{Cu}\left(\mathrm{SO}_{4}\right) \cdot 5\left(\mathrm{H}_{2} \mathrm{O}\right)$ \\
\hline & Quartz & $\mathrm{SiO}_{2}$ \\
\hline & Anorthite & $\mathrm{CaAl}_{2} \mathrm{Si}_{2} \mathrm{O}_{8}$ \\
\hline & Alum-Na & $\mathrm{NaAl}\left(\mathrm{SO}_{4}\right)_{2} \cdot 12\left(\mathrm{H}_{2} \mathrm{O}\right)$ \\
\hline & Melanterite & $\mathrm{Fe}^{+2(} \mathrm{SO}_{4)} \cdot 7\left(\mathrm{H}_{2} \mathrm{O}\right)$ \\
\hline \multirow[t]{3}{*}{ LN-PW2-P1 } & Quartz & $\mathrm{SiO}_{2}$ \\
\hline & Muscovite & $\mathrm{KAl}_{2} \mathrm{Si}_{3} \mathrm{AlO}_{10}(\mathrm{OH})_{2}$ \\
\hline & Gypsum & $\mathrm{CaSO}_{4} \cdot 2\left(\mathrm{H}_{2} \mathrm{O}\right)$ \\
\hline \multirow[t]{4}{*}{ LN-VWD-P1 } & Ettringite & $\mathrm{Ca}_{6} \mathrm{Al}_{2}\left(\mathrm{SO}_{4}\right)_{3}(\mathrm{OH})_{12} \cdot 26\left(\mathrm{H}_{2} \mathrm{O}\right)$ \\
\hline & Calcite & $\mathrm{Ca}\left(\mathrm{CO}_{3}\right)$ \\
\hline & Quartz & $\mathrm{SiO}_{2}$ \\
\hline & Alunogen & $\mathrm{Al}_{2}\left(\mathrm{SO}_{4}\right)_{3} \cdot 17\left(\mathrm{H}_{2} \mathrm{O}\right)$ \\
\hline \multirow[t]{3}{*}{ LN-VWD-P2 } & Gypsum & $\mathrm{Ca}\left(\mathrm{SO}_{4}\right) \cdot 2\left(\mathrm{H}_{2} \mathrm{O}\right)$ \\
\hline & Quartz & $\mathrm{SiO}_{2}$ \\
\hline & Ettringite & $\mathrm{Ca}_{6} \mathrm{Al}_{2}\left(\mathrm{SO}_{4}\right)_{3}(\mathrm{OH})_{12} \cdot 26\left(\mathrm{H}_{2} \mathrm{O}\right)$ \\
\hline
\end{tabular}




\subsubsection{Pierina}

Secondary minerals identified at Pierina in a study conducted by Klohn Crippen Berger (2012)

include alunite, calcite, gypsum, chalcanthite, paracoquimbite, coquimbite, ferriocopiapite, zincocopiapite, brochantite and antlerite.

\subsection{P-WRD}

Three secondary precipitates were collected next to waste rock drainage water. These include Fe oxides, Fe oxides with some lighter coloured areas and some flaky darker brown pieces, and brown-beige colored precipitates. In this sample, quartz $\left(\mathrm{SiO}_{2}\right)$, jarosite, montmorillonite $\left((\mathrm{Na}, \mathrm{Ca})_{0.3}(\mathrm{Al}\right.$, $\mathrm{Mg})_{2} \mathrm{Si}_{4} \mathrm{O}_{10}(\mathrm{OH})_{2} \cdot \mathrm{xH}_{2} \mathrm{O}$ ) were identified based on the chemistry analyzed by Analytical Services Unit at Queen's University, physical properties of the sample such as colour and XRD analyses. Bulk chemistry results show high concentrations in $\mathrm{Al}, \mathrm{As}, \mathrm{Ca}, \mathrm{Fe}, \mathrm{Mg}, \mathrm{P}, \mathrm{Na}, \mathrm{S}$. All elements in this list are accounted for by identified mineralogy with the exception of As and P (Figure 4-50, Table 4-28).

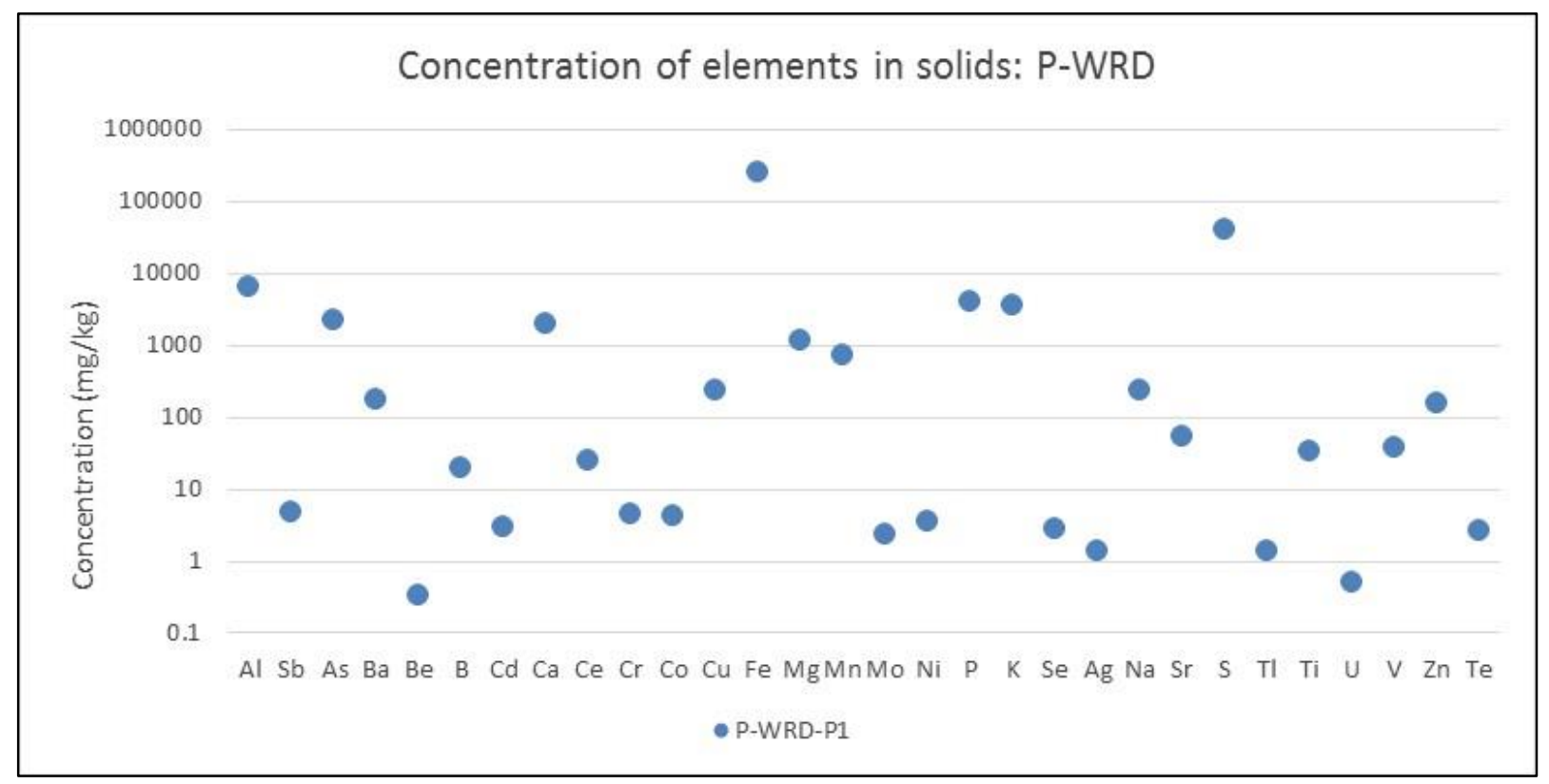

Figure 4-50 Concentration of elements in $\mathrm{mg} / \mathrm{kg}$ in the solid sample P-WRD-P1 from ICP-OES analysis. 


\subsection{P-EC}

Secondary samples at P-EC were collected from water filled Emilio Cocha pit. These are brownish beige coloured with no obvious mineral structures. Minerals observed in P-EC-P1 include alunite $\left(\mathrm{K}\left(\mathrm{Al}_{3}\left(\mathrm{SO}_{4}\right)_{2}(\mathrm{OH})_{6}\right)\right)$, spangolite $\left(\mathrm{Cu}_{6} \mathrm{Al}\left(\mathrm{SO}_{4}\right)(\mathrm{OH})_{12} \mathrm{Cl} \cdot 3\left(\mathrm{H}_{2} \mathrm{O}\right)\right)$, quartz $\left(\mathrm{SiO}_{2}\right)$ and montmorillonite $\left((\mathrm{Na}, \mathrm{Ca})_{0.3}(\mathrm{Al}, \mathrm{Mg})_{2} \mathrm{Si}_{4} \mathrm{O}_{10}(\mathrm{OH})_{2} \cdot x\left(\mathrm{H}_{2} \mathrm{O}\right)\right)($ Table 4-28). The most elevated elemental concentrations are in Al, Ca, Fe, Mg, Mn, K, P, S, Zn (Figure 4-51).

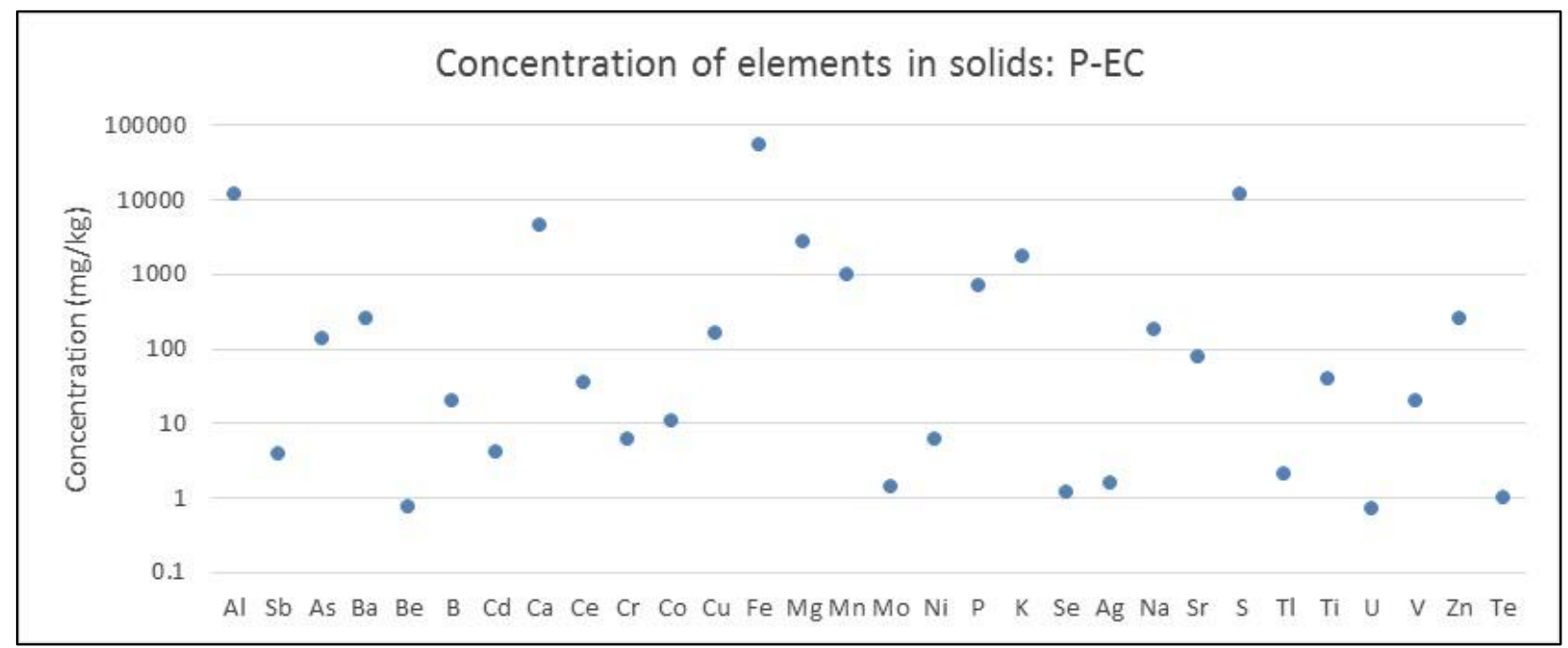

Figure 4-51 Concentration of elements in $\mathrm{mg} / \mathrm{kg}$ in the solid sample P-EC from ICP-OES analysis.

\subsection{P-PW}

Mixed white, yellow and cream coloured secondary precipitates were collected from the pit wall.

P-PW1-P-b and P-PW1-P-c show high concentrations of Al, As, $\mathrm{Ca}, \mathrm{Cu}, \mathrm{Fe}$, and S (Figure 4-52). Minerals include romerite $\left(\mathrm{Fe}^{2+} \mathrm{Fe}^{3+}{ }_{2}\left(\mathrm{SO}_{4}\right)_{4} \cdot 14\left(\mathrm{H}_{2} \mathrm{O}\right)\right)$, coquimbite $\left.\left(\mathrm{Fe}_{1.62} \mathrm{Al}_{0.38}\right)\left(\mathrm{SO}_{4}\right)_{3} \cdot 9\left(\mathrm{H}_{2} \mathrm{O}\right)\right)$, and quartz in P-PW1-Pb, and coquimbite $\left.\left(\mathrm{Fe}_{1.62} \mathrm{Al}_{0.38}\right)\left(\mathrm{SO}_{4}\right)_{3} \cdot\left(\mathrm{H}_{2} \mathrm{O}\right)_{9}\right)$, romerite $\left(\mathrm{Fe}^{2+} \mathrm{Fe}^{3+}{ }_{2}\left(\mathrm{SO}_{4}\right)_{4} \cdot 14\left(\mathrm{H}_{2} \mathrm{O}\right)\right)$ and likely magnesiocopiapite in P-PW1-P-c (Table 4-28). Alunite is a common alteration mineral found at HS epithermal deposits. Coquimbite is a water soluble efflorescent mineral commonly produced by oxidation with Fe sulfide minerals (Romero et al., 2006). Romerite also forms from the oxidation of Fe sulfides (Chou et al., 2013). 
ESEM analyses conducted on carbon coated mounted stubs from samples P-PW1-Pb and P-PW1Pc. At least 3 distinct phases were identified from the MSP stubs of sample P-PW1-Pc, clearly demonstrating differing morphology and chemistry (Figure 4-53): (1) fine grained mass of Fe Al sulfate mineral (likely halotrichite) (2) microcrystalline of halite (3) euhedral radial intergrowth of Fe Al sulfate crystallites. Seven different phases were identified by ESEM within the sample P-PW1-Pb (Figure 4-54), including: (1) Platy, hexagonal crystallites of an Al sulfate mineral (2) Columnar Fe Al sulfate (3) stacked hexagonal and platy Fe Al sulfates with surficial crusts of $\mathrm{Cu}$ and As aggregates (4) hexagonal and platy Fe Al sulfate interpreted as the aluminium endmember of coquimbite, aluminocoquimbite, forming rosettes (5) Platy hexagonal Fe sulfates (6) fibrous and columnar aggregate of probable aluminocoquimbite (7) granular kaolinite. 


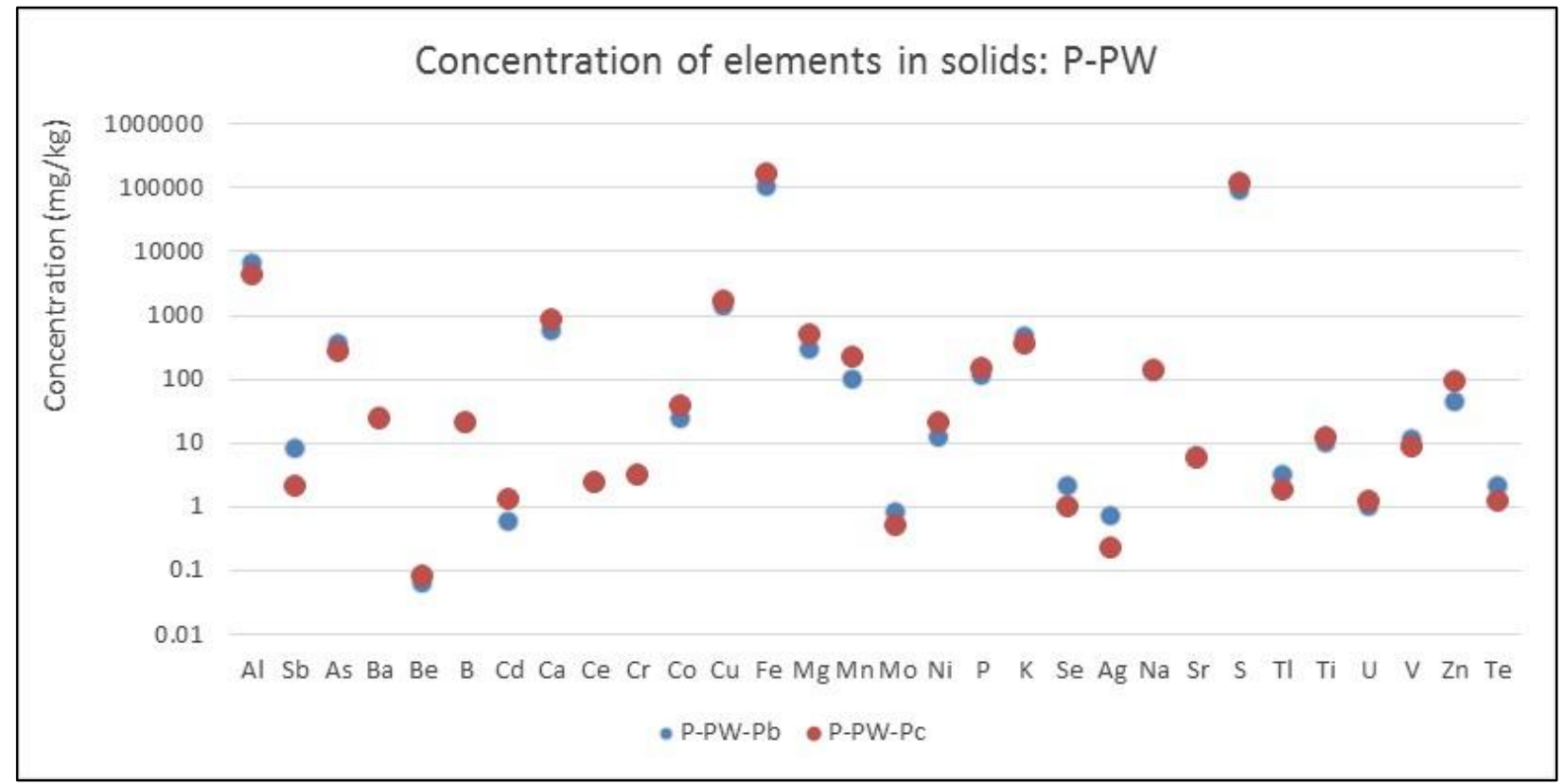

Figure 4-52 Concentration of elements in $\mathrm{mg} / \mathrm{kg}$ in the solid sample P-PW-Pb and P-PW-Pc from ICP-OES analysis.
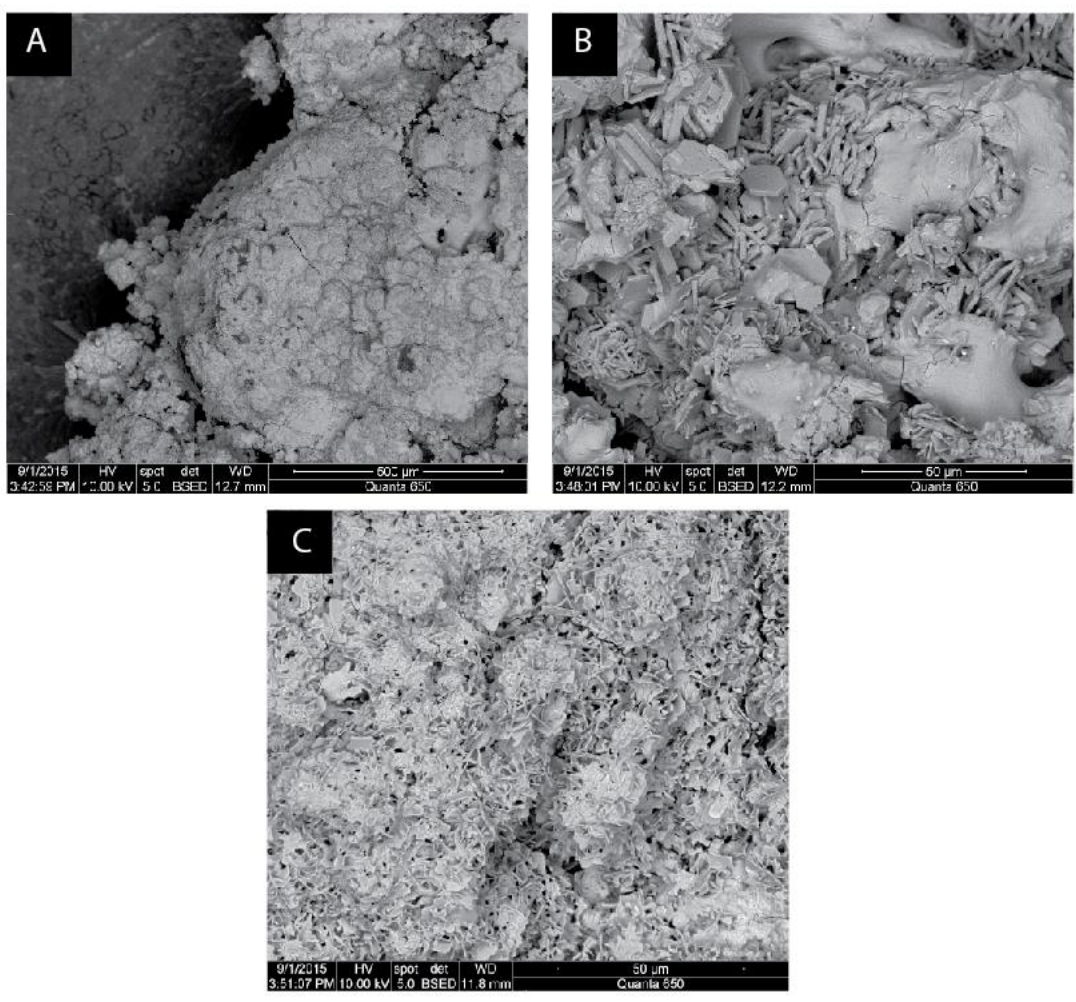

Figure 4-53 ESEM images of P-PW1-Pc sample. (A) Fine grained mass of Fe Al sulfate mineral (likely halotrichite) (B) Crusts of halite forming on euhedral radial intergrowth of Fe Al sulfate crystallites. (C) Radial intergrowths of Fe Al sulfate minerals with trace amount of $\mathrm{Mg}$, perhaps as a contaminant from the epoxy used. 

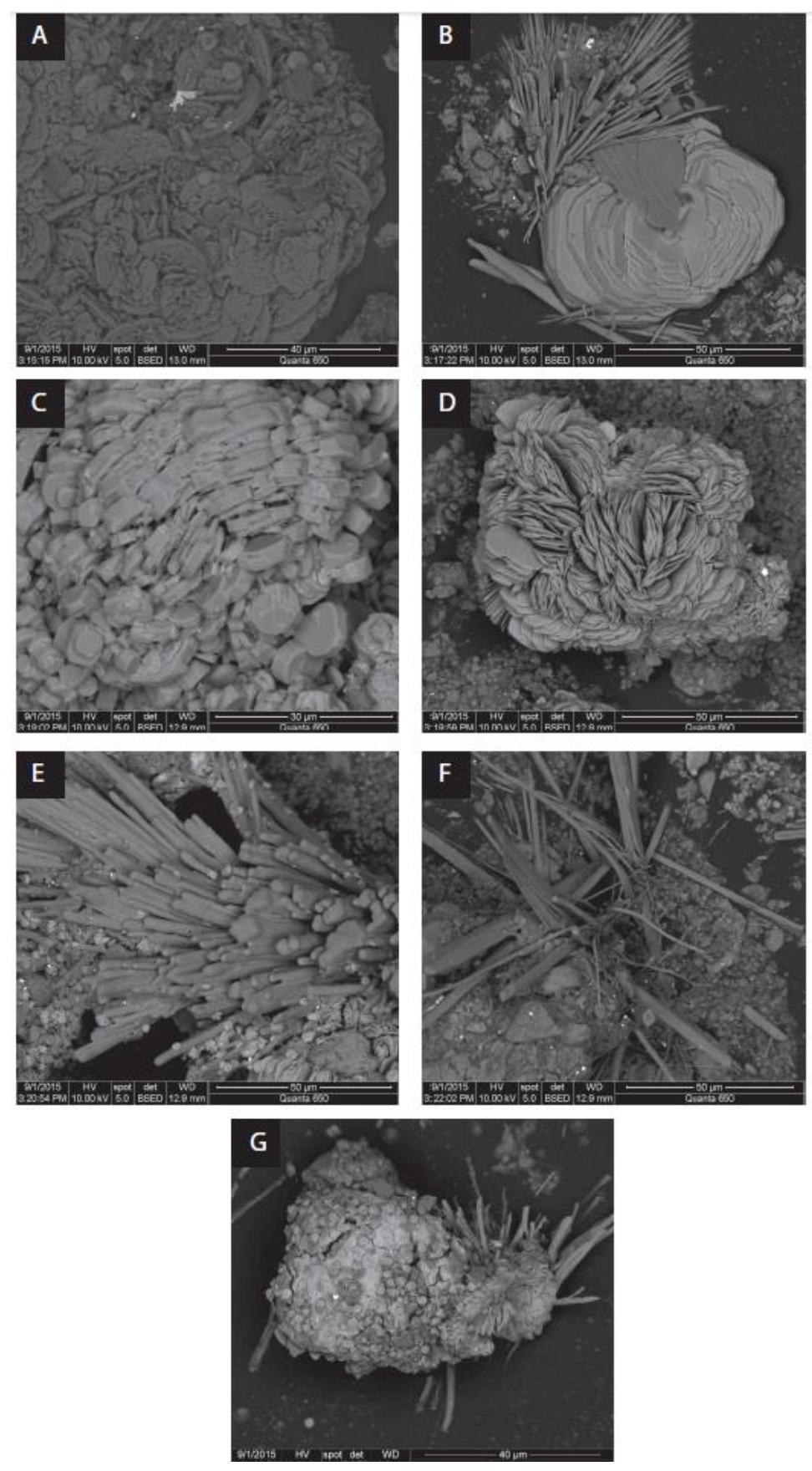

Figure 4-54 ESEM images of sample P-PW1-Pb. (A) Platy, hexagonal crystallites of an Al sulfate mineral.(B) Columnar Fe Al sulfate seemingly growing on a rosette of Fe sulfate with less Al. (C) Intergrowth of stacked hexagonal and platy Fe Al sulfates with crusts of $\mathrm{Cu}$ aggregates forming on the surface of the minerals. (D) Platy hexagonal Fe Al sulfate interpreted as aluminocoquimbite forming rosettes (E) Platy hexagonal Fe sulfates on columnar Fe Al sulfate. Unidentified Fe sulfate minerals appear as larger subhedral aggregates. (F) Fibrous and columnar aggregate of probable aluminocoquimbite with granular kaolinite. (G) Columnar aggregates of Fe Al sulfate, smooth and bright phase are a mixture of Fe sulfates with $\mathrm{Cu}$ and quartz and platy hexagonal crystallites of Fe Al sulfates with evidence of As. 
Table 4-28 Minerals identified with bulk XRD from samples collected at Pierina mine.

\begin{tabular}{|c|c|c|}
\hline Sample & Minerals & Chemical Formula \\
\hline \multirow[t]{3}{*}{ P-EC-P1 } & Mus covite & $\mathrm{KAl}_{2} \mathrm{Si}_{3} \mathrm{AlO}_{10}(\mathrm{OH})_{2}$ \\
\hline & Quartz & $\mathrm{SiO}_{2}$ \\
\hline & Gypsum & $\mathrm{Ca}\left(\mathrm{SO}_{4}\right) \cdot 2\left(\mathrm{H}_{2} \mathrm{O}\right)$ \\
\hline P-PW1-P-a & No bulk XRD & \\
\hline \multirow[t]{3}{*}{ P-PW1-P-b } & Romerite & $\mathrm{Fe}^{2+} \mathrm{Fe}^{3+}{ }_{2}\left(\mathrm{SO}_{4}\right)_{4} \cdot 14\left(\mathrm{H}_{2} \mathrm{O}\right)$ \\
\hline & Coquimbite & $\left(\mathrm{Fe}_{1.62} \mathrm{Al}_{0.38}\right)\left(\mathrm{SO}_{4}\right)_{3} \cdot 9\left(\mathrm{H}_{2} \mathrm{O}\right)$ \\
\hline & Quartz & $\mathrm{SiO}_{2}$ \\
\hline \multirow[t]{3}{*}{ P-PW1-P-C } & Coquimbite & $\left(\mathrm{Fe}_{1.54} \mathrm{Al}_{0.46}\right)\left(\mathrm{SO}_{4}\right)_{3} \cdot 9\left(\mathrm{H}_{2} \mathrm{O}\right)$ \\
\hline & Romerite & $\mathrm{Fe}^{2+} \mathrm{Fe}^{3+}{ }_{2}\left(\mathrm{SO}_{4}\right)_{4} \cdot 14\left(\mathrm{H}_{2} \mathrm{O}\right)$ \\
\hline & Magnesiocoiapite & $\mathrm{MgFe}_{4}\left(\mathrm{SO}_{4}\right)_{6}(\mathrm{OH})_{2} \cdot 2 \mathrm{O}\left(\mathrm{H}_{2} \mathrm{O}\right)$ \\
\hline P-PW1-P-d & No bulk XRD & \\
\hline \multirow[t]{3}{*}{ P-WRD } & Quartz & $\mathrm{SiO}_{2}$ \\
\hline & Jarosite & $\mathrm{KFe}_{3}\left(\mathrm{SO}_{4}\right)_{2}(\mathrm{OH})_{6}$ \\
\hline & Montmorillonite & $(\mathrm{Na}, \mathrm{Ca})_{0.3}(\mathrm{Al}, \mathrm{Mg})_{2} \mathrm{Si}_{4} \mathrm{O}_{10}(\mathrm{OH})_{2} \cdot \times\left(\mathrm{H}_{2} \mathrm{O}\right)$ \\
\hline
\end{tabular}




\subsubsection{Trace element association with minerals}

Semi-quantitative amounts of trace elements associated with certain minerals were identified by the analysis of MCA spectra collected from the $\mu \mathrm{XRF}$ maps. This analysis was conducted for spots where the mineral had already been identified by $\mu \mathrm{XRD}$. In order to calculate weight percentages of the trace elements given count values from the $\mu \mathrm{XRF}$ maps, these were normalized to Fe or $\mathrm{Cu}$ depending on the spectra (Table 4-31). For the calculations, a matrix of either $\mathrm{Cu}\left(\mathrm{SO}_{4}\right)$ or $\mathrm{Fe}\left(\mathrm{SO}_{4}\right)$ was assumed based on the energy dispersive spectra. Furthermore, compositionally, almost all analyses are dominated by $\mathrm{Cu}$ or Fe. If the Fe phases here are oxides rather than sulfates, the uncertainty is very small since $S$ and $O$ have similar absorption at the energy of analysis. Sulfur and $\mathrm{O}$ concentrations are fixed at 20 and 40 weight percent. Results show that blodite is host to $\mathrm{Cu}, \mathrm{Mn}, \mathrm{Zn}, \mathrm{Ca}, \mathrm{Co}, \mathrm{Fe}$, and $\mathrm{Ni}$ in approximately decreasing order. Alunite is host to $\mathrm{Cu}, \mathrm{Zn}, \mathrm{Ca}, \mathrm{Mn}, \mathrm{Fe}, \mathrm{Ti}, \mathrm{Co}, \mathrm{Ni}$ and As in decreasing order. Hexahydrite contains $\mathrm{Cu}$, $\mathrm{Zn}, \mathrm{Fe}, \mathrm{Mn}, \mathrm{As}, \mathrm{Ni}, \mathrm{Ti}$ or $\mathrm{Ti}, \mathrm{As}, \mathrm{Co}$, and $\mathrm{Ni}$ in decreasing order. Goethite shows significant variation with regards to trace elements from one spot to the next. In fact, the order of elements is different in all 7 spots analyzed with goethite being identified as the primary mineral (Table 4-30). Copper and Zn, have been observed by Manceau et al. (2000) to be incorporated into the structure of goethite, which may also be the case here. However, it is also possible that the elements are associated with a different mineral if another phase, perhaps amorphous, is present but not identified through $\mu \mathrm{XRD}$ analysis. 
Table 4-29 Elements associated to blodite, alunite, hexahydrite and goethite in decreasing order within samples from El Indio.

\begin{tabular}{ll}
\hline Minerals & Associated elements \\
\hline Blodite & $\mathrm{Cu}, \mathrm{Mn}, \mathrm{Zn}, \mathrm{Ca}, \mathrm{Co}, \mathrm{Fe}, \mathrm{Ni}$ \\
Alunite & $\mathrm{Cu}, \mathrm{Zn}, \mathrm{Ca}, \mathrm{Mn}, \mathrm{Fe}, \mathrm{Ti}, \mathrm{Co}, \mathrm{Ni}$ \\
Hexahydrite $\mathrm{Cu}, \mathrm{Zn}, \mathrm{Fe}, \mathrm{Mn}, \mathrm{As}, \mathrm{Ni}, \mathrm{Ti}$ \\
Goethite & $\mathrm{Cu}, \mathrm{K}, \mathrm{Mn}, \mathrm{As}$ \\
\hline
\end{tabular}

Table 4-30 Elements associated to goethite in decreasing order within samples from El Indio.

\begin{tabular}{|c|c|c|}
\hline Sample & Mineral $\mu$ XRD & Associated elements \\
\hline IN28-P2-04-xrd2 & \multirow{7}{*}{ 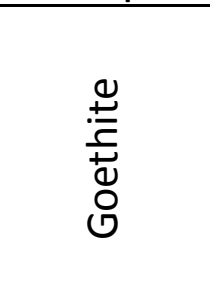 } & $\mathrm{Cu}>\mathrm{Mn}>\mathrm{K}>\mathrm{Zn}>\mathrm{Ca}>\mathrm{As}>\mathrm{Ti}>\mathrm{Co}$ \\
\hline IN28-P4-01-xrd1 & & $\mathrm{K}>\mathrm{As}>\mathrm{Ti}>\mathrm{Mn}>\mathrm{Co}>\mathrm{Cu}>\mathrm{Zn}$ \\
\hline IN28-P4-01-xrd2 & & $\mathrm{Mn}>\mathrm{As}>\mathrm{K}>\mathrm{Co}>\mathrm{Ti}>\mathrm{Ca}>\mathrm{Cu}>\mathrm{Ni}$ \\
\hline IN28-P4-01-xrd10 & & $\mathrm{K}>\mathrm{Ca}>\mathrm{Ti}>\mathrm{Mn}>\mathrm{Ni}>\mathrm{Br}>\mathrm{Co}>\mathrm{Cu}>\mathrm{Zn}>\mathrm{As}$ \\
\hline IN28-P4-02-xrd3 & & $\mathrm{K}>\mathrm{Ti}>\mathrm{Mn}>\mathrm{Co}>\mathrm{Ca}>\mathrm{Cu}>\mathrm{Ni}>\mathrm{Zn}>\mathrm{As}$ \\
\hline IN28-P4-04-xrd1 & & $\mathrm{K}>\mathrm{C} \mathrm{a}>\mathrm{Ti}>\mathrm{Mn}>\mathrm{Co}>\mathrm{As}>\mathrm{Cu}$ \\
\hline IN28-P4-04-xrd2 & & $\mathrm{Ti}>\mathrm{Mn}>\mathrm{Co}>\mathrm{Cu}>\mathrm{As}$ \\
\hline
\end{tabular}


Table 4-31 Trace elements determined with $\mu$ XRF (weight percent).

\begin{tabular}{|c|c|c|c|c|c|c|c|c|}
\hline \multirow{2}{*}{\multicolumn{2}{|c|}{$\begin{array}{l}\text { IN13-P1-03-XRD2 } \\
\text { Blodite }\end{array}$}} & \multirow{2}{*}{\multicolumn{3}{|c|}{$\begin{array}{l}\text { IN13-P1-07-xrd6 } \\
\text { Blodite }\end{array}$}} & \multicolumn{3}{|c|}{ IN13-P3-01-xrd13 } & \multirow[b]{3}{*}{ Ratios (Cu) } \\
\hline & & & & & & Anhydrite & & \\
\hline Component & Wt $\%$ & Ratios (Cu) & Component & Wt\% & Ratios (Cu) & Component & Wt\% & \\
\hline $\mathrm{Cu}$ & 40 & 1.0 & $\mathrm{Cu}$ & 40 & 1.0 & $\mathrm{Ca}$ & 150 & 3.8 \\
\hline $\mathrm{Mn}$ & 28 & 0.7 & Mn & 22 & 0.55 & $\mathrm{Zn}$ & 115 & 2.9 \\
\hline $\mathrm{Zn}$ & 14 & 0.35 & $\mathrm{Zn}$ & 10 & 0.26 & Mn & 70 & 1.8 \\
\hline $\mathrm{Ca}$ & 3.5 & 0.087 & $\mathrm{Fe}$ & 0.99 & 0.025 & $\mathrm{Cu}$ & 40 & 1.0 \\
\hline Co & 0.99 & 0.025 & & & & $\mathrm{Ti}$ & 14 & 0.36 \\
\hline $\mathrm{Fe}$ & 0.70 & 0.018 & & & & $\mathrm{Fe}$ & 8.5 & 0.21 \\
\hline \multirow[t]{2}{*}{$\mathrm{Ni}$} & 0.77 & 0.019 & & & & As & 1.3 & 0.033 \\
\hline & & & & & & $\mathrm{Br}$ & 1.4 & 0.035 \\
\hline \multicolumn{2}{|c|}{ IN13-P1-05-XRD5 } & & \multicolumn{2}{|c|}{ IN28-P2-04-xrd2 } & & \multicolumn{2}{|c|}{ IN28-p4-01-xrd1 } & \\
\hline \multicolumn{2}{|c|}{ Alunite } & & \multicolumn{2}{|c|}{ Goethite } & & \multicolumn{2}{|c|}{ Goethite } & \\
\hline Component & Wt\% & Ratios (Cu) & Component & Wt\% & Ratio(Fe) & Component & Wt\% & Ratio(Fe) \\
\hline $\mathrm{Cu}$ & 40 & 1.0 & $\mathrm{Fe}$ & 40 & 1.0 & $\mathrm{Fe}$ & 40 & 1.0 \\
\hline $\mathrm{Zn}$ & 17 & 0.42 & $\mathrm{Cu}$ & 6.0 & 0.15 & K & 2.8 & 0.071 \\
\hline $\mathrm{Ca}$ & 13 & 0.32 & $M n$ & 5.0 & 0.12 & As & 1.9 & 0.046 \\
\hline$M n$ & 12 & 0.31 & K & 2.2 & 0.056 & $\mathrm{Ti}$ & 0.78 & 0.020 \\
\hline $\mathrm{Fe}$ & 4.8 & 0.12 & $\mathrm{Zn}$ & 1.2 & 0.031 & $M n$ & 0.74 & 0.019 \\
\hline $\mathrm{Ti}$ & 2.0 & 0.050 & $\mathrm{Ca}$ & 0.80 & 0.020 & Co & 0.28 & 0.0069 \\
\hline Co & 0.28 & 0.0070 & As & 0.68 & 0.017 & $\mathrm{Cu}$ & 0.19 & 0.0046 \\
\hline $\mathrm{Ni}$ & 0.23 & 0.0058 & $\mathrm{Ti}$ & 0.59 & 0.015 & $\mathrm{Zn}$ & 0.021 & 0.00053 \\
\hline As & 0.13 & 0.0031 & Co & 0.31 & 0.0078 & & & \\
\hline $\mathrm{Rb}$ & 0.52 & 0.013 & & & & & & \\
\hline \multicolumn{2}{|c|}{ IN28-P4-01-xrd2 } & & \multicolumn{2}{|c|}{ IN28-P4-01-xrd10 } & & \multicolumn{2}{|c|}{ IN28-P4-02-xrd3 } & \\
\hline \multicolumn{2}{|c|}{ Goethite } & & \multicolumn{2}{|c|}{ Goethite } & & \multicolumn{2}{|c|}{ Goethite } & \\
\hline Component & Wt $\%$ & Ratio(Fe) & Component & Wt\% & Ratio(Fe) & Component & Wt\% & Ratio(Fe) \\
\hline $\mathrm{Fe}$ & 40 & 1.0 & $\mathrm{Fe}$ & 40 & 1.0 & $\mathrm{Fe}$ & 40 & 1.0 \\
\hline$M n$ & 4.2 & 0.11 & K & 3.8 & 0.095 & K & 1.7 & 0.042 \\
\hline As & 3.4 & 0.085 & $\mathrm{Ca}$ & 1 & 0.025 & $\mathrm{Ti}$ & 0.94 & 0.024 \\
\hline K & 2.7 & 0.067 & $\mathrm{Ti}$ & 0.91 & 0.023 & $M n$ & 0.79 & 0.020 \\
\hline Co & 0.96 & 0.024 & $\mathrm{Mn}$ & 0.83 & 0.021 & Co & 0.73 & 0.018 \\
\hline $\mathrm{Ti}$ & 0.75 & 0.019 & $\mathrm{Ni}$ & 0.18 & 0.0044 & $\mathrm{Ca}$ & 0.57 & 0.014 \\
\hline $\mathrm{Ca}$ & 0.64 & 0.016 & $\mathrm{Br}$ & 0.081 & 0.0020 & $\mathrm{Cu}$ & 0.18 & 0.0046 \\
\hline $\mathrm{Cu}$ & 0.086 & 0.0022 & Co & 0.019 & 0.00047 & $\mathrm{Ni}$ & 0.018 & 0.00044 \\
\hline \multirow[t]{3}{*}{$\mathrm{Ni}$} & 0.063 & 0.0016 & $\mathrm{Cu}$ & 0.01 & 0.00025 & $\mathrm{Zn}$ & 0.012 & 0.00031 \\
\hline & & & $\mathrm{Zn}$ & 0.0078 & 0.00019 & As & 0.0052 & 0.00013 \\
\hline & & & As & 0.001 & 0.00003 & & & \\
\hline \multicolumn{2}{|c|}{ IN28-P4-04-xrd1 } & & \multicolumn{2}{|c|}{ IN28-P4-04-xrd2 } & & IN28-P2-04-xrd & & \\
\hline Goethite & & & Goethite & & & Hexahydrite & & \\
\hline Component & Wt $\%$ & Ratio(Fe) & Component & Wt\% & Ratio(Fe) & Component & Wt\% & Ratio (Cu) \\
\hline $\mathrm{Fe}$ & 40 & 1.0 & $\mathrm{Fe}$ & 40 & 1.0 & $\mathrm{Cu}$ & 40 & 1.0 \\
\hline K & 2.0 & 0.049 & $\mathrm{Ti}$ & 0.53 & 0.013 & $\mathrm{Zn}$ & 16 & 0.41 \\
\hline $\mathrm{Ca}$ & 0.81 & 0.020 & Mn & 0.36 & 0.0089 & $\mathrm{Fe}$ & 15 & 0.38 \\
\hline $\mathrm{Ti}$ & 0.63 & 0.016 & $\mathrm{Co}$ & 0.50 & 0.012 & Mn & 6.7 & 0.17 \\
\hline Mn & 0.55 & 0.014 & $\mathrm{Cu}$ & 0.050 & 0.0012 & As & 5.3 & 0.13 \\
\hline Co & 0.56 & 0.014 & As & 0.038 & 0.00094 & $\mathrm{Ni}$ & 2.8 & 0.069 \\
\hline As & 0.084 & 0.0021 & & & & $\mathrm{Ti}$ & 1.0 & 0.026 \\
\hline $\mathrm{Cu}$ & 0.037 & 0.00093 & & & & & & \\
\hline
\end{tabular}


Table 4-32 Trace elements determined with $\mu$ XRF (weight percent).

\begin{tabular}{|c|c|c|c|c|c|c|c|c|}
\hline \multicolumn{3}{|l|}{ IN28-P2-04-xrd9 } & \multicolumn{3}{|l|}{ IN13-P1-01-XRD3 } & \multicolumn{3}{|l|}{ IN13-P2-02-xrd1 } \\
\hline Hexahydrite & & & Loweite & & & Loweite & & \\
\hline Component & Wt\% & Ratio(Cu) & Component & Wt\% & Ratios (Cu) & Component & Wt\% & Ratios (Cu) \\
\hline $\mathrm{Cu}$ & 40 & 1.0 & $\mathrm{Cu}$ & 40 & 1.0 & $\mathrm{Cu}$ & 40 & 1.0 \\
\hline $\mathrm{Zn}$ & 18 & 0.46 & Mn & 33 & 0.83 & Mn & 29 & 0.73 \\
\hline $\mathrm{Fe}$ & 12 & 0.30 & $\mathrm{Zn}$ & 4.4 & 0.11 & As & 8.1 & 0.20 \\
\hline Mn & 11 & 0.27 & Co & 1.5 & 0.038 & & & \\
\hline $\mathrm{Ti}$ & 0.81 & 0.020 & $\mathrm{Ni}$ & 1.3 & 0.032 & & & \\
\hline As & 0.40 & 0.010 & $\mathrm{Fe}$ & 0.84 & 0.021 & & & \\
\hline Co & 0.16 & 0.0039 & & & & & & \\
\hline $\mathrm{Ni}$ & 0.22 & 0.0055 & & & & & & \\
\hline \multicolumn{3}{|c|}{ IN13-P5-01-xrd10 } & \multicolumn{3}{|l|}{ IN13-P5-02-xrd10 } & \multicolumn{3}{|l|}{ IN13-P5-03-xrd2 } \\
\hline Loweite & & & Loweite & & & Loweite & & \\
\hline Component & Wt $\%$ & Ratios (Cu) & Component & Wt\% & Ratios (Fe) & Component & Wt $\%$ & Ratio(Fe) \\
\hline $\mathrm{Cu}$ & 40 & 1.0 & $\mathrm{Fe}$ & 40 & 1.0 & $\mathrm{Fe}$ & 40 & 1.0 \\
\hline $\mathrm{Fe}$ & 26 & 0.64 & $\mathrm{Ca}$ & 13 & 0.33 & $\mathrm{Cu}$ & 40 & 1.00 \\
\hline $\mathrm{Zn}$ & 25 & 0.63 & $\mathrm{Cu}$ & 13 & 0.33 & Mn & 27 & 0.67 \\
\hline Mn & 16 & 0.41 & K & 11 & 0.28 & K & 19 & 0.47 \\
\hline $\mathrm{Ti}$ & 2.7 & 0.068 & Mn & 7.6 & 0.19 & $\mathrm{Ca}$ & 11 & 0.29 \\
\hline Co & 1.7 & 0.042 & $\mathrm{Ti}$ & 5.1 & 0.13 & $\mathrm{Zn}$ & 4.3 & 0.11 \\
\hline \multirow[t]{5}{*}{$\mathrm{Ni}$} & 1.2 & 0.030 & $\mathrm{Zn}$ & 1.7 & 0.042 & $\mathrm{Ti}$ & 1.4 & 0.034 \\
\hline & & & $\mathrm{Ni}$ & 0.58 & 0.014 & Co & 1.2 & 0.030 \\
\hline & & & Co & 0.49 & 0.012 & As & 0.23 & 0.0057 \\
\hline & & & As & 0.12 & 0.0031 & & & \\
\hline & & & $\mathrm{Br}$ & 0.027 & 0.00068 & & & \\
\hline
\end{tabular}




\section{Chapter 5 \\ Discussion}

\subsection{Discussion of geochemical characterization of waters}

\subsubsection{Field parameters}

Field parameters for surface waters collected at the 3 sites are listed in Table 4-7, Table 4-8, Table

4-9. At El Indio, conductivity measurements increased significantly downstream from $458 \mu \mathrm{S} / \mathrm{cm}$ to 1789 $\mu \mathrm{S} / \mathrm{cm}$ suggesting that ions were being added to the solution over the course of the downstream flow. As such, attenuation processes for sequestering ions from the solution during the sampling period may be relatively ineffective as the stream increases concentrations of dissolved species. The Eh measurements at El Indio suggest that IN28 and IN2 have a slightly higher redox capacity (higher Eh values), a variation that may impact the mobility of certain elements in the river system. IN23 has the highest $\mathrm{pH}(7.31)$ as it represents a natural stream before it enters the mine site. The lowest temperature and $\mathrm{pH}$ are measured at IN2, the sampling site found closest downstream to the Pastos Largos settling pond. Otherwise, temperature is fairly consistent amongst measured sites. The $\mathrm{pH}$ of $\mathrm{IN}-13$ increases $1-2 \mathrm{pH}$ units as a result of surficial water input from a nearby stream. A correlation between temperature and $\mathrm{pH}$ or conductivity was not observed at this mine. Based on temporal data collected from Barrick Gold Corporation, sample site IN28 is representative of the largest single flow into the mine drainage system.

At Lagunas Norte, specific conductance is highest at LN-DAR-1. A large concentration of dissolved salts is expected in these waters because the sample site represents leachate from the waste rock pile. This sampling location also has the lowest $\mathrm{pH}$ out of all measured sites because of its direct association with the waste rock pile, which is of acid sulfates HS origin. The waters collected from the pit wall (LNPW1 and LN-PW2) have near neutral pH measurements likely because they have not been exposed to acid sulfates and oxidizing sulfides that would acidify the waters. The ORP demonstrates that LN-DW-B-11 (1.74 V) and LN-PW2 (6.4 V) have the lowest Eh values, which decreases the mobility of elements such as 
$\mathrm{Pb}, \mathrm{Cd}, \mathrm{As}, \mathrm{Mn}, \mathrm{Al}, \mathrm{Fe}$. At Pierina, specific conductance measurements are highest at P-WRD and $\mathrm{pH}$ is the lowest, consistent with the observation that this solution is representative of waste rock drainage. The temperature values are positively correlated with specific conductance measurements at this mine, implying that temperature should always be recorded as it controls and influences specific conductance measurements.

Although samples were collected during one field season, seasonal variations including rainfall, weathering rates and temperature changes are expected to have an influence on the field variable values collected. Temperature of these streams is expected to rise in the summer months, thereby potentially increasing the values of specific conductance of the streams. Moreover, research from Sracek et al. (2010) demonstrate the effects of seasonal changes such as humidity, precipitation and evaporation. Sracek et al. (2010) have studied precipitated efflorescent salts in Cu-Co chemical leaching plant wastes in Zambia, and their precipitation sequences in evaporation experiments. The acidic waters of $\mathrm{Na}-\mathrm{Mg}-\mathrm{SO}_{4}$ type underwent evaporation and demonstrated gradual increase in the concentration of $\mathrm{Na}, \mathrm{Mg}$, and $\mathrm{SO}_{4}$, a sharp increase in the concentration of $\mathrm{K}$, and a decrease in the concentration of $\mathrm{Ca}$. The changes in these concentrations during evaporation experiments demonstrate the control of certain elements by precipitation of specific phases. It is clear that evaporative concentration is a prominent process at these mine sites due to the presence of the various types of hydrated to dehydrated precipitates such as hexahydrite and starkeyite. Moreover, the variations in elemental concentrations in solution throughout the mines can be attributed to the types of primary minerals oxidizing, to the secondary minerals dissolving or (re)forming, as well as the varying affinities of trace elements and aqueous species to mineral surfaces. These secondary minerals will be further discussed in section 5.2. Finally, the field parameters are not uncommon for deposits with ARD but do show variability from site to site and between mines. 


\subsubsection{Comments on ultrafiltration and colloidal stability}

Throughout the various sampling sites, trace metals and other elements in solution are thought

to be partitioned between colloids and aqueous species. Studies by Hiemenz et al., 1997; Zanker et al. (2003) consider colloids to be part of the dissolved fraction $(<0.45 \mu \mathrm{m})$, and smaller particles to be suspended particulate matter. Hiemenz and Rajagopalan (1997) and Zanker et al. (2003) further define colloids as suspended material in aqueous systems with linear dimensions between $10^{-6} \mathrm{~m}$ to $10^{-9} \mathrm{~m}$. The colloids in this study have arbitrarily been defined as anything less than $0.45 \mu \mathrm{m}$, which falls in the range of $10^{-6} \mathrm{~m}$ to $10^{-9} \mathrm{~m}$. Colloids have large surface area to volume ratio resulting in a greater number of sites for reactivity and surface charge leading to an increased adsorption capacity, thereby facilitating the transport of particle reactive elements (Hassellöv et al., 2007).

In order for colloids to flocculate, settle out of solution and form secondary precipitates, their surface charge must be altered, or must be subjected to significant chemical or physical changes (Langmuir, 1997). Studies by Zanker et al. (2002) show that colloid particles are intermediates in the precipitate formation process, further increasing the importance of colloids in this study. The equation provided from Everett (1988) describes the numerous variables involved in the stability ratio of colloids (W).

$$
\log W=V \max / k T
$$

Equation 5.1

$\mathrm{V}_{\max }$ is the free-energy barrier that prevents coagulation, $\mathrm{k}$ is the Boltzmann constant and $\mathrm{T}$ represents temperature in Kelvins. Change in chemistry, temperature or pressure of the solution can cause colloid instability. Colloidal instability is observed when $V_{\max }=k T$. Coagulation for the formation of a colloid occurs most easily at a specific $\mathrm{pH}$ called the point of zero net proton charge (PZNPC). With the increase of ionic strength, coagulation over a broader range of $\mathrm{pH}$ is observed as a result of the compression of the diffuse layer reducing particle repulsion (Liang et al., 1990). The differences in elemental concentrations between the colloidal and dissolved phases from ultrafiltered and filtered samples at Pierina and Lagunas Norte can be attributed to variation in ionic strength. Ultrafiltered samples always show lower ionic strength 
than filtered samples. Generally, it is observed that there are more colloids when the ionic strength is greater at Pierina (Table 4-10, Table 4-11) but such a statement does not hold true for samples from Lagunas Norte where no correlation is observed (Table 4-12, Table 4-13). This may be explained by the pronounced argillic alteration at Pierina which is absent at Lagunas Norte. If these clays are present as a colloidal fraction, it is possible for them to have ions adsorbed onto their surface and increasing the ionic strength of the solution by releasing them into the solution. Ions will be released should there be changes in chemistry, temperature or pressure of the solution.

Comparison of the filtered and ultrafiltered water demonstrates that colloids should be observed on the filters; however, the ESEM results do not show any. Although some of the samples filtered were orange-brown, no staining of filter paper was observed. It is also possible that colloids are not observed at Lagunas Norte and Pierina as a result of low relative concentrations (Table 5-1, Table 5-2). Masses expected on filters were calculated for $60 \mathrm{~mL}$ of sample; hence, concentrations from Table 4-11 and Table 4-13 were converted into ppm units and subsequently multiplied by 60 . Finally, small sections of the filter paper were analyzed. It is a possibility that other parts of the filter paper did contain more colloids. The lack of colloids can be understood with the collection and analysis of more samples on site.

Table 5-1 Calculated mass of colloids present at each sampling site at Pierina.

\begin{tabular}{cccccc}
\hline Elements & Units & P-ARD-17-W & P-WRD-W & P-PD-W & P-EC-W \\
\hline $\mathrm{Al}$ & $\mathrm{mg}$ & 0.0030 & 1.0 & 0.26 & 0.1000 \\
$\mathrm{As}$ & $\mathrm{mg}$ & 0.00036 & 0.0028 & 0.024 & $\mathrm{NA}$ \\
$\mathrm{Ca}$ & $\mathrm{mg}$ & 0.0030 & 1.4 & 0.14 & 0 \\
$\mathrm{Cu}$ & $\mathrm{mg}$ & 0.0024 & 0.12 & $\mathrm{NA}$ & 0.0160 \\
$\mathrm{Fe}$ & $\mathrm{mg}$ & 0.033 & 1.4 & 0.80 & 0.1000 \\
$\mathrm{Mg}$ & $\mathrm{mg}$ & 0.0024 & 0.18 & 0.0080 & 0 \\
$\mathrm{Mn}$ & $\mathrm{mg}$ & 0.0060 & 2.2 & 0.16 & 0.42 \\
$\mathrm{~K}$ & $\mathrm{mg}$ & 0.0060 & $\mathrm{NA}$ & 0.0020 & 0.0060 \\
$\mathrm{Na}$ & $\mathrm{mg}$ & 0.0060 & 0.060 & 0.0080 & 0.060 \\
$\mathrm{Sr}$ & $\mathrm{mg}$ & 0 & 0.016 & 0.00014 & 0.0024 \\
$\mathrm{~S}$ & $\mathrm{mg}$ & 0 & 6.6 & 0.40 & 4.2 \\
$\mathrm{Zn}$ & $\mathrm{mg}$ & $\mathrm{NA}$ & 0.52 & 0.28 & 0.28 \\
TOTAL & $\mathrm{mg}$ & 0.0622 & 13.5 & 2.1 & 5.2 \\
\hline
\end{tabular}


Table 5-2 Calculated mass of colloids present at each sampling site at Lagunas Norte.

\begin{tabular}{|c|c|c|c|c|c|c|c|c|}
\hline Elements & Units & LN-SP3-W & LN-SP3-W2 & LN-DW-B-11-W & LN-DAR-1-W & LN-BP & LN-PW2-W & LN-VWD-W \\
\hline Al & $\mathrm{mg}$ & 0.0014 & 0.21 & 0.12 & 0.80 & 0.027 & 0 & 0.60 \\
\hline As & $\mathrm{mg}$ & 0 & 0 & 0.014 & NA & 0 & 0 & 0.0010 \\
\hline $\mathrm{Ca}$ & $\mathrm{mg}$ & 0 & 0.60 & 0 & 1.2 & 0.24 & 0.80 & 2.4 \\
\hline $\mathrm{Cu}$ & $\mathrm{mg}$ & 0.036 & 0.0027 & 0.60 & 0.080 & 0.012 & 0 & 0 \\
\hline $\mathrm{Fe}$ & $\mathrm{mg}$ & 0.030 & 0.42 & 0 & 1.2 & 0.090 & NA & 2.7 \\
\hline $\mathrm{Mg}$ & $\mathrm{mg}$ & 0.060 & 0.12 & NA & 0.40 & 0.018 & 0.0018 & 0.48 \\
\hline$M n$ & $\mathrm{mg}$ & 0.034 & 0.024 & 0.0040 & 0.0030 & 0.0030 & 0 & NA \\
\hline K & $\mathrm{mg}$ & 0.0060 & NA & NA & 0 & 0.0060 & 0.0020 & NA \\
\hline $\mathbf{S}$ & $\mathrm{mg}$ & 1.2 & 9.0 & 0.20 & 6.0 & 9.0 & 50 & NA \\
\hline $\mathrm{Zn}$ & $\mathrm{mg}$ & 0.010 & 0.0060 & 0.026 & 0 & 0.0010 & 0 & 0.030 \\
\hline TOTAL & $\mathrm{mg}$ & 1.4 & 10.4 & 0.96 & 9.7 & 9.4 & 50.8 & 6.2 \\
\hline
\end{tabular}

\subsubsection{PHREEQC modelling}

The results from PHREEQC modeling indicate which minerals may have precipitated. Many elements (Ag, Be, Ce, Co, Cr, Cs, Dy, Er, Eu, Ga, Gd, Ge, Hf, Ho, Ir, La, Lu, Mo, Nb, Nd, Pd, Pr, Pt, Rh, Re, $\mathrm{Ru}, \mathrm{Sb}, \mathrm{Se}, \mathrm{Sm}, \mathrm{Sn}, \mathrm{Sr}, \mathrm{Ta}, \mathrm{Tb}, \mathrm{Te}, \mathrm{Th}, \mathrm{Tl}, \mathrm{V}, \mathrm{W}, \mathrm{Y}, \mathrm{Yb}, \mathrm{Zr}$ ) were missing from the database and were subsequently not incorporated in the calculations; however, these are only present in trace amounts and are not expected to form secondary precipitates. The ESEM, $\mu$ XRF maps and $\mu$ XRD were methods used to identify trace elements that may be adsorbed onto precipitates or incorporated in the minerals structure. Furthermore, all the potentially oversaturated phases at the mines, identified by diffraction methods, are not present within the WATEQ database, which was used in this research. Commonly observed precipitates such as blodite, loweite, hexahydrite and magnesiopcopiapite are missing from the WATEQ database. These minerals were also missing from MINTEQ, PHREEQC and PITZER databases. In fact, even some minerals present in the WATEQ database were nonexistent in PHREEQC database (i.e. atacamite, alum-k, magnesite, scorodite, chalcanthite, and antlerite). Specifically, only 21 of 38 minerals identified by a combination of XRD, $\mu X R D$, ESEM and bulk geochemistry data are found in the WATEQ database (Table 5-3). The geochemical modeling of aqueous solutions is limited to the availability of thermodynamic data and underlying assumptions of geochemical equilibrium that apply (Hammarstrom et al., 2005).

The SI indices computed from filtered samples and ultrafiltered samples were compared and show similar oversaturated minerals in both cases, implying that the concentrations between the two sample types are similar. The precipitates identified from XRD, bulk chemical analyses from the sites are 
compared to the oversaturated minerals from PHREEQC and demonstrate major differences. Although sulfates were the most commonly identified minerals, PHREEQC results only show the occurrence of only 2 sulfates: alunite and basaluminite. This is the result of many sulfates missing from the database. Oversaturated minerals modeled by PHREEQC are generally Fe-oxides, $\mathrm{Cu}$ and $\mathrm{Fe}$ oxides, $\mathrm{Fe}$ oxyhydroxides, Al oxyhydroxides. When comparing XRD identified minerals to bulk geochemistry results, there do not seem to be enough Al or Fe minerals identified that account for the measured amount of Al or Fe present in the sample. Most sampled sites at El Indio and Lagunas Norte do not show any Fe minerals even though they are the most concentrated elements. It is possible for these Fe and Al oxides to be present as amorphous material, which would explain why they are not identified with XRD analysis (Figure 5.1). An elevated background in the XRD pattern suggested some amorphous material may be present.

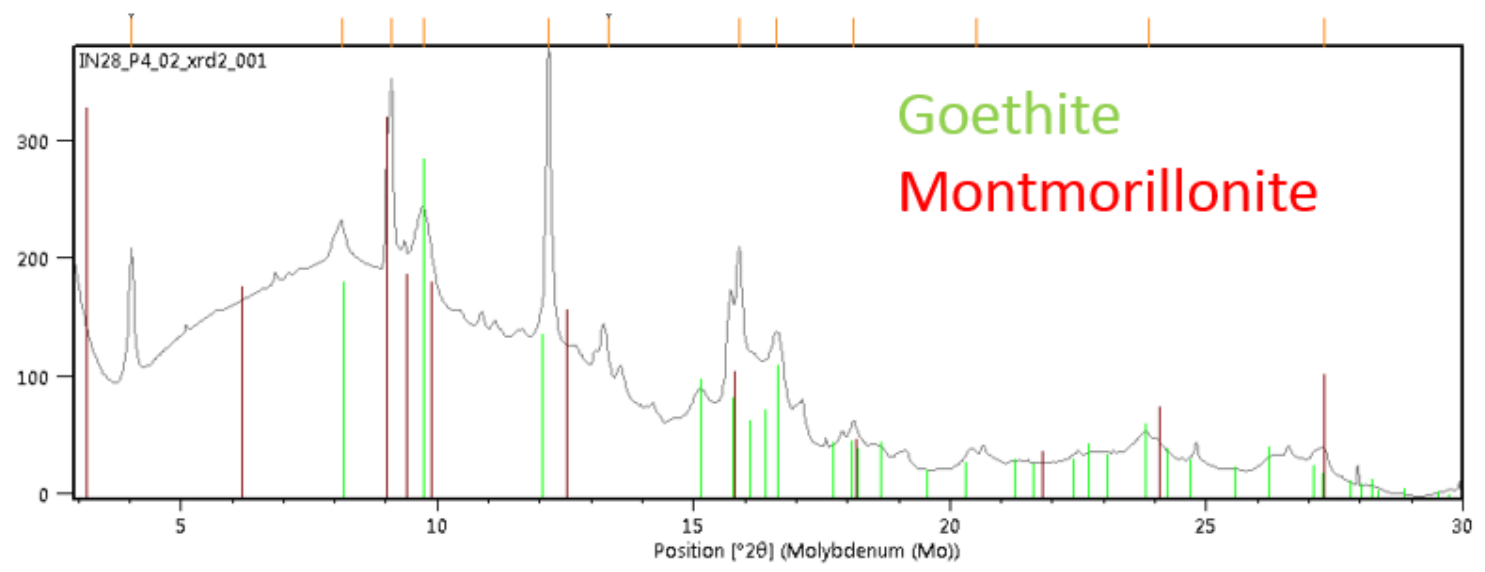

Figure 5-1 $\mu$ XRD spectra collected from sample IN28-P4 on XRD location 02-xrd1-001. The two identified minerals include goethite and montmorillonite. The elevated background is indicative of a third phase that is present but likely amorphous.

Results from forward modeling by concentrating waters 20-fold (Section 4.1.4: PHREEQC modelling) suggest an increased number of $\mathrm{Fe}, \mathrm{Al}$ and $\mathrm{Mn}$ oxyhydroxides, as well as $\mathrm{Cu}$ and Fe sulfates formed from these concentrated waters. These concentrated solutions show more similarities with precipitates identified (i.e. anhydrite, gypsum, alunite, jarosite), since they show a greater mixture of minerals. However, there are still some precipitates observed commonly in this study that are missing 
from the database such as romerite, coquimbite, magnesiocopiapite, antlerite, chalcanthite, scorodite, blodite, loweite, etc. Many of the Fe-oxides, Mn oxyhydroxides, $\mathrm{Cu}$ and Fe oxides, Fe oxyhydroxides, $\mathrm{Al}$ oxyhydroxides are not as prominent in the secondary precipitates identified with diffraction methods. This may be attributed to that fact that many of these minerals are amorphous, as explained in the previous paragraph. 
Table 5-3 List of all minerals identified at El Indio, Lagunas Norte and Pierina mines with respective mineral formulae and indications of whether they are found in the WATEQ database that was used in PHREEQC. This comparison demonstrates that about $45 \%$ of the minerals identified by alternative methods are unaccounted for in this database.

\begin{tabular}{|c|c|c|c|c|c|}
\hline Mineral & Chemical formula & In WATEQ database? & Mineral & Chemical formula & In WATEQ database? \\
\hline Albite & $\left(\mathrm{Na}_{0.84} \mathrm{Ca}_{0.16}\right) \mathrm{Al}_{1.16} \mathrm{Si}_{2.84} \mathrm{O}_{8}$ & yes & Dietrichite & $\mathrm{ZnAl}_{2}\left(\mathrm{SO}_{4}\right)_{4} \cdot 22\left(\mathrm{H}_{2} \mathrm{O}\right)$ & no \\
\hline Alunite & $\mathrm{KAl}_{3}\left(\mathrm{SO}_{4}\right)_{2}(\mathrm{OH})_{6}$ & yes & Scorodite & $\mathrm{FeAsO}_{4} \cdot 2\left(\mathrm{H}_{2} \mathrm{O}\right)$ & yes \\
\hline Anorthite & $\left(\mathrm{Na}_{0.45} \mathrm{Ca}_{0.55}\right)\left(\mathrm{Al}_{1.55} \mathrm{Si}_{2.45} \mathrm{O}_{8}\right)$ & yes & Ettringite & $\mathrm{Ca}_{6}\left(\mathrm{Al}(\mathrm{OH})_{6}\left(\mathrm{SO}_{4}\right)_{3} \cdot 26\left(\mathrm{H}_{2} \mathrm{O}\right)\right.$ & no \\
\hline Quartz & $\mathrm{SiO}_{2}$ & yes & Magnesioaubertite & $(\mathrm{Mg}, \mathrm{Cu}) \mathrm{Al}\left(\mathrm{SO}_{4}\right)_{2} \mathrm{Cl} \cdot 14\left(\mathrm{H}_{2} \mathrm{O}\right)$ & no \\
\hline Halite & $\mathrm{NaCl}$ & yes & Chrysocolla & $(\mathrm{Cu}, \mathrm{Mg}) \mathrm{SiO}_{3} \cdot\left(\mathrm{H}_{2} \mathrm{O}\right)$ & no \\
\hline Orthoclase & $\mathrm{K}\left(\mathrm{AlSi}_{3}\right) \mathrm{O}_{8}$ & yes & Magnesite & $\mathrm{Mg}\left(\mathrm{CO}_{3}\right)$ & yes \\
\hline Montmorillonte & $\mathrm{Na}_{0.3}(\mathrm{Al}, \mathrm{Mg})_{2} \mathrm{Si}_{4} \mathrm{O}_{10}(\mathrm{OH})_{2} \cdot \mathrm{x}\left(\mathrm{H}_{2} \mathrm{O}\right)$ & yes & Goethite & $\mathrm{FeO}(\mathrm{OH})$ & yes \\
\hline Kaolinite & $\mathrm{Al}_{2} \mathrm{Si}_{2} \mathrm{O}_{5}(\mathrm{OH})_{4}$ & no & Fibroferrite & $\mathrm{Fe}(\mathrm{OH})\left(\mathrm{SO}_{4}\right) \cdot 5\left(\mathrm{H}_{2} \mathrm{O}\right)$ & no \\
\hline Aphthitalite & $(\mathrm{K}, \mathrm{Na})_{3} \mathrm{Na}\left(\mathrm{SO}_{4}\right)_{2}$ & no & Hematite & $\mathrm{Fe}_{2} \mathrm{O}_{3}$ & yes \\
\hline Changoite & $\mathrm{Na}_{2} \mathrm{Zn}\left(\mathrm{SO}_{4}\right)_{2} \cdot 4\left(\mathrm{H}_{2} \mathrm{O}\right)$ & no & Magnetite & $\mathrm{Fe}_{2} \mathrm{O}_{3}$ & yes \\
\hline Atacamite & $\mathrm{Cu}_{2} \mathrm{Cl}(\mathrm{OH})_{3}$ & yes & Gibbsite & $\mathrm{Al}(\mathrm{OH})_{3}$ & yes \\
\hline Alunogen & $\mathrm{Al}_{2}\left(\mathrm{SO}_{4}\right)_{3} \cdot 17\left(\mathrm{H}_{2} \mathrm{O}\right)$ & no & Bohemite & $\mathrm{AlO}(\mathrm{OH})$ & yes \\
\hline Alum-K & $\mathrm{KAl}\left(\mathrm{SO}_{4}\right)_{2} \cdot 12\left(\mathrm{H}_{2} \mathrm{O}\right)$ & yes & Chalcanthite & $\mathrm{Cu}(\mathrm{SO} 4) \cdot 5\left(\mathrm{H}_{2} \mathrm{O}\right)$ & yes \\
\hline Alum-Na & $\mathrm{NaAl}\left(\mathrm{SO}_{4}\right)_{2} \cdot 12\left(\mathrm{H}_{2} \mathrm{O}\right)$ & yes & Antlerite & $\left(\mathrm{Cu}_{3}(\mathrm{OH})_{4}\left(\mathrm{SO}_{4}\right)\right.$ & yes \\
\hline Natroalunite & $\left(\mathrm{Na}_{0.75} \mathrm{~K}_{0.25}\right) \mathrm{Al}_{3}\left(\mathrm{SO}_{4}\right)_{2}(\mathrm{OH})_{6}$ & yes & Poitevinite & $\mathrm{Cu}\left(\mathrm{SO}_{4}\right) \cdot\left(\mathrm{H}_{2} \mathrm{O}\right)$ & no \\
\hline Natrojarosite & $\mathrm{NaFe}_{3}\left(\mathrm{SO}_{4}\right)_{2}(\mathrm{OH})_{6}$ & yes & Bonattite & $\mathrm{Cu}\left(\mathrm{SO}_{4}\right) \cdot 3\left(\mathrm{H}_{2} \mathrm{O}\right)$ & no \\
\hline Jarosite & $\mathrm{KFe}_{3}^{3+}(\mathrm{OH})_{6}\left(\mathrm{SO}_{4}\right)_{2}$ & yes & Starkeyite & $\mathrm{Mg}(\mathrm{SO} 4) \cdot 4\left(\mathrm{H}_{2} \mathrm{O}\right)$ & no \\
\hline Magensiocopiapite & $\mathrm{MgFe}_{4}{ }^{+3}\left(\mathrm{SO}_{4}\right)_{6}(\mathrm{OH})_{2} \cdot 20\left(\mathrm{H}_{2} \mathrm{O}\right)$ & no & Hexahydrite & $\mathrm{Mg}\left(\mathrm{SO}_{4}\right) \cdot 6\left(\mathrm{H}_{2} \mathrm{O}\right)$ & no \\
\hline Romerite & $\mathrm{Fe}^{2+} \mathrm{Fe}_{2}^{3+}\left(\mathrm{SO}_{4}\right)_{4} \cdot 14\left(\mathrm{H}_{2} \mathrm{O}\right)$ & no & Epsomite & $\mathrm{Mg}\left(\mathrm{SO}_{4}\right) \cdot 7\left(\mathrm{H}_{2} \mathrm{O}\right)$ & no \\
\hline Coquimbite & $\left(\mathrm{Fe}_{1.54} \mathrm{Al}_{0.46}\right)\left(\mathrm{SO}_{4}\right)_{3} \cdot 9\left(\mathrm{H}_{2} \mathrm{O}\right)$ & no & D'ansite & $\mathrm{Na}_{21} \mathrm{Mg}\left(\mathrm{SO}_{4}\right)_{10} \mathrm{Cl}{ }_{3}$ & no \\
\hline Melanterite & $\mathrm{Fe}\left(\mathrm{SO}_{4}\right) \cdot 7\left(\mathrm{H}_{2} \mathrm{O}\right)$ & yes & Loweite & $\mathrm{Na}_{12} \mathrm{Mg}_{7}\left(\mathrm{SO}_{4}\right)_{13} \cdot 15\left(\mathrm{H}_{2} \mathrm{O}\right)$ & no \\
\hline Aluminocopiapite & $\mathrm{Al}_{2 / 3} \mathrm{Fe}_{4}\left(\mathrm{SO}_{4}\right)_{6}(\mathrm{OH})_{2} \cdot 20\left(\mathrm{H}_{2} \mathrm{O}\right)$ & no & Blodite & $\mathrm{Na}_{2} \mathrm{Mg}\left(\mathrm{SO}_{4}\right)_{2} \cdot 4\left(\mathrm{H}_{2} \mathrm{O}\right)$ & no \\
\hline Gypsum & $\mathrm{Ca}\left(\mathrm{SO}_{4}\right) \cdot 2\left(\mathrm{H}_{2} \mathrm{O}\right)$ & yes & Boyleite & $(\mathrm{Zn}, \mathrm{Mg})\left(\mathrm{SO}_{4}\right) \cdot 4\left(\mathrm{H}_{2} \mathrm{O}\right)$ & no \\
\hline Anhydrite & $\mathrm{Ca}\left(\mathrm{SO}_{4}\right)$ & yes & & & \\
\hline
\end{tabular}




\subsubsection{Bulk geochemistry and comparison to effluent regulations}

The analyzed waters (i.e streams within mines, waste rock leachate, pit wall drainage) demonstrate that El Indio, Lagunas Norte and Pierina are producing ARD with low $\mathrm{pH}$, high electrical conductivity, high sulfate, high TDS and high metal concentrations. The metals present in solution are reflective of the solid-phase metals identified and the primary mineralogy. The primary mineral contributing to ARD at Pierina is mainly pyrite, as well as jarosite and alunite. As the jarosite and alunite dissolve, the $\mathrm{Al}$ and Fe hydrolyze and contribute to acidity. Elevated concentrations of $\mathrm{Al}, \mathrm{Ca}, \mathrm{Fe}, \mathrm{Cu}, \mathrm{Mg}$, $\mathrm{Mn}, \mathrm{K}, \mathrm{Na}, \mathrm{SO}_{4}$ and $\mathrm{Zn}$ are present dissolved in solution. The known enrichments of $\mathrm{As}, \mathrm{Cu}$ and $\mathrm{Zn}$, in the primary minerals suggest that these elements were also expected in relatively high concentrations in solution (Klohn Crippen Berger, 2012a). The dissolved ions $\mathrm{Na}^{+}, \mathrm{Al}^{3+}, \mathrm{Ca}^{2+}, \mathrm{Mg}^{2+}$ and $\mathrm{K}^{+}$, are likely derived through chemical weathering of plagioclase, anorthite, hornblende, biotite identified in the dacite flowdome complex, the andesite and the rhyodacitic domes (Spencer, 2000). The minerals that may be formed from these waters depend on the ratios of cations in solution and on the relative solubility of the primary sulfide and sulfate minerals. The results of geochemical modelling from this study and a previous study from Klohn Crippen Berger (2012), both classify Pierina waters as $\mathrm{Al}_{-} \mathrm{SO}_{4}$ waters and $\mathrm{Ca}-\mathrm{SO}_{4}$ waters with secondary minerals that can control the $\mathrm{Pb}, \mathrm{Zn}$ and $\mathrm{Cu}$ aqueous concentrations.

The elemental concentrations of waters were compared to the effluent regulations in Peru and Chile to have an understanding of exceedances and mitigation efforts (i.e., appropriate water treatment technology). The values stated below will only exceed regulations once they leave Barrick Gold Corporation property. Various elements demonstrate exceedances in effluent regulations of Chile and Peru respectively (Table 5-4); however, comparisons to regulations are only for reference as some active and passive water treatments are currently in place to mitigate these effluent concentrations before reaching compliance points. Comparison to effluent guidelines provides some indication of how much treatment is required. The following comparison exercise is a typical first step in assessing the level of 
mitigation required prior to discharge. At Lagunas Norte, As exceeds its Peruvian limits by 2 orders of magnitude at LN-DW-B-11, by a single order of magnitude at LN-DAR-1 and LN-VWD. Cadmium is very near its exceedance limit at LN-SP3, and 1 order of magnitude greater at sample sites LN-DW-B-11, LNDAR-1 and LN-VWD. Chromium exceeds the Peruvian effluent guidelines by a few units at sites LN-DAR-1 and LN-VWD. Both $\mathrm{Cu}$ and Fe concentrations are 2 to 4 orders of magnitude higher than limits at all sites except those collected from the pit wall. Lead only shows exceedances at LN-DW-B-11. Finally, Zn shows exceedances of 2 orders of magnitude or less except at LN-PW1 and LN-PW2. These samples represent untreated leachate and exact concentrations may be found in Table 4-3 and Table 4-4.

At Pierina, the samples demonstrate exceedances in As limits of 1 to 2 orders of magnitude at all sample sites except P-EC and P-ARD-17. Concentrations may be found in Table 4-5 and Table-4-6. All samples except for P-ARD17 are 1-2 orders of magnitude higher than the Peruvian limits. All chromium concentrations are below Peruvian effluent guidelines and all Fe concentrations are above these guidelines. Zinc exceedances exist at all site, Cu exceedances exist at all sites except at P-PD whereas lead exceedances only exist at P-PD and P-EC. Waters were not analyzed post treatment at this site. Active HDS treatment via oxidation and lime addition is the normally effective treatment technology for the suite of parameters listed in Tables 5-4 and Table 5-5, and is the current technology used at both Pierina and Lagunas Norte. These plants are also presently being upgraded to include a reverse osmosis (RO) stage. As previously mentioned, mitigation at El Indio consists of cover placements, water diversions and passive treatment at the Pastos Largos pond via gravity settling. The El Indio water quality permit has been grandfathered in and this mine site is regulated for $\mathrm{pH}, \mathrm{As}$, Fe and $\mathrm{Cu}$ based on a dry and wet year basis. 
Table 5-4 Peruvian effluent guidelines for mine sites in mg/L from 2010 (Klohn Crippen Berger, 2012a).

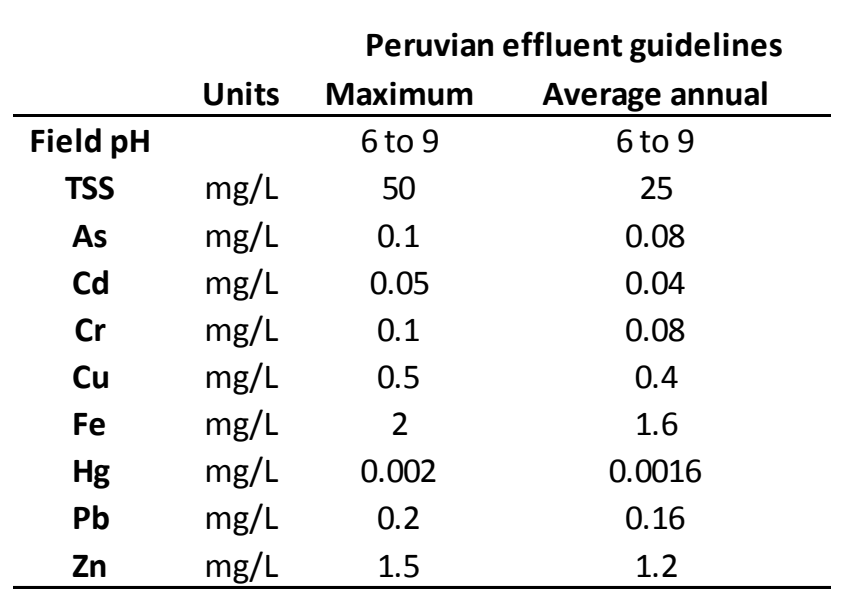

\subsubsection{Comparison with published values}

Water chemistry results sampled from El Indio, Lagunas Norte and Pierina were plotted against values from other HS epithermal deposits summarized by Plumlee et al. (1999) including Summitville and Red Mountain Pass in Colorado, Goldfield and Paradise Peak in Nevada, and Mount Macintosh in British Colombia. 


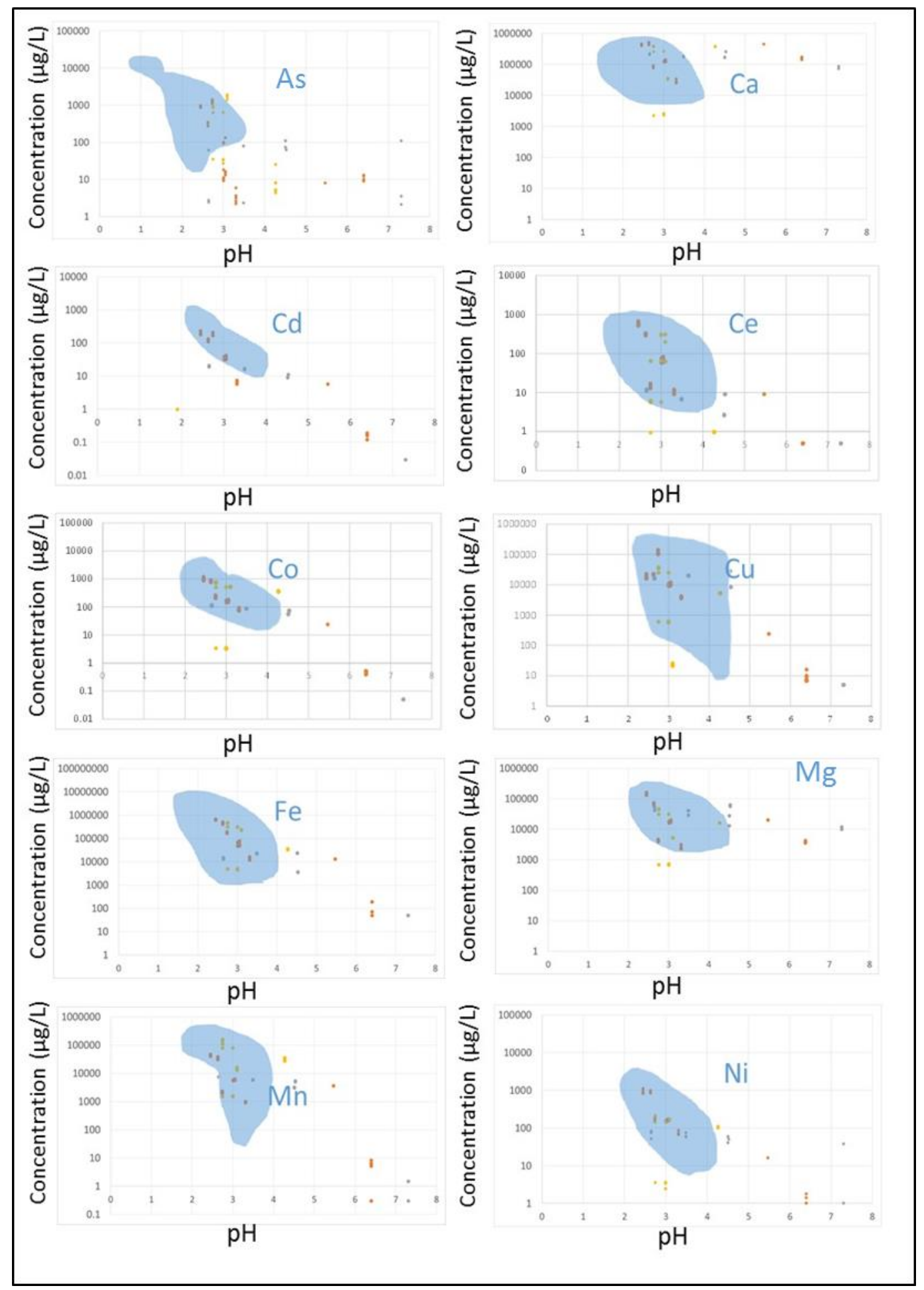

Figure 5-2 Comparison of data collected from El Indio (orange), Lagunas Norte (blue) and Pierina (yellow), compared to HS deposits studied by Plumlee et al. (1999) for elements As, Ca, Cd, Co, Cu, Fe, Mg, Mn, Ni. 
Figure 5-2 demonstrates that water chemistry at sample sites are similar to data collected from Plumlee et al. (1999) and are therefore typical of HS epithermal deposits. Approximately $60-70 \%$ of the data points collected from the mine sites are similar to values collected by Plumlee (1999). This research has contributed to a wider range of $\mathrm{pH}$ values that were not observed at other HS epithermal deposits. Water treatment methods at El Indio, Lagunas Norte and Pierina should continue with current treatment such as neutralization of effluent by HDS production via hydrated lime addition and sedimentation, as well as planned reverse osmosis.

\subsection{Discussion of secondary precipitate occurrences and characterization}

\subsubsection{Elemental correlations}

Spearman correlation matrices were created with the bulk ICP-MS data in order to observe relationships between major, minor and trace elements, and to interpret elemental association and possible substitution mechanisms. The standard error of the coefficient $(\sigma)$ was determined by Pearson in 1907 and follows equation 5.2.

$$
\sigma=0.6325 / \sqrt{n-1}
$$

This value is used to measure the precision of the estimate of the coefficient, where larger values imply less precision. The variable $\mathrm{n}$ represents the sample size. As such, with a smaller sample size, there is an increase in standard error of coefficient. The sample size is 20 at El Indio, 6 at Lagunas Norte and 5 at Pierina. These sample sizes yield standard errors of coefficient of $0.1454,0.2836$ and 0.3163 for El Indio, Lagunas Norte and Pierina respectively. As a result, the correlations from El Indio are the most reliable ones.

The secondary minerals identified account for most of the elemental correlations at Lagunas Norte, Pierina and El Indio. Moderate to strong positive correlations between Fe and As, $\mathrm{Zn}$ and $\mathrm{Cd}$, and $\mathrm{Na}$ and $\mathrm{Mg}$ at $\mathrm{El}$ Indio are likely the result of the occurrence and dissolution of primary minerals such as pyrite, enargite, sphalerite, chalcopyrite and covellite (source), and the resulting formation of secondary 
precipitates (sink). Based on the minerals identified at El Indio, the correlation of elements Fe and As can be related to the occurrences of scorodite $\left(\mathrm{FeAsO}_{4} \cdot \mathrm{H}_{2} \mathrm{O}\right)$ which is known to be secondary because it is intergrown with other phases, and the occurrence of melanterite with adsorbed As. The association of arsenic with melanterite was also noted in research conducted by Cheng et al. (2009) that studies the geochemical processes controlling the release, speciation, and distribution of inorganic As in mine drainage. Similarly, the correlation between $\mathrm{Na}$ and $\mathrm{Mg}$ is likely a result of positively identified $\mathrm{Na}-\mathrm{Mg}$ sulfates such as blodite, loweite. Jamieson et al. (1999) have documented the occurrence of some Fesulfate minerals that precipitate from acid mine waters and incorporate substantial amounts of $\mathrm{Zn}$ and other elements in solid solution at Iron Mountain, California. It is assumed that $\mathrm{Zn}$ and $\mathrm{Cd}$ can enter the crystal lattice preferentially because of their higher ionic potential, and our results do show a very strong correlation in the Spearman matrix created for El Indio, suggesting they would be hosted in the same phases. The correlations observed at the mines studied for this research agree with the findings by Jamieson et al. (1999) that state that potentially hazardous elements such as $\mathrm{Zn}, \mathrm{Cu}, \mathrm{Cd}$ and $\mathrm{As}$ are commonly sequestered in secondary minerals by substitution and adsorption. Since SEM-EMPA analysis was not conducted to show how the secondary precipitates incorporate trace elements, this statistical information was used to make inferences. The $\mathrm{Cu}-\mathrm{Zn}$ correlations $(\mathrm{R}=0.84), \mathrm{Cu}-\mathrm{Ni}(\mathrm{R}=0.76)$ and $\mathrm{Cu}-\mathrm{Mn}$ $(R=0.69)$, suggest that the $\mathrm{Cu}-\mathrm{Cl}$ mineral identified at El Indio through ESEM as probable atacamite, may store $\mathrm{Zn}, \mathrm{Ni}$ and $\mathrm{Mn}$. The $\mathrm{Mg}-\mathrm{Mn}(\mathrm{R}=0.78), \mathrm{Mg}-\mathrm{Ni}(\mathrm{R}=0.73), \mathrm{Mg}-\mathrm{K}(\mathrm{R}=0.76)$ correlations suggest that $\mathrm{Mg}$ or Mg-Na sulfates identified at El Indio may store Mn, Ni, and K. Research by Sracek et al. (2010) has identified $\mathrm{Co}$ and $\mathrm{Mn}$ in blodite from samples collected at a leaching plant in Zambia. Cobalt, $\mathrm{Zn}$ and $\mathrm{Cu}$ are known to be sequestered as solid solution within Fe- and Fe-Al sulfate minerals (Hammarstrom et al., 2005).

Moreover, elements demonstrating correlations may also be due to elements entering solution at the same time as a result of dissolution. For example, the oxidation of pyrite and enargite can release 
many elements of interest into solution together, which may coprecipitate within the sulfate system. Table 5-5 modified from Lottermoser et al. (2000) lists common sulfides, as well as the minor and trace elements that may substitute within the structure. Table 5-6 from Smith (1999) lists the pH ranges that are usually equivalent to observed adsorption edges for divalent metal sorption ( $\mathrm{Cu}, \mathrm{Pb}, \mathrm{Hg}, \mathrm{Zn}, \mathrm{Co}, \mathrm{Ni}$, $\mathrm{Cd}, \mathrm{Mn}, \mathrm{Mg}, \mathrm{Ca}, \mathrm{Sr}$ ) on Fe or Al-oxide minerals, the critical ranges, which were identified at all mine sites (a majority through PHREEQC analysis). Hence, any of the elements listed may show strong positive correlations with Fe or $\mathrm{Al}$ depending on the $\mathrm{pH}$ of the solution, which typically ranged values from less than 3 to greater than 6 . The critical range of sorption of anions will be closer to the neutral range (i.e. As, Se). Negative correlations of elements may be indicative of competitive substitution where the inclusion of an element prevents another from entering the mineral structure. This may be observed between Fe and $\mathrm{Mg}$ at El Indio (-0.89). These two elements fit Goldschmidt's rules of substitution since their charges are identical and their atomic radii differ less than $15 \%$.

Table 5-5 Sulfide minerals, chemical formulas and minor or trace elements that may partake in cation substitution (Lottermoser et al., 2010).

\begin{tabular}{lll}
\hline Mineral name & Chemical Formula & Minor and trace element substitution \\
\hline Chalcopyrite & $\mathrm{CuFeS}_{2}$ & $\mathrm{Ag}, \mathrm{As}, \mathrm{Bi}, \mathrm{Cd}, \mathrm{Co}, \mathrm{Cr}, \mathrm{In}, \mathrm{Mn}, \mathrm{Mo}, \mathrm{Ni}, \mathrm{Pb}, \mathrm{Sb}, \mathrm{Se}, \mathrm{Sn}, \mathrm{Tn}, \mathrm{V}, \mathrm{Zn}$ \\
Galena & $\mathrm{PbS}$ & $\mathrm{Ag}, \mathrm{As}, \mathrm{Bi}, \mathrm{Cd}, \mathrm{Cu}, \mathrm{Fe}, \mathrm{Hg}, \mathrm{Mn}, \mathrm{Ni}, \mathrm{Sb}, \mathrm{Se}, \mathrm{Sn}, \mathrm{Tl}, \mathrm{Zn}$ \\
Marcasite & $\mathrm{FeS}_{2}$ & $\mathrm{As}, \mathrm{Hg}, \mathrm{Se}, \mathrm{Sn}, \mathrm{Ti}, \mathrm{Tl}, \mathrm{Pb}, \mathrm{V}$ \\
Pyrite & $\mathrm{FeS}_{2}$ & $\mathrm{Ag}, \mathrm{As}, \mathrm{Au}, \mathrm{Bi}, \mathrm{Cd}, \mathrm{Co}, \mathrm{Ga}, \mathrm{Ge}, \mathrm{Hg}, \mathrm{In}, \mathrm{Mo}, \mathrm{Ni}, \mathrm{Pb}, \mathrm{Sb}, \mathrm{Se}, \mathrm{Sn}, \mathrm{Ti}, \mathrm{Tl}, \mathrm{V}$ \\
Pyrrhotite & $\mathrm{Fe}_{1-\mathrm{x}} \mathrm{Ag}, \mathrm{As}, \mathrm{Co}, \mathrm{Cr}, \mathrm{Cu}, \mathrm{Mo}, \mathrm{Ni}, \mathrm{Pb}, \mathrm{Se}, \mathrm{Sn}, \mathrm{V}, \mathrm{Zn}$ \\
Sphalerite & $\mathrm{ZnS}$ & $\mathrm{Ag}, \mathrm{As}, \mathrm{Ba}, \mathrm{Cu}, \mathrm{Cd}, \mathrm{Co}, \mathrm{Cr}, \mathrm{Fe}, \mathrm{Ga}, \mathrm{Ge}, \mathrm{Hg}, \mathrm{In}, \mathrm{Mn}, \mathrm{Mo}, \mathrm{Ni}, \mathrm{Sb}, \mathrm{Se}, \mathrm{Sn}, \mathrm{Tl}, \mathrm{V}$ \\
\hline
\end{tabular}

Table 5-6 The critical ranges for sorption of divalent metal cations on hydrous Fe and Al oxides (Smith, 1999).

\begin{tabular}{cc}
\hline Cation & Critical pH Range \\
\hline $\mathrm{Cu}, \mathrm{Pb}, \mathrm{Hg}$ & 3 to 5 \\
$\mathrm{Zn}, \mathrm{Co}, \mathrm{Ni}, \mathrm{Cd}$ & 5 to 6.5 \\
$\mathrm{Mn}$ & 6.5 to 7.5 \\
$\mathrm{Mg}, \mathrm{Ca}, \mathrm{Sr}$ & 6.5 to 9 \\
\hline
\end{tabular}


The Spearman correlation matrix created for Lagunas Norte highlights the strongest correlations between elements as $\mathrm{Zn}$ and $\mathrm{Cd}$, and $\mathrm{S}$ and $\mathrm{Ni}$. The correlation of $\mathrm{Zn}$ and $\mathrm{Cd}$, two elements of similar charge and ionic radii, is explained by the fact that both may be sequestered in secondary minerals by substitution or adsorption. Also, both $\mathrm{Zn}$ and $\mathrm{Cd}$ originate in the same mineral (sphalerite) and are commonly found substituting each other. The source of $\mathrm{Ni}$ and $\mathrm{S}$ at Lagunas Norte is likely pyrite, and since no Ni-sulfate minerals were identified, this information suggests that $\mathrm{Ni}$ is either adsorbed on a sulfate mineral, or substituting another element within the crystal lattice, likely $\mathrm{Cu}$ or Fe.

Statistical analyses at Pierina revealed various strong correlations, notably between $\mathrm{Ca}$ and $\mathrm{Cd}$, $\mathrm{Mg}$ and $\mathrm{Cd}, \mathrm{Mn}$ and $\mathrm{Cd}, \mathrm{Zn}$ and $\mathrm{Cd}, \mathrm{Ca}$ and $\mathrm{Mg}, \mathrm{Ca}$ and $\mathrm{Mn}, \mathrm{Al}$ and $\mathrm{Cu}, \mathrm{Al}$ and $\mathrm{Ag}, \mathrm{Al}$ and $\mathrm{S}, \mathrm{Fe}$ and $\mathrm{As}, \mathrm{Cu}$ and S. Out of these numerous pairs of correlated elements, Al and S can be explained by the presence of coquimbite, Fe and As can be explained by the presence of romerite and jarosite and the sorption of As on these minerals, $\mathrm{Ca}$ and $\mathrm{Mg}$ by the presence of montmorillonite, $\mathrm{Zn}, \mathrm{Cu}$ and $\mathrm{Cd}$ as elements that commonly sequestered in secondary minerals by substitution and adsorption. Unaccounted pairs might be a result of minimal precision of the Spearman matrix due to the low number of sample numbers from Pierina.

The GSECARS X-ray Map Viewer software from synchrotron microanalysis also incorporates statistical analyses to make correlation plots. This data can be used occasionally to see trends, but can also lead to data misinterpretation. Often, the assumption that ROI counts directly relate to elemental abundance is made. This supposition is false, as other variable such as thickness of the sample and selfabsorption effects will give differing fluorescence counts. As such, statistical analyses were not conducted on the micron scaled data collected from the synchrotron.

\subsubsection{Secondary minerals identified in ARD}

The interaction between mine waters and the secondary precipitates formed is representative of a dynamic system. Hypergene processes in the deposit ore bodies have resulted in the formation of highly 
concentrated solutions, from which secondary minerals were crystallized. The mineralogical and chemical compositions of the secondary minerals identified reflect the composition of the waters from which they form. For example, ettringite can only form from Al-Ca-SO - -rich waters. Subsequently, these minerals can undergo transformations resulting from decreasing moisture or increasing temperatures (Buckby et al., 2003). Authors such as Jambor et al. (2000), and Nordstrom \& Alpers (1999) describe the paragenetic sequence relating to the Fe-sulfate minerals that form from evaporating acid mine drainage. Nordstrom \& Alpers (1999) demonstrates a paragenetic sequence of Fe-sulfate minerals from pyrite oxidation as early to late rozenite, copiapite, romerite, coquimbite, jarosite. A similar sequence was expected within this study, but cannot be confirmed. It is a possibility that only a portion of this sequence is present since we do not have the whole range of conditions at the sites.

The secondary precipitates at the mine sites studied here likely formed by a combination of several processes including: the oxidation and hydrolysis of dissolved cations, mixing of acid mine waters with neutral $\mathrm{pH}$ waters, oxidation of sulfides in humid air and the concentration of mine water due to evaporation (Lottermoser, 2010c; Carbone et al., 2013; Romero et al., 2006; Frau, 2000). The oxidation of the primary minerals, which are mostly sulfides, at El Indio, Lagunas Norte and Pierina deposits, the hydrolysis of Fe and Al leached from primary minerals, as well as the low buffering capacity of the host rocks has created ARD. The results of mineralogical analyses indicate that the mineralogy of the secondary minerals forming at these three settings is variable but the most common minerals can be placed into 3 broad groups: 1) hydrous Na-, Mg-, Ca-, and other metal-sulfates such as blodite, hexahydrate and gypsum 2) Fe-oxides, oxyhydroxides and oxyhydroxysulphates such as ferrihydrites, goethite, scorodite and jarosite 3) other metal rich, low crystalline phases such as basaluminite-like Al minerals, and few oxides, hydroxide, arsenates, carbonates and silicates in decreasing order. All identified minerals are listed in Table 5-3, and those discussed in the following section can be observed in Table 5-7. 
Table 5-7 Names and formulae of minerals discussed in following sections.

\begin{tabular}{|c|c|c|c|}
\hline \multicolumn{2}{|c|}{ Fe-sulfates and Al-sulfates } & \multicolumn{2}{|c|}{ Fe-Al oxyhydroxides } \\
\hline Minerals & Formula & Minerals & Formula \\
\hline Alunogen & $\mathrm{Al}_{2}\left(\mathrm{SO}_{4}\right)_{3} \cdot 17\left(\mathrm{H}_{2} \mathrm{O}\right)$ & Scorodite & $\mathrm{Fe}\left(\mathrm{AsO}_{4}\right) \cdot 2\left(\mathrm{H}_{2} \mathrm{O}\right)$ \\
\hline Alum-K & $\mathrm{KAI}\left(\mathrm{SO}_{4}\right)_{2} \cdot 12\left(\mathrm{H}_{2} \mathrm{O}\right)$ & Goethite & $\mathrm{FeO}(\mathrm{OH})$ \\
\hline Alum-Na & $\operatorname{NaAl}\left(\mathrm{SO}_{4}\right)_{2} \cdot 12\left(\mathrm{H}_{2} \mathrm{O}\right)$ & Fibroferrite & $\mathrm{Fe}(\mathrm{OH})\left(\mathrm{SO}_{4}\right) \cdot 5\left(\mathrm{H}_{2} \mathrm{O}\right)$ \\
\hline Natrojarosite & $\mathrm{NaFe}_{3}\left(\mathrm{SO}_{4}\right)_{2}(\mathrm{OH})_{6}$ & Hematite & $\mathrm{Fe}_{2} \mathrm{O}_{3}$ \\
\hline Jarosite & $\mathrm{KFe}_{3}^{3+}(\mathrm{OH})_{6}\left(\mathrm{SO}_{4}\right)_{2}$ & Magnetite & $\mathrm{Fe}_{2} \mathrm{O}_{3}$ \\
\hline Magensiocopiapite & $\mathrm{MgFe}_{4}{ }^{+3}\left(\mathrm{SO}_{4}\right)_{6}(\mathrm{OH})_{2} \cdot 2 \mathrm{O}\left(\mathrm{H}_{2} \mathrm{O}\right)$ & Gibbsite & $\mathrm{Al}(\mathrm{OH})_{3}$ \\
\hline Romerite & $\mathrm{Fe}^{2+} \mathrm{Fe}_{2}^{3+}\left(\mathrm{SO}_{4}\right)_{4} \cdot 14\left(\mathrm{H}_{2} \mathrm{O}\right)$ & Bohemite & $\mathrm{AlO}(\mathrm{OH})$ \\
\hline Coquimbite & $\left(\mathrm{Fe}_{1.54} \mathrm{Al}_{0.46}\right)\left(\mathrm{SO}_{4}\right)_{3} \cdot 9\left(\mathrm{H}_{2} \mathrm{O}\right)$ & & \\
\hline Melanterite & $\mathrm{Fe}\left(\mathrm{SO}_{4}\right) \cdot 7\left(\mathrm{H}_{2} \mathrm{O}\right)$ & & \\
\hline Aluminocopiapite & $\mathrm{Al}_{2 / 3} \mathrm{Fe}_{4}\left(\mathrm{SO}_{4}\right)_{6}(\mathrm{OH})_{2} \cdot 2 \mathrm{O}\left(\mathrm{H}_{2} \mathrm{O}\right)$ & & \\
\hline Alunite & $\mathrm{KAl}_{3}\left(\mathrm{SO}_{4}\right)_{2}(\mathrm{OH})_{6}$ & & \\
\hline \multicolumn{2}{|c|}{$\mathrm{Na-Mg-K \text {-Casulfates }}$} & \multicolumn{2}{|c|}{ Cu-sulfates } \\
\hline Minerals & Formula & Minerals & Formula \\
\hline Starkeyite & $\mathrm{Mg}(\mathrm{SO} 4) \cdot 4\left(\mathrm{H}_{2} \mathrm{O}\right)$ & Chalcanthite & $\mathrm{Cu}(\mathrm{SO} 4) \cdot 5\left(\mathrm{H}_{2} \mathrm{O}\right)$ \\
\hline Hexahydrite & $\mathrm{Mg}\left(\mathrm{SO}_{4}\right) \cdot 6\left(\mathrm{H}_{2} \mathrm{O}\right)$ & Antlerite & $\left(\mathrm{Cu}_{3}(\mathrm{OH})_{4}\left(\mathrm{SO}_{4}\right)\right.$ \\
\hline Epsomite & $\mathrm{Mg}\left(\mathrm{SO}_{4}\right) \cdot 7\left(\mathrm{H}_{2} \mathrm{O}\right)$ & Poitevinite & $\mathrm{Cu}\left(\mathrm{SO}_{4}\right) \cdot\left(\mathrm{H}_{2} \mathrm{O}\right)$ \\
\hline Gypsum & $\mathrm{Ca}\left(\mathrm{SO}_{4}\right) \cdot 2\left(\mathrm{H}_{2} \mathrm{O}\right)$ & Bonattite & $\mathrm{Cu}\left(\mathrm{SO}_{4}\right) \cdot 3\left(\mathrm{H}_{2} \mathrm{O}\right)$ \\
\hline Anhydrite & $\mathrm{Ca}\left(\mathrm{SO}_{4}\right)$ & & \\
\hline D'ansite & $\mathrm{Na}_{21} \mathrm{Mg}\left(\mathrm{SO}_{4}\right)_{10} \mathrm{Cl}_{3}$ & & \\
\hline Loweite & $\mathrm{Na}_{12} \mathrm{Mg}_{7}\left(\mathrm{SO}_{4}\right)_{13} \cdot 15\left(\mathrm{H}_{2} \mathrm{O}\right)$ & & \\
\hline Blodite & $\mathrm{Na}_{2} \mathrm{Mg}\left(\mathrm{SO}_{4}\right)_{2} \cdot 4\left(\mathrm{H}_{2} \mathrm{O}\right)$ & & \\
\hline Boyleite & $(\mathrm{Zn}, \mathrm{Mg})\left(\mathrm{SO}_{4}\right) \cdot 4\left(\mathrm{H}_{2} \mathrm{O}\right)$ & & \\
\hline
\end{tabular}

Hence, the most common secondary minerals observed include simple hydrous metals sulfates with divalent metal cations, simple hydrous metals sulfates with trivalent metal cations, mixed divalenttrivalent hydrous metal sulfates in order of occurrence. The most commonly occurring secondary minerals at Lagunas Norte were identified as gypsum, chalcanthite and alum-Na. Various phases were identified through $\mu \mathrm{XRD}$ including antlerite, chrysocolla, scorodite and poitevinite. As observed by their mineral formulae, chalcanthite, antlerite and poitevinite are hydrated or less hydrated versions of one another. At El Indio, blodite, loweite, gypsum, halite, hexahydrite, starkeyite, and magnesiocopiapite secondary minerals are amongst the most common. The most ubiquitous secondary precipitates at Pierina are romerite, coquimbite, magnesiocopiapite and jarosite. These efflorescent minerals thereby exhibit a range of crystal habits appearing to be related to their morphology. These results are in agreement with 
previous studies on post-mining secondary minerals found in sulfidic mine wastes (Lottermoser, 2010c). The occurrence of the soluble precipitates provides valuable information about the reactions that have occurred, as well as the compositions of the solutions from which they formed and the types of primary minerals that likely weathered, leading to their formation (Jambor et al., 2000).

Although the waters were enriched in $\mathrm{Fe}$, as a result of the primary pyrite minerals as well as other Al or Fe minerals being oxidized, most of the secondary precipitates identified from El Indio, Lagunas Norte and Pierina mines were $\mathrm{Na}$ and $\mathrm{Mg}$ hydrated sulfates. Goethite and hematite, the most common forms of ferric oxide and oxyhydroxide respectively, are known to have slow growth kinetics at surficial temperatures observed at El Indio, Lagunas Norte and Pierina, and are therefore poorly crystalline (Carbone et al., 2005; Keith et al., 2001; Lottermoser, 2010b). As explained by Lottermoser et al. (2010b), all precipitates will not be crystalline. In fact, many can be poorly crystalline or amorphous. Furthermore, the first minerals that precipitate have the tendency of being poorly crystalline, metastable phases that may transform into more stable phases over time, explaining why minimal Fe minerals were identified (Carbone et al., 2005; Jönsson et al., 2006). This further explains the presence of few Al-minerals identified (Nordstrom et al., 1999; Nordstrom, 2011). Nevertheless, PHREEQC modeling using the WATEQ database identifies a number of Fe and $\mathrm{Al}$ oxyhydroxydes that may be representative of the minerals present at these sites. Non-crystalline Fe and Al minerals are present in these samples, as per PHREEQC modeling and geochemical information, but were not identified by diffraction methods. Hydrous sufaltes may also dehydrate to less hydrous compositions such as the case of observed minerals hexadyrite and starkeyite at El Indio.

This thesis further supports statements made in research by Buckby et al., (2003) Jambor et al., (2000) in that the composition of the secondary minerals reflects the composition of the waters from which they precipitated, and that the composition of waters directly influences the mineralogy of secondary precipitates, particularly in arid settings (Spencer, 2000). In the case of the mines characterized 
for this study, PHREEQC modeling demonstrated an additional set of secondary precipitates, most likely present as secondary precipitates, yet left unidentified due to their amorphous nature. In all mines, the secondary precipitates formed act as sinks of various elements during the dry season; however, they also act as sources of elemental loading as they become dissolved during the wet season (Klohn Crippen Berger, 2012b). Nordstrom et al. (1999), have created a list of common secondary minerals whose solubilities can control the amount of metals found in solution. It may be observed in Table 5-8 that many of those minerals are also found at Lagunas Notre, El Indio, or Pierina as per analytical tests conducted on solid samples and forward modelling of solutions.

Table 5-8 Minerals whose solubilities are likely to control metal concentrations in mine waters (Nordstrom et al., 1999). The minerals names highlighted in red represent minerals identified on site.

\begin{tabular}{ll}
\hline Solubility equilibrium likely & Solubility equilibrium possible \\
\hline alunogen & alunite \\
anglesite & ankerite \\
basaluminite & antlerite \\
calcite & atacamite, paratacamite \\
cerussite & azurite \\
chalcanthite & bronchantite \\
epsomite & chrysocolla \\
ferrihydrite & goethite \\
gibbsite & hemimorphite \\
goslarite & hematite \\
gypsum & hydrozincite \\
halotrichite & jarosite \\
manganese oxides & kaolinite \\
melanterite & kutnohorite \\
otavite & malachite \\
rhodochrosite & natroalunite \\
schwertmannite & natrojarosite \\
scorodite & plumbojarosite \\
siderite & \\
silica & \\
smithsonite & \\
witherite & \\
&
\end{tabular}




\subsubsection{Na-Mg-K- Ca sulfates}

Many of the minerals at El Indio are Na-Mg sulfate minerals that have described by Lottermoser (2010c) as post-mining secondary minerals identified in mine waste. Hydrated Mg-sulfates and $\mathrm{Na}-\mathrm{Mg}$ sulfates have also been identified on irrigated paddy soils in the Soudano-Sahelian region of Niger that are unrelated to mining (Ducloux et al., 1994). Leduc (2010) states that Na-Mg hydrates sulfate are commonly found in inland saline lake systems and are known to occur in various hydration states, depending on temperature, relative humidity and brine concentration. Demartin et al. (2012) have recorded similar minerals forming from fumaroles, which are modern day analogues of epithermal deposits. The source of $\mathrm{Na}, \mathrm{Mg}, \mathrm{K}$ and $\mathrm{S}$ are probably the primary minerals formed at $\mathrm{El}$ Indio such as pyrite, enargite, alunite, feldspars, pyroxenes and hornblende. The $\mathrm{Na}-\mathrm{K}-\mathrm{Ca}-\mathrm{Mg}$ sulfate salts found at the mines in this study are variable and range from simple anhydrous salt anhydrite, to simple hydrous salts such as gypsum, to variably hydrated Mg-sulfates such as hexahydrite, epsomite and starkeyite, to mixed salts of cation pairs (Jambor et al., 2000). The secondary precipitates identified during this study include gypsum, loweite, $\mathrm{Mg}$ and $\mathrm{Zn}$ endmembers of the blodite group (blodite, changoite), hexahydrite and starkeyite (Table 5-7). The most common simple Ca sulfate salts such as gypsum and anhydrite are the least soluble out of all minerals in this section (Spencer, 2000), but can also be dehydration products of some samples. Finding anhydrite is unusual because this mineral tends to form at temperatures above $40^{\circ} \mathrm{C}$ (Jambor et al., 2000); however, its identification is supported by $\mu \mathrm{XRD}$. Solubility of minerals in grams per kilogram were calculated by Spencer (2000) using thermochemical model of Harvie et al.(1984) and temperatures below $25^{\circ} \mathrm{C}$. The solubility of mixed cation minerals varies and will likely fall between the solubility values of the cations involved.

A sudden rainfall event can cause the dissolution of the minerals previously formed. The $\mathrm{Na}-\mathrm{Mg}$ or Ca-sulfates identified are not acid forming upon precipitation or dissolution (Buckby et al., 2003), therefore cannot contribute to the low pH measured throughout El Indio. However, their dissolution 
following is known to be responsible for the high contents of dissolved salts in the measured streams (Buckby et al., 2003). Blodite-type compounds have the chemical formula $\mathrm{Na}_{2} \mathrm{Me}\left(\mathrm{SO}_{4}\right)\left(\mathrm{H}_{2} \mathrm{O}\right)_{4}$ where $\mathrm{K}$ may replace some $\mathrm{Na}$ and $\mathrm{Me}=\mathrm{Mg}, \mathrm{Co}, \mathrm{Ni}, \mathrm{Zn}$ (Spencer, 2000). Blodite-type structures are built of $\left[\mathrm{Me}\left(\mathrm{H}_{2} \mathrm{O}\right)_{4}\left(\mathrm{SO}_{4}\right)_{2}\right]^{2-}$ molecules that are linked $\mathrm{NaO}_{6}$ polyhedra and hydrogen bonds (Stoilova and Wildner, 2004). Changoite is also in the blodite group but contains $\mathrm{Zn}$ in its mineral formula instead of $\mathrm{Mg}$. Hexahydrite is a mineral from the hexahydrite group of monoclinic sulfates of the type $\mathrm{Me}^{2+} \mathrm{SO}_{4} \cdot 6\left(\mathrm{H}_{2} \mathrm{O}\right)$ and has been formed by Mg-rich waters (Jambor et al., 2000). Although generally, the minerals of this group are found as the oxidation product of sulfide deposits, hexahydrite has been identified as a precipitate in various settings (i.e. diamond mine waste, saline lakes, soils, weathered mine wastes) (Jambor et al., 2000; Rollo and Jamieson, 2006; Peterson, 2011; Whittig et al.,1982). At El Indio sample site IN13, hexahydrate has likely dehydrated to starkeyite since both mineral are observed at the same location. The dehydration may have occurred at the sampling site or during transportation prior to sample preparation. Hexahydrite may hydrate to epsomite, or dehydrate to kieserite as demonstrated in Figure 5-3. In this figure, the relative humidity $(45-90 \%)$ and temperature variation $\left(5-30^{\circ}\right)$ conditions at El Indio are represented, showing potential phases that may occur. From research conducted east-southeast of Calingasta, Argentina, Peterson (2011) has identified hexahydrite veins with soft surficial dusting of starkeyite as a result of dehydration. Hence, this study is in agreement with observations by Peterson (2011). Also in agreement with Peterson (2011), the hydrated Mg-sulfate minerals are commonly found as mixtures. Chou and Seal (2003) have further reviewed literature relating to the epsomite-hexahydritevapor equilibrium. 


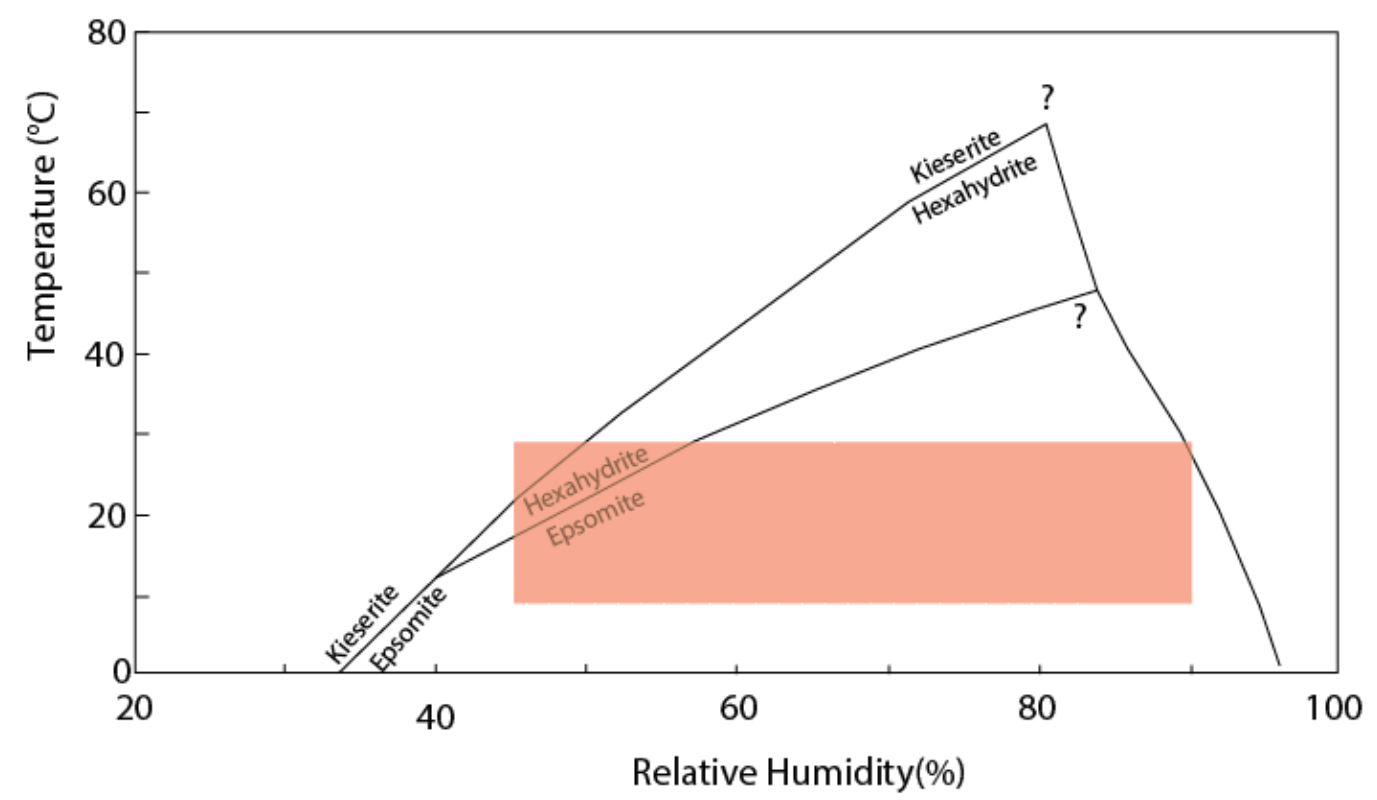

Figure 5-3 Hydrogenetic grids for hydrated metal-sulfate salts kieserite, hexahydrite, and epsomite. The curves are representative of experimentally determined dehydration reactions to temperature and relative humidity conducted by Hammarstrom et al. (2005). The questions marks indicate uncertain reaction phase boundaries. The red box represents approximate temperature and humidity conditions at El Indio (Barrick Gold Corporation, personal communication).

Similar minerals to those at El Indio (i.e. gypsum, hexahydrite, starkeyite, loweite, blodite) have been identified in the Upper Colorado River Basin as efflorescences on the Mancos Shale. These minerals reflect the compositions of the solutions from which they have precipitated. As such, solutions that formed these minerals at Mancos Shale, were enriched in $\mathrm{SO}_{4}, \mathrm{Na}, \mathrm{Mg}, \mathrm{K}, \mathrm{Ca}$ and $\mathrm{Zn}$ and these minerals are important sinks of these elements during the dry season.

\subsubsection{Cu-sulfates and Cu-silicates}

This group of secondary precipitates was amongst the most common at Lagunas Norte and was also observed at El Indio. The minerals in this section are expected to be soluble because they are simple hydrous metal sulfates (Lottermoser, 2010c). The oxidation of primary minerals such as chalcopyrite (CuFeS $)$, enargite $\left(\mathrm{Cu}_{3} \mathrm{AsS}_{4}\right)$, tennantite $\left(\mathrm{Cu}_{12} \mathrm{As}_{4} \mathrm{~S}_{13}\right)$, chalcocite $\left(\mathrm{Cu}_{2} \mathrm{~S}\right)$, bornite $\left(\mathrm{Cu}_{5} \mathrm{FeS}_{4}\right)$, digenite $\left(\mathrm{Cu}_{9} \mathrm{~S}_{5}\right)$ at El Indio to the formation of these various sulfates of $\mathrm{Cu}$. The primary $\mathrm{Cu}$-mineral identified Lagunas Norte and Pierina is enargite. The Lagunas Norte and Pierina deposits represent mineralization formed 
closer to the surface than that at the El Indio deposit, explaining the abundance of Cu-sulfides that tend to mineralize at greater depths (Arribas, 1995).

The Cu sulfates at El Indio were only identified using ESEM analysis of the mounted bulk sample. Due to the significant amount of primary Cu minerals present at El Indio, a larger amount of secondary $\mathrm{Cu}$ sulfate minerals were expected to have been identified in the field. Selective sampling and specific sampling period could have influenced the amount of $\mathrm{Cu}$ minerals identified in the field. It was only possible to collect from a few locations, perhaps leading to missed $\mathrm{Cu}$ minerals. It is also likely that the $\mathrm{Cu}$ minerals at El Indio were dissolved due to rainfall.

Copper-sulfates were identified in 2 out of 3 samples collected from the pit-wall at the Lagunas Norte Mine and include antlerite, chalcanthite and poitevinite (Table 5-7). Antlerite $\left(\mathrm{Cu}_{3}(\mathrm{OH})_{4}\left(\mathrm{SO}_{4}\right)\right.$ is a mineral metastable at ambient temperature. Chalcanthite is the $\mathrm{Cu}$ endmember of the triclinic $\mathrm{Cu}, \mathrm{Mg}$, $\mathrm{Mn}$ and Fe pentahydrates of the chancanthite group, and is generally of common occurrence (Jambor et al., 2000). Solid-solution incorporation of $\mathrm{Mg}$ or $\mathrm{Zn}$ has been observed at $25^{\circ} \mathrm{C}$ by Balarew et al. (1975). Poitevinite is formed as a result of the dehydration of chalcanthite. Hence, this mineral could have formed after it was sampled. Antlerite, chalcanthite, and poitevinite must have formed from Cu-rich waters, and are all important in the retention of $\mathrm{Cu}$ at the respective sites in which they occur. Based on superposition 
of El Indio temperature and humidity conditions onto hydrogenetic grids, it becomes evident that chalcanthite would likely occur at El Indio.

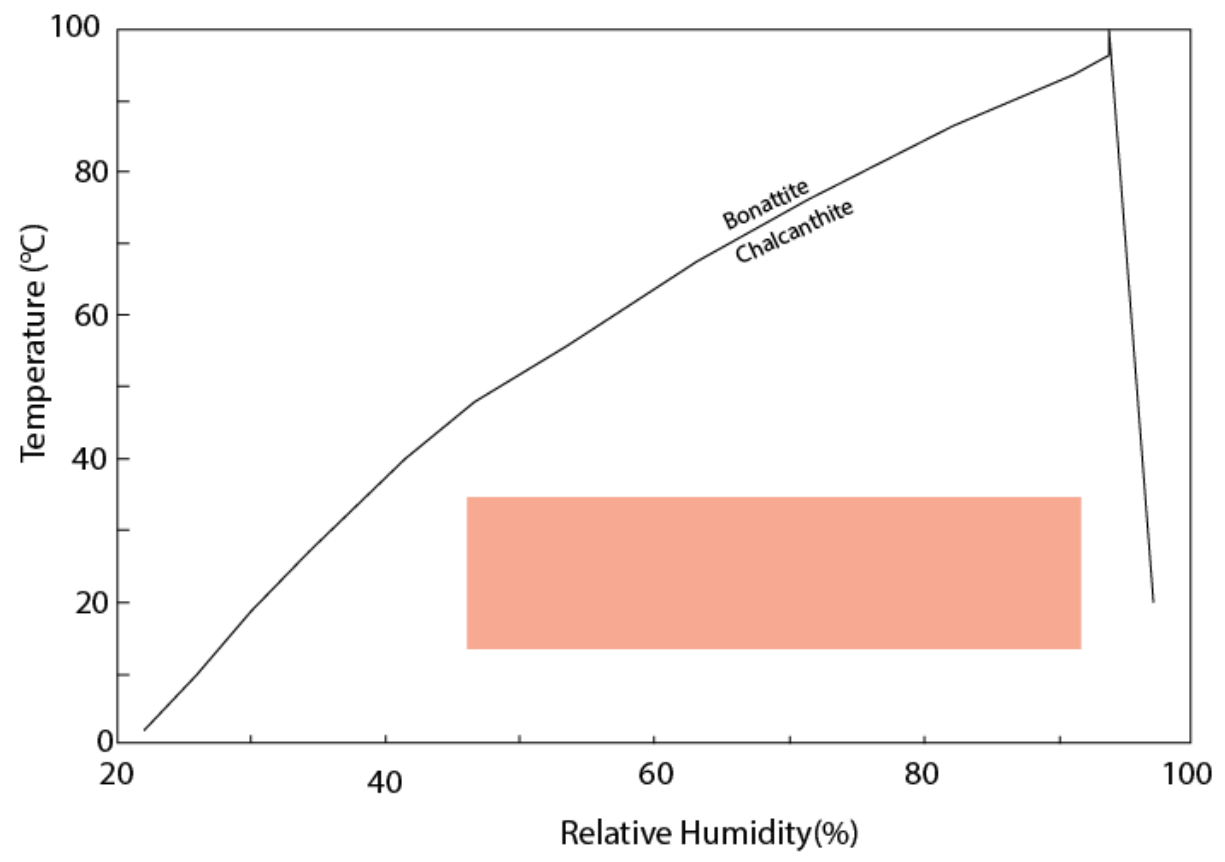

Figure 5-4 Hydrogenetic grids for hydrated metal-sulfate salts bonattite and chalcanthite. The curves are representative of experimentally determined dehydration reactions to temperature and relative humidity conducted by Hammarstrom et al. (2005). The red box represents approximate temperature and humidity conditions at El Indio (Barrick Gold Corporation, personal communication).

\subsubsection{Fe-Al oxyhydroxides}

XRD analyses have allowed identifying Fe-oxyhydroxides and Fe-oxides that are likely found at El Indio, Lagunas Norte and Pierina mines. Geochemical modeling has also predicted that similar minerals would precipitate in these settings. These minerals were rarely identified through XRD or $\mu$ XRD because of their microcrystalline or amorphous nature, or selective sampling. The source of Fe is expected to have entered into waters through the oxidation of primary minerals such as the ubiquitous pyrite and other Fesulfides. Fe-oxyhydroxides are commonly occurring ARD minerals (Buckby et al., 2003; Jönsson et al., 2006; Romero et al., 2011; Jambor et al., 2000; Nordstrom et al., 1999). 


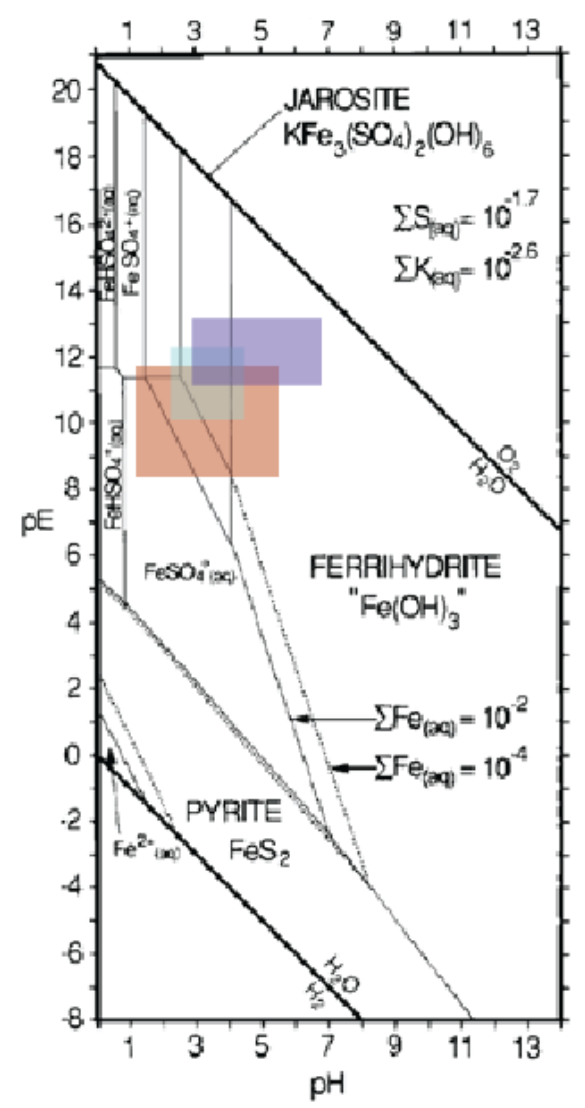

Figure 5-5 pE-pH diagram, showing the stable solid phases in Fe-S-K-O-H system at $\mathrm{T}=\mathbf{2 5 ^ { \circ }} \mathrm{C}$ and $\mathbf{1}$ bar. The activities are airon $=10^{-1.0}, a_{\text {sulfur }}=10^{-1.7}$, $a_{\text {potassium }}=10^{-2.6}$ and are congruent with activities observed in collected samples. The stability from A to B, there are changes in activities of elements in play (modified from Alpers and Brimhall, 1989). The range of pe and $\mathrm{pH}$ conditions for each mine vary and is displayed in orange (El Indio), blue (Pierina), purple (Lagunas Norte) based on collected field data. Increasingly reducing conditions may dissolve Fe-sulfates and encourage the precipitation of Fe-sulfides. Increasingly acidic and/reducing conditions will reduce the stability of ferrihydrite and jarosite, leading to dissolution or alteration to other phases.

Munk et al. (2006) have conducted laboratory experiments studying the geochemical evolution of solutions derived by experimental weathering of sulfide-bearing rocks. Their results indicate that changes in $\mathrm{pH}$ and the formation of $\mathrm{Fe}$ and $\mathrm{Al}$ oxyhydroxides affect the chemical composition of the solution. Specifically, these authors have stated that an increase in $\mathrm{pH}$ to a value of around 5.1 causes Fe and Al oxyhydroxides to precipitate, which would scavenge cations from solution via sorption. Thus, their presence can significantly affect water quality as they promote attenuation of metals. However, if more acidic conditions are created, then metals may desorb and will be released in solution (Schwertmann et al., 1983). Based on geochemical modeling, scorodite, goethite, hematite, magnetite, gibbsite, diaspore, 
bohemite are likely precipitated at El Indio (Table 5-7). Scorodite, fibroferrite, hematite, magnetite, gibbsite, bohemite likely precipitated at Lagunas Norte and goethite, hematite, magnetite, gibbsite, diaspore, bohemite show SI>0 at Pierina (Table 5-7). Few of these minerals (i.e scorodite, goethite, hematite) were identified by diffraction methods; however, given the chemistry of the studied secondary precipitates and waters, we assume that these minerals are actually present. Goethite is found in lowtemperature environments. This mineral is formed through the weathering of other Fe-rich minerals. Goethite forms under surface conditions since its precipitation is a result of Fe oxidation from 2+ to 3+. The disintegration or oxidation of arsenopyrite, pyrite and other sulfides leads to the precipitation of Fe such as scorodite and ferrihydrite. Scorodite is commonly found in hydrothermal deposits as a weathering product of arsenopyrite in mine waste (DeSisto et al., 2011). Ferrihydrite is a common host for metal sorption in aqueous systems (Klohn Crippen Berger, 2012b; Dzombak and Morel, 1990). Schwertmann and Murad (1983) have stated that ferrihydrite dissolves and reprecipitates as goethite outside of a $\mathrm{pH}$ range of 5 and 9.

The presence of abundant Fe oxides at El Indio, Lagunas Norte and Pierina mines suggests that the waters in which they precipitated are well oxidized, and this is supported by the ORP measurements collected in the field (Table 4-7, Table 4-8, Table 4-9). Ferric minerals are representative of a more advanced stage of oxidation relative to the $\mathrm{Fe}^{2+}$ sulfates. The secondary precipitates discussed in this section have generally been formed from Fe- or Al- rich waters, and retain Fe and Al, and other elements that may be adsorbed on them. More Fe and Al oxides were identified by a combination of XRD and $\mu$ XRD methods, at all mine sites. Selective sampling and the amorphous nature of some of these precipitates may explain the lack of such minerals identified with methods measuring diffraction.

\subsubsection{Fe-Al sulfates or hydroxysulfates}

Iron-sulfates commonly occur at El Indio, Lagunas Norte and Pierina mines. Melanterite, magnesiocopiapite, jarosite, natrojarosite were identified at El Indio (Table 5-7). Aluminocopiapite, 
melanterite and hydroniumjarosite were found at Lagunas Norte and romerite, coquimbite, jarosite and magnesiocopiapite were present at Pierina (Table 5-7). Magnesiocopiapite is a mineral of the copiapite group with the general formula $A^{2+} R^{3+}{ }_{4}\left(\mathrm{SO}_{4}\right)_{6}(\mathrm{OH})_{2} \cdot 2 \mathrm{H}_{2} \mathrm{O}$ where $\mathrm{R}$ is represented by $\mathrm{Fe}^{3+}$, and is likely formed by $\mathrm{Fe}^{2+}$ poor waters. Substitution of $\mathrm{Al}$ and $\mathrm{Fe}^{3+}$ in the $\mathrm{A}^{2+}$ is a possibility, which is trivalent instead of mixed divalent. Magnesiocopiapite minerals from the Richmond Mine at Iron Mountain have been identified under the ESEM as 10-50 $\mu \mathrm{m}$ plate crystals (Jamieson et al., 2005; Jambor et al., 2000). Minerals from the copiapite group are likely to be precipitated from solutions with $\mathrm{pH}>2.0$, but can also form as an alteration product of mineral precipitates (Buckby et al., 2003). According to Jambor et al. (2000), coquimbite $\left(\mathrm{Fe}_{2}\left(\mathrm{SO}_{4}\right)_{3} \cdot 9 \mathrm{H}_{2} \mathrm{O}\right)$ and alunogen $\left(\mathrm{Al}_{2}\left(\mathrm{SO}_{4}\right)_{3} \cdot 17 \mathrm{H}_{2} \mathrm{O}\right)$ are the most commonly occurring secondary precipitates with trivalent cations. The stream waters that formed coquimbite were likely $\mathrm{Fe}^{3+}$ rich; coexisting waters were rich in Fe. Vaniman et al. (2004) have studied the hydration and dehydration of hydrous $\mathrm{Fe}^{3+}$ sulfates, notably coquimbite, kornelite and botryogen. Specifically, it is discovered that although coquimbite, botryogen and kornelite structures all contain independent $\mathrm{H}_{2} \mathrm{O}$ molecules, reversible dehydration reactions similar to the epsomite to hexahydrite reaction for $\mathrm{Mg}$-sulfates was not observed. The lack of botryogen and kornelite at the mine sites in this study further confirm this theory as the three minerals may have been identified if reversible dehydration reactions did take place. In samples collected from IN28, Na has substituted for K, creating a mineral called natroalunite. Sracek et al. (2010) have identified that melanterite and rozenite may store significant amounts of $\mathrm{Cu}$, Co and $\mathrm{Zn}$. Alunite $\mathrm{KAl}_{3}\left(\mathrm{SO}_{4}\right)_{2}(\mathrm{OH})_{6}$ is an alteration mineral that occurs at $\mathrm{HS}$ epithermal deposits in volcanic rocks. Alunite is a version of jarosite where $\mathrm{Al}$ has replaced $\mathrm{Fe}^{3+}$. Alunite is a primary mineral and is ubiquitous throughout HS epithermal deposits, including Pierina, but can also be a secondary mineral (Rainbow, 2009). As described by Jensen et al. (1971), stable sulfur isotopes can be used to distinguish between the primary and secondary alunite, where $S$ of the primary alunite will be enriched in $S^{34}$. The secondary precipitates discussed in this section have generally been formed from Fe- or Al- rich waters, and are 
essential for the retention and storage of $\mathrm{Fe}, \mathrm{Al}, \mathrm{As}$ and $\mathrm{SO}_{4}$. Jarosite and melanterite represent an important family of hydrated $\mathrm{Fe}_{-} \mathrm{SO}_{4}$ minerals that are commonly found in acid environments (Nordstrom and Alpers, 1999; Jamieson et al., 2005; Klohn Crippen Berger, 2012a). The relative humidity and temperature conditions of rozenite and melanterite are displayed on Figure 5-6 with relative humidity and temperature conditions at El Indio highlighted. Based on this diagram, both rozenite and melanterite may be observed at El Indio.

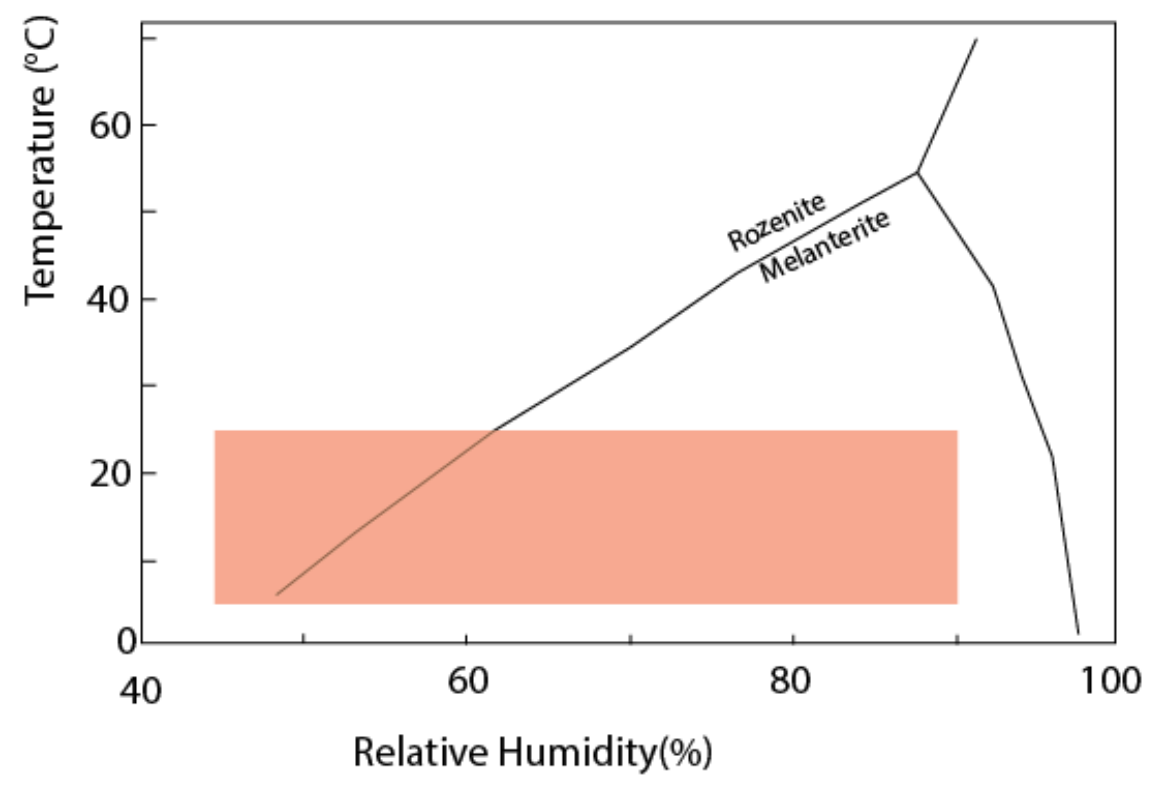

Figure 5-6 Hydrogenetic grids for hydrated metal-sulfate salts rozenite and melanterite. The curves are representative of experimentally determined dehydration reactions to temperature and relative humidity conducted by Hammarstrom et al. (2005). The questions marks indicate uncertain reaction phase boundaries. The red box represents approximate temperature and humidity conditions at El Indio (Barrick Gold Corporation, personal communication).

Studies conducted by Carrero et al., (2015) study the sorption capacity of trace elements in solution by Fe and Al-hydroxysulfates. Less research pertaining to sorption has been conducted on Alhydroxysulfates formed in ARD settings because they are less common than Fe-hydroxysulfates. Carrero and his coauthors reconfirm the affinity of basaluminite with $\mathrm{Si}$ and $\mathrm{Cu}$, and of schwertmannite for As and $\mathrm{Cr}$, and discover previously unidentified affinity of basaluminite for As and Cr. Basaluminite from El Indio, Lagunas Norte, and Pierina may demonstrate similar results. 


\subsubsection{Comparison of analytical methods}

Through the analysis of bulk samples with ESEM, various morphologies of minerals were observed as well as identification of elements, providing a semi-quantitative analysis of minerals. Targeting textures or morphologies of interest allowed quick identification of the major elements. The hydration state could not be measured with the ESEM. Also, some elements have similar K or L X-ray adsorption energies, including $\mathrm{Pb}$ with $\mathrm{As}, \mathrm{Mg}$ with As and $\mathrm{As}$ with $\mathrm{Sb}$. Hence, an overlap of their peaks was an issue while attempting to identify these elements on the spectra. Previous research on Fe and Al hydroxysulfate minerals by Bigham and Nordstrom (2000) states that crystal morphology of most minerals is variable and therefore not a reliable tool for identification. Most of these minerals could not be positively identified only with the use of the ESEM. A number of morphologies were observed and associated with corresponding groups of minerals. For example, $\mathrm{Na}-\mathrm{Mg}$ sulfates tend to occur as euhedral isometric clusters.

Synchrotron-based analyses including $\mu \mathrm{XRD}$ and $\mu \mathrm{XRF}$ were indispensable to mineral identification and elemental associations. A significant number of unknown phases from samples collected at El Indio were identified through $\mu \mathrm{XRD}$ analysis with HighScore ${ }^{\mathrm{TM}}$ peak matching software. The elemental mapping by $\mu \mathrm{XRF}$, led to the identification of trace elements in some minerals. The association of trace elements with minerals was only conducted on spots analyzed by $\mu$ XRD spots that show a single identified phase. The observed diffraction of assumed single phase does not mean that no other phases exist within the 2 $\mu \mathrm{m}$ volume of the beam size, and it is possible that there are amorphous phases or those coarse to diffract under these conditions. Furthermore, not all phases could be identified because of complex mineral mixtures present in samples. Peak overlap such as that observed for ESEM spectra was also an issue for the MCA spectra collected from $\mu$ XRF maps.

Bulk XRD analysis identified the most common and most coarsely-crystalline phases in the powdered samples. MicroXRD analysis showed that each sample with intergrowths of multiple phases observed. Hence, the resolution of bulk XRD analysis is not great enough to identify all phases present in 
the sample. The differences observed between bulk XRD and $\mu$ XRD can be explained by the differing resolutions of the tools used, types of samples analyzed, scales of analysis and sample preparation. The micron-scaled beam used at the synchrotron and the $\mu \mathrm{XRF}$ maps created allow for target selection whereas the bulk results only show the most abundant and crystalline phases. The analytical methods used for this study complemented one another, improving the quality of results.

X-ray fluorescence maps were created at selected areas of the thin section (Figure 4-26, Figure 4-27, Figure 4-33, Figure 4-35, Figure 4-36) and XRF spectra, as well as $\mu$ XRD were compared at all sites. The objective of comparing minerals identified by $\mu \mathrm{XRD}$ to elements occurring in the $\mu \mathrm{XRF}$ spectra was to identify which elements are associated with the identified minerals, including those not in the mineral formulae. Of these 185 sites, only 26 sites showed a single phase and were used to observe elementmineral associations. Since mixtures of minerals are observed through $\mu \mathrm{XRD}$ and $\mu \mathrm{XRF}$, and are also evident through ESEM analysis, it is also likely that some elements are from nearby minerals due to the resolution of the beam. The spot size of the incident beam is 2 microns. Although we have seen the diffraction pattern of a single mineral, phases may exist within that $2 \mu \mathrm{m}$ volume that are amorphous or too coarse to identify by $\mu \mathrm{XRD}$. Synchrotron microanalysis was useful but limited by beamtime availability.

\subsection{Predicted metal mobility in mine waste conditions}

Analysis of the results from El Indio, Lagunas Norte and Pierina has demonstrated that the release

of major, minor and trace elements into stream water depends on the $\mathrm{pH}$-Eh conditions, and the precipitation and dissolution of mineral phases. The mobility of major, minor and trace elements are also controlled by the formation of highly soluble sulfate minerals identified. It is shown that a number of elements are attenuated by secondary mineral precipitation at El Indio, Lagunas Norte, and Pierina mines. A great number of cations can be incorporated in synthetic goethite, including: $\mathrm{Al}, \mathrm{Ni}, \mathrm{Zn}, \mathrm{Cd}, \mathrm{Cr}, \mathrm{Ga}, \mathrm{V}$, Mn, Co, Sc, Pb, Ge and Si (Inouye et al., 1972; Lim-Numez and Gilkes, 1985; Stiers and Schwertmann, 1985; Vandenberghe et al., 198; Cornell and Giovanoli, 1987; Diaz et al, 1989). Micro-XRF spot analysis was 
conducted on goethite sampled from El Indio, and has shown an association with $\mathrm{Cu}, \mathrm{K}, \mathrm{Mn}, \mathrm{Ti}, \mathrm{Zn}, \mathrm{As}, \mathrm{K}$, $\mathrm{Co}, \mathrm{Br}, \mathrm{Ca}$, Ni. These elements are assumed to be adsorbed onto the mineral, incorporated within the crystal structure or to be associated with other phases and accidentally detected by the synchrotron beam. The critical ranges of sorption of these elements are listed in Table 5-6 and match the $\mathrm{pH}$ conditions of the solutions at the sample sites. Based on results from $\mu$ XRF spot analysis of samples from El Indio and Lagunas Norte, the elements $\mathrm{Cu}, \mathrm{Mn}, \mathrm{Zn}, \mathrm{Ca}, \mathrm{Co}, \mathrm{Fe}$, and $\mathrm{Ni}$ are attenuated by the precipitation of blodite whereas $\mathrm{Cu}, \mathrm{K}, \mathrm{Zn}, \mathrm{Ca}, \mathrm{Mn}, \mathrm{Fe}, \mathrm{Ti}, \mathrm{Co}, \mathrm{Ni}$ and $\mathrm{As}$ are attenuated by alunite. Hexahydrite contains $\mathrm{Cu}, \mathrm{Zn}$, $\mathrm{Fe}, \mathrm{Mn}, \mathrm{As}, \mathrm{Ni}, \mathrm{Ti}$ or $\mathrm{Ti}, \mathrm{As}, \mathrm{Co}$, and $\mathrm{Ni}$ and may control their mobility. Its precipitation will decrease the mobility of the listed elements. The lower values of $\mathrm{K}$ in some waters show that this element has been retained likely a result of the precipitation of jarosite. Studies by Romero et al. (2011) further demonstrate that $\mathrm{Na}$ and $\mathrm{Pb}$ could be retained by jarosite when these elements substitute for $\mathrm{K}$ to form natrojarosite and plumbojarosite. Cadmium and Zn can be easily released in HS epithermal settings as they are highly mobile in very acidic environments (Romero et al., 2011; Nordstrom et al., 1999; Plumlee, 1999); however, $\mathrm{Pb}$ is a very immobile element. Sulfate is attenuated throughout all mines with the formation of the various sulfate minerals. Arsenate is also known to substitute for sulfate in the jarosite structure (Dutrizac et al., 1987; Savage et al., 2005).

\subsection{Implications of research to water treatment at sites}

Both passive and active water treatment present are effective methods in attenuating metal concentrations in waters flowing out of the mine sites. If traditional water treatment fails to meet parameter requirements, Barrick Gold Corporation can consider capturing the sulfate-rich secondary precipitates by mechanically enhanced pond-evaporation and precipitation of efflorescent salts, methods which have shown to contain trace metals and may allow to efficiently capture elements of interest. Significant pre-treatment is required for volume reduction and quality control (MEND, 2014). This method may prove to be expensive as a result of disposal costs of the highly soluble metal sulfate salts present, as 
well as due to the requirement for a significantly high amount of energy required as a result of abundant rainfall or snowfall at the Peruvian sites and seasonal snowmelt at El Indio.

Most secondary minerals identified at the mine sites are sulfates, and the waters also demonstrate significant concentrations of sulfate. Due to the lower environmental risks and regulatory standards for sulfate comparatively to those for acidity and dissolved metals, minimal attention is given to the mitigation of sulfate in ARD treatment (Lorax Environmental, 2003). However, sulfate has recently become an important indicator of environmental compliance to the mining industry as concern is increasing over the impact sulfate can have on the salinity of receiving waters (Philippe et al., 2015). Furthermore, issues associated with excess sulfate in mine process waters include reduction to toxic HS gas, scale formation, decreased metallurgical production recovery, and increase in cost related to mitigation, control and treatment (Philippe et al., 2015). Recovering sulfate from solution will decrease all of these.

The long-term objective of this research project was to investigate methods of extracting metals from acid mine waste in order to minimize the environmental impact of the drainage and offset remediation costs. Hence, the price of the extracted commodity will also be taken into account to further understand extraction viability (i.e., market conditions). To determine whether an element will be of economic value, the mass of metal that could be recovered was calculated and compared to commodity prices. A few important assumptions were made including that the flow rate is constant, that an average concentration of elements can be used, that there are only 7 elements that can be recovered $(\mathrm{Al}, \mathrm{Cu}, \mathrm{Mg}$, $\mathrm{Mn}, \mathrm{Ni} \mathrm{Pb}, \mathrm{Zn})$, and that the commodity price is unchanged throughout the year. Furthermore, capital expenditure is not included in this section, but will also have significant impact on offsetting treatment costs depending on applied flow technology. This analysis focuses primarily on operational costs.

Commodity prices were collected on October $14^{\text {th }}, 2015$ and were used for calculations (Table 5-9). These values are subject to change, inferring that values calculated in this section are only estimates. 
Water treatment costs (i.e HDS, ion exchange, nanofiltration and RO) are estimated at $0.20 \$-1.00 \$$ per cubic meter for ARD and recovery costs are generally similar (MEND, 2014). The average flow rates are calculated at 9,555,723,360 L/year at El Indio; 493,061,049 L/year at Lagunas Norte, and 128,107,116 L/year. According to these numbers, water treatment costs will fall between $\$ 1,911,144-\$ 9,555,723$ at $\mathrm{El}$ Indio, $\$ 98,612-\$ 493,061$ at Lagunas Norte, $\$ 25,621-\$ 128,107$ at Pierina. Recovery costs will be similar, but additional to water treatment costs. The averaged values of recoverable metals, assuming $100 \%$ recovery, were calculated at approximately $\$ 6,160,703$ at El Indio; $\$ 1,434,913$ at Lagunas Norte, and $\$ 21,987$ at Pierina (Table 5-10, Table 5-11, Table 5-12). The averaged values of recoverable metals, assuming $85 \%$ recovery, were also calculated at approximately $\$ 2,565,367$ at El Indio; $\$ 121,164$ at Lagunas Norte, and $\$ 5,318$ at Pierina. However, since the best case scenario was calculated, $100 \%$ recovery values were used. The treatment costs and average value of recoverable metals were calculated from data provided by Barrick Gold Corporation.

Table 5-9 List of economic prices of elements analysed at mine sites as per stock values on October $14^{\text {th }}, 2015$. Prices are provided in units of $\$ / \mathrm{kg}$ and then converted to $\$ / \mathrm{mg}$ to compare and calculate average annual income through assuming $100 \%$ recovery. The commodity prices collected on October $14^{\text {th }}, 2015$ were used for calculations and were retrieved from www.infomine.com.

\begin{tabular}{ccc}
\hline Element & Unit & Price \\
\hline $\mathrm{Al}$ & $\$ / \mathrm{kg}$ & 1.61 \\
$\mathrm{Cu}$ & $\$ / \mathrm{kg}$ & 6.91 \\
$\mathrm{Mg}$ & $\$ / \mathrm{kg}$ & 2.07 \\
$\mathrm{Mn}$ & $\$ / \mathrm{kg}$ & 1.75 \\
$\mathrm{Ni}$ & $\$ / \mathrm{kg}$ & 16.96 \\
$\mathrm{~Pb}$ & $\$ / \mathrm{kg}$ & 1.80 \\
$\mathrm{Zn}$ & $\$ / \mathrm{kg}$ & 1.84 \\
\hline
\end{tabular}

Annual flow rates (L/Year) are multiplied by the concentration of elements in solution $(\mathrm{mg} / \mathrm{L})$, which are subsequently multiplied by the price of the commodity, providing us with a value of recoverable element per site. The profit per year is averaged between each sampled site, assuming a closed system, and values for each element are summed to provide a grossly estimated total in USD per year (Table 5-12). Since the goal is cost reduction, net treatment cost per year was averaged because if metals are removed 
from one site, this will influence the quantity at the next site. These values were then compared to the water treatment costs provided earlier. The net treatment cost was calculated by subtraction water treatment costs (WTC) and recovery costs (RC) from the summed total metal value (Equation 5.3).

$$
\text { Net treatment cost }=(W T C+R C)-M V
$$

Equation 5.3

Even in the best case scenario of $100 \%$ metal recovery, values indicate that Barrick Gold Corporation cannot significantly offset treatment costs from the recovery of elements $\mathrm{Al}, \mathrm{Cu}, \mathrm{Mg}, \mathrm{Mn}, \mathrm{Ni}, \mathrm{Pb}$, and $\mathrm{Zn}$ at any of the sites. In fact, assuming that recovery costs are greater than treatment costs, the company may lose substantial capital by recovering these metals. Nevertheless, water treatment must decrease the values of these elements to environmentally acceptable concentrations, as described in section 5.1.5. The values of metal concentration can change in the waters depending on mining activities, changes in climate and precipitation. It is also important to note that the previous calculations are preliminary analysis conducted on bulk averages for the abovementioned suite of metals and flow. Barrick Gold Corporation should consider looking at seasonal flows to potentially recover metals part of the year. Although a plant startup cost, a capital cost, is associated with this strategy, strategic recovery may allow to offset water costs. Moreover, targeting the recovery of the most valuable metals on the market and cheapest for recovery may aid in offsetting costs. The calculations in this section are not selective in this regard. 
Table 5-10 Sampling sites, flow rates, and elemental concentrations ( $\mathrm{Al}, \mathrm{Cu}, \mathrm{Fe}, \mathrm{Mg}, \mathrm{Mn}, \mathrm{Ni}, \mathrm{Pb}, \mathrm{Zn}$ ) as per collection data provided by Barrick Gold Corporation between 1900-2014.

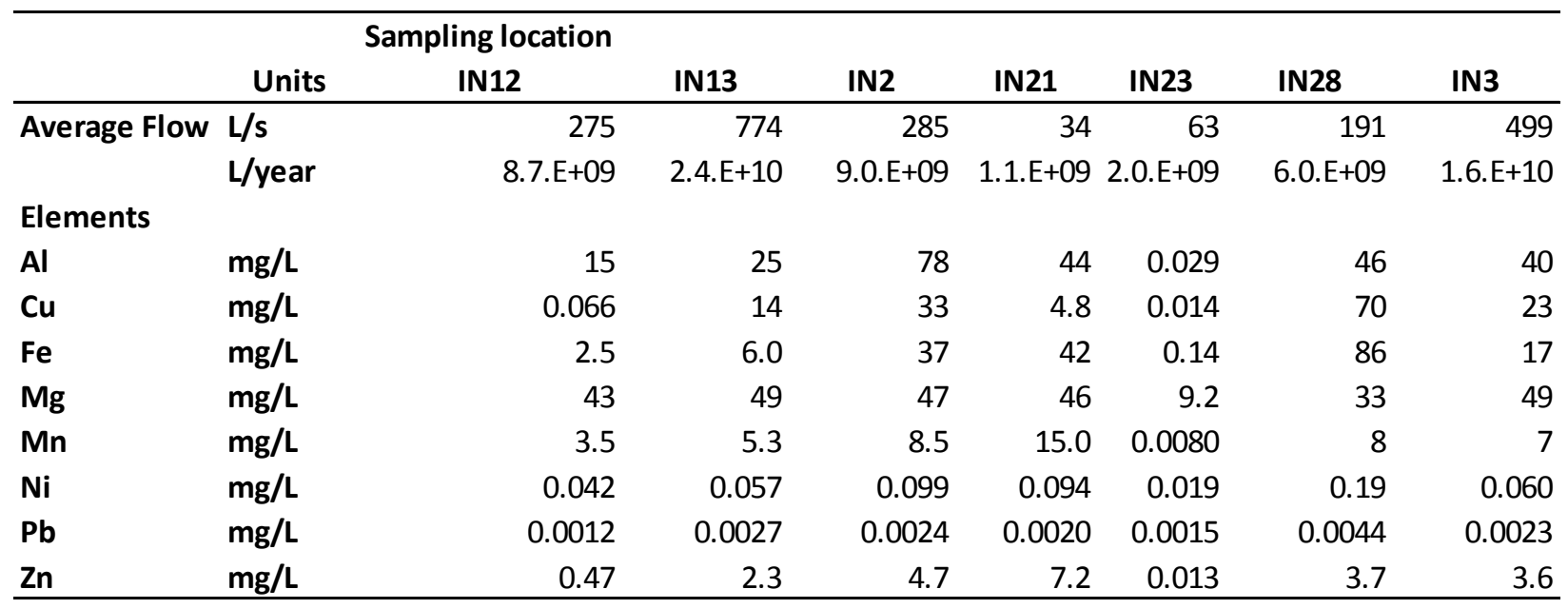

Table 5-11 Amount of recoverable metals from each sampled site in $\mathrm{mg} / \mathrm{year}$ by multiplying concentration with annual flow rate.

\begin{tabular}{lrrrrrrrr}
\hline Elements & Units & \multicolumn{1}{c}{ IN12 } & \multicolumn{1}{c}{ IN13 } & \multicolumn{1}{c}{ IN2 } & \multicolumn{1}{c}{ IN21 } & IN23 & \multicolumn{1}{c}{ IN28 } & \multicolumn{1}{c}{ IN3 } \\
\hline $\mathrm{Al}$ & kg/year & 127,135 & 598,025 & 699,865 & 48,111 & 58 & 278,921 & 629,320 \\
$\mathrm{Cu}$ & $\mathrm{kg} /$ year & 567 & 343,925 & 297,801 & 5,223 & 28 & 424,419 & 361,859 \\
$\mathrm{Mg}$ & $\mathrm{kg} /$ year & 374,650 & $1,192,877$ & 421,444 & 49,682 & 18,285 & 198,988 & 764,624 \\
$\mathrm{Mn}$ & $\mathrm{kg} /$ year & 30,658 & 128,636 & 75,819 & 16,264 & 16 & 50,109 & 102,264 \\
$\mathrm{Ni}$ & $\mathrm{kg} /$ year & 364 & 1,379 & 886 & 102 & 38 & 1,123 & 947 \\
$\mathrm{~Pb}$ & $\mathrm{~kg} /$ year & 10 & 66 & 22 & 2 & 3 & 27 & 36 \\
$\mathrm{Zn}$ & $\mathrm{kg} /$ year & 4,097 & 56,873 & 42,171 & 7,786 & 26 & 22,157 & 56,009 \\
\hline
\end{tabular}

Table 5-12 Amount in USD per year was calculated by multiplying $\mathrm{mg} /$ year values from Table 5-10 with appropriate economic prices in Table 5-8.

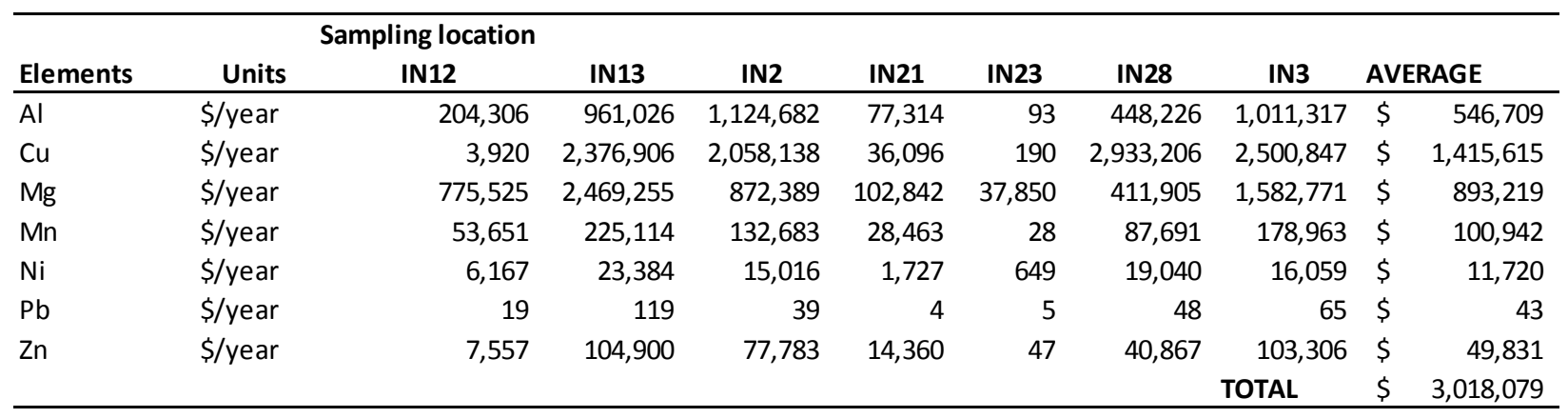

El Indio mitigation has been cover placements, water diversions and passive treatment at Pastos Largos gravity settling pond. pH adjustment via lime addition and sedimentation are practiced at Pierina 
with HDS. Reverse osmosis (RO) plants are currently being built (Thomaz, 2006; BGC, 2014b). Active treatment via lime neutralization and (HDS) generation is conducted at Lagunas Norte (Thomaz, 2006; BGC, 2014b). Plants at this site are being upgraded for RO due to changes in environmental legislation. The most common form of chemical treatment, which is currently used at Lagunas Norte and Pierina, is the addition of lime in order to precipitate sulfate in the form of gypsum. Lime can be added as limestone $\left(\mathrm{CaCO}_{3}\right)$, calcium oxide, calcium hydroxide $\left(\mathrm{Ca}(\mathrm{OH})_{2}\right)$, and hydrated lime. Soda ash $\left(\mathrm{Na}_{2} \mathrm{CO}_{3}\right)$ is also required at times to balance the precipitation reaction. The process produces low density (LDS) or HDS containing gypsum and iron oxyhydroxides with adsorbed metals. ARD at Pierina has been calculated by Klohn Crippen Berger (2012) to persist for several decades to hundreds of years after closure based on the available sulfur. Since the majority of the acidity generated is related to the dissolved Fe and Al concentrations, precipitating these two elements out of solution can have significant impact on the quality of effluent waters at all sites (Klohn Crippen Berger, 2012a). Based on mineralogy observed at El Indio, K, As, $\mathrm{Al}, \mathrm{SO}_{4}, \mathrm{Ca}, \mathrm{Cu} \mathrm{Fe}, \mathrm{Zn}, \mathrm{Cu}, \mathrm{Co}, \mathrm{Mn}, \mathrm{Al}, \mathrm{Na}, \mathrm{Pb}$ and $\mathrm{Mn}$ can be attenuated by precipitation of secondary minerals and ideal lattice substitutions and/or sorption of these elements. Based on mineralogy observed at Lagunas Norte and Pierina, $\mathrm{Cu}, \mathrm{Fe}, \mathrm{SO}_{4}, \mathrm{Ca}, \mathrm{Na}, \mathrm{As}, \mathrm{Mg}$, and $\mathrm{K}, \mathrm{Al}, \mathrm{Ca}, \mathrm{Fe}, \mathrm{SO}_{4}, \mathrm{Mg}$ respectively can be attenuated by ideal lattice substitutions and/or sorption. Finally, selective removal of elements can be conducted by ion exchange. This method would be ideal for elements that are not removed by lime neutralization, such as As. The high toxicity of this element acts as a strong incentive for removing it rather than allowing its precipitation in sludge (MEND Treatment Committee, 2013). Elements that behave similarly to As remain in solution and must be removed by other treatment methods such as ion exchange. 


\section{Chapter 6 \\ Conclusions}

The main objective of this study was to characterize the waters and secondary precipitates from El Indio, Lagunas Norte and Pierina mines. The trace element contents of the secondary sulfate minerals were documented with $\mu \mathrm{XRF}$ analyses. An idea of potential adsorption or substitutions was also observed through elemental correlations from Spearman diagrams. The following conclusions are based on selected sample sites.

Conclusion 1: No one instrument or method can be used to identify secondary precipitates from mine drainage and determine the trace element content of those precipitates (Table 4-20, Table 4-27. Table 4-28). In this study, minerals were identified with the use of bulk diffraction and their chemical composition was studied with the use of semi-quantitative $\mu \mathrm{XRF}$ analyses. Several geochemical analytical techniques were used to obtain data at various scales, thereby providing the researcher with a more accurate and holistic understanding of the geochemistry of studied mines. Analyses by ICP-MS and ICPOES were essential in understanding the bulk composition of the samples collected. The characterization of textures and their associated elements was accomplished through ESEM analysis conducted on unpolished bulk samples, mounted on stubs. Conventional X-ray diffraction analyses were instrumental in the general description of the most common and crystalline phases within the samples analyzed. The synchrotron ( $\mu \mathrm{XRF}$ and $\mu \mathrm{XRD}$ ) was a critical tool that identified previously unobserved phases, and gave insight on the distribution of elements within certain secondary precipitates. Images and chemical information collected with the ESEM demonstrate the wide array of morphologies of Na-Mg sulfates, and other sulfate salts. This research demonstrates that morphology, in itself, cannot be used to identify the precipitates observed at our sites. As such, the data collected from each analytical technique complemented the other, and the combined use of these methods and techniques increased the quality of results. For future reference, microprobe analysis should be conducted prior to lifting of thin sections. 
Conclusion 2: These secondary precipitates pose analytical challenges as a result of their complex chemistry, instability with varying temperature and humidity conditions, and the intergrowths of multiple phases from the micron to bulk scales. Specifically, the $\mu \mathrm{XRD}$ analyses are collected from an area of approximately $2 \mu \mathrm{m}$ in diameter, and over $90 \%$ of these analyzed spots show 2 or more positively identified phases. The ESEM observations of the unpolished, mounted samples also indicate complex mixtures at the micron scale (refer to figures that show this). Moreover some of the phases observed may not represent those stable under field conditions as a result of changes in humidity in the laboratory or within the analytical instruments.

Conclusion 3: Sulfate salts incorporate or host, as adsorbed species, a specific suite of minor and trace metals or elements of concern. Based on the samples analyzed by $\mu \mathrm{XRF}$, blodite is host to $\mathrm{Cu}, \mathrm{Mn}, \mathrm{Zn}, \mathrm{Ca}$, $\mathrm{Co}, \mathrm{Fe}$, and $\mathrm{Ni}$ in approximately decreasing order. Alunite is host to $\mathrm{Cu}, \mathrm{K}, \mathrm{Zn}, \mathrm{Ca}, \mathrm{Mn}, \mathrm{Fe}, \mathrm{Ti}, \mathrm{Co}, \mathrm{Ni}$ and $\mathrm{As}$ in decreasing order. Hexahydrite contains $\mathrm{Cu}, \mathrm{Zn}, \mathrm{Fe}, \mathrm{Mn}, \mathrm{As}, \mathrm{Ni}, \mathrm{Ti}$ or $\mathrm{Ti}, \mathrm{As}, \mathrm{Co}$, and $\mathrm{Ni}$ in decreasing order. Spearman correlations suggest the other minerals host specific elements, but this requires further testing. Considerable amounts of metals can also be attenuated by the precipitation and formation of chrysocolla, boyleite, hexahydrite, starkeyite, epsomite, magnesiocopiapite, dietrichite, melanterite and scorodite at El Indio, chalcanthite, hydroniumjarosite, antlerite, scorodite, poitevinite, and fibroferrite at Lagunas Norte, and romerite, coquimbite, jarosite and magnesiocopipiate at Pierina. These minerals are likely only temporary storage sites for the elements that compose them as a result of the relatively high solubility of these elements and their sensitivity to changes in $\mathrm{pH}$.

Conclusion 4: Geochemical modeling provided information on poorly-crystalline phases not detected by XRD. Although PHREEQC databases do not include thermodynamic information on many of the minerals observed as precipitates at these sites, the software predicted that Fe and Al oxyhydroxide would precipitate. Bulk chemical data were in agreement with these results but their amorphous nature meant that they were not recognized by diffraction tools. 
Conclusion 5: Generally, the waters and secondary precipitates are characteristic of HS epithermal deposits, although a few minerals are very rare or not previously recognized in this setting (i.e. blodite, loweite). According to the Piper diagrams, analyzed waters are of the $\mathrm{Ca}_{-} \mathrm{SO}_{4}$ type and typical of mine drainage. The $\mathrm{pH}$ range was acidic (3.4-6.7 at El Indio, 2.9 to 6.2 at Lagunas Norte, 2.6-3.1 at Pierina) at all sample sites with the exception of IN23 at El Indio (pH 6.7), and LN-PW2 at Lagunas Norte (pH 6.2). Major elements in waters sampled from El Indio include $\mathrm{Ca}$ and $\mathrm{S}$, minor elements include $\mathrm{Al}, \mathrm{Cu}, \mathrm{Mg}, \mathrm{Mn}, \mathrm{K}, \mathrm{Fe}$ and $\mathrm{Na}$, and trace elements are $\mathrm{As}, \mathrm{Co}, \mathrm{Ni}, \mathrm{Sr}, \mathrm{Pb}, \mathrm{Cd}$, and $\mathrm{Zn}$. Differences in elemental concentrations are observed at Lagunas Norte where major elements consist of $\mathrm{Al}, \mathrm{Ca}, \mathrm{Fe}$, and $\mathrm{S}$, minor elements comprise $\mathrm{Cu}, \mathrm{Mn}, \mathrm{Na}, \mathrm{Zn}$ and $\mathrm{Mg}$, and trace elements are $\mathrm{As}, \mathrm{Pb}, \mathrm{Ni}$ and $\mathrm{K}$. Iron, $\mathrm{Ca}$ and $\mathrm{S}$ are the most concentrated elements at Pierina, with $\mathrm{Al}, \mathrm{Cu}, \mathrm{Mg}, \mathrm{Zn}$ and $\mathrm{Mn}$ as minor elements and $\mathrm{As}, \mathrm{Cd}, \mathrm{Co}, \mathrm{Pb}, \mathrm{K}, \mathrm{Na}$ as trace elements.

Conclusion 6: Mined HS epithermal deposits such as El Indio, Lagunas Norte and Pierina provide the right conditions to allow the development of a wide variety of highly soluble secondary precipitates that were previously unidentified at these mines. The mineralogy of the secondary minerals forming at these three settings is variable but can be placed into 3 broad groups: 1) hydrous $\mathrm{Na-}, \mathrm{Mg}$-, $\mathrm{Ca}-$, $\mathrm{Cu}$ - and other metal-sulfates such as blodite, hexahydrite and gypsum 2) Fe-oxides, oxyhydroxides and oxyhydroxysulfates such as ferrihydrites, goethite, scorodite and jarosite 3) other metal rich, low crystalline phases such as basaluminite-like Al minerals, and few oxides, hydroxide, arsenates, carbonates and silicates in decreasing order.The first group is predominant at El Indio, the second group was most common at El Indio and Pierina, and Cu-sulfates were ubiquitous at Lagunas Norte.

Conclusion 7: The precipitates formed in the streams, stream beds and the surface of rocks are dependent on the chemical variations of the circulating solution during their formation. The most concentrated ions are generally similar in secondary precipitates and in solution. For example, at sample site IN28, both water and secondary precipitates are most heavily concentrated in $\mathrm{Al}, \mathrm{Ca}, \mathrm{Fe}, \mathrm{Cu}, \mathrm{Na}, \mathrm{Zn}$ 
and S. This sampling reflects a specific and single point in space and time. Furthermore, concentration of solutions using PHREEQC modeling has demonstrated an expected change in secondary precipitates forming through evaporation, presumably through time. An increased number of $\mathrm{Fe}, \mathrm{Al}$ and $\mathrm{Mn}$ oxyhydroxides, as well as $\mathrm{Cu}$ and Fe sulfates formed from modeling of these concentrated waters; others, not found in the database are also expect to precipitate.

Conclusion 8: The occurrence of secondary precipitates stands as evidence purporting that sulfide oxidation at these mine sites is ongoing. The sulfide rich geology in these studied mines and resulting sulfide wastes are presently being oxidized to be leaving such a high signature of sulfate in the analyzed streams. The dissolution of primary Fe and Al minerals from the original lithology is also adding to the acidity of these streams.

Conclusion 9: Calculations demonstrate that quantities of economic metals that may be recovered from waters are not substantial enough to significantly offset water treatment costs when considering operational expenditure. Based on calculations, Barrick Gold Corporation may lose money on recovery costs; however, it is recommended that specific elements with high economic value and low recovery cost be targeted for a greater return margin, and that metal recovery be conducted during a specific temporal timeframe. Assumptions included a constant flow rate, an average concentration of elements, that there are only 7 recoverable elements and that the commodity price is unchanged throughout the year. Furthermore, capital expenditure was not taken into account, and the focus of the calculations was solely on operational expenditure.

\subsection{Future work}

Although this work provides researchers with insight into the aqueous and secondary precipitate geochemistry, as well as some controls of elemental mobility at El Indio, Lagunas Norte and Pierina, some uncertainties remain. The concentrations of elements measured by the several analytical techniques and statistical analyses give an understanding about the minerals that may be hosting important elements. 
However, there is an uncertainty related to these correlations on how representative they may be of the overall chemistry of all secondary precipitates present at the mine sites. It is suggested that more samples be collected, specifically from Lagunas Norte and Pierina during the dry season, for a representative sample size decreasing the standard error value.

From field sampling, selection of sample to be made into thin sections, selection of areas and specific spots analyzed for $\mu \mathrm{XRF}$ and $\mu \mathrm{XRD}$, sampling methods and sample preparation introduce bias to the analysis at various stages of the project. Most of the samples chosen to be made into thin sections were based on the abundances of peaks observed in bulk XRD, since these were interpreted as potentially representative of mixtures that would be more easily identified by finer scaled analyses. This decision skewed mineralogical results towards giving an impression that $\mathrm{Na}-\mathrm{Mg}$ oxyhydroxide sulfates are more omnipresent than they actually are. This was caused by the fact that the Na-Mg oxyhydroxide sulfates had an elevated number of peaks. A more varied selection could have been more representative if it captured the nature of other minerals present. In future work, samples with many peaks and some with fewer peaks should be considered to be made into thin sections. Moreover, because of this limitation on the number of samples that could be analyzed and the types of analysis conducted, the researchers were unable to observe element-mineral associations for many of the minerals present throughout the mines. This decreases the degree to which these results may be extrapolated to the respective deposit. Semiquantitative element analysis was conducted on samples collected from 2 sites at El Indio and 1 from Lagunas Norte. The number of samples made and analyzed depended on time required to make thin sections prior to synchrotron work. Time was also a factor during synchrotron analysis, limiting the number of samples that could be semi-quantitatively characterized to 2 days. Furthermore, not all elemental correlations that were made could be explained, and further mineralogical work should be conducted to understand them. 
To address these questions and uncertainties, a number of other experiments and analyses are suggested:

- A representative amount of thin sections from each mine should be made and analyzed at various scales. Petrographic work will be necessary to conduct prior to thin section lifting for synchrotron analysis, in order to identify any genetic relationships visible. Additional analysis with EXAFS (extended X-ray absorption fine structure spectroscopy), which can be measured at the synchrotron can provide information on bond length and distances between atoms allowing to identify molecular structures and elemental inclusions in the mineral structures (Foster et al., 1998). Such analyses will allow a better understanding of solid solutions, as well as speciation of elements. Hence, the association of elements to minerals can be further described allowing for a better understanding of element mobility.

- Multiple site visits and additional collection of water and solid samples from all mines throughout the wet and dry seasons would be necessary to document the seasonal changes in water quality and secondary metal-salt sulfates. Long-term water quality monitoring is also of importance in order to identify the seasons with peak metal concentrations to develop efficient remediation methods.

- A portable X-ray diffractometer should be used in future work, in order to distinguish minerals while conducting field work, as demonstrated by Peterson (2011). It may be more difficult to identify all minerals in mixtures since peaks are wider on the portable XRD, but will still provide a general understanding of the types of minerals observed.

- EMPA analyses should be conducted on polished thin sections. The ESEM work provided semiquantitative data and would be well complemented with quantitative data from the microprobe.

- Further modeling using PHREEQC could be used to predict and understand the formation of precipitates. The thermodynamic data for more minerals, specifically sulfate hydrates can be 
added to the database. The log-Ksp values from solubility diagrams could be used in PHREEQC to see how this alters the potential occurrence of minerals. With regards to PHREEQC, geochemical modeling can be further used to understand how responsive different acid water compositions may be to active or passive treatment (Plumlee et al., 1999). The chemistry of waters can be modeled to demonstrate progressive neutralization by lime addition or dilution to estimate the types of precipitates formed. As such, the optimal $\mathrm{pH}$ of waters from mines can be identified to which they would be treated. Research by Wanty et al. (1990) and Plumlee et al. (1990) state that some metals such as As or Mo that form oxyanions or strong carbonate complexes (i.e. U) can desorb at high $\mathrm{pH}$ values. As such, treatment to very high $\mathrm{pH}$ values can lead to the release of these harmful elements.

- Reitveld analysis of the XRD and $\mu$ XRD spectra should be conducted to understand the quantity of the secondary minerals present within the collected samples. The focus of this specific research was based on the identification and not quantification. 


\section{Chapter 7 \\ References}

Alpers, C.N., and Brimhall, G.H., 1989, Paleohydrologic evolution and geochemical dynamics of cumulative supergene metal enrichment at La Escondida, Atacama Desert, northern Chile: Economic Geology, v. 84, p. 229-255, doi: 10.2113/gsecongeo.84.2.229.

Alpers, C. N., Nordstrom, D.K., Burchard, J.M., 1992, Compilation and interpretation of water-quality and discharge data for acidic mine waters at Iron Mountain, Shasta County, California, 1940-91.

Ariza, L.M., 1998, River of vitriol: Scientific American, v. 279, p. 15-18.

Arribas, A., 1995, Characteristics of high-sulfidation epithermal deposits, and their relation to magmatic fluid: Mineralogical Association of Canada Short Course Series, v. 23, p. 419-454, doi: 10.1186/2193-1801-3-130.

Aube, B., 2004, The science of treating acid mine drainage and smelter effluents.

Back, M. E., Walford, P.C., 1996, Mineralogy of the Wendy pit, El Indio-Tambo gold deposit, Chile, in 23rd Rochester Minerological Symposium.

Balarew, C., Karaivanova, V., Aslanian, S., 1975, Kristall Technik 8, in Isomorphic relations among the heptahydrate fates of divalent metals, p. 115-125.

Barradas, S., 2014, Lagunas Norte mine, Peru: Mining Weekly.

Belanger, M., 2003, Technical Report: La Coipa Mine, Chile.

BGC, 2014a, Lagunas Norte: Sustentabilidad.

BGC, 2015, Pierina.

BGC, 2014b, Pierina: Sustentabilidad.

Bissig, T., Clark, A.H., Lee, J.K.W., and von Quadt, A., 2003, Petrogenetic and metallogenetic responses to Miocene slab flattening: New constraints from the El Indio-Pascua Au-Ag-Cu belt, Chile/Argentina: Mineralium Deposita, v. 38, p. 844-862, doi: 10.1007/s00126-003-0375-y.

Bonett, D.G., and Wright, T. a., 2000, Sample size requirements for estimating Pearson, Kendall and Spearman correlations: Psychometrika, v. 65, p. 23-28, doi: 10.1007/BF02294183.

Bowell, R.J., Rees, S.B., and Parshley, J. V., 2000, Geochemical predictions of metal leaching and acid generation: Geologic controls and baseline assessment: Geology and ore deposits, p. 799-823.

Buckby, T., Black, S., Coleman, M.L., and Hodson, M.E., 2003, Fe-sulphate-rich evaporative mineral precipitates from the Rio Tinto, southwest Spain: v. 67, p. 263-278, doi: 10.1180/0026461036720104.

Buurman, P., 1975, In vitro weathering products of pyrite: Geolegie enMijnbouw, v. 54, p. 101-105.

Camus, F., 1990, The geology of hydrothermal gold deposits in Chile: Journal of Geochemical Exploration, v. 36, p. 197-232, doi: 10.1016/0375-6742(90)90056-G.

Carbone, C., Di Benedetto, F., Marescotti, P., Martinelli, A., Sangregorio, C., Cipriani, C., Lucchetti, G., and Romanelli, M., 2005, Genetic evolution of nanocrystalline Fe oxide and oxyhydroxide assemblages from the Libiola mine (eastern Liguria, Italy): structural and microstructural investigations: European Journal of Mineralogy , v. 17, p. 785-795, doi: 10.1127/09351221/2005/0017-0785. 
Carbone, C., Dinelli, E., Marescotti, P., Gasparotto, G., and Lucchetti, G., 2013, The role of AMD secondary minerals in controlling environmental pollution: Indications from bulk leaching tests: Journal of Geochemical Exploration, v. 132, p. 188-200, doi: 10.1016/j.gexplo.2013.07.001.

Carrero, S., Pérez-lópez, R., Fernandez-martinez, A., Cruz-hernández, P., Ayora, C., and Poulain, A., 2015, The potential role of aluminium hydroxysulphates in the removal of contaminants in acid mine drainage: Chemical Geology, v. 417, p. 414-423, doi: 10.1016/j.chemgeo.2015.10.020.

Cerpa, L.M., Bissig, T., Kyser, K., McEwan, C., Macassi, A., and Rios, H.W., 2013, Lithologic controls on mineralization at the Lagunas Norte high-sulfidation epithermal gold deposit, northern Peru: Mineralium Deposita, v. 48, p. 653-673, doi: 10.1007/s00126-013-0455-6.

Charchaflié, D., Tosdal, R.M., and Mortensen, J.K., 2007, Geologic framework of the Veladero highsulfidation epithermal deposit area, Cordillera Frontal, Argentina: Economic Geology, v. 102, p. 171-192, doi: 10.2113/gsecongeo.102.2.171.

Charykova, M. V., Krivovichev, V.G., and Depmeir, W., 2010, Thermodynamics of arsenates, selenites, and sulfates in the oxidation zone of sulfide ores: I. Thermodynamic constants at ambient conditions: Geology of Ore Deposits, v. 52, p. 689-700, doi: 10.1134/\$1075701510080015.

Cheng, H., Hu, Y., Luo, J., Xu, B., and Zhao, J., 2009, Geochemical processes controlling fate and transport of arsenic in acid mine drainage (AMD) and natural systems: Journal of Hazardous Materials, v. 165, p. 13-26, doi: 10.1016/j.jhazmat.2008.10.070.

Chou, I.M., Seal, R.R., and Wang, A., 2013, The stability of sulfate and hydrated sulfate minerals near ambient conditions and their significance in environmental and planetary sciences: Journal of Asian Earth Sciences, v. 62, p. 734-758, doi: 10.1016/j.jseaes.2012.11.027.

Chouinard, A., Williams-Jones, A.E., Leonardson, R.W., Hodgson, C.J., Silva, P., Téllez, C., Vega, J., and Rojas, F., 2005, Geology and genesis of the multistage high-sulfidation epithermal Pascua Au-Ag-Cu deposit, Chile and Argentina: Economic Geology, v. 100, p. 463-490, doi: 10.2113/gsecongeo.100.3.463.

Corbett, G.J., and Leach, T.M., 1998, Southwest Pacific rim gold-copper systems: structure, alteration and mineralization. Society of Economic Geologists, Special Publication, 6.: , p. 236.

Craze, M., 2001, Canadian Mining Journal: South America.

Dagenhart, T.J., 1980, The acid mine drainage of Contrary Creek, Louisa County, Virginia: Factors causing variations in sstream water chemistry: University of Virginia, Charlottesville, Virginia.

Deer, W.A., Howie, R.A., and Zussman, J., 1992, An introduction to the rock-forming minerals (Harlow/Wiley, Ed.): New York, 696 p.

Demartin, F., Campostrini, I., Castellano, C., Gramaccioli, C.M., and Russo, M., 2012, D'ansite-(Mn) and d'ansite-(Fe), Na two new minerals from volcanic fumaroles: Mineralogical Magazine, v. 76, p. 2773-2783, doi: 10.1180/minmag.2012.076.7.10.

Ducloux, J., Guero, Y., Fallavier, P., and Valet, S., 1994, Mineralogy of salt efflorescences in paddy field soils of Kollo, southern Niger: Geoderma, v. 64, p. 57-71, doi: 10.1016/0016-7061(94)90089-2.

Dupon, D., and Figueroa, L., 2015, Overview of sulfate treatment technologies: Including waste stream management, in ICARD Suflate Treatment Short Course, Santiago.

Dutrizac, J.E., and Jambor, J.L., 2000, Jarosites and their application in hydrometallurgy, in Sulfate Minerals: Crysallography, geochemistry, and environmental significance, p. 405-452.

Dutrizac, J.E., Jambor, J.L., and Chen, T.T., 1987, The behaviour of arsenic during jarosite precipitation: 
reactions at 150 degrees $C$ and the mechanism of arsenic precipitation: Canadian metallurgist, $p$. 103-115.

Dzombak, D.A., Morel, F.M.M., 1990, Surface complexation modeling: hydrous ferric oxide (Wiley and Sons, Ed.): New York, 393 p.

Evans, L., Ehasoo, G., Altman, K.A., 2012, Technical report on the Lagunas Norte mine, La Libertad region, Peru.

Fang, J.H., Robinson, P.D., 1970, Crystal structures and mineral chemistry of hydrated ferric sulphates: I. The crystal structure of coquimbite: American Mineralogist, v. 55, p. 1534-1540.

Ferris, F.G., Tazaki, K., Fyfe, W.S., 1989, Iron oxides in acid mine drainage environments and their association with bacteria: Chemical Geology, v. 74, p. 321-330.

Ficklin, W.H., Mosier, E.L., 2000, Field methods for sampling and analysis of environmental samples for unstable and selected stable constituents, in The environmental geochemistry of mineral deposits, p. 249-264.

Foster, A.L., Brown, G.E., Jr., Tingle, T.N., Parks, G.A., 1998, Quantitative arsenic speciation in mine tailings using X-ray absorption spectroscopy: American Mineralogist, p. 553-568.

Frau, F., 2000, The formation-dissolution-precipitation cycle of melanterite at the abandoned pyrite mine of Genna Luas in Sardinia, Italy: environmental implications: Mineralogical Magazine, v. 64, p. 995-1006, doi: 10.1180/002646100550001.

George, L., Ludwick, W., and Chahbandour, J., 2009, Case study: Site-wide water balance of the Pierina Gold Mine, Peru: Tailings and Mine Waste '08 - Proceedings of the 12th International Conference, p. 369-380.

Hammarstrom, J.M., Seal, R.R., Meier, a. L., and Kornfeld, J.M., 2005, Secondary sulfate minerals associated with acid drainage in the eastern US: Recycling of metals and acidity in surficial environments: Chemical Geology, v. 215, p. 407-431, doi: 10.1016/j.chemgeo.2004.06.053.

Harvie, C.E., Nancy, M., and Weare, J.H., 1984, The prediction of mineral solubilities in natural waters: The Na-K-Mg-Ca-H-Cl- SO4-OH-HCO3-C03-CO2-H2O system to high ionic strengths at $25^{\circ} \mathrm{C}: \mathrm{v} .48, \mathrm{p}$. 723-751.

Hassellöv, M., Buesseler, K.O., Pike, S.M., and Dai, M., 2007, Application of cross-flow ultrafiltration for the determination of colloidal abundances in suboxic ferrous-rich ground waters: Science of the Total Environment, v. 372, p. 636-644, doi: 10.1016/j.scitotenv.2006.10.001.

Heberlein, D., 2008, Spatial and temporal zonation at the El Indio Cu-Au-Ag Deposit, Chile : Evidence for an evolving high sulfidation epithermal system.

Hedenquist, J.W., Arribas, R.A., and Gonzalez-Urien, E., 2000, Exploration of Epithermal Gold Deposits: SEG Reviews, v. 13, p. 245-277.

Hedenquist, J.W., and Lowenstern, J.B., 1994, The role of magmas in the formation of hydrothermal ore deposits: Nature, v. 370.

Hiemenz, P.C., Rajagopalan, R., 1997, Principles of colloid and surface chemistry: Marcel Dekker, Inc.

Jambor, J.L., Nordstrom, D.K., and Alpers, C.N., 2000, Metal-sulfate salts from sulfide mineral oxidation: Reviews in Mineralogy and Geochemistry, v. 40, p. 303-350, doi: 10.2138/rmg.2000.40.6.

Jamieson, H.E., 2011, Geochemistry and mineralogy of solid mine waste: Essential knowledge for predicting environmental impact: Elements, v. 7, p. 381-386, doi: 10.2113/gselements.7.6.381. 
Jamieson, H.E., Alpers, C.N., Nordstrom, D.K., and Peterson, R.C., 1999, Substitution of zinc and other metals in iron-sulfates minerals at Iron Mountain, California.

Jamieson, H.E., Robinson, C., Alpers, C.N., McCleskey, R.B., Nordstrom, D.K., and Peterson, R.C., 2005, Major and trace element composition of copiapite-group minerals and coexisting water from the Richmond mine, Iron Mountain, California: Chemical Geology, v. 215, p. 387-405, doi: 10.1016/j.chemgeo.2004.10.001.

Jamieson, H.E., Walker, S.R., Andrade, C.F., Wrye, L. a., Rasmussen, P.E., Lanzirotti, A., and Parsons, M.B., 2011, Identification and Characterization of Arsenic and Metal Compounds in Contaminated Soil, Mine Tailings, and House Dust Using Synchrotron-Based Microanalysis: Human and Ecological Risk Assessment: An International Journal, v. 17, p. 1292-1309, doi: 10.1080/10807039.2011.618415.

Jamieson, H.E., Walker, S.R., and Parsons, M.B., 2015, Mineralogical characterization of mine waste: Applied Geochemistry, doi: 10.1016/j.apgeochem.2014.12.014.

Jannas, R.R., Beane, R.E., and Ahler, B. a, 1990, Gold and copper mineralization at the El Indio deposit , Chile: Journal of Geochemical Exploration, v. 36, p. 233-266.

Jensen, M.L., Ashley, R.P., and Albers, J.P., 1971, Primary and secondary sulfates at Goldfield, Nevada: Economic Geology, v. 66, p. 618-626, doi: 10.2113/gsecongeo.66.4.618.

Jönsson, J., Jönsson, J., and Lövgren, L., 2006, Precipitation of secondary Fe(III) minerals from acid mine drainage: Applied Geochemistry, v. 21, p. 437-445, doi: 10.1016/j.apgeochem.2005.12.008.

Kay, S.M., Mpodozis, C., and Coira, B., 1999, Neogene magmatism, tectonism, and mineral deposits of the Central Andes: Society of Economic Geologists Special Publication 7, p. 27-59.

Keith, D.C., Runnells, D.D., Esposito, K.J., Chermak, J. a., Levy, D.B., Hannula, S.R., Watts, M., and Hall, L., 2001, Geochemical models of the impact of acidic groundwater and evaporative sulfate salts on Boulder Creek at Iron Mountain, California: Applied Geochemistry, v. 16, p. 947-961, doi: 10.1016/S0883-2927(00)00080-9.

Keith, D. C., Runnells, D.D., 1998, Chemistry, mineralogy, and effects of efflorescent sulfate salts in acid mine drainage areas, in Geological Society of America,.

Keith, D.C., Runnells, D.D, Esposito, K.J., Chermak, J.A., Hannula, S.R., 1999, Efflorescent sulfate salts: Chemistry, mineralogy, and effect on ARD streams, in Tailings and Mine Waste '99, 6th international conference, Balkema, Rotterdam, The Netherlands, p. 573-579.

Kerrich, R., Goldfarb, R.J., and Richards, J.P., 2005, 100th Anniversary Special Paper: Metallogenic Provinces in an Evolving Geodynamic Framework: Economic Geology 100th anniversary, p. 10971133.

Klohn Crippen Berger, 2012a, Pierina geochemistry.

Klohn Crippen Berger, 2012b, Pierina: ARD/ML characterization.

Krieger, G.R., Hattemer-Frey, H.A., and Kester, J.E., 2000, Bioavailability of metals in the environment: Implications for health risk assessment, in The environmental geochemistry of mineral deposits, $\mathrm{p}$. 357-361.

Lacroix, P.A., 2012, Technical report on the Tres Cruces project, North Central Peru:.

Langmuir, D., 1997, Aqueous environmental geochemistry: New York, US, Prentice Hall.

Leduc, E.M.S., 2010, Hydrated sodium-magnesium sulfate minerals associated with inland saline 
systems: Queen's University, 140 p.

Lehman, A., 2005, Jump for basic univariate and multivariate statistics: A step-by-step guide (C. N. S. Press, Ed.): 123 p.

Liang, L., Morgan, J.J., 1990, Chemical aspects of iron oxide coagulation in water. Laboratory studies and implications for natural systems: Aquatic Sciences, v. 52, p. 32-55.

Lindgren, W., 1922, A suggestion for the terminology of certain mineral deposits: Economic Geology, v. 17, p. 292-294.

Lorax Environmental, 2003, Treatment of Sulphate in Mine Effluents: , p. 1-129.

Lottermoser, B.G., 2010a, Introduction to mine wastes, in Mine Wastes (Third Edition): Characterization, Treatment and Environmental Impacts, Springer, p. 1-41.

Lottermoser, B.G., 2010b, Mine water, in Mine Wastes (Third Edition): Characterization, Treatment and Environmental Impacts, Springer, p. 119-203.

Lottermoser, B.G., 2010c, Sulfidic mine wastes, in Mine Wastes (Third Edition): Characterization, Treatment and Environmental Impacts, Springer, p. 43-117.

Lottermoser, B.G., 2010d, Tailings, in Mine Wastes (Third Edition): Characterization, Treatment and Environmental Impacts, Springer, p. 205-241.

Majzlan, J., 2006, Thermodynamic properties and crystal structure refinement of ferricopiapite, coquimbite, rhomboclase, and Fe2(SO4)3(H2O)5: European Journal of Mineralogy, v. 18, p. 175186, doi: 10.1127/0935-1221/2006/0018-0175.

Manceau, A., Schlegel, M.., Musso, M., Sole, V.A., Gauthier, C., Petit, P.., and Trolard, F., 2000, Crystal chemistry of trace elements in natural and synthetic goethite: Geochimica et Cosmochimica Acta, v. 64, p. 3643-3661, doi: 10.1016/S0016-7037(00)00427-0.

Martin, M.W., Clavero R., J., and Mpodozis M., C., 1999, Late Paleozoic to Early Jurassic tectonic development of the high Andean Principal Cordillera, El Indio Region, Chile: Journal of South American Earth Sciences, v. 12, p. 33-49, doi: 10.1016/S0895-9811(99)00003-6.

Matýsek, D., Jirásek, J., Osovsky, M., and Skupien, P., 2014, Minerals formed by the weathering of sulfides in mines of the Czech part of the Upper Silesian Basin: Mineralogical Magazine, v. 78, p. 1265-1286, doi: 10.1180/minmag.2014.078.5.12.

McNulty, B.A., and Farber, D.L., 1998, The Cordillera Blanca fault zone; a deep-seated detachment in the Peruvian Andes: Geological Society of America.

MEND, 2014, Study to Identify BATEA for the Management and Control of Effluent Quality from Mines Study to Identify BATEA for the Management and Control of Effluent.

MEND Treatment Committee, 2013, Study on metals recovery/recycling from acid mine drainage:.

Montgomery, A.T., 2012, Metallogenetic controls on Miocene high-sulphidation epithermal gold mineralization, Alto Chicama district, La Libertat, Northern Peru: Queen's University, 1-436 p.

Munk, L., Faure, G., and Koski, R., 2006, Geochemical evolution of solutions derived from experimental weathering of sulfide-bearing rocks: Applied Geochemistry, v. 21, p. 1123-1134, doi: 10.1016/j.apgeochem.2006.04.003.

Nicholson, R.V., 1994, Iron-sulfide oxidation mechanisms: Laboratory Studies, in Blowes, D.W, Jambor, J.L. ed., The environmental geochemistry of sulfide mine-wastes, Nepean, Ont. Canada.

Nordstrom, D.K., 2009, Acid rock drainage and climate change: Journal of Geochemical Exploration, v. 
100, p. 97-104, doi: 10.1016/j.gexplo.2008.08.002.

Nordstrom, D.K., 2011, Hydrogeochemical processes governing the origin, transport and fate of major and trace elements from mine wastes and mineralized rock to surface waters: Applied Geochemistry, v. 26, p. 1777-1791, doi: 10.1016/j.apgeochem.2011.06.002.

Nordstrom, D. K., Alpers, C.N., 1999, Geochemistry of acid mine waters, in Plumle, G.S., L.M.J. ed., The environmental geochemistry of mineral deposits, Michigan, Society of Economic Geologists.

Oyarzun, R., Lillo, J., Higueras, P., Oyarzún, J., and Maturana, H., 2004, Strong arsenic enrichment in sediments from the Elqui watershed, Northern Chile: Industrial (gold mining at El Indio-Tambo district) vs. geologic processes: Journal of Geochemical Exploration, v. 84, p. 53-64, doi: 10.1016/j.gexplo.2004.03.002.

Oyarzun, R., Lillo, J., Oyarzun, J., and Higueras, P., 2007, Plate interactions, evolving magmatic styles, and inheritance of structural paths: Development of the gold-rich, Miocene El Indio epithermal belt, Northern Chile: International Geology Review, v. 49, p. 844-853, doi: 10.2747/0020-6814.49.9.844.

Peterson, R.C., 2011, Cranswickite MgSO4\{middle dot\}4H2O, a new mineral from Calingasta, Argentina: American Mineralogist, v. 96, p. 869-877, doi: 10.2138/am.2011.3673.

Peterson, R.O.C., 2003, The relationship between Cu content and distortion in the atomic structure of melanterite from the Richmond mine, Iron Mountain, California: v. 41, p. 937-949.

Peterson, R.C., Hammarstrom, J.M., and Seal, R.R., 2006, Alpersite ( Mg , Cu ) SO 4 · 7H 2 O , a new mineral of the melanterite group, and cuprian pentahydrite : Their occurrence within mine waste: v. 91, p. 261-269, doi: 10.2138/am.2006.1911.

Philippe, R., and Kirk, L., 2015, Regulatory drivers, effluent limits and toxicity under current and future legislation, in ICARD Suflate Treatment Short Course, Santiago.

Pilger, R.H., 1984, Cenozoic plate kinematics, subduction and magmatism: South American Andes: Journal of the Geological Society of Londin, v. 141, p. 793-802.

Plumlee, G.S., 1999, The environmental geology of mineral deposits, in The environmental geochemistry of mineral deposits, Denver, Society of Economic Geologists, p. 71-116.

Plumlee, G.S., Smith, K.S., Ficklin, W.H., and Mosier, E.L., 1999, The environmental geochemistry of mineral deposits, in The environmental geochemistry of mineral deposits Part B: Case studies and research topics, REviews in Economic Geology, p. 373-432.

Plumlee, G. S., Smith, K. S., Ficklin, W.H., 1994, Geoenvironmental models of mineral deposits, and geology-based mineral-environmental assessments of public lands:.

Pouiller, F., 2011, Barrick closure plan at El Indio serves as model: Mining Weekly.

Rainbow, A., 2009, Genesis and evolution of the Pierina high-sulfidation epithermal Au-Ag deposit, Ancash, Peru: Queen's University, 1-277 p.

Rainbow, A., Clark, A.H., and Kyser, T.K., 2005, The Pierina epithermal Au - Ag deposit, Ancash, Peru : paragenetic relationships, alunite textures, and stable-isotope geochemistry: v. 215, p. 235-252, doi: 10.1016/j.chemgeo.2004.06.050.

Ransome, F.L., 1907, The association of alunite with gold in the Goldfield district, Nevada: Economic Geology, v. 2, p. 667-692.

Robert, F., Brommecker, R., Bourne, B., Dobak, P., McEwan, C., Rowe, R., and Zhou, X., 2007, Models and exploration methods for major gold deposit types: Ore Deposits and Exploration Technology, v. 48, 
p. 691-711.

Robinson, C., 2000, The role of jarosite and copiapite in the chemical evolution of acid drainage waters, Richmond Mine, Iron Mountain, California.

Rollo, H. a., and Jamieson, H.E., 2006, Interaction of diamond mine waste and surface water in the Canadian Arctic: Applied Geochemistry, v. 21, p. 1522-1538, doi: 10.1016/j.apgeochem.2006.05.008.

Romero, A., González, I., and Galán, E., 2011, Stream water geochemistry from mine wastes in Peña de Hierro, Riotinto area, SW Spain: A case of extreme acid mine drainage: Environmental Earth Sciences, v. 62, p. 645-656, doi: 10.1007/s12665-010-0554-y.

Romero, A., González, I., and Galán, E., 2006, The role of efflorescent sulfates in the storage of trace elements in stream waters polluted by acid mine-drainage: The case of Peña del Hierro, Southwestern Spain: Canadian Mineralogist, v. 44, p. 1431-1446, doi: 10.2113/gscanmin.44.6.1431.

Rowland, J. V., and Simmons, S.F., 2012, Hydrologic, Magmatic , and Tectonic Controls on Hydrothermal Flow , Taupo Volcanic Zone, New Zealand : Implications for the Formation of Epithermal Vein Deposits: Economic Geology, p. 427-457.

Savage, K.S., Bird, D.K., and O'Day, P.A., 2005, Arsenic speciation in synthetic jarosite: Chemical Geology, v. 215 , p. 473-498.

Schindler, M., Huminicki, D.M.C., and Hawthorne, F.C., 2006, Sulfate minerals. I. Bond topology and chemical composition: Canadian Mineralogist, v. 44, p. 1403-1429, doi: 10.2113/gscanmin.44.6.1403.

Schwertmann, U., Murad, E., 1983, The effect of $\mathrm{pH}$ on the formation of goethite and hematite from ferrihydrite: Clays and Clay Minerals, v. 31, p. 277-284.

Smith, K.S., 1999, Metal sorption on mineral surfaces: An overview with examples relating to mineral deposits, in The environmental geochemistry of mineral deposits, Denver, CO, p. 161-182.

Smith, K.S., and Huyck, H.L.O., 2000, An overview of the abundance, relative mobility, bioavailability, and human toxicity of metals, in The environmental geochemistry of mineral deposits, p. 29-64.

Spencer, R.J., 2000, Sulfate minerals in evaporite deposits, in Sulfate Minerals: Crysallography, geochemistry, and environmental significance, p. 173-189.

Sracek, O., Veselovský, F., Kříbek, B., Malec, J., and Jehlička, J., 2010, Geochemistry, mineralogy and environmental impact of precipitated efflorescent salts at the Kabwe Cu-Co chemical leaching plant in Zambia: Applied Geochemistry, v. 25, p. 1815-1824, doi:

10.1016/j.apgeochem.2010.09.008.

Steiger, M., Linnow, K., Ehrhardt, D., and Rohde, M., 2011, Decomposition reactions of magnesium sulfate hydrates and phase equilibria in the $\mathrm{MgSO}_{4}-\mathrm{H}_{2} \mathrm{O}$ and $\mathrm{Na}^{+}-\mathrm{Mg}^{2+}-\mathrm{Cl}--\mathrm{SO}_{4}{ }^{2-}-\mathrm{H}_{2} \mathrm{O}$ systems with implications for Mars: Geochimica et Cosmochimica Acta, v. 75, p. 3600-3626, doi: 10.1016/j.gca.2011.03.038.

Stoffregen, R.E., Alpers, C.N., and Jambor, J.L., 2000, Alunite-jarosite crystallogrpahy, thermodynamics, and geochronology, in Sulfate Minerals: Crysallography, geochemistry, and environmental significance, p. 453-479.

Stoilova, D., and Wildner, M., 2004, Blödite-type compounds Na2Me(SO4)2·4H2O (Me=Mg, Co, Ni, Zn): crystal structures and hydrogen bonding systems: Journal of Molecular Structure, v. 706, p. 57-63, 
doi: 10.1016/j.molstruc.2004.01.070.

Szakáll, S., Foldvári, M., and Kovács-pálffy, P., 1997, Secondary sulphate minerals from Hungary: , p. 763.

Taylor, B.E., 2007, Epithermal Gold Deposits: Mineral Deposits of Canada, p. 113-139.

Taylor, D., Bassett, H., 1952, The system Al2(SO4)3-H2SO4-H2O: Journal of Chemical Society, p. 44314442.

Thomaz, C., 2006, Lagunas Norte mine, Peru: Mining Weekly.

Triantafyllidis, S., and Skarpelis, N., 2006, Mineral formation in an acid pit lake from a high-sulfidation ore deposit: Kirki, NE Greece: Journal of Geochemical Exploration, v. 88, p. 68-71, doi: 10.1016/j.gexplo.2005.08.017.

Vaniman, D.T., Bish, D.L., Chipera, S.J., Fialips, C.I., Carey, J.W., and Feldman, W.C., 2004, Magnesium sulphate salts and the history of water on Mars: Nature, v. 431, p. 663-665, doi: 10.1038/nature02973.

Whittig, L. D., Deyo, A.E., Tanji, K.., 1982, No Title: Soil Science Society of America, v. 46, p. 645-651.

Zanker, H., Moll, H., Richter, W., Brendler, V., Hennig, C., Reich, T., Kluge, A., and Huttig, G., 2002, The colloid chemistry of acid rock drainage solution from an abandoned $\mathrm{Zn}-\mathrm{Pb}-\mathrm{Ag}$ mine: Applied Geochemistry, v. 17, p. 633-648.

Zanker, H., Richter, W., Huttig, G., 2003, Scavenging and immobilization of trace contaminants by colloids in waters of abandoned ore mines: Physiochemical Engineering Aspects, v. 217, p. 21-31.

Zvereva, V.P., Pyatakov, A.D., Yastremskaya, E.., 2015, Estimation of influence of mine waters of cassiterite-sulfide deposits on hydrosphere in Komsomol'sk and Kavalerovo districts of the far east. 


\section{Appendix A: Sampling site locations}

Table 0-1: List of sample types and sampling dates for specific locations

\begin{tabular}{|l|l|l|}
\hline Sample Site & Sampling Date & Type of Sample procured \\
\hline IN-23 & May 7, 2014 & WNA, DNA \\
\hline IN-28 & May 7, 2014 & Water, secondary precipitates, \\
& RNA, DNA \\
\hline RMATR & May 7, 2014 & Water, secondary precipitates, \\
& RNA, DNA \\
\hline IN-2 & May 7, 2014 & Water, secondary precipitates, \\
& & RNA, DNA \\
\hline IN-13 & May 8, 2014 & Water, secondary precipitates, \\
& & RNA, DNA \\
\hline
\end{tabular}

Table 0-2: Sample UTM coordinates and elevation

\begin{tabular}{|l|l|l|l|}
\hline Sample Site & Elevation $(\mathrm{m})$ & UTM (N) & UTM (E) \\
\hline IN-23 & 4100 & 6709647 & 0407489 \\
\hline IN-28 & 3650 & 6705697 & 0405670 \\
\hline RMATR & 3550 & 6704938 & 0404246 \\
\hline IN-2 & 3250 & 6699644 & 0401358 \\
\hline IN-13 & 2080 & 6760128 & 0365587 \\
\hline
\end{tabular}

Table 0-3: List of sample types and sampling dates for specific locations at Lagunas Norte Sample Site Sampling Date

Type of Sample procured 


\begin{tabular}{|c|c|c|}
\hline LN-DAR-1 & May 13, 2014 & $\begin{array}{l}\text { Water (full suite), } \\
\text { secondary precipitates, } \\
\text { RNA, DNA }\end{array}$ \\
\hline LN-SP-3 & May 13, 2014 & $\begin{array}{l}\text { Water (full suite), } \\
\text { secondary precipitates, } \\
\text { RNA, DNA }\end{array}$ \\
\hline LN-DW-B-11 & May 13, 2014 & Water (full suite) \\
\hline ARD Water treatment plant & May 14, 2014 & Sludge sample, RNA, DNA \\
\hline LN-SP-3 & May 14, 2014 & $\begin{array}{l}\text { Water resampled (full } \\
\text { suite) }\end{array}$ \\
\hline LN-PW-1 & May 14, 2014 & Water (UA only) \\
\hline LN-BP & May 14, 2014 & $\begin{array}{l}\text { Water (full suite), } \\
\text { secondary precipitates, } \\
\text { RNA, DNA }\end{array}$ \\
\hline LN-PW-2 & May 14, 2014 & $\begin{array}{l}\text { Water (full suite), } \\
\text { secondary precipitates, } \\
\text { RNA, DNA }\end{array}$ \\
\hline LN-VWD & May 14, 2014 & $\begin{array}{l}\text { Water (full suite), } \\
\text { secondary precipitates, } \\
\text { RNA, DNA }\end{array}$ \\
\hline
\end{tabular}


Table 0-4: Sample UTM coordinates and elevation at Lagunas Norte

\begin{tabular}{|l|l|l|l|}
\hline Sample Site & Elevation (m) & UTM (N) & UTM (E) \\
\hline LN-DAR-1 & 4200 & 9119899 & 0807547 \\
\hline LN-SP-3 & 4007 & 9111805 & 0810251 \\
\hline LN-DW-B-11 & 3903 & 9111696 & 0796497 \\
\hline LN-PW-1 & 3683 & 9124710 & 0803521 \\
\hline LN-BP & 3951 & 9119813 & 0806361 \\
\hline LN-PW-2 & 3926 & 9120600 & 0804039 \\
\hline LN-VWD & 3951 & 9122653 & 0803623 \\
\hline
\end{tabular}

Table 0-5: List of sample types at Pierina and sampling dates for specific locations

\begin{tabular}{|l|l|l|}
\hline Sample Site & Sampling Date & Type of Sample procured \\
\hline P-WRD-stream1 & $17-M a y-14$ & YSI only \\
\hline P-WRD-stream2 & $17-M a y-14$ & YSI only \\
\hline P-WRD & $17-M a y-14$ & Water (full suite), secondary precipitates, RNA, DNA \\
\hline P-ARD-17 (tunnel) & $17-M a y-14$ & Water (full suite), RNA, DNA \\
\hline P-PD (trucks) & $18-M a y-14$ & Water (full suite), secondary precipitates \\
\hline P-EC & 18-May-14 & Water (full suite), secondary precipitates, RNA, DNA \\
\hline
\end{tabular}


Table 0-6: Pierina sample UTM coordinates and elevation

\begin{tabular}{|l|l|l|l|}
\hline Sample Site & Elevation $(\mathrm{m})$ & UTM (N) & UTM (E) \\
\hline P-WRD & 4104 & 8952826 & 215121 \\
\hline P-ARD-17 & 3867 & 8952904 & 216985 \\
\hline P-PD & 3842 & 8954442 & 216053 \\
\hline P-PW1 & 3847 & 8954451 & 216072 \\
\hline P-PW2 & 3851 & 8955127 & 216235 \\
\hline P-EC & 3813 & 8955127 & 216225 \\
\hline
\end{tabular}




\section{Appendix B: PHREEQC modeling minerals with $\mathrm{SI} \geq 0$}

Electrical imbalance greater than $10 \%$ can be created by laboratory error or sampling error. Electrical balance of waters from field sites calculated by PHREEQC shows values below $10 \%$ for all samples, except for FA triplicate of sample P-EC-W (78\%) and FA duplicate of LN-VWD-W (28\%). These samples were discarded from future analysis and interpretation.

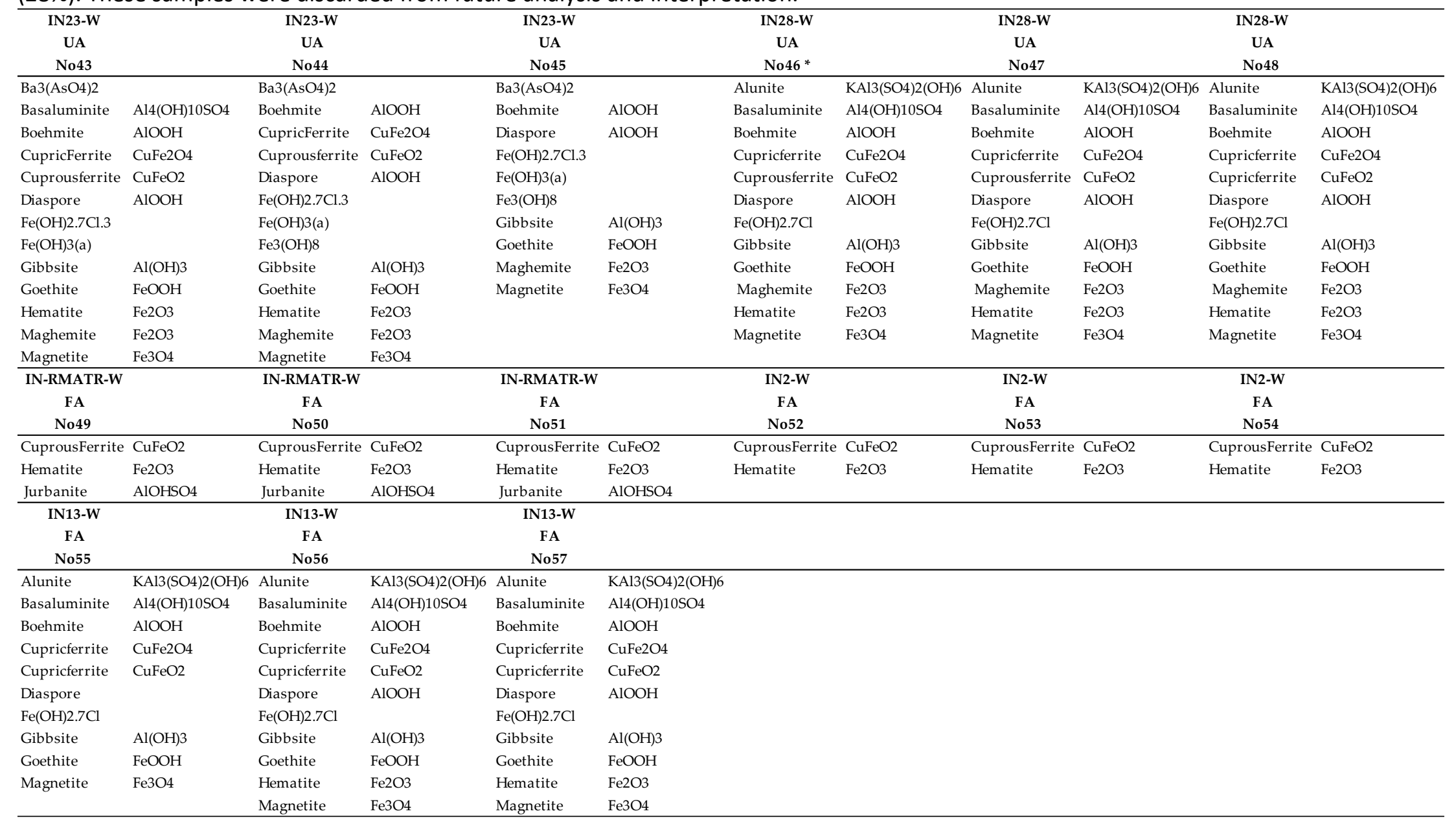




\begin{tabular}{|c|c|c|c|c|c|c|c|c|c|c|c|}
\hline LN-SP3-W & & LN-DW-B-11-W & & LN-DW-B-11-W & & LN-DW-B-11-W & & LN-SP3-W & & LN-SP3-W & \\
\hline FA & & FA & & FA & & FA & & FA & & FA & \\
\hline No1 & & No2 & & No3 & & No4 & & No5 & & No6 & \\
\hline CuprousFerrite & $\mathrm{CuFeO} 2$ & As & & As & & As & & CuprousFerrite & $\mathrm{CuFeO} 2$ & CuprousFerrite & $\mathrm{CuFeO} 2$ \\
\hline $\mathrm{Fe}(\mathrm{OH}) 2.7 \mathrm{Cl} .3$ & & $\mathrm{Cu}$ & & $\mathrm{Cu}$ & & $\mathrm{Cu}$ & & $\mathrm{Fe}(\mathrm{OH}) 2.7 \mathrm{Cl} .3$ & & $\mathrm{Fe}(\mathrm{OH}) 2.7 \mathrm{Cl} .3$ & \\
\hline Goethite & $\mathrm{FeOOH}$ & Cuprite & $\mathrm{Cu} 2 \mathrm{O}$ & Cuprite & $\mathrm{Cu} 2 \mathrm{O}$ & Cuprite & $\mathrm{Cu} 2 \mathrm{O}$ & Goethite & $\mathrm{FeOOH}$ & Goethite & $\mathrm{FeOOH}$ \\
\hline \multirow[t]{3}{*}{ Hematite } & $\mathrm{Fe} 2 \mathrm{O} 3$ & CuprousFerrite & $\mathrm{CuFeO} 2$ & CuprousFerrite & $\mathrm{CuFeO} 2$ & CuprousFerrite & $\mathrm{CuFeO} 2$ & Hematite & $\mathrm{Fe} 2 \mathrm{O} 3$ & Hematite & $\mathrm{Fe} 2 \mathrm{O} 3$ \\
\hline & & $\mathrm{U} 4 \mathrm{O} 9(\mathrm{c})$ & $\mathrm{U} 4 \mathrm{O} 9(\mathrm{c})$ & $\mathrm{U} 4 \mathrm{O} 9(\mathrm{c})$ & $\mathrm{U} 4 \mathrm{O} 9(\mathrm{c})$ & & & & & & \\
\hline & & Uraninite & $\mathrm{UO} 2$ & Uraninite & UO2 & Uraninite & $\mathrm{UO} 2$ & & & & \\
\hline LN-DAR-1-W & & LN-DAR-1-W & & LN-DAR-1-W & & LN-BP-W & & LN-BP-W & & LN-PW2-W & \\
\hline FA & & FA & & FA & & FA & & FA & & FA & \\
\hline No8 & & No9 & & No10 & & No11* & & No12 & & No13 & \\
\hline CuprousFerrite & $\mathrm{CuFeO} 2$ & CuprousFerrite & $\mathrm{CuFeO} 2$ & CuprousFerrite & $\mathrm{CuFeO} 2$ & CuprousFerrite & $\mathrm{CuFeO} 2$ & CuprousFerrite & $\mathrm{CuFeO} 2$ & Basaluminite & $\mathrm{Al} 4(\mathrm{OH}) 10 \mathrm{SO} 4$ \\
\hline $\mathrm{Fe}(\mathrm{OH}) 2.7 \mathrm{Cl} .3$ & & $\mathrm{Fe}(\mathrm{OH}) 2.7 \mathrm{Cl} .3$ & & $\mathrm{Fe}(\mathrm{OH}) 2.7 \mathrm{Cl} .3$ & & $\mathrm{Fe}(\mathrm{OH}) 2.7 \mathrm{Cl} .3$ & & $\mathrm{Fe}(\mathrm{OH}) 2.7 \mathrm{Cl} .3$ & & Boehmite & $\mathrm{AlOOH}$ \\
\hline Goethite & $\mathrm{FeOOH}$ & Goethite & $\mathrm{FeOOH}$ & Goethite & $\mathrm{FeOOH}$ & Goethite & $\mathrm{FeOOH}$ & Goethite & $\mathrm{FeOOH}$ & $\mathrm{Cu}$ & \\
\hline Hematite & $\mathrm{Fe} 2 \mathrm{O} 3$ & Hematite & $\mathrm{Fe} 2 \mathrm{O} 3$ & Hematite & $\mathrm{Fe} 2 \mathrm{O} 3$ & Hematite & $\mathrm{Fe} 2 \mathrm{O} 3$ & Hematite & $\mathrm{Fe} 2 \mathrm{O} 3$ & Cuprite & $\mathrm{Cu} 2 \mathrm{O}$ \\
\hline \multirow[t]{5}{*}{ Magnetite } & $\mathrm{Fe} 3 \mathrm{O} 4$ & Magnetite & $\mathrm{Fe} 3 \mathrm{O} 4$ & Magnetite & $\mathrm{Fe} 3 \mathrm{O} 4$ & & & & & CuprousFerrite & $\mathrm{CuFeO} 2$ \\
\hline & & & & & & & & & & Diaspore & $\mathrm{AlOOH}$ \\
\hline & & & & & & & & & & Gibbsite & $\mathrm{Al}(\mathrm{OH}) 3$ \\
\hline & & & & & & & & & & UO2(a) & \\
\hline & & & & & & & & & & Uraninite & $\mathrm{UO} 2$ \\
\hline LN-PW2-W & & LN-PW2-W & & LN-VWD-W & & LN-VWD-W & & LN-SP3-W2 & & LN-SP3-W2 & \\
\hline FA & & FA & & FA & & FA & & FA & & FA & \\
\hline No14 & & No15 & & No16 & & No17 & & No18 & & No19 & \\
\hline Basaluminite & $\mathrm{Al} 4(\mathrm{OH}) 10 \mathrm{SO} 4$ & Basaluminite & $\mathrm{Al} 4(\mathrm{OH}) 10 \mathrm{SO} 4$ & CuprousFerrite & $\mathrm{CuFeO} 2$ & CuprousFerrite & $\mathrm{CuFeO} 2$ & CuprousFerrite & $\mathrm{CuFeO} 2$ & CuprousFerrite & $\mathrm{CuFeO} 2$ \\
\hline Boehmite & $\mathrm{AlOOH}$ & Boehmite & $\mathrm{AlOOH}$ & $\mathrm{Fe}(\mathrm{OH}) 2.7 \mathrm{Cl} .3$ & & $\mathrm{Fe}(\mathrm{OH}) 2.7 \mathrm{Cl} .3$ & & $\mathrm{Fe}(\mathrm{OH}) 2.7 \mathrm{Cl} .3$ & & $\mathrm{Fe}(\mathrm{OH}) 2.7 \mathrm{Cl} .3$ & \\
\hline $\mathrm{Cu}$ & & $\mathrm{Cu}$ & & Goethite & $\mathrm{FeOOH}$ & Goethite & $\mathrm{FeOOH}$ & Goethite & $\mathrm{FeOOH}$ & Goethite & $\mathrm{FeOOH}$ \\
\hline Cuprite & $\mathrm{Cu} 2 \mathrm{O}$ & Cuprite & $\mathrm{Cu} 2 \mathrm{O}$ & Hematite & $\mathrm{Fe} 2 \mathrm{O} 3$ & Hematite & $\mathrm{Fe} 2 \mathrm{O} 3$ & Hematite & $\mathrm{Fe} 2 \mathrm{O} 3$ & Hematite & $\mathrm{Fe} 2 \mathrm{O} 3$ \\
\hline CuprousFerrite & $\mathrm{CuFeO} 2$ & CuprousFerrite & $\mathrm{CuFeO} 2$ & Magnetite & $\mathrm{Fe} 3 \mathrm{O} 4$ & Magnetite & $\mathrm{Fe} 3 \mathrm{O} 4$ & & & Magnetite & $\mathrm{Fe} 3 \mathrm{O} 4$ \\
\hline Diaspore & $\mathrm{AlOOH}$ & Diaspore & $\mathrm{AlOOH}$ & & & & & & & & \\
\hline Gibbsite & $\mathrm{Al}(\mathrm{OH}) 3$ & UO2(a) & & & & & & & & & \\
\hline UO2(a) & & Uraninite & $\mathrm{UO} 2$ & & & & & & & & \\
\hline Uraninite & $\mathrm{UO} 2$ & & & & & & & & & & \\
\hline LN-DW-B-11-W & & LN-PW2-W & & LN-SP3-W & & LN-DAR-1-W & & LN-BP-W & & LN-SP3-W2 & \\
\hline FFA & & FFA & & FFA & & FFA & & FFA & & FFA & \\
\hline No21 & & No22 & & No23 & & No24 & & No25 & & No26 & \\
\hline Arsenic & AS & Boehmite & $\mathrm{AlOOH}$ & CuprousFerrite & $\mathrm{CuFeO} 2$ & CuprousFerrite & $\mathrm{CuFeO} 2$ & CuprousFerrite & $\mathrm{CuFeO} 2$ & CuprousFerrite & $\mathrm{CuFeO} 2$ \\
\hline Copper & $\mathrm{Cu}$ & Copper & & $\mathrm{Fe}(\mathrm{OH}) 2.7 \mathrm{Cl} .3$ & & $\mathrm{Fe}(\mathrm{OH}) 2.7 \mathrm{Cl} .3$ & & $\mathrm{Fe}(\mathrm{OH}) 2.7 \mathrm{Cl} .3$ & & $\mathrm{Fe}(\mathrm{OH}) 2.7 \mathrm{Cl} .3$ & \\
\hline Cuprite & $\mathrm{Cu} 2 \mathrm{O}$ & Gibbsite & $\mathrm{Al}(\mathrm{OH}) 3$ & Goethite & $\mathrm{FeOOH}$ & Goethite & $\mathrm{FeOOH}$ & Goethite & $\mathrm{FeOOH}$ & Goethite & $\mathrm{FeOOH}$ \\
\hline CuprousFerrite & $\mathrm{CuFeO} 2$ & $\mathrm{UO} 2$ & amorph & & & Hematite & $\mathrm{Fe} 2 \mathrm{O} 3$ & Hematite & $\mathrm{Fe} 2 \mathrm{O} 3$ & Hematite & $\mathrm{Fe} 2 \mathrm{O} 3$ \\
\hline $\mathrm{U} 4 \mathrm{O} 9$ & & Uraninite & $\mathrm{UO} 2$ & & & Magnetite & $\mathrm{Fe} 3 \mathrm{O} 4$ & & & Magnetite & $\mathrm{Fe} 3 \mathrm{O} 4$ \\
\hline Uraninite & $\mathrm{UO} 2$ & & & & & & & & & & \\
\hline
\end{tabular}




\begin{tabular}{|c|c|c|c|c|c|c|c|c|c|c|c|}
\hline LN-VWD-W & & LN-DAR-1-W & & LN-DAR-1-W & & LN-DW-B-11-W & & LN-DW-B-11-W & & LN-SP3-W & \\
\hline FFA & & UA & & UA & & UA & & UA & & UA & \\
\hline No27 * & & No28 & & No29* & & No30 & & No31 & & No32 & \\
\hline CuprousFerrite & $\mathrm{CuFeO} 2$ & CuprousFerrite & $\mathrm{CuFeO} 2$ & CuprousFerrite & $\mathrm{CuFeO} 2$ & As & & As & & CuprousFerrite & $\mathrm{CuFeO} 2$ \\
\hline $\mathrm{Fe}(\mathrm{OH}) 2.7 \mathrm{Cl} .3$ & & $\mathrm{Fe}(\mathrm{OH}) 2.7 \mathrm{Cl} .3$ & & $\mathrm{Fe}(\mathrm{OH}) 2.7 \mathrm{Cl} .3$ & & $\mathrm{Cu}$ & & $\mathrm{Cu}$ & & $\mathrm{Fe}(\mathrm{OH}) 2.7 \mathrm{Cl} .3$ & \\
\hline Goethite & $\mathrm{FeOOH}$ & Goethite & $\mathrm{FeOOH}$ & Goethite & $\mathrm{FeOOH}$ & Cuprite & $\mathrm{Cu} 2 \mathrm{O}$ & Cuprite & $\mathrm{Cu} 2 \mathrm{O}$ & Goethite & $\mathrm{FeOOH}$ \\
\hline Hematite & $\mathrm{Fe} 2 \mathrm{O} 3$ & Hematite & $\mathrm{Fe} 2 \mathrm{O} 3$ & Hematite & $\mathrm{Fe} 2 \mathrm{O} 3$ & Cuprous ferrite & $\mathrm{CuFeO} 2$ & Cuprous ferrite & $\mathrm{CuFeO} 2$ & Hematite & $\mathrm{Fe} 2 \mathrm{O} 3$ \\
\hline Magnetite & $\mathrm{Fe} 3 \mathrm{O} 4$ & Magnetite & $\mathrm{Fe} 3 \mathrm{O} 4$ & Magnetite & $\mathrm{Fe} 3 \mathrm{O} 4$ & $\mathrm{U} 4 \mathrm{O} 9(\mathrm{c})$ & & $\mathrm{U} 4 \mathrm{O} 9(\mathrm{c})$ & & Magnetite & $\mathrm{Fe} 3 \mathrm{O} 4$ \\
\hline LN-SP3-W & & LN-SP3-W2 & & LN-PW-W & & LN-BP-W & & LN-BP-W & & LN-PW2-W & \\
\hline UA & & UA & & UA & & UA & & UA & & UA & \\
\hline No33 & & No35 & & No36 & & No37 & & No38 & & No39 & \\
\hline CuprousFerrite & $\mathrm{CuFeO} 2$ & Cuprous ferrite & $\mathrm{CuFeO} 2$ & $\mathrm{Al}(\mathrm{OH}) 3(\mathrm{a})$ & & Cuprous ferrite & $\mathrm{CuFeO} 2$ & Cuprous ferrite & $\mathrm{CuFeO} 2$ & $\mathrm{Al}(\mathrm{OH}) 3(\mathrm{a})$ & \\
\hline $\mathrm{Fe}(\mathrm{OH}) 2.7 \mathrm{Cl} .3$ & & $\mathrm{Fe}(\mathrm{OH}) 2.7 \mathrm{Cl} 3$ & & Boehmite & $\mathrm{AlOOH}$ & $\mathrm{Fe}(\mathrm{OH}) 2.7 \mathrm{Cl} 3$ & & $\mathrm{Fe}(\mathrm{OH}) 2.7 \mathrm{Cl} 3$ & & Basaluminite & $\mathrm{Al} 4(\mathrm{OH}) 10 \mathrm{SO} 4$ \\
\hline Goethite & $\mathrm{FeOOH}$ & Goethite & $\mathrm{FeOOH}$ & CuMetal & $\mathrm{Cu}$ & Goethite & $\mathrm{FeOOH}$ & Goethite & $\mathrm{FeOOH}$ & Boehmite & $\mathrm{AlOOH}$ \\
\hline Hematite & $\mathrm{Fe} 2 \mathrm{O} 3$ & Hematite & $\mathrm{Fe} 2 \mathrm{O} 3$ & CupricFerrite & $\mathrm{CuFe} 2 \mathrm{O} 4$ & Hematite & $\mathrm{Fe} 2 \mathrm{O} 3$ & Hematite & $\mathrm{Fe} 2 \mathrm{O} 3$ & CuMetal & $\mathrm{Cu}$ \\
\hline \multirow[t]{9}{*}{ Magnetite } & $\mathrm{Fe} 3 \mathrm{O} 4$ & Magnetite & $\mathrm{Fe} 3 \mathrm{O} 4$ & Cuprite & $\mathrm{Cu} 2 \mathrm{O}$ & & & & & Cuprite & $\mathrm{Cu} 2 \mathrm{O}$ \\
\hline & & & & Cuprous ferrite & $\mathrm{CuFeO} 2$ & & & & & Cuprous ferrite & $\mathrm{CuFeO} 2$ \\
\hline & & & & Diaspore & $\mathrm{AlOOH}$ & & & & & Diaspore & $\mathrm{AlOOH}$ \\
\hline & & & & Gibbsite & $\mathrm{Al}(\mathrm{OH}) 3$ & & & & & Gibbsite & $\mathrm{Al}(\mathrm{OH}) 3$ \\
\hline & & & & Goethite & $\mathrm{FeOOH}$ & & & & & UO2(a) & \\
\hline & & & & Hematite & $\mathrm{Fe} 2 \mathrm{O} 3$ & & & & & Uraninite(c) & $\mathrm{UO} 2$ \\
\hline & & & & Magnetite & $\mathrm{Fe} 3 \mathrm{O} 4$ & & & & & & \\
\hline & & & & $\mathrm{U} 4 \mathrm{O} 9$ (c) & & & & & & & \\
\hline & & & & Uraninite(c) & $\mathrm{UO} 2$ & & & & & & \\
\hline LN-PW2-W & & LN-VWD-W & & & & & & & & & \\
\hline UA & & UA & & & & & & & & & \\
\hline No40 & & No41 & & & & & & & & & \\
\hline$\overline{\mathrm{Al}(\mathrm{OH}) 3(\mathrm{a})}$ & & Cuprousferrite & $\mathrm{CuFeO} 2$ & & & & & & & & \\
\hline Basaluminite & $\mathrm{Al} 4(\mathrm{OH}) 10 \mathrm{SO} 4$ & Goethite & $\mathrm{FeOOH}$ & & & & & & & & \\
\hline Boehmite & $\mathrm{AlOOH}$ & $\mathrm{Fe}(\mathrm{OH}) 2.7 \mathrm{Cl} .3$ & & & & & & & & & \\
\hline CuMetal & $\mathrm{Cu}$ & Hematite & $\mathrm{Fe} 2 \mathrm{O} 3$ & & & & & & & & \\
\hline Cuprite & $\mathrm{Cu} 2 \mathrm{O}$ & Magnetite & $\mathrm{Fe} 3 \mathrm{O} 4$ & & & & & & & & \\
\hline Cuprous ferrite & $\mathrm{CuFeO} 2$ & & & & & & & & & & \\
\hline Diaspore & $\mathrm{AlOOH}$ & & & & & & & & & & \\
\hline Gibbsite & $\mathrm{Al}(\mathrm{OH}) 3$ & & & & & & & & & & \\
\hline \multicolumn{12}{|l|}{ UO2(a) } \\
\hline Uraninite(c) & UO2 & & & & & & & & & & \\
\hline
\end{tabular}




\begin{tabular}{|c|c|c|c|c|c|c|c|c|c|c|c|}
\hline P-ARD17-W & & P-EC-W & & P-WRD-W & & P-PD-W & & P-ARD17-W & & P-WRD-W & \\
\hline FFA & & FFA & & FFA & & FFA & & UA & & UA & \\
\hline No60 & & No61 & & No62 & & No63 & & No65 * & & No66 & \\
\hline CuprousFerrite & $\mathrm{CuFeO} 2$ & Alunite & $\mathrm{KAl} 3(\mathrm{SO} 4) 2(\mathrm{OH}) 6$ & CuprousFerrite & $\mathrm{CuFeO} 2$ & CuprousFerrite & $\mathrm{CuFeO} 2$ & CuprousFerrite & $\mathrm{CuFeO} 2$ & CuprousFerrite & $\mathrm{CuFeO} 2$ \\
\hline Goethite & $\mathrm{FeOOH}$ & Basaluminite & $\mathrm{Al} 4(\mathrm{OH}) 10 \mathrm{SO} 4$ & $\mathrm{Fe}(\mathrm{OH}) 2.7 \mathrm{Cl} .3$ & & Goethite & $\mathrm{FeOOH}$ & Goethite & $\mathrm{FeOOH}$ & Hematite & $\mathrm{Fe} 2 \mathrm{O} 3$ \\
\hline & & Boehmite & $\mathrm{AlOOH}$ & Goethite & $\mathrm{FeOOH}$ & Hematite & $\mathrm{Fe} 2 \mathrm{O} 3$ & Hematite & $\mathrm{Fe} 2 \mathrm{O} 3$ & & \\
\hline & & CupricFerrite & $\mathrm{CuFe} 2 \mathrm{O} 4$ & Magnetite & $\mathrm{Fe} 3 \mathrm{O} 4$ & & & & & & \\
\hline & & CuprousFerrite & $\mathrm{CuFeO} 2$ & & & & & & & & \\
\hline & & Diaspore & $\mathrm{AlOOH}$ & & & & & & & & \\
\hline & & $\mathrm{Fe}(\mathrm{OH}) 2.7 \mathrm{Cl} .3$ & & & & & & & & & \\
\hline & & Gibbsite & $\mathrm{Al}(\mathrm{OH}) 3$ & & & & & & & & \\
\hline & & Goethite & $\mathrm{FeOOH}$ & & & & & & & & \\
\hline & & Hematite & $\mathrm{Fe} 2 \mathrm{O} 3$ & & & & & & & & \\
\hline & & Magnetite & $\mathrm{Fe} 3 \mathrm{O} 4$ & & & & & & & & \\
\hline P-ARD17-W & & P-WRD-W & & P-EC-W & & P-EC-W & & P-PD-W & & P-PD-W & \\
\hline UA & & UA & & UA & & UA & & UA & & UA & \\
\hline No67 & & No68 & & No69 & & No70 & & No71 & & No72 & \\
\hline CuprousFerrite & $\mathrm{CuFeO} 2$ & CuprousFerrite & $\mathrm{CuFeO} 2$ & Alunite & KAl3(SO4)2(OH)6 & Alunite & KAl3(SO4)2(OH)6 & CuprousFerrite & $\mathrm{CuFeO} 2$ & CuprousFerrite & $\mathrm{CuFeO} 2$ \\
\hline $\mathrm{Fe}(\mathrm{OH}) 2.7 \mathrm{Cl} .3$ & & $\mathrm{Fe}(\mathrm{OH}) 2.7 \mathrm{Cl} .3$ & & Basaluminite & $\mathrm{Al} 4(\mathrm{OH}) 10 \mathrm{SO} 4$ & Basaluminite & $\mathrm{Al} 4(\mathrm{OH}) 10 \mathrm{SO} 4$ & Goethite & $\mathrm{FeOOH}$ & Goethite & $\mathrm{FeOOH}$ \\
\hline Goethite & $\mathrm{FeOOH}$ & Goethite & $\mathrm{FeOOH}$ & Boehmite & $\mathrm{AlOOH}$ & Boehmite & $\mathrm{AlOOH}$ & Hematite & $\mathrm{Fe} 2 \mathrm{O} 3$ & Hematite & $\mathrm{Fe} 2 \mathrm{O} 3$ \\
\hline Hematite & $\mathrm{Fe} 2 \mathrm{O} 3$ & Magnetite & $\mathrm{Fe} 3 \mathrm{O} 4$ & CupricFerrite & $\mathrm{CuFe} 2 \mathrm{O} 4$ & CupricFerrite & $\mathrm{CuFe} 2 \mathrm{O} 4$ & & & & \\
\hline Magnetite & $\mathrm{Fe} 3 \mathrm{O} 4$ & & & CuprousFerrite & $\mathrm{CuFeO} 2$ & CuprousFerrite & $\mathrm{CuFeO} 2$ & & & & \\
\hline & & & & Diaspore & $\mathrm{AlOOH}$ & Diaspore & $\mathrm{AlOOH}$ & & & & \\
\hline & & & & $\mathrm{Fe}(\mathrm{OH}) 2.7 \mathrm{Cl} .3$ & & $\mathrm{Fe}(\mathrm{OH}) 2.7 \mathrm{Cl} .3$ & & & & & \\
\hline & & & & Gibbsite & $\mathrm{Al}(\mathrm{OH}) 3$ & Gibbsite & $\mathrm{Al}(\mathrm{OH}) 3$ & & & & \\
\hline & & & & Goethite & $\mathrm{FeOOH}$ & Goethite & $\mathrm{FeOOH}$ & & & & \\
\hline & & & & Hematite & $\mathrm{Fe} 2 \mathrm{O} 3$ & Hematite & $\mathrm{Fe} 2 \mathrm{O} 3$ & & & & \\
\hline & & & & Magnetite & $\mathrm{Fe} 3 \mathrm{O} 4$ & Magnetite & $\mathrm{Fe} 3 \mathrm{O} 4$ & & & & \\
\hline P-ARD-17-W & & P-ARD-17-W & & P-WRD-W & & P-WRD-W & & P-WRD-W & & P-PD-W & \\
\hline FA & & FA & & FA & & FA & & FA & & FA & \\
\hline No73 & & No74 & & No76 & & No77 & & No78 & & No79 & \\
\hline CuprousFerrite & $\mathrm{CuFeO} 2$ & CuprousFerrite & $\mathrm{CuFeO} 2$ & CuprousFerrite & $\mathrm{CuFeO} 2$ & CuprousFerrite & $\mathrm{CuFeO} 2$ & CuprousFerrite & $\mathrm{CuFeO} 2$ & CuprousFerrite & $\mathrm{CuFeO} 2$ \\
\hline Goethite & $\mathrm{FeOOH}$ & Goethite & $\mathrm{FeOOH}$ & $\mathrm{Fe}(\mathrm{OH}) 2.7 \mathrm{Cl} .3$ & & $\mathrm{Fe}(\mathrm{OH}) 2.7 \mathrm{Cl} .3$ & & $\mathrm{Fe}(\mathrm{OH}) 2.7 \mathrm{Cl} .3$ & & Goethite & $\mathrm{FeOOH}$ \\
\hline Hematite & $\mathrm{Fe} 2 \mathrm{O} 3$ & Hematite & $\mathrm{Fe} 2 \mathrm{O} 3$ & Goethite & $\mathrm{FeOOH}$ & Goethite & $\mathrm{FeOOH}$ & Goethite & $\mathrm{FeOOH}$ & Hematite & $\mathrm{Fe} 2 \mathrm{O} 3$ \\
\hline & & & & Hematite & $\mathrm{Fe} 2 \mathrm{O} 3$ & Hematite & $\mathrm{Fe} 2 \mathrm{O} 3$ & Hematite & $\mathrm{Fe} 2 \mathrm{O} 3$ & & \\
\hline & & & & Magnetite & $\mathrm{Fe} 3 \mathrm{O} 4$ & Magnetite & $\mathrm{Fe} 3 \mathrm{O} 4$ & Magnetite & $\mathrm{Fe} 3 \mathrm{O} 4$ & & \\
\hline
\end{tabular}




\begin{tabular}{|c|c|c|c|c|c|c|c|c|c|}
\hline P-PD-W & & P-PD-W & & P-EC-W & & P-EC-W & & P-EC-W & \\
\hline FA & & FA & & FA & & FA & & FA & \\
\hline No 80 & & No 81 & & No 82 & & No 83 & & No84* & \\
\hline CuprousFerrite & $\mathrm{CuFeO} 2$ & CuprousFerrite & $\mathrm{CuFeO} 2$ & Alunite & $\mathrm{KAl} 3(\mathrm{SO} 4) 2(\mathrm{OH}) 6$ & Alunite & KAl3(SO4)2(OH)6 & CupricFerrite & $\mathrm{CuFe2O} 4$ \\
\hline Goethite & $\mathrm{FeOOH}$ & Goethite & $\mathrm{FeOOH}$ & Basaluminite & $\mathrm{Al}(\mathrm{OH}) 10 \mathrm{SO} 4$ & Basaluminite & $\mathrm{Al} 4(\mathrm{OH}) 10 \mathrm{SO} 4$ & CuprousFerrite & $\mathrm{CuFeO} 2$ \\
\hline \multirow[t]{9}{*}{ Hematite } & $\mathrm{Fe} 2 \mathrm{O} 3$ & Hematite & $\mathrm{Fe} 2 \mathrm{O} 3$ & Boehmite & $\mathrm{AlOOH}$ & Boehmite & $\mathrm{AlOOH}$ & Diaspore & $\mathrm{AlOOH}$ \\
\hline & & & & CupricFerrite & $\mathrm{CuFe} 2 \mathrm{O} 4$ & CupricFerrite & $\mathrm{CuFe} 2 \mathrm{O} 4$ & $\mathrm{Fe}(\mathrm{OH}) 2.7 \mathrm{Cl} .3$ & \\
\hline & & & & CuprousFerrite & $\mathrm{CuFeO} 2$ & CuprousFerrite & $\mathrm{CuFeO} 2$ & Gibbsite & $\mathrm{Al}(\mathrm{OH}) 3$ \\
\hline & & & & Diaspore & $\mathrm{AlOOH}$ & Diaspore & $\mathrm{AlOOH}$ & Goethite & $\mathrm{FeOOH}$ \\
\hline & & & & $\mathrm{Fe}(\mathrm{OH}) 2.7 \mathrm{Cl} .3$ & & $\mathrm{Fe}(\mathrm{OH}) 2.7 \mathrm{Cl} .3$ & & Hematite & $\mathrm{Fe} 2 \mathrm{O} 3$ \\
\hline & & & & Gibbsite & $\mathrm{Al}(\mathrm{OH}) 3$ & Gibbsite & $\mathrm{Al}(\mathrm{OH}) 3$ & Magnetite & $\mathrm{Fe} 3 \mathrm{O} 4$ \\
\hline & & & & Goethite & $\mathrm{FeOOH}$ & Goethite & $\mathrm{FeOOH}$ & & \\
\hline & & & & Hematite & $\mathrm{Fe} 2 \mathrm{O} 3$ & Hematite & $\mathrm{Fe} 2 \mathrm{O} 3$ & & \\
\hline & & & & Magnetite & $\mathrm{Fe} 3 \mathrm{O} 4$ & Magnetite & $\mathrm{Fe} 3 \mathrm{O} 4$ & & \\
\hline
\end{tabular}




\section{Appendix C: PHREEQC modeling with $\mathrm{SI} \geq 0$ in solutions concentrated 20 fold}

\begin{tabular}{|c|c|c|c|c|c|c|c|c|c|c|c|}
\hline \multirow{3}{*}{$\begin{array}{c}\text { LN-SP3-W } \\
\text { Conc.1X } \\
\text { CuprousFerrite }\end{array}$} & & & & \multicolumn{4}{|l|}{ LN-DW-B-11-W } & \multicolumn{4}{|l|}{ LN-DAR-1-W } \\
\hline & & \multicolumn{2}{|l|}{ Conc.20X } & \multicolumn{2}{|l|}{ Conc.1X } & \multicolumn{2}{|l|}{ Conc.20X } & \multicolumn{2}{|l|}{ Conc.1X } & \multicolumn{2}{|l|}{ Conc.20X } \\
\hline & CuFeO2 & $\mathrm{Al}(\mathrm{OH}) 3(\mathrm{a})$ & & As & & As2S3(am) & & CuprousFerrite & CuFeO2 & CuprousFerrite & $\mathrm{CuFeO} 2$ \\
\hline $\mathrm{Fe}(\mathrm{OH}) 2.7 \mathrm{Cl} .3$ & & Alunite & $\mathrm{KAl} 3(\mathrm{SO} 4) 2(\mathrm{OH}) 6$ & $\mathrm{Cu}$ & & As & & $\mathrm{Fe}(\mathrm{OH}) 2.7 \mathrm{Cl} .3$ & & $\mathrm{Fe}(\mathrm{OH}) 2.7 \mathrm{Cl} .3$ & \\
\hline Goethite & $\mathrm{FeOOH}$ & Barite & $\mathrm{BaSO}_{4}$ & Cuprite & Cu2O & Blaubleil & Cu0.9Cu0.2S & Goethite & $\mathrm{FeOOH}$ & Goethite & $\mathrm{FeOOH}$ \\
\hline \multirow[t]{27}{*}{ Hematite } & $\mathrm{Fe} 2 \mathrm{O} 3$ & Basaluminite & $\mathrm{Al} 4(\mathrm{OH}) 10 \mathrm{SO} 4$ & CuprousFerrite & CuFeO2 & Chalcocite & Cu2C & Hematite & $\mathrm{Fe} 2 \mathrm{O} 3$ & Hematite & $\mathrm{Fe} 2 \mathrm{O} 3$ \\
\hline & & Boehmite & $\mathrm{AlOOH}$ & U409(c) & U409(c) & Chalcopyrite & CuFes2 & Magnetite & Fe3O4 & & \\
\hline & & Birnessite & $\mathrm{MnO} 2$ & Uraninite & UO2 & $\mathrm{Cu}$ & & & & & \\
\hline & & Bixbyite & $\mathrm{Mn} 2 \mathrm{O} 3$ & & & Cuprite & Cu2O & & & & \\
\hline & & Boehmite & $\mathrm{AlOOH}$ & & & CuprousFerrite & $\mathrm{CuFeO2}$ & & & & \\
\hline & & Bronchantite & $\mathrm{Cu} 4(\mathrm{OH}) 6 \mathrm{SO} 4$ & & & Djurleite & Cu0.066Cu1. & 8685 & & & \\
\hline & & $\mathrm{Cu}(\mathrm{OH}) 2$ & & & & Galena & $\mathrm{PbS}$ & & & & \\
\hline & & Cu3(AsO4)2: & $6 \mathrm{H} 2 \mathrm{O}$ & & & Greenockite & CdS & & & & \\
\hline & & CuprousFerrite & $\mathrm{CuFeO} 2$ & & & Orpiment & As $2 S_{3}$ & & & & \\
\hline & & Diaspore & $\mathrm{AlOOH}$ & & & Sphalerite & $\mathrm{ZnS}$ & & & & \\
\hline & & $\mathrm{Fe}(\mathrm{OH}) 2.7 \mathrm{Cl} .3$ & & & & Uraninite & UO2 & & & & \\
\hline & & $\mathrm{Fe}(\mathrm{OH}) 3$ & & & & & & & & & \\
\hline & & $\mathrm{Fe} 3(\mathrm{OH}) 8$ & & & & & & & & & \\
\hline & & Gibbsite & $\mathrm{Al}(\mathrm{OH}) 3$ & & & & & & & & \\
\hline & & Goethite & $\mathrm{FeOOH}$ & & & & & & & & \\
\hline & & Hausmannite & Mn3O4 & & & & & & & & \\
\hline & & Hematite & $\mathrm{Fe} 2 \mathrm{O} 3$ & & & & & & & & \\
\hline & & Jarosite-K & $\mathrm{KFe} 3(\mathrm{SO} 4) 2(\mathrm{OH}) 6$ & & & & & & & & \\
\hline & & Jarosite-Na & $\mathrm{NaFe} 3(\mathrm{SO} 4) 2(\mathrm{OH}) 6$ & & & & & & & & \\
\hline & & Jarosite-H & $(\mathrm{H} 3 \mathrm{O}) \mathrm{Fe} 3(\mathrm{SO} 4) 2(\mathrm{OH}) 6$ & & & & & & & & \\
\hline & & Jurbanite & $\mathrm{AlOHSO} 4$ & & & & & & & & \\
\hline & & Maghemite & $\mathrm{Fe} 2 \mathrm{O} 3$ & & & & & & & & \\
\hline & & Magnetite & $\mathrm{Fe} 3 \mathrm{O} 4$ & & & & & & & & \\
\hline & & Manganite & $\mathrm{MnOOH}$ & & & & & & & & \\
\hline & & Langite & $\mathrm{Cu} 4(\mathrm{OH}) 6 \mathrm{SO} 4: \mathrm{H} 2 \mathrm{O}$ & & & & & & & & \\
\hline & & Nsutite & $\mathrm{MnO2}$ & & & & & & & & \\
\hline & & Tenorite & $\mathrm{CuO}$ & & & & & & & & \\
\hline
\end{tabular}




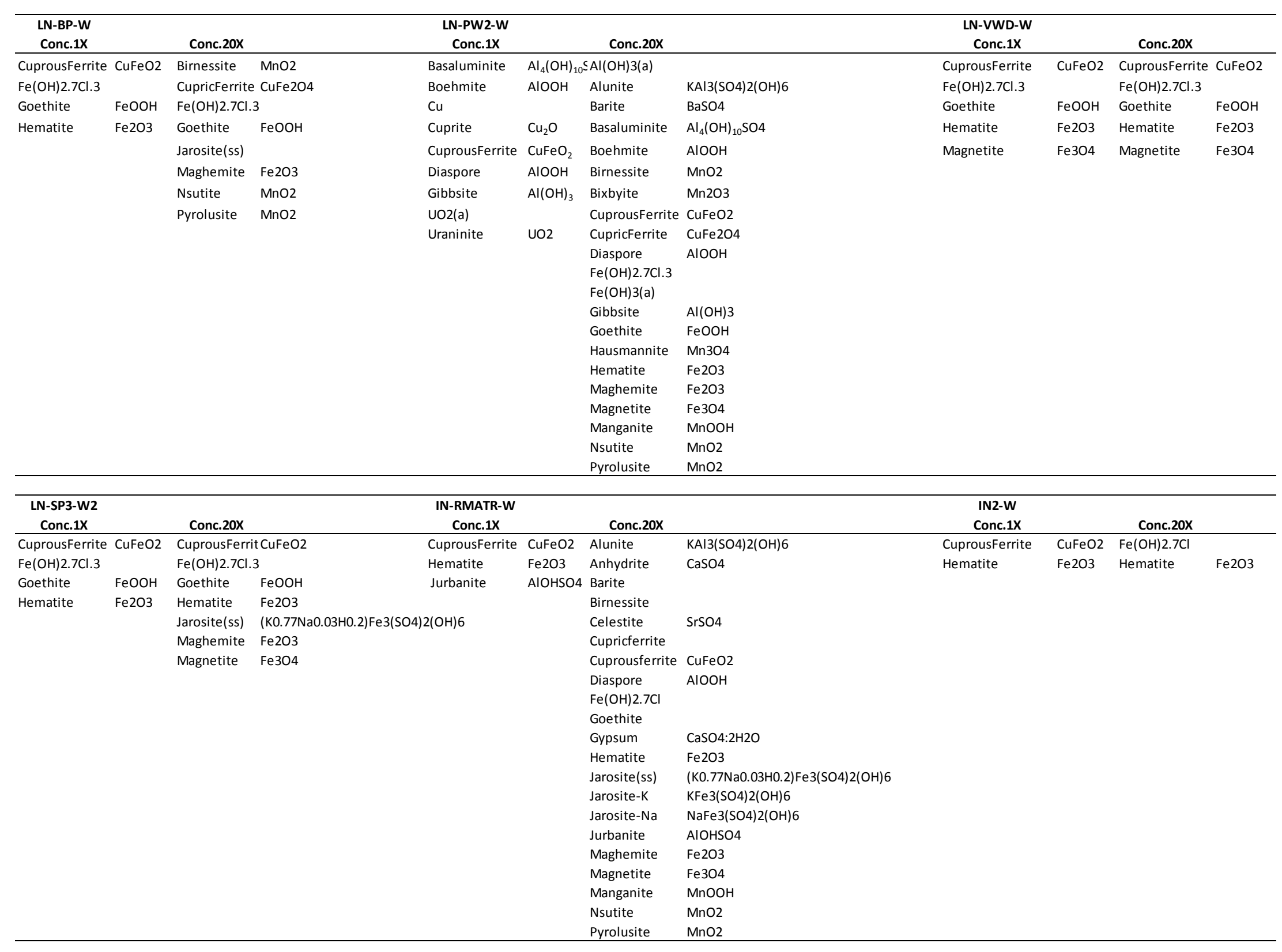




\begin{tabular}{|c|c|c|c|c|c|c|c|c|c|c|}
\hline \multirow{3}{*}{$\begin{array}{l}\text { IN13-W } \\
\text { Conc.1X } \\
\text { Alunite }\end{array}$} & \multicolumn{7}{|c|}{ P-WRD-W } & \multicolumn{3}{|l|}{ P-PD-W } \\
\hline & \multicolumn{3}{|c|}{ Conc.20X } & \multicolumn{2}{|l|}{ Conc.1X } & \multicolumn{2}{|l|}{ Conc.20X } & \multicolumn{2}{|l|}{ Conc.1X } & Conc.20X \\
\hline & $\mathrm{KAl}_{3}\left(\mathrm{SO}_{4}\right)_{2}(\mathrm{OH})$ & IAl(OH)3(a) & & CuprousFerrite & CuFeO2 & CuprousFerrite & CuFeO2 & CuprousFerrite & CuFeO2 & $\mathrm{Fe}(\mathrm{OH}) 2.7 \mathrm{Cl} .3$ \\
\hline Basaluminite & $\mathrm{Al} 4(\mathrm{OH}) 10 \mathrm{SO} 4$ & Alunite & $\mathrm{KAl} 3(\mathrm{SO} 4) 2(\mathrm{OH}) 6$ & $\mathrm{Fe}(\mathrm{OH}) 2.7 \mathrm{Cl} .3$ & & $\mathrm{Fe}(\mathrm{OH}) 2.7 \mathrm{Cl} .3$ & & Goethite & $\mathrm{FeOOH}$ & Goethite $\mathrm{FeOOH}$ \\
\hline Boehmite & $\mathrm{AlOOH}$ & $\mathrm{Ba} 3(\mathrm{AsO} 4) 2$ & & Goethite & $\mathrm{FeOOH}$ & Goethite & $\mathrm{FeOOH}$ & Hematite & $\mathrm{Fe} 2 \mathrm{O} 3$ & Hematite $\mathrm{Fe} 2 \mathrm{O} 3$ \\
\hline Cupricferrite & CuFe2O4 & Boehmite & $\mathrm{AlOOH}$ & Hematite & $\mathrm{Fe} 2 \mathrm{O} 3$ & Hematite & $\mathrm{Fe} 2 \mathrm{O} 3$ & & & Magnetite $\mathrm{Fe} 3 \mathrm{O} 4$ \\
\hline Cuprousferrite & CuFeO2 & Birnessite & $\mathrm{MnO} 2$ & Magnetite & Fe3O4 & Magnetite & Fe3O4 & & & \\
\hline Diaspore & $\mathrm{AlOOH}$ & Bixbyite & $\mathrm{Mn} 2 \mathrm{O} 3$ & & & & & & & \\
\hline $\mathrm{Fe}(\mathrm{OH}) 2.7 \mathrm{Cl}$ & & Cupricferrite & CuFe2O4 & & & & & & & \\
\hline Gibbsite & $\mathrm{Al}(\mathrm{OH}) 3$ & Cupricferrite & CuFeO2 & & & & & & & \\
\hline Goethite & $\mathrm{FeOOH}$ & Diaspore & $\mathrm{AlOOH}$ & & & & & & & \\
\hline \multirow[t]{15}{*}{ Magnetite } & Fe3O4 & $\mathrm{Fe}(\mathrm{OH}) 2.7 \mathrm{Cl}$ & & & & & & & & \\
\hline & & $\mathrm{Fe}(\mathrm{OH}) 3(\mathrm{a})$ & & & & & & & & \\
\hline & & $\mathrm{Fe} 3(\mathrm{OH}) 8$ & & & & & & & & \\
\hline & & Gibbsite & $\mathrm{Al}(\mathrm{OH}) 3$ & & & & & & & \\
\hline & & Goethite & $\mathrm{FeOOH}$ & & & & & & & \\
\hline & & Hematite & $\mathrm{Fe} 2 \mathrm{O} 3$ & & & & & & & \\
\hline & & Jarosite(ss) & (K0.77NaO.03HO & D.2) $\mathrm{Fe} 3(\mathrm{SO} 4) 2(\mathrm{O}$ & H) 6 & & & & & \\
\hline & & Jarosite-K & $\mathrm{KFe} 3(\mathrm{SO} 4) 2(\mathrm{OH}$ & & & & & & & \\
\hline & & Jarosite-Na & $\mathrm{NaFe} 3(\mathrm{SO} 4) 2(\mathrm{O}$ & H) 6 & & & & & & \\
\hline & & Jurbanite & $\mathrm{AlOHSO} 4$ & & & & & & & \\
\hline & & Maghemite & $\mathrm{Fe} 2 \mathrm{O} 3$ & & & & & & & \\
\hline & & Magnetite & $\mathrm{Fe} 304$ & & & & & & & \\
\hline & & Manganite & $\mathrm{MnOOH}$ & & & & & & & \\
\hline & & Nsutite & $\mathrm{MnO2}$ & & & & & & & \\
\hline & & Pyrolusite & $\mathrm{MnO} 2$ & & & & & & & \\
\hline \multicolumn{11}{|l|}{ P-EC-W } \\
\hline Conc.1X & & Conc.20X & & & & & & & & \\
\hline Alunite & \multicolumn{2}{|c|}{$\mathrm{KAl} 3(\mathrm{SO} 4)_{2}(\mathrm{OH}) \cdot$ Alunite } & \multicolumn{3}{|l|}{$\mathrm{KAl}_{3}\left(\mathrm{SO}_{4}\right)_{2}(\mathrm{OH})_{6}$} & & & & & \\
\hline Basaluminite & $\mathrm{Al} 4(\mathrm{OH}) 10 \mathrm{SO} 4$ & Barite & $\mathrm{BaSO} 4$ & & & & & & & \\
\hline Boehmite & $\mathrm{AlOOH}$ & Birnessite & $\mathrm{MnO} 2$ & & & & & & & \\
\hline CupricFerrite & CuFe2O4 & Bixbyite & $\mathrm{Mn} 2 \mathrm{O} 3$ & & & & & & & \\
\hline CuprousFerrite & CuFeO2 & CupricFerrite & CuFe2O4 & & & & & & & \\
\hline Diaspore & $\mathrm{AlOOH}$ & Diaspore & $\mathrm{AlOOH}$ & & & & & & & \\
\hline $\mathrm{Fe}(\mathrm{OH}) 2.7 \mathrm{Cl} .3$ & & $\mathrm{Fe}(\mathrm{OH}) 2.7 \mathrm{Cl} .3$ & & & & & & & & \\
\hline Gibbsite & $\mathrm{Al}(\mathrm{OH}) 3$ & $\mathrm{Fe}(\mathrm{OH}) 3$ & & & & & & & & \\
\hline Goethite & $\mathrm{FeOOH}$ & Gibbsite & $\mathrm{Al}(\mathrm{OH}) 3$ & & & & & & & \\
\hline Hematite & $\mathrm{Fe} 2 \mathrm{O} 3$ & Goethite & $\mathrm{FeOOH}$ & & & & & & & \\
\hline Magnetite & Fe3O4 & Hematite & $\mathrm{Fe} 2 \mathrm{O} 3$ & & & & & & & \\
\hline & & Jarosite(ss) & (K0.77NaO.03HO & 0.2) $\mathrm{Fe} 3\left(\mathrm{SO}^{2}\right) 2(\mathrm{O}$ & H) 6 & & & & & \\
\hline & & Jarosite-K & $\mathrm{KFe} 3(\mathrm{SO} 4) 2(\mathrm{OH}$ & & & & & & & \\
\hline & & Jarosite-Na & $\mathrm{NaFe} 3(\mathrm{SO} 4) 2(\mathrm{O}$ & H) 6 & & & & & & \\
\hline & & Maghemite & $\mathrm{Fe} 2 \mathrm{O} 3$ & & & & & & & \\
\hline & & Magnetite & $\mathrm{Fe} 304$ & & & & & & & \\
\hline & & Manganite & $\mathrm{MnOOH}$ & & & & & & & \\
\hline & & Nsutite & $\mathrm{MnO2}$ & & & & & & & \\
\hline & & Pyrolusite & $\mathrm{MnO} 2$ & & & & & & & \\
\hline
\end{tabular}




\section{Appendix D: Comparison of methods ICP-MS \& ICP-OES}

The two types of analyses conducted for bulk chemical characterization of secondary precipitates and waters were ICP-MS and ICP-OES. Filtered and acidified samples from all mines were combined for the following comparative graphics. Major elements ( $\mathrm{Al}, \mathrm{Ca}, \mathrm{Mg}, \mathrm{Fe}, \mathrm{Na}, \mathrm{Cu}, \mathrm{S})$ were plotted as a scatterplot with the concentration of the element as measured by ICP-OES on the Y-axis, and the concentration of the element as measured by ICP-MS on the X-axis. A 1:1 trend-line, as well as $\mathrm{R}^{2}$ values were added. There is a high degree of correlation between the results from the two methods. Hence, results from both analyses for the major elements can be used without any discrepancy. Due to higher detection limits for ICP-OES, results from ICP-MS were used for interpretation and discussion of major, minor and trace elements.

Digiprep LS Block (72 position) with disposable digitubes was used for these analyses. $6 \mathrm{~mL}$ of $\mathrm{HCl}$ and $2 \mathrm{~mL}$ of nitric acid were used with approximately $0.5 \mathrm{~g}$ of sample for digestion. $7 \mathrm{~mL}$ of water was then added and the samples heated at $90^{\circ} \mathrm{C}$ for a period of 5 hours reducing the volume to fewer milliliters. The temperature is controlled using an attached controller unit. Samples were then covered with disposable plastic watch-glasses when they were being digested. This prevented contamination from the fume hood, and also helped slow down the loss of acid fumes. Since the controller has a shut off feature, the samples were digested for exactly the same time and temperature on each run. The block was preheated before the samples were added. Samples were then filtered using Whatman No 42 filter papers and the filtrate was diluted by a factor of 10 for analysis on the IC-PMS (Agilent 7700x). There was no dilution necessary for ICP-OES (Varian Vista Pro - Axial) analysis. 


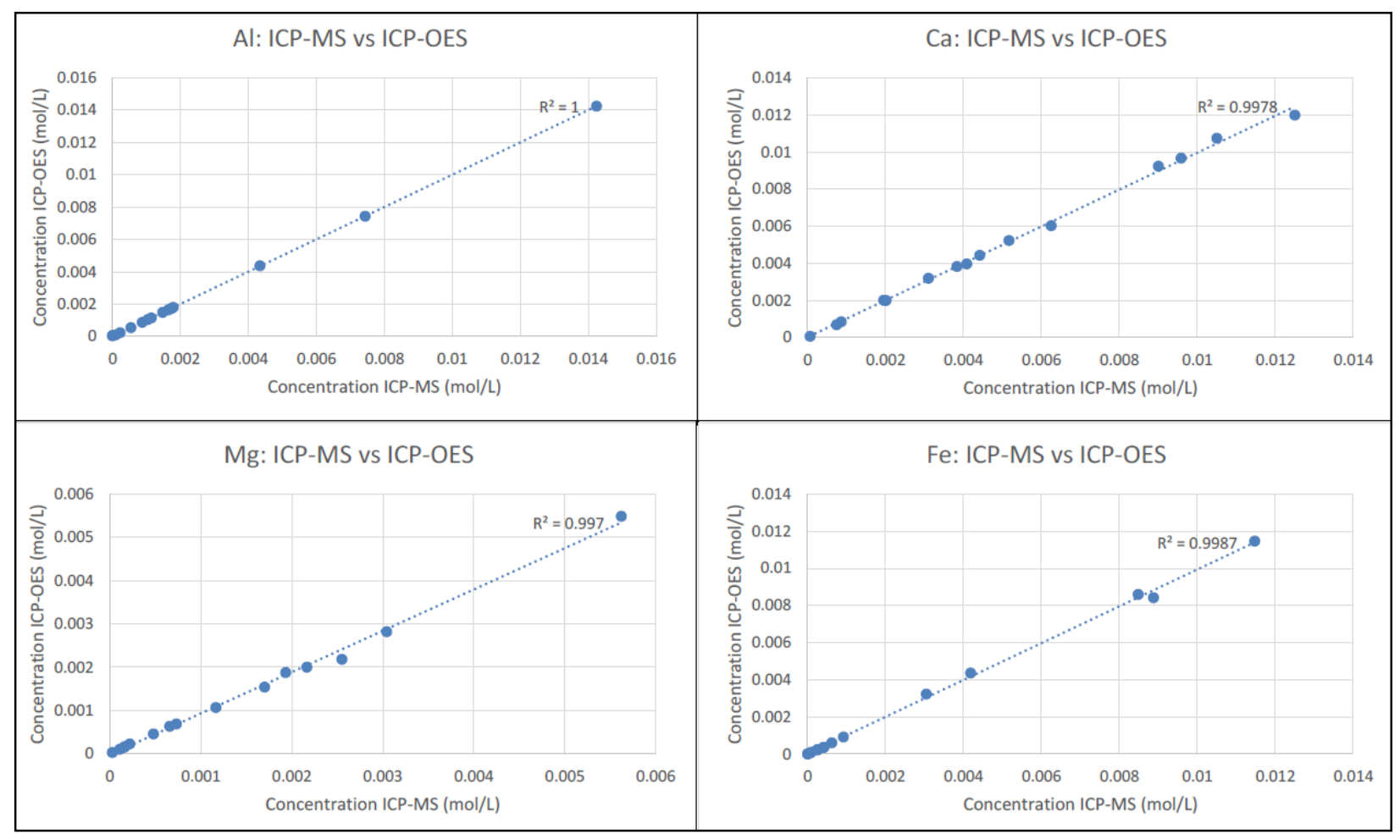

Figure 0-1: Plots comparing the concentrations determined by ICP-MS (x-axis) and ICP-OES ( $y$-axis) for major elements $\mathrm{Al}, \mathrm{Ca}, \mathrm{Mg}$ and Fe.

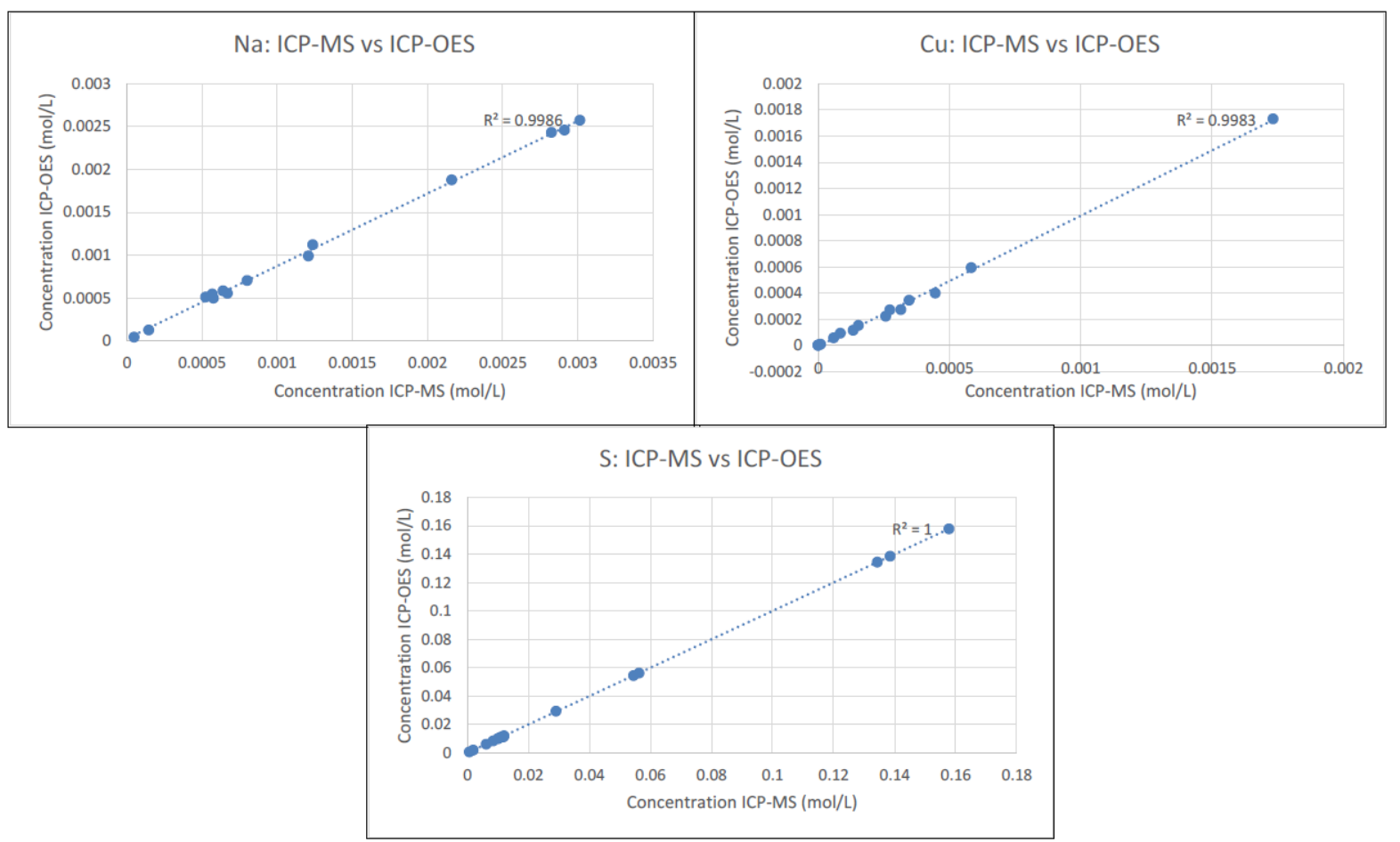

Figure 0-2: Plots comparing the concentrations determined by ICP-MS ( $x$-axis) and ICP-OES ( $y$-axis) for major elements $\mathrm{Na}, \mathrm{Cu}$ and $\mathrm{S}$. 


\section{Appendix E: QAQC \& chemistry of secondary precipitates}

Sample blanks, standard reference material, as well as experimental replicates were included for the lab QA/QC. Lab blanks show trace amounts of contamination of $\mathrm{Cu}, \mathrm{Li}, \mathrm{K}, \mathrm{Na}$ and $\mathrm{S}$ as a result of carryover from samples with high concentrations; however, because the concentrations of these elements are extremely high this contamination is considered minor and does not affect the results. Reagent blanks were used as laboratory blanks that are the same acid concentration as for samples. These blanks get digested in the same containers as the samples and are also filtered in the same way as the samples to provide us with the method blanks. The method blank is multiplied by the same nominal dilution factor as the samples for ICP-OES and ICP-MS. These samples may have been contaminated by elements present in the laboratory setting.

Precision was determined by calculating the relative percent difference (RPD) of lab duplicates. QA/QC results for metals and anions confirm that all lab duplicates are within $20 \%$ precision with the exceptions of trace elements $\mathrm{B}, \mathrm{P}, \mathrm{Be}, \mathrm{Ce}, \mathrm{Eu}, \mathrm{Ga}, \mathrm{Tb}$, and $\mathrm{Y}$. 


\begin{tabular}{|c|c|c|c|c|c|c|}
\hline & Symbol & Units & $\begin{array}{l}\text { All Mine Sites } \\
\text { Detection limit }\end{array}$ & Blank & Blank & \%Diff Blanks \\
\hline Aluminium & $\mathrm{Al}$ & $\mathrm{ug} / \mathrm{g}$ & 10 & 23 & 19 & $19 \%$ \\
\hline Antimony & $\mathrm{Sb}$ & $u g / g$ & 1 & 1 & 1 & $0 \%$ \\
\hline Arsenic & As & $u g / g$ & 1 & 1 & 0.5 & $0 \%$ \\
\hline Barium & $\mathrm{Ba}$ & $u g / g$ & 1 & 1 & 1.0 & $0 \%$ \\
\hline Beryllium & $\mathrm{Be}$ & $u g / g$ & 0 & 0 & 0.05 & $0 \%$ \\
\hline Boron & $B$ & $u g / g$ & 20 & 20 & 20 & $0 \%$ \\
\hline Cadmium & $\mathrm{Cd}$ & $u g / g$ & 0 & 0 & 0.05 & $0 \%$ \\
\hline Calcium & $\mathrm{Ca}$ & $u g / g$ & 100 & 100 & 100 & $0 \%$ \\
\hline Cerium & $\mathrm{Ce}$ & $\mathrm{ug} / \mathrm{g}$ & 0 & 0 & 0.05 & $0 \%$ \\
\hline Cesium & Cs & $u g / g$ & - & - & - & - \\
\hline Chromium & $\mathrm{Cr}$ & $\mathrm{ug} / \mathrm{g}$ & 1 & 1 & 1 & $0 \%$ \\
\hline Cobalt & Co & $\mathrm{ug} / \mathrm{g}$ & 0 & 0 & 0.1 & $0 \%$ \\
\hline Copper & $\mathrm{Cu}$ & $\mathrm{ug} / \mathrm{g}$ & 2 & 2 & 42.0 & $182 \%$ \\
\hline Dysprosium & Dy & $u g / g$ & 0 & 0 & 0.025 & $0 \%$ \\
\hline Erbium & $\mathrm{Er}$ & $\mathrm{ug} / \mathrm{g}$ & 0 & 0 & 0.025 & $0 \%$ \\
\hline Europium & $\mathrm{Eu}$ & $u g / g$ & 0 & 0 & 0.025 & $0 \%$ \\
\hline Gadolinium & Gd & $\mathrm{ug} / \mathrm{g}$ & 0 & 0 & 0.025 & $0 \%$ \\
\hline Gallium & $\mathrm{Ga}$ & $u g / g$ & 1 & 1 & 0.5 & $0 \%$ \\
\hline Germanium & $\mathrm{Ge}$ & $\mathrm{ug} / \mathrm{g}$ & 5 & 5 & 5 & $0 \%$ \\
\hline Hafnium & $\mathrm{Hf}$ & $u g / g$ & - & - & - & - \\
\hline Holonium & Ho & $\mathrm{ug} / \mathrm{g}$ & 0 & 0 & 0.025 & $0 \%$ \\
\hline Iridium & Ir & $u g / g$ & 0 & 0 & 0.1 & $0 \%$ \\
\hline Iron & $\mathrm{Fe}$ & $u g / g$ & 20 & 20 & 20 & $0 \%$ \\
\hline Lanthanum & $\mathrm{La}$ & $u g / g$ & 0 & 0 & 0.05 & $0 \%$ \\
\hline Lead & $\mathrm{Pb}$ & $u g / g$ & 1 & 1 & 1 & $0 \%$ \\
\hline Lithium & $\mathrm{Li}$ & $\mathrm{ug} / \mathrm{g}$ & 1 & 0.62 & 2.5 & $121 \%$ \\
\hline Lutetium & $\mathrm{Lu}$ & $\mathrm{ug} / \mathrm{g}$ & 0 & 0 & 0.025 & $0 \%$ \\
\hline Magnesium & $\mathrm{Mg}$ & $u g / g$ & 20 & 20 & 20 & $0 \%$ \\
\hline Manganese & $\mathrm{Mn}$ & $u g / g$ & 1 & 1 & 1.0 & $0 \%$ \\
\hline Molybdenum & Mo & $\mathrm{ug} / \mathrm{g}$ & 1 & 1 & 0.5 & $0 \%$ \\
\hline Neodymium & $\mathrm{Nd}$ & $u g / g$ & 0 & 0 & 0.025 & $0 \%$ \\
\hline Nickel & $\mathrm{Ni}$ & $\mathrm{ug} / \mathrm{g}$ & 1 & 1 & 0.5 & $0 \%$ \\
\hline Niobium & $\mathrm{Nb}$ & $\mathrm{ug} / \mathrm{g}$ & 0 & 0 & 0.05 & $0 \%$ \\
\hline Palladium & $\mathrm{Pd}$ & $\mathrm{ug} / \mathrm{g}$ & - & - & - & - \\
\hline Phosphorus & $\mathrm{P}$ & $u g / g$ & 20 & 20 & 20 & $0 \%$ \\
\hline Platinum & $\mathrm{Pt}$ & $\mathrm{ug} / \mathrm{g}$ & 0 & 0 & 0.05 & $0 \%$ \\
\hline Potassium & $\mathrm{K}$ & $u g / g$ & 50 & 50 & 89 & $56 \%$ \\
\hline Praseodymium & $\operatorname{Pr}$ & $\mathrm{ug} / \mathrm{g}$ & 0 & 0 & 0.025 & $0 \%$ \\
\hline Rhenium & $\operatorname{Re}$ & $u g / g$ & 0 & 0 & 0.05 & $0 \%$ \\
\hline Rhodium & $\mathrm{Rh}$ & $\mathrm{ug} / \mathrm{g}$ & 0 & 0 & 0.05 & $0 \%$ \\
\hline Rubidium & $\mathrm{Rb}$ & $u g / g$ & 0 & 0 & 0.25 & $0 \%$ \\
\hline Ruthenium & $\mathrm{Ru}$ & $\mathrm{ug} / \mathrm{g}$ & 0 & 0 & 0.05 & $0 \%$ \\
\hline Samarium & $\mathrm{Sm}$ & $u g / g$ & 0 & 0 & 0.0 & $0 \%$ \\
\hline Selenium & $\mathrm{Se}$ & $u g / g$ & 0 & 0 & 0.25 & $0 \%$ \\
\hline Silver & $\mathrm{Ag}$ & $u g / g$ & 0 & 0 & 0.1 & $0 \%$ \\
\hline Sodium & $\mathrm{Na}$ & $\mathrm{ug} / \mathrm{g}$ & 75 & 75 & 100 & $29 \%$ \\
\hline Strontium & $\mathrm{Sr}$ & $\mathrm{ug} / \mathrm{g}$ & 1 & 1 & 1 & $0 \%$ \\
\hline Sulfur & $S$ & $u g / g$ & 25 & 25 & 35 & $33 \%$ \\
\hline Tantalum & $\mathrm{Ta}$ & $\mathrm{ug} / \mathrm{g}$ & 0 & 0 & 0.025 & $0 \%$ \\
\hline Terbium & $\mathrm{Tb}$ & $\mathrm{ug} / \mathrm{g}$ & 0 & 0 & 0.025 & $0 \%$ \\
\hline Tellurium & $\mathrm{Te}$ & $\mathrm{ug} / \mathrm{g}$ & 0 & 0 & 0.1 & $0 \%$ \\
\hline Thalium & $\mathrm{Tl}$ & $\mathrm{ug} / \mathrm{g}$ & 0 & 0 & 0.025 & $0 \%$ \\
\hline Thorium & Th & $\mathrm{ug} / \mathrm{g}$ & - & - & - & - \\
\hline Thulium & $\operatorname{Tm}$ & $\mathrm{ug} / \mathrm{g}$ & 0 & 0 & 0.025 & $0 \%$ \\
\hline Tin & Sn & $\mathrm{ug} / \mathrm{g}$ & 0 & 0 & 0.2 & $0 \%$ \\
\hline Titanium & $\mathrm{Ti}$ & $\mathrm{ug} / \mathrm{g}$ & 1 & 1 & 1 & $0 \%$ \\
\hline Tungsten & W & $u g / g$ & 0 & 0 & 0.1 & $0 \%$ \\
\hline Uranium & U & $u g / g$ & 0 & 0 & 0.025 & $0 \%$ \\
\hline Vanadium & V & $\mathrm{ug} / \mathrm{g}$ & 0 & 0 & 0.1 & $0 \%$ \\
\hline Ytterbium & $\mathrm{Yb}$ & $u g / g$ & 0 & 0 & 0.0 & $0 \%$ \\
\hline Yttrium & $Y$ & $\mathrm{ug} / \mathrm{g}$ & 0 & 0 & 0.3 & $0 \%$ \\
\hline Zinc & $\mathrm{Zn}$ & $u g / g$ & 5 & 5 & 5.3 & $6 \%$ \\
\hline Zirconium & $\mathrm{Zr}$ & $\mathrm{ug} / \mathrm{g}$ & 1 & 1 & 0.5 & $0 \%$ \\
\hline
\end{tabular}




\begin{tabular}{|c|c|c|c|c|c|c|}
\hline & & & Sample name & IN13-P2 & IN13-P2 & \multirow[b]{2}{*}{ \%Diff } \\
\hline & Symbol & Units & Detection limit & \multicolumn{2}{|c|}{ Lab Duplicate } & \\
\hline Aluminium & $\mathrm{Al}$ & $u g / g$ & 10 & 11000 & 11000 & $0 \%$ \\
\hline Antimony & $\mathrm{Sb}$ & $u g / g$ & 1 & 7.4 & 7.2 & $3 \%$ \\
\hline Arsenic & As & $u g / g$ & 1 & 5.5 & 5.6 & $2 \%$ \\
\hline Barium & $\mathrm{Ba}$ & $u g / g$ & 1 & 1.0 & 1 & $0 \%$ \\
\hline Beryllium & $\mathrm{Be}$ & $u g / g$ & 0 & 2.9 & 3.0 & $3 \%$ \\
\hline Boron & $B$ & $u g / g$ & 20 & 470 & 760 & $47 \%$ \\
\hline Cadmium & $\mathrm{Cd}$ & $u g / g$ & 0 & 10 & 11 & $10 \%$ \\
\hline Calcium & $\mathrm{Ca}$ & $u g / g$ & 100 & 1300 & 1400 & $7 \%$ \\
\hline Cerium & $\mathrm{Ce}$ & $u g / g$ & 0 & 0.40 & 0.37 & $8 \%$ \\
\hline Cesium & Cs & $u g / g$ & - & - & - & - \\
\hline Chromium & $\mathrm{Cr}$ & $u g / g$ & 1 & 1 & 1 & $0 \%$ \\
\hline Cobalt & Co & $u g / g$ & 0 & 44 & 44 & $0 \%$ \\
\hline Copper & $\mathrm{Cu}$ & $u g / g$ & 2 & 4800 & 5500 & $14 \%$ \\
\hline Dysprosium & Dy & $u g / g$ & 0 & 0.20 & 0.20 & $0 \%$ \\
\hline Erbium & $\mathrm{Er}$ & $u g / g$ & 0 & 0.22 & 0.23 & $4 \%$ \\
\hline Europium & $\mathrm{Eu}$ & $u g / g$ & 0 & 0 & 0 & $0 \%$ \\
\hline Gadolinium & Gd & $u g / g$ & 0 & 0.14 & 0.14 & $0 \%$ \\
\hline Gallium & $\mathrm{Ga}$ & $u g / g$ & 1 & 1 & 1 & $0 \%$ \\
\hline Germanium & $\mathrm{Ge}$ & $u g / g$ & 5 & 5 & 5 & $0 \%$ \\
\hline Hafnium & $\mathrm{Hf}$ & $u g / g$ & - & - & - & - \\
\hline Holonium & $\mathrm{Ho}$ & $u g / g$ & 0 & 0.055 & 0.061 & $10 \%$ \\
\hline Iridium & Ir & $u g / g$ & 0 & 0 & 0 & $0 \%$ \\
\hline Iron & $\mathrm{Fe}$ & $u g / g$ & 20 & 220 & 220 & $0 \%$ \\
\hline Lanthanum & $\mathrm{La}$ & $u g / g$ & 0 & 0.22 & 0.23 & $4 \%$ \\
\hline Lead & $\mathrm{Pb}$ & $u g / g$ & 1 & 0.62 & 0.69 & $11 \%$ \\
\hline Lithium & $\mathrm{Li}$ & $u g / g$ & 1 & 1400 & 1400 & $0 \%$ \\
\hline Lutetium & $\mathrm{Lu}$ & $u g / g$ & 0 & 0.048 & 0.047 & $2 \%$ \\
\hline Magnesium & $\mathrm{Mg}$ & $u g / g$ & 20 & 39000 & 40000 & $3 \%$ \\
\hline Manganese & $\mathrm{Mn}$ & $u g / g$ & 1 & 4500 & 4900 & $9 \%$ \\
\hline Molybdenum & Mo & $u g / g$ & 1 & 1 & 1 & $0 \%$ \\
\hline Neodymium & $\mathrm{Nd}$ & $u g / g$ & 0 & 0.22 & 0.19 & $15 \%$ \\
\hline Nickel & $\mathrm{Ni}$ & $u g / g$ & 1 & 29 & 30 & $3 \%$ \\
\hline Niobium & $\mathrm{Nb}$ & $u g / g$ & 0 & 0 & 0 & $0 \%$ \\
\hline Palladium & $\mathrm{Pd}$ & $u g / g$ & - & - & - & - \\
\hline Phosphorus & $\mathrm{P}$ & $u g / g$ & 20 & 130 & 100 & $26 \%$ \\
\hline Platinum & $\mathrm{Pt}$ & $u g / g$ & 0 & 0 & 0 & $0 \%$ \\
\hline Potassium & $\mathrm{K}$ & $u g / g$ & 50 & 8400 & 8900 & $6 \%$ \\
\hline Praseodymium & Pr & $u g / g$ & 0 & 0.047 & 0.045 & $4 \%$ \\
\hline Rhenium & $\mathrm{Re}$ & $u g / g$ & 0 & 0.21 & 0.23 & $9 \%$ \\
\hline Rhodium & $\mathrm{Rh}$ & $u g / g$ & 0 & 0 & 0 & $0 \%$ \\
\hline Rubidium & $\mathrm{Rb}$ & $u g / g$ & 0 & 54 & 59 & $9 \%$ \\
\hline Ruthenium & $\mathrm{Ru}$ & $u g / g$ & 0 & 0 & 0 & $0 \%$ \\
\hline Samarium & $\mathrm{Sm}$ & $u g / g$ & 0 & 0.048 & 0.044 & $9 \%$ \\
\hline Selenium & $\mathrm{Se}$ & $u g / g$ & 0 & 0.25 & 0 & $0 \%$ \\
\hline Silver & $\mathrm{Ag}$ & $u g / g$ & 0 & 0 & 0 & $0 \%$ \\
\hline Sodium & $\mathrm{Na}$ & $u g / g$ & 75 & 130000 & 140000 & $7 \%$ \\
\hline Strontium & $\mathrm{Sr}$ & $u g / g$ & 1 & 31 & 30 & $3 \%$ \\
\hline Sulfur & $S$ & $u g / g$ & 25 & 110000 & 120000 & $9 \%$ \\
\hline Tantalum & $\mathrm{Ta}$ & $u g / g$ & 0 & 0 & 0 & $0 \%$ \\
\hline Terbium & $\mathrm{Tb}$ & $u g / g$ & 0 & 0.027 & 0 & $8 \%$ \\
\hline Tellurium & $\mathrm{Te}$ & $u g / g$ & 0 & 0 & 0 & $0 \%$ \\
\hline Thalium & $\mathrm{T}$ & $u g / g$ & 0 & 0.18 & 0.20 & $11 \%$ \\
\hline Thorium & Th & $u g / g$ & - & - & - & - \\
\hline Thulium & $\mathrm{Tm}$ & $u g / g$ & 0 & 0.036 & 0.034 & $6 \%$ \\
\hline Tin & Sn & $u g / g$ & 0 & 0 & 0 & $0 \%$ \\
\hline Titanium & $\mathrm{Ti}$ & $u g / g$ & 1 & 5.1 & 5.6 & $9 \%$ \\
\hline Tungsten & W & $u g / g$ & 0 & 0 & 0 & $0 \%$ \\
\hline Uranium & $U$ & $u g / g$ & 0 & 4.6 & 5.0 & $8 \%$ \\
\hline Vanadium & V & $u g / g$ & 0 & 0.38 & 0.40 & $5 \%$ \\
\hline Ytterbium & $\mathrm{Yb}$ & $u g / g$ & 0 & 0.27 & 0.25 & $8 \%$ \\
\hline Yttrium & $\mathrm{Y}$ & $u g / g$ & 0 & 2.5 & 2.5 & $0 \%$ \\
\hline Zinc & $\mathrm{Zn}$ & $u g / g$ & 5 & 1400 & 1600 & $13 \%$ \\
\hline Zirconium & $\mathrm{Zr}$ & $\mathrm{ug} / \mathrm{g}$ & 1 & 1 & 1 & $0 \%$ \\
\hline
\end{tabular}




\begin{tabular}{|c|c|c|c|c|c|c|}
\hline & \multirow[b]{2}{*}{ Symbol } & \multirow[b]{2}{*}{ Units } & \multirow{2}{*}{$\begin{array}{c}\text { Sample name } \\
\text { Detection limit }\end{array}$} & P-PW-Pc & P-PW-Pc & \multirow[b]{2}{*}{ \%Diff } \\
\hline & & & & \multicolumn{2}{|c|}{ Lab Duplicate } & \\
\hline Aluminium & $\mathrm{Al}$ & $u g / g$ & 10 & 4400 & 4400 & $0 \%$ \\
\hline Antimony & $\mathrm{Sb}$ & $\mathrm{ug} / \mathrm{g}$ & 1 & 2.1 & 2.1 & $0 \%$ \\
\hline Arsenic & As & $u g / g$ & 1 & 270 & 240 & $12 \%$ \\
\hline Barium & $\mathrm{Ba}$ & $u g / g$ & 1 & 27 & 22 & $20 \%$ \\
\hline Beryllium & $\mathrm{Be}$ & $\mathrm{ug} / \mathrm{g}$ & 0 & 0.093 & 0.067 & $33 \%$ \\
\hline Boron & $\mathrm{B}$ & $u g / g$ & 20 & 20 & 20 & $0 \%$ \\
\hline Cadmium & $\mathrm{Cd}$ & $u g / g$ & 0 & 1.3 & 1.3 & $0 \%$ \\
\hline Calcium & $\mathrm{Ca}$ & $\mathrm{ug} / \mathrm{g}$ & 100 & 730 & 920 & $23 \%$ \\
\hline Cerium & $\mathrm{Ce}$ & $\mathrm{ug} / \mathrm{g}$ & 0 & 2.6 & 2.3 & $12 \%$ \\
\hline Cesium & Cs & $\mathrm{ug} / \mathrm{g}$ & - & - & - & - \\
\hline Chromium & $\mathrm{Cr}$ & $\mathrm{ug} / \mathrm{g}$ & 1 & 3.4 & 3.0 & $13 \%$ \\
\hline Cobalt & Co & $u g / g$ & 0 & 40 & 37 & $8 \%$ \\
\hline Copper & $\mathrm{Cu}$ & $u g / g$ & 2 & 1800 & 1600 & $12 \%$ \\
\hline Dysprosium & Dy & $\mathrm{ug} / \mathrm{g}$ & 0 & 0.21 & 0.20 & $5 \%$ \\
\hline Erbium & $\mathrm{Er}$ & $u g / g$ & 0 & 0.10 & 0.097 & $3 \%$ \\
\hline Europium & $\mathrm{Eu}$ & $u g / g$ & 0 & 0.071 & 0.049 & $37 \%$ \\
\hline Gadolinium & Gd & $\mathrm{ug} / \mathrm{g}$ & 0 & 0.25 & 0.21 & $17 \%$ \\
\hline Gallium & $\mathrm{Ga}$ & $\mathrm{ug} / \mathrm{g}$ & 1 & 5.1 & 4.1 & $22 \%$ \\
\hline Germanium & $\mathrm{Ge}$ & $u g / g$ & 5 & 5 & 5 & $0 \%$ \\
\hline Hafnium & $\mathrm{Hf}$ & $\mathrm{ug} / \mathrm{g}$ & - & - & - & - \\
\hline Holonium & $\mathrm{Ho}$ & $\mathrm{ug} / \mathrm{g}$ & 0 & 0.040 & 0.034 & $16 \%$ \\
\hline Iridium & Ir & $u g / g$ & 0 & 0 & 0 & $0 \%$ \\
\hline Iron & $\mathrm{Fe}$ & $u g / g$ & 20 & 170000 & 150000 & $13 \%$ \\
\hline Lanthanum & $\mathrm{La}$ & $\mathrm{ug} / \mathrm{g}$ & 0 & 1.3 & 1.1 & $17 \%$ \\
\hline Lead & $\mathrm{Pb}$ & $u g / g$ & 1 & 120 & 120 & $0 \%$ \\
\hline Lithium & $\mathrm{Li}$ & $\mathrm{ug} / \mathrm{g}$ & 1 & 2.7 & 2.1 & $25 \%$ \\
\hline Lutetium & $\mathrm{Lu}$ & $\mathrm{ug} / \mathrm{g}$ & 0 & 0 & 0 & $0 \%$ \\
\hline Magnesium & $\mathrm{Mg}$ & $\mathrm{ug} / \mathrm{g}$ & 20 & 500 & 480 & $4 \%$ \\
\hline Manganese & $\mathrm{Mn}$ & $u g / g$ & 1 & 220 & 230 & $4 \%$ \\
\hline Molybdenum & Mo & $\mathrm{ug} / \mathrm{g}$ & 1 & 0.53 & 1 & $6 \%$ \\
\hline Neodymium & $\mathrm{Nd}$ & $\mathrm{ug} / \mathrm{g}$ & 0 & 1.3 & 1.2 & $8 \%$ \\
\hline Nickel & $\mathrm{Ni}$ & $u g / g$ & 1 & 22 & 20 & $10 \%$ \\
\hline Niobium & $\mathrm{Nb}$ & $\mathrm{ug} / \mathrm{g}$ & 0 & 0.066 & 0.060 & $10 \%$ \\
\hline Palladium & $\mathrm{Pd}$ & $u g / g$ & - & - & - & - \\
\hline Phosphorus & $\mathrm{P}$ & $\mathrm{ug} / \mathrm{g}$ & 20 & 150 & 150 & $0 \%$ \\
\hline Platinum & $\mathrm{Pt}$ & $\mathrm{ug} / \mathrm{g}$ & 0 & 0 & 0 & $0 \%$ \\
\hline Potassium & $\mathrm{K}$ & $u g / g$ & 50 & 380 & 330 & $14 \%$ \\
\hline Praseodymium & $\mathrm{Pr}$ & $u g / g$ & 0 & 0.32 & 0.28 & $13 \%$ \\
\hline Rhenium & $\mathrm{Re}$ & $\mathrm{ug} / \mathrm{g}$ & 0 & 0 & 0 & $0 \%$ \\
\hline Rhodium & $\mathrm{Rh}$ & $\mathrm{ug} / \mathrm{g}$ & 0 & 0 & 0 & $0 \%$ \\
\hline Rubidium & $\mathrm{Rb}$ & $\mathrm{ug} / \mathrm{g}$ & 0 & 1.7 & 1.5 & $13 \%$ \\
\hline Ruthenium & $\mathrm{Ru}$ & $\mathrm{ug} / \mathrm{g}$ & 0 & 0 & 0 & $0 \%$ \\
\hline Samarium & $\mathrm{Sm}$ & $\mathrm{ug} / \mathrm{g}$ & 0 & 0.26 & 0.24 & $8 \%$ \\
\hline Selenium & $\mathrm{Se}$ & $u g / g$ & 0 & 1.0 & 1.1 & $10 \%$ \\
\hline Silver & $\mathrm{Ag}$ & $\mathrm{ug} / \mathrm{g}$ & 0 & 0.23 & 0.21 & $9 \%$ \\
\hline Sodium & $\mathrm{Na}$ & $u g / g$ & 75 & 140 & 130 & $7 \%$ \\
\hline Strontium & $\mathrm{Sr}$ & $\mathrm{ug} / \mathrm{g}$ & 1 & 6.1 & 5.3 & $14 \%$ \\
\hline Sulfur & $S$ & $\mathrm{ug} / \mathrm{g}$ & 25 & 120000 & 110000 & $9 \%$ \\
\hline Tantalum & $\mathrm{Ta}$ & $\mathrm{ug} / \mathrm{g}$ & 0 & 0 & 0 & $0 \%$ \\
\hline Terbium & $\mathrm{Tb}$ & $\mathrm{ug} / \mathrm{g}$ & 0 & 0.035 & 0.028 & $22 \%$ \\
\hline Tellurium & $\mathrm{Te}$ & $\mathrm{ug} / \mathrm{g}$ & 0 & 1.2 & 1.2 & $0 \%$ \\
\hline Thalium & $\mathrm{T}$ & $u g / g$ & 0 & 1.8 & 1.7 & $6 \%$ \\
\hline Thorium & Th & $\mathrm{ug} / \mathrm{g}$ & - & - & - & - \\
\hline Thulium & $\mathrm{Tm}$ & $\mathrm{ug} / \mathrm{g}$ & 0 & 0 & 0 & $0 \%$ \\
\hline Tin & Sn & $\mathrm{ug} / \mathrm{g}$ & 0 & 2.9 & 2.7 & $7 \%$ \\
\hline Titanium & $\mathrm{Ti}$ & $u g / g$ & 1 & 12 & 13 & $8 \%$ \\
\hline Tungsten & W & $\mathrm{ug} / \mathrm{g}$ & 0 & 0.20 & 0.18 & $11 \%$ \\
\hline Uranium & $U$ & $\mathrm{ug} / \mathrm{g}$ & 0 & 1.3 & 1.2 & $8 \%$ \\
\hline Vanadium & $\mathrm{V}$ & $\mathrm{ug} / \mathrm{g}$ & 0 & 9.2 & 8.2 & $11 \%$ \\
\hline Ytterbium & $\mathrm{Yb}$ & $u g / g$ & 0 & 0.091 & 0.080 & $13 \%$ \\
\hline Yttrium & $\mathrm{Y}$ & $\mathrm{ug} / \mathrm{g}$ & 0 & 1.1 & 0.86 & $24 \%$ \\
\hline Zinc & $\mathrm{Zn}$ & $u g / g$ & 5 & 89 & 94 & $5 \%$ \\
\hline Zirconium & $\mathrm{Zr}$ & $\mathrm{ug} / \mathrm{g}$ & 1 & 2.3 & 1.9 & $19 \%$ \\
\hline
\end{tabular}




\begin{tabular}{|c|c|c|c|c|c|c|c|}
\hline & & & Sample name & & & & \\
\hline & Symbol & Units & Detection limit & IN13-P1 & IN13-P3 & IN13-P4 & IN13-P5 \\
\hline Aluminium & $\mathrm{Al}$ & $\mathrm{ug} / \mathrm{g}$ & 10 & 10000 & 5800 & 6300 & 8500 \\
\hline Antimony & $\mathrm{Sb}$ & $u g / g$ & 1 & 220 & 6.7 & 2.5 & 1.1 \\
\hline Arsenic & As & $u g / g$ & 1 & 11 & 18 & 46 & 30 \\
\hline Barium & $\mathrm{Ba}$ & $u g / g$ & 1 & 3.8 & 4.7 & 13 & 6.3 \\
\hline Beryllium & $\mathrm{Be}$ & $u g / g$ & 0 & 1.7 & 1.0 & 1.4 & 3.0 \\
\hline Boron & B & $\mathrm{ug} / \mathrm{g}$ & 20 & 140 & 690 & 130 & 160 \\
\hline Cadmium & $\mathrm{Cd}$ & $\mathrm{ug} / \mathrm{g}$ & 0 & 7.5 & 7.9 & 11 & 9.1 \\
\hline Calcium & $\mathrm{Ca}$ & $u g / g$ & 100 & 19000 & 9800 & 20000 & 22000 \\
\hline Cerium & $\mathrm{Ce}$ & $\mathrm{ug} / \mathrm{g}$ & 0 & 2.6 & 2.3 & 6.3 & 5.0 \\
\hline Cesium & Cs & $\mathrm{ug} / \mathrm{g}$ & - & - & - & - & - \\
\hline Chromium & $\mathrm{Cr}$ & $\mathrm{ug} / \mathrm{g}$ & 1 & 1 & 1 & 1.4 & 1 \\
\hline Cobalt & Co & $u g / g$ & 0 & 49 & 50 & 43 & 51 \\
\hline Copper & $\mathrm{Cu}$ & $u g / g$ & 2 & 3100 & 3400 & 3000 & 4800 \\
\hline Dysprosium & Dy & $\mathrm{ug} / \mathrm{g}$ & 0 & 0.66 & 0.41 & 0.66 & 1.1 \\
\hline Erbium & $\mathrm{Er}$ & $\mathrm{ug} / \mathrm{g}$ & 0 & 0.43 & 0.25 & 0.39 & 0.63 \\
\hline Europium & Eu & $\mathrm{ug} / \mathrm{g}$ & 0 & 0.13 & 0.11 & 0.19 & 0.23 \\
\hline Gadolinium & $\mathrm{Gd}$ & $\mathrm{ug} / \mathrm{g}$ & 0 & 0.72 & 0.43 & 0.86 & 1.1 \\
\hline Gallium & $\mathrm{Ga}$ & $\mathrm{ug} / \mathrm{g}$ & 1 & 1 & 1 & 1.6 & 0.63 \\
\hline Germanium & $\mathrm{Ge}$ & $\mathrm{ug} / \mathrm{g}$ & 5 & 5 & 5 & 5 & 5 \\
\hline Hafnium & $\mathrm{Hf}$ & $u g / g$ & - & - & - & - & - \\
\hline Holonium & $\mathrm{Ho}$ & $\mathrm{ug} / \mathrm{g}$ & 0 & 0.15 & 0.086 & 0.14 & 0.22 \\
\hline Iridium & Ir & $\mathrm{ug} / \mathrm{g}$ & 0 & 0 & 0 & 0 & 0 \\
\hline Iron & $\mathrm{Fe}$ & $\mathrm{ug} / \mathrm{g}$ & 20 & 1500 & 1600 & 5900 & 2600 \\
\hline Lanthanum & $\mathrm{La}$ & $\mathrm{ug} / \mathrm{g}$ & 0 & 1.2 & 0.97 & 2.9 & 2.4 \\
\hline Lead & $\mathrm{Pb}$ & $u g / g$ & 1 & 1.0 & 1.3 & 3.8 & 1.7 \\
\hline Lithium & $\mathrm{Li}$ & $\mathrm{ug} / \mathrm{g}$ & 1 & 570 & 1000 & 890 & 1100 \\
\hline Lutetium & Lu & $\mathrm{ug} / \mathrm{g}$ & 0 & 0.057 & 0.042 & 0.048 & 0.095 \\
\hline Magnesium & $\mathrm{Mg}$ & $\mathrm{ug} / \mathrm{g}$ & 20 & 39000 & 45000 & 38000 & 39000 \\
\hline Manganese & $\mathrm{Mn}$ & $\mathrm{ug} / \mathrm{g}$ & 1 & 4500 & 8000 & 4500 & 5000 \\
\hline Molybdenum & Mo & $\mathrm{ug} / \mathrm{g}$ & 1 & 1 & 1 & 1 & 1 \\
\hline Neodymium & $\mathrm{Nd}$ & $\mathrm{ug} / \mathrm{g}$ & 0 & 1.7 & 1.4 & 3.4 & 3.2 \\
\hline Nickel & $\mathrm{Ni}$ & $\mathrm{ug} / \mathrm{g}$ & 1 & 32 & 35 & 27 & 37 \\
\hline Niobium & $\mathrm{Nb}$ & $\mathrm{ug} / \mathrm{g}$ & 0 & 0 & 0 & 0.18 & 0.068 \\
\hline Palladium & $\mathrm{Pd}$ & $\mathrm{ug} / \mathrm{g}$ & - & - & - & - & - \\
\hline Phosphorus & $P$ & $\mathrm{ug} / \mathrm{g}$ & 20 & 91 & 110 & 200 & 130 \\
\hline Platinum & $\mathrm{Pt}$ & $\mathrm{ug} / \mathrm{g}$ & 0 & 0 & 0 & 0 & 0 \\
\hline Potassium & $\mathrm{K}$ & $\mathrm{ug} / \mathrm{g}$ & 50 & 7800 & 6800 & 6600 & 10000 \\
\hline Praseodymium & $\mathrm{Pr}$ & $\mathrm{ug} / \mathrm{g}$ & 0 & 0.39 & 0.32 & 0.83 & 0.72 \\
\hline Rhenium & $\operatorname{Re}$ & $\mathrm{ug} / \mathrm{g}$ & 0 & 0.13 & 0.24 & 0.13 & 0.24 \\
\hline Rhodium & $\mathrm{Rh}$ & $\mathrm{ug} / \mathrm{g}$ & 0 & 0 & 0 & 0 & 0 \\
\hline Rubidium & $\mathrm{Rb}$ & $\mathrm{ug} / \mathrm{g}$ & 0 & 68 & 58 & 49 & 69 \\
\hline Ruthenium & $\mathrm{Ru}$ & $\mathrm{ug} / \mathrm{g}$ & 0 & 0 & 0 & 0 & 0 \\
\hline Samarium & $\mathrm{Sm}$ & $\mathrm{ug} / \mathrm{g}$ & 0 & 0.47 & 0.36 & 0.74 & 0.78 \\
\hline Selenium & $\mathrm{Se}$ & $\mathrm{ug} / \mathrm{g}$ & 0 & 0 & 0.52 & 0 & 0.56 \\
\hline Silver & $\mathrm{Ag}$ & $\mathrm{ug} / \mathrm{g}$ & 0 & 0 & 0.32 & 0.29 & 0 \\
\hline Sodium & $\mathrm{Na}$ & $\mathrm{ug} / \mathrm{g}$ & 75 & 120000 & 120000 & 120000 & 110000 \\
\hline Strontium & $\mathrm{Sr}$ & $\mathrm{ug} / \mathrm{g}$ & 1 & 130 & 49 & 100 & 140 \\
\hline Sulfur & $S$ & $\mathrm{ug} / \mathrm{g}$ & 25 & 140000 & 83000 & 98000 & 130000 \\
\hline Tantalum & $\mathrm{Ta}$ & $\mathrm{ug} / \mathrm{g}$ & 0 & 0 & 0 & 0 & 0 \\
\hline Terbium & $\mathrm{Tb}$ & $\mathrm{ug} / \mathrm{g}$ & 0 & 0.12 & 0.062 & 0.12 & 0.17 \\
\hline Tellurium & $\mathrm{Te}$ & $\mathrm{ug} / \mathrm{g}$ & 0 & 0 & 0 & 0 & 0 \\
\hline Thalium & $\mathrm{Tl}$ & $\mathrm{ug} / \mathrm{g}$ & 0 & 0.18 & 0.63 & 0.31 & 0.21 \\
\hline Thorium & Th & $\mathrm{ug} / \mathrm{g}$ & - & - & - & - & - \\
\hline Thulium & $\mathrm{Tm}$ & $\mathrm{ug} / \mathrm{g}$ & 0 & 0.060 & 0.038 & 0.053 & 0.091 \\
\hline Tin & Sn & $\mathrm{ug} / \mathrm{g}$ & 0 & 0.32 & 0 & 0 & 0 \\
\hline Titanium & $\mathrm{Ti}$ & $\mathrm{ug} / \mathrm{g}$ & 1 & 42 & 45 & 140 & 54 \\
\hline Tungsten & W & $\mathrm{ug} / \mathrm{g}$ & 0 & 0 & 0 & 0.13 & 0 \\
\hline Uranium & $U$ & $\mathrm{ug} / \mathrm{g}$ & 0 & 2.8 & 3.5 & 3.4 & 4.9 \\
\hline Vanadium & V & $\mathrm{ug} / \mathrm{g}$ & 0 & 1.9 & 3.0 & 9.8 & 4.7 \\
\hline Ytterbium & $\mathrm{Yb}$ & $\mathrm{ug} / \mathrm{g}$ & 0 & 0.40 & 0.24 & 0.31 & 0.58 \\
\hline Yttrium & $\mathrm{Y}$ & $\mathrm{ug} / \mathrm{g}$ & 0 & 4.9 & 3.0 & 4.3 & 8.0 \\
\hline Zinc & $\mathrm{Zn}$ & $\mathrm{ug} / \mathrm{g}$ & 5 & 1100 & 2700 & 1500 & 1400 \\
\hline Zirconium & $\mathrm{Zr}$ & $u g / g$ & 1 & 0.64 & 1 & 1.6 & 0.86 \\
\hline
\end{tabular}




\begin{tabular}{|c|c|c|c|c|c|c|c|c|}
\hline & \multicolumn{4}{|c|}{ Sample name } & \multirow[b]{2}{*}{ IN28-P4 } & \multirow[b]{2}{*}{ IN2-P1 } & \multirow[b]{2}{*}{ IN2-P2 } & \multirow[b]{2}{*}{ IN2-P3 } \\
\hline & Symbol & Units & Detection limit & IN28-P2 & & & & \\
\hline Aluminium & Al & ug/g & 10 & 39000 & 4300 & 11000 & 14000 & 23000 \\
\hline Antimony & $\mathrm{Sb}$ & $\mathrm{ug} / \mathrm{g}$ & 1 & 5.4 & 6.8 & 32 & 37 & 18 \\
\hline Arsenic & As & ug/g & 1 & 230 & 200 & 1600 & 950 & 610 \\
\hline Barium & $\mathrm{Ba}$ & $u g / g$ & 1 & 16 & 36 & 77 & 120 & 33 \\
\hline Beryllium & $\mathrm{Be}$ & $u g / g$ & 0 & 2.4 & 0.099 & 0.34 & 0.52 & 2.1 \\
\hline Boron & B & $u g / g$ & 20 & 25 & 31 & $<20$ & $<20$ & 98 \\
\hline Cadmium & $\mathrm{Cd}$ & $\mathrm{ug} / \mathrm{g}$ & 0 & 12 & 0.080 & 0.12 & 0.27 & 11 \\
\hline Calcium & $\mathrm{Ca}$ & $\mathrm{ug} / \mathrm{g}$ & 100 & 1200 & 520 & 2200 & 3800 & 39000 \\
\hline Cerium & $\mathrm{Ce}$ & $\mathrm{ug} / \mathrm{g}$ & 0 & 2.7 & 2.4 & 11 & 17 & 8.8 \\
\hline Cesium & Cs & $u g / g$ & - & - & - & - & - & - \\
\hline Chromium & $\mathrm{Cr}$ & $u g / g$ & 1 & 5.5 & 1.9 & 11 & 16 & 4.5 \\
\hline Cobalt & Co & $u g / g$ & 0 & 35 & 0.39 & 4.7 & 6.5 & 51 \\
\hline Copper & $\mathrm{Cu}$ & $u g / g$ & 2 & 14000 & 420 & 640 & 740 & 6900 \\
\hline Dysprosium & Dy & $\mathrm{ug} / \mathrm{g}$ & 0 & 1.4 & 0.11 & 0.68 & 0.96 & 1.6 \\
\hline Erbium & $\mathrm{Er}$ & $u g / g$ & 0 & 0.82 & 0.056 & 0.30 & 0.41 & 0.75 \\
\hline Europium & $\mathrm{Eu}$ & $u g / g$ & 0 & 0.20 & 0.043 & 0.30 & 0.44 & 0.41 \\
\hline Gadolinium & $\mathrm{Gd}$ & $u g / g$ & 0 & 1.1 & 0.14 & 0.95 & 1.4 & 1.8 \\
\hline Gallium & $\mathrm{Ga}$ & $u g / g$ & 1 & 1.5 & 0.98 & 5.4 & 8.0 & 3.5 \\
\hline Germanium & $\mathrm{Ge}$ & $u g / g$ & 5 & 5 & 5 & $<5.0$ & $<5.0$ & $<5.0$ \\
\hline Hafnium & $\mathrm{Hf}$ & $\mathrm{ug} / \mathrm{g}$ & - & - & - & - & - & - \\
\hline Holonium & Ho & $\mathrm{ug} / \mathrm{g}$ & 0 & 0.28 & 0 & 0.11 & 0.15 & 0.27 \\
\hline Iridium & Ir & $\mathrm{ug} / \mathrm{g}$ & 0 & 0 & 0 & $<0.1$ & $<0.1$ & $<0.1$ \\
\hline Iron & $\mathrm{Fe}$ & $\mathrm{ug} / \mathrm{g}$ & 20 & 30000 & 270000 & 320000 & 300000 & 100000 \\
\hline Lanthanum & La & $\mathrm{ug} / \mathrm{g}$ & 0 & 1.0 & 1.2 & 5.2 & 8.1 & 3.7 \\
\hline Lead & $\mathrm{Pb}$ & $u g / g$ & 1 & 8.5 & 22 & 30 & 43 & 15 \\
\hline Lithium & $\mathrm{Li}$ & $u g / g$ & 1 & 190 & 4.6 & 11 & 16 & 220 \\
\hline Lutetium & Lu & $u g / g$ & 0 & 0.085 & 0 & 0.033 & 0.041 & 0.073 \\
\hline Magnesium & $\mathrm{Mg}$ & $u g / g$ & 20 & 21000 & 340 & 3700 & 5300 & 23000 \\
\hline Manganese & $\mathrm{Mn}$ & $u g / g$ & 1 & 6700 & 240 & 440 & 550 & 4400 \\
\hline Molybdenum & Mo & $\mathrm{ug} / \mathrm{g}$ & 1 & 1 & 1 & 7.5 & 9.4 & 2.2 \\
\hline Neodymium & $\mathrm{Nd}$ & $\mathrm{ug} / \mathrm{g}$ & 0 & 1.8 & 1.1 & 5.3 & 7.9 & 5.0 \\
\hline Nickel & $\mathrm{Ni}$ & $\mathrm{ug} / \mathrm{g}$ & 1 & 27 & 0.92 & 2.9 & 9.4 & 38 \\
\hline Niobium & $\mathrm{Nb}$ & $u g / g$ & 0 & 0 & 0.073 & 0.33 & 0.57 & 0.42 \\
\hline Palladium & $\mathrm{Pd}$ & $u g / g$ & - & - & - & - & - & - \\
\hline Phosphorus & $P$ & $u g / g$ & 20 & 400 & 430 & 630 & 560 & 360 \\
\hline Platinum & $\mathrm{Pt}$ & $u g / g$ & 0 & 0 & 0 & $<0.05$ & $<0.05$ & $<0.05$ \\
\hline Potassium & $\mathrm{K}$ & $u g / g$ & 50 & 440 & 1200 & 1300 & 2100 & 2900 \\
\hline Praseodymium & $\operatorname{Pr}$ & $\mathrm{ug} / \mathrm{g}$ & 0 & 0.36 & 0.29 & 1.3 & 2.0 & 1.2 \\
\hline Rhenium & $\mathrm{Re}$ & $\mathrm{ug} / \mathrm{g}$ & 0 & 0.057 & 0 & $<0.05$ & $<0.05$ & 0.13 \\
\hline Rhodium & $\mathrm{Rh}$ & $\mathrm{ug} / \mathrm{g}$ & 0 & 0 & 0 & $<0.05$ & $<0.05$ & $<0.05$ \\
\hline Rubidium & $\mathrm{Rb}$ & $u g / g$ & 0 & 4.1 & 7.2 & 9.5 & 16 & 26 \\
\hline Ruthenium & $\mathrm{Ru}$ & $\mathrm{ug} / \mathrm{g}$ & 0 & 0 & 0 & $<0.05$ & $<0.05$ & $<0.05$ \\
\hline Samarium & $\mathrm{Sm}$ & $\mathrm{ug} / \mathrm{g}$ & 0 & 0.64 & 0.23 & 1.0 & 1.7 & 1.3 \\
\hline Selenium & $\mathrm{Se}$ & $\mathrm{ug} / \mathrm{g}$ & 0 & 0.59 & 0.34 & 2.0 & 1.7 & 1.1 \\
\hline Silver & $\mathrm{Ag}$ & $\mathrm{ug} / \mathrm{g}$ & 0 & 0.44 & 0.43 & 0.26 & 0.60 & 1.5 \\
\hline Sodium & $\mathrm{Na}$ & $u g / g$ & 75 & 1400 & 310 & 340 & 730 & 22000 \\
\hline Strontium & $\mathrm{Sr}$ & $u g / g$ & 1 & 9.9 & 28 & 46 & 67 & 150 \\
\hline Sulfur & $S$ & $\mathrm{ug} / \mathrm{g}$ & 25 & 140000 & 22000 & 32000 & 31000 & 120000 \\
\hline Tantalum & $\mathrm{Ta}$ & $u g / g$ & 0 & 0 & 0 & $<0.025$ & $<0.025$ & $<0.025$ \\
\hline Terbium & $\mathrm{Tb}$ & $u g / g$ & 0 & 0.20 & 0 & 0.14 & 0.18 & 0.26 \\
\hline Tellurium & $\mathrm{Te}$ & $\mathrm{ug} / \mathrm{g}$ & 0 & 0.77 & 0.39 & 1.7 & 2.9 & 3.6 \\
\hline Thalium & $\mathrm{TI}$ & $u g / g$ & 0 & 0.032 & 0.36 & 0.10 & 1.1 & 0.10 \\
\hline Thorium & Th & $u g / g$ & - & - & - & - & - & - \\
\hline Thulium & $\mathrm{Tm}$ & $\mathrm{ug} / \mathrm{g}$ & 0 & 0.11 & 0 & 0.036 & 0.052 & 0.095 \\
\hline Tin & Sn & $\mathrm{ug} / \mathrm{g}$ & 0 & 0.32 & 0.27 & 0.64 & 1.2 & 0.46 \\
\hline Titanium & $\mathrm{Ti}$ & $u g / g$ & 1 & 17 & 72 & 450 & 590 & 440 \\
\hline Tungsten & W & $\mathrm{ug} / \mathrm{g}$ & 0 & 0.34 & 0.35 & 2.9 & 2.8 & 0.82 \\
\hline Uranium & $U$ & $\mathrm{ug} / \mathrm{g}$ & 0 & 7.8 & 0.32 & 0.59 & 0.93 & 6.4 \\
\hline Vanadium & $\mathrm{V}$ & $u g / g$ & 0 & 8.2 & 47 & 34 & 48 & 22 \\
\hline Ytterbium & $\mathrm{Yb}$ & $u g / g$ & 0 & 0.67 & 0.037 & 0.22 & 0.31 & 0.60 \\
\hline Yttrium & $\mathrm{Y}$ & $\mathrm{ug} / \mathrm{g}$ & 0 & 8.4 & 0.39 & 2.7 & 4.3 & 7.7 \\
\hline Zinc & $\mathrm{Zn}$ & $\mathrm{ug} / \mathrm{g}$ & 5 & 4600 & 49 & 52 & 74 & 2000 \\
\hline Zirconium & $\mathrm{Zr}$ & $\mathrm{ug} / \mathrm{g}$ & 1 & 1 & 0.55 & 2.7 & 5.8 & 3.0 \\
\hline
\end{tabular}




\begin{tabular}{|c|c|c|c|c|c|c|c|}
\hline & & & Sample name & & & & \\
\hline & Symbol & Units & Detection limit & LNPW2-P1 & LNPW1-P2 & LNPW1-P1 & LN-VWD-P2 \\
\hline Aluminium & $\mathrm{Al}$ & $u g / g$ & 10 & 15000 & 250 & 250 & 8900 \\
\hline Antimony & $\mathrm{Sb}$ & $\mathrm{ug} / \mathrm{g}$ & 1 & 90 & 45 & 66 & 1.1 \\
\hline Arsenic & As & $u g / g$ & 1 & 490 & 130 & 200 & 15 \\
\hline Barium & $\mathrm{Ba}$ & $u g / g$ & 1 & 95 & 43 & 2.4 & 36 \\
\hline Beryllium & $\mathrm{Be}$ & $\mathrm{ug} / \mathrm{g}$ & 0 & 1.8 & $<0.05$ & 0 & 3.3 \\
\hline Boron & $\mathrm{B}$ & $\mathrm{ug} / \mathrm{g}$ & 20 & $<20$ & $<20$ & 20 & $<20$ \\
\hline Cadmium & $\mathrm{Cd}$ & $u g / g$ & 0 & 3.1 & 1.4 & 1.7 & 6.4 \\
\hline Calcium & $\mathrm{Ca}$ & $u g / g$ & 100 & 10000 & 4000 & 2400 & 200000 \\
\hline Cerium & $\mathrm{Ce}$ & $\mathrm{ug} / \mathrm{g}$ & 0 & 42 & 0.66 & 0.50 & 21 \\
\hline Cesium & Cs & $u g / g$ & - & - & - & - & - \\
\hline Chromium & $\mathrm{Cr}$ & $\mathrm{ug} / \mathrm{g}$ & 1 & 4.9 & 2.3 & 2.5 & 20 \\
\hline Cobalt & Co & $\mathrm{ug} / \mathrm{g}$ & 0 & 10 & 110 & 120 & 43 \\
\hline Copper & $\mathrm{Cu}$ & $\mathrm{ug} / \mathrm{g}$ & 2 & 150 & 180000 & 210000 & 950 \\
\hline Dysprosium & Dy & $\mathrm{ug} / \mathrm{g}$ & 0 & 2.2 & 0.037 & 0.054 & 1.4 \\
\hline Erbium & $\mathrm{Er}$ & $u g / g$ & 0 & 0.65 & $<0.025$ & 0.026 & 0.75 \\
\hline Europium & $\mathrm{Eu}$ & $u g / g$ & 0 & 1.0 & $<0.025$ & 0 & 0.45 \\
\hline Gadolinium & Gd & $\mathrm{ug} / \mathrm{g}$ & 0 & 3.4 & 0.072 & 0.065 & 1.8 \\
\hline Gallium & $\mathrm{Ga}$ & $\mathrm{ug} / \mathrm{g}$ & 1 & 6.8 & $<0.5$ & 1 & 3.6 \\
\hline Germanium & $\mathrm{Ge}$ & $\mathrm{ug} / \mathrm{g}$ & 5 & $<5.0$ & $<5.0$ & 5 & $<5.0$ \\
\hline Hafnium & $\mathrm{Hf}$ & $u g / g$ & - & - & - & - & - \\
\hline Holonium & Ho & $\mathrm{ug} / \mathrm{g}$ & 0 & 0.26 & $<0.025$ & 0 & 0.26 \\
\hline Iridium & Ir & $\mathrm{ug} / \mathrm{g}$ & 0 & $<0.1$ & $<0.1$ & 0 & $<0.1$ \\
\hline Iron & $\mathrm{Fe}$ & $\mathrm{ug} / \mathrm{g}$ & 20 & 59000 & 42000 & 19000 & 30000 \\
\hline Lanthanum & La & $\mathrm{ug} / \mathrm{g}$ & 0 & 19 & 0.37 & 0.18 & 8.1 \\
\hline Lead & $\mathrm{Pb}$ & $\mathrm{ug} / \mathrm{g}$ & 1 & 370 & 110 & 4.4 & 2.9 \\
\hline Lithium & $\mathrm{Li}$ & $\mathrm{ug} / \mathrm{g}$ & 1 & 11 & 0.63 & 1.8 & 1.7 \\
\hline Lutetium & Lu & $u g / g$ & 0 & 0.072 & $<0.025$ & 0 & 0.088 \\
\hline Magnesium & $\mathrm{Mg}$ & $u g / g$ & 20 & 3500 & 230 & 170 & 8200 \\
\hline Manganese & $\mathrm{Mn}$ & $\mathrm{ug} / \mathrm{g}$ & 1 & 610 & 75 & 82 & 1700 \\
\hline Molybdenum & Mo & $\mathrm{ug} / \mathrm{g}$ & 1 & 110 & 2.6 & 0.70 & $<0.5$ \\
\hline Neodymium & $\mathrm{Nd}$ & $\mathrm{ug} / \mathrm{g}$ & 0 & 20 & 0.37 & 0.36 & 8.0 \\
\hline Nickel & $\mathrm{Ni}$ & $u g / g$ & 1 & 6.4 & 37 & 39 & 44 \\
\hline Niobium & $\mathrm{Nb}$ & $\mathrm{ug} / \mathrm{g}$ & 0 & 0.13 & $<0.05$ & 0 & 0.57 \\
\hline Palladium & $\mathrm{Pd}$ & $\mathrm{ug} / \mathrm{g}$ & - & - & - & - & - \\
\hline Phosphorus & $P$ & $\mathrm{ug} / \mathrm{g}$ & 20 & 340 & $<20$ & 420 & 460 \\
\hline Platinum & $\mathrm{Pt}$ & $\mathrm{ug} / \mathrm{g}$ & 0 & $<0.05$ & $<0.05$ & 0 & $<0.05$ \\
\hline Potassium & $\mathrm{K}$ & $\mathrm{ug} / \mathrm{g}$ & 50 & 1600 & 150 & 81 & 470 \\
\hline Praseodymium & $\operatorname{Pr}$ & $u g / g$ & 0 & 4.8 & 0.086 & 0.078 & 1.9 \\
\hline Rhenium & $\operatorname{Re}$ & $u g / g$ & 0 & $<0.05$ & $<0.05$ & 0 & $<0.05$ \\
\hline Rhodium & $\mathrm{Rh}$ & $u g / g$ & 0 & $<0.05$ & 0.099 & 0.083 & $<0.05$ \\
\hline Rubidium & $\mathrm{Rb}$ & $u g / g$ & 0 & 11 & 0.28 & 0 & 2.4 \\
\hline Ruthenium & $\mathrm{Ru}$ & $\mathrm{ug} / \mathrm{g}$ & 0 & $<0.05$ & $<0.05$ & 0 & $<0.05$ \\
\hline Samarium & Sm & $\mathrm{ug} / \mathrm{g}$ & 0 & 4.0 & 0.072 & 0.083 & 1.7 \\
\hline Selenium & $\mathrm{Se}$ & $u g / g$ & 0 & 2.5 & 35 & 39 & 0.63 \\
\hline Silver & $\mathrm{Ag}$ & $\mathrm{ug} / \mathrm{g}$ & 0 & 2.0 & 2.6 & 0.49 & $<0.1$ \\
\hline Sodium & $\mathrm{Na}$ & $\mathrm{ug} / \mathrm{g}$ & 75 & 330 & 170 & 170 & 160 \\
\hline Strontium & $\mathrm{Sr}$ & $\mathrm{ug} / \mathrm{g}$ & 1 & 130 & 4.7 & 2.4 & 150 \\
\hline Sulfur & $S$ & $\mathrm{ug} / \mathrm{g}$ & 25 & 4400 & 120000 & 120000 & 130000 \\
\hline Tantalum & $\mathrm{Ta}$ & $\mathrm{ug} / \mathrm{g}$ & 0 & $<0.025$ & $<0.025$ & 0 & $<0.025$ \\
\hline Terbium & $\mathrm{Tb}$ & $\mathrm{ug} / \mathrm{g}$ & 0 & 0.42 & $<0.025$ & 0 & 0.24 \\
\hline Tellurium & $\mathrm{Te}$ & $u g / g$ & 0 & 0.84 & 6.0 & 15 & 0.16 \\
\hline Thalium & $\mathrm{TI}$ & $u g / g$ & 0 & 0.99 & 0.20 & 0.40 & 0.13 \\
\hline Thorium & Th & $u g / g$ & - & - & - & - & - \\
\hline Thulium & $\mathrm{Tm}$ & $\mathrm{ug} / \mathrm{g}$ & 0 & 0.081 & $<0.025$ & 0 & 0.092 \\
\hline Tin & $\mathrm{Sn}$ & $\mathrm{ug} / \mathrm{g}$ & 0 & 6.1 & 2.9 & 0.52 & 0.38 \\
\hline Titanium & $\mathrm{Ti}$ & $\mathrm{ug} / \mathrm{g}$ & 1 & 45 & 3.2 & 1 & 280 \\
\hline Tungsten & W & $\mathrm{ug} / \mathrm{g}$ & 0 & 1.3 & $<0.1$ & 0 & 0.15 \\
\hline Uranium & U & $\mathrm{ug} / \mathrm{g}$ & 0 & 2.0 & 0.24 & 0.095 & 1.5 \\
\hline Vanadium & V & $\mathrm{ug} / \mathrm{g}$ & 0 & 39 & 1.2 & 0.27 & 12 \\
\hline Ytterbium & $\mathrm{Yb}$ & $\mathrm{ug} / \mathrm{g}$ & 0 & 0.54 & $<0.025$ & 0 & 0.63 \\
\hline Yttrium & $Y$ & $\mathrm{ug} / \mathrm{g}$ & 0 & 8.8 & $<0.25$ & 0 & 8.0 \\
\hline Zinc & $\mathrm{Zn}$ & $\mathrm{ug} / \mathrm{g}$ & 5 & 290 & 100 & 170 & 180 \\
\hline Zirconium & $\mathrm{Zr}$ & $u g / g$ & 1 & 1.9 & $<0.5$ & 1 & 9.9 \\
\hline
\end{tabular}




\begin{tabular}{|c|c|c|c|c|c|c|}
\hline & & & Sample name & & & \\
\hline & Symbol & Units & Detection limit & LN-VWD-P1 & LN-DAR01 & LN-SP3-P1 \\
\hline Aluminium & $\mathrm{Al}$ & $u g / g$ & 10 & 7900 & 5200 & 13000 \\
\hline Antimony & $\mathrm{Sb}$ & $u g / g$ & 1 & 1.5 & 32 & 5.5 \\
\hline Arsenic & As & $u g / g$ & 1 & 21 & 460 & 60 \\
\hline Barium & $\mathrm{Ba}$ & $u g / g$ & 1 & 73 & 98 & 46 \\
\hline Beryllium & $\mathrm{Be}$ & $u g / g$ & 0 & 0.46 & 0.12 & 0.19 \\
\hline Boron & B & $u g / g$ & 20 & $<20$ & $<20$ & $<20$ \\
\hline Cadmium & $\mathrm{Cd}$ & $u g / g$ & 0 & 0.13 & 0.16 & 0.094 \\
\hline Calcium & $\mathrm{Ca}$ & $u g / g$ & 100 & 420000 & 2600 & 180 \\
\hline Cerium & $\mathrm{Ce}$ & $u g / g$ & 0 & 10 & 11 & 9.8 \\
\hline Cesium & Cs & $u g / g$ & - & - & - & - \\
\hline Chromium & $\mathrm{Cr}$ & $u g / g$ & 1 & 36 & 4.2 & $<1.0$ \\
\hline Cobalt & Co & $\mathrm{ug} / \mathrm{g}$ & 0 & 1.9 & 2.4 & 0.42 \\
\hline Copper & $\mathrm{Cu}$ & $\mathrm{ug} / \mathrm{g}$ & 2 & 42 & 48 & 32 \\
\hline Dysprosium & Dy & $\mathrm{ug} / \mathrm{g}$ & 0 & 0.76 & 0.54 & 0.21 \\
\hline Erbium & $\mathrm{Er}$ & $u g / g$ & 0 & 0.41 & 0.22 & 0.075 \\
\hline Europium & $\mathrm{Eu}$ & $\mathrm{ug} / \mathrm{g}$ & 0 & 0.20 & 0.24 & 0.20 \\
\hline Gadolinium & $\mathrm{Gd}$ & $\mathrm{ug} / \mathrm{g}$ & 0 & 0.82 & 0.82 & 0.49 \\
\hline Gallium & $\mathrm{Ga}$ & $\mathrm{ug} / \mathrm{g}$ & 1 & 2.9 & 5.2 & 3.6 \\
\hline Germanium & $\mathrm{Ge}$ & $\mathrm{ug} / \mathrm{g}$ & 5 & $<5.0$ & $<5.0$ & $<5.0$ \\
\hline Hafnium & $\mathrm{Hf}$ & $u g / g$ & - & - & - & - \\
\hline Holonium & Ho & $u g / g$ & 0 & 0.13 & 0.085 & 0.035 \\
\hline Iridium & Ir & $u g / g$ & 0 & $<0.1$ & $<0.1$ & $<0.1$ \\
\hline Iron & $\mathrm{Fe}$ & $\mathrm{ug} / \mathrm{g}$ & 20 & 6500 & 67000 & 28000 \\
\hline Lanthanum & La & $\mathrm{ug} / \mathrm{g}$ & 0 & 5.2 & 5.2 & 5.2 \\
\hline Lead & $\mathrm{Pb}$ & $\mathrm{ug} / \mathrm{g}$ & 1 & 2.0 & 30 & 88 \\
\hline Lithium & $\mathrm{Li}$ & $\mathrm{ug} / \mathrm{g}$ & 1 & 2.6 & 2.7 & 2.8 \\
\hline Lutetium & $\mathrm{Lu}$ & $\mathrm{ug} / \mathrm{g}$ & 0 & 0.055 & 0.026 & $<0.025$ \\
\hline Magnesium & $\mathrm{Mg}$ & $\mathrm{ug} / \mathrm{g}$ & 20 & 14000 & 1700 & 1900 \\
\hline Manganese & $\mathrm{Mn}$ & $u g / g$ & 1 & 130 & 180 & 110 \\
\hline Molybdenum & Mo & $\mathrm{ug} / \mathrm{g}$ & 1 & 0.69 & 3.0 & 5.6 \\
\hline Neodymium & $\mathrm{Nd}$ & $u g / g$ & 0 & 4.8 & 5.4 & 4.5 \\
\hline Nickel & $\mathrm{Ni}$ & $u g / g$ & 1 & 7.1 & 2.0 & $<0.5$ \\
\hline Niobium & $\mathrm{Nb}$ & $u g / g$ & 0 & 0.53 & 0.35 & 0.34 \\
\hline Palladium & $P d$ & $u g / g$ & - & - & - & - \\
\hline Phosphorus & $\mathrm{P}$ & $\mathrm{ug} / \mathrm{g}$ & 20 & 560 & 1200 & 360 \\
\hline Platinum & $\mathrm{Pt}$ & $\mathrm{ug} / \mathrm{g}$ & 0 & $<0.05$ & $<0.05$ & $<0.05$ \\
\hline Potassium & $\mathrm{K}$ & $\mathrm{ug} / \mathrm{g}$ & 50 & 760 & 1400 & 730 \\
\hline Praseodymium & $\mathrm{Pr}$ & $\mathrm{ug} / \mathrm{g}$ & 0 & 1.2 & 1.4 & 1.2 \\
\hline Rhenium & $\operatorname{Re}$ & $\mathrm{ug} / \mathrm{g}$ & 0 & $<0.05$ & $<0.05$ & $<0.05$ \\
\hline Rhodium & $\mathrm{Rh}$ & $u g / g$ & 0 & $<0.05$ & $<0.05$ & $<0.05$ \\
\hline Rubidium & $\mathrm{Rb}$ & $\mathrm{ug} / \mathrm{g}$ & 0 & 3.2 & 4.2 & 4.9 \\
\hline Ruthenium & $\mathrm{Ru}$ & $\mathrm{ug} / \mathrm{g}$ & 0 & $<0.05$ & $<0.05$ & $<0.05$ \\
\hline Samarium & $\mathrm{Sm}$ & $\mathrm{ug} / \mathrm{g}$ & 0 & 0.92 & 1.0 & 0.77 \\
\hline Selenium & $\mathrm{Se}$ & $u g / g$ & 0 & 0.66 & 3.5 & 3.8 \\
\hline Silver & $\mathrm{Ag}$ & $u g / g$ & 0 & $<0.1$ & 0.41 & 0.14 \\
\hline Sodium & $\mathrm{Na}$ & $u g / g$ & 75 & 150 & 520 & 120 \\
\hline Strontium & $\mathrm{Sr}$ & $\mathrm{ug} / \mathrm{g}$ & 1 & 150 & 57 & 10 \\
\hline Sulfur & $S$ & $\mathrm{ug} / \mathrm{g}$ & 25 & 18000 & 9800 & 750 \\
\hline Tantalum & $\mathrm{Ta}$ & $\mathrm{ug} / \mathrm{g}$ & 0 & $<0.025$ & $<0.025$ & $<0.025$ \\
\hline Terbium & $\mathrm{Tb}$ & $\mathrm{ug} / \mathrm{g}$ & 0 & 0.12 & 0.10 & 0.056 \\
\hline Tellurium & $\mathrm{Te}$ & $\mathrm{ug} / \mathrm{g}$ & 0 & $<0.1$ & 0.94 & 0.59 \\
\hline Thalium & $\mathrm{TI}$ & $\mathrm{ug} / \mathrm{g}$ & 0 & $<0.025$ & 0.038 & 0.13 \\
\hline Thorium & Th & $\mathrm{ug} / \mathrm{g}$ & - & - & - & - \\
\hline Thulium & $\mathrm{Tm}$ & $\mathrm{ug} / \mathrm{g}$ & 0 & 0.063 & 0.028 & $<0.025$ \\
\hline Tin & Sn & $u g / g$ & 0 & 0.54 & 2.0 & 1.3 \\
\hline Titanium & $\mathrm{Ti}$ & $u g / g$ & 1 & 440 & 340 & 63 \\
\hline Tungsten & W & $u g / g$ & 0 & 0.19 & 0.14 & $<0.1$ \\
\hline Uranium & $U$ & $u g / g$ & 0 & 1.6 & 0.27 & 0.13 \\
\hline Vanadium & V & $u g / g$ & 0 & 15 & 38 & 13 \\
\hline Ytterbium & $\mathrm{Yb}$ & $\mathrm{ug} / \mathrm{g}$ & 0 & 0.37 & 0.18 & 0.056 \\
\hline Yttrium & $Y$ & $\mathrm{ug} / \mathrm{g}$ & 0 & 4.3 & 2.2 & 0.71 \\
\hline Zinc & $\mathrm{Zn}$ & $\mathrm{ug} / \mathrm{g}$ & 5 & 26 & 38 & 24 \\
\hline Zirconium & $\mathrm{Zr}$ & $\mathrm{ug} / \mathrm{g}$ & 1 & 15 & 1.8 & $<0.5$ \\
\hline
\end{tabular}




\begin{tabular}{|c|c|c|c|c|c|c|c|}
\hline & \multicolumn{4}{|c|}{ Sample name } & \multirow[b]{2}{*}{ RMATR-P2 } & \multirow[b]{2}{*}{ RMATR-P3 } & \multirow[b]{2}{*}{ RMATR-P4 } \\
\hline & Symbol & Units & Detection limit & RMATR-P1 & & & \\
\hline Aluminium & Al & ug/g & 10 & 26000 & 15000 & 18000 & 8000 \\
\hline Antimony & $\mathrm{Sb}$ & $u g / g$ & 1 & 2.4 & 14 & 6.5 & 1.9 \\
\hline Arsenic & As & $u g / g$ & 1 & 140 & 520 & 570 & 66 \\
\hline Barium & $\mathrm{Ba}$ & $u g / g$ & 1 & 33 & 19 & 38 & 22 \\
\hline Beryllium & $\mathrm{Be}$ & $u g / g$ & 0 & 3.5 & 1.3 & 1.8 & 0.52 \\
\hline Boron & $\mathrm{B}$ & $u g / g$ & 20 & 30 & 22 & 51 & $<20$ \\
\hline Cadmium & $\mathrm{Cd}$ & $\mathrm{ug} / \mathrm{g}$ & 0 & 15 & 6.6 & 8.2 & 3.4 \\
\hline Calcium & $\mathrm{Ca}$ & $\mathrm{ug} / \mathrm{g}$ & 100 & 24000 & 66000 & 11000 & 150000 \\
\hline Cerium & $\mathrm{Ce}$ & $\mathrm{ug} / \mathrm{g}$ & 0 & 3.3 & 9.8 & 6.3 & 7.2 \\
\hline Cesium & Cs & $\mathrm{ug} / \mathrm{g}$ & - & - & - & - & - \\
\hline Chromium & $\mathrm{Cr}$ & $u g / g$ & 1 & 3.0 & 5.1 & 12 & 1.8 \\
\hline Cobalt & Co & $u g / g$ & 0 & 59 & 36 & 41 & 20 \\
\hline Copper & $\mathrm{Cu}$ & $u g / g$ & 2 & 15000 & 7900 & 8100 & 3600 \\
\hline Dysprosium & Dy & $\mathrm{ug} / \mathrm{g}$ & 0 & 1.6 & 2.8 & 0.82 & 3.3 \\
\hline Erbium & $\mathrm{Er}$ & $u g / g$ & 0 & 0.95 & 1.3 & 0.48 & 1.5 \\
\hline Europium & $\mathrm{Eu}$ & $u g / g$ & 0 & 0.31 & 0.71 & 0.23 & 0.76 \\
\hline Gadolinium & $\mathrm{Gd}$ & $u g / g$ & 0 & 1.4 & 3.2 & 1.0 & 3.5 \\
\hline Gallium & $\mathrm{Ga}$ & $u g / g$ & 1 & 1.3 & 2.3 & 3.0 & 1.2 \\
\hline Germanium & $\mathrm{Ge}$ & $\mathrm{ug} / \mathrm{g}$ & 5 & $<5.0$ & $<5.0$ & $<5.0$ & $<5.0$ \\
\hline Hafnium & $\mathrm{Hf}$ & $\mathrm{ug} / \mathrm{g}$ & - & - & - & - & - \\
\hline Holonium & Ho & $\mathrm{ug} / \mathrm{g}$ & 0 & 0.31 & 0.48 & 0.16 & 0.57 \\
\hline Iridium & Ir & $\mathrm{ug} / \mathrm{g}$ & 0 & $<0.1$ & $<0.1$ & $<0.1$ & $<0.1$ \\
\hline Iron & $\mathrm{Fe}$ & $u g / g$ & 20 & 16000 & 57000 & 75000 & 12000 \\
\hline Lanthanum & $\mathrm{La}$ & $\mathrm{ug} / \mathrm{g}$ & 0 & 1.2 & 3.5 & 2.6 & 2.3 \\
\hline Lead & $\mathrm{Pb}$ & $\mathrm{ug} / \mathrm{g}$ & 1 & 11 & 36 & 30 & 31 \\
\hline Lithium & $\mathrm{Li}$ & $\mathrm{ug} / \mathrm{g}$ & 1 & 380 & 120 & 260 & 53 \\
\hline Lutetium & Lu & $\mathrm{ug} / \mathrm{g}$ & 0 & 0.12 & 0.12 & 0.057 & 0.11 \\
\hline Magnesium & $\mathrm{Mg}$ & $u g / g$ & 20 & 31000 & 15000 & 22000 & 8900 \\
\hline Manganese & $\mathrm{Mn}$ & $\mathrm{ug} / \mathrm{g}$ & 1 & 6100 & 2500 & 3900 & 960 \\
\hline Molybdenum & Mo & $u g / g$ & 1 & 2.5 & 3.8 & 1.6 & 4.2 \\
\hline Neodymium & $\mathrm{Nd}$ & $\mathrm{ug} / \mathrm{g}$ & 0 & 2.5 & 7.1 & 3.4 & 6.1 \\
\hline Nickel & $\mathrm{Ni}$ & $\mathrm{ug} / \mathrm{g}$ & 1 & 43 & 24 & 40 & 13 \\
\hline Niobium & $\mathrm{Nb}$ & $\mathrm{ug} / \mathrm{g}$ & 0 & $<0.05$ & 0.097 & 0.51 & 0.064 \\
\hline Palladium & $\mathrm{Pd}$ & $u g / g$ & - & - & - & - & - \\
\hline Phosphorus & $\mathrm{P}$ & $u g / g$ & 20 & 77 & 290 & 590 & 86 \\
\hline Platinum & $\mathrm{Pt}$ & $u g / g$ & 0 & $<0.05$ & $<0.05$ & $<0.05$ & $<0.05$ \\
\hline Potassium & $\mathrm{K}$ & $u g / g$ & 50 & 4400 & 1400 & 2600 & 5400 \\
\hline Praseodymium & $\operatorname{Pr}$ & $\mathrm{ug} / \mathrm{g}$ & 0 & 0.48 & 1.4 & 0.80 & 1.1 \\
\hline Rhenium & $\mathrm{Re}$ & $\mathrm{ug} / \mathrm{g}$ & 0 & 0.21 & 0.052 & 0.094 & $<0.05$ \\
\hline Rhodium & $\mathrm{Rh}$ & $\mathrm{ug} / \mathrm{g}$ & 0 & $<0.05$ & $<0.05$ & $<0.05$ & $<0.05$ \\
\hline Rubidium & $\mathrm{Rb}$ & $u g / g$ & 0 & 45 & 14 & 22 & 55 \\
\hline Ruthenium & $\mathrm{Ru}$ & $\mathrm{ug} / \mathrm{g}$ & 0 & $<0.05$ & $<0.05$ & $<0.05$ & $<0.05$ \\
\hline Samarium & $\mathrm{Sm}$ & $\mathrm{ug} / \mathrm{g}$ & 0 & 0.80 & 2.2 & 0.77 & 2.1 \\
\hline Selenium & $\mathrm{Se}$ & $\mathrm{ug} / \mathrm{g}$ & 0 & 2.2 & 1.2 & 1.0 & 1.1 \\
\hline Silver & $\mathrm{Ag}$ & $\mathrm{ug} / \mathrm{g}$ & 0 & 0.14 & 0.87 & 0.38 & 0.13 \\
\hline Sodium & $\mathrm{Na}$ & $u g / g$ & 75 & 36000 & 19000 & 25000 & 10000 \\
\hline Strontium & $\mathrm{Sr}$ & $u g / g$ & 1 & 140 & 170 & 48 & 670 \\
\hline Sulfur & $S$ & $u g / g$ & 25 & 170000 & 140000 & 91000 & 170000 \\
\hline Tantalum & $\mathrm{Ta}$ & $u g / g$ & 0 & $<0.025$ & $<0.025$ & $<0.025$ & $<0.025$ \\
\hline Terbium & $\mathrm{Tb}$ & $u g / g$ & 0 & 0.25 & 0.47 & 0.14 & 0.55 \\
\hline Tellurium & $\mathrm{Te}$ & $\mathrm{ug} / \mathrm{g}$ & 0 & 0.27 & 0.86 & 0.34 & 0.13 \\
\hline Thalium & $\mathrm{Tl}$ & $u g / g$ & 0 & 0.11 & 0.082 & 0.068 & 0.20 \\
\hline Thorium & Th & $u g / g$ & - & - & - & - & - \\
\hline Thulium & $\mathrm{Tm}$ & $u g / g$ & 0 & 0.14 & 0.16 & 0.060 & 0.17 \\
\hline Tin & $\mathrm{Sn}$ & $u g / g$ & 0 & $<0.20$ & 0.74 & 0.53 & 0.26 \\
\hline Titanium & $\mathrm{Ti}$ & $\mathrm{ug} / \mathrm{g}$ & 1 & 24 & 58 & 780 & 50 \\
\hline Tungsten & W & $u g / g$ & 0 & 0.43 & 0.57 & 0.58 & 0.26 \\
\hline Uranium & $U$ & $\mathrm{ug} / \mathrm{g}$ & 0 & 9.8 & 7.6 & 6.1 & 1.5 \\
\hline Vanadium & V & $u g / g$ & 0 & 5.9 & 9.4 & 40 & 3.8 \\
\hline Ytterbium & $\mathrm{Yb}$ & $u g / g$ & 0 & 0.88 & 0.98 & 0.43 & 1.0 \\
\hline Yttrium & $\mathrm{Y}$ & $u g / g$ & 0 & 10 & 13 & 4.7 & 16 \\
\hline Zinc & $\mathrm{Zn}$ & $\mathrm{ug} / \mathrm{g}$ & 5 & 3600 & 1500 & 2300 & 520 \\
\hline Zirconium & $\mathrm{Zr}$ & $\mathrm{ug} / \mathrm{g}$ & 1 & $<0.5$ & $<0.5$ & $<0.5$ & $<0.5$ \\
\hline
\end{tabular}




\begin{tabular}{|c|c|c|c|c|c|c|c|}
\hline & & & Sample name & & & & \\
\hline & Symbol & Units & Detection limit & P-PWL-Pb & P-PWL-Pc & P-WRD & P-EC-P1 \\
\hline Aluminium & $\mathrm{Al}$ & $\mathrm{ug} / \mathrm{g}$ & 10 & 6500 & 4400 & 6500 & 12000 \\
\hline Antimony & $\mathrm{Sb}$ & $u g / g$ & 1 & 8.0 & 2.1 & 4.7 & 3.9 \\
\hline Arsenic & As & $u g / g$ & 1 & 350 & 260 & 2200 & 140 \\
\hline Barium & $\mathrm{Ba}$ & $\mathrm{ug} / \mathrm{g}$ & 1 & 25 & 24 & 180 & 260 \\
\hline Beryllium & $\mathrm{Be}$ & $u g / g$ & 0 & 0.061 & 0.080 & 0.34 & 0.74 \\
\hline Boron & $\mathrm{B}$ & $\mathrm{ug} / \mathrm{g}$ & 20 & 20 & 20 & $<20$ & $<20$ \\
\hline Cadmium & $\mathrm{Cd}$ & $u g / g$ & 0 & 0.56 & 1.3 & 3.0 & 4.2 \\
\hline Calcium & $\mathrm{Ca}$ & $u g / g$ & 100 & 560 & 820 & 2000 & 4600 \\
\hline Cerium & $\mathrm{Ce}$ & $\mathrm{ug} / \mathrm{g}$ & 0 & 2.4 & 2.4 & 25 & 35 \\
\hline Cesium & Cs & $\mathrm{ug} / \mathrm{g}$ & - & - & - & - & - \\
\hline Chromium & $\mathrm{Cr}$ & $\mathrm{ug} / \mathrm{g}$ & 1 & 3.1 & 3.2 & 4.5 & 6.0 \\
\hline Cobalt & Co & $\mathrm{ug} / \mathrm{g}$ & 0 & 24 & 38 & 4.2 & 11 \\
\hline Copper & $\mathrm{Cu}$ & $\mathrm{ug} / \mathrm{g}$ & 2 & 1400 & 1700 & 240 & 160 \\
\hline Dysprosium & Dy & $\mathrm{ug} / \mathrm{g}$ & 0 & 0.13 & 0.20 & 0.81 & 1.7 \\
\hline Erbium & $\mathrm{Er}$ & $u g / g$ & 0 & 0.070 & 0.098 & 0.34 & 0.66 \\
\hline Europium & $\mathrm{Eu}$ & $\mathrm{ug} / \mathrm{g}$ & 0 & 0.044 & 0.060 & 0.53 & 0.79 \\
\hline Gadolinium & $\mathrm{Gd}$ & $\mathrm{ug} / \mathrm{g}$ & 0 & 0.16 & 0.23 & 1.5 & 2.6 \\
\hline Gallium & $\mathrm{Ga}$ & $\mathrm{ug} / \mathrm{g}$ & 1 & 5.6 & 4.6 & 7.0 & 7.8 \\
\hline Germanium & $\mathrm{Ge}$ & $\mathrm{ug} / \mathrm{g}$ & 5 & 5 & 5 & $<5.0$ & $<5.0$ \\
\hline Hafnium & $\mathrm{Hf}$ & $\mathrm{ug} / \mathrm{g}$ & - & - & - & - & - \\
\hline Holonium & Ho & $\mathrm{ug} / \mathrm{g}$ & 0 & 0.025 & 0.037 & 0.13 & 0.24 \\
\hline Iridium & Ir & $\mathrm{ug} / \mathrm{g}$ & 0 & 0 & 0 & $<0.1$ & $<0.1$ \\
\hline Iron & $\mathrm{Fe}$ & $\mathrm{ug} / \mathrm{g}$ & 20 & 100000 & 160000 & 260000 & 54000 \\
\hline Lanthanum & $\mathrm{La}$ & $\mathrm{ug} / \mathrm{g}$ & 0 & 1.2 & 1.2 & 13 & 17 \\
\hline Lead & $\mathrm{Pb}$ & $\mathrm{ug} / \mathrm{g}$ & 1 & 290 & 120 & 390 & 290 \\
\hline Lithium & $\mathrm{Li}$ & $\mathrm{ug} / \mathrm{g}$ & 1 & 2.5 & 2.4 & 3.5 & 7.5 \\
\hline Lutetium & $\mathrm{Lu}$ & $\mathrm{ug} / \mathrm{g}$ & 0 & 0 & 0 & 0.031 & 0.062 \\
\hline Magnesium & $\mathrm{Mg}$ & $\mathrm{ug} / \mathrm{g}$ & 20 & 290 & 490 & 1200 & 2700 \\
\hline Manganese & $\mathrm{Mn}$ & $\mathrm{ug} / \mathrm{g}$ & 1 & 100 & 220 & 710 & 1000 \\
\hline Molybdenum & Mo & $\mathrm{ug} / \mathrm{g}$ & 1 & 0.83 & 0.50 & 2.3 & 1.4 \\
\hline Neodymium & $\mathrm{Nd}$ & $\mathrm{ug} / \mathrm{g}$ & 0 & 1.1 & 1.2 & 11 & 17 \\
\hline Nickel & $\mathrm{Ni}$ & $\mathrm{ug} / \mathrm{g}$ & 1 & 12 & 21 & 3.5 & 6.0 \\
\hline Niobium & $\mathrm{Nb}$ & $\mathrm{ug} / \mathrm{g}$ & 0 & 0.060 & 0.063 & 0.16 & 0.12 \\
\hline Palladium & $\mathrm{Pd}$ & $\mathrm{ug} / \mathrm{g}$ & - & - & - & - & - \\
\hline Phosphorus & $P$ & $\mathrm{ug} / \mathrm{g}$ & 20 & 110 & 150 & 4000 & 720 \\
\hline Platinum & $\mathrm{Pt}$ & $\mathrm{ug} / \mathrm{g}$ & 0 & 0 & 0 & $<0.05$ & $<0.05$ \\
\hline Potassium & $\mathrm{K}$ & $\mathrm{ug} / \mathrm{g}$ & 50 & 450 & 360 & 3500 & 1700 \\
\hline Praseodymium & $\operatorname{Pr}$ & $\mathrm{ug} / \mathrm{g}$ & 0 & 0.27 & 0.30 & 2.8 & 4.0 \\
\hline Rhenium & $\operatorname{Re}$ & $\mathrm{ug} / \mathrm{g}$ & 0 & 0 & 0 & $<0.05$ & $<0.05$ \\
\hline Rhodium & $\mathrm{Rh}$ & $\mathrm{ug} / \mathrm{g}$ & 0 & 0 & 0 & $<0.05$ & $<0.05$ \\
\hline Rubidium & $\mathrm{Rb}$ & $\mathrm{ug} / \mathrm{g}$ & 0 & 2.1 & 1.6 & 7.6 & 12 \\
\hline Ruthenium & $\mathrm{Ru}$ & $\mathrm{ug} / \mathrm{g}$ & 0 & 0 & 0 & $<0.05$ & $<0.05$ \\
\hline Samarium & $\mathrm{Sm}$ & $\mathrm{ug} / \mathrm{g}$ & 0 & 0.18 & 0.25 & 2.0 & 3.2 \\
\hline Selenium & $\mathrm{Se}$ & $\mathrm{ug} / \mathrm{g}$ & 0 & 2.1 & 1.0 & 2.9 & 1.2 \\
\hline Silver & $\mathrm{Ag}$ & $\mathrm{ug} / \mathrm{g}$ & 0 & 0.72 & 0.22 & 1.4 & 1.6 \\
\hline Sodium & $\mathrm{Na}$ & $\mathrm{ug} / \mathrm{g}$ & 75 & 130 & 140 & 240 & 180 \\
\hline Strontium & $\mathrm{Sr}$ & $\mathrm{ug} / \mathrm{g}$ & 1 & 6.3 & 5.7 & 53 & 76 \\
\hline Sulfur & 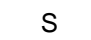 & $\mathrm{ug} / \mathrm{g}$ & 25 & 89000 & 120000 & 40000 & 12000 \\
\hline Tantalum & $\mathrm{Ta}$ & $\mathrm{ug} / \mathrm{g}$ & 0 & 0 & 0 & $<0.025$ & $<0.025$ \\
\hline Terbium & $\mathrm{Tb}$ & $\mathrm{ug} / \mathrm{g}$ & 0 & 0 & 0.032 & 0.18 & 0.32 \\
\hline Tellurium & $\mathrm{Te}$ & $\mathrm{ug} / \mathrm{g}$ & 0 & 2.1 & 1.2 & 2.7 & 1.0 \\
\hline Thalium & $\mathrm{TI}$ & $\mathrm{ug} / \mathrm{g}$ & 0 & 3.2 & 1.8 & 1.4 & 2.1 \\
\hline Thorium & Th & $\mathrm{ug} / \mathrm{g}$ & - & - & - & - & - \\
\hline Thulium & $\mathrm{Tm}$ & $\mathrm{ug} / \mathrm{g}$ & 0 & 0 & 0 & 0.035 & 0.084 \\
\hline Tin & Sn & $\mathrm{ug} / \mathrm{g}$ & 0 & 17 & 2.8 & 1.6 & 2.2 \\
\hline Titanium & $\mathrm{Ti}$ & $\mathrm{ug} / \mathrm{g}$ & 1 & 9.5 & 12 & 33 & 40 \\
\hline Tungsten & W & $\mathrm{ug} / \mathrm{g}$ & 0 & 0.29 & 0.19 & 0.26 & 0.15 \\
\hline Uranium & $U$ & $\mathrm{ug} / \mathrm{g}$ & 0 & 0.97 & 1.2 & 0.52 & 0.73 \\
\hline Vanadium & $\mathrm{V}$ & $\mathrm{ug} / \mathrm{g}$ & 0 & 11 & 8.7 & 37 & 20 \\
\hline Ytterbium & $\mathrm{Yb}$ & $\mathrm{ug} / \mathrm{g}$ & 0 & 0.057 & 0.086 & 0.23 & 0.49 \\
\hline Yttrium & $Y$ & $\mathrm{ug} / \mathrm{g}$ & 0 & 0.61 & 0.98 & 3.5 & 7.0 \\
\hline Zinc & $\mathrm{Zn}$ & $\mathrm{ug} / \mathrm{g}$ & 5 & 42 & 92 & 160 & 260 \\
\hline Zirconium & $\mathrm{Zr}$ & $\mathrm{ug} / \mathrm{g}$ & 1 & 3.3 & 2.1 & 1.5 & 2.0 \\
\hline
\end{tabular}




\section{Appendix F: QAQC water}

Sample blanks, field blanks, standard reference material, as well as experimental and field replicates were included for the lab QA/QC. Lab blanks show no contamination; however, field blanks demonstrate detectable levels of $\mathrm{Al}$ and $\mathrm{S}$ at Lagunas Norte and $\mathrm{Al}, \mathrm{Ni}, \mathrm{Zn}$ at Pierina. These samples may have been contaminated by the accidental incorporation of dust in the area.

Precision was determined by calculating the relative percent difference (RPD) of field or lab duplicates or triplicates. QA/QC results for metals and anions confirm that all lab duplicates are within $20 \%$ precision with the exceptions of Eu, $\mathrm{Zr}$, Ti at Lagunas Norte and $\mathrm{Pb}, \mathrm{Cd}$, Fe at El Indio. Field duplicates are within $20 \%$ precision except for $\mathrm{Ag}, \mathrm{As}, \mathrm{Cd}, \mathrm{Co}, \mathrm{Cr}, \mathrm{Cu}, \mathrm{Dy}, \mathrm{Eu}, \mathrm{Ga}, \mathrm{K}, \mathrm{Pb}, \mathrm{Sb}, \mathrm{Te}, \mathrm{Tb}, \mathrm{Tm}, \mathrm{Zr}$, $\mathrm{Yb}$ at Lagunas Norte, As, Ge, Eu, Mn, Pb, Se, Zr at El Indio, and Eu Zr, $\mathrm{Tl}, \mathrm{Ti}, \mathrm{Yb}$ and $\mathrm{Ge}$ at Pierina. Precision may be poor due to the concentrations of these elements being close to the detection limit.

Accuracy, the measure of how close a measured quantity is to its true value, was determined by calculating the RPD of the standard reference material. Both precision and accuracy values for all samples are found in Appendix A. RPD is labelled "\%Diff" in Appendix A. To evaluate accuracy of the lab measurements, the RPD of in-house standard reference material (EU-H-4) was calculated. All elements are within $10 \%$ accuracy with the exception of $\mathrm{U}, \mathrm{Sb}, \mathrm{Mn}, \mathrm{Na}, \mathrm{Ca}$, and $\mathrm{Mo}$, which are below $11 \%$ accuracy. Aqueous solutions are electrically neutral, the total number of cations must equal the total number of anions.

\begin{tabular}{ll}
\hline Analysis & Analytical Services Unit, Queen's University \\
QA/QC & Lab Blanks - Verification for contamination during laboratory analysis \\
& Experimental/Field Blanks - Verification for contamination during experiments \\
& Lab Duplicates - Verification for precision \\
& Experimental/Field Duplicates - Verification for precision \\
& Certified Reference Materials - Verification for accuracy \\
Calculations & Relative Standard Difference $=[(A-B) /((A+B) / 2)] \times 100$, where $A$ is the original \\
& concentration, B is duplicate concentration. Good agreement is $\pm 20 \%$. \\
\hline
\end{tabular}




\begin{tabular}{|c|c|c|c|c|c|c|c|c|c|}
\hline & \multicolumn{9}{|c|}{ Certified Reference Material (Samples 1-27) } \\
\hline & Symbol & Units & Detection limit & Control 1 & Control 1 Target & Control 2 & Control 2 Target & $\%$ Diff C1\& C1T & \% Diff C2 \& C2T \\
\hline Metals & & & & & & & & & \\
\hline Aluminium & Al & $\mu \mathrm{g} / \mathrm{L}$ & 5 & 25 & 25 & - & - & $0 \%$ & \\
\hline Antimony & $\mathrm{Sb}$ & $\mu \mathrm{g} / \mathrm{L}$ & 2 & - & - & 26 & 25 & - & $4 \%$ \\
\hline Arsenic & As & $\mu \mathrm{g} / \mathrm{L}$ & 2 & 26 & 25 & - & - & $4 \%$ & - \\
\hline Barium & Ва & $\mu \mathrm{g} / \mathrm{L}$ & 0 & 24 & 25 & - & - & $4 \%$ & - \\
\hline Beryllium & $\mathrm{Be}$ & $\mu \mathrm{g} / \mathrm{L}$ & 0 & 23 & 25 & - & - & $8 \%$ & - \\
\hline Boron & B & $\mu \mathrm{g} / \mathrm{L}$ & 1000 & 2000 & 2000 & - & - & $0 \%$ & - \\
\hline Cadmium & $\mathrm{Cd}$ & $\mu \mathrm{g} / \mathrm{L}$ & 0 & 24 & 25 & - & - & $4 \%$ & - \\
\hline Calcium & $\mathrm{Ca}$ & $\mu \mathrm{g} / \mathrm{L}$ & 300 & - & - & - & - & - & - \\
\hline Cerium & $\mathrm{Ce}$ & $\mu \mathrm{g} / \mathrm{L}$ & 1 & 23 & 25 & - & - & $8 \%$ & - \\
\hline Cesium & Cs & $\mu \mathrm{g} / \mathrm{L}$ & - & - & - & - & - & - & - \\
\hline Chromium & $\mathrm{Cr}$ & $\mu \mathrm{g} / \mathrm{L}$ & 5 & 24 & 25 & - & - & $4 \%$ & - \\
\hline Cobalt & Co & $\mu \mathrm{g} / \mathrm{L}$ & 0 & 24 & 25 & - & - & $4 \%$ & - \\
\hline Copper & $\mathrm{Cu}$ & $\mu \mathrm{g} / \mathrm{L}$ & 5 & 24 & 25 & - & - & $4 \%$ & - \\
\hline Dysprosium & Dy & $\mu \mathrm{g} / \mathrm{L}$ & 0 & 22 & 25 & - & - & $13 \%$ & - \\
\hline Erbium & $\mathrm{Er}$ & $\mu \mathrm{g} / \mathrm{L}$ & 0 & 23 & 25 & - & - & $8 \%$ & - \\
\hline Europium & $\mathrm{Eu}$ & $\mu \mathrm{g} / \mathrm{L}$ & 0 & 23 & 25 & - & - & $8 \%$ & - \\
\hline Gadolinium & Gd & $\mu \mathrm{g} / \mathrm{L}$ & 0 & 22 & 25 & - & - & $13 \%$ & - \\
\hline Gallium & Ga & $\mu \mathrm{g} / \mathrm{L}$ & 5 & 26 & 25 & - & - & $4 \%$ & - \\
\hline Germanium & Ge & $\mu \mathrm{g} / \mathrm{L}$ & 1 & - & - & 25 & 25 & - & $0 \%$ \\
\hline Hafnium & $\mathrm{Hf}$ & $\mu \mathrm{g} / \mathrm{L}$ & - & - & - & - & - & - & - \\
\hline Holonium & Ho & $\mu \mathrm{g} / \mathrm{L}$ & 0 & 24 & 25 & - & - & $4 \%$ & - \\
\hline Iridium & Ir & $\mu \mathrm{g} / \mathrm{L}$ & 1 & - & - & - & - & - & - \\
\hline Iron & $\mathrm{Fe}$ & $\mu \mathrm{g} / \mathrm{L}$ & 50 & 25 & 25 & - & - & $0 \%$ & - \\
\hline Lanthanum & La & $\mu \mathrm{g} / \mathrm{L}$ & 0 & 23 & 25 & - & - & $8 \%$ & - \\
\hline Lead & $\mathrm{Pb}$ & $\mu \mathrm{g} / \mathrm{L}$ & 0 & 23 & 25 & - & - & $8 \%$ & - \\
\hline Lithium & $\mathrm{Li}$ & $\mu \mathrm{g} / \mathrm{L}$ & 2 & - & - & - & - & - & - \\
\hline Lutetium & Lu & $\mu \mathrm{g} / \mathrm{L}$ & 0 & 22 & 25 & - & - & $13 \%$ & - \\
\hline Magnesium & $\mathrm{Mg}$ & $\mu \mathrm{g} / \mathrm{L}$ & 30 & 25 & 25 & - & - & $0 \%$ & - \\
\hline Manganese & $\mathrm{Mn}$ & $\mu \mathrm{g} / \mathrm{L}$ & 0 & 24 & 25 & - & - & $4 \%$ & - \\
\hline Molybdenum & Mo & $\mu \mathrm{g} / \mathrm{L}$ & 10 & - & - & 24 & 25 & - & $4 \%$ \\
\hline Neodymium & $\mathrm{Nd}$ & $\mu \mathrm{g} / \mathrm{L}$ & 0 & 22 & 25 & - & - & $13 \%$ & - \\
\hline Nickel & $\mathrm{Ni}$ & $\mu \mathrm{g} / \mathrm{L}$ & 1 & 24 & 25 & - & - & $4 \%$ & - \\
\hline Niobium & $\mathrm{Nb}$ & $\mu \mathrm{g} / \mathrm{L}$ & 0 & - & - & 25 & 25 & - & $0 \%$ \\
\hline Palladium & $P d$ & $\mu \mathrm{g} / \mathrm{L}$ & - & - & - & - & - & & - \\
\hline Phosphorus & $P$ & $\mu \mathrm{g} / \mathrm{L}$ & 1000 & 32000 & 30000 & - & - & $6 \%$ & - \\
\hline Platinum & $\mathrm{Pt}$ & $\mu \mathrm{g} / \mathrm{L}$ & 0 & - & - & - & - & - & - \\
\hline Potassium & $\mathrm{K}$ & $\mu \mathrm{g} / \mathrm{L}$ & 200 & 28 & 25 & - & - & $11 \%$ & - \\
\hline Praseodymium & $\mathrm{Pr}$ & $\mu \mathrm{g} / \mathrm{L}$ & 0 & 23 & 25 & - & - & $8 \%$ & - \\
\hline Rhenium & $\operatorname{Re}$ & $\mu \mathrm{g} / \mathrm{L}$ & 0 & - & - & - & - & - & - \\
\hline Rhodium & $\mathrm{Rh}$ & $\mu \mathrm{g} / \mathrm{L}$ & 0 & - & - & - & - & - & - \\
\hline Rubidium & $\mathrm{Rb}$ & $\mu \mathrm{g} / \mathrm{L}$ & 1 & 23 & 25 & - & - & $8 \%$ & - \\
\hline Ruthenium & $\mathrm{Ru}$ & $\mu \mathrm{g} / \mathrm{L}$ & 0 & - & - & - & - & - & - \\
\hline Samarium & Sm & $\mu \mathrm{g} / \mathrm{L}$ & 0 & 22 & 25 & - & - & $13 \%$ & - \\
\hline Selenium & $\mathrm{Se}$ & $\mu \mathrm{g} / \mathrm{L}$ & 1 & 24 & 25 & - & - & $4 \%$ & - \\
\hline Silver & $\mathrm{Ag}$ & $\mu \mathrm{g} / \mathrm{L}$ & 0 & 24 & 25 & - & - & $4 \%$ & - \\
\hline Sodium & $\mathrm{Na}$ & $\mu \mathrm{g} / \mathrm{L}$ & 200 & - & - & - & - & - & - \\
\hline Strontium & $\mathrm{Sr}$ & $\mu \mathrm{g} / \mathrm{L}$ & 1 & 25 & 25 & - & - & $0 \%$ & - \\
\hline Sulfur & $\mathrm{s}$ & $\mu \mathrm{g} / \mathrm{L}$ & 1000 & 31000 & 30000 & - & - & $3 \%$ & - \\
\hline Tantalum & $\mathrm{Ta}$ & $\mu \mathrm{g} / \mathrm{L}$ & 0 & - & - & 25 & 25 & - & $0 \%$ \\
\hline Terbium & $\mathrm{Tb}$ & $\mu \mathrm{g} / \mathrm{L}$ & 0 & - & - & - & - & - & - \\
\hline Tellurium & $\mathrm{Te}$ & $\mu \mathrm{g} / \mathrm{L}$ & 1 & - & - & 23 & 25 & - & $8 \%$ \\
\hline Thalium & $\mathrm{TI}$ & $\mu \mathrm{g} / \mathrm{L}$ & 0 & 24 & 25 & - & - & $4 \%$ & - \\
\hline Thorium & Th & $\mu \mathrm{g} / \mathrm{L}$ & - & - & - & - & - & & - \\
\hline Thulium & $\mathrm{Tm}$ & $\mu \mathrm{g} / \mathrm{L}$ & 0 & 24 & 25 & - & - & $4 \%$ & - \\
\hline $\operatorname{Tin} * *$ & Sn & $\mu \mathrm{g} / \mathrm{L}$ & 3 & - & - & 24 & 25 & - & $4 \%$ \\
\hline Titanium & $\mathrm{Ti}$ & $\mu \mathrm{g} / \mathrm{L}$ & 3 & - & - & 26 & 25 & - & $4 \%$ \\
\hline Tungsten & w & $\mu \mathrm{g} / \mathrm{L}$ & 1 & - & - & 23 & 25 & - & $8 \%$ \\
\hline Uranium & u & $\mu \mathrm{g} / \mathrm{L}$ & 0 & 25 & 25 & - & - & $0 \%$ & - \\
\hline Vanadium & v & $\mu \mathrm{g} / \mathrm{L}$ & 0 & 24 & 25 & - & - & $4 \%$ & - \\
\hline Ytterbium & $\mathrm{Yb}$ & $\mu \mathrm{g} / \mathrm{L}$ & 0 & 23 & 25 & - & - & $8 \%$ & - \\
\hline Yttrium & $Y$ & $\mu \mathrm{g} / \mathrm{L}$ & 1 & - & - & - & - & - & - \\
\hline Zinc & $\mathrm{Zn}$ & $\mu \mathrm{g} / \mathrm{L}$ & 10 & 24 & 25 & - & - & $4 \%$ & - \\
\hline Zirconium & $\mathrm{Zr}$ & $\mu \mathrm{g} / \mathrm{L}$ & 0 & - & - & 24 & 25 & - & $4 \%$ \\
\hline
\end{tabular}




\begin{tabular}{|c|c|c|c|c|c|c|}
\hline & \multirow[b]{2}{*}{ Symbol } & \multirow[b]{2}{*}{ Units } & \multirow[b]{2}{*}{ Detection limit } & \multicolumn{3}{|c|}{ Certified Reference Material (Samples 1-27) } \\
\hline & & & & EU-H-4 & EU-H-4 Target & \%Diff EU-H-4 \& target \\
\hline \multicolumn{7}{|l|}{ Metals } \\
\hline Aluminium & $\mathrm{Al}$ & $\mu \mathrm{g} / \mathrm{L}$ & 5 & 390 & 420 & $5 \%$ \\
\hline Antimony & $\mathrm{Sb}$ & $\mu g / L$ & 2 & 540 & 520 & $4 \%$ \\
\hline Arsenic & As & $\mu g / L$ & 2 & 810 & 780 & $1 \%$ \\
\hline Barium & $\mathrm{Ba}$ & $\mu \mathrm{g} / \mathrm{L}$ & 0 & 1000 & 1100 & $10 \%$ \\
\hline Beryllium & $\mathrm{Be}$ & $\mu \mathrm{g} / \mathrm{L}$ & 0 & 420 & 460 & $9 \%$ \\
\hline Boron & B & $\mu g / L$ & 1000 & 700 & 710 & $4 \%$ \\
\hline Cadmium & $\mathrm{Cd}$ & $\mu \mathrm{g} / \mathrm{L}$ & 0 & 250 & 270 & $8 \%$ \\
\hline Calcium & $\mathrm{Ca}$ & $\mu \mathrm{g} / \mathrm{L}$ & 300 & 45000 & 41000 & $11 \%$ \\
\hline Cerium & $\mathrm{Ce}$ & $\mu \mathrm{g} / \mathrm{L}$ & 1 & - & - & - \\
\hline Cesium & Cs & $\mu g / L$ & - & - & - & - \\
\hline Chromium & $\mathrm{Cr}$ & $\mu \mathrm{g} / \mathrm{L}$ & 5 & 400 & 400 & $3 \%$ \\
\hline Cobalt & Co & $\mu \mathrm{g} / \mathrm{L}$ & 0 & 500 & 500 & $4 \%$ \\
\hline Copper & $\mathrm{Cu}$ & $\mu \mathrm{g} / \mathrm{L}$ & 5 & 760 & 740 & $1 \%$ \\
\hline Dysprosium & Dy & $\mu \mathrm{g} / \mathrm{L}$ & 0 & - & - & - \\
\hline Erbium & $\mathrm{Er}$ & $\mu g / L$ & 0 & - & - & - \\
\hline Europium & $\mathrm{Eu}$ & $\mu g / L$ & 0 & - & - & - \\
\hline Gadolinium & $\mathrm{Gd}$ & $\mu \mathrm{g} / \mathrm{L}$ & 0 & - & - & - \\
\hline Gallium & $\mathrm{Ga}$ & $\mu \mathrm{g} / \mathrm{L}$ & 5 & - & - & - \\
\hline Germanium & $\mathrm{Ge}$ & $\mu \mathrm{g} / \mathrm{L}$ & 1 & - & - & - \\
\hline Hafnium & $\mathrm{Hf}$ & $\mu \mathrm{g} / \mathrm{L}$ & - & - & - & - \\
\hline Holonium & Ho & $\mu \mathrm{g} / \mathrm{L}$ & 0 & - & - & - \\
\hline Iridium & Ir & $\mu g / L$ & 1 & - & - & - \\
\hline Iron & $\mathrm{Fe}$ & $\mu g / L$ & 50 & 580 & 580 & $2 \%$ \\
\hline Lanthanum & La & $\mu \mathrm{g} / \mathrm{L}$ & 0 & - & - & - \\
\hline Lead & $\mathrm{Pb}$ & $\mu \mathrm{g} / \mathrm{L}$ & 0 & 580 & 610 & $5 \%$ \\
\hline Lithium & $\mathrm{Li}$ & $\mu g / L$ & 2 & - & - & - \\
\hline Lutetium & Lu & $\mu \mathrm{g} / \mathrm{L}$ & 0 & - & - & - \\
\hline Magnesium & $\mathrm{Mg}$ & $\mu \mathrm{g} / \mathrm{L}$ & 30 & 24000 & 25000 & $0 \%$ \\
\hline Manganese & $\mathrm{Mn}$ & $\mu g / L$ & 0 & 460 & 450 & $2 \%$ \\
\hline Molybdenum & Mo & $\mu g / L$ & 10 & 700 & 720 & $13 \%$ \\
\hline Neodymium & $\mathrm{Nd}$ & $\mu \mathrm{g} / \mathrm{L}$ & 0 & - & - & - \\
\hline Nickel & $\mathrm{Ni}$ & $\mu \mathrm{g} / \mathrm{L}$ & 1 & 730 & 740 & $4 \%$ \\
\hline Niobium & $\mathrm{Nb}$ & $\mu \mathrm{g} / \mathrm{L}$ & 0 & - & - & - \\
\hline Palladium & $\mathrm{Pd}$ & $\mu \mathrm{g} / \mathrm{L}$ & - & - & - & - \\
\hline Phosphorus & $\mathrm{P}$ & $\mu \mathrm{g} / \mathrm{L}$ & 1000 & 11000 & 11000 & $0 \%$ \\
\hline Platinum & $\mathrm{Pt}$ & $\mu \mathrm{g} / \mathrm{L}$ & 0 & - & - & - \\
\hline Potassium & K & $\mu \mathrm{g} / \mathrm{L}$ & 200 & 42000 & 45000 & $7 \%$ \\
\hline Praseodymium & $\mathrm{Pr}$ & $\mu \mathrm{g} / \mathrm{L}$ & 0 & - & - & - \\
\hline Rhenium & $\operatorname{Re}$ & $\mu \mathrm{g} / \mathrm{L}$ & 0 & - & - & - \\
\hline Rhodium & $\mathrm{Rh}$ & $\mu \mathrm{g} / \mathrm{L}$ & 0 & - & - & - \\
\hline Rubidium & $\mathrm{Rb}$ & $\mu \mathrm{g} / \mathrm{L}$ & 1 & - & - & - \\
\hline Ruthenium & $\mathrm{Ru}$ & $\mu \mathrm{g} / \mathrm{L}$ & 0 & - & - & - \\
\hline Samarium & $\mathrm{Sm}$ & $\mu \mathrm{g} / \mathrm{L}$ & 0 & - & - & - \\
\hline Selenium & $\mathrm{Se}$ & $\mu \mathrm{g} / \mathrm{L}$ & 1 & 130 & 140 & $7 \%$ \\
\hline Silver & $\mathrm{Ag}$ & $\mu \mathrm{g} / \mathrm{L}$ & 0 & - & - & - \\
\hline Sodium & $\mathrm{Na}$ & $\mu \mathrm{g} / \mathrm{L}$ & 200 & 46000 & 46000 & $0 \%$ \\
\hline Strontium & $\mathrm{Sr}$ & $\mu \mathrm{g} / \mathrm{L}$ & 1 & 940 & 910 & $2 \%$ \\
\hline Sulfur & $S$ & $\mu \mathrm{g} / \mathrm{L}$ & 1000 & - & - & - \\
\hline Tantalum & $\mathrm{Ta}$ & $\mu \mathrm{g} / \mathrm{L}$ & 0 & - & - & - \\
\hline Terbium & $\mathrm{Tb}$ & $\mu \mathrm{g} / \mathrm{L}$ & 0 & - & - & - \\
\hline Tellurium & $\mathrm{Te}$ & $\mu \mathrm{g} / \mathrm{L}$ & 1 & - & - & - \\
\hline Thalium & $\mathrm{Tl}$ & $\mu \mathrm{g} / \mathrm{L}$ & 0 & 370 & 390 & $3 \%$ \\
\hline Thorium & Th & $\mu \mathrm{g} / \mathrm{L}$ & - & - & - & - \\
\hline Thulium & $\mathrm{Tm}$ & $\mu \mathrm{g} / \mathrm{L}$ & 0 & - & - & - \\
\hline Tin ** & Sn & $\mu \mathrm{g} / \mathrm{L}$ & 3 & - & - & - \\
\hline Titanium & $\mathrm{Ti}$ & $\mu \mathrm{g} / \mathrm{L}$ & 3 & - & - & - \\
\hline Tungsten & w & $\mu \mathrm{g} / \mathrm{L}$ & 1 & - & - & - \\
\hline Uranium & U & $\mu \mathrm{g} / \mathrm{L}$ & 0 & 90 & 99 & $12 \%$ \\
\hline Vanadium & v & $\mu \mathrm{g} / \mathrm{L}$ & 0 & 810 & 820 & $5 \%$ \\
\hline Ytterbium & $\mathrm{Yb}$ & $\mu \mathrm{g} / \mathrm{L}$ & 0 & - & - & - \\
\hline Yttrium & $Y$ & $\mu \mathrm{g} / \mathrm{L}$ & 1 & - & - & - \\
\hline Zinc & $\mathrm{Zn}$ & $\mu \mathrm{g} / \mathrm{L}$ & 10 & 880 & 870 & $2 \%$ \\
\hline Zirconium & $\mathrm{Zr}$ & $\mu \mathrm{g} / \mathrm{L}$ & 0 & - & - & - \\
\hline
\end{tabular}




\begin{tabular}{|c|c|c|c|c|c|c|c|c|c|}
\hline & \multicolumn{9}{|c|}{ Certified Reference Material (Samples 28-59) } \\
\hline & Symbol & Units & Detection limit & Control 1 & Control 1 Target & Control 2 & Control 2 Target & \%Diff C1-C1T & \%Diff C2-C2t \\
\hline \multicolumn{10}{|l|}{ Metals } \\
\hline Aluminium & $\mathrm{Al}$ & $\mu \mathrm{g} / \mathrm{L}$ & 5 & 25 & 25 & - & - & $0 \%$ & - \\
\hline Antimony & $\mathrm{Sb}$ & $\mu \mathrm{g} / \mathrm{L}$ & 2 & - & - & 25 & 25 & - & $0 \%$ \\
\hline Arsenic & As & $\mu \mathrm{g} / \mathrm{L}$ & 2 & 28 & 25 & - & - & $11 \%$ & - \\
\hline Barium & $\mathrm{Ba}$ & $\mu g / L$ & 0 & 24 & 25 & - & - & $4 \%$ & - \\
\hline Beryllium & $\mathrm{Be}$ & $\mu \mathrm{g} / \mathrm{L}$ & 0 & 24 & 25 & - & - & $4 \%$ & - \\
\hline Boron & B & $\mu \mathrm{g} / \mathrm{L}$ & 1000 & 2100 & 2000 & - & - & $5 \%$ & - \\
\hline Cadmium & $\mathrm{Cd}$ & $\mu \mathrm{g} / \mathrm{L}$ & 0 & 24 & 25 & - & - & $4 \%$ & - \\
\hline Calcium & $\mathrm{Ca}$ & $\mu \mathrm{g} / \mathrm{L}$ & 300 & - & - & - & - & - & - \\
\hline Cerium & $\mathrm{Ce}$ & $\mu \mathrm{g} / \mathrm{L}$ & 1 & 24 & 25 & - & - & $4 \%$ & - \\
\hline Cesium & Cs & $\mu \mathrm{g} / \mathrm{L}$ & - & - & - & - & - & - & - \\
\hline Chromium & $\mathrm{Cr}$ & $\mu \mathrm{g} / \mathrm{L}$ & 5 & 25 & 25 & - & - & $0 \%$ & - \\
\hline Cobalt & Co & $\mu \mathrm{g} / \mathrm{L}$ & 0 & 25 & 25 & - & - & $0 \%$ & - \\
\hline Copper & $\mathrm{Cu}$ & $\mu \mathrm{g} / \mathrm{L}$ & 5 & 26 & 25 & - & - & $4 \%$ & - \\
\hline Dysprosium & Dy & $\mu \mathrm{g} / \mathrm{L}$ & 0 & 23 & 25 & - & - & $8 \%$ & - \\
\hline Erbium & $\mathrm{Er}$ & $\mu \mathrm{g} / \mathrm{L}$ & 0 & 24 & 25 & - & - & $4 \%$ & - \\
\hline Europium & $\mathrm{Eu}$ & $\mu \mathrm{g} / \mathrm{L}$ & 0 & 26 & 25 & - & - & $4 \%$ & - \\
\hline Gadolinium & Gd & $\mu \mathrm{g} / \mathrm{L}$ & 0 & 23 & 25 & - & - & $8 \%$ & - \\
\hline Gallium & Ga & $\mu \mathrm{g} / \mathrm{L}$ & 5 & 29 & 25 & - & - & $15 \%$ & - \\
\hline Germanium & $\mathrm{Ge}$ & $\mu \mathrm{g} / \mathrm{L}$ & 1 & - & - & 24 & 25 & - & $4 \%$ \\
\hline Hafnium & $\mathrm{Hf}$ & $\mu \mathrm{g} / \mathrm{L}$ & - & - & - & - & - & - & - \\
\hline Holonium & Ho & $\mu \mathrm{g} / \mathrm{L}$ & 0 & 24 & 25 & - & - & $4 \%$ & - \\
\hline Iridium & Ir & $\mu \mathrm{g} / \mathrm{L}$ & 1 & - & - & - & - & - & - \\
\hline Iron & $\mathrm{Fe}$ & $\mu \mathrm{g} / \mathrm{L}$ & 50 & 26 & 25 & - & - & $4 \%$ & - \\
\hline Lanthanum & La & $\mu \mathrm{g} / \mathrm{L}$ & 0 & 24 & 25 & - & - & $4 \%$ & - \\
\hline Lead & $\mathrm{Pb}$ & $\mu \mathrm{g} / \mathrm{L}$ & 0 & 24 & 25 & - & - & $4 \%$ & - \\
\hline Lithium & $\mathrm{Li}$ & $\mu \mathrm{g} / \mathrm{L}$ & 2 & - & - & - & - & - & - \\
\hline Lutetium & $\mathrm{Lu}$ & $\mu \mathrm{g} / \mathrm{L}$ & 0 & 22 & 25 & - & - & $13 \%$ & - \\
\hline Magnesium & $\mathrm{Mg}$ & $\mu \mathrm{g} / \mathrm{L}$ & 30 & 25 & 25 & - & - & $0 \%$ & - \\
\hline Manganese & $\mathrm{Mn}$ & $\mu \mathrm{g} / \mathrm{L}$ & 0 & 25 & 25 & - & - & $0 \%$ & - \\
\hline Molybdenum & Mo & $\mu \mathrm{g} / \mathrm{L}$ & 10 & - & - & 26 & 25 & - & $4 \%$ \\
\hline Neodymium & $\mathrm{Nd}$ & $\mu \mathrm{g} / \mathrm{L}$ & 0 & 23 & 25 & - & - & $8 \%$ & - \\
\hline Nickel & $\mathrm{Ni}$ & $\mu \mathrm{g} / \mathrm{L}$ & 1 & 25 & 25 & - & - & $0 \%$ & - \\
\hline Niobium & $\mathrm{Nb}$ & $\mu \mathrm{g} / \mathrm{L}$ & 0 & - & - & 26 & 25 & - & $4 \%$ \\
\hline Palladium & $\mathrm{Pd}$ & $\mu \mathrm{g} / \mathrm{L}$ & - & - & - & - & - & - & - \\
\hline Phosphorus & $\mathrm{P}$ & $\mu \mathrm{g} / \mathrm{L}$ & 1000 & 32000 & 30000 & - & - & $6 \%$ & - \\
\hline Platinum & $\mathrm{Pt}$ & $\mu \mathrm{g} / \mathrm{L}$ & 0 & - & - & - & - & - & - \\
\hline Potassium & K & $\mu \mathrm{g} / \mathrm{L}$ & 200 & - & 25 & - & - & - & - \\
\hline Praseodymium & $\mathrm{Pr}$ & $\mu \mathrm{g} / \mathrm{L}$ & 0 & 24 & 25 & - & - & $4 \%$ & - \\
\hline Rhenium & $\operatorname{Re}$ & $\mu \mathrm{g} / \mathrm{L}$ & 0 & - & - & - & - & - & - \\
\hline Rhodium & $\mathrm{Rh}$ & $\mu \mathrm{g} / \mathrm{L}$ & 0 & - & - & - & - & - & - \\
\hline Rubidium & $\mathrm{Rb}$ & $\mu \mathrm{g} / \mathrm{L}$ & 1 & 25 & 25 & - & - & $0 \%$ & - \\
\hline Ruthenium & $\mathrm{Ru}$ & $\mu \mathrm{g} / \mathrm{L}$ & 0 & - & - & - & - & - & - \\
\hline Samarium & $\mathrm{Sm}$ & $\mu \mathrm{g} / \mathrm{L}$ & 0 & 23 & 25 & - & - & $8 \%$ & - \\
\hline Selenium & Se & $\mu \mathrm{g} / \mathrm{L}$ & 1 & 25 & 25 & - & - & $0 \%$ & - \\
\hline Silver & $\mathrm{Ag}$ & $\mu \mathrm{g} / \mathrm{L}$ & 0 & 26 & 25 & - & - & $4 \%$ & - \\
\hline Sodium & $\mathrm{Na}$ & $\mu \mathrm{g} / \mathrm{L}$ & 200 & - & - & - & - & - & - \\
\hline Strontium & $\mathrm{Sr}$ & $\mu \mathrm{g} / \mathrm{L}$ & 1 & 27 & 25 & - & - & $8 \%$ & - \\
\hline Sulfur & $\mathrm{s}$ & $\mu \mathrm{g} / \mathrm{L}$ & 1000 & 31000 & 30000 & - & - & $3 \%$ & - \\
\hline Tantalum & $\mathrm{Ta}$ & $\mu \mathrm{g} / \mathrm{L}$ & 0 & - & - & 25 & 25 & - & $0 \%$ \\
\hline Terbium & $\mathrm{Tb}$ & $\mu \mathrm{g} / \mathrm{L}$ & 0 & - & - & - & - & - & - \\
\hline Tellurium & $\mathrm{Te}$ & $\mu \mathrm{g} / \mathrm{L}$ & 1 & - & - & 22 & 25 & - & $13 \%$ \\
\hline Thalium & $\mathrm{Tl}$ & $\mu \mathrm{g} / \mathrm{L}$ & 0 & 24 & 25 & - & - & $4 \%$ & - \\
\hline Thorium & Th & $\mu \mathrm{g} / \mathrm{L}$ & - & - & - & - & - & - & - \\
\hline Thulium & $\mathrm{Tm}$ & $\mu \mathrm{g} / \mathrm{L}$ & 0 & 24 & 25 & - & - & $4 \%$ & - \\
\hline $\operatorname{Tin} * *$ & Sn & $\mu \mathrm{g} / \mathrm{L}$ & 3 & - & - & 24 & 25 & - & $4 \%$ \\
\hline Titanium & $\mathrm{Ti}$ & $\mu \mathrm{g} / \mathrm{L}$ & 3 & - & - & 25 & 25 & - & $0 \%$ \\
\hline Tungsten & w & $\mu \mathrm{g} / \mathrm{L}$ & 1 & - & - & 25 & 25 & - & $0 \%$ \\
\hline Uranium & u & $\mu \mathrm{g} / \mathrm{L}$ & 0 & 25 & 25 & - & - & $0 \%$ & - \\
\hline Vanadium & v & $\mu \mathrm{g} / \mathrm{L}$ & 0 & 26 & 25 & - & - & $4 \%$ & - \\
\hline Ytterbium & $\mathrm{Yb}$ & $\mu \mathrm{g} / \mathrm{L}$ & 0 & 24 & 25 & - & - & $4 \%$ & - \\
\hline Yttrium & $Y$ & $\mu \mathrm{g} / \mathrm{L}$ & 1 & - & - & - & - & - & - \\
\hline Zinc & $\mathrm{Zn}$ & $\mu \mathrm{g} / \mathrm{L}$ & 10 & 25 & 25 & - & - & $0 \%$ & - \\
\hline Zirconium & $\mathrm{Zr}$ & $\mu \mathrm{g} / \mathrm{L}$ & 0 & - & - & 25 & 25 & - & $0 \%$ \\
\hline
\end{tabular}




\begin{tabular}{|c|c|c|c|c|c|c|}
\hline & \multirow[b]{2}{*}{ Symbol } & \multirow[b]{2}{*}{ Units } & \multirow[b]{2}{*}{ Detection limit } & \multicolumn{3}{|c|}{ Certified Reference Material (Samples 28-59) } \\
\hline & & & & EU-H-4 & EU-H-4 Target & \%Diff EU-H-4 \& target \\
\hline Metals & & & & 390 & 420 & $7 \%$ \\
\hline Aluminium & Al & $\mu \mathrm{g} / \mathrm{L}$ & 5 & 540 & 520 & $4 \%$ \\
\hline Antimony & $\mathrm{Sb}$ & $\mu \mathrm{g} / \mathrm{L}$ & 2 & 810 & 780 & $4 \%$ \\
\hline Arsenic & As & $\mu \mathrm{g} / \mathrm{L}$ & 2 & 1000 & 1100 & $10 \%$ \\
\hline Barium & $\mathrm{Ba}$ & $\mu \mathrm{g} / \mathrm{L}$ & 0 & 420 & 460 & $9 \%$ \\
\hline Beryllium & $\mathrm{Be}$ & $\mu \mathrm{g} / \mathrm{L}$ & 0 & 700 & 710 & $1 \%$ \\
\hline Boron & B & $\mu \mathrm{g} / \mathrm{L}$ & 1000 & 250 & 270 & $8 \%$ \\
\hline Cadmium & $\mathrm{Cd}$ & $\mu \mathrm{g} / \mathrm{L}$ & 0 & 45000 & 41000 & $9 \%$ \\
\hline Calcium & $\mathrm{Ca}$ & $\mu \mathrm{g} / \mathrm{L}$ & 300 & - & - & - \\
\hline Cerium & $\mathrm{Ce}$ & $\mu \mathrm{g} / \mathrm{L}$ & 1 & - & - & - \\
\hline Cesium & Cs & $\mu \mathrm{g} / \mathrm{L}$ & - & 400 & 400 & $0 \%$ \\
\hline Chromium & $\mathrm{Cr}$ & $\mu g / L$ & 5 & 500 & 500 & $0 \%$ \\
\hline Cobalt & Co & $\mu \mathrm{g} / \mathrm{L}$ & 0 & 760 & 740 & $3 \%$ \\
\hline Copper & $\mathrm{Cu}$ & $\mu \mathrm{g} / \mathrm{L}$ & 5 & - & - & - \\
\hline Dysprosium & Dy & $\mu \mathrm{g} / \mathrm{L}$ & 0 & - & - & - \\
\hline Erbium & $\mathrm{Er}$ & $\mu \mathrm{g} / \mathrm{L}$ & 0 & - & - & - \\
\hline Europium & $\mathrm{Eu}$ & $\mu \mathrm{g} / \mathrm{L}$ & 0 & - & - & - \\
\hline Gadolinium & $\mathrm{Gd}$ & $\mu \mathrm{g} / \mathrm{L}$ & 0 & - & - & - \\
\hline Gallium & Ga & $\mu \mathrm{g} / \mathrm{L}$ & 5 & - & - & - \\
\hline Germanium & Ge & $\mu \mathrm{g} / \mathrm{L}$ & 1 & - & - & - \\
\hline Hafnium & $\mathrm{Hf}$ & $\mu \mathrm{g} / \mathrm{L}$ & - & - & - & - \\
\hline Holonium & Ho & $\mu \mathrm{g} / \mathrm{L}$ & 0 & - & - & - \\
\hline Iridium & Ir & $\mu \mathrm{g} / \mathrm{L}$ & 1 & 580 & 580 & $0 \%$ \\
\hline Iron & $\mathrm{Fe}$ & $\mu \mathrm{g} / \mathrm{L}$ & 50 & - & - & - \\
\hline Lanthanum & La & $\mu \mathrm{g} / \mathrm{L}$ & 0 & 580 & 610 & $5 \%$ \\
\hline Lead & $\mathrm{Pb}$ & $\mu \mathrm{g} / \mathrm{L}$ & 0 & - & - & - \\
\hline Lithium & $\mathrm{Li}$ & $\mu \mathrm{g} / \mathrm{L}$ & 2 & - & - & - \\
\hline Lutetium & Lu & $\mu \mathrm{g} / \mathrm{L}$ & 0 & 24000 & 25000 & $4 \%$ \\
\hline Magnesium & $\mathrm{Mg}$ & $\mu \mathrm{g} / \mathrm{L}$ & 30 & 460 & 450 & $2 \%$ \\
\hline Manganese & $\mathrm{Mn}$ & $\mu \mathrm{g} / \mathrm{L}$ & 0 & 700 & 720 & $3 \%$ \\
\hline Molybdenum & Mo & $\mu \mathrm{g} / \mathrm{L}$ & 10 & - & - & - \\
\hline Neodymium & $\mathrm{Nd}$ & $\mu \mathrm{g} / \mathrm{L}$ & 0 & 730 & 740 & $1 \%$ \\
\hline Nickel & $\mathrm{Ni}$ & $\mu \mathrm{g} / \mathrm{L}$ & 1 & - & - & - \\
\hline Niobium & $\mathrm{Nb}$ & $\mu \mathrm{g} / \mathrm{L}$ & 0 & - & - & - \\
\hline Palladium & $\mathrm{Pd}$ & $\mu \mathrm{g} / \mathrm{L}$ & - & 11000 & 11000 & $0 \%$ \\
\hline Phosphorus & $P$ & $\mu g / L$ & 1000 & - & - & - \\
\hline Platinum & $\mathrm{Pt}$ & $\mu \mathrm{g} / \mathrm{L}$ & 0 & 42000 & 45000 & $7 \%$ \\
\hline Potassium & $\mathrm{K}$ & $\mu \mathrm{g} / \mathrm{L}$ & 200 & - & - & - \\
\hline Praseodymium & $\mathrm{Pr}$ & $\mu \mathrm{g} / \mathrm{L}$ & 0 & - & - & - \\
\hline Rhenium & $\operatorname{Re}$ & $\mu \mathrm{g} / \mathrm{L}$ & 0 & - & - & - \\
\hline Rhodium & $\mathrm{Rh}$ & $\mu \mathrm{g} / \mathrm{L}$ & 0 & - & - & - \\
\hline Rubidium & $\mathrm{Rb}$ & $\mu g / L$ & 1 & - & - & - \\
\hline Ruthenium & $\mathrm{Ru}$ & $\mu \mathrm{g} / \mathrm{L}$ & 0 & - & - & - \\
\hline Samarium & $\mathrm{Sm}$ & $\mu \mathrm{g} / \mathrm{L}$ & 0 & 130 & 140 & $7 \%$ \\
\hline Selenium & Se & $\mu \mathrm{g} / \mathrm{L}$ & 1 & - & - & - \\
\hline Silver & $\mathrm{Ag}$ & $\mu \mathrm{g} / \mathrm{L}$ & 0 & 46000 & 46000 & $0 \%$ \\
\hline Sodium & $\mathrm{Na}$ & $\mu \mathrm{g} / \mathrm{L}$ & 200 & 940 & 910 & $3 \%$ \\
\hline Strontium & $\mathrm{Sr}$ & $\mu \mathrm{g} / \mathrm{L}$ & 1 & - & - & - \\
\hline Sulfur & $\mathrm{S}$ & $\mu \mathrm{g} / \mathrm{L}$ & 1000 & - & - & - \\
\hline Tantalum & $\mathrm{Ta}$ & $\mu \mathrm{g} / \mathrm{L}$ & 0 & - & - & - \\
\hline Terbium & $\mathrm{Tb}$ & $\mu \mathrm{g} / \mathrm{L}$ & 0 & - & - & - \\
\hline Tellurium & $\mathrm{Te}$ & $\mu \mathrm{g} / \mathrm{L}$ & 1 & 370 & 390 & $5 \%$ \\
\hline Thalium & $\mathrm{Tl}$ & $\mu \mathrm{g} / \mathrm{L}$ & 0 & - & - & - \\
\hline Thorium & Th & $\mu g / L$ & - & - & - & - \\
\hline Thulium & $\mathrm{Tm}$ & $\mu \mathrm{g} / \mathrm{L}$ & 0 & - & - & - \\
\hline $\operatorname{Tin} * *$ & Sn & $\mu \mathrm{g} / \mathrm{L}$ & 3 & - & - & - \\
\hline Titanium & $\mathrm{Ti}$ & $\mu \mathrm{g} / \mathrm{L}$ & 3 & - & - & - \\
\hline Tungsten & W & $\mu \mathrm{g} / \mathrm{L}$ & 1 & 90 & 99 & $10 \%$ \\
\hline Uranium & U & $\mu \mathrm{g} / \mathrm{L}$ & 0 & 810 & 820 & $1 \%$ \\
\hline Vanadium & v & $\mu \mathrm{g} / \mathrm{L}$ & 0 & - & - & - \\
\hline Ytterbium & $\mathrm{Yb}$ & $\mu \mathrm{g} / \mathrm{L}$ & 0 & - & - & - \\
\hline Yttrium & $\mathrm{Y}$ & $\mu \mathrm{g} / \mathrm{L}$ & 1 & 880 & 870 & $1 \%$ \\
\hline Zinc & $\mathrm{Zn}$ & $\mu \mathrm{g} / \mathrm{L}$ & 10 & - & - & - \\
\hline Zirconium & $\mathrm{Zr}$ & $\mu \mathrm{g} / \mathrm{L}$ & 0 & & & \\
\hline
\end{tabular}




\begin{tabular}{|c|c|c|c|c|c|c|c|c|c|}
\hline & \multicolumn{9}{|c|}{ Certified Reference Material (Samples 60-84) } \\
\hline & Symbol & Units & Detection limit & Control 1 & Control 1 Target & Control 2 & Control 2 Target & \%Diff C1-C1T & \%Diff C2-C2t \\
\hline \multicolumn{10}{|l|}{ Metals } \\
\hline Aluminium & Al & $\mu \mathrm{g} / \mathrm{L}$ & 5 & 26 & 25 & - & - & $4 \%$ & - \\
\hline Antimony & $\mathrm{Sb}$ & $\mu \mathrm{g} / \mathrm{L}$ & 2 & - & - & 24 & 25 & - & $4 \%$ \\
\hline Arsenic & As & $\mu \mathrm{g} / \mathrm{L}$ & 2 & 25 & 25 & - & - & $0 \%$ & - \\
\hline Barium & $\mathrm{Ba}$ & $\mu \mathrm{g} / \mathrm{L}$ & 0 & 24 & 25 & - & - & $4 \%$ & - \\
\hline Beryllium & $\mathrm{Be}$ & $\mu \mathrm{g} / \mathrm{L}$ & 0 & 23 & 25 & - & - & $8 \%$ & - \\
\hline Boron & B & $\mu \mathrm{g} / \mathrm{L}$ & 1000 & 1900 & 2000 & - & - & $5 \%$ & - \\
\hline Cadmium & $\mathrm{Cd}$ & $\mu \mathrm{g} / \mathrm{L}$ & 0 & 23 & 25 & - & - & $8 \%$ & - \\
\hline Calcium & $\mathrm{Ca}$ & $\mu \mathrm{g} / \mathrm{L}$ & 300 & - & - & - & - & - & - \\
\hline Cerium & $\mathrm{Ce}$ & $\mu \mathrm{g} / \mathrm{L}$ & 1 & 23 & 25 & - & - & $8 \%$ & - \\
\hline Cesium & Cs & $\mu \mathrm{g} / \mathrm{L}$ & - & - & - & - & - & - & - \\
\hline Chromium & $\mathrm{Cr}$ & $\mu \mathrm{g} / \mathrm{L}$ & 5 & 23 & 25 & - & - & $8 \%$ & - \\
\hline Cobalt & Co & $\mu \mathrm{g} / \mathrm{L}$ & 0 & 23 & 25 & - & - & $8 \%$ & - \\
\hline Copper & $\mathrm{Cu}$ & $\mu \mathrm{g} / \mathrm{L}$ & 5 & 24 & 25 & - & - & $4 \%$ & - \\
\hline Dysprosium & Dy & $\mu \mathrm{g} / \mathrm{L}$ & 0 & 22 & 25 & - & - & $13 \%$ & - \\
\hline Erbium & $\mathrm{Er}$ & $\mu \mathrm{g} / \mathrm{L}$ & 0 & 22 & 25 & - & - & $13 \%$ & - \\
\hline Europium & $\mathrm{Eu}$ & $\mu \mathrm{g} / \mathrm{L}$ & 0 & 23 & 25 & - & - & $8 \%$ & - \\
\hline Gadolinium & Gd & $\mu \mathrm{g} / \mathrm{L}$ & 0 & 22 & 25 & - & - & $13 \%$ & - \\
\hline Gallium & Ga & $\mu \mathrm{g} / \mathrm{L}$ & 5 & 25 & 25 & - & - & $0 \%$ & - \\
\hline Germanium & $\mathrm{Ge}$ & $\mu \mathrm{g} / \mathrm{L}$ & 1 & - & - & 24 & 25 & - & $4 \%$ \\
\hline Hafnium & $\mathrm{Hf}$ & $\mu \mathrm{g} / \mathrm{L}$ & - & - & - & - & - & - & - \\
\hline Holonium & Ho & $\mu \mathrm{g} / \mathrm{L}$ & 0 & 23 & 25 & - & - & $8 \%$ & - \\
\hline Iridium & Ir & $\mu \mathrm{g} / \mathrm{L}$ & 1 & - & - & - & - & - & - \\
\hline Iron & $\mathrm{Fe}$ & $\mu \mathrm{g} / \mathrm{L}$ & 50 & 26 & 25 & - & - & $4 \%$ & - \\
\hline Lanthanum & La & $\mu \mathrm{g} / \mathrm{L}$ & 0 & 23 & 25 & - & - & $8 \%$ & - \\
\hline Lead & $\mathrm{Pb}$ & $\mu \mathrm{g} / \mathrm{L}$ & 0 & 23 & 25 & - & - & $8 \%$ & - \\
\hline Lithium & $\mathrm{Li}$ & $\mu \mathrm{g} / \mathrm{L}$ & 2 & - & - & - & - & - & - \\
\hline Lutetium & $\mathrm{Lu}$ & $\mu \mathrm{g} / \mathrm{L}$ & 0 & 21 & 25 & - & - & $17 \%$ & - \\
\hline Magnesium & $\mathrm{Mg}$ & $\mu \mathrm{g} / \mathrm{L}$ & 30 & 26 & 25 & - & - & $4 \%$ & - \\
\hline Manganese & $\mathrm{Mn}$ & $\mu \mathrm{g} / \mathrm{L}$ & 0 & 24 & 25 & - & - & $4 \%$ & - \\
\hline Molybdenum & Mo & $\mu \mathrm{g} / \mathrm{L}$ & 10 & - & - & 24 & 25 & - & $4 \%$ \\
\hline Neodymium & $\mathrm{Nd}$ & $\mu \mathrm{g} / \mathrm{L}$ & 0 & 22 & 25 & - & - & $13 \%$ & - \\
\hline Nickel & $\mathrm{Ni}$ & $\mu \mathrm{g} / \mathrm{L}$ & 1 & 23 & 25 & - & - & $8 \%$ & - \\
\hline Niobium & $\mathrm{Nb}$ & $\mu \mathrm{g} / \mathrm{L}$ & 0 & - & - & 24 & 25 & - & $4 \%$ \\
\hline Palladium & $\mathrm{Pd}$ & $\mu \mathrm{g} / \mathrm{L}$ & - & - & - & - & - & - & - \\
\hline Phosphorus & $\mathrm{P}$ & $\mu \mathrm{g} / \mathrm{L}$ & 1000 & 30000 & 30000 & - & - & $0 \%$ & - \\
\hline Platinum & $\mathrm{Pt}$ & $\mu \mathrm{g} / \mathrm{L}$ & 0 & - & - & - & - & - & - \\
\hline Potassium & $\mathrm{K}$ & $\mu \mathrm{g} / \mathrm{L}$ & 200 & 24 & 25 & - & - & $4 \%$ & - \\
\hline Praseodymium & $\mathrm{Pr}$ & $\mu \mathrm{g} / \mathrm{L}$ & 0 & 23 & 25 & - & - & $8 \%$ & - \\
\hline Rhenium & $\operatorname{Re}$ & $\mu \mathrm{g} / \mathrm{L}$ & 0 & - & - & - & - & - & - \\
\hline Rhodium & $\mathrm{Rh}$ & $\mu \mathrm{g} / \mathrm{L}$ & 0 & - & - & - & - & - & - \\
\hline Rubidium & $\mathrm{Rb}$ & $\mu \mathrm{g} / \mathrm{L}$ & 1 & 24 & 25 & - & - & $4 \%$ & - \\
\hline Ruthenium & $\mathrm{Ru}$ & $\mu \mathrm{g} / \mathrm{L}$ & 0 & - & - & - & - & - & - \\
\hline Samarium & $\mathrm{Sm}$ & $\mu \mathrm{g} / \mathrm{L}$ & 0 & 22 & 25 & - & - & $13 \%$ & - \\
\hline Selenium & Se & $\mu \mathrm{g} / \mathrm{L}$ & 1 & 23 & 25 & - & - & $8 \%$ & - \\
\hline Silver & $\mathrm{Ag}$ & $\mu \mathrm{g} / \mathrm{L}$ & 0 & 23 & 25 & - & - & $8 \%$ & - \\
\hline Sodium & $\mathrm{Na}$ & $\mu \mathrm{g} / \mathrm{L}$ & 200 & - & - & - & - & - & - \\
\hline Strontium & $\mathrm{Sr}$ & $\mu \mathrm{g} / \mathrm{L}$ & 1 & 25 & 25 & - & - & $0 \%$ & - \\
\hline Sulfur & $\mathrm{s}$ & $\mu \mathrm{g} / \mathrm{L}$ & 1000 & 29000 & 30000 & - & - & $3 \%$ & - \\
\hline Tantalum & $\mathrm{Ta}$ & $\mu \mathrm{g} / \mathrm{L}$ & 0 & - & - & 24 & 25 & - & $4 \%$ \\
\hline Terbium & $\mathrm{Tb}$ & $\mu \mathrm{g} / \mathrm{L}$ & 0 & - & - & - & - & - & - \\
\hline Tellurium & $\mathrm{Te}$ & $\mu \mathrm{g} / \mathrm{L}$ & 1 & - & - & 23 & 25 & - & $8 \%$ \\
\hline Thalium & $\mathrm{Tl}$ & $\mu \mathrm{g} / \mathrm{L}$ & 0 & 23 & 25 & - & - & $8 \%$ & - \\
\hline Thorium & Th & $\mu \mathrm{g} / \mathrm{L}$ & - & - & - & - & - & - & - \\
\hline Thulium & $\mathrm{Tm}$ & $\mu \mathrm{g} / \mathrm{L}$ & 0 & 23 & 25 & - & - & $8 \%$ & - \\
\hline $\operatorname{Tin} * *$ & Sn & $\mu \mathrm{g} / \mathrm{L}$ & 3 & - & - & 25 & 25 & - & $0 \%$ \\
\hline Titanium & $\mathrm{Ti}$ & $\mu \mathrm{g} / \mathrm{L}$ & 3 & - & - & 26 & 25 & - & $4 \%$ \\
\hline Tungsten & w & $\mu \mathrm{g} / \mathrm{L}$ & 1 & - & - & 23 & 25 & - & $8 \%$ \\
\hline Uranium & u & $\mu \mathrm{g} / \mathrm{L}$ & 0 & 24 & 25 & - & - & $4 \%$ & - \\
\hline Vanadium & v & $\mu \mathrm{g} / \mathrm{L}$ & 0 & 24 & 25 & - & - & $4 \%$ & - \\
\hline Ytterbium & $\mathrm{Yb}$ & $\mu \mathrm{g} / \mathrm{L}$ & 0 & 22 & 25 & - & - & $13 \%$ & - \\
\hline Yttrium & $Y$ & $\mu \mathrm{g} / \mathrm{L}$ & 1 & - & - & - & - & - & - \\
\hline Zinc & $\mathrm{Zn}$ & $\mu \mathrm{g} / \mathrm{L}$ & 10 & 24 & 25 & - & - & $4 \%$ & - \\
\hline Zirconium & $\mathrm{Zr}$ & $\mu \mathrm{g} / \mathrm{L}$ & 0 & - & - & 23 & 25 & - & $8 \%$ \\
\hline
\end{tabular}




\begin{tabular}{|c|c|c|c|c|c|c|}
\hline & \multirow[b]{2}{*}{ Symbol } & \multirow[b]{2}{*}{ Units } & \multirow[b]{2}{*}{ Detection limit } & \multicolumn{3}{|c|}{ Certified Reference Material (Samples 60-84) } \\
\hline & & & & EU-H-4 & EU-H-4 Target & \%Diff EU-H-4 \& target \\
\hline \multicolumn{7}{|l|}{ Metals } \\
\hline Aluminium & $\mathrm{Al}$ & $\mu \mathrm{g} / \mathrm{L}$ & 5 & 420 & 420 & $0 \%$ \\
\hline Antimony & $\mathrm{Sb}$ & $\mu g / L$ & 2 & 590 & 520 & $13 \%$ \\
\hline Arsenic & As & $\mu g / L$ & 2 & 850 & 780 & $9 \%$ \\
\hline Barium & $\mathrm{Ba}$ & $\mu \mathrm{g} / \mathrm{L}$ & 0 & 1000 & 1100 & $10 \%$ \\
\hline Beryllium & $\mathrm{Be}$ & $\mu \mathrm{g} / \mathrm{L}$ & 0 & 470 & 460 & $2 \%$ \\
\hline Boron & B & $\mu g / L$ & 1000 & 720 & 710 & $1 \%$ \\
\hline Cadmium & $\mathrm{Cd}$ & $\mu \mathrm{g} / \mathrm{L}$ & 0 & 270 & 270 & $0 \%$ \\
\hline Calcium & $\mathrm{Ca}$ & $\mu \mathrm{g} / \mathrm{L}$ & 300 & 50000 & 41000 & $20 \%$ \\
\hline Cerium & $\mathrm{Ce}$ & $\mu \mathrm{g} / \mathrm{L}$ & 1 & - & - & - \\
\hline Cesium & Cs & $\mu g / L$ & - & - & - & - \\
\hline Chromium & $\mathrm{Cr}$ & $\mu \mathrm{g} / \mathrm{L}$ & 5 & 410 & 400 & $2 \%$ \\
\hline Cobalt & Co & $\mu g / L$ & 0 & 510 & 500 & $2 \%$ \\
\hline Copper & $\mathrm{Cu}$ & $\mu \mathrm{g} / \mathrm{L}$ & 5 & 760 & 740 & $3 \%$ \\
\hline Dysprosium & Dy & $\mu \mathrm{g} / \mathrm{L}$ & 0 & - & - & - \\
\hline Erbium & $\mathrm{Er}$ & $\mu g / L$ & 0 & - & - & - \\
\hline Europium & $\mathrm{Eu}$ & $\mu g / L$ & 0 & - & - & - \\
\hline Gadolinium & $\mathrm{Gd}$ & $\mu \mathrm{g} / \mathrm{L}$ & 0 & - & - & - \\
\hline Gallium & $\mathrm{Ga}$ & $\mu \mathrm{g} / \mathrm{L}$ & 5 & - & - & - \\
\hline Germanium & $\mathrm{Ge}$ & $\mu \mathrm{g} / \mathrm{L}$ & 1 & - & - & - \\
\hline Hafnium & $\mathrm{Hf}$ & $\mu \mathrm{g} / \mathrm{L}$ & - & - & - & - \\
\hline Holonium & $\mathrm{Ho}$ & $\mu \mathrm{g} / \mathrm{L}$ & 0 & - & - & - \\
\hline Iridium & Ir & $\mu g / L$ & 1 & - & - & - \\
\hline Iron & $\mathrm{Fe}$ & $\mu g / L$ & 50 & 650 & 580 & $11 \%$ \\
\hline Lanthanum & La & $\mu \mathrm{g} / \mathrm{L}$ & 0 & - & - & - \\
\hline Lead & $\mathrm{Pb}$ & $\mu \mathrm{g} / \mathrm{L}$ & 0 & 650 & 610 & $6 \%$ \\
\hline Lithium & $\mathrm{Li}$ & $\mu \mathrm{g} / \mathrm{L}$ & 2 & - & - & - \\
\hline Lutetium & Lu & $\mu \mathrm{g} / \mathrm{L}$ & 0 & - & - & - \\
\hline Magnesium & $\mathrm{Mg}$ & $\mu \mathrm{g} / \mathrm{L}$ & 30 & 28000 & 25000 & $11 \%$ \\
\hline Manganese & $\mathrm{Mn}$ & $\mu g / L$ & 0 & 480 & 450 & $6 \%$ \\
\hline Molybdenum & Mo & $\mu g / L$ & 10 & 720 & 720 & $0 \%$ \\
\hline Neodymium & $\mathrm{Nd}$ & $\mu \mathrm{g} / \mathrm{L}$ & 0 & - & - & - \\
\hline Nickel & $\mathrm{Ni}$ & $\mu \mathrm{g} / \mathrm{L}$ & 1 & 750 & 740 & $1 \%$ \\
\hline Niobium & $\mathrm{Nb}$ & $\mu \mathrm{g} / \mathrm{L}$ & 0 & - & - & - \\
\hline Palladium & $\mathrm{Pd}$ & $\mu \mathrm{g} / \mathrm{L}$ & - & - & - & - \\
\hline Phosphorus & $\mathrm{P}$ & $\mu \mathrm{g} / \mathrm{L}$ & 1000 & 11000 & 11000 & $0 \%$ \\
\hline Platinum & $\mathrm{Pt}$ & $\mu \mathrm{g} / \mathrm{L}$ & 0 & - & - & - \\
\hline Potassium & K & $\mu \mathrm{g} / \mathrm{L}$ & 200 & 47000 & 45000 & $4 \%$ \\
\hline Praseodymium & $\mathrm{Pr}$ & $\mu \mathrm{g} / \mathrm{L}$ & 0 & - & - & - \\
\hline Rhenium & $\mathrm{Re}$ & $\mu \mathrm{g} / \mathrm{L}$ & 0 & - & - & - \\
\hline Rhodium & $\mathrm{Rh}$ & $\mu \mathrm{g} / \mathrm{L}$ & 0 & - & - & - \\
\hline Rubidium & $\mathrm{Rb}$ & $\mu \mathrm{g} / \mathrm{L}$ & 1 & - & - & - \\
\hline Ruthenium & $\mathrm{Ru}$ & $\mu \mathrm{g} / \mathrm{L}$ & 0 & - & - & - \\
\hline Samarium & $\mathrm{Sm}$ & $\mu \mathrm{g} / \mathrm{L}$ & 0 & - & - & - \\
\hline Selenium & $\mathrm{Se}$ & $\mu \mathrm{g} / \mathrm{L}$ & 1 & 140 & 140 & $0 \%$ \\
\hline Silver & $\mathrm{Ag}$ & $\mu \mathrm{g} / \mathrm{L}$ & 0 & - & - & - \\
\hline Sodium & $\mathrm{Na}$ & $\mu \mathrm{g} / \mathrm{L}$ & 200 & 51000 & 46000 & $10 \%$ \\
\hline Strontium & $\mathrm{Sr}$ & $\mu \mathrm{g} / \mathrm{L}$ & 1 & 980 & 910 & $7 \%$ \\
\hline Sulfur & $S$ & $\mu \mathrm{g} / \mathrm{L}$ & 1000 & - & - & - \\
\hline Tantalum & $\mathrm{Ta}$ & $\mu \mathrm{g} / \mathrm{L}$ & 0 & - & - & - \\
\hline Terbium & $\mathrm{Tb}$ & $\mu \mathrm{g} / \mathrm{L}$ & 0 & - & - & - \\
\hline Tellurium & $\mathrm{Te}$ & $\mu \mathrm{g} / \mathrm{L}$ & 1 & - & - & - \\
\hline Thalium & $\mathrm{Tl}$ & $\mu \mathrm{g} / \mathrm{L}$ & 0 & 410 & 390 & $5 \%$ \\
\hline Thorium & Th & $\mu \mathrm{g} / \mathrm{L}$ & - & - & - & - \\
\hline Thulium & $\mathrm{Tm}$ & $\mu \mathrm{g} / \mathrm{L}$ & 0 & - & - & - \\
\hline Tin ** & Sn & $\mu \mathrm{g} / \mathrm{L}$ & 3 & - & - & - \\
\hline Titanium & $\mathrm{Ti}$ & $\mu \mathrm{g} / \mathrm{L}$ & 3 & - & - & - \\
\hline Tungsten & w & $\mu \mathrm{g} / \mathrm{L}$ & 1 & - & - & - \\
\hline Uranium & U & $\mu \mathrm{g} / \mathrm{L}$ & 0 & 110 & 99 & $11 \%$ \\
\hline Vanadium & v & $\mu \mathrm{g} / \mathrm{L}$ & 0 & 840 & 820 & $2 \%$ \\
\hline Ytterbium & $\mathrm{Yb}$ & $\mu \mathrm{g} / \mathrm{L}$ & 0 & - & - & - \\
\hline Yttrium & $Y$ & $\mu \mathrm{g} / \mathrm{L}$ & 1 & - & - & - \\
\hline Zinc & $\mathrm{Zn}$ & $\mu \mathrm{g} / \mathrm{L}$ & 10 & 900 & 870 & $3 \%$ \\
\hline Zirconium & $\mathrm{Zr}$ & $\mu \mathrm{g} / \mathrm{L}$ & 0 & - & - & - \\
\hline
\end{tabular}




\begin{tabular}{|c|c|c|c|c|c|c|c|c|c|}
\hline & \multirow[b]{2}{*}{ Symbol } & \multirow[b]{2}{*}{ Units } & Mine site & \multicolumn{2}{|c|}{ Lagunas Norte } & \multicolumn{2}{|c|}{ El Indio } & \multicolumn{2}{|c|}{ Pierina } \\
\hline & & & Detection limit & t Blank & Blank & Blank & Blank & Blank & Blank \\
\hline Aluminium & $\mathrm{Al}$ & $\mu \mathrm{g} / \mathrm{L}$ & 5 & 5 & 5 & 5 & 5 & 5 & 5 \\
\hline Antimony & $\mathrm{Sb}$ & $\mu \mathrm{g} / \mathrm{L}$ & 2 & 2 & 2 & 2 & 2 & 2 & 2 \\
\hline Arsenic & As & $\mu \mathrm{g} / \mathrm{L}$ & 2 & 2 & 2 & 2 & 2 & 2 & 2 \\
\hline Barium & $\mathrm{Ba}$ & $\mu \mathrm{g} / \mathrm{L}$ & 0 & 0.2 & 0.2 & 0.2 & 0.2 & 0 & 0 \\
\hline Beryllium & $\mathrm{Be}$ & $\mu \mathrm{g} / \mathrm{L}$ & 0 & 0.2 & 0.2 & 0.2 & 0.2 & 0 & 0 \\
\hline Boron & B & $\mu \mathrm{g} / \mathrm{L}$ & 1000 & 1000 & 1000 & 1000 & 1000 & 1000 & 1000 \\
\hline Cadmium & $\mathrm{Cd}$ & $\mu \mathrm{g} / \mathrm{L}$ & 0 & 0.03 & 0.03 & 0.03 & 0.03 & 0 & 0 \\
\hline Calcium & $\mathrm{Ca}$ & $\mu \mathrm{g} / \mathrm{L}$ & 300 & 300 & 300 & 300 & 300 & 300 & 300 \\
\hline Cerium & $\mathrm{Ce}$ & $\mu \mathrm{g} / \mathrm{L}$ & 1 & 0.5 & 0.5 & 0.5 & 0.5 & 1 & 1 \\
\hline Cesium & Cs & $\mu \mathrm{g} / \mathrm{L}$ & - & - & - & - & - & - & - \\
\hline Chromium & $\mathrm{Cr}$ & $\mu \mathrm{g} / \mathrm{L}$ & 5 & 5 & 5 & 5 & 5 & 5 & 5 \\
\hline Cobalt & Co & $\mu \mathrm{g} / \mathrm{L}$ & 0 & 0.05 & 0.05 & 0.05 & 0.05 & 0 & 0 \\
\hline Copper & $\mathrm{Cu}$ & $\mu \mathrm{g} / \mathrm{L}$ & 5 & 5.0 & 5.0 & 5.0 & 5.0 & 5 & 5 \\
\hline Dysprosium & Dy & $\mu \mathrm{g} / \mathrm{L}$ & 0 & 0.1 & 0.1 & 0.1 & 0.1 & 0 & 0 \\
\hline Erbium & $\mathrm{Er}$ & $\mu \mathrm{g} / \mathrm{L}$ & 0 & 0.1 & 0.1 & 0.1 & 0.1 & 0 & 0 \\
\hline Europium & $\mathrm{Eu}$ & $\mu \mathrm{g} / \mathrm{L}$ & 0 & 0.03 & 0.03 & 0.03 & 0.03 & 0 & 0 \\
\hline Gadolinium & $\mathrm{Gd}$ & $\mu \mathrm{g} / \mathrm{L}$ & 0 & 0.1 & 0.1 & 0.1 & 0.1 & 0 & 0 \\
\hline Gallium & $\mathrm{Ga}$ & $\mu \mathrm{g} / \mathrm{L}$ & 5 & 5 & 5 & 5 & 5 & 5 & 5 \\
\hline Germanium & $\mathrm{Ge}$ & $\mu \mathrm{g} / \mathrm{L}$ & 1 & 1 & 1 & 1 & 1 & 1 & 1 \\
\hline Hafnium & $\mathrm{Hf}$ & $\mu \mathrm{g} / \mathrm{L}$ & - & - & - & - & - & - & - \\
\hline Holonium & $\mathrm{Ho}$ & $\mu \mathrm{g} / \mathrm{L}$ & 0 & 0.05 & 0.05 & 0.05 & 0.05 & 0 & 0 \\
\hline Iridium & Ir & $\mu \mathrm{g} / \mathrm{L}$ & 1 & 0.5 & 0.5 & 0.5 & 0.5 & 1 & 1 \\
\hline Iron & $\mathrm{Fe}$ & $\mu \mathrm{g} / \mathrm{L}$ & 50 & 50 & 50 & 50 & 50 & 50 & 50 \\
\hline Lanthanum & La & $\mu \mathrm{g} / \mathrm{L}$ & 0 & 0.4 & 0.4 & 0.4 & 0.4 & 0 & 0 \\
\hline Lead & $\mathrm{Pb}$ & $\mu \mathrm{g} / \mathrm{L}$ & 0 & 0 & 0 & 0 & 0 & 0 & 0 \\
\hline Lithium & $\mathrm{Li}$ & $\mu \mathrm{g} / \mathrm{L}$ & 2 & 2 & 2 & 2 & 2 & 2 & 2 \\
\hline Lutetium & Lu & $\mu \mathrm{g} / \mathrm{L}$ & 0 & 0.05 & 0.05 & 0.05 & 0.05 & 0 & 0 \\
\hline Magnesium & $\mathrm{Mg}$ & $\mu \mathrm{g} / \mathrm{L}$ & 30 & 30.000 & 30.000 & 30.000 & 30.000 & 30 & 30 \\
\hline Manganese & $\mathrm{Mn}$ & $\mu \mathrm{g} / \mathrm{L}$ & 0 & 0.3 & 0.3 & 0.3 & 0.3 & 0 & 0.90 \\
\hline Molybdenum & Mo & $\mu \mathrm{g} / \mathrm{L}$ & 10 & 10.0 & 10.0 & 10.0 & 10.0 & 10 & 10 \\
\hline Neodymium & $\mathrm{Nd}$ & $\mu \mathrm{g} / \mathrm{L}$ & 0 & 0.1 & 0.1 & 0.1 & 0.1 & 0 & 0 \\
\hline Nickel & $\mathrm{Ni}$ & $\mu \mathrm{g} / \mathrm{L}$ & 1 & 1 & 1 & 1 & 1 & 1 & 1 \\
\hline Niobium & $\mathrm{Nb}$ & $\mu \mathrm{g} / \mathrm{L}$ & 0 & 0.05 & 0.05 & 0.05 & 0.05 & 0 & 0 \\
\hline Palladium & $\mathrm{Pd}$ & $\mu \mathrm{g} / \mathrm{L}$ & - & - & - & - & - & - & - \\
\hline Phosphorus & $P$ & $\mu \mathrm{g} / \mathrm{L}$ & 1000 & 1000 & 1000 & 1000 & 1000 & 1000 & 1000 \\
\hline Platinum & $\mathrm{Pt}$ & $\mu \mathrm{g} / \mathrm{L}$ & 0 & 0.05 & 0.05 & 0.05 & 0.05 & 0 & 0 \\
\hline Potassium & $\mathrm{K}$ & $\mu \mathrm{g} / \mathrm{L}$ & 200 & 200 & 200 & 200 & 200 & 200 & 200 \\
\hline Praseodymium & $\mathrm{Pr}$ & $\mu \mathrm{g} / \mathrm{L}$ & 0 & 0.1 & 0.1 & 0.1 & 0.1 & 0 & 0 \\
\hline Rhenium & $\operatorname{Re}$ & $\mu \mathrm{g} / \mathrm{L}$ & 0 & 0.2 & 0.2 & 0.2 & 0.2 & 0 & 0 \\
\hline Rhodium & $\mathrm{Rh}$ & $\mu \mathrm{g} / \mathrm{L}$ & 0 & 0.1 & 0.1 & 0.1 & 0.1 & 0 & 0 \\
\hline Rubidium & $\mathrm{Rb}$ & $\mu \mathrm{g} / \mathrm{L}$ & 1 & 1 & 1 & 1 & 1 & 1 & 1 \\
\hline Ruthenium & $\mathrm{Ru}$ & $\mu \mathrm{g} / \mathrm{L}$ & 0 & 0.1 & 0.1 & 0.1 & 0.1 & 0 & 0 \\
\hline Samarium & $\mathrm{Sm}$ & $\mu \mathrm{g} / \mathrm{L}$ & 0 & 0.1 & 0.1 & 0.1 & 0.1 & 0 & 0 \\
\hline Selenium & $\mathrm{Se}$ & $\mu \mathrm{g} / \mathrm{L}$ & 1 & 1 & 1 & 1 & 1 & 1 & 1 \\
\hline Silver & $\mathrm{Ag}$ & $\mu \mathrm{g} / \mathrm{L}$ & 0 & 0.1 & 0.1 & 0.1 & 0.1 & 0 & 0 \\
\hline Sodium & $\mathrm{Na}$ & $\mu \mathrm{g} / \mathrm{L}$ & 200 & 200 & 200 & 200 & 200 & 200 & 200 \\
\hline Strontium & $\mathrm{Sr}$ & $\mu \mathrm{g} / \mathrm{L}$ & 1 & 1 & 1 & 1 & 1 & 1 & 1 \\
\hline Sulfur & $\mathrm{S}$ & $\mu \mathrm{g} / \mathrm{L}$ & 1000 & 1000 & 1000 & 1000 & 1000 & 1000 & 1000 \\
\hline Tantalum & $\mathrm{Ta}$ & $\mu \mathrm{g} / \mathrm{L}$ & 0 & 0.05 & 0.05 & 0.05 & 0.05 & 0 & 0 \\
\hline Terbium & $\mathrm{Tb}$ & $\mu \mathrm{g} / \mathrm{L}$ & 0 & 0.050 & 0.050 & 0.050 & 0.050 & 0 & 0 \\
\hline Tellurium & $\mathrm{Te}$ & $\mu \mathrm{g} / \mathrm{L}$ & 1 & 0.5 & 0.5 & 0.5 & 0.5 & 1 & 1 \\
\hline Thalium & $\mathrm{Tl}$ & $\mu \mathrm{g} / \mathrm{L}$ & 0 & 0.1 & 0.1 & 0.1 & 0.1 & 0 & 0 \\
\hline Thorium & Th & $\mu \mathrm{g} / \mathrm{L}$ & - & - & - & - & - & - & - \\
\hline Thulium & $\mathrm{Tm}$ & $\mu \mathrm{g} / \mathrm{L}$ & 0 & 0.05 & 0.05 & 0.05 & 0.05 & 0 & 0 \\
\hline $\operatorname{Tin} * *$ & Sn & $\mu \mathrm{g} / \mathrm{L}$ & 3 & 3.0 & 3.0 & 3 & 3 & 3 & 3 \\
\hline Titanium & $\mathrm{Ti}$ & $\mu \mathrm{g} / \mathrm{L}$ & 3 & 3 & 3 & 3 & 3 & 3 & 3 \\
\hline Tungsten & W & $\mu \mathrm{g} / \mathrm{L}$ & 1 & 0.5 & 0.5 & 0.5 & 0.5 & 1 & 1 \\
\hline Uranium & $\mathrm{U}$ & $\mu \mathrm{g} / \mathrm{L}$ & 0 & 0.02 & 0.02 & 0.02 & 0.02 & 0 & 0 \\
\hline Vanadium & V & $\mu \mathrm{g} / \mathrm{L}$ & 0 & 0.3 & 0.3 & 0.3 & 0.3 & 0 & 0 \\
\hline Ytterbium & $\mathrm{Yb}$ & $\mu \mathrm{g} / \mathrm{L}$ & 0 & 0.2 & 0.2 & 0.2 & 0.2 & 0 & 0 \\
\hline Yttrium & $Y$ & $\mu \mathrm{g} / \mathrm{L}$ & 1 & 1.0 & 1.0 & 1.0 & 1.0 & 1 & 1 \\
\hline Zinc & $\mathrm{Zn}$ & $\mu \mathrm{g} / \mathrm{L}$ & 10 & 10.0 & 10.0 & 10.0 & 10.0 & 10 & 10 \\
\hline Zirconium & $\mathrm{Zr}$ & $\mu \mathrm{g} / \mathrm{L}$ & 0 & 0.1 & 0.1 & 0.1 & 0.1 & 0 & 0 \\
\hline
\end{tabular}




\begin{tabular}{|c|c|c|c|c|c|c|c|c|c|}
\hline & Symbol & Units & $\begin{array}{l}\text { Sample name } \\
\text { Sample type } \\
\text { Sample number } \\
\text { Detection limit }\end{array}$ & $\begin{array}{l}\text { SP3-W } \\
\text { FA } \\
\text { No1 }\end{array}$ & $\begin{array}{c}\text { SP3-W } \\
\text { FA } \\
\text { No5 } \\
\text { Field Triplicate } \\
\end{array}$ & $\begin{array}{c}\text { SP3-W } \\
\text { FA } \\
\text { No6 }\end{array}$ & \%Diff 5-1 & \% Diff 5-6 & \% Diff 6-1 \\
\hline \multicolumn{10}{|l|}{ Sample description } \\
\hline \multicolumn{10}{|l|}{ Anions } \\
\hline Fluoride & $\mathrm{F}$ & $\mathrm{mg} / \mathrm{L}$ & $<0.05$ & $<2.0$ & $<2.0$ & $<2.0$ & - & - & - \\
\hline Chloride & $\mathrm{Cl}$ & $\mathrm{mg} / \mathrm{L}$ & $<0.05$ & $<2.0$ & $<2.0$ & $<2.0$ & - & - & - \\
\hline Nitrite & $\mathrm{NO}_{2-}$ & $\mathrm{mg} / \mathrm{L}$ & $<0.05$ & $<2.0$ & $<2.0$ & $<2.0$ & - & - & - \\
\hline Nitrate & $\mathrm{NO}_{3}^{-}$ & $\mathrm{mg} / \mathrm{L}$ & $<0.05$ & 3.8 & 3.8 & 3.8 & - & - & - \\
\hline Sulphate & $\mathrm{SO}_{42-}$ & $\mathrm{mg} / \mathrm{L}$ & $<0.10$ & 690.0 & 690.0 & 690.0 & - & - & - \\
\hline $\mathrm{pH}$ & & - & & 2.9 & 2.9 & 2.9 & - & - & - \\
\hline \multicolumn{10}{|l|}{ Metals } \\
\hline Aluminium & Al & $\mu \mathrm{g} / \mathrm{L}$ & 5 & 47000 & 48000 & 47000 & $2 \%$ & $2 \%$ & $0 \%$ \\
\hline Antimony & $\mathrm{Sb}$ & $\mu \mathrm{g} / \mathrm{L}$ & 2 & 2 & 2 & 2 & $0 \%$ & $0 \%$ & $0 \%$ \\
\hline Arsenic & As & $\mu \mathrm{g} / \mathrm{L}$ & 2 & 9.1 & 11 & 10 & $19 \%$ & $10 \%$ & $9 \%$ \\
\hline Barium & $\mathrm{Ba}$ & $\mu \mathrm{g} / \mathrm{L}$ & 0 & 54 & 52 & 52 & $4 \%$ & $0 \%$ & $4 \%$ \\
\hline Beryllium & $\mathrm{Be}$ & $\mu \mathrm{g} / \mathrm{L}$ & 0 & 7.3 & 7.3 & 7.3 & $0 \%$ & $0 \%$ & $0 \%$ \\
\hline Boron & B & $\mu \mathrm{g} / \mathrm{L}$ & 1000 & 1000 & 1000 & 1000 & $0 \%$ & $0 \%$ & $0 \%$ \\
\hline Cadmium & $\mathrm{Cd}$ & $\mu \mathrm{g} / \mathrm{L}$ & 0 & 34 & 33 & 33 & $3 \%$ & $0 \%$ & $3 \%$ \\
\hline Calcium & $\mathrm{Ca}$ & $\mu \mathrm{g} / \mathrm{L}$ & 300 & 120000 & 120000 & 120000 & $0 \%$ & $0 \%$ & $0 \%$ \\
\hline Cerium & $\mathrm{Ce}$ & $\mu \mathrm{g} / \mathrm{L}$ & 1 & 62 & 61 & 61 & $2 \%$ & $0 \%$ & $2 \%$ \\
\hline Cesium & Cs & $\mu \mathrm{g} / \mathrm{L}$ & - & - & - & - & - & - & - \\
\hline Chromium & $\mathrm{Cr}$ & $\mu \mathrm{g} / \mathrm{L}$ & 5 & 13 & 17 & 13 & $27 \%$ & $27 \%$ & $0 \%$ \\
\hline Cobalt & Co & $\mu \mathrm{g} / \mathrm{L}$ & 0 & 150 & 150 & 150 & $0 \%$ & $0 \%$ & $0 \%$ \\
\hline Copper & $\mathrm{Cu}$ & $\mu \mathrm{g} / \mathrm{L}$ & 5 & 9600 & 9700 & 9500 & $1 \%$ & $2 \%$ & $1 \%$ \\
\hline Dysprosium & Dy & $\mu \mathrm{g} / \mathrm{L}$ & 0 & 7.6 & 7.4 & 7.4 & $3 \%$ & $0 \%$ & $3 \%$ \\
\hline Erbium & $\mathrm{Er}$ & $\mu \mathrm{g} / \mathrm{L}$ & 0 & 3.7 & 3.6 & 3.6 & $3 \%$ & $0 \%$ & $3 \%$ \\
\hline Europium & $\mathrm{Eu}$ & $\mu \mathrm{g} / \mathrm{L}$ & 0 & 2.9 & 2.5 & 2.5 & $15 \%$ & $0 \%$ & $15 \%$ \\
\hline Gadolinium & $\mathrm{Gd}$ & $\mu \mathrm{g} / \mathrm{L}$ & 0 & 9.6 & 9.7 & 9.5 & $1 \%$ & $2 \%$ & $1 \%$ \\
\hline Gallium & $\mathrm{Ga}$ & $\mu \mathrm{g} / \mathrm{L}$ & 5 & 8.5 & 7.7 & 8.4 & $10 \%$ & $9 \%$ & $1 \%$ \\
\hline Germanium & $\mathrm{Ge}$ & $\mu \mathrm{g} / \mathrm{L}$ & 1 & 3.3 & 3.0 & 3.1 & $10 \%$ & $3 \%$ & $6 \%$ \\
\hline Hafnium & $\mathrm{Hf}$ & $\mu \mathrm{g} / \mathrm{L}$ & - & - & - & - & - & - & - \\
\hline Holonium & Ho & $\mu \mathrm{g} / \mathrm{L}$ & 0 & 1.4 & 1.4 & 1.4 & $0 \%$ & $0 \%$ & $0 \%$ \\
\hline Iridium & $\operatorname{lr}$ & $\mu \mathrm{g} / \mathrm{L}$ & 1 & 1 & 1 & 1 & $0 \%$ & $0 \%$ & $0 \%$ \\
\hline Iron & $\mathrm{Fe}$ & $\mu \mathrm{g} / \mathrm{L}$ & 50 & 49000 & 48000 & 48000 & $2 \%$ & $0 \%$ & $2 \%$ \\
\hline Lanthanum & La & $\mu \mathrm{g} / \mathrm{L}$ & 0 & 29 & 28 & 29 & $4 \%$ & $4 \%$ & $0 \%$ \\
\hline Lead & $\mathrm{Pb}$ & $\mu \mathrm{g} / \mathrm{L}$ & 0 & 30 & 30 & 30 & $0 \%$ & $0 \%$ & $0 \%$ \\
\hline Lithium & $\mathrm{Li}$ & $\mu \mathrm{g} / \mathrm{L}$ & 2 & 16 & 16 & 16 & $0 \%$ & $0 \%$ & $0 \%$ \\
\hline Lutetium & $\mathrm{Lu}$ & $\mu \mathrm{g} / \mathrm{L}$ & 0 & 0.38 & 0.38 & 0.38 & $0 \%$ & $0 \%$ & $0 \%$ \\
\hline Magnesium & $\mathrm{Mg}$ & $\mu \mathrm{g} / \mathrm{L}$ & 30 & 17000 & 17000 & 17000 & $0 \%$ & $0 \%$ & $0 \%$ \\
\hline Manganese & $\mathrm{Mn}$ & $\mu \mathrm{g} / \mathrm{L}$ & 0 & 5600 & 5800 & 5800 & $4 \%$ & $0 \%$ & $4 \%$ \\
\hline Molybdenum & Mo & $\mu \mathrm{g} / \mathrm{L}$ & 10 & 10 & 10 & 10 & $0 \%$ & $0 \%$ & $0 \%$ \\
\hline Neodymium & $\mathrm{Nd}$ & $\mu \mathrm{g} / \mathrm{L}$ & 0 & 36 & 36 & 36 & $0 \%$ & $0 \%$ & $0 \%$ \\
\hline Nickel & $\mathrm{Ni}$ & $\mu \mathrm{g} / \mathrm{L}$ & 1 & 140 & 140 & 140 & $0 \%$ & $0 \%$ & $0 \%$ \\
\hline Niobium & $\mathrm{Nb}$ & $\mu \mathrm{g} / \mathrm{L}$ & 0 & 0 & 0 & 0 & $0 \%$ & $0 \%$ & $0 \%$ \\
\hline Palladium & $\mathrm{Pd}$ & $\mu \mathrm{g} / \mathrm{L}$ & - & - & - & - & - & - & - \\
\hline Phosphorus & $\mathrm{P}$ & $\mu \mathrm{g} / \mathrm{L}$ & 1000 & 1000 & 1000 & 1000 & $0 \%$ & $0 \%$ & $0 \%$ \\
\hline Platinum & $\mathrm{Pt}$ & $\mu \mathrm{g} / \mathrm{L}$ & 0 & 0 & 0 & 0 & $0 \%$ & $0 \%$ & $0 \%$ \\
\hline Potassium & $\mathrm{K}$ & $\mu \mathrm{g} / \mathrm{L}$ & 200 & 2400 & 2500 & 2300 & $4 \%$ & $8 \%$ & $4 \%$ \\
\hline Praseodymium & $\operatorname{Pr}$ & $\mu \mathrm{g} / \mathrm{L}$ & 0 & 8.6 & 8.5 & 8.8 & $1 \%$ & $3 \%$ & $2 \%$ \\
\hline Rhenium & $\mathrm{Re}$ & $\mu \mathrm{g} / \mathrm{L}$ & 0 & 0 & 0 & 0 & $0 \%$ & $0 \%$ & $0 \%$ \\
\hline Rhodium & $\mathrm{Rh}$ & $\mu \mathrm{g} / \mathrm{L}$ & 0 & 0 & 0 & 0 & $0 \%$ & $0 \%$ & $0 \%$ \\
\hline Rubidium & $\mathrm{Rb}$ & $\mu \mathrm{g} / \mathrm{L}$ & 1 & 4.6 & 4.4 & 4.4 & $4 \%$ & $0 \%$ & $4 \%$ \\
\hline Ruthenium & $\mathrm{Ru}$ & $\mu \mathrm{g} / \mathrm{L}$ & 0 & 0 & 0 & 0 & $0 \%$ & $0 \%$ & $0 \%$ \\
\hline Samarium & Sm & $\mu \mathrm{g} / \mathrm{L}$ & 0 & 8.5 & 8.6 & 8.3 & $1 \%$ & $4 \%$ & $2 \%$ \\
\hline Selenium & $\mathrm{Se}$ & $\mu \mathrm{g} / \mathrm{L}$ & 1 & 6.3 & 6.0 & 6.0 & $5 \%$ & $0 \%$ & $5 \%$ \\
\hline Silver & $\mathrm{Ag}$ & $\mu \mathrm{g} / \mathrm{L}$ & 0 & 0 & 0 & 0 & $0 \%$ & $0 \%$ & $0 \%$ \\
\hline Sodium & $\mathrm{Na}$ & $\mu \mathrm{g} / \mathrm{L}$ & 200 & 12000 & 12000 & 12000 & $0 \%$ & $0 \%$ & $0 \%$ \\
\hline Strontium & $\mathrm{Sr}$ & $\mu \mathrm{g} / \mathrm{L}$ & 1 & 630 & 610 & 620 & $3 \%$ & $2 \%$ & $2 \%$ \\
\hline Sulfur & $S$ & $\mu \mathrm{g} / \mathrm{L}$ & 1000 & 270000 & 270000 & 270000 & $0 \%$ & $0 \%$ & $0 \%$ \\
\hline Tantalum & Ta & $\mu \mathrm{g} / \mathrm{L}$ & 0 & 0 & 0 & 0 & $0 \%$ & $0 \%$ & $0 \%$ \\
\hline Terbium & $\mathrm{Tb}$ & $\mu \mathrm{g} / \mathrm{L}$ & 0 & 1.4 & 1.4 & 1.4 & $0 \%$ & $0 \%$ & $0 \%$ \\
\hline Tellurium & $\mathrm{Te}$ & $\mu \mathrm{g} / \mathrm{L}$ & 1 & 1 & 0.75 & 0.66 & $40 \%$ & $13 \%$ & $28 \%$ \\
\hline Thalium & $\mathrm{Tl}$ & $\mu \mathrm{g} / \mathrm{L}$ & 0 & 0.65 & 0.59 & 0.58 & $10 \%$ & $2 \%$ & $11 \%$ \\
\hline Thorium & Th & $\mu \mathrm{g} / \mathrm{L}$ & - & - & - & - & - & - & - \\
\hline Thulium & $\mathrm{Tm}$ & $\mu \mathrm{g} / \mathrm{L}$ & 0 & 0.49 & 0.46 & 0.44 & $6 \%$ & $4 \%$ & $11 \%$ \\
\hline Tin $* *$ & Sn & $\mu \mathrm{g} / \mathrm{L}$ & 3 & 3.0 & 3.0 & 3.0 & $0 \%$ & $0 \%$ & $0 \%$ \\
\hline Titanium & $\mathrm{Ti}$ & $\mu \mathrm{g} / \mathrm{L}$ & 3 & 3 & 3 & 3 & $0 \%$ & $0 \%$ & $0 \%$ \\
\hline Tungsten & w & $\mu \mathrm{g} / \mathrm{L}$ & 1 & 1 & 1 & 1 & $0 \%$ & $0 \%$ & $0 \%$ \\
\hline Uranium & $u$ & $\mu \mathrm{g} / \mathrm{L}$ & 0 & 3.0 & 3.0 & 3.0 & $0 \%$ & $0 \%$ & $0 \%$ \\
\hline Vanadium & v & $\mu \mathrm{g} / \mathrm{L}$ & 0 & 0 & 0 & 0 & $0 \%$ & $0 \%$ & $0 \%$ \\
\hline Ytterbium & $\mathrm{Yb}$ & $\mu \mathrm{g} / \mathrm{L}$ & 0 & 2.8 & 2.7 & 2.8 & $4 \%$ & $4 \%$ & $0 \%$ \\
\hline Yttrium & $Y$ & $\mu \mathrm{g} / \mathrm{L}$ & 1 & 42 & 43 & 42 & $2 \%$ & $2 \%$ & $0 \%$ \\
\hline Zinc & $\mathrm{Zn}$ & $\mu \mathrm{g} / \mathrm{L}$ & 10 & 2000 & 2100 & 2100 & $5 \%$ & $0 \%$ & $5 \%$ \\
\hline Zirconium & $\mathrm{Zr}$ & $\mu \mathrm{g} / \mathrm{L}$ & 0 & 0.13 & 0.13 & 0.13 & $0 \%$ & $0 \%$ & $0 \%$ \\
\hline
\end{tabular}




\begin{tabular}{|c|c|c|c|c|c|c|c|}
\hline & & & $\begin{array}{l}\text { Sample name } \\
\text { Sample type } \\
\text { Sample number }\end{array}$ & $\begin{array}{c}\text { SP3-W } \\
\text { FFA } \\
\text { No23 }\end{array}$ & $\begin{array}{c}\text { SP3-W } \\
\text { UA } \\
\text { No32 }\end{array}$ & $\begin{array}{c}\text { SP3-W } \\
\text { UA } \\
\text { No33 }\end{array}$ & \%Diff 32-33 \\
\hline & Symbol & Units & Detection limit & \multirow{2}{*}{\multicolumn{4}{|c|}{ Field Duplicate }} \\
\hline \multicolumn{4}{|l|}{ Sample description } & & & & \\
\hline \multicolumn{8}{|l|}{ Anions } \\
\hline Fluoride & $\mathrm{F}$ & $\mathrm{mg} / \mathrm{L}$ & $<0.05$ & $<2.0$ & 0.0 & $<2.0$ & - \\
\hline Chloride & $\mathrm{Cl}$ & $\mathrm{mg} / \mathrm{L}$ & $<0.05$ & $<2.0$ & $<2.0$ & $<2.0$ & - \\
\hline Nitrite & $\mathrm{NO}_{2-}$ & $\mathrm{mg} / \mathrm{L}$ & $<0.05$ & $<2.0$ & $<2.0$ & $<2.0$ & - \\
\hline Nitrate & $\mathrm{NO}_{3}-$ & $\mathrm{mg} / \mathrm{L}$ & $<0.05$ & 3.8 & 3.8 & 3.8 & - \\
\hline Sulphate & $\mathrm{SO}_{42-}$ & $\mathrm{mg} / \mathrm{L}$ & $<0.10$ & 690.0 & 690.0 & 690.0 & - \\
\hline $\mathrm{pH}$ & & - & & 2.9 & 2.9 & 2.9 & - \\
\hline \multicolumn{8}{|l|}{ Metals } \\
\hline Aluminium & $\mathrm{Al}$ & $\mu \mathrm{g} / \mathrm{L}$ & 5 & 45000 & 47000 & 45000 & $4 \%$ \\
\hline Antimony & $\mathrm{Sb}$ & $\mu \mathrm{g} / \mathrm{L}$ & 2 & 2 & 7.9 & 7.3 & $8 \%$ \\
\hline Arsenic & As & $\mu \mathrm{g} / \mathrm{L}$ & 2 & 18 & 99 & 93 & $6 \%$ \\
\hline Barium & $\mathrm{Ba}$ & $\mu \mathrm{g} / \mathrm{L}$ & 0 & 50 & 72 & 72 & $0 \%$ \\
\hline Beryllium & $\mathrm{Be}$ & $\mu \mathrm{g} / \mathrm{L}$ & 0 & 6.7 & 8.1 & 8.1 & $0 \%$ \\
\hline Boron & B & $\mu \mathrm{g} / \mathrm{L}$ & 1000 & 1000 & $<1000$ & $<1000$ & $0 \%$ \\
\hline Cadmium & $\mathrm{Cd}$ & $\mu \mathrm{g} / \mathrm{L}$ & 0 & 31 & 39 & 39 & $0 \%$ \\
\hline Calcium & $\mathrm{Ca}$ & $\mu \mathrm{g} / \mathrm{L}$ & 300 & 120000 & 130000 & 130000 & $0 \%$ \\
\hline Cerium & $\mathrm{Ce}$ & $\mu \mathrm{g} / \mathrm{L}$ & 1 & 58 & 76 & 75 & $1 \%$ \\
\hline Cesium & Cs & $\mu \mathrm{g} / \mathrm{L}$ & - & - & - & - & - \\
\hline Chromium & $\mathrm{Cr}$ & $\mu \mathrm{g} / \mathrm{L}$ & 5 & 13 & 16 & 16 & $0 \%$ \\
\hline Cobalt & Co & $\mu \mathrm{g} / \mathrm{L}$ & 0 & 150 & 170 & 170 & $0 \%$ \\
\hline Copper & $\mathrm{Cu}$ & $\mu \mathrm{g} / \mathrm{L}$ & 5 & 9000 & 11000 & 11000 & $0 \%$ \\
\hline Dysprosium & Dy & $\mu \mathrm{g} / \mathrm{L}$ & 0 & 7.3 & 9.1 & 9.2 & $1 \%$ \\
\hline Erbium & $\mathrm{Er}$ & $\mu \mathrm{g} / \mathrm{L}$ & 0 & 3.6 & 4.6 & 4.6 & $0 \%$ \\
\hline Europium & $\mathrm{Eu}$ & $\mu \mathrm{g} / \mathrm{L}$ & 0 & 2.5 & 3.3 & 3.1 & $6 \%$ \\
\hline Gadolinium & $\mathrm{Gd}$ & $\mu \mathrm{g} / \mathrm{L}$ & 0 & 8.7 & 12 & 11 & $9 \%$ \\
\hline Gallium & $\mathrm{Ga}$ & $\mu \mathrm{g} / \mathrm{L}$ & 5 & 8.0 & 8.9 & 11 & $21 \%$ \\
\hline Germanium & $\mathrm{Ge}$ & $\mu \mathrm{g} / \mathrm{L}$ & 1 & 3.3 & 3.6 & 3.4 & $6 \%$ \\
\hline Hafnium & $\mathrm{Hf}$ & $\mu \mathrm{g} / \mathrm{L}$ & - & - & - & - & - \\
\hline Holonium & Ho & $\mu \mathrm{g} / \mathrm{L}$ & 0 & 1.4 & 1.7 & 1.7 & $0 \%$ \\
\hline Iridium & Ir & $\mu \mathrm{g} / \mathrm{L}$ & 1 & 1 & $<0.5$ & $<0.5$ & $0 \%$ \\
\hline Iron & $\mathrm{Fe}$ & $\mu \mathrm{g} / \mathrm{L}$ & 50 & 47000 & 69000 & 68000 & $1 \%$ \\
\hline Lanthanum & La & $\mu \mathrm{g} / \mathrm{L}$ & 0 & 27 & 36 & 35 & $3 \%$ \\
\hline Lead & $\mathrm{Pb}$ & $\mu \mathrm{g} / \mathrm{L}$ & 0 & 29 & 41 & 40 & $2 \%$ \\
\hline Lithium & $\mathrm{Li}$ & $\mu \mathrm{g} / \mathrm{L}$ & 2 & 14 & 19 & 19 & $0 \%$ \\
\hline Lutetium & Lu & $\mu \mathrm{g} / \mathrm{L}$ & 0 & 0.36 & 0.44 & 0.44 & $0 \%$ \\
\hline Magnesium & $\mathrm{Mg}$ & $\mu \mathrm{g} / \mathrm{L}$ & 30 & 16000 & 18000 & 18000 & $0 \%$ \\
\hline Manganese & $\mathrm{Mn}$ & $\mu \mathrm{g} / \mathrm{L}$ & 0 & 5500 & 5800 & 5600 & $4 \%$ \\
\hline Molybdenum & Mo & $\mu \mathrm{g} / \mathrm{L}$ & 10 & 10 & $<10$ & $<10$ & $0 \%$ \\
\hline Neodymium & $\mathrm{Nd}$ & $\mu \mathrm{g} / \mathrm{L}$ & 0 & 34 & 45 & 45 & $0 \%$ \\
\hline Nickel & $\mathrm{Ni}$ & $\mu \mathrm{g} / \mathrm{L}$ & 1 & 140 & 160 & 160 & $0 \%$ \\
\hline Niobium & $\mathrm{Nb}$ & $\mu \mathrm{g} / \mathrm{L}$ & 0 & 0 & $<0.05$ & $<0.05$ & $0 \%$ \\
\hline Palladium & $\mathrm{Pd}$ & $\mu \mathrm{g} / \mathrm{L}$ & - & - & - & - & - \\
\hline Phosphorus & $\mathrm{P}$ & $\mu \mathrm{g} / \mathrm{L}$ & 1000 & 1000 & $<1000$ & $<1000$ & $0 \%$ \\
\hline Platinum & $\mathrm{Pt}$ & $\mu \mathrm{g} / \mathrm{L}$ & 0 & 0 & $<0.05$ & $<0.05$ & $0 \%$ \\
\hline Potassium & $\mathrm{K}$ & $\mu \mathrm{g} / \mathrm{L}$ & 200 & 2300 & 2700 & 2700 & $0 \%$ \\
\hline Praseodymium & $\mathrm{Pr}$ & $\mu \mathrm{g} / \mathrm{L}$ & 0 & 8.2 & 10 & 10 & $0 \%$ \\
\hline Rhenium & $\mathrm{Re}$ & $\mu \mathrm{g} / \mathrm{L}$ & 0 & 0 & $<0.2$ & $<0.2$ & $0 \%$ \\
\hline Rhodium & $\mathrm{Rh}$ & $\mu \mathrm{g} / \mathrm{L}$ & 0 & 0 & $<0.1$ & $<0.1$ & $0 \%$ \\
\hline Rubidium & $\mathrm{Rb}$ & $\mu \mathrm{g} / \mathrm{L}$ & 1 & 4.3 & 5.7 & 5.6 & $2 \%$ \\
\hline Ruthenium & $\mathrm{Ru}$ & $\mu \mathrm{g} / \mathrm{L}$ & 0 & 0 & $<0.1$ & $<0.1$ & $0 \%$ \\
\hline Samarium & Sm & $\mu \mathrm{g} / \mathrm{L}$ & 0 & 8.0 & 10 & 11 & $10 \%$ \\
\hline Selenium & Se & $\mu \mathrm{g} / \mathrm{L}$ & 1 & 4.9 & 7.3 & 7.4 & $1 \%$ \\
\hline Silver & $\mathrm{Ag}$ & $\mu \mathrm{g} / \mathrm{L}$ & 0 & 0 & $<0.1$ & 0.17 & $52 \%$ \\
\hline Sodium & $\mathrm{Na}$ & $\mu \mathrm{g} / \mathrm{L}$ & 200 & 12000 & 14000 & 13000 & $7 \%$ \\
\hline Strontium & $\mathrm{Sr}$ & $\mu \mathrm{g} / \mathrm{L}$ & 1 & 590 & 720 & 710 & $1 \%$ \\
\hline Sulfur & $\mathrm{s}$ & $\mu \mathrm{g} / \mathrm{L}$ & 1000 & 250000 & 270000 & 270000 & $0 \%$ \\
\hline Tantalum & $\mathrm{Ta}$ & $\mu \mathrm{g} / \mathrm{L}$ & 0 & 0 & $<0.05$ & $<0.05$ & $0 \%$ \\
\hline Terbium & $\mathrm{Tb}$ & $\mu \mathrm{g} / \mathrm{L}$ & 0 & 1.4 & 1.8 & 1.7 & $6 \%$ \\
\hline Tellurium & $\mathrm{Te}$ & $\mu \mathrm{g} / \mathrm{L}$ & 1 & 1.4 & 0.91 & 1.2 & $27 \%$ \\
\hline Thalium & $\mathrm{Tl}$ & $\mu \mathrm{g} / \mathrm{L}$ & 0 & 0.60 & 0.48 & 0.49 & $2 \%$ \\
\hline Thorium & Th & $\mu \mathrm{g} / \mathrm{L}$ & - & - & - & - & - \\
\hline Thulium & $\mathrm{Tm}$ & $\mu \mathrm{g} / \mathrm{L}$ & 0 & 0.46 & 0.55 & 0.56 & $2 \%$ \\
\hline $\operatorname{Tin} * *$ & Sn & $\mu \mathrm{g} / \mathrm{L}$ & 3 & 3.0 & $<3.0$ & $<3.0$ & $0 \%$ \\
\hline Titanium & $\mathrm{Ti}$ & $\mu \mathrm{g} / \mathrm{L}$ & 3 & 3 & 7.5 & 4.7 & $46 \%$ \\
\hline Tungsten & w & $\mu \mathrm{g} / \mathrm{L}$ & 1 & 1 & $<0.5$ & $<0.5$ & $0 \%$ \\
\hline Uranium & U & $\mu \mathrm{g} / \mathrm{L}$ & 0 & 2.7 & 3.7 & 3.7 & $0 \%$ \\
\hline Vanadium & V & $\mu \mathrm{g} / \mathrm{L}$ & 0 & 0 & 2.3 & 2.3 & $0 \%$ \\
\hline Ytterbium & $\mathrm{Yb}$ & $\mu \mathrm{g} / \mathrm{L}$ & 0 & 2.5 & 3.4 & 3.4 & $0 \%$ \\
\hline Yttrium & Y & $\mu \mathrm{g} / \mathrm{L}$ & 1 & 42 & 51 & 49 & $4 \%$ \\
\hline Zinc & $\mathrm{Zn}$ & $\mu \mathrm{g} / \mathrm{L}$ & 10 & 1900 & 2000 & 1900 & $5 \%$ \\
\hline Zirconium & $\mathrm{Zr}$ & $\mu \mathrm{g} / \mathrm{L}$ & 0 & 0.25 & 0.31 & 0.37 & $18 \%$ \\
\hline
\end{tabular}




\begin{tabular}{|c|c|c|c|c|c|c|c|}
\hline & & & $\begin{array}{l}\text { Sample name } \\
\text { Sample type } \\
\text { Sample number }\end{array}$ & $\begin{array}{c}\text { DW-B-11-W } \\
\text { FFA } \\
\text { No21 }\end{array}$ & $\begin{array}{c}\text { DW-B-11-W } \\
\text { UA } \\
\text { No30 }\end{array}$ & $\begin{array}{c}\text { DW-B-11-W } \\
\text { UA } \\
\text { No31 }\end{array}$ & \%Diff 30-31 \\
\hline & Symbol & Units & Detection limit & \multirow{2}{*}{\multicolumn{4}{|c|}{ Field Duplicate }} \\
\hline \multicolumn{4}{|l|}{ Sample description } & & & & \\
\hline \multicolumn{8}{|l|}{ Anions } \\
\hline Fluoride & $\mathrm{F}$ & $\mathrm{mg} / \mathrm{L}$ & $<0.05$ & $<2.0$ & $<2.0$ & $<2.0$ & - \\
\hline Chloride & $\mathrm{Cl}$ & $\mathrm{mg} / \mathrm{L}$ & $<0.05$ & $<2.0$ & $<2.0$ & $<2.0$ & - \\
\hline Nitrite & $\mathrm{NO}_{2-}^{-}$ & $\mathrm{mg} / \mathrm{L}$ & $<0.05$ & $<2.0$ & $<2.0$ & $<2.0$ & - \\
\hline Nitrate & $\mathrm{NO}_{3}-$ & $\mathrm{mg} / \mathrm{L}$ & $<0.05$ & $<2.0$ & $<2.0$ & $<2.0$ & - \\
\hline Sulphate & $\mathrm{SO}_{42-}$ & $\mathrm{mg} / \mathrm{L}$ & $<0.10$ & 845.0 & 845.0 & 845.0 & - \\
\hline $\mathrm{pH}$ & & - & & 2.8 & 2.8 & 2.8 & - \\
\hline \multicolumn{8}{|l|}{ Metals } \\
\hline Aluminium & Al & $\mu \mathrm{g} / \mathrm{L}$ & 5 & 26000 & 28000 & 26000 & $7 \%$ \\
\hline Antimony & $\mathrm{Sb}$ & $\mu \mathrm{g} / \mathrm{L}$ & 2 & 210 & 240 & 240 & $0 \%$ \\
\hline Arsenic & As & $\mu \mathrm{g} / \mathrm{L}$ & 2 & 1100 & 1300 & 1200 & $8 \%$ \\
\hline Barium & $\mathrm{Ba}$ & $\mu \mathrm{g} / \mathrm{L}$ & 0 & 15 & 18 & 18 & $0 \%$ \\
\hline Beryllium & $\mathrm{Be}$ & $\mu \mathrm{g} / \mathrm{L}$ & 0 & 1.8 & 1.9 & 1.8 & $5 \%$ \\
\hline Boron & B & $\mu \mathrm{g} / \mathrm{L}$ & 1000 & 1000 & $<1000$ & $<1000$ & $0 \%$ \\
\hline Cadmium & $\mathrm{Cd}$ & $\mu \mathrm{g} / \mathrm{L}$ & 0 & 170 & 210 & 200 & $5 \%$ \\
\hline Calcium & $\mathrm{Ca}$ & $\mu \mathrm{g} / \mathrm{L}$ & 300 & 78000 & 91000 & 89000 & $2 \%$ \\
\hline Cerium & $\mathrm{Ce}$ & $\mu \mathrm{g} / \mathrm{L}$ & 1 & 14 & 17 & 16 & $6 \%$ \\
\hline Cesium & Cs & $\mu \mathrm{g} / \mathrm{L}$ & - & - & - & - & - \\
\hline Chromium & $\mathrm{Cr}$ & $\mu \mathrm{g} / \mathrm{L}$ & 5 & 24 & 29 & 28 & $4 \%$ \\
\hline Cobalt & Co & $\mu \mathrm{g} / \mathrm{L}$ & 0 & 220 & 260 & 260 & $0 \%$ \\
\hline Copper & $\mathrm{Cu}$ & $\mu \mathrm{g} / \mathrm{L}$ & 5 & 100000 & 140000 & 140000 & $0 \%$ \\
\hline Dysprosium & Dy & $\mu \mathrm{g} / \mathrm{L}$ & 0 & 1.8 & 2.2 & 2.1 & $5 \%$ \\
\hline Erbium & $\mathrm{Er}$ & $\mu \mathrm{g} / \mathrm{L}$ & 0 & 1.0 & 1.2 & 1.1 & $9 \%$ \\
\hline Europium & $\mathrm{Eu}$ & $\mu \mathrm{g} / \mathrm{L}$ & 0 & 0.63 & 0.68 & 0.84 & $21 \%$ \\
\hline Gadolinium & $\mathrm{Gd}$ & $\mu \mathrm{g} / \mathrm{L}$ & 0 & 2.3 & 2.8 & 2.7 & $4 \%$ \\
\hline Gallium & $\mathrm{Ga}$ & $\mu \mathrm{g} / \mathrm{L}$ & 5 & 14 & 17 & 13 & $27 \%$ \\
\hline Germanium & $\mathrm{Ge}$ & $\mu \mathrm{g} / \mathrm{L}$ & 1 & 3.2 & 3.6 & 3.6 & $0 \%$ \\
\hline Hafnium & $\mathrm{Hf}$ & $\mu \mathrm{g} / \mathrm{L}$ & - & - & - & - & - \\
\hline Holonium & Ho & $\mu \mathrm{g} / \mathrm{L}$ & 0 & 0.36 & 0.42 & 0.42 & $0 \%$ \\
\hline Iridium & Ir & $\mu \mathrm{g} / \mathrm{L}$ & 1 & 1 & $<0.5$ & $<0.5$ & $0 \%$ \\
\hline Iron & $\mathrm{Fe}$ & $\mu \mathrm{g} / \mathrm{L}$ & 50 & 170000 & 190000 & 190000 & $0 \%$ \\
\hline Lanthanum & La & $\mu \mathrm{g} / \mathrm{L}$ & 0 & 6.2 & 7.8 & 7.4 & $5 \%$ \\
\hline Lead & $\mathrm{Pb}$ & $\mu \mathrm{g} / \mathrm{L}$ & 0 & 280 & 360 & 350 & $3 \%$ \\
\hline Lithium & $\mathrm{Li}$ & $\mu \mathrm{g} / \mathrm{L}$ & 2 & 14 & 19 & 18 & $5 \%$ \\
\hline Lutetium & $\mathrm{Lu}$ & $\mu \mathrm{g} / \mathrm{L}$ & 0 & 0.12 & 0.15 & 0.14 & $7 \%$ \\
\hline Magnesium & $\mathrm{Mg}$ & $\mu \mathrm{g} / \mathrm{L}$ & 30 & 4100 & 4700 & 4600 & $2 \%$ \\
\hline Manganese & $\mathrm{Mn}$ & $\mu \mathrm{g} / \mathrm{L}$ & 0 & 2000 & 2300 & 2100 & $9 \%$ \\
\hline Molybdenum & Mo & $\mu \mathrm{g} / \mathrm{L}$ & 10 & 10 & 11 & 12 & $9 \%$ \\
\hline Neodymium & $\mathrm{Nd}$ & $\mu \mathrm{g} / \mathrm{L}$ & 0 & 9.3 & 12 & 11 & $9 \%$ \\
\hline Nickel & $\mathrm{Ni}$ & $\mu \mathrm{g} / \mathrm{L}$ & 1 & 160 & 190 & 180 & $5 \%$ \\
\hline Niobium & $\mathrm{Nb}$ & $\mu \mathrm{g} / \mathrm{L}$ & 0 & 0 & $<0.05$ & $<0.05$ & $0 \%$ \\
\hline Palladium & $\mathrm{Pd}$ & $\mu \mathrm{g} / \mathrm{L}$ & - & - & - & - & - \\
\hline Phosphorus & $\mathrm{P}$ & $\mu \mathrm{g} / \mathrm{L}$ & 1000 & 1000 & $<1000$ & $<1000$ & $0 \%$ \\
\hline Platinum & $\mathrm{Pt}$ & $\mu \mathrm{g} / \mathrm{L}$ & 0 & 0 & $<0.05$ & $<0.05$ & $0 \%$ \\
\hline Potassium & $\mathrm{K}$ & $\mu \mathrm{g} / \mathrm{L}$ & 200 & 1200 & 1200 & 1300 & $8 \%$ \\
\hline Praseodymium & $\mathrm{Pr}$ & $\mu \mathrm{g} / \mathrm{L}$ & 0 & 2.1 & 2.5 & 2.5 & $0 \%$ \\
\hline Rhenium & $\mathrm{Re}$ & $\mu \mathrm{g} / \mathrm{L}$ & 0 & 0 & $<0.2$ & $<0.2$ & $0 \%$ \\
\hline Rhodium & $\mathrm{Rh}$ & $\mu \mathrm{g} / \mathrm{L}$ & 0 & 0 & $<0.1$ & $<0.1$ & $0 \%$ \\
\hline Rubidium & $\mathrm{Rb}$ & $\mu \mathrm{g} / \mathrm{L}$ & 1 & 5.4 & 6.8 & 6.5 & $5 \%$ \\
\hline Ruthenium & $\mathrm{Ru}$ & $\mu \mathrm{g} / \mathrm{L}$ & 0 & 0 & $<0.1$ & $<0.1$ & $0 \%$ \\
\hline Samarium & $\mathrm{Sm}$ & $\mu \mathrm{g} / \mathrm{L}$ & 0 & 2.0 & 2.6 & 2.6 & $0 \%$ \\
\hline Selenium & $\mathrm{Se}$ & $\mu \mathrm{g} / \mathrm{L}$ & 1 & 3.1 & 4.2 & 3.8 & $10 \%$ \\
\hline Silver & $\mathrm{Ag}$ & $\mu \mathrm{g} / \mathrm{L}$ & 0 & 0 & $<0.1$ & $<0.1$ & $0 \%$ \\
\hline Sodium & $\mathrm{Na}$ & $\mu \mathrm{g} / \mathrm{L}$ & 200 & 15000 & 17000 & 16000 & $6 \%$ \\
\hline Strontium & $\mathrm{Sr}$ & $\mu \mathrm{g} / \mathrm{L}$ & 1 & 350 & 410 & 410 & $0 \%$ \\
\hline Sulfur & $\mathrm{S}$ & $\mu \mathrm{g} / \mathrm{L}$ & 1000 & 320000 & 330000 & 320000 & $3 \%$ \\
\hline Tantalum & $\mathrm{Ta}$ & $\mu \mathrm{g} / \mathrm{L}$ & 0 & 0 & $<0.05$ & $<0.05$ & $0 \%$ \\
\hline Terbium & $\mathrm{Tb}$ & $\mu \mathrm{g} / \mathrm{L}$ & 0 & 0.33 & 0.42 & 0.41 & $2 \%$ \\
\hline Tellurium & $\mathrm{Te}$ & $\mu \mathrm{g} / \mathrm{L}$ & 1 & 20 & 40 & 42 & $5 \%$ \\
\hline Thalium & $\mathrm{Tl}$ & $\mu \mathrm{g} / \mathrm{L}$ & 0 & 9.7 & 12 & 11 & $9 \%$ \\
\hline Thorium & Th & $\mu \mathrm{g} / \mathrm{L}$ & - & - & - & - & - \\
\hline Thulium & $\mathrm{Tm}$ & $\mu \mathrm{g} / \mathrm{L}$ & 0 & 0.12 & 0.16 & 0.15 & $6 \%$ \\
\hline $\operatorname{Tin} * *$ & Sn & $\mu \mathrm{g} / \mathrm{L}$ & 3 & 3.0 & $<3.0$ & $<3.0$ & $0 \%$ \\
\hline Titanium & $\mathrm{Ti}$ & $\mu \mathrm{g} / \mathrm{L}$ & 3 & 3 & $<3.0$ & $<3.0$ & $0 \%$ \\
\hline Tungsten & w & $\mu \mathrm{g} / \mathrm{L}$ & 1 & 1 & $<0.5$ & $<0.5$ & $0 \%$ \\
\hline Uranium & $\mathrm{U}$ & $\mu \mathrm{g} / \mathrm{L}$ & 0 & 3.8 & 4.7 & 4.5 & $4 \%$ \\
\hline Vanadium & v & $\mu \mathrm{g} / \mathrm{L}$ & 0 & 8.3 & 11 & 10 & $10 \%$ \\
\hline Ytterbium & $\mathrm{Yb}$ & $\mu \mathrm{g} / \mathrm{L}$ & 0 & 0.81 & 1.1 & 0.96 & $14 \%$ \\
\hline Yttrium & $Y$ & $\mu \mathrm{g} / \mathrm{L}$ & 1 & 11 & 12 & 12 & $0 \%$ \\
\hline Zinc & $\mathrm{Zn}$ & $\mu \mathrm{g} / \mathrm{L}$ & 10 & 4600 & 4800 & 4500 & $6 \%$ \\
\hline Zirconium & $\mathrm{Zr}$ & $\mu \mathrm{g} / \mathrm{L}$ & 0 & 0.23 & 0.19 & $<0.1$ & $62 \%$ \\
\hline
\end{tabular}




\begin{tabular}{|c|c|c|c|c|c|c|c|c|c|}
\hline & Symbol & Units & $\begin{array}{l}\text { Sample name } \\
\text { Sample type } \\
\text { Sample number } \\
\text { Detection limit }\end{array}$ & $\begin{array}{c}\text { DW-B-11-W } \\
\text { FA } \\
\text { No2 }\end{array}$ & $\begin{array}{c}\text { DW-B-11-W } \\
\text { FA } \\
\text { No3 } \\
\text { Field Triplicate }\end{array}$ & $\begin{array}{c}\text { DW-B-11-W } \\
\text { FA } \\
\text { No4 }\end{array}$ & \% Diff 2-3 & \%Diff 3-4 & \% Diff 2-4 \\
\hline \multicolumn{10}{|l|}{ Sample description } \\
\hline \multicolumn{10}{|l|}{ Anions } \\
\hline Fluoride & $\mathrm{F}$ & $\mathrm{mg} / \mathrm{L}$ & $<0.05$ & $<2.0$ & $<2.0$ & $<2.0$ & - & - & - \\
\hline Chloride & $\mathrm{Cl}$ & $\mathrm{mg} / \mathrm{L}$ & $<0.05$ & $<2.0$ & $<2.0$ & $<2.0$ & - & - & - \\
\hline Nitrite & $\mathrm{NO}_{2-}$ & $\mathrm{mg} / \mathrm{L}$ & $<0.05$ & $<2.0$ & $<2.0$ & $<2.0$ & - & - & - \\
\hline Nitrate & $\mathrm{NO}_{3}-$ & $\mathrm{mg} / \mathrm{L}$ & $<0.05$ & $<2.0$ & $<2.0$ & $<2.0$ & - & - & - \\
\hline Sulphate & $\mathrm{SO}_{42-}$. & $\mathrm{mg} / \mathrm{L}$ & $<0.10$ & 845.0 & 845.0 & 845.0 & - & - & - \\
\hline $\mathrm{pH}$ & & - & & 2.8 & 2.8 & 2.8 & - & - & - \\
\hline \multicolumn{10}{|l|}{ Metals } \\
\hline Aluminium & Al & $\mu \mathrm{g} / \mathrm{L}$ & 5 & 27000 & 29000 & 28000 & $7 \%$ & $4 \%$ & $4 \%$ \\
\hline Antimony & $\mathrm{Sb}$ & $\mu \mathrm{g} / \mathrm{L}$ & 2 & 210 & 210 & 210 & $0 \%$ & $0 \%$ & $0 \%$ \\
\hline Arsenic & As & $\mu \mathrm{g} / \mathrm{L}$ & 2 & 1300 & 1400 & 1300 & $7 \%$ & $7 \%$ & $0 \%$ \\
\hline Barium & $\mathrm{Ba}$ & $\mu \mathrm{g} / \mathrm{L}$ & 0 & 15 & 15 & 15 & $0 \%$ & $0 \%$ & $0 \%$ \\
\hline Beryllium & $\mathrm{Be}$ & $\mu \mathrm{g} / \mathrm{L}$ & 0 & 1.8 & 1.8 & 1.8 & $0 \%$ & $0 \%$ & $0 \%$ \\
\hline Boron & B & $\mu \mathrm{g} / \mathrm{L}$ & 1000 & 1000 & 1000 & 1000 & $0 \%$ & $0 \%$ & $0 \%$ \\
\hline Cadmium & $\mathrm{Cd}$ & $\mu \mathrm{g} / \mathrm{L}$ & 0 & 170 & 170 & 170 & $0 \%$ & $0 \%$ & $0 \%$ \\
\hline Calcium & $\mathrm{Ca}$ & $\mu \mathrm{g} / \mathrm{L}$ & 300 & 78000 & 80000 & 76000 & $3 \%$ & $5 \%$ & $3 \%$ \\
\hline Cerium & $\mathrm{Ce}$ & $\mu \mathrm{g} / \mathrm{L}$ & 1 & 13 & 13 & 13 & $0 \%$ & $0 \%$ & $0 \%$ \\
\hline Cesium & Cs & $\mu \mathrm{g} / \mathrm{L}$ & - & - & - & - & - & - & - \\
\hline Chromium & $\mathrm{Cr}$ & $\mu \mathrm{g} / \mathrm{L}$ & 5 & 23 & 24 & 23 & $4 \%$ & $4 \%$ & $0 \%$ \\
\hline Cobalt & Co & $\mu \mathrm{g} / \mathrm{L}$ & 0 & 210 & 220 & 210 & $5 \%$ & $5 \%$ & $0 \%$ \\
\hline Copper & $\mathrm{Cu}$ & $\mu \mathrm{g} / \mathrm{L}$ & 5 & 110000 & 110000 & 110000 & $0 \%$ & $0 \%$ & $0 \%$ \\
\hline Dysprosium & Dy & $\mu \mathrm{g} / \mathrm{L}$ & 0 & 1.8 & 1.7 & 1.8 & $6 \%$ & $6 \%$ & $0 \%$ \\
\hline Erbium & $\mathrm{Er}$ & $\mu \mathrm{g} / \mathrm{L}$ & 0 & 0.94 & 0.91 & 0.89 & $3 \%$ & $2 \%$ & $5 \%$ \\
\hline Europium & $\mathrm{Eu}$ & $\mu \mathrm{g} / \mathrm{L}$ & 0 & 0.58 & 0.66 & 0.74 & $13 \%$ & $11 \%$ & $24 \%$ \\
\hline Gadolinium & $\mathrm{Gd}$ & $\mu \mathrm{g} / \mathrm{L}$ & 0 & 2.3 & 2.2 & 2.2 & $4 \%$ & $0 \%$ & $4 \%$ \\
\hline Gallium & $\mathrm{Ga}$ & $\mu \mathrm{g} / \mathrm{L}$ & 5 & 12 & 13 & 13 & $8 \%$ & $0 \%$ & $8 \%$ \\
\hline Germanium & $\mathrm{Ge}$ & $\mu \mathrm{g} / \mathrm{L}$ & 1 & 3.6 & 3.3 & 3.5 & $9 \%$ & $6 \%$ & $3 \%$ \\
\hline Hafnium & $\mathrm{Hf}$ & $\mu \mathrm{g} / \mathrm{L}$ & - & - & - & - & - & - & - \\
\hline Holonium & Ho & $\mu \mathrm{g} / \mathrm{L}$ & 0 & 0.33 & 0.35 & 0.34 & $6 \%$ & $3 \%$ & $3 \%$ \\
\hline Iridium & Ir & $\mu \mathrm{g} / \mathrm{L}$ & 1 & 1 & 1 & 1 & $0 \%$ & $0 \%$ & $0 \%$ \\
\hline Iron & $\mathrm{Fe}$ & $\mu \mathrm{g} / \mathrm{L}$ & 50 & 170000 & 170000 & 170000 & $0 \%$ & $0 \%$ & $0 \%$ \\
\hline Lanthanum & La & $\mu \mathrm{g} / \mathrm{L}$ & 0 & 6.0 & 5.9 & 6.0 & $2 \%$ & $2 \%$ & $0 \%$ \\
\hline Lead & $\mathrm{Pb}$ & $\mu \mathrm{g} / \mathrm{L}$ & 0 & 290 & 280 & 290 & $4 \%$ & $4 \%$ & $0 \%$ \\
\hline Lithium & $\mathrm{Li}$ & $\mu \mathrm{g} / \mathrm{L}$ & 2 & 15 & 15 & 15 & $0 \%$ & $0 \%$ & $0 \%$ \\
\hline Lutetium & Lu & $\mu \mathrm{g} / \mathrm{L}$ & 0 & 0.12 & 0.11 & 0.12 & $9 \%$ & $9 \%$ & $0 \%$ \\
\hline Magnesium & $\mathrm{Mg}$ & $\mu \mathrm{g} / \mathrm{L}$ & 30 & 3900 & 4100 & 4000 & $5 \%$ & $2 \%$ & $3 \%$ \\
\hline Manganese & $\mathrm{Mn}$ & $\mu \mathrm{g} / \mathrm{L}$ & 0 & 2200 & 2300 & 2200 & $4 \%$ & $4 \%$ & $0 \%$ \\
\hline Molybdenum & Mo & $\mu \mathrm{g} / \mathrm{L}$ & 10 & 10 & 10 & 10 & $0 \%$ & $0 \%$ & $0 \%$ \\
\hline Neodymium & $\mathrm{Nd}$ & $\mu \mathrm{g} / \mathrm{L}$ & 0 & 8.8 & 8.9 & 8.7 & $1 \%$ & $2 \%$ & $1 \%$ \\
\hline Nickel & $\mathrm{Ni}$ & $\mu \mathrm{g} / \mathrm{L}$ & 1 & 150 & 150 & 150 & $0 \%$ & $0 \%$ & $0 \%$ \\
\hline Niobium & $\mathrm{Nb}$ & $\mu \mathrm{g} / \mathrm{L}$ & 0 & 0 & 0 & 0 & $0 \%$ & $0 \%$ & $0 \%$ \\
\hline Palladium & $\mathrm{Pd}$ & $\mu \mathrm{g} / \mathrm{L}$ & - & - & - & - & - & - & - \\
\hline Phosphorus & $P$ & $\mu \mathrm{g} / \mathrm{L}$ & 1000 & 1000 & 1100 & 1000 & $10 \%$ & $10 \%$ & $0 \%$ \\
\hline Platinum & $\mathrm{Pt}$ & $\mu \mathrm{g} / \mathrm{L}$ & 0 & 0 & 0 & 0 & $0 \%$ & $0 \%$ & $0 \%$ \\
\hline Potassium & K & $\mu \mathrm{g} / \mathrm{L}$ & 200 & 1100 & 1200 & 1100 & $9 \%$ & $9 \%$ & $0 \%$ \\
\hline Praseodymium & $\operatorname{Pr}$ & $\mu \mathrm{g} / \mathrm{L}$ & 0 & 2.0 & 2.0 & 2.0 & $0 \%$ & $0 \%$ & $0 \%$ \\
\hline Rhenium & $\operatorname{Re}$ & $\mu \mathrm{g} / \mathrm{L}$ & 0 & 0 & 0 & 0 & $0 \%$ & $0 \%$ & $0 \%$ \\
\hline Rhodium & $\mathrm{Rh}$ & $\mu \mathrm{g} / \mathrm{L}$ & 0 & 0 & 0 & 0 & $0 \%$ & $0 \%$ & $0 \%$ \\
\hline Rubidium & $\mathrm{Rb}$ & $\mu \mathrm{g} / \mathrm{L}$ & 1 & 5.4 & 5.3 & 5.4 & $2 \%$ & $2 \%$ & $0 \%$ \\
\hline Ruthenium & $\mathrm{Ru}$ & $\mu \mathrm{g} / \mathrm{L}$ & 0 & 0 & 0 & 0 & $0 \%$ & $0 \%$ & $0 \%$ \\
\hline Samarium & $\mathrm{Sm}$ & $\mu \mathrm{g} / \mathrm{L}$ & 0 & 2.0 & 1.9 & 1.8 & $5 \%$ & $5 \%$ & $11 \%$ \\
\hline Selenium & Se & $\mu \mathrm{g} / \mathrm{L}$ & 1 & 2.9 & 2.6 & 2.6 & $11 \%$ & $0 \%$ & $11 \%$ \\
\hline Silver & $\mathrm{Ag}$ & $\mu \mathrm{g} / \mathrm{L}$ & 0 & 0 & 0 & 0 & $0 \%$ & $0 \%$ & $0 \%$ \\
\hline Sodium & $\mathrm{Na}$ & $\mu \mathrm{g} / \mathrm{L}$ & 200 & 14000 & 15000 & 15000 & $7 \%$ & $0 \%$ & $7 \%$ \\
\hline Strontium & $\mathrm{Sr}$ & $\mu \mathrm{g} / \mathrm{L}$ & 1 & 350 & 340 & 350 & $3 \%$ & $3 \%$ & $0 \%$ \\
\hline Sulfur & $\mathrm{s}$ & $\mu \mathrm{g} / \mathrm{L}$ & 1000 & 320000 & 330000 & 320000 & $3 \%$ & $3 \%$ & $0 \%$ \\
\hline Tantalum & $\mathrm{Ta}$ & $\mu \mathrm{g} / \mathrm{L}$ & 0 & 0 & 0 & 0 & $0 \%$ & $0 \%$ & $0 \%$ \\
\hline Terbium & $\mathrm{Tb}$ & $\mu \mathrm{g} / \mathrm{L}$ & 0 & 0.34 & 0.34 & 0.31 & $0 \%$ & $9 \%$ & $9 \%$ \\
\hline Tellurium & $\mathrm{Te}$ & $\mu \mathrm{g} / \mathrm{L}$ & 1 & 37 & 38 & 38 & $3 \%$ & $0 \%$ & $3 \%$ \\
\hline Thalium & $\mathrm{TI}$ & $\mu \mathrm{g} / \mathrm{L}$ & 0 & 9.6 & 9.6 & 9.5 & $0 \%$ & $1 \%$ & $1 \%$ \\
\hline Thorium & Th & $\mu \mathrm{g} / \mathrm{L}$ & - & - & - & - & - & - & - \\
\hline Thulium & $\mathrm{Tm}$ & $\mu \mathrm{g} / \mathrm{L}$ & 0 & 0.12 & 0.11 & 0.11 & $9 \%$ & $0 \%$ & $9 \%$ \\
\hline $\operatorname{Tin} * *$ & Sn & $\mu \mathrm{g} / \mathrm{L}$ & 3 & 3.0 & 3.0 & 3.0 & $0 \%$ & $0 \%$ & $0 \%$ \\
\hline Titanium & $\mathrm{Ti}$ & $\mu \mathrm{g} / \mathrm{L}$ & 3 & 3 & 3 & 3 & $0 \%$ & $0 \%$ & $0 \%$ \\
\hline Tungsten & w & $\mu \mathrm{g} / \mathrm{L}$ & 1 & 1 & 1 & 1 & $0 \%$ & $0 \%$ & $0 \%$ \\
\hline Uranium & U & $\mu \mathrm{g} / \mathrm{L}$ & 0 & 3.7 & 3.7 & 3.7 & $0 \%$ & $0 \%$ & $0 \%$ \\
\hline Vanadium & v & $\mu \mathrm{g} / \mathrm{L}$ & 0 & 8.2 & 7.7 & 7.5 & $6 \%$ & $3 \%$ & $9 \%$ \\
\hline Ytterbium & $\mathrm{Yb}$ & $\mu \mathrm{g} / \mathrm{L}$ & 0 & 0.74 & 0.75 & 0.76 & $1 \%$ & $1 \%$ & $3 \%$ \\
\hline Yttrium & $Y$ & $\mu \mathrm{g} / \mathrm{L}$ & 1 & 10 & 10 & 11 & $0 \%$ & $10 \%$ & $10 \%$ \\
\hline Zinc & $\mathrm{Zn}$ & $\mu \mathrm{g} / \mathrm{L}$ & 10 & 4900 & 5100 & 5100 & $4 \%$ & $0 \%$ & $4 \%$ \\
\hline Zirconium & $\mathrm{Zr}$ & $\mu \mathrm{g} / \mathrm{L}$ & 0 & 0 & 0 & 0 & $0 \%$ & $0 \%$ & $0 \%$ \\
\hline
\end{tabular}




\begin{tabular}{|c|c|c|c|c|c|c|c|c|}
\hline & & & $\begin{array}{l}\text { Sample name } \\
\text { Sample type } \\
\text { Sample number }\end{array}$ & $\begin{array}{c}\text { SP3-W2 } \\
\text { FA } \\
\text { No18 }\end{array}$ & $\begin{array}{c}\text { SP3-W2 } \\
\text { FA } \\
\text { No19 }\end{array}$ & $\begin{array}{c}\text { SP3-W2 } \\
\text { FFA } \\
\text { No26 }\end{array}$ & $\begin{array}{c}\text { SP3-W3 } \\
\text { UA } \\
\text { No35 }\end{array}$ & \%Diff 18-19 \\
\hline & Symbol & Units & Detection limit & \multicolumn{2}{|c|}{ Field Duplicate } & & & \\
\hline \multicolumn{9}{|l|}{ Sample description } \\
\hline \multicolumn{9}{|l|}{ Anions } \\
\hline Fluoride & $\mathrm{F}$ & $\mathrm{mg} / \mathrm{L}$ & $<0.05$ & $<2.0$ & $<2.0$ & $<2.0$ & $<2.0$ & - \\
\hline Chloride & $\mathrm{Cl}$ & $\mathrm{mg} / \mathrm{L}$ & $<0.05$ & $<2.0$ & $<2.0$ & $<2.0$ & $<2.0$ & - \\
\hline Nitrite & $\mathrm{NO}_{2-}$ & $\mathrm{mg} / \mathrm{L}$ & $<0.05$ & $<2.0$ & $<2.0$ & $<2.0$ & $<2.0$ & - \\
\hline Nitrate & $\mathrm{NO}_{3}-$ & $\mathrm{mg} / \mathrm{L}$ & $<0.05$ & 4.0 & 4.0 & 4.0 & 4.0 & - \\
\hline Sulphate & $\mathrm{SO}_{42-}$ & $\mathrm{mg} / \mathrm{L}$ & $<0.10$ & 750.0 & 750.0 & 750.0 & 750.0 & - \\
\hline $\mathrm{pH}$ & & - & & 2.9 & 2.9 & 2.9 & 2.9 & - \\
\hline \multicolumn{9}{|l|}{ Metals } \\
\hline Aluminium & Al & $\mu \mathrm{g} / \mathrm{L}$ & 5 & 49000 & 50000 & 46000 & 49000 & $2 \%$ \\
\hline Antimony & $\mathrm{Sb}$ & $\mu \mathrm{g} / \mathrm{L}$ & 2 & 2 & 2 & 2 & 11 & $0 \%$ \\
\hline Arsenic & As & $\mu \mathrm{g} / \mathrm{L}$ & 2 & 13 & 15 & 16 & 130 & $14 \%$ \\
\hline Barium & $\mathrm{Ba}$ & $\mu \mathrm{g} / \mathrm{L}$ & 0 & 56 & 58 & 51 & 80 & $4 \%$ \\
\hline Beryllium & $\mathrm{Be}$ & $\mu \mathrm{g} / \mathrm{L}$ & 0 & 7.6 & 7.7 & 6.6 & 8.7 & $1 \%$ \\
\hline Boron & B & $\mu \mathrm{g} / \mathrm{L}$ & 1000 & 1000 & 1000 & 1000 & $<1000$ & $0 \%$ \\
\hline Cadmium & $\mathrm{Cd}$ & $\mu \mathrm{g} / \mathrm{L}$ & 0 & 37 & 38 & 32 & 42 & $3 \%$ \\
\hline Calcium & $\mathrm{Ca}$ & $\mu \mathrm{g} / \mathrm{L}$ & 300 & 130000 & 130000 & 120000 & 140000 & $0 \%$ \\
\hline Cerium & $\mathrm{Ce}$ & $\mu \mathrm{g} / \mathrm{L}$ & 1 & 69 & 70 & 60 & 83 & $1 \%$ \\
\hline Cesium & Cs & $\mu \mathrm{g} / \mathrm{L}$ & - & - & - & - & - & - \\
\hline Chromium & $\mathrm{Cr}$ & $\mu \mathrm{g} / \mathrm{L}$ & 5 & 15 & 16 & 13 & 17 & $6 \%$ \\
\hline Cobalt & Co & $\mu \mathrm{g} / \mathrm{L}$ & 0 & 170 & 180 & 150 & 180 & $6 \%$ \\
\hline Copper & $\mathrm{Cu}$ & $\mu \mathrm{g} / \mathrm{L}$ & 5 & 9900 & 10000 & 9500 & 12000 & $1 \%$ \\
\hline Dysprosium & Dy & $\mu \mathrm{g} / \mathrm{L}$ & 0 & 8.6 & 8.6 & 7.4 & 10 & $0 \%$ \\
\hline Erbium & $\mathrm{Er}$ & $\mu \mathrm{g} / \mathrm{L}$ & 0 & 4.1 & 4.4 & 3.7 & 4.9 & $7 \%$ \\
\hline Europium & $\mathrm{Eu}$ & $\mu \mathrm{g} / \mathrm{L}$ & 0 & 3.0 & 3.1 & 2.7 & 3.5 & $3 \%$ \\
\hline Gadolinium & $\mathrm{Gd}$ & $\mu \mathrm{g} / \mathrm{L}$ & 0 & 11 & 11 & 9.3 & 13 & $0 \%$ \\
\hline Gallium & $\mathrm{Ga}$ & $\mu \mathrm{g} / \mathrm{L}$ & 5 & 8.0 & 9.3 & 8.0 & 9.9 & $15 \%$ \\
\hline Germanium & $\mathrm{Ge}$ & $\mu \mathrm{g} / \mathrm{L}$ & 1 & 3.3 & 3.4 & 2.9 & 3.9 & $3 \%$ \\
\hline Hafnium & $\mathrm{Hf}$ & $\mu \mathrm{g} / \mathrm{L}$ & - & - & - & - & - & - \\
\hline Holonium & Ho & $\mu \mathrm{g} / \mathrm{L}$ & 0 & 1.6 & 1.5 & 1.4 & 1.9 & $6 \%$ \\
\hline Iridium & Ir & $\mu \mathrm{g} / \mathrm{L}$ & 1 & 1 & 1 & 1 & $<0.5$ & $0 \%$ \\
\hline Iron & $\mathrm{Fe}$ & $\mu \mathrm{g} / \mathrm{L}$ & 50 & 56000 & 56000 & 49000 & 79000 & $0 \%$ \\
\hline Lanthanum & La & $\mu \mathrm{g} / \mathrm{L}$ & 0 & 32 & 32 & 28 & 39 & $0 \%$ \\
\hline Lead & $\mathrm{Pb}$ & $\mu \mathrm{g} / \mathrm{L}$ & 0 & 33 & 34 & 29 & 45 & $3 \%$ \\
\hline Lithium & $\mathrm{Li}$ & $\mu \mathrm{g} / \mathrm{L}$ & 2 & 17 & 17 & 14 & 21 & $0 \%$ \\
\hline Lutetium & $\mathrm{Lu}$ & $\mu \mathrm{g} / \mathrm{L}$ & 0 & 0.43 & 0.42 & 0.37 & 0.51 & $2 \%$ \\
\hline Magnesium & $\mathrm{Mg}$ & $\mu \mathrm{g} / \mathrm{L}$ & 30 & 19000 & 19000 & 17000 & 20000 & $0 \%$ \\
\hline Manganese & $\mathrm{Mn}$ & $\mu \mathrm{g} / \mathrm{L}$ & 0 & 6100 & 6100 & 5700 & 6200 & $0 \%$ \\
\hline Molybdenum & Mo & $\mu \mathrm{g} / \mathrm{L}$ & 10 & 10 & 10 & 10 & $<10$ & $0 \%$ \\
\hline Neodymium & $\mathrm{Nd}$ & $\mu \mathrm{g} / \mathrm{L}$ & 0 & 40 & 41 & 35 & 49 & $2 \%$ \\
\hline Nickel & $\mathrm{Ni}$ & $\mu \mathrm{g} / \mathrm{L}$ & 1 & 170 & 170 & 150 & 170 & $0 \%$ \\
\hline Niobium & $\mathrm{Nb}$ & $\mu \mathrm{g} / \mathrm{L}$ & 0 & 0 & 0 & 0 & $<0.05$ & $0 \%$ \\
\hline Palladium & $\mathrm{Pd}$ & $\mu \mathrm{g} / \mathrm{L}$ & - & - & - & - & - & - \\
\hline Phosphorus & $\mathrm{P}$ & $\mu \mathrm{g} / \mathrm{L}$ & 1000 & 1000 & 1000 & 1000 & $<1000$ & $0 \%$ \\
\hline Platinum & $\mathrm{Pt}$ & $\mu \mathrm{g} / \mathrm{L}$ & 0 & 0 & 0 & 0 & $<0.05$ & $0 \%$ \\
\hline Potassium & $\mathrm{K}$ & $\mu \mathrm{g} / \mathrm{L}$ & 200 & 2700 & 2700 & 3100 & 2800 & $0 \%$ \\
\hline Praseodymium & $\operatorname{Pr}$ & $\mu \mathrm{g} / \mathrm{L}$ & 0 & 9.7 & 9.9 & 8.5 & 11 & $2 \%$ \\
\hline Rhenium & $\operatorname{Re}$ & $\mu \mathrm{g} / \mathrm{L}$ & 0 & 0 & 0 & 0 & $<0.2$ & $0 \%$ \\
\hline Rhodium & $\mathrm{Rh}$ & $\mu \mathrm{g} / \mathrm{L}$ & 0 & 0 & 0 & 0 & $<0.1$ & $0 \%$ \\
\hline Rubidium & $\mathrm{Rb}$ & $\mu \mathrm{g} / \mathrm{L}$ & 1 & 4.6 & 4.8 & 5.7 & 6.0 & $4 \%$ \\
\hline Ruthenium & $\mathrm{Ru}$ & $\mu \mathrm{g} / \mathrm{L}$ & 0 & 0 & 0 & 0 & $<0.1$ & $0 \%$ \\
\hline Samarium & $\mathrm{Sm}$ & $\mu \mathrm{g} / \mathrm{L}$ & 0 & 9.5 & 9.9 & 8.0 & 11 & $4 \%$ \\
\hline Selenium & $\mathrm{Se}$ & $\mu \mathrm{g} / \mathrm{L}$ & 1 & 6.9 & 7.8 & 6.8 & 8.8 & $12 \%$ \\
\hline Silver & $\mathrm{Ag}$ & $\mu \mathrm{g} / \mathrm{L}$ & 0 & 0.83 & 0.90 & 0.78 & 0.12 & $8 \%$ \\
\hline Sodium & $\mathrm{Na}$ & $\mu \mathrm{g} / \mathrm{L}$ & 200 & 15000 & 15000 & 14000 & 14000 & $0 \%$ \\
\hline Strontium & $\mathrm{Sr}$ & $\mu \mathrm{g} / \mathrm{L}$ & 1 & 680 & 680 & 610 & 760 & $0 \%$ \\
\hline Sulfur & $\mathrm{s}$ & $\mu \mathrm{g} / \mathrm{L}$ & 1000 & 3800000 & 4100000 & 3800000 & 270000 & $8 \%$ \\
\hline Tantalum & $\mathrm{Ta}$ & $\mu \mathrm{g} / \mathrm{L}$ & 0 & 0 & 0 & 0 & $<0.05$ & $0 \%$ \\
\hline Terbium & $\mathrm{Tb}$ & $\mu \mathrm{g} / \mathrm{L}$ & 0 & 1.6 & 1.6 & 1.4 & 1.9 & $0 \%$ \\
\hline Tellurium & $\mathrm{Te}$ & $\mu \mathrm{g} / \mathrm{L}$ & 1 & 0.65 & 0.62 & 0.81 & 1.2 & $5 \%$ \\
\hline Thalium & $\mathrm{Tl}$ & $\mu \mathrm{g} / \mathrm{L}$ & 0 & 0.69 & 0.64 & 0.62 & 0.59 & $8 \%$ \\
\hline Thorium & Th & $\mu \mathrm{g} / \mathrm{L}$ & - & - & - & - & - & - \\
\hline Thulium & $\mathrm{Tm}$ & $\mu \mathrm{g} / \mathrm{L}$ & 0 & 0.52 & 0.54 & 0.46 & 0.63 & $4 \%$ \\
\hline $\operatorname{Tin} * *$ & Sn & $\mu \mathrm{g} / \mathrm{L}$ & 3 & 3.0 & 3.0 & 3.0 & $<3.0$ & $0 \%$ \\
\hline Titanium & $\mathrm{Ti}$ & $\mu \mathrm{g} / \mathrm{L}$ & 3 & 3 & 3 & 3 & 12 & $0 \%$ \\
\hline Tungsten & w & $\mu \mathrm{g} / \mathrm{L}$ & 1 & 1 & 1 & 1 & $<0.5$ & $0 \%$ \\
\hline Uranium & U & $\mu \mathrm{g} / \mathrm{L}$ & 0 & 3.3 & 3.4 & 2.9 & 4.0 & $3 \%$ \\
\hline Vanadium & $v$ & $\mu \mathrm{g} / \mathrm{L}$ & 0 & 0 & 0 & 0 & 3.5 & $0 \%$ \\
\hline Ytterbium & $\mathrm{Yb}$ & $\mu \mathrm{g} / \mathrm{L}$ & 0 & 3.1 & 3.2 & 2.7 & 3.7 & $3 \%$ \\
\hline Yttrium & $Y$ & $\mu \mathrm{g} / \mathrm{L}$ & 1 & 50 & 49 & 44 & 52 & $2 \%$ \\
\hline Zinc & $\mathrm{Zn}$ & $\mu \mathrm{g} / \mathrm{L}$ & 10 & 2100 & 2100 & 2000 & 2000 & $0 \%$ \\
\hline Zirconium & $\mathrm{Zr}$ & $\mu \mathrm{g} / \mathrm{L}$ & 0 & 0.29 & 0.44 & 0.27 & 0.38 & $41 \%$ \\
\hline
\end{tabular}




\begin{tabular}{|c|c|c|c|c|c|c|c|c|c|}
\hline & Symbol & Units & $\begin{array}{l}\text { Sample name } \\
\text { Sample type } \\
\text { Sample number } \\
\text { Detection limit }\end{array}$ & $\begin{array}{c}\text { DAR-1-W } \\
\text { FA } \\
\text { No8 }\end{array}$ & $\begin{array}{c}\text { DAR-1-W } \\
\text { FA } \\
\text { No9 } \\
\text { Field Triplicate } \\
\end{array}$ & $\begin{array}{c}\text { *DAR-1-W } \\
\text { FA } \\
\text { No10 }\end{array}$ & \%Diff 8-9 & \% Diff 9-10 & \%Diff $10-8$ \\
\hline \multicolumn{10}{|l|}{ Sample description } \\
\hline \multicolumn{10}{|l|}{ Anions } \\
\hline Fluoride & $\mathrm{F}$ & $\mathrm{mg} / \mathrm{L}$ & $<0.05$ & $<5.0$ & $<5.0$ & $<5.0$ & - & - & - \\
\hline Chloride & $\mathrm{Cl}$ & $\mathrm{mg} / \mathrm{L}$ & $<0.05$ & $<5.0$ & $<5.0$ & $<5.0$ & - & - & - \\
\hline Nitrite & $\mathrm{NO}_{2-}^{-}$ & $\mathrm{mg} / \mathrm{L}$ & $<0.05$ & $<5.0$ & $<5.0$ & $<5.0$ & - & - & - \\
\hline Nitrate & $\mathrm{NO}_{3}-$ & $\mathrm{mg} / \mathrm{L}$ & $<0.05$ & 9.5 & 9.5 & 9.5 & - & - & - \\
\hline Sulphate & $\mathrm{SO}_{42-}$ & $\mathrm{mg} / \mathrm{L}$ & $<0.10$ & 5400.0 & 5400.0 & 5400.0 & - & - & - \\
\hline $\mathrm{pH}$ & & - & & 2.6 & 2.6 & 2.6 & - & - & - \\
\hline \multicolumn{10}{|l|}{ Metals } \\
\hline Aluminium & Al & $\mu \mathrm{g} / \mathrm{L}$ & 5 & 380000 & 380000 & 390000 & $0 \%$ & $3 \%$ & $3 \%$ \\
\hline Antimony & $\mathrm{Sb}$ & $\mu \mathrm{g} / \mathrm{L}$ & 2 & 3.1 & 3.2 & 4.0 & $3 \%$ & $22 \%$ & $25 \%$ \\
\hline Arsenic & As & $\mu \mathrm{g} / \mathrm{L}$ & 2 & 920 & 950 & 890 & $3 \%$ & $7 \%$ & $3 \%$ \\
\hline Barium & $\mathrm{Ba}$ & $\mu \mathrm{g} / \mathrm{L}$ & 0 & 8.4 & 8.3 & 12 & $1 \%$ & $36 \%$ & $35 \%$ \\
\hline Beryllium & $\mathrm{Be}$ & $\mu \mathrm{g} / \mathrm{L}$ & 0 & 46 & 47 & 52 & $2 \%$ & $10 \%$ & $12 \%$ \\
\hline Boron & $\mathrm{B}$ & $\mu \mathrm{g} / \mathrm{L}$ & 1000 & 1000 & 1000 & 1000 & $0 \%$ & $0 \%$ & $0 \%$ \\
\hline Cadmium & $\mathrm{Cd}$ & $\mu \mathrm{g} / \mathrm{L}$ & 0 & 180 & 180 & 200 & $0 \%$ & $11 \%$ & $11 \%$ \\
\hline Calcium & $\mathrm{Ca}$ & $\mu \mathrm{g} / \mathrm{L}$ & 300 & 400000 & 400000 & 460000 & $0 \%$ & $14 \%$ & $14 \%$ \\
\hline Cerium & $\mathrm{Ce}$ & $\mu \mathrm{g} / \mathrm{L}$ & 1 & 520 & 540 & 610 & $4 \%$ & $12 \%$ & $16 \%$ \\
\hline Cesium & Cs & $\mu \mathrm{g} / \mathrm{L}$ & - & - & - & - & - & - & - \\
\hline Chromium & $\mathrm{Cr}$ & $\mu \mathrm{g} / \mathrm{L}$ & 5 & 74 & 76 & 88 & $3 \%$ & $15 \%$ & $17 \%$ \\
\hline Cobalt & Co & $\mu \mathrm{g} / \mathrm{L}$ & 0 & 890 & 910 & 1000 & $2 \%$ & $9 \%$ & $12 \%$ \\
\hline Copper & $\mathrm{Cu}$ & $\mu \mathrm{g} / \mathrm{L}$ & 5 & 17000 & 18000 & 17000 & $6 \%$ & $6 \%$ & $0 \%$ \\
\hline Dysprosium & Dy & $\mu \mathrm{g} / \mathrm{L}$ & 0 & 65 & 67 & 75 & $3 \%$ & $11 \%$ & $14 \%$ \\
\hline Erbium & $\mathrm{Er}$ & $\mu \mathrm{g} / \mathrm{L}$ & 0 & 33 & 34 & 38 & $3 \%$ & $11 \%$ & $14 \%$ \\
\hline Europium & Eu & $\mu \mathrm{g} / \mathrm{L}$ & 0 & 23 & 23 & 27 & $0 \%$ & $16 \%$ & $16 \%$ \\
\hline Gadolinium & $\mathrm{Gd}$ & $\mu \mathrm{g} / \mathrm{L}$ & 0 & 80 & 83 & 93 & $4 \%$ & $11 \%$ & $15 \%$ \\
\hline Gallium & $\mathrm{Ga}$ & $\mu \mathrm{g} / \mathrm{L}$ & 5 & 58 & 58 & 69 & $0 \%$ & $17 \%$ & $17 \%$ \\
\hline Germanium & $\mathrm{Ge}$ & $\mu \mathrm{g} / \mathrm{L}$ & 1 & 27 & 28 & 33 & $4 \%$ & $16 \%$ & $20 \%$ \\
\hline Hafnium & $\mathrm{Hf}$ & $\mu \mathrm{g} / \mathrm{L}$ & - & - & - & - & - & - & - \\
\hline Holonium & Ho & $\mu \mathrm{g} / \mathrm{L}$ & 0 & 12 & 13 & 15 & $8 \%$ & $14 \%$ & $22 \%$ \\
\hline Iridium & Ir & $\mu \mathrm{g} / \mathrm{L}$ & 1 & 1 & 1 & 1 & $0 \%$ & $0 \%$ & $0 \%$ \\
\hline Iron & $\mathrm{Fe}$ & $\mu \mathrm{g} / \mathrm{L}$ & 50 & 640000 & 630000 & 650000 & $2 \%$ & $3 \%$ & $2 \%$ \\
\hline Lanthanum & La & $\mu \mathrm{g} / \mathrm{L}$ & 0 & 240 & 250 & 280 & $4 \%$ & $11 \%$ & $15 \%$ \\
\hline Lead & $\mathrm{Pb}$ & $\mu \mathrm{g} / \mathrm{L}$ & 0 & 2.9 & 2.8 & 4.7 & $4 \%$ & $51 \%$ & $47 \%$ \\
\hline Lithium & $\mathrm{Li}$ & $\mu \mathrm{g} / \mathrm{L}$ & 2 & 110 & 110 & 120 & $0 \%$ & $9 \%$ & $9 \%$ \\
\hline Lutetium & Lu & $\mu \mathrm{g} / \mathrm{L}$ & 0 & 3.2 & 3.3 & 3.7 & $3 \%$ & $11 \%$ & $14 \%$ \\
\hline Magnesium & $\mathrm{Mg}$ & $\mu \mathrm{g} / \mathrm{L}$ & 30 & 130000 & 130000 & 150000 & $0 \%$ & $14 \%$ & $14 \%$ \\
\hline Manganese & $\mathrm{Mn}$ & $\mu \mathrm{g} / \mathrm{L}$ & 0 & 40000 & 42000 & 40000 & $5 \%$ & $5 \%$ & $0 \%$ \\
\hline Molybdenum & Mo & $\mu \mathrm{g} / \mathrm{L}$ & 10 & 10 & 10 & 10 & $0 \%$ & $0 \%$ & $0 \%$ \\
\hline Neodymium & $\mathrm{Nd}$ & $\mu \mathrm{g} / \mathrm{L}$ & 0 & 300 & 310 & 350 & $3 \%$ & $12 \%$ & $15 \%$ \\
\hline Nickel & $\mathrm{Ni}$ & $\mu \mathrm{g} / \mathrm{L}$ & 1 & 820 & 830 & 960 & $1 \%$ & $15 \%$ & $16 \%$ \\
\hline Niobium & $\mathrm{Nb}$ & $\mu \mathrm{g} / \mathrm{L}$ & 0 & 0.19 & 0.20 & 0.23 & $5 \%$ & $14 \%$ & $19 \%$ \\
\hline Palladium & $\mathrm{Pd}$ & $\mu \mathrm{g} / \mathrm{L}$ & - & - & - & - & - & - & - \\
\hline Phosphorus & $\mathrm{P}$ & $\mu \mathrm{g} / \mathrm{L}$ & 1000 & 6800 & 6600 & 6800 & $3 \%$ & $3 \%$ & $0 \%$ \\
\hline Platinum & $\mathrm{Pt}$ & $\mu \mathrm{g} / \mathrm{L}$ & 0 & 0 & 0 & 0 & $0 \%$ & $0 \%$ & $0 \%$ \\
\hline Potassium & $\mathrm{K}$ & $\mu \mathrm{g} / \mathrm{L}$ & 200 & 1200 & 1300 & 1400 & $8 \%$ & $7 \%$ & $15 \%$ \\
\hline Praseodymium & $\operatorname{Pr}$ & $\mu \mathrm{g} / \mathrm{L}$ & 0 & 71 & 73 & 82 & $3 \%$ & $12 \%$ & $14 \%$ \\
\hline Rhenium & $\operatorname{Re}$ & $\mu \mathrm{g} / \mathrm{L}$ & 0 & 0 & 0 & 0 & $0 \%$ & $0 \%$ & $0 \%$ \\
\hline Rhodium & $\mathrm{Rh}$ & $\mu \mathrm{g} / \mathrm{L}$ & 0 & 0 & 0 & 0 & $0 \%$ & $0 \%$ & $0 \%$ \\
\hline Rubidium & $\mathrm{Rb}$ & $\mu \mathrm{g} / \mathrm{L}$ & 1 & 8.6 & 8.6 & 9.9 & $0 \%$ & $14 \%$ & $14 \%$ \\
\hline Ruthenium & $\mathrm{Ru}$ & $\mu \mathrm{g} / \mathrm{L}$ & 0 & 0 & 0 & 0 & $0 \%$ & $0 \%$ & $0 \%$ \\
\hline Samarium & $\mathrm{Sm}$ & $\mu \mathrm{g} / \mathrm{L}$ & 0 & 71 & 73 & 83 & $3 \%$ & $13 \%$ & $16 \%$ \\
\hline Selenium & $\mathrm{Se}$ & $\mu \mathrm{g} / \mathrm{L}$ & 1 & 20 & 21 & 24 & $5 \%$ & $13 \%$ & $18 \%$ \\
\hline Silver & $\mathrm{Ag}$ & $\mu \mathrm{g} / \mathrm{L}$ & 0 & 0 & 0 & 0 & $0 \%$ & $0 \%$ & $0 \%$ \\
\hline Sodium & $\mathrm{Na}$ & $\mu \mathrm{g} / \mathrm{L}$ & 200 & 27000 & 27000 & 31000 & $0 \%$ & $14 \%$ & $14 \%$ \\
\hline Strontium & $\mathrm{Sr}$ & $\mu \mathrm{g} / \mathrm{L}$ & 1 & 2100 & 2000 & 2100 & $5 \%$ & $5 \%$ & $0 \%$ \\
\hline Sulfur & $\mathrm{s}$ & $\mu \mathrm{g} / \mathrm{L}$ & 1000 & 1700000 & 1900000 & 1800000 & $11 \%$ & $5 \%$ & $6 \%$ \\
\hline Tantalum & $\mathrm{Ta}$ & $\mu \mathrm{g} / \mathrm{L}$ & 0 & 0 & 0.051 & 0.060 & $2 \%$ & $16 \%$ & $18 \%$ \\
\hline Terbium & $\mathrm{Tb}$ & $\mu \mathrm{g} / \mathrm{L}$ & 0 & 12 & 12 & 14 & $0 \%$ & $15 \%$ & $15 \%$ \\
\hline Tellurium & $\mathrm{Te}$ & $\mu \mathrm{g} / \mathrm{L}$ & 1 & 1.8 & 2.1 & 2.6 & $15 \%$ & $21 \%$ & $36 \%$ \\
\hline Thalium & $\mathrm{Tl}$ & $\mu \mathrm{g} / \mathrm{L}$ & 0 & 0.28 & 0.30 & 0.33 & $7 \%$ & $10 \%$ & $16 \%$ \\
\hline Thorium & Th & $\mu \mathrm{g} / \mathrm{L}$ & - & - & - & - & - & - & - \\
\hline Thulium & $\mathrm{Tm}$ & $\mu \mathrm{g} / \mathrm{L}$ & 0 & 4.1 & 4.2 & 4.7 & $2 \%$ & $11 \%$ & $14 \%$ \\
\hline $\operatorname{Tin} * *$ & Sn & $\mu \mathrm{g} / \mathrm{L}$ & 3 & 3.0 & 3.0 & 3.0 & $0 \%$ & $0 \%$ & $0 \%$ \\
\hline Titanium & $\mathrm{Ti}$ & $\mu \mathrm{g} / \mathrm{L}$ & 3 & 26 & 22 & 28 & $17 \%$ & $24 \%$ & $7 \%$ \\
\hline Tungsten & w & $\mu \mathrm{g} / \mathrm{L}$ & 1 & 1 & 1 & 1 & $0 \%$ & $0 \%$ & $0 \%$ \\
\hline Uranium & $U$ & $\mu \mathrm{g} / \mathrm{L}$ & 0 & 21 & 22 & 25 & $5 \%$ & $13 \%$ & $17 \%$ \\
\hline Vanadium & v & $\mu \mathrm{g} / \mathrm{L}$ & 0 & 24 & 23 & 27 & $4 \%$ & $16 \%$ & $12 \%$ \\
\hline Ytterbium & $\mathrm{Yb}$ & $\mu \mathrm{g} / \mathrm{L}$ & 0 & 24 & 24 & 28 & $0 \%$ & $15 \%$ & $15 \%$ \\
\hline Yttrium & $Y$ & $\mu \mathrm{g} / \mathrm{L}$ & 1 & 350 & 370 & 420 & $6 \%$ & $13 \%$ & $18 \%$ \\
\hline Zinc & $\mathrm{Zn}$ & $\mu \mathrm{g} / \mathrm{L}$ & 10 & 14000 & 14000 & 14000 & $0 \%$ & $0 \%$ & $0 \%$ \\
\hline Zirconium & $\mathrm{Zr}$ & $\mu \mathrm{g} / \mathrm{L}$ & 0 & 1.7 & 1.8 & 2.3 & $6 \%$ & $24 \%$ & $30 \%$ \\
\hline
\end{tabular}




\begin{tabular}{|c|c|c|c|c|c|c|c|}
\hline & & & $\begin{array}{l}\text { Sample name } \\
\text { Sample type } \\
\text { Sample number }\end{array}$ & $\begin{array}{l}\text { DAR-1-W } \\
\text { FFA } \\
\text { No24 }\end{array}$ & $\begin{array}{c}\text { DAR-1-W } \\
\text { UA } \\
\text { No28 }\end{array}$ & $\begin{array}{c}\text { DAR-1-W } \\
\text { UA } \\
\text { No29* }\end{array}$ & \% Diff 28-29 \\
\hline & Symbol & Units & Detection limit & \multirow{2}{*}{\multicolumn{4}{|c|}{ Field Duplicate }} \\
\hline \multicolumn{4}{|l|}{ Sample description } & & & & \\
\hline \multicolumn{8}{|l|}{ Anions } \\
\hline Fluoride & $\mathrm{F}$ & $\mathrm{mg} / \mathrm{L}$ & $<0.05$ & $<5.0$ & $<5.0$ & $<5.0$ & - \\
\hline Chloride & $\mathrm{Cl}$ & $\mathrm{mg} / \mathrm{L}$ & $<0.05$ & $<5.0$ & $<5.0$ & $<5.0$ & - \\
\hline Nitrite & $\mathrm{NO}_{2-}$ & $\mathrm{mg} / \mathrm{L}$ & $<0.05$ & $<5.0$ & $<5.0$ & $<5.0$ & - \\
\hline Nitrate & $\mathrm{NO}_{3}^{-}$ & $\mathrm{mg} / \mathrm{L}$ & $<0.05$ & 9.5 & 9.5 & 9.5 & - \\
\hline Sulphate & $\mathrm{SO}_{42-}$ & $\mathrm{mg} / \mathrm{L}$ & $<0.10$ & 5400.0 & 5400.0 & 5400.0 & - \\
\hline $\mathrm{pH}$ & & - & & 2.6 & 2.6 & 2.6 & - \\
\hline \multicolumn{8}{|l|}{ Metals } \\
\hline Aluminium & $\mathrm{Al}$ & $\mu g / L$ & 5 & 370000 & 370000 & 360000 & $3 \%$ \\
\hline Antimony & $\mathrm{Sb}$ & $\mu \mathrm{g} / \mathrm{L}$ & 2 & 3.6 & 4.5 & 3.5 & $25 \%$ \\
\hline Arsenic & As & $\mu \mathrm{g} / \mathrm{L}$ & 2 & 960 & 850 & 910 & $7 \%$ \\
\hline Barium & $\mathrm{Ba}$ & $\mu \mathrm{g} / \mathrm{L}$ & 0 & 8.8 & 11 & 9.6 & $14 \%$ \\
\hline Beryllium & $\mathrm{Be}$ & $\mu \mathrm{g} / \mathrm{L}$ & 0 & 45 & 62 & 53 & $16 \%$ \\
\hline Boron & B & $\mu \mathrm{g} / \mathrm{L}$ & 1000 & 1000 & $<1000$ & $<1000$ & $0 \%$ \\
\hline Cadmium & $\mathrm{Cd}$ & $\mu \mathrm{g} / \mathrm{L}$ & 0 & 180 & 230 & 200 & $14 \%$ \\
\hline Calcium & $\mathrm{Ca}$ & $\mu \mathrm{g} / \mathrm{L}$ & 300 & 400000 & 420000 & 440000 & $5 \%$ \\
\hline Cerium & $\mathrm{Ce}$ & $\mu \mathrm{g} / \mathrm{L}$ & 1 & 530 & 680 & 580 & $16 \%$ \\
\hline Cesium & Cs & $\mu \mathrm{g} / \mathrm{L}$ & - & - & - & - & - \\
\hline Chromium & $\mathrm{Cr}$ & $\mu \mathrm{g} / \mathrm{L}$ & 5 & 77 & 100 & 84 & $17 \%$ \\
\hline Cobalt & Co & $\mu \mathrm{g} / \mathrm{L}$ & 0 & 930 & 1200 & 1000 & $18 \%$ \\
\hline Copper & $\mathrm{Cu}$ & $\mu \mathrm{g} / \mathrm{L}$ & 5 & 16000 & 23000 & 20000 & $14 \%$ \\
\hline Dysprosium & Dy & $\mu \mathrm{g} / \mathrm{L}$ & 0 & 65 & 86 & 74 & $15 \%$ \\
\hline Erbium & $\mathrm{Er}$ & $\mu \mathrm{g} / \mathrm{L}$ & 0 & 33 & 43 & 36 & $18 \%$ \\
\hline Europium & $\mathrm{Eu}$ & $\mu \mathrm{g} / \mathrm{L}$ & 0 & 23 & 31 & 26 & $18 \%$ \\
\hline Gadolinium & $\mathrm{Gd}$ & $\mu \mathrm{g} / \mathrm{L}$ & 0 & 80 & 110 & 92 & $18 \%$ \\
\hline Gallium & $\mathrm{Ga}$ & $\mu \mathrm{g} / \mathrm{L}$ & 5 & 59 & 90 & 72 & $22 \%$ \\
\hline Germanium & $\mathrm{Ge}$ & $\mu \mathrm{g} / \mathrm{L}$ & 1 & 28 & 35 & 28 & $22 \%$ \\
\hline Hafnium & $\mathrm{Hf}$ & $\mu \mathrm{g} / \mathrm{L}$ & - & - & - & - & - \\
\hline Holonium & $\mathrm{Ho}$ & $\mu \mathrm{g} / \mathrm{L}$ & 0 & 13 & 16 & 14 & $13 \%$ \\
\hline Iridium & Ir & $\mu \mathrm{g} / \mathrm{L}$ & 1 & 1 & $<0.5$ & $<0.5$ & $0 \%$ \\
\hline Iron & $\mathrm{Fe}$ & $\mu \mathrm{g} / \mathrm{L}$ & 50 & 620000 & 670000 & 660000 & $2 \%$ \\
\hline Lanthanum & La & $\mu \mathrm{g} / \mathrm{L}$ & 0 & 240 & 310 & 270 & $14 \%$ \\
\hline Lead & $\mathrm{Pb}$ & $\mu \mathrm{g} / \mathrm{L}$ & 0 & 3.3 & 3.9 & 4.1 & $5 \%$ \\
\hline Lithium & $\mathrm{Li}$ & $\mu \mathrm{g} / \mathrm{L}$ & 2 & 100 & 150 & 130 & $14 \%$ \\
\hline Lutetium & Lu & $\mu \mathrm{g} / \mathrm{L}$ & 0 & 3.3 & 4.2 & 3.5 & $18 \%$ \\
\hline Magnesium & $\mathrm{Mg}$ & $\mu \mathrm{g} / \mathrm{L}$ & 30 & 130000 & 160000 & 140000 & $13 \%$ \\
\hline Manganese & $\mathrm{Mn}$ & $\mu \mathrm{g} / \mathrm{L}$ & 0 & 40000 & 44000 & 47000 & $7 \%$ \\
\hline Molybdenum & Mo & $\mu \mathrm{g} / \mathrm{L}$ & 10 & 10 & $<10$ & $<10$ & $0 \%$ \\
\hline Neodymium & $\mathrm{Nd}$ & $\mu \mathrm{g} / \mathrm{L}$ & 0 & 300 & 400 & 350 & $13 \%$ \\
\hline Nickel & $\mathrm{Ni}$ & $\mu \mathrm{g} / \mathrm{L}$ & 1 & 850 & 1100 & 920 & $18 \%$ \\
\hline Niobium & $\mathrm{Nb}$ & $\mu \mathrm{g} / \mathrm{L}$ & 0 & 0.20 & 0.25 & 0.22 & $13 \%$ \\
\hline Palladium & $\mathrm{Pd}$ & $\mu \mathrm{g} / \mathrm{L}$ & - & - & - & - & - \\
\hline Phosphorus & $P$ & $\mu \mathrm{g} / \mathrm{L}$ & 1000 & 6600 & 6400 & 6300 & $2 \%$ \\
\hline Platinum & $\mathrm{Pt}$ & $\mu \mathrm{g} / \mathrm{L}$ & 0 & 0 & $<0.05$ & $<0.05$ & $0 \%$ \\
\hline Potassium & $\mathrm{K}$ & $\mu \mathrm{g} / \mathrm{L}$ & 200 & 1300 & 1500 & 1400 & $7 \%$ \\
\hline Praseodymium & $\operatorname{Pr}$ & $\mu \mathrm{g} / \mathrm{L}$ & 0 & 71 & 97 & 80 & $19 \%$ \\
\hline Rhenium & $\operatorname{Re}$ & $\mu \mathrm{g} / \mathrm{L}$ & 0 & 0 & $<0.2$ & $<0.2$ & $0 \%$ \\
\hline Rhodium & $\mathrm{Rh}$ & $\mu \mathrm{g} / \mathrm{L}$ & 0 & 0 & $<0.1$ & $<0.1$ & $0 \%$ \\
\hline Rubidium & $\mathrm{Rb}$ & $\mu \mathrm{g} / \mathrm{L}$ & 1 & 8.4 & 11 & 9.7 & $13 \%$ \\
\hline Ruthenium & $\mathrm{Ru}$ & $\mu \mathrm{g} / \mathrm{L}$ & 0 & 0 & $<0.1$ & $<0.1$ & $0 \%$ \\
\hline Samarium & $\mathrm{Sm}$ & $\mu \mathrm{g} / \mathrm{L}$ & 0 & 72 & 97 & 82 & $17 \%$ \\
\hline Selenium & Se & $\mu \mathrm{g} / \mathrm{L}$ & 1 & 19 & 26 & 24 & $8 \%$ \\
\hline Silver & $\mathrm{Ag}$ & $\mu \mathrm{g} / \mathrm{L}$ & 0 & 0 & $<0.1$ & $<0.1$ & $0 \%$ \\
\hline Sodium & $\mathrm{Na}$ & $\mu \mathrm{g} / \mathrm{L}$ & 200 & 28000 & 33000 & 28000 & $16 \%$ \\
\hline Strontium & $\mathrm{Sr}$ & $\mu \mathrm{g} / \mathrm{L}$ & 1 & 2000 & 2000 & 2000 & $0 \%$ \\
\hline Sulfur & $\mathrm{s}$ & $\mu \mathrm{g} / \mathrm{L}$ & 1000 & 1700000 & 1800000 & 1800000 & $0 \%$ \\
\hline Tantalum & $\mathrm{Ta}$ & $\mu \mathrm{g} / \mathrm{L}$ & 0 & 0.052 & 0.077 & 0.068 & $12 \%$ \\
\hline Terbium & $\mathrm{Tb}$ & $\mu \mathrm{g} / \mathrm{L}$ & 0 & 12 & 16 & 14 & $13 \%$ \\
\hline Tellurium & $\mathrm{Te}$ & $\mu \mathrm{g} / \mathrm{L}$ & 1 & 1.9 & 2.2 & 2.2 & $0 \%$ \\
\hline Thalium & $\mathrm{Tl}$ & $\mu \mathrm{g} / \mathrm{L}$ & 0 & 0.30 & 0.22 & $<0.1$ & $75 \%$ \\
\hline Thorium & Th & $\mu \mathrm{g} / \mathrm{L}$ & - & - & - & - & - \\
\hline Thulium & $\mathrm{Tm}$ & $\mu \mathrm{g} / \mathrm{L}$ & 0 & 4.1 & 5.3 & 4.5 & $16 \%$ \\
\hline $\operatorname{Tin} * *$ & Sn & $\mu \mathrm{g} / \mathrm{L}$ & 3 & 3.0 & $<3.0$ & $<3.0$ & $0 \%$ \\
\hline Titanium & $\mathrm{Ti}$ & $\mu \mathrm{g} / \mathrm{L}$ & 3 & 20 & 27 & 25 & $8 \%$ \\
\hline Tungsten & w & $\mu \mathrm{g} / \mathrm{L}$ & 1 & 1 & $<0.5$ & $<0.5$ & $0 \%$ \\
\hline Uranium & $\mathrm{U}$ & $\mu \mathrm{g} / \mathrm{L}$ & 0 & 21 & 28 & 24 & $15 \%$ \\
\hline Vanadium & v & $\mu \mathrm{g} / \mathrm{L}$ & 0 & 24 & 31 & 26 & $18 \%$ \\
\hline Ytterbium & $\mathrm{Yb}$ & $\mu \mathrm{g} / \mathrm{L}$ & 0 & 24 & 31 & 26 & $18 \%$ \\
\hline Yttrium & $Y$ & $\mu \mathrm{g} / \mathrm{L}$ & 1 & 370 & 480 & 400 & $18 \%$ \\
\hline Zinc & $\mathrm{Zn}$ & $\mu \mathrm{g} / \mathrm{L}$ & 10 & 14000 & 13000 & 13000 & $0 \%$ \\
\hline Zirconium & $\mathrm{Zr}$ & $\mu \mathrm{g} / \mathrm{L}$ & 0 & 1.9 & 3.3 & 2.4 & $32 \%$ \\
\hline
\end{tabular}




\begin{tabular}{|c|c|c|c|c|c|c|}
\hline & & & $\begin{array}{l}\text { Sample name } \\
\text { Sample type } \\
\text { Sample number }\end{array}$ & $\begin{array}{c}\text { LN-BP-W } \\
\text { FA } \\
\text { No11* }\end{array}$ & $\begin{array}{c}\text { LN-BP-W } \\
\text { FA } \\
\text { No12 }\end{array}$ & \%Diff 11-12 \\
\hline & Symbol & Units & Detection limit & \multicolumn{2}{|c|}{ Field Duplicate } & \\
\hline \multicolumn{7}{|l|}{ Sample description } \\
\hline \multicolumn{7}{|l|}{ Anions } \\
\hline Fluoride & $\mathrm{F}$ & $\mathrm{mg} / \mathrm{L}$ & $<0.05$ & $<0.25$ & $<0.25$ & - \\
\hline Chloride & $\mathrm{Cl}$ & $\mathrm{mg} / \mathrm{L}$ & $<0.05$ & 0.7 & 0.7 & - \\
\hline Nitrite & $\mathrm{NO}_{2-}^{-}$ & $\mathrm{mg} / \mathrm{L}$ & $<0.05$ & $<0.25$ & $<0.25$ & - \\
\hline Nitrate & $\mathrm{NO}_{3}-$ & $\mathrm{mg} / \mathrm{L}$ & $<0.05$ & 7.8 & 7.8 & - \\
\hline Sulphate & $\mathrm{SO}_{42-}$ & $\mathrm{mg} / \mathrm{L}$ & $<0.10$ & 190.0 & 190.0 & - \\
\hline $\mathrm{pH}$ & & - & & 3.0 & 3.0 & - \\
\hline \multicolumn{7}{|l|}{ Metals } \\
\hline Aluminium & Al & $\mu \mathrm{g} / \mathrm{L}$ & 5 & 6200 & 6300 & $2 \%$ \\
\hline Antimony & $\mathrm{Sb}$ & $\mu \mathrm{g} / \mathrm{L}$ & 2 & 2 & 2 & $0 \%$ \\
\hline Arsenic & As & $\mu \mathrm{g} / \mathrm{L}$ & 2 & 3.6 & 2.6 & $32 \%$ \\
\hline Barium & $\mathrm{Ba}$ & $\mu \mathrm{g} / \mathrm{L}$ & 0 & 42 & 35 & $18 \%$ \\
\hline Beryllium & $\mathrm{Be}$ & $\mu \mathrm{g} / \mathrm{L}$ & 0 & 0.26 & 0 & $26 \%$ \\
\hline Boron & B & $\mu \mathrm{g} / \mathrm{L}$ & 1000 & 1000 & 1000 & $0 \%$ \\
\hline Cadmium & $\mathrm{Cd}$ & $\mu \mathrm{g} / \mathrm{L}$ & 0 & 7.4 & 6.0 & $21 \%$ \\
\hline Calcium & $\mathrm{Ca}$ & $\mu \mathrm{g} / \mathrm{L}$ & 300 & 34000 & 28000 & $19 \%$ \\
\hline Cerium & $\mathrm{Ce}$ & $\mu \mathrm{g} / \mathrm{L}$ & 1 & 12 & 9.3 & $25 \%$ \\
\hline Cesium & Cs & $\mu \mathrm{g} / \mathrm{L}$ & - & - & - & - \\
\hline Chromium & $\mathrm{Cr}$ & $\mu \mathrm{g} / \mathrm{L}$ & 5 & 5 & 5 & $0 \%$ \\
\hline Cobalt & Co & $\mu \mathrm{g} / \mathrm{L}$ & 0 & 94 & 78 & $19 \%$ \\
\hline Copper & $\mathrm{Cu}$ & $\mu \mathrm{g} / \mathrm{L}$ & 5 & 3800 & 3800 & $0 \%$ \\
\hline Dysprosium & Dy & $\mu \mathrm{g} / \mathrm{L}$ & 0 & 1.2 & 0.93 & $25 \%$ \\
\hline Erbium & $\mathrm{Er}$ & $\mu \mathrm{g} / \mathrm{L}$ & 0 & 0.61 & 0.53 & $14 \%$ \\
\hline Europium & $\mathrm{Eu}$ & $\mu \mathrm{g} / \mathrm{L}$ & 0 & 0.51 & 0.36 & $34 \%$ \\
\hline Gadolinium & $\mathrm{Gd}$ & $\mu \mathrm{g} / \mathrm{L}$ & 0 & 1.6 & 1.3 & $21 \%$ \\
\hline Gallium & $\mathrm{Ga}$ & $\mu \mathrm{g} / \mathrm{L}$ & 5 & 5 & 5 & $0 \%$ \\
\hline Germanium & $\mathrm{Ge}$ & $\mu \mathrm{g} / \mathrm{L}$ & 1 & 1 & 1 & $0 \%$ \\
\hline Hafnium & $\mathrm{Hf}$ & $\mu \mathrm{g} / \mathrm{L}$ & - & - & - & - \\
\hline Holonium & Ho & $\mu \mathrm{g} / \mathrm{L}$ & 0 & 0.22 & 0.19 & $15 \%$ \\
\hline Iridium & Ir & $\mu \mathrm{g} / \mathrm{L}$ & 1 & 1 & 1 & $0 \%$ \\
\hline Iron & $\mathrm{Fe}$ & $\mu \mathrm{g} / \mathrm{L}$ & 50 & 16000 & 13000 & $21 \%$ \\
\hline Lanthanum & La & $\mu \mathrm{g} / \mathrm{L}$ & 0 & 5.0 & 4.1 & $20 \%$ \\
\hline Lead & $\mathrm{Pb}$ & $\mu \mathrm{g} / \mathrm{L}$ & 0 & 50 & 41 & $20 \%$ \\
\hline Lithium & $\mathrm{Li}$ & $\mu \mathrm{g} / \mathrm{L}$ & 2 & 4.3 & 3.5 & $21 \%$ \\
\hline Lutetium & Lu & $\mu \mathrm{g} / \mathrm{L}$ & 0 & 0.060 & 0.053 & $12 \%$ \\
\hline Magnesium & $\mathrm{Mg}$ & $\mu \mathrm{g} / \mathrm{L}$ & 30 & 3100 & 2500 & $21 \%$ \\
\hline Manganese & $\mathrm{Mn}$ & $\mu \mathrm{g} / \mathrm{L}$ & 0 & 1000 & 930 & $7 \%$ \\
\hline Molybdenum & Mo & $\mu \mathrm{g} / \mathrm{L}$ & 10 & 10 & 10 & $0 \%$ \\
\hline Neodymium & $\mathrm{Nd}$ & $\mu \mathrm{g} / \mathrm{L}$ & 0 & 7.0 & 5.6 & $22 \%$ \\
\hline Nickel & $\mathrm{Ni}$ & $\mu \mathrm{g} / \mathrm{L}$ & 1 & 86 & 71 & $19 \%$ \\
\hline Niobium & $\mathrm{Nb}$ & $\mu \mathrm{g} / \mathrm{L}$ & 0 & 0 & 0 & $0 \%$ \\
\hline Palladium & $\mathrm{Pd}$ & $\mu \mathrm{g} / \mathrm{L}$ & - & - & - & - \\
\hline Phosphorus & $\mathrm{P}$ & $\mu \mathrm{g} / \mathrm{L}$ & 1000 & 1000 & 1000 & $0 \%$ \\
\hline Platinum & Pt & $\mu \mathrm{g} / \mathrm{L}$ & 0 & 0 & 0 & $0 \%$ \\
\hline Potassium & K & $\mu \mathrm{g} / \mathrm{L}$ & 200 & 1900 & 1500 & $24 \%$ \\
\hline Praseodymium & $\operatorname{Pr}$ & $\mu \mathrm{g} / \mathrm{L}$ & 0 & 1.6 & 1.3 & $21 \%$ \\
\hline Rhenium & $\operatorname{Re}$ & $\mu \mathrm{g} / \mathrm{L}$ & 0 & 0 & 0 & $0 \%$ \\
\hline Rhodium & $\mathrm{Rh}$ & $\mu \mathrm{g} / \mathrm{L}$ & 0 & 0 & 0 & $0 \%$ \\
\hline Rubidium & $\mathrm{Rb}$ & $\mu \mathrm{g} / \mathrm{L}$ & 1 & 4.8 & 4.0 & $18 \%$ \\
\hline Ruthenium & $\mathrm{Ru}$ & $\mu \mathrm{g} / \mathrm{L}$ & 0 & 0 & 0 & $0 \%$ \\
\hline Samarium & $\mathrm{Sm}$ & $\mu \mathrm{g} / \mathrm{L}$ & 0 & 1.4 & 1.2 & $15 \%$ \\
\hline Selenium & $\mathrm{Se}$ & $\mu \mathrm{g} / \mathrm{L}$ & 1 & 26 & 21 & $21 \%$ \\
\hline Silver & $\mathrm{Ag}$ & $\mu \mathrm{g} / \mathrm{L}$ & 0 & 2.0 & 1.5 & $29 \%$ \\
\hline Sodium & $\mathrm{Na}$ & $\mu \mathrm{g} / \mathrm{L}$ & 200 & 18000 & 14000 & $25 \%$ \\
\hline Strontium & $\mathrm{Sr}$ & $\mu \mathrm{g} / \mathrm{L}$ & 1 & 110 & 90 & $20 \%$ \\
\hline Sulfur & $\mathrm{s}$ & $\mu \mathrm{g} / \mathrm{L}$ & 1000 & 4600000 & 4100000 & $11 \%$ \\
\hline Tantalum & $\mathrm{Ta}$ & $\mu \mathrm{g} / \mathrm{L}$ & 0 & 0 & 0 & $0 \%$ \\
\hline Terbium & $\mathrm{Tb}$ & $\mu \mathrm{g} / \mathrm{L}$ & 0 & 0.22 & 0.17 & $26 \%$ \\
\hline Tellurium & $\mathrm{Te}$ & $\mu \mathrm{g} / \mathrm{L}$ & 1 & 1 & 1 & $0 \%$ \\
\hline Thalium & $\mathrm{TI}$ & $\mu \mathrm{g} / \mathrm{L}$ & 0 & 2.2 & 1.9 & $15 \%$ \\
\hline Thorium & Th & $\mu \mathrm{g} / \mathrm{L}$ & - & - & - & - \\
\hline Thulium & $\mathrm{Tm}$ & $\mu \mathrm{g} / \mathrm{L}$ & 0 & 0.079 & 0.057 & $32 \%$ \\
\hline $\operatorname{Tin} * *$ & Sn & $\mu \mathrm{g} / \mathrm{L}$ & 3 & 3.0 & 3.0 & $0 \%$ \\
\hline Titanium & $\mathrm{Ti}$ & $\mu \mathrm{g} / \mathrm{L}$ & 3 & 3 & 3 & $0 \%$ \\
\hline Tungsten & w & $\mu \mathrm{g} / \mathrm{L}$ & 1 & 1 & 1 & $0 \%$ \\
\hline Uranium & U & $\mu \mathrm{g} / \mathrm{L}$ & 0 & 0.41 & 0.34 & $19 \%$ \\
\hline Vanadium & v & $\mu \mathrm{g} / \mathrm{L}$ & 0 & 0 & 0 & $0 \%$ \\
\hline Ytterbium & $\mathrm{Yb}$ & $\mu \mathrm{g} / \mathrm{L}$ & 0 & 0.42 & 0.35 & $18 \%$ \\
\hline Yttrium & Y & $\mu \mathrm{g} / \mathrm{L}$ & 1 & 7.0 & 6.2 & $12 \%$ \\
\hline Zinc & $\mathrm{Zn}$ & $\mu \mathrm{g} / \mathrm{L}$ & 10 & 120 & 94 & $24 \%$ \\
\hline Zirconium & $\mathrm{Zr}$ & $\mu \mathrm{g} / \mathrm{L}$ & 0 & 0.16 & 0 & $46 \%$ \\
\hline
\end{tabular}




\begin{tabular}{|c|c|c|c|c|c|c|c|}
\hline & & & $\begin{array}{l}\text { Sample name } \\
\text { Sample type } \\
\text { Sample number }\end{array}$ & $\begin{array}{c}\text { LN-BP-W } \\
\text { FFA } \\
\text { No25 }\end{array}$ & $\begin{array}{c}\text { LN-BP-W } \\
\text { UA } \\
\text { No37 }\end{array}$ & $\begin{array}{c}\text { LN-BP-W } \\
\text { UA } \\
\text { No38 }\end{array}$ & \%Diff 37-38 \\
\hline & Symbol & Units & Detection limit & \multirow{2}{*}{\multicolumn{4}{|c|}{ Field Duplicate }} \\
\hline \multicolumn{4}{|l|}{ Sample description } & & & & \\
\hline \multicolumn{8}{|l|}{ Anions } \\
\hline Fluoride & $\mathrm{F}$ & $\mathrm{mg} / \mathrm{L}$ & $<0.05$ & $<0.25$ & $<0.25$ & $<0.25$ & - \\
\hline Chloride & $\mathrm{Cl}$ & $\mathrm{mg} / \mathrm{L}$ & $<0.05$ & 0.7 & 0.7 & 0.7 & - \\
\hline Nitrite & $\mathrm{NO}_{2-}$ & $\mathrm{mg} / \mathrm{L}$ & $<0.05$ & $<0.25$ & $<0.25$ & $<0.25$ & - \\
\hline Nitrate & $\mathrm{NO}_{3}-$ & $\mathrm{mg} / \mathrm{L}$ & $<0.05$ & 7.8 & 7.8 & 7.8 & - \\
\hline Sulphate & $\mathrm{SO}_{42-}$ & $\mathrm{mg} / \mathrm{L}$ & $<0.10$ & 190.0 & 190.0 & 190.0 & - \\
\hline $\mathrm{pH}$ & & - & & 3.0 & 3.0 & 3.0 & - \\
\hline \multicolumn{8}{|l|}{ Metals } \\
\hline Aluminium & Al & $\mu g / L$ & 5 & 5800 & 6200 & 6100 & $2 \%$ \\
\hline Antimony & $\mathrm{Sb}$ & $\mu \mathrm{g} / \mathrm{L}$ & 2 & 2 & $<2.0$ & $<2.0$ & $0 \%$ \\
\hline Arsenic & As & $\mu \mathrm{g} / \mathrm{L}$ & 2 & 5.9 & 3.1 & 2.2 & $34 \%$ \\
\hline Barium & $\mathrm{Ba}$ & $\mu \mathrm{g} / \mathrm{L}$ & 0 & 35 & 37 & 36 & $3 \%$ \\
\hline Beryllium & $\mathrm{Be}$ & $\mu \mathrm{g} / \mathrm{L}$ & 0 & 0 & $<0.2$ & $<0.2$ & $0 \%$ \\
\hline Boron & B & $\mu \mathrm{g} / \mathrm{L}$ & 1000 & 1000 & $<1000$ & $<1000$ & $0 \%$ \\
\hline Cadmium & $\mathrm{Cd}$ & $\mu \mathrm{g} / \mathrm{L}$ & 0 & 5.8 & 6.7 & 6.5 & $3 \%$ \\
\hline Calcium & $\mathrm{Ca}$ & $\mu \mathrm{g} / \mathrm{L}$ & 300 & 27000 & 26000 & 25000 & $4 \%$ \\
\hline Cerium & $\mathrm{Ce}$ & $\mu \mathrm{g} / \mathrm{L}$ & 1 & 9.1 & 11 & 11 & $0 \%$ \\
\hline Cesium & Cs & $\mu \mathrm{g} / \mathrm{L}$ & - & - & - & - & - \\
\hline Chromium & $\mathrm{Cr}$ & $\mu \mathrm{g} / \mathrm{L}$ & 5 & 5 & $<5.0$ & $<5.0$ & $0 \%$ \\
\hline Cobalt & Co & $\mu \mathrm{g} / \mathrm{L}$ & 0 & 77 & 76 & 75 & $1 \%$ \\
\hline Copper & $\mathrm{Cu}$ & $\mu \mathrm{g} / \mathrm{L}$ & 5 & 3600 & 4200 & 4000 & $5 \%$ \\
\hline Dysprosium & Dy & $\mu \mathrm{g} / \mathrm{L}$ & 0 & 0.87 & 1.0 & 1.0 & $0 \%$ \\
\hline Erbium & $\mathrm{Er}$ & $\mu \mathrm{g} / \mathrm{L}$ & 0 & 0.45 & 0.59 & 0.57 & $3 \%$ \\
\hline Europium & $\mathrm{Eu}$ & $\mu \mathrm{g} / \mathrm{L}$ & 0 & 0.40 & 0.45 & 0.40 & $12 \%$ \\
\hline Gadolinium & $\mathrm{Gd}$ & $\mu \mathrm{g} / \mathrm{L}$ & 0 & 1.2 & 1.5 & 1.4 & $7 \%$ \\
\hline Gallium & $\mathrm{Ga}$ & $\mu \mathrm{g} / \mathrm{L}$ & 5 & 5 & $<5.0$ & $<5.0$ & $0 \%$ \\
\hline Germanium & $\mathrm{Ge}$ & $\mu \mathrm{g} / \mathrm{L}$ & 1 & 1 & $<1.0$ & $<1.0$ & $0 \%$ \\
\hline Hafnium & $\mathrm{Hf}$ & $\mu \mathrm{g} / \mathrm{L}$ & - & - & - & - & - \\
\hline Holonium & Ho & $\mu \mathrm{g} / \mathrm{L}$ & 0 & 0.18 & 0.21 & 0.20 & $5 \%$ \\
\hline Iridium & Ir & $\mu \mathrm{g} / \mathrm{L}$ & 1 & 1 & $<0.5$ & $<0.5$ & $0 \%$ \\
\hline Iron & $\mathrm{Fe}$ & $\mu \mathrm{g} / \mathrm{L}$ & 50 & 13000 & 13000 & 12000 & $8 \%$ \\
\hline Lanthanum & La & $\mu \mathrm{g} / \mathrm{L}$ & 0 & 4.0 & 4.7 & 4.5 & $4 \%$ \\
\hline Lead & $\mathrm{Pb}$ & $\mu \mathrm{g} / \mathrm{L}$ & 0 & 40 & 49 & 49 & $0 \%$ \\
\hline Lithium & $\mathrm{Li}$ & $\mu \mathrm{g} / \mathrm{L}$ & 2 & 3.4 & 3.9 & 3.8 & $3 \%$ \\
\hline Lutetium & Lu & $\mu \mathrm{g} / \mathrm{L}$ & 0 & 0 & 0.064 & 0.054 & $17 \%$ \\
\hline Magnesium & $\mathrm{Mg}$ & $\mu \mathrm{g} / \mathrm{L}$ & 30 & 2500 & 2500 & 2300 & $8 \%$ \\
\hline Manganese & $\mathrm{Mn}$ & $\mu \mathrm{g} / \mathrm{L}$ & 0 & 910 & 980 & 930 & $5 \%$ \\
\hline Molybdenum & Mo & $\mu \mathrm{g} / \mathrm{L}$ & 10 & 10 & $<10$ & $<10$ & $0 \%$ \\
\hline Neodymium & $\mathrm{Nd}$ & $\mu \mathrm{g} / \mathrm{L}$ & 0 & 5.4 & 6.6 & 6.4 & $3 \%$ \\
\hline Nickel & $\mathrm{Ni}$ & $\mu \mathrm{g} / \mathrm{L}$ & 1 & 69 & 69 & 67 & $3 \%$ \\
\hline Niobium & $\mathrm{Nb}$ & $\mu \mathrm{g} / \mathrm{L}$ & 0 & 0 & $<0.05$ & $<0.05$ & $0 \%$ \\
\hline Palladium & $\mathrm{Pd}$ & $\mu \mathrm{g} / \mathrm{L}$ & - & - & - & - & - \\
\hline Phosphorus & $P$ & $\mu \mathrm{g} / \mathrm{L}$ & 1000 & 1000 & $<1000$ & $<1000$ & $0 \%$ \\
\hline Platinum & $\mathrm{Pt}$ & $\mu \mathrm{g} / \mathrm{L}$ & 0 & 0 & $<0.05$ & $<0.05$ & $0 \%$ \\
\hline Potassium & $\mathrm{K}$ & $\mu \mathrm{g} / \mathrm{L}$ & 200 & 1600 & 1400 & 1300 & $7 \%$ \\
\hline Praseodymium & $\mathrm{Pr}$ & $\mu \mathrm{g} / \mathrm{L}$ & 0 & 1.3 & 1.5 & 1.5 & $0 \%$ \\
\hline Rhenium & $\mathrm{Re}$ & $\mu \mathrm{g} / \mathrm{L}$ & 0 & 0 & $<0.2$ & $<0.2$ & $0 \%$ \\
\hline Rhodium & $\mathrm{Rh}$ & $\mu \mathrm{g} / \mathrm{L}$ & 0 & 0 & $<0.1$ & $<0.1$ & $0 \%$ \\
\hline Rubidium & $\mathrm{Rb}$ & $\mu \mathrm{g} / \mathrm{L}$ & 1 & 3.8 & 4.4 & 4.4 & $0 \%$ \\
\hline Ruthenium & $\mathrm{Ru}$ & $\mu \mathrm{g} / \mathrm{L}$ & 0 & 0 & $<0.1$ & $<0.1$ & $0 \%$ \\
\hline Samarium & $\mathrm{Sm}$ & $\mu \mathrm{g} / \mathrm{L}$ & 0 & 1.1 & 1.3 & 1.3 & $0 \%$ \\
\hline Selenium & $\mathrm{Se}$ & $\mu \mathrm{g} / \mathrm{L}$ & 1 & 20 & 26 & 25 & $4 \%$ \\
\hline Silver & $\mathrm{Ag}$ & $\mu \mathrm{g} / \mathrm{L}$ & 0 & 1.5 & 2.1 & 1.9 & $10 \%$ \\
\hline Sodium & $\mathrm{Na}$ & $\mu \mathrm{g} / \mathrm{L}$ & 200 & 14000 & 14000 & 13000 & $7 \%$ \\
\hline Strontium & $\mathrm{Sr}$ & $\mu \mathrm{g} / \mathrm{L}$ & 1 & 86 & 93 & 89 & $4 \%$ \\
\hline Sulfur & $\mathrm{s}$ & $\mu \mathrm{g} / \mathrm{L}$ & 1000 & 4200000 & 6300000 & 5600000 & $12 \%$ \\
\hline Tantalum & $\mathrm{Ta}$ & $\mu \mathrm{g} / \mathrm{L}$ & 0 & 0 & $<0.05$ & $<0.05$ & $0 \%$ \\
\hline Terbium & $\mathrm{Tb}$ & $\mu \mathrm{g} / \mathrm{L}$ & 0 & 0.17 & 0.21 & 0.22 & $5 \%$ \\
\hline Tellurium & $\mathrm{Te}$ & $\mu \mathrm{g} / \mathrm{L}$ & 1 & 1 & $<0.5$ & $<0.5$ & $0 \%$ \\
\hline Thalium & $\mathrm{Tl}$ & $\mu \mathrm{g} / \mathrm{L}$ & 0 & 1.8 & 1.9 & 1.9 & $0 \%$ \\
\hline Thorium & Th & $\mu \mathrm{g} / \mathrm{L}$ & - & - & - & - & - \\
\hline Thulium & $\mathrm{Tm}$ & $\mu \mathrm{g} / \mathrm{L}$ & 0 & 0.056 & 0.076 & 0.076 & $0 \%$ \\
\hline $\operatorname{Tin} * *$ & Sn & $\mu \mathrm{g} / \mathrm{L}$ & 3 & 3.0 & $<3.0$ & $<3.0$ & $0 \%$ \\
\hline Titanium & $\mathrm{Ti}$ & $\mu \mathrm{g} / \mathrm{L}$ & 3 & 3 & $<3.0$ & $<3.0$ & $0 \%$ \\
\hline Tungsten & w & $\mu \mathrm{g} / \mathrm{L}$ & 1 & 1 & $<0.5$ & $<0.5$ & $0 \%$ \\
\hline Uranium & $u$ & $\mu \mathrm{g} / \mathrm{L}$ & 0 & 0.37 & 0.39 & 0.37 & $5 \%$ \\
\hline Vanadium & $\mathrm{v}$ & $\mu \mathrm{g} / \mathrm{L}$ & 0 & 0 & $<0.3$ & $<0.3$ & $0 \%$ \\
\hline Ytterbium & $\mathrm{Yb}$ & $\mu \mathrm{g} / \mathrm{L}$ & 0 & 0.34 & 0.51 & 0.40 & $24 \%$ \\
\hline Yttrium & $\mathrm{Y}$ & $\mu \mathrm{g} / \mathrm{L}$ & 1 & 5.7 & 6.3 & 5.8 & $8 \%$ \\
\hline Zinc & $\mathrm{Zn}$ & $\mu \mathrm{g} / \mathrm{L}$ & 10 & 96 & 91 & 83 & $9 \%$ \\
\hline Zirconium & $\mathrm{Zr}$ & $\mu \mathrm{g} / \mathrm{L}$ & 0 & 0.24 & 0.23 & 0.15 & $42 \%$ \\
\hline
\end{tabular}




\begin{tabular}{|c|c|c|c|c|c|c|c|c|c|}
\hline & Symbol & Units & $\begin{array}{l}\text { Sample name } \\
\text { Sample type } \\
\text { Sample number } \\
\text { Detection limit }\end{array}$ & $\begin{array}{c}\text { LN-PW2-W } \\
\text { FA } \\
\text { No13 }\end{array}$ & $\begin{array}{c}\text { LN-PW2-W } \\
\text { FA } \\
\text { No14 } \\
\text { Field Triplicate } \\
\end{array}$ & $\begin{array}{c}\text { LN-PW2-W } \\
\text { FA } \\
\text { No15 }\end{array}$ & \%Diff 13-14 & \%Diff 14-15 & $\%$ Diff 13-15 \\
\hline \multicolumn{10}{|l|}{ Sample description } \\
\hline \multicolumn{10}{|l|}{ Anions } \\
\hline Fluoride & $\mathrm{F}$ & $\mathrm{mg} / \mathrm{L}$ & $<0.05$ & $<2.0$ & $<2.0$ & $<2.0$ & - & - & - \\
\hline Chloride & $\mathrm{Cl}$ & $\mathrm{mg} / \mathrm{L}$ & $<0.05$ & 6.4 & 6.4 & 6.4 & - & - & - \\
\hline Nitrite & $\mathrm{NO}_{2-}^{-}$ & $\mathrm{mg} / \mathrm{L}$ & $<0.05$ & $<2.0$ & $<2.0$ & $<2.0$ & - & - & - \\
\hline Nitrate & $\mathrm{NO}_{3}-$ & $\mathrm{mg} / \mathrm{L}$ & $<0.05$ & $<2.0$ & $<2.0$ & $<2.0$ & - & - & - \\
\hline Sulphate & $\mathrm{SO}_{42-}$ & $\mathrm{mg} / \mathrm{L}$ & $<0.10$ & 310.0 & 310.0 & 310.0 & - & - & - \\
\hline $\mathrm{pH}$ & & - & & 6.2 & 6.2 & 6.2 & - & - & - \\
\hline \multicolumn{10}{|l|}{ Metals } \\
\hline Aluminium & Al & $\mu \mathrm{g} / \mathrm{L}$ & 5 & 59 & 59 & 63 & $0 \%$ & $7 \%$ & $7 \%$ \\
\hline Antimony & $\mathrm{Sb}$ & $\mu \mathrm{g} / \mathrm{L}$ & 2 & 5.7 & 6.2 & 6.9 & $8 \%$ & $11 \%$ & $19 \%$ \\
\hline Arsenic & As & $\mu \mathrm{g} / \mathrm{L}$ & 2 & 8.9 & 9.4 & 9.0 & $5 \%$ & $4 \%$ & $1 \%$ \\
\hline Barium & $\mathrm{Ba}$ & $\mu \mathrm{g} / \mathrm{L}$ & 0 & 25 & 25 & 27 & $0 \%$ & $8 \%$ & $8 \%$ \\
\hline Beryllium & $\mathrm{Be}$ & $\mu \mathrm{g} / \mathrm{L}$ & 0 & 0 & 0 & 0 & $0 \%$ & $0 \%$ & $0 \%$ \\
\hline Boron & B & $\mu \mathrm{g} / \mathrm{L}$ & 1000 & 1000 & 1000 & 1000 & $0 \%$ & $0 \%$ & $0 \%$ \\
\hline Cadmium & $\mathrm{Cd}$ & $\mu \mathrm{g} / \mathrm{L}$ & 0 & 0.17 & 0.12 & 0.18 & $34 \%$ & $40 \%$ & $6 \%$ \\
\hline Calcium & $\mathrm{Ca}$ & $\mu \mathrm{g} / \mathrm{L}$ & 300 & 150000 & 150000 & 160000 & $0 \%$ & $6 \%$ & $6 \%$ \\
\hline Cerium & $\mathrm{Ce}$ & $\mu \mathrm{g} / \mathrm{L}$ & 1 & 1 & 1 & 1 & $0 \%$ & $0 \%$ & $0 \%$ \\
\hline Cesium & Cs & $\mu \mathrm{g} / \mathrm{L}$ & - & - & - & - & - & - & - \\
\hline Chromium & $\mathrm{Cr}$ & $\mu \mathrm{g} / \mathrm{L}$ & 5 & 5 & 5 & 5 & $0 \%$ & $0 \%$ & $0 \%$ \\
\hline Cobalt & Co & $\mu \mathrm{g} / \mathrm{L}$ & 0 & 0.41 & 0.53 & 0.51 & $26 \%$ & $4 \%$ & $22 \%$ \\
\hline Copper & $\mathrm{Cu}$ & $\mu \mathrm{g} / \mathrm{L}$ & 5 & 10 & 7.5 & 6.9 & $29 \%$ & $8 \%$ & $37 \%$ \\
\hline Dysprosium & Dy & $\mu \mathrm{g} / \mathrm{L}$ & 0 & 0 & 0 & 0 & $0 \%$ & $0 \%$ & $0 \%$ \\
\hline Erbium & $\mathrm{Er}$ & $\mu \mathrm{g} / \mathrm{L}$ & 0 & 0 & 0 & 0 & $0 \%$ & $0 \%$ & $0 \%$ \\
\hline Europium & $\mathrm{Eu}$ & $\mu \mathrm{g} / \mathrm{L}$ & 0 & 0 & 0 & 0 & $0 \%$ & $0 \%$ & $0 \%$ \\
\hline Gadolinium & $\mathrm{Gd}$ & $\mu \mathrm{g} / \mathrm{L}$ & 0 & 0 & 0 & 0 & $0 \%$ & $0 \%$ & $0 \%$ \\
\hline Gallium & $\mathrm{Ga}$ & $\mu \mathrm{g} / \mathrm{L}$ & 5 & 5 & 5 & 5 & $0 \%$ & $0 \%$ & $0 \%$ \\
\hline Germanium & $\mathrm{Ge}$ & $\mu \mathrm{g} / \mathrm{L}$ & 1 & 1 & 1 & 1 & $0 \%$ & $0 \%$ & $0 \%$ \\
\hline Hafnium & $\mathrm{Hf}$ & $\mu \mathrm{g} / \mathrm{L}$ & - & - & - & - & - & - & - \\
\hline Holonium & Ho & $\mu \mathrm{g} / \mathrm{L}$ & 0 & 0 & 0 & 0 & $0 \%$ & $0 \%$ & $0 \%$ \\
\hline Iridium & Ir & $\mu \mathrm{g} / \mathrm{L}$ & 1 & 1 & 1 & 1 & $0 \%$ & $0 \%$ & $0 \%$ \\
\hline Iron & $\mathrm{Fe}$ & $\mu \mathrm{g} / \mathrm{L}$ & 50 & 50 & 50 & 50 & $0 \%$ & $0 \%$ & $0 \%$ \\
\hline Lanthanum & La & $\mu \mathrm{g} / \mathrm{L}$ & 0 & 0 & 0 & 0 & $0 \%$ & $0 \%$ & $0 \%$ \\
\hline Lead & $\mathrm{Pb}$ & $\mu \mathrm{g} / \mathrm{L}$ & 0 & 0.24 & 0.25 & 0.21 & $4 \%$ & $17 \%$ & $13 \%$ \\
\hline Lithium & $\mathrm{Li}$ & $\mu \mathrm{g} / \mathrm{L}$ & 2 & 10 & 11 & 11 & $10 \%$ & $0 \%$ & $10 \%$ \\
\hline Lutetium & $\mathrm{Lu}$ & $\mu \mathrm{g} / \mathrm{L}$ & 0 & 0 & 0 & 0 & $0 \%$ & $0 \%$ & $0 \%$ \\
\hline Magnesium & $\mathrm{Mg}$ & $\mu \mathrm{g} / \mathrm{L}$ & 30 & 3800 & 3800 & 4100 & $0 \%$ & $8 \%$ & $8 \%$ \\
\hline Manganese & $\mathrm{Mn}$ & $\mu \mathrm{g} / \mathrm{L}$ & 0 & 6.0 & 5.2 & 6.5 & $14 \%$ & $22 \%$ & $8 \%$ \\
\hline Molybdenum & Mo & $\mu \mathrm{g} / \mathrm{L}$ & 10 & 36 & 35 & 37 & $3 \%$ & $6 \%$ & $3 \%$ \\
\hline Neodymium & $\mathrm{Nd}$ & $\mu \mathrm{g} / \mathrm{L}$ & 0 & 0 & 0 & 0 & $0 \%$ & $0 \%$ & $0 \%$ \\
\hline Nickel & $\mathrm{Ni}$ & $\mu \mathrm{g} / \mathrm{L}$ & 1 & 1.8 & 1 & 1 & $57 \%$ & $0 \%$ & $57 \%$ \\
\hline Niobium & $\mathrm{Nb}$ & $\mu \mathrm{g} / \mathrm{L}$ & 0 & 0 & 0 & 0 & $0 \%$ & $0 \%$ & $0 \%$ \\
\hline Palladium & $\mathrm{Pd}$ & $\mu \mathrm{g} / \mathrm{L}$ & - & - & - & - & - & - & - \\
\hline Phosphorus & $P$ & $\mu \mathrm{g} / \mathrm{L}$ & 1000 & 1000 & 1000 & 1000 & $0 \%$ & $0 \%$ & $0 \%$ \\
\hline Platinum & $\mathrm{Pt}$ & $\mu \mathrm{g} / \mathrm{L}$ & 0 & 0 & 0 & 0 & $0 \%$ & $0 \%$ & $0 \%$ \\
\hline Potassium & $\mathrm{K}$ & $\mu \mathrm{g} / \mathrm{L}$ & 200 & 360 & 330 & 440 & $9 \%$ & $29 \%$ & $20 \%$ \\
\hline Praseodymium & $\mathrm{Pr}$ & $\mu \mathrm{g} / \mathrm{L}$ & 0 & 0 & 0 & 0 & $0 \%$ & $0 \%$ & $0 \%$ \\
\hline Rhenium & $\mathrm{Re}$ & $\mu \mathrm{g} / \mathrm{L}$ & 0 & 0 & 0 & 0 & $0 \%$ & $0 \%$ & $0 \%$ \\
\hline Rhodium & $\mathrm{Rh}$ & $\mu \mathrm{g} / \mathrm{L}$ & 0 & 0 & 0 & 0 & $0 \%$ & $0 \%$ & $0 \%$ \\
\hline Rubidium & $\mathrm{Rb}$ & $\mu \mathrm{g} / \mathrm{L}$ & 1 & 1 & 1 & 1 & $0 \%$ & $0 \%$ & $0 \%$ \\
\hline Ruthenium & $\mathrm{Ru}$ & $\mu \mathrm{g} / \mathrm{L}$ & 0 & 0 & 0 & 0 & $0 \%$ & $0 \%$ & $0 \%$ \\
\hline Samarium & $\mathrm{Sm}$ & $\mu \mathrm{g} / \mathrm{L}$ & 0 & 0 & 0 & 0 & $0 \%$ & $0 \%$ & $0 \%$ \\
\hline Selenium & $\mathrm{Se}$ & $\mu \mathrm{g} / \mathrm{L}$ & 1 & 4.7 & 4.3 & 5.3 & $9 \%$ & $21 \%$ & $12 \%$ \\
\hline Silver & $\mathrm{Ag}$ & $\mu \mathrm{g} / \mathrm{L}$ & 0 & 0.99 & 0.85 & 0.96 & $15 \%$ & $12 \%$ & $3 \%$ \\
\hline Sodium & $\mathrm{Na}$ & $\mu \mathrm{g} / \mathrm{L}$ & 200 & 27000 & 27000 & 29000 & $0 \%$ & $7 \%$ & $7 \%$ \\
\hline Strontium & $\mathrm{Sr}$ & $\mu \mathrm{g} / \mathrm{L}$ & 1 & 1000 & 1000 & 1100 & $0 \%$ & $10 \%$ & $10 \%$ \\
\hline Sulfur & $\mathrm{s}$ & $\mu \mathrm{g} / \mathrm{L}$ & 1000 & 4000000 & 4700000 & 4600000 & $16 \%$ & $2 \%$ & $14 \%$ \\
\hline Tantalum & Ta & $\mu \mathrm{g} / \mathrm{L}$ & 0 & 0 & 0 & 0 & $0 \%$ & $0 \%$ & $0 \%$ \\
\hline Terbium & $\mathrm{Tb}$ & $\mu \mathrm{g} / \mathrm{L}$ & 0 & 0 & 0 & 0 & $0 \%$ & $0 \%$ & $0 \%$ \\
\hline Tellurium & $\mathrm{Te}$ & $\mu \mathrm{g} / \mathrm{L}$ & 1 & 1 & 1 & 1 & $0 \%$ & $0 \%$ & $0 \%$ \\
\hline Thalium & $\mathrm{TI}$ & $\mu \mathrm{g} / \mathrm{L}$ & 0 & 0 & 0 & 0 & $0 \%$ & $0 \%$ & $0 \%$ \\
\hline Thorium & Th & $\mu \mathrm{g} / \mathrm{L}$ & - & - & - & - & - & - & - \\
\hline Thulium & $\mathrm{Tm}$ & $\mu \mathrm{g} / \mathrm{L}$ & 0 & 0 & 0 & 0 & $0 \%$ & $0 \%$ & $0 \%$ \\
\hline $\operatorname{Tin} * *$ & Sn & $\mu \mathrm{g} / \mathrm{L}$ & 3 & 3.0 & 3.0 & 3.0 & $0 \%$ & $0 \%$ & $0 \%$ \\
\hline Titanium & $\mathrm{Ti}$ & $\mu \mathrm{g} / \mathrm{L}$ & 3 & 3 & 3 & 3 & $0 \%$ & $0 \%$ & $0 \%$ \\
\hline Tungsten & w & $\mu \mathrm{g} / \mathrm{L}$ & 1 & 1 & 1 & 1 & $0 \%$ & $0 \%$ & $0 \%$ \\
\hline Uranium & $U$ & $\mu \mathrm{g} / \mathrm{L}$ & 0 & 1.2 & 1.1 & 1.2 & $9 \%$ & $9 \%$ & $0 \%$ \\
\hline Vanadium & $\mathrm{v}$ & $\mu \mathrm{g} / \mathrm{L}$ & 0 & 0.66 & 0.66 & 0.70 & $0 \%$ & $6 \%$ & $6 \%$ \\
\hline Ytterbium & $\mathrm{Yb}$ & $\mu \mathrm{g} / \mathrm{L}$ & 0 & 0 & 0 & 0 & $0 \%$ & $0 \%$ & $0 \%$ \\
\hline Yttrium & $Y$ & $\mu \mathrm{g} / \mathrm{L}$ & 1 & 1 & 1 & 1 & $0 \%$ & $0 \%$ & $0 \%$ \\
\hline Zinc & $\mathrm{Zn}$ & $\mu \mathrm{g} / \mathrm{L}$ & 10 & 10 & 10 & 10 & $0 \%$ & $0 \%$ & $0 \%$ \\
\hline Zirconium & $\mathrm{Zr}$ & $\mu \mathrm{g} / \mathrm{L}$ & 0 & 0.11 & 0.19 & 0.13 & $53 \%$ & $38 \%$ & $17 \%$ \\
\hline
\end{tabular}




\begin{tabular}{|c|c|c|c|c|c|c|c|}
\hline & & & $\begin{array}{l}\text { Sample name } \\
\text { Sample type } \\
\text { Sample number }\end{array}$ & $\begin{array}{l}\text { LN-PW2-W } \\
\text { FFA } \\
\text { No22 }\end{array}$ & $\begin{array}{c}\text { LN-PW2-W } \\
\text { UA } \\
\text { No39 }\end{array}$ & $\begin{array}{c}\text { LN-PW2-W } \\
\text { UA } \\
\text { No40 }\end{array}$ & \%Diff 39-40 \\
\hline & Symbol & Units & Detection limit & \multirow{2}{*}{\multicolumn{4}{|c|}{ Field Duplicate }} \\
\hline \multicolumn{4}{|l|}{ Sample description } & & & & \\
\hline \multicolumn{8}{|l|}{ Anions } \\
\hline Fluoride & $\mathrm{F}$ & $\mathrm{mg} / \mathrm{L}$ & $<0.05$ & $<2.0$ & $<2.0$ & $<2.0$ & - \\
\hline Chloride & $\mathrm{Cl}$ & $\mathrm{mg} / \mathrm{L}$ & $<0.05$ & 6.4 & 6.4 & 6.4 & - \\
\hline Nitrite & $\mathrm{NO}_{2-}$ & $\mathrm{mg} / \mathrm{L}$ & $<0.05$ & $<2.0$ & $<2.0$ & $<2.0$ & - \\
\hline Nitrate & $\mathrm{NO}_{3}-$ & $\mathrm{mg} / \mathrm{L}$ & $<0.05$ & $<2.0$ & $<2.0$ & $<2.0$ & - \\
\hline Sulphate & $\mathrm{SO}_{42-}$ & $\mathrm{mg} / \mathrm{L}$ & $<0.10$ & 310.0 & 310.0 & 310.0 & - \\
\hline $\mathrm{pH}$ & & - & & 6.2 & 6.2 & 6.2 & - \\
\hline \multicolumn{8}{|l|}{ Metals } \\
\hline Aluminium & $\mathrm{Al}$ & $\mu \mathrm{g} / \mathrm{L}$ & 5 & 60 & 130 & 120 & $8 \%$ \\
\hline Antimony & $\mathrm{Sb}$ & $\mu \mathrm{g} / \mathrm{L}$ & 2 & 5.7 & 7.2 & 6.2 & $15 \%$ \\
\hline Arsenic & As & $\mu \mathrm{g} / \mathrm{L}$ & 2 & 12 & 13 & 10 & $26 \%$ \\
\hline Barium & $\mathrm{Ba}$ & $\mu \mathrm{g} / \mathrm{L}$ & 0 & 23 & 32 & 29 & $10 \%$ \\
\hline Beryllium & $\mathrm{Be}$ & $\mu \mathrm{g} / \mathrm{L}$ & 0 & 0 & $<0.2$ & $<0.2$ & $0 \%$ \\
\hline Boron & B & $\mu \mathrm{g} / \mathrm{L}$ & 1000 & 1000 & $<1000$ & $<1000$ & $0 \%$ \\
\hline Cadmium & $\mathrm{Cd}$ & $\mu \mathrm{g} / \mathrm{L}$ & 0 & 0.12 & 0.16 & 0.19 & $17 \%$ \\
\hline Calcium & $\mathrm{Ca}$ & $\mu \mathrm{g} / \mathrm{L}$ & 300 & 140000 & 170000 & 150000 & $13 \%$ \\
\hline Cerium & $\mathrm{Ce}$ & $\mu \mathrm{g} / \mathrm{L}$ & 1 & 1 & $<0.5$ & $<0.5$ & $0 \%$ \\
\hline Cesium & Cs & $\mu \mathrm{g} / \mathrm{L}$ & - & - & - & - & - \\
\hline Chromium & $\mathrm{Cr}$ & $\mu \mathrm{g} / \mathrm{L}$ & 5 & 5 & $<5.0$ & $<5.0$ & $0 \%$ \\
\hline Cobalt & Co & $\mu \mathrm{g} / \mathrm{L}$ & 0 & 0.39 & 0.51 & 0.44 & $15 \%$ \\
\hline Copper & $\mathrm{Cu}$ & $\mu \mathrm{g} / \mathrm{L}$ & 5 & 16 & 9.4 & 6.7 & $34 \%$ \\
\hline Dysprosium & Dy & $\mu \mathrm{g} / \mathrm{L}$ & 0 & 0 & $<0.1$ & $<0.1$ & $0 \%$ \\
\hline Erbium & $\mathrm{Er}$ & $\mu \mathrm{g} / \mathrm{L}$ & 0 & 0 & $<0.1$ & $<0.1$ & $0 \%$ \\
\hline Europium & $\mathrm{Eu}$ & $\mu \mathrm{g} / \mathrm{L}$ & 0 & 0 & $<0.03$ & $<0.03$ & $0 \%$ \\
\hline Gadolinium & $\mathrm{Gd}$ & $\mu \mathrm{g} / \mathrm{L}$ & 0 & 0 & $<0.1$ & $<0.1$ & $0 \%$ \\
\hline Gallium & $\mathrm{Ga}$ & $\mu \mathrm{g} / \mathrm{L}$ & 5 & 5 & $<5.0$ & $<5.0$ & $0 \%$ \\
\hline Germanium & $\mathrm{Ge}$ & $\mu \mathrm{g} / \mathrm{L}$ & 1 & 1 & $<1.0$ & $<1.0$ & $0 \%$ \\
\hline Hafnium & $\mathrm{Hf}$ & $\mu \mathrm{g} / \mathrm{L}$ & - & - & - & - & - \\
\hline Holonium & Ho & $\mu \mathrm{g} / \mathrm{L}$ & 0 & 0 & $<0.05$ & $<0.05$ & $0 \%$ \\
\hline Iridium & Ir & $\mu \mathrm{g} / \mathrm{L}$ & 1 & 1 & $<0.5$ & $<0.5$ & $0 \%$ \\
\hline Iron & $\mathrm{Fe}$ & $\mu \mathrm{g} / \mathrm{L}$ & 50 & 72 & 190 & 190 & $0 \%$ \\
\hline Lanthanum & La & $\mu \mathrm{g} / \mathrm{L}$ & 0 & 0 & $<0.4$ & $<0.4$ & $0 \%$ \\
\hline Lead & $\mathrm{Pb}$ & $\mu \mathrm{g} / \mathrm{L}$ & 0 & 0.45 & 2.7 & 2.6 & $4 \%$ \\
\hline Lithium & $\mathrm{Li}$ & $\mu \mathrm{g} / \mathrm{L}$ & 2 & 9.8 & 13 & 13 & $0 \%$ \\
\hline Lutetium & Lu & $\mu \mathrm{g} / \mathrm{L}$ & 0 & 0 & $<0.05$ & $<0.05$ & $0 \%$ \\
\hline Magnesium & $\mathrm{Mg}$ & $\mu \mathrm{g} / \mathrm{L}$ & 30 & 3600 & 4300 & 3900 & $10 \%$ \\
\hline Manganese & $\mathrm{Mn}$ & $\mu \mathrm{g} / \mathrm{L}$ & 0 & 8.3 & $<0.3$ & $<0.3$ & $0 \%$ \\
\hline Molybdenum & Mo & $\mu \mathrm{g} / \mathrm{L}$ & 10 & 34 & 43 & 41 & $5 \%$ \\
\hline Neodymium & $\mathrm{Nd}$ & $\mu \mathrm{g} / \mathrm{L}$ & 0 & 0 & $<0.1$ & $<0.1$ & $0 \%$ \\
\hline Nickel & $\mathrm{Ni}$ & $\mu \mathrm{g} / \mathrm{L}$ & 1 & 1.4 & $<1.0$ & $<1.0$ & $0 \%$ \\
\hline Niobium & $\mathrm{Nb}$ & $\mu \mathrm{g} / \mathrm{L}$ & 0 & 0 & $<0.05$ & $<0.05$ & $0 \%$ \\
\hline Palladium & $\mathrm{Pd}$ & $\mu \mathrm{g} / \mathrm{L}$ & - & - & - & - & - \\
\hline Phosphorus & $\mathrm{P}$ & $\mu \mathrm{g} / \mathrm{L}$ & 1000 & 1000 & $<1000$ & $<1000$ & $0 \%$ \\
\hline Platinum & $\mathrm{Pt}$ & $\mu \mathrm{g} / \mathrm{L}$ & 0 & 0 & $<0.05$ & $<0.05$ & $0 \%$ \\
\hline Potassium & $\mathrm{K}$ & $\mu \mathrm{g} / \mathrm{L}$ & 200 & 350 & 340 & 300 & $13 \%$ \\
\hline Praseodymium & $\operatorname{Pr}$ & $\mu \mathrm{g} / \mathrm{L}$ & 0 & 0 & $<0.1$ & $<0.1$ & $0 \%$ \\
\hline Rhenium & $\mathrm{Re}$ & $\mu \mathrm{g} / \mathrm{L}$ & 0 & 0 & $<0.2$ & $<0.2$ & $0 \%$ \\
\hline Rhodium & $\mathrm{Rh}$ & $\mu \mathrm{g} / \mathrm{L}$ & 0 & 0 & $<0.1$ & $<0.1$ & $0 \%$ \\
\hline Rubidium & $\mathrm{Rb}$ & $\mu \mathrm{g} / \mathrm{L}$ & 1 & 1 & $<1.0$ & $<1.0$ & $0 \%$ \\
\hline Ruthenium & $\mathrm{Ru}$ & $\mu \mathrm{g} / \mathrm{L}$ & 0 & 0 & $<0.1$ & $<0.1$ & $0 \%$ \\
\hline Samarium & $\mathrm{Sm}$ & $\mu \mathrm{g} / \mathrm{L}$ & 0 & 0 & $<0.1$ & $<0.1$ & $0 \%$ \\
\hline Selenium & $\mathrm{Se}$ & $\mu \mathrm{g} / \mathrm{L}$ & 1 & 3.7 & 4.3 & 3.9 & $10 \%$ \\
\hline Silver & $\mathrm{Ag}$ & $\mu \mathrm{g} / \mathrm{L}$ & 0 & 0.70 & $<0.1$ & $<0.1$ & $0 \%$ \\
\hline Sodium & $\mathrm{Na}$ & $\mu \mathrm{g} / \mathrm{L}$ & 200 & 26000 & 29000 & 27000 & $7 \%$ \\
\hline Strontium & $\mathrm{Sr}$ & $\mu \mathrm{g} / \mathrm{L}$ & 1 & 990 & 1000 & 1200 & $18 \%$ \\
\hline Sulfur & $\mathrm{s}$ & $\mu \mathrm{g} / \mathrm{L}$ & 1000 & 3600000 & 130000 & 120000 & $8 \%$ \\
\hline Tantalum & $\mathrm{Ta}$ & $\mu \mathrm{g} / \mathrm{L}$ & 0 & 0 & $<0.05$ & $<0.05$ & $0 \%$ \\
\hline Terbium & $\mathrm{Tb}$ & $\mu \mathrm{g} / \mathrm{L}$ & 0 & 0 & $<0.05$ & $<0.05$ & $0 \%$ \\
\hline Tellurium & $\mathrm{Te}$ & $\mu \mathrm{g} / \mathrm{L}$ & 1 & 1 & $<0.5$ & $<0.5$ & $0 \%$ \\
\hline Thalium & $\mathrm{Tl}$ & $\mu \mathrm{g} / \mathrm{L}$ & 0 & 0.15 & $<0.1$ & $<0.1$ & $0 \%$ \\
\hline Thorium & Th & $\mu \mathrm{g} / \mathrm{L}$ & - & - & - & - & - \\
\hline Thulium & $\mathrm{Tm}$ & $\mu \mathrm{g} / \mathrm{L}$ & 0 & 0 & $<0.05$ & $<0.05$ & $0 \%$ \\
\hline $\operatorname{Tin} * *$ & Sn & $\mu \mathrm{g} / \mathrm{L}$ & 3 & 3.0 & $<3.0$ & $<3.0$ & $0 \%$ \\
\hline Titanium & $\mathrm{Ti}$ & $\mu \mathrm{g} / \mathrm{L}$ & 3 & 3 & $<3.0$ & $<3.0$ & $0 \%$ \\
\hline Tungsten & w & $\mu \mathrm{g} / \mathrm{L}$ & 1 & 1 & $<0.5$ & $<0.5$ & $0 \%$ \\
\hline Uranium & u & $\mu \mathrm{g} / \mathrm{L}$ & 0 & 0.99 & 1.5 & 1.4 & $7 \%$ \\
\hline Vanadium & v & $\mu \mathrm{g} / \mathrm{L}$ & 0 & 0.44 & 0.88 & 0.89 & $1 \%$ \\
\hline Ytterbium & $\mathrm{Yb}$ & $\mu \mathrm{g} / \mathrm{L}$ & 0 & 0 & $<0.2$ & $<0.2$ & $0 \%$ \\
\hline Yttrium & $Y$ & $\mu \mathrm{g} / \mathrm{L}$ & 1 & 1 & $<1.0$ & $<1.0$ & $0 \%$ \\
\hline Zinc & $\mathrm{Zn}$ & $\mu \mathrm{g} / \mathrm{L}$ & 10 & 10 & $<10$ & $<10$ & $0 \%$ \\
\hline Zirconium & $\mathrm{Zr}$ & $\mu \mathrm{g} / \mathrm{L}$ & 0 & 0.14 & $<0.1$ & $<0.1$ & $0 \%$ \\
\hline
\end{tabular}




\begin{tabular}{|c|c|c|c|c|c|c|}
\hline & & & $\begin{array}{l}\text { Sample name } \\
\text { Sample type } \\
\text { Sample number }\end{array}$ & $\begin{array}{c}\text { LN-VWD-W } \\
\text { FA } \\
\text { No16 }\end{array}$ & $\begin{array}{l}\text { LN-VWD-W } \\
\text { FA } \\
\text { No17 }\end{array}$ & \%Diff 16-17 \\
\hline & Symbol & Units & Detection limit & \multicolumn{2}{|c|}{ Field Duplicate } & \\
\hline \multicolumn{7}{|l|}{ Sample description } \\
\hline \multicolumn{7}{|l|}{ Anions } \\
\hline Fluoride & $\mathrm{F}$ & $\mathrm{mg} / \mathrm{L}$ & $<0.05$ & $<5.0$ & $<5.0$ & - \\
\hline Chloride & $\mathrm{Cl}$ & $\mathrm{mg} / \mathrm{L}$ & $<0.05$ & $<5.0$ & $<5.0$ & - \\
\hline Nitrite & $\mathrm{NO}_{2}-$ & $\mathrm{mg} / \mathrm{L}$ & $<0.05$ & $<5.0$ & $<5.0$ & - \\
\hline Nitrate & $\mathrm{NO}_{3}-$ & $\mathrm{mg} / \mathrm{L}$ & $<0.05$ & 20.2 & 20.2 & - \\
\hline Sulphate & $\mathrm{SO}_{42-}$ & $\mathrm{mg} / \mathrm{L}$ & $<0.10$ & 3600.0 & 3600.0 & - \\
\hline $\mathrm{pH}$ & & - & & 2.6 & 2.6 & - \\
\hline \multicolumn{7}{|l|}{ Metals } \\
\hline Aluminium & $\mathrm{Al}$ & $\mu \mathrm{g} / \mathrm{L}$ & 5 & 200000 & 200000 & $0 \%$ \\
\hline Antimony & $\mathrm{Sb}$ & $\mu \mathrm{g} / \mathrm{L}$ & 2 & 2 & 2 & $0 \%$ \\
\hline Arsenic & As & $\mu \mathrm{g} / \mathrm{L}$ & 2 & 330 & 340 & $3 \%$ \\
\hline Barium & $\mathrm{Ba}$ & $\mu \mathrm{g} / \mathrm{L}$ & 0 & 11 & 11 & $0 \%$ \\
\hline Beryllium & $\mathrm{Be}$ & $\mu \mathrm{g} / \mathrm{L}$ & 0 & 47 & 47 & $0 \%$ \\
\hline Boron & B & $\mu \mathrm{g} / \mathrm{L}$ & 1000 & 1000 & 1000 & $0 \%$ \\
\hline Cadmium & $\mathrm{Cd}$ & $\mu \mathrm{g} / \mathrm{L}$ & 0 & 130 & 130 & $0 \%$ \\
\hline Calcium & $\mathrm{Ca}$ & $\mu \mathrm{g} / \mathrm{L}$ & 300 & 490000 & 510000 & $4 \%$ \\
\hline Cerium & $\mathrm{Ce}$ & $\mu \mathrm{g} / \mathrm{L}$ & 1 & 330 & 330 & $0 \%$ \\
\hline Cesium & Cs & $\mu \mathrm{g} / \mathrm{L}$ & - & - & - & \\
\hline Chromium & $\mathrm{Cr}$ & $\mu \mathrm{g} / \mathrm{L}$ & 5 & 110 & 120 & $9 \%$ \\
\hline Cobalt & Co & $\mu \mathrm{g} / \mathrm{L}$ & 0 & 900 & 920 & $2 \%$ \\
\hline Copper & $\mathrm{Cu}$ & $\mu \mathrm{g} / \mathrm{L}$ & 5 & 21000 & 23000 & $9 \%$ \\
\hline Dysprosium & Dy & $\mu \mathrm{g} / \mathrm{L}$ & 0 & 36 & 35 & $3 \%$ \\
\hline Erbium & $\mathrm{Er}$ & $\mu \mathrm{g} / \mathrm{L}$ & 0 & 18 & 18 & $0 \%$ \\
\hline Europium & $\mathrm{Eu}$ & $\mu \mathrm{g} / \mathrm{L}$ & 0 & 12 & 13 & $8 \%$ \\
\hline Gadolinium & $\mathrm{Gd}$ & $\mu \mathrm{g} / \mathrm{L}$ & 0 & 44 & 44 & $0 \%$ \\
\hline Gallium & $\mathrm{Ga}$ & $\mu \mathrm{g} / \mathrm{L}$ & 5 & 36 & 39 & $8 \%$ \\
\hline Germanium & $\mathrm{Ge}$ & $\mu \mathrm{g} / \mathrm{L}$ & 1 & 16 & 16 & $0 \%$ \\
\hline Hafnium & $\mathrm{Hf}$ & $\mu \mathrm{g} / \mathrm{L}$ & - & - & - & \\
\hline Holonium & Ho & $\mu \mathrm{g} / \mathrm{L}$ & 0 & 6.6 & 6.7 & $2 \%$ \\
\hline Iridium & Ir & $\mu \mathrm{g} / \mathrm{L}$ & 1 & 1 & 1 & $0 \%$ \\
\hline Iron & $\mathrm{Fe}$ & $\mu \mathrm{g} / \mathrm{L}$ & 50 & 490000 & 500000 & $2 \%$ \\
\hline Lanthanum & La & $\mu \mathrm{g} / \mathrm{L}$ & 0 & 150 & 150 & $0 \%$ \\
\hline Lead & $\mathrm{Pb}$ & $\mu \mathrm{g} / \mathrm{L}$ & 0 & 6.8 & 6.8 & $0 \%$ \\
\hline Lithium & $\mathrm{Li}$ & $\mu \mathrm{g} / \mathrm{L}$ & 2 & 82 & 82 & $0 \%$ \\
\hline Lutetium & $\mathrm{Lu}$ & $\mu \mathrm{g} / \mathrm{L}$ & 0 & 2.0 & 2.1 & $5 \%$ \\
\hline Magnesium & $\mathrm{Mg}$ & $\mu \mathrm{g} / \mathrm{L}$ & 30 & 73000 & 75000 & $3 \%$ \\
\hline Manganese & $\mathrm{Mn}$ & $\mu \mathrm{g} / \mathrm{L}$ & 0 & 31000 & 34000 & $9 \%$ \\
\hline Molybdenum & Mo & $\mu \mathrm{g} / \mathrm{L}$ & 10 & 10 & 10 & $0 \%$ \\
\hline Neodymium & $\mathrm{Nd}$ & $\mu \mathrm{g} / \mathrm{L}$ & 0 & 170 & 170 & $0 \%$ \\
\hline Nickel & $\mathrm{Ni}$ & $\mu \mathrm{g} / \mathrm{L}$ & 1 & 960 & 990 & $3 \%$ \\
\hline Niobium & $\mathrm{Nb}$ & $\mu \mathrm{g} / \mathrm{L}$ & 0 & 0.078 & 0.083 & $6 \%$ \\
\hline Palladium & $\mathrm{Pd}$ & $\mu \mathrm{g} / \mathrm{L}$ & - & - & - & \\
\hline Phosphorus & $P$ & $\mu \mathrm{g} / \mathrm{L}$ & 1000 & 1700 & 1600 & $6 \%$ \\
\hline Platinum & $\mathrm{Pt}$ & $\mu \mathrm{g} / \mathrm{L}$ & 0 & 0 & 0 & $0 \%$ \\
\hline Potassium & $\mathrm{K}$ & $\mu \mathrm{g} / \mathrm{L}$ & 200 & 920 & 990 & $7 \%$ \\
\hline Praseodymium & $\mathrm{Pr}$ & $\mu \mathrm{g} / \mathrm{L}$ & 0 & 41 & 40 & $2 \%$ \\
\hline Rhenium & $\operatorname{Re}$ & $\mu \mathrm{g} / \mathrm{L}$ & 0 & 0 & 0 & $0 \%$ \\
\hline Rhodium & $\mathrm{Rh}$ & $\mu \mathrm{g} / \mathrm{L}$ & 0 & 0 & 0 & $0 \%$ \\
\hline Rubidium & $\mathrm{Rb}$ & $\mu \mathrm{g} / \mathrm{L}$ & 1 & 12 & 12 & $0 \%$ \\
\hline Ruthenium & $\mathrm{Ru}$ & $\mu \mathrm{g} / \mathrm{L}$ & 0 & 0 & 0 & $0 \%$ \\
\hline Samarium & $\mathrm{Sm}$ & $\mu \mathrm{g} / \mathrm{L}$ & 0 & 40 & 40 & $0 \%$ \\
\hline Selenium & Se & $\mu \mathrm{g} / \mathrm{L}$ & 1 & 24 & 24 & $0 \%$ \\
\hline Silver & $\mathrm{Ag}$ & $\mu \mathrm{g} / \mathrm{L}$ & 0 & 0.88 & 0.79 & $11 \%$ \\
\hline Sodium & $\mathrm{Na}$ & $\mu \mathrm{g} / \mathrm{L}$ & 200 & 49000 & 50000 & $2 \%$ \\
\hline Strontium & $\mathrm{Sr}$ & $\mu \mathrm{g} / \mathrm{L}$ & 1 & 3000 & 2900 & $3 \%$ \\
\hline Sulfur & $\mathrm{s}$ & $\mu \mathrm{g} / \mathrm{L}$ & 1000 & 4900000 & 5200000 & $6 \%$ \\
\hline Tantalum & $\mathrm{Ta}$ & $\mu \mathrm{g} / \mathrm{L}$ & 0 & 0 & 0 & $0 \%$ \\
\hline Terbium & $\mathrm{Tb}$ & $\mu \mathrm{g} / \mathrm{L}$ & 0 & 6.6 & 6.5 & $2 \%$ \\
\hline Tellurium & $\mathrm{Te}$ & $\mu \mathrm{g} / \mathrm{L}$ & 1 & 2.9 & 2.4 & $19 \%$ \\
\hline Thalium & $\mathrm{TI}$ & $\mu \mathrm{g} / \mathrm{L}$ & 0 & 0.58 & 0.62 & $7 \%$ \\
\hline Thorium & Th & $\mu \mathrm{g} / \mathrm{L}$ & - & - & - & \\
\hline Thulium & $\mathrm{Tm}$ & $\mu \mathrm{g} / \mathrm{L}$ & 0 & 2.3 & 2.3 & $0 \%$ \\
\hline $\operatorname{Tin} * *$ & Sn & $\mu \mathrm{g} / \mathrm{L}$ & 3 & 3.0 & 3.0 & $0 \%$ \\
\hline Titanium & $\mathrm{Ti}$ & $\mu \mathrm{g} / \mathrm{L}$ & 3 & 9.8 & 6.9 & $35 \%$ \\
\hline Tungsten & w & $\mu \mathrm{g} / \mathrm{L}$ & 1 & 1 & 1 & $0 \%$ \\
\hline Uranium & $u$ & $\mu \mathrm{g} / \mathrm{L}$ & 0 & 21 & 21 & $0 \%$ \\
\hline Vanadium & v & $\mu \mathrm{g} / \mathrm{L}$ & 0 & 26 & 27 & $4 \%$ \\
\hline Ytterbium & $\mathrm{Yb}$ & $\mu \mathrm{g} / \mathrm{L}$ & 0 & 14 & 14 & $0 \%$ \\
\hline Yttrium & $Y$ & $\mu \mathrm{g} / \mathrm{L}$ & 1 & 190 & 190 & $0 \%$ \\
\hline Zinc & $\mathrm{Zn}$ & $\mu \mathrm{g} / \mathrm{L}$ & 10 & 7300 & 6700 & $9 \%$ \\
\hline Zirconium & $\mathrm{Zr}$ & $\mu \mathrm{g} / \mathrm{L}$ & 0 & 2.2 & 2.4 & $9 \%$ \\
\hline
\end{tabular}




\begin{tabular}{|c|c|c|c|c|c|c|}
\hline & Symbol & Units & $\begin{array}{l}\text { Sample name } \\
\text { Sample type } \\
\text { Sample number } \\
\text { Detection limit }\end{array}$ & $\begin{array}{l}\text { LN-VWD-W } \\
\text { FFA } \\
\text { No27 * }\end{array}$ & $\begin{array}{l}\text { LN-VWD-W } \\
\text { UA } \\
\text { No41 }\end{array}$ & $\begin{array}{c}\text { LN-PW-W } \\
\text { UA } \\
\text { No36 }\end{array}$ \\
\hline \multicolumn{7}{|l|}{ Sample description } \\
\hline \multicolumn{7}{|l|}{ Anions } \\
\hline Fluoride & $\mathrm{F}$ & $\mathrm{mg} / \mathrm{L}$ & $<0.05$ & $<5.0$ & $<5.0$ & - \\
\hline Chloride & $\mathrm{Cl}$ & $\mathrm{mg} / \mathrm{L}$ & $<0.05$ & $<5.0$ & $<5.0$ & - \\
\hline Nitrite & $\mathrm{NO}_{2-}^{-}$ & $\mathrm{mg} / \mathrm{L}$ & $<0.05$ & $<5.0$ & $<5.0$ & - \\
\hline Nitrate & $\mathrm{NO}_{3}-$ & $\mathrm{mg} / \mathrm{L}$ & $<0.05$ & 20.2 & 20.2 & - \\
\hline Sulphate & $\mathrm{SO}_{42-}$ & $\mathrm{mg} / \mathrm{L}$ & $<0.10$ & 3600.0 & 3600.0 & - \\
\hline $\mathrm{pH}$ & & - & & 2.6 & 2.6 & - \\
\hline \multicolumn{7}{|l|}{ Metals } \\
\hline Aluminium & Al & $\mu \mathrm{g} / \mathrm{L}$ & 5 & 190000 & 200000 & 2600 \\
\hline Antimony & $\mathrm{Sb}$ & $\mu \mathrm{g} / \mathrm{L}$ & 2 & 2 & $<2.0$ & 2.1 \\
\hline Arsenic & As & $\mu \mathrm{g} / \mathrm{L}$ & 2 & 320 & 270 & 8.0 \\
\hline Barium & $\mathrm{Ba}$ & $\mu \mathrm{g} / \mathrm{L}$ & 0 & 9.6 & 11 & 18 \\
\hline Beryllium & $\mathrm{Be}$ & $\mu \mathrm{g} / \mathrm{L}$ & 0 & 41 & 45 & 0.21 \\
\hline Boron & B & $\mu \mathrm{g} / \mathrm{L}$ & 1000 & 1000 & $<1000$ & $<1000$ \\
\hline Cadmium & $\mathrm{Cd}$ & $\mu \mathrm{g} / \mathrm{L}$ & 0 & 110 & 120 & 5.7 \\
\hline Calcium & $\mathrm{Ca}$ & $\mu \mathrm{g} / \mathrm{L}$ & 300 & 460000 & 420000 & 440000 \\
\hline Cerium & $\mathrm{Ce}$ & $\mu \mathrm{g} / \mathrm{L}$ & 1 & 290 & 320 & 9.1 \\
\hline Cesium & Cs & $\mu \mathrm{g} / \mathrm{L}$ & - & - & - & - \\
\hline Chromium & $\mathrm{Cr}$ & $\mu \mathrm{g} / \mathrm{L}$ & 5 & 110 & 100 & $<5.0$ \\
\hline Cobalt & Co & $\mu \mathrm{g} / \mathrm{L}$ & 0 & 820 & 770 & 24 \\
\hline Copper & $\mathrm{Cu}$ & $\mu \mathrm{g} / \mathrm{L}$ & 5 & 22000 & 21000 & 240 \\
\hline Dysprosium & Dy & $\mu \mathrm{g} / \mathrm{L}$ & 0 & 30 & 35 & 0.96 \\
\hline Erbium & $\mathrm{Er}$ & $\mu \mathrm{g} / \mathrm{L}$ & 0 & 16 & 18 & 0.49 \\
\hline Europium & Eu & $\mu \mathrm{g} / \mathrm{L}$ & 0 & 10 & 10 & 0.36 \\
\hline Gadolinium & Gd & $\mu \mathrm{g} / \mathrm{L}$ & 0 & 38 & 44 & 1.1 \\
\hline Gallium & $\mathrm{Ga}$ & $\mu \mathrm{g} / \mathrm{L}$ & 5 & 34 & 35 & $<5.0$ \\
\hline Germanium & $\mathrm{Ge}$ & $\mu \mathrm{g} / \mathrm{L}$ & 1 & 15 & 13 & $<1.0$ \\
\hline Hafnium & $\mathrm{Hf}$ & $\mu \mathrm{g} / \mathrm{L}$ & - & - & - & - \\
\hline Holonium & Ho & $\mu \mathrm{g} / \mathrm{L}$ & 0 & 6.0 & 6.8 & 0.20 \\
\hline Iridium & Ir & $\mu \mathrm{g} / \mathrm{L}$ & 1 & 1 & $<0.5$ & $<0.5$ \\
\hline Iron & $\mathrm{Fe}$ & $\mu \mathrm{g} / \mathrm{L}$ & 50 & 450000 & 410000 & 13000 \\
\hline Lanthanum & La & $\mu \mathrm{g} / \mathrm{L}$ & 0 & 130 & 140 & 4.6 \\
\hline Lead & $\mathrm{Pb}$ & $\mu \mathrm{g} / \mathrm{L}$ & 0 & 7.0 & 7.1 & 12 \\
\hline Lithium & Li & $\mu \mathrm{g} / \mathrm{L}$ & 2 & 70 & 83 & 8.3 \\
\hline Lutetium & Lu & $\mu \mathrm{g} / \mathrm{L}$ & 0 & 1.8 & 2.1 & $<0.05$ \\
\hline Magnesium & $\mathrm{Mg}$ & $\mu \mathrm{g} / \mathrm{L}$ & 30 & 66000 & 61000 & 20000 \\
\hline Manganese & $\mathrm{Mn}$ & $\mu \mathrm{g} / \mathrm{L}$ & 0 & 33000 & 38000 & 3600 \\
\hline Molybdenum & Mo & $\mu \mathrm{g} / \mathrm{L}$ & 10 & 10 & $<10$ & 28 \\
\hline Neodymium & $\mathrm{Nd}$ & $\mu \mathrm{g} / \mathrm{L}$ & 0 & 150 & 170 & 4.7 \\
\hline Nickel & $\mathrm{Ni}$ & $\mu \mathrm{g} / \mathrm{L}$ & 1 & 900 & 830 & 16 \\
\hline Niobium & $\mathrm{Nb}$ & $\mu \mathrm{g} / \mathrm{L}$ & 0 & 0.12 & 0.078 & $<0.05$ \\
\hline Palladium & $\mathrm{Pd}$ & $\mu \mathrm{g} / \mathrm{L}$ & - & - & - & - \\
\hline Phosphorus & $P$ & $\mu \mathrm{g} / \mathrm{L}$ & 1000 & 1600 & 1500 & $<1000$ \\
\hline Platinum & $\mathrm{Pt}$ & $\mu \mathrm{g} / \mathrm{L}$ & 0 & 0 & $<0.05$ & $<0.05$ \\
\hline Potassium & $\mathrm{K}$ & $\mu \mathrm{g} / \mathrm{L}$ & 200 & 980 & 720 & 2000 \\
\hline Praseodymium & $\mathrm{Pr}$ & $\mu \mathrm{g} / \mathrm{L}$ & 0 & 36 & 40 & 1.2 \\
\hline Rhenium & $\operatorname{Re}$ & $\mu \mathrm{g} / \mathrm{L}$ & 0 & 0 & $<0.2$ & $<0.2$ \\
\hline Rhodium & $\mathrm{Rh}$ & $\mu \mathrm{g} / \mathrm{L}$ & 0 & 0 & $<0.1$ & $<0.1$ \\
\hline Rubidium & $\mathrm{Rb}$ & $\mu \mathrm{g} / \mathrm{L}$ & 1 & 11 & 12 & 15 \\
\hline Ruthenium & $\mathrm{Ru}$ & $\mu \mathrm{g} / \mathrm{L}$ & 0 & 0 & $<0.1$ & $<0.1$ \\
\hline Samarium & $\mathrm{Sm}$ & $\mu \mathrm{g} / \mathrm{L}$ & 0 & 34 & 41 & 1.0 \\
\hline Selenium & $\mathrm{Se}$ & $\mu \mathrm{g} / \mathrm{L}$ & 1 & 22 & 25 & 5.2 \\
\hline Silver & $\mathrm{Ag}$ & $\mu \mathrm{g} / \mathrm{L}$ & 0 & 0.88 & 0.83 & 0.47 \\
\hline Sodium & $\mathrm{Na}$ & $\mu \mathrm{g} / \mathrm{L}$ & 200 & 45000 & 40000 & 35000 \\
\hline Strontium & $\mathrm{Sr}$ & $\mu \mathrm{g} / \mathrm{L}$ & 1 & 2800 & 2900 & 2200 \\
\hline Sulfur & $S$ & $\mu \mathrm{g} / \mathrm{L}$ & 1000 & 5200000 & 7000000 & 360000 \\
\hline Tantalum & $\mathrm{Ta}$ & $\mu \mathrm{g} / \mathrm{L}$ & 0 & 0 & $<0.05$ & $<0.05$ \\
\hline Terbium & $\mathrm{Tb}$ & $\mu \mathrm{g} / \mathrm{L}$ & 0 & 5.6 & 6.6 & 0.17 \\
\hline Tellurium & $\mathrm{Te}$ & $\mu \mathrm{g} / \mathrm{L}$ & 1 & 4.2 & 2.8 & $<0.5$ \\
\hline Thalium & $\mathrm{Tl}$ & $\mu \mathrm{g} / \mathrm{L}$ & 0 & 0.50 & 0.35 & 0.12 \\
\hline Thorium & Th & $\mu \mathrm{g} / \mathrm{L}$ & - & - & - & - \\
\hline Thulium & $\mathrm{Tm}$ & $\mu \mathrm{g} / \mathrm{L}$ & 0 & 2.0 & 2.4 & 0.059 \\
\hline $\operatorname{Tin} * *$ & Sn & $\mu \mathrm{g} / \mathrm{L}$ & 3 & 3.0 & $<3.0$ & $<3.0$ \\
\hline Titanium & $\mathrm{Ti}$ & $\mu \mathrm{g} / \mathrm{L}$ & 3 & 8.0 & 3.9 & $<3.0$ \\
\hline Tungsten & w & $\mu \mathrm{g} / \mathrm{L}$ & 1 & 1 & $<0.5$ & $<0.5$ \\
\hline Uranium & $U$ & $\mu \mathrm{g} / \mathrm{L}$ & 0 & 18 & 22 & 0.75 \\
\hline Vanadium & $v$ & $\mu \mathrm{g} / \mathrm{L}$ & 0 & 22 & 23 & 1.4 \\
\hline Ytterbium & $\mathrm{Yb}$ & $\mu \mathrm{g} / \mathrm{L}$ & 0 & 13 & 15 & 0.38 \\
\hline Yttrium & $\mathrm{Y}$ & $\mu \mathrm{g} / \mathrm{L}$ & 1 & 180 & 160 & 5.1 \\
\hline Zinc & $\mathrm{Zn}$ & $\mu \mathrm{g} / \mathrm{L}$ & 10 & 6500 & 6800 & 210 \\
\hline Zirconium & $\mathrm{Zr}$ & $\mu \mathrm{g} / \mathrm{L}$ & 0 & 2.0 & 2.1 & 0.10 \\
\hline
\end{tabular}




\begin{tabular}{|c|c|c|c|c|c|c|c|c|c|}
\hline & Symbol & Units & $\begin{array}{l}\text { Sample name } \\
\text { Sample type } \\
\text { Sample number } \\
\text { Detection limit }\end{array}$ & $\begin{array}{l}\text { IN23-W } \\
\text { UA } \\
\text { No43 }\end{array}$ & $\begin{array}{c}\text { IN23-W } \\
\text { FA } \\
\text { No44 } \\
\text { Field Triplicate } \\
\end{array}$ & $\begin{array}{l}\text { IN23-W } \\
\text { FA } \\
\text { No45 }\end{array}$ & \%Diff 43-44 & \%Diff 44-45 & \%Diff 43-45 \\
\hline \multicolumn{10}{|l|}{ Sample description } \\
\hline \multicolumn{10}{|l|}{ Anions } \\
\hline Fluoride & $\mathrm{F}$ & $\mathrm{mg} / \mathrm{L}$ & $<0.05$ & $<2.0$ & $<2.0$ & $<2.0$ & - & - & - \\
\hline Chloride & $\mathrm{Cl}$ & $\mathrm{mg} / \mathrm{L}$ & $<0.05$ & 16.0 & 16.0 & 16.0 & - & - & - \\
\hline Nitrite & $\mathrm{NO}_{2}-$ & $\mathrm{mg} / \mathrm{L}$ & $<0.05$ & $<2.0$ & $<2.0$ & $<2.0$ & - & - & - \\
\hline Nitrate & $\mathrm{NO}_{3}-$ & $\mathrm{mg} / \mathrm{L}$ & $<0.05$ & 6.5 & 6.5 & 6.5 & - & - & - \\
\hline Sulphate & $\mathrm{SO}_{42}-$ & $\mathrm{mg} / \mathrm{L}$ & $<0.10$ & 870.0 & 870.0 & 870.0 & - & - & - \\
\hline $\mathrm{pH}$ & & - & & 6.7 & 6.7 & 6.7 & - & - & - \\
\hline \multicolumn{10}{|l|}{ Metals } \\
\hline Aluminium & Al & $\mu \mathrm{g} / \mathrm{L}$ & 5 & $<5.0$ & $<5.0$ & $<5.0$ & $0 \%$ & $0 \%$ & $0 \%$ \\
\hline Antimony & $\mathrm{Sb}$ & $\mu \mathrm{g} / \mathrm{L}$ & 2 & $<2.0$ & $<2.0$ & $<2.0$ & $0 \%$ & $0 \%$ & $0 \%$ \\
\hline Arsenic & As & $\mu \mathrm{g} / \mathrm{L}$ & 2 & 3.0 & 3.5 & 2.1 & $15 \%$ & $50 \%$ & $35 \%$ \\
\hline Barium & $\mathrm{Ba}$ & $\mu \mathrm{g} / \mathrm{L}$ & 0 & 21 & 25 & 25 & $17 \%$ & $0 \%$ & $17 \%$ \\
\hline Beryllium & $\mathrm{Be}$ & $\mu \mathrm{g} / \mathrm{L}$ & 0 & $<0.2$ & $<0.2$ & $<0.2$ & $0 \%$ & $0 \%$ & $0 \%$ \\
\hline Boron & B & $\mu \mathrm{g} / \mathrm{L}$ & 1000 & $<1000$ & $<1000$ & $<1000$ & $0 \%$ & $0 \%$ & $0 \%$ \\
\hline Cadmium & $\mathrm{Cd}$ & $\mu \mathrm{g} / \mathrm{L}$ & 0 & $<0.03$ & $<0.03$ & $<0.03$ & $0 \%$ & $0 \%$ & $0 \%$ \\
\hline Calcium & $\mathrm{Ca}$ & $\mu \mathrm{g} / \mathrm{L}$ & 300 & 71000 & 84000 & 86000 & $17 \%$ & $2 \%$ & $19 \%$ \\
\hline Cerium & $\mathrm{Ce}$ & $\mu \mathrm{g} / \mathrm{L}$ & 1 & $<0.5$ & $<0.5$ & $<0.5$ & $0 \%$ & $0 \%$ & $0 \%$ \\
\hline Cesium & Cs & $\mu \mathrm{g} / \mathrm{L}$ & - & - & - & - & & - & \\
\hline Chromium & $\mathrm{Cr}$ & $\mu \mathrm{g} / \mathrm{L}$ & 5 & $<5.0$ & $<5.0$ & $<5.0$ & $0 \%$ & $0 \%$ & $0 \%$ \\
\hline Cobalt & Co & $\mu \mathrm{g} / \mathrm{L}$ & 0 & $<0.05$ & $<0.05$ & $<0.05$ & $0 \%$ & $0 \%$ & $0 \%$ \\
\hline Copper & $\mathrm{Cu}$ & $\mu \mathrm{g} / \mathrm{L}$ & 5 & $<5.0$ & $<5.0$ & $<5.0$ & $0 \%$ & $0 \%$ & $0 \%$ \\
\hline Dysprosium & Dy & $\mu \mathrm{g} / \mathrm{L}$ & 0 & $<0.1$ & $<0.1$ & $<0.1$ & $0 \%$ & $0 \%$ & $0 \%$ \\
\hline Erbium & $\mathrm{Er}$ & $\mu \mathrm{g} / \mathrm{L}$ & 0 & $<0.1$ & $<0.1$ & $<0.1$ & $0 \%$ & $0 \%$ & $0 \%$ \\
\hline Europium & $\mathrm{Eu}$ & $\mu \mathrm{g} / \mathrm{L}$ & 0 & $<0.03$ & $<0.03$ & $<0.03$ & $0 \%$ & $0 \%$ & $0 \%$ \\
\hline Gadolinium & $\mathrm{Gd}$ & $\mu \mathrm{g} / \mathrm{L}$ & 0 & $<0.1$ & $<0.1$ & $<0.1$ & $0 \%$ & $0 \%$ & $0 \%$ \\
\hline Gallium & $\mathrm{Ga}$ & $\mu \mathrm{g} / \mathrm{L}$ & 5 & $<5.0$ & $<5.0$ & $<5.0$ & $0 \%$ & $0 \%$ & $0 \%$ \\
\hline Germanium & $\mathrm{Ge}$ & $\mu \mathrm{g} / \mathrm{L}$ & 1 & $<1.0$ & $<1.0$ & $<1.0$ & $0 \%$ & $0 \%$ & $0 \%$ \\
\hline Hafnium & $\mathrm{Hf}$ & $\mu \mathrm{g} / \mathrm{L}$ & - & - & - & - & & - & \\
\hline Holonium & $\mathrm{Ho}$ & $\mu \mathrm{g} / \mathrm{L}$ & 0 & $<0.05$ & $<0.05$ & $<0.05$ & $0 \%$ & $0 \%$ & $0 \%$ \\
\hline Iridium & Ir & $\mu \mathrm{g} / \mathrm{L}$ & 1 & $<0.5$ & $<0.5$ & $<0.5$ & $0 \%$ & $0 \%$ & $0 \%$ \\
\hline Iron & $\mathrm{Fe}$ & $\mu \mathrm{g} / \mathrm{L}$ & 50 & $<50$ & $<50$ & $<50$ & $0 \%$ & $0 \%$ & $0 \%$ \\
\hline Lanthanum & La & $\mu \mathrm{g} / \mathrm{L}$ & 0 & $<0.4$ & $<0.4$ & $<0.4$ & $0 \%$ & $0 \%$ & $0 \%$ \\
\hline Lead & $\mathrm{Pb}$ & $\mu \mathrm{g} / \mathrm{L}$ & 0 & $<0.2$ & $<0.2$ & $<0.2$ & $0 \%$ & $0 \%$ & $0 \%$ \\
\hline Lithium & $\mathrm{Li}$ & $\mu \mathrm{g} / \mathrm{L}$ & 2 & 2.0 & 2.4 & 2.4 & $18 \%$ & $0 \%$ & $18 \%$ \\
\hline Lutetium & Lu & $\mu \mathrm{g} / \mathrm{L}$ & 0 & $<0.05$ & $<0.05$ & $<0.05$ & $0 \%$ & $0 \%$ & $0 \%$ \\
\hline Magnesium & $\mathrm{Mg}$ & $\mu \mathrm{g} / \mathrm{L}$ & 30 & 10000 & 12000 & 13000 & $18 \%$ & $8 \%$ & $26 \%$ \\
\hline Manganese & $\mathrm{Mn}$ & $\mu \mathrm{g} / \mathrm{L}$ & 0 & $<0.3$ & 1.5 & 1.5 & $133 \%$ & $0 \%$ & $133 \%$ \\
\hline Molybdenum & Mo & $\mu \mathrm{g} / \mathrm{L}$ & 10 & $<10$ & $<10$ & $<10$ & $0 \%$ & $0 \%$ & $0 \%$ \\
\hline Neodymium & $\mathrm{Nd}$ & $\mu \mathrm{g} / \mathrm{L}$ & 0 & $<0.1$ & $<0.1$ & $<0.1$ & $0 \%$ & $0 \%$ & $0 \%$ \\
\hline Nickel & $\mathrm{Ni}$ & $\mu \mathrm{g} / \mathrm{L}$ & 1 & $<1.0$ & $<1.0$ & $<1.0$ & $0 \%$ & $0 \%$ & $0 \%$ \\
\hline Niobium & $\mathrm{Nb}$ & $\mu \mathrm{g} / \mathrm{L}$ & 0 & $<0.05$ & $<0.05$ & $<0.05$ & $0 \%$ & $0 \%$ & $0 \%$ \\
\hline Palladium & $\mathrm{Pd}$ & $\mu \mathrm{g} / \mathrm{L}$ & - & - & - & - & & - & \\
\hline Phosphorus & $\mathrm{P}$ & $\mu \mathrm{g} / \mathrm{L}$ & 1000 & $<1000$ & $<1000$ & $<1000$ & $0 \%$ & $0 \%$ & $0 \%$ \\
\hline Platinum & $\mathrm{Pt}$ & $\mu \mathrm{g} / \mathrm{L}$ & 0 & $<0.05$ & $<0.05$ & $<0.05$ & $0 \%$ & $0 \%$ & $0 \%$ \\
\hline Potassium & $\mathrm{K}$ & $\mu \mathrm{g} / \mathrm{L}$ & 200 & 1100 & 1100 & 1200 & $0 \%$ & $9 \%$ & $9 \%$ \\
\hline Praseodymium & $\operatorname{Pr}$ & $\mu \mathrm{g} / \mathrm{L}$ & 0 & $<0.1$ & $<0.1$ & $<0.1$ & $0 \%$ & $0 \%$ & $0 \%$ \\
\hline Rhenium & $\operatorname{Re}$ & $\mu \mathrm{g} / \mathrm{L}$ & 0 & $<0.2$ & $<0.2$ & $<0.2$ & $0 \%$ & $0 \%$ & $0 \%$ \\
\hline Rhodium & $\mathrm{Rh}$ & $\mu \mathrm{g} / \mathrm{L}$ & 0 & $<0.1$ & $<0.1$ & $<0.1$ & $0 \%$ & $0 \%$ & $0 \%$ \\
\hline Rubidium & $\mathrm{Rb}$ & $\mu \mathrm{g} / \mathrm{L}$ & 1 & 1.3 & 1.5 & 1.6 & $14 \%$ & $6 \%$ & $21 \%$ \\
\hline Ruthenium & $\mathrm{Ru}$ & $\mu \mathrm{g} / \mathrm{L}$ & 0 & $<0.1$ & $<0.1$ & $<0.1$ & $0 \%$ & $0 \%$ & $0 \%$ \\
\hline Samarium & $\mathrm{Sm}$ & $\mu \mathrm{g} / \mathrm{L}$ & 0 & $<0.1$ & $<0.1$ & $<0.1$ & $0 \%$ & $0 \%$ & $0 \%$ \\
\hline Selenium & $\mathrm{Se}$ & $\mu \mathrm{g} / \mathrm{L}$ & 1 & 1.1 & $<1.0$ & 1.4 & $10 \%$ & $33 \%$ & $24 \%$ \\
\hline Silver & $\mathrm{Ag}$ & $\mu \mathrm{g} / \mathrm{L}$ & 0 & $<0.1$ & $<0.1$ & $<0.1$ & $0 \%$ & $0 \%$ & $0 \%$ \\
\hline Sodium & $\mathrm{Na}$ & $\mu \mathrm{g} / \mathrm{L}$ & 200 & 16000 & 19000 & 20000 & $17 \%$ & $5 \%$ & $22 \%$ \\
\hline Strontium & $\mathrm{Sr}$ & $\mu \mathrm{g} / \mathrm{L}$ & 1 & 720 & 840 & 860 & $15 \%$ & $2 \%$ & $18 \%$ \\
\hline Sulfur & $\mathrm{S}$ & $\mu \mathrm{g} / \mathrm{L}$ & 1000 & 64000 & 63000 & 59000 & $2 \%$ & $7 \%$ & $8 \%$ \\
\hline Tantalum & $\mathrm{Ta}$ & $\mu \mathrm{g} / \mathrm{L}$ & 0 & $<0.05$ & $<0.05$ & $<0.05$ & $0 \%$ & $0 \%$ & $0 \%$ \\
\hline Terbium & Tb & $\mu \mathrm{g} / \mathrm{L}$ & 0 & $<0.05$ & $<0.05$ & $<0.05$ & $0 \%$ & $0 \%$ & $0 \%$ \\
\hline Tellurium & $\mathrm{Te}$ & $\mu \mathrm{g} / \mathrm{L}$ & 1 & $<0.5$ & $<0.5$ & $<0.5$ & $0 \%$ & $0 \%$ & $0 \%$ \\
\hline Thalium & $\mathrm{TI}$ & $\mu \mathrm{g} / \mathrm{L}$ & 0 & $<0.1$ & $<0.1$ & $<0.1$ & $0 \%$ & $0 \%$ & $0 \%$ \\
\hline Thorium & Th & $\mu \mathrm{g} / \mathrm{L}$ & - & - & - & - & & - & \\
\hline Thulium & $\mathrm{Tm}$ & $\mu \mathrm{g} / \mathrm{L}$ & 0 & $<0.05$ & $<0.05$ & $<0.05$ & $0 \%$ & $0 \%$ & $0 \%$ \\
\hline $\operatorname{Tin} * *$ & Sn & $\mu \mathrm{g} / \mathrm{L}$ & 3 & $<3.0$ & $<3.0$ & $<3.0$ & $0 \%$ & $0 \%$ & $0 \%$ \\
\hline Titanium & $\mathrm{Ti}$ & $\mu \mathrm{g} / \mathrm{L}$ & 3 & $<3.0$ & $<3.0$ & $<3.0$ & $0 \%$ & $0 \%$ & $0 \%$ \\
\hline Tungsten & w & $\mu \mathrm{g} / \mathrm{L}$ & 1 & $<0.5$ & $<0.5$ & $<0.5$ & $0 \%$ & $0 \%$ & $0 \%$ \\
\hline Uranium & U & $\mu \mathrm{g} / \mathrm{L}$ & 0 & 1.2 & 1.3 & 1.4 & $8 \%$ & $7 \%$ & $15 \%$ \\
\hline Vanadium & $\mathrm{v}$ & $\mu \mathrm{g} / \mathrm{L}$ & 0 & 0.32 & 0.34 & 0.34 & $6 \%$ & $0 \%$ & $6 \%$ \\
\hline Ytterbium & $\mathrm{Yb}$ & $\mu \mathrm{g} / \mathrm{L}$ & 0 & $<0.2$ & $<0.2$ & $<0.2$ & $0 \%$ & $0 \%$ & $0 \%$ \\
\hline Yttrium & $\mathrm{Y}$ & $\mu \mathrm{g} / \mathrm{L}$ & 1 & $<1.0$ & $<1.0$ & $<1.0$ & $0 \%$ & $0 \%$ & $0 \%$ \\
\hline Zinc & $\mathrm{Zn}$ & $\mu \mathrm{g} / \mathrm{L}$ & 10 & $<10$ & $<10$ & $<10$ & $0 \%$ & $0 \%$ & $0 \%$ \\
\hline Zirconium & $\mathrm{Zr}$ & $\mu \mathrm{g} / \mathrm{L}$ & 0 & $<0.1$ & $<0.1$ & $<0.1$ & $0 \%$ & $0 \%$ & $0 \%$ \\
\hline
\end{tabular}




\begin{tabular}{|c|c|c|c|c|c|c|c|c|c|}
\hline & Symbol & Units & $\begin{array}{l}\text { Sample name } \\
\text { Sample type } \\
\text { Sample number } \\
\text { Detection limit }\end{array}$ & $\begin{array}{l}\text { IN28-W } \\
\text { FA } \\
\text { No46* }\end{array}$ & $\begin{array}{c}\text { IN28-W } \\
\text { FA } \\
\text { No47 } \\
\text { Field Triplicate } \\
\end{array}$ & $\begin{array}{l}\text { IN28-W } \\
\text { FA } \\
\text { No48 }\end{array}$ & \%Diff 46-47 & \%Diff 48-47 & \%Diff 48-46 \\
\hline \multicolumn{10}{|l|}{ Sample description } \\
\hline \multicolumn{10}{|l|}{ Anions } \\
\hline Fluoride & $\mathrm{F}$ & $\mathrm{mg} / \mathrm{L}$ & $<0.05$ & 2.7 & 2.7 & 2.7 & - & - & - \\
\hline Chloride & $\mathrm{Cl}$ & $\mathrm{mg} / \mathrm{L}$ & $<0.05$ & 8.9 & 8.9 & 8.9 & - & - & - \\
\hline Nitrite & $\mathrm{NO}_{2}-$ & $\mathrm{mg} / \mathrm{L}$ & $<0.05$ & $<2.0$ & $<2.0$ & $<2.0$ & - & - & - \\
\hline Nitrate & $\mathrm{NO}_{3}-$ & $\mathrm{mg} / \mathrm{L}$ & $<0.05$ & $<2.0$ & $<2.0$ & $<2.0$ & - & - & - \\
\hline Sulphate & $\mathrm{SO}_{42}-$ & $\mathrm{mg} / \mathrm{L}$ & $<0.10$ & 670.0 & 670.0 & 670.0 & - & - & - \\
\hline $\mathrm{pH}$ & & - & & 4.4 & 4.4 & 4.4 & - & - & - \\
\hline \multicolumn{10}{|l|}{ Metals } \\
\hline Aluminium & Al & $\mu \mathrm{g} / \mathrm{L}$ & 5 & 15000 & 14000 & 15000 & $13 \%$ & $6.90 \%$ & $0.00 \%$ \\
\hline Antimony & $\mathrm{Sb}$ & $\mu \mathrm{g} / \mathrm{L}$ & 2 & $<2.0$ & $<2.0$ & $<2.0$ & $0 \%$ & $0.00 \%$ & $0.00 \%$ \\
\hline Arsenic & As & $\mu \mathrm{g} / \mathrm{L}$ & 2 & 110 & 110 & 110 & $0 \%$ & $0.00 \%$ & $0.00 \%$ \\
\hline Barium & $\mathrm{Ba}$ & $\mu \mathrm{g} / \mathrm{L}$ & 0 & 8.4 & 8.5 & 8.4 & $1 \%$ & $1.18 \%$ & $0.00 \%$ \\
\hline Beryllium & $\mathrm{Be}$ & $\mu \mathrm{g} / \mathrm{L}$ & 0 & 1.8 & 1.8 & 1.8 & $0 \%$ & $0.00 \%$ & $0.00 \%$ \\
\hline Boron & B & $\mu \mathrm{g} / \mathrm{L}$ & 1000 & 1800 & 1700 & 1800 & $11 \%$ & $5.71 \%$ & $0.00 \%$ \\
\hline Cadmium & $\mathrm{Cd}$ & $\mu \mathrm{g} / \mathrm{L}$ & 0 & 9.0 & 9.1 & 9.2 & $0 \%$ & $1.09 \%$ & $2.20 \%$ \\
\hline Calcium & $\mathrm{Ca}$ & $\mu \mathrm{g} / \mathrm{L}$ & 300 & 160000 & 160000 & 170000 & $0 \%$ & $6.06 \%$ & $6.06 \%$ \\
\hline Cerium & $\mathrm{Ce}$ & $\mu \mathrm{g} / \mathrm{L}$ & 1 & 2.6 & 2.7 & 2.7 & - & $0.00 \%$ & $3.77 \%$ \\
\hline Cesium & Cs & $\mu \mathrm{g} / \mathrm{L}$ & - & - & - & - & - & - & - \\
\hline Chromium & $\mathrm{Cr}$ & $\mu \mathrm{g} / \mathrm{L}$ & 5 & $<5.0$ & $<5.0$ & $<5.0$ & $0 \%$ & $0.00 \%$ & $0.00 \%$ \\
\hline Cobalt & Co & $\mu \mathrm{g} / \mathrm{L}$ & 0 & 55 & 56 & 57 & $0 \%$ & $1.77 \%$ & $3.57 \%$ \\
\hline Copper & $\mathrm{Cu}$ & $\mu \mathrm{g} / \mathrm{L}$ & 5 & 28000 & 28000 & 29000 & $0 \%$ & $3.51 \%$ & $3.51 \%$ \\
\hline Dysprosium & Dy & $\mu \mathrm{g} / \mathrm{L}$ & 0 & 1.6 & 1.7 & 1.7 & $3 \%$ & $0.00 \%$ & $6.06 \%$ \\
\hline Erbium & $\mathrm{Er}$ & $\mu \mathrm{g} / \mathrm{L}$ & 0 & 0.62 & 0.72 & 0.67 & $5 \%$ & $7.19 \%$ & $7.75 \%$ \\
\hline Europium & $\mathrm{Eu}$ & $\mu \mathrm{g} / \mathrm{L}$ & 0 & 0.42 & 0.51 & 0.48 & $1 \%$ & $6.06 \%$ & $13.33 \%$ \\
\hline Gadolinium & $\mathrm{Gd}$ & $\mu \mathrm{g} / \mathrm{L}$ & 0 & 2.0 & 2.1 & 2.1 & $2 \%$ & $0.00 \%$ & $4.88 \%$ \\
\hline Gallium & $\mathrm{Ga}$ & $\mu \mathrm{g} / \mathrm{L}$ & 5 & $<5.0$ & $<5.0$ & $<5.0$ & $0 \%$ & $0.00 \%$ & $0.00 \%$ \\
\hline Germanium & $\mathrm{Ge}$ & $\mu \mathrm{g} / \mathrm{L}$ & 1 & 1.4 & 1.4 & $<1.0$ & - & $33.33 \%$ & $33.33 \%$ \\
\hline Hafnium & $\mathrm{Hf}$ & $\mu \mathrm{g} / \mathrm{L}$ & - & - & - & - & - & - & - \\
\hline Holonium & $\mathrm{Ho}$ & $\mu \mathrm{g} / \mathrm{L}$ & 0 & 0.28 & 0.27 & 0.27 & $3 \%$ & $0.00 \%$ & $3.64 \%$ \\
\hline Iridium & Ir & $\mu \mathrm{g} / \mathrm{L}$ & 1 & $<0.5$ & $<0.5$ & $<0.5$ & $0 \%$ & $0.00 \%$ & $0.00 \%$ \\
\hline Iron & $\mathrm{Fe}$ & $\mu \mathrm{g} / \mathrm{L}$ & 50 & 23000 & 23000 & 24000 & $0 \%$ & $4.26 \%$ & $4.26 \%$ \\
\hline Lanthanum & La & $\mu \mathrm{g} / \mathrm{L}$ & 0 & 0.90 & 0.91 & 0.91 & $0 \%$ & $0.00 \%$ & $1.10 \%$ \\
\hline Lead & $\mathrm{Pb}$ & $\mu \mathrm{g} / \mathrm{L}$ & 0 & 0.54 & 0.52 & 0.55 & $0 \%$ & $5.61 \%$ & $1.83 \%$ \\
\hline Lithium & $\mathrm{Li}$ & $\mu \mathrm{g} / \mathrm{L}$ & 2 & 440 & 450 & 460 & $5 \%$ & $2.20 \%$ & $4.44 \%$ \\
\hline Lutetium & Lu & $\mu \mathrm{g} / \mathrm{L}$ & 0 & 0.053 & 0.066 & 0.055 & $0 \%$ & $18.18 \%$ & $3.70 \%$ \\
\hline Magnesium & $\mathrm{Mg}$ & $\mu \mathrm{g} / \mathrm{L}$ & 30 & 28000 & 28000 & 29000 & $0 \%$ & $3.51 \%$ & $3.51 \%$ \\
\hline Manganese & $\mathrm{Mn}$ & $\mu \mathrm{g} / \mathrm{L}$ & 0 & 3200 & 3000 & 3200 & $12 \%$ & $6.45 \%$ & $0.00 \%$ \\
\hline Molybdenum & Mo & $\mu \mathrm{g} / \mathrm{L}$ & 10 & $<10$ & $<10$ & $<10$ & $0 \%$ & $0.00 \%$ & $0.00 \%$ \\
\hline Neodymium & $\mathrm{Nd}$ & $\mu \mathrm{g} / \mathrm{L}$ & 0 & 2.2 & 2.3 & 2.5 & $0 \%$ & $8.33 \%$ & $12.77 \%$ \\
\hline Nickel & $\mathrm{Ni}$ & $\mu \mathrm{g} / \mathrm{L}$ & 1 & 38 & 40 & 40 & $11 \%$ & $0.00 \%$ & $5.13 \%$ \\
\hline Niobium & $\mathrm{Nb}$ & $\mu \mathrm{g} / \mathrm{L}$ & 0 & $<0.05$ & $<0.05$ & $<0.05$ & - & $0.00 \%$ & $0.00 \%$ \\
\hline Palladium & $\mathrm{Pd}$ & $\mu \mathrm{g} / \mathrm{L}$ & - & - & - & - & - & - & - \\
\hline Phosphorus & $P$ & $\mu \mathrm{g} / \mathrm{L}$ & 1000 & $<1000$ & $<1000$ & $<1000$ & $0 \%$ & $0.00 \%$ & $0.00 \%$ \\
\hline Platinum & $\mathrm{Pt}$ & $\mu \mathrm{g} / \mathrm{L}$ & 0 & $<0.05$ & $<0.05$ & $<0.05$ & $0 \%$ & $0.00 \%$ & $0.00 \%$ \\
\hline Potassium & $\mathrm{K}$ & $\mu \mathrm{g} / \mathrm{L}$ & 200 & 12000 & 12000 & 13000 & $0 \%$ & $8.00 \%$ & $8.00 \%$ \\
\hline Praseodymium & $\operatorname{Pr}$ & $\mu \mathrm{g} / \mathrm{L}$ & 0 & 0.44 & 0.44 & 0.44 & $0 \%$ & $0.00 \%$ & $0.00 \%$ \\
\hline Rhenium & $\operatorname{Re}$ & $\mu \mathrm{g} / \mathrm{L}$ & 0 & $<0.2$ & $<0.2$ & $<0.2$ & $0 \%$ & $0.00 \%$ & $0.00 \%$ \\
\hline Rhodium & $\mathrm{Rh}$ & $\mu \mathrm{g} / \mathrm{L}$ & 0 & $<0.1$ & $<0.1$ & $<0.1$ & $0 \%$ & $0.00 \%$ & $0.00 \%$ \\
\hline Rubidium & $\mathrm{Rb}$ & $\mu \mathrm{g} / \mathrm{L}$ & 1 & 120 & 120 & 120 & $0 \%$ & $0.00 \%$ & $0.00 \%$ \\
\hline Ruthenium & $\mathrm{Ru}$ & $\mu \mathrm{g} / \mathrm{L}$ & 0 & $<0.1$ & $<0.1$ & $<0.1$ & $0 \%$ & $0.00 \%$ & $0.00 \%$ \\
\hline Samarium & $\mathrm{Sm}$ & $\mu \mathrm{g} / \mathrm{L}$ & 0 & 1.1 & 1.1 & 1.1 & $0 \%$ & $0.00 \%$ & $0.00 \%$ \\
\hline Selenium & $\mathrm{Se}$ & $\mu \mathrm{g} / \mathrm{L}$ & 1 & $<1.0$ & $<1.0$ & $<1.0$ & $0 \%$ & $0.00 \%$ & $0.00 \%$ \\
\hline Silver & $\mathrm{Ag}$ & $\mu \mathrm{g} / \mathrm{L}$ & 0 & $<0.1$ & $<0.1$ & $<0.1$ & $0 \%$ & $0.00 \%$ & $0.00 \%$ \\
\hline Sodium & $\mathrm{Na}$ & $\mu \mathrm{g} / \mathrm{L}$ & 200 & 68000 & 68000 & 71000 & $0 \%$ & $4.32 \%$ & $4.32 \%$ \\
\hline Strontium & $\mathrm{Sr}$ & $\mu \mathrm{g} / \mathrm{L}$ & 1 & 1000 & 960 & 1000 & $0 \%$ & $4.08 \%$ & $0.00 \%$ \\
\hline Sulfur & $\mathrm{S}$ & $\mu \mathrm{g} / \mathrm{L}$ & 1000 & 270000 & 270000 & 270000 & $0 \%$ & $0.00 \%$ & $0.00 \%$ \\
\hline Tantalum & $\mathrm{Ta}$ & $\mu \mathrm{g} / \mathrm{L}$ & 0 & $<0.05$ & $<0.05$ & $<0.05$ & $0 \%$ & $0.00 \%$ & $0.00 \%$ \\
\hline Terbium & Tb & $\mu \mathrm{g} / \mathrm{L}$ & 0 & 0.32 & 0.32 & 0.33 & $0 \%$ & $3.08 \%$ & $3.08 \%$ \\
\hline Tellurium & $\mathrm{Te}$ & $\mu \mathrm{g} / \mathrm{L}$ & 1 & $<0.5$ & $<0.5$ & $<0.5$ & $0 \%$ & $0.00 \%$ & $0.00 \%$ \\
\hline Thalium & $\mathrm{TI}$ & $\mu \mathrm{g} / \mathrm{L}$ & 0 & 0.28 & 0.26 & 0.29 & - & $10.91 \%$ & $3.51 \%$ \\
\hline Thorium & Th & $\mu \mathrm{g} / \mathrm{L}$ & - & - & - & - & - & - & - \\
\hline Thulium & $\mathrm{Tm}$ & $\mu \mathrm{g} / \mathrm{L}$ & 0 & 0.076 & 0.088 & 0.085 & $1 \%$ & $3.47 \%$ & $11.18 \%$ \\
\hline $\operatorname{Tin} * *$ & Sn & $\mu \mathrm{g} / \mathrm{L}$ & 3 & $<3.0$ & $<3.0$ & $<3.0$ & $0 \%$ & $0.00 \%$ & $0.00 \%$ \\
\hline Titanium & $\mathrm{Ti}$ & $\mu \mathrm{g} / \mathrm{L}$ & 3 & $<3.0$ & $<3.0$ & $<3.0$ & $0 \%$ & $0.00 \%$ & $0.00 \%$ \\
\hline Tungsten & w & $\mu \mathrm{g} / \mathrm{L}$ & 1 & $<0.5$ & $<0.5$ & $<0.5$ & $0 \%$ & $0.00 \%$ & $0.00 \%$ \\
\hline Uranium & U & $\mu \mathrm{g} / \mathrm{L}$ & 0 & 2.9 & 2.8 & 2.9 & $3 \%$ & $3.51 \%$ & $0.00 \%$ \\
\hline Vanadium & $\mathrm{v}$ & $\mu \mathrm{g} / \mathrm{L}$ & 0 & $<0.3$ & $<0.3$ & $<0.3$ & $0 \%$ & $0.00 \%$ & $0.00 \%$ \\
\hline Ytterbium & $\mathrm{Yb}$ & $\mu \mathrm{g} / \mathrm{L}$ & 0 & 0.44 & 0.45 & 0.47 & $0 \%$ & $4.35 \%$ & $6.59 \%$ \\
\hline Yttrium & $\mathrm{Y}$ & $\mu \mathrm{g} / \mathrm{L}$ & 1 & 7.0 & 7.2 & 6.9 & $0 \%$ & $4.26 \%$ & $1.44 \%$ \\
\hline Zinc & $\mathrm{Zn}$ & $\mu \mathrm{g} / \mathrm{L}$ & 10 & 2000 & 1900 & 2000 & $10 \%$ & $5.13 \%$ & $0.00 \%$ \\
\hline Zirconium & $\mathrm{Zr}$ & $\mu \mathrm{g} / \mathrm{L}$ & 0 & $<0.1$ & $<0.1$ & 42 & $0 \%$ & $199.05 \%$ & $199.05 \%$ \\
\hline
\end{tabular}




\begin{tabular}{|c|c|c|c|c|c|c|c|c|c|}
\hline & Symbol & Units & $\begin{array}{l}\text { Sample name } \\
\text { Sample type } \\
\text { Sample number } \\
\text { Detection limit }\end{array}$ & $\begin{array}{l}\text { IN-RMATR-W } \\
\text { FA } \\
\text { No49 }\end{array}$ & $\begin{array}{c}\text { IN-RMATR-W } \\
\text { FA } \\
\text { No50 } \\
\text { Field Triplicate } \\
\end{array}$ & $\begin{array}{l}\text { IN-RMATR-W } \\
\text { FA } \\
\text { No51 }\end{array}$ & \%Diff 49-50 & \%Diff 49-51 & \%Diff 50-51 \\
\hline \multicolumn{10}{|l|}{ Sample description } \\
\hline \multicolumn{10}{|l|}{ Anions } \\
\hline Fluoride & $\mathrm{F}$ & $\mathrm{mg} / \mathrm{L}$ & $<0.05$ & 3.8 & 3.8 & 3.8 & - & - & - \\
\hline Chloride & $\mathrm{Cl}$ & $\mathrm{mg} / \mathrm{L}$ & $<0.05$ & 14.0 & 14.0 & 14.0 & - & - & - \\
\hline Nitrite & $\mathrm{NO}_{2-}^{-}$ & $\mathrm{mg} / \mathrm{L}$ & $<0.05$ & $<2.0$ & $<2.0$ & $<2.0$ & - & - & - \\
\hline Nitrate & $\mathrm{NO}_{3}-$ & $\mathrm{mg} / \mathrm{L}$ & $<0.05$ & $<2.0$ & $<2.0$ & $<2.0$ & - & - & - \\
\hline Sulphate & $\mathrm{SO}_{42-}$ & $\mathrm{mg} / \mathrm{L}$ & $<0.10$ & 860.0 & 860.0 & 860.0 & - & - & - \\
\hline $\mathrm{pH}$ & & - & & 3.5 & 3.5 & 3.5 & - & - & - \\
\hline \multicolumn{10}{|l|}{ Metals } \\
\hline Aluminium & Al & $\mu \mathrm{g} / \mathrm{L}$ & 5 & 30000 & 31000 & 31000 & $3.28 \%$ & $3.28 \%$ & $0.00 \%$ \\
\hline Antimony & $\mathrm{Sb}$ & $\mu \mathrm{g} / \mathrm{L}$ & 2 & $<2.0$ & $<2.0$ & $<2.0$ & $0.00 \%$ & $0.00 \%$ & $0.00 \%$ \\
\hline Arsenic & As & $\mu \mathrm{g} / \mathrm{L}$ & 2 & 74 & 78 & 79 & $5.26 \%$ & $6.54 \%$ & $1.27 \%$ \\
\hline Barium & $\mathrm{Ba}$ & $\mu \mathrm{g} / \mathrm{L}$ & 0 & 6.9 & 6.9 & 7.1 & $0.00 \%$ & $2.86 \%$ & $2.86 \%$ \\
\hline Beryllium & $\mathrm{Be}$ & $\mu \mathrm{g} / \mathrm{L}$ & 0 & 2.8 & 2.8 & 2.9 & $0.00 \%$ & $3.51 \%$ & $3.51 \%$ \\
\hline Boron & B & $\mu \mathrm{g} / \mathrm{L}$ & 1000 & 1600 & 1600 & 1600 & $0.00 \%$ & $0.00 \%$ & $0.00 \%$ \\
\hline Cadmium & $\mathrm{Cd}$ & $\mu \mathrm{g} / \mathrm{L}$ & 0 & 17 & 16 & 17 & $6.06 \%$ & $0.00 \%$ & $6.06 \%$ \\
\hline Calcium & $\mathrm{Ca}$ & $\mu \mathrm{g} / \mathrm{L}$ & 300 & 180000 & 170000 & 180000 & $5.71 \%$ & $0.00 \%$ & $5.71 \%$ \\
\hline Cerium & $\mathrm{Ce}$ & $\mu \mathrm{g} / \mathrm{L}$ & 1 & 6.6 & 6.7 & 7.0 & $1.50 \%$ & $5.88 \%$ & $4.38 \%$ \\
\hline Cesium & Cs & $\mu \mathrm{g} / \mathrm{L}$ & - & - & - & - & - & - & - \\
\hline Chromium & $\mathrm{Cr}$ & $\mu \mathrm{g} / \mathrm{L}$ & 5 & $<5.0$ & $<5.0$ & $<5.0$ & $0.00 \%$ & $0.00 \%$ & $0.00 \%$ \\
\hline Cobalt & Co & $\mu \mathrm{g} / \mathrm{L}$ & 0 & 87 & 87 & 89 & $0.00 \%$ & $2.27 \%$ & $2.27 \%$ \\
\hline Copper & $\mathrm{Cu}$ & $\mu \mathrm{g} / \mathrm{L}$ & 5 & 20000 & 20000 & 20000 & $0.00 \%$ & $0.00 \%$ & $0.00 \%$ \\
\hline Dysprosium & Dy & $\mu \mathrm{g} / \mathrm{L}$ & 0 & 3.3 & 3.2 & 3.3 & $3.08 \%$ & $0.00 \%$ & $3.08 \%$ \\
\hline Erbium & $\mathrm{Er}$ & $\mu \mathrm{g} / \mathrm{L}$ & 0 & 1.6 & 1.7 & 1.7 & $6.06 \%$ & $6.06 \%$ & $0.00 \%$ \\
\hline Europium & $\mathrm{Eu}$ & $\mu \mathrm{g} / \mathrm{L}$ & 0 & 0.74 & 0.77 & 0.80 & $3.97 \%$ & $7.79 \%$ & $3.82 \%$ \\
\hline Gadolinium & $\mathrm{Gd}$ & $\mu \mathrm{g} / \mathrm{L}$ & 0 & 3.5 & 3.3 & 3.6 & $5.88 \%$ & $2.82 \%$ & $8.70 \%$ \\
\hline Gallium & $\mathrm{Ga}$ & $\mu \mathrm{g} / \mathrm{L}$ & 5 & $<5.0$ & $<5.0$ & $<5.0$ & $0.00 \%$ & $0.00 \%$ & $0.00 \%$ \\
\hline Germanium & $\mathrm{Ge}$ & $\mu \mathrm{g} / \mathrm{L}$ & 1 & 1.3 & 1.0 & 1.3 & $26.09 \%$ & $0.00 \%$ & $26.09 \%$ \\
\hline Hafnium & $\mathrm{Hf}$ & $\mu \mathrm{g} / \mathrm{L}$ & - & - & - & - & - & - & - \\
\hline Holonium & Ho & $\mu \mathrm{g} / \mathrm{L}$ & 0 & 0.64 & 0.60 & 0.65 & $6.45 \%$ & $1.55 \%$ & $8.00 \%$ \\
\hline Iridium & Ir & $\mu \mathrm{g} / \mathrm{L}$ & 1 & $<0.5$ & $<0.5$ & $<0.5$ & $0.00 \%$ & $0.00 \%$ & $0.00 \%$ \\
\hline Iron & $\mathrm{Fe}$ & $\mu \mathrm{g} / \mathrm{L}$ & 50 & 23000 & 22000 & 23000 & $4.44 \%$ & $0.00 \%$ & $4.44 \%$ \\
\hline Lanthanum & La & $\mu \mathrm{g} / \mathrm{L}$ & 0 & 1.9 & 1.9 & 2.0 & $0.00 \%$ & $5.13 \%$ & $5.13 \%$ \\
\hline Lead & $\mathrm{Pb}$ & $\mu \mathrm{g} / \mathrm{L}$ & 0 & 0.82 & 1.1 & 0.80 & $29.17 \%$ & $2.47 \%$ & $31.58 \%$ \\
\hline Lithium & $\mathrm{Li}$ & $\mu \mathrm{g} / \mathrm{L}$ & 2 & 460 & 460 & 470 & $0.00 \%$ & $2.15 \%$ & $2.15 \%$ \\
\hline Lutetium & Lu & $\mu \mathrm{g} / \mathrm{L}$ & 0 & 0.15 & 0.16 & 0.17 & $6.45 \%$ & $12.50 \%$ & $6.06 \%$ \\
\hline Magnesium & $\mathrm{Mg}$ & $\mu \mathrm{g} / \mathrm{L}$ & 30 & 41000 & 41000 & 42000 & $0.00 \%$ & $2.41 \%$ & $2.41 \%$ \\
\hline Manganese & $\mathrm{Mn}$ & $\mu \mathrm{g} / \mathrm{L}$ & 0 & 5800 & 6000 & 6000 & $3.39 \%$ & $3.39 \%$ & $0.00 \%$ \\
\hline Molybdenum & Mo & $\mu \mathrm{g} / \mathrm{L}$ & 10 & $<10$ & $<10$ & $<10$ & $0.00 \%$ & $0.00 \%$ & $0.00 \%$ \\
\hline Neodymium & $\mathrm{Nd}$ & $\mu \mathrm{g} / \mathrm{L}$ & 0 & 5.9 & 6.1 & 5.8 & $3.33 \%$ & $1.71 \%$ & $5.04 \%$ \\
\hline Nickel & $\mathrm{Ni}$ & $\mu \mathrm{g} / \mathrm{L}$ & 1 & 59 & 57 & 60 & $3.45 \%$ & $1.68 \%$ & $5.13 \%$ \\
\hline Niobium & $\mathrm{Nb}$ & $\mu \mathrm{g} / \mathrm{L}$ & 0 & $<0.05$ & $<0.05$ & $<0.05$ & $0.00 \%$ & $0.00 \%$ & $0.00 \%$ \\
\hline Palladium & $\mathrm{Pd}$ & $\mu \mathrm{g} / \mathrm{L}$ & - & - & - & - & - & - & - \\
\hline Phosphorus & $P$ & $\mu \mathrm{g} / \mathrm{L}$ & 1000 & $<1000$ & $<1000$ & $<1000$ & $0.00 \%$ & $0.00 \%$ & $0.00 \%$ \\
\hline Platinum & $\mathrm{Pt}$ & $\mu \mathrm{g} / \mathrm{L}$ & 0 & $<0.05$ & $<0.05$ & $<0.05$ & $0.00 \%$ & $0.00 \%$ & $0.00 \%$ \\
\hline Potassium & $\mathrm{K}$ & $\mu \mathrm{g} / \mathrm{L}$ & 200 & 12000 & 11000 & 12000 & $8.70 \%$ & $0.00 \%$ & $8.70 \%$ \\
\hline Praseodymium & $\operatorname{Pr}$ & $\mu \mathrm{g} / \mathrm{L}$ & 0 & 1.1 & 1.0 & 1.1 & $9.52 \%$ & $0.00 \%$ & $9.52 \%$ \\
\hline Rhenium & $\operatorname{Re}$ & $\mu \mathrm{g} / \mathrm{L}$ & 0 & $<0.2$ & $<0.2$ & $<0.2$ & $0.00 \%$ & $0.00 \%$ & $0.00 \%$ \\
\hline Rhodium & $\mathrm{Rh}$ & $\mu \mathrm{g} / \mathrm{L}$ & 0 & $<0.1$ & $<0.1$ & $<0.1$ & $0.00 \%$ & $0.00 \%$ & $0.00 \%$ \\
\hline Rubidium & $\mathrm{Rb}$ & $\mu \mathrm{g} / \mathrm{L}$ & 1 & 120 & 110 & 120 & $8.70 \%$ & $0.00 \%$ & $8.70 \%$ \\
\hline Ruthenium & $\mathrm{Ru}$ & $\mu \mathrm{g} / \mathrm{L}$ & 0 & $<0.1$ & $<0.1$ & $<0.1$ & $0.00 \%$ & $0.00 \%$ & $0.00 \%$ \\
\hline Samarium & $\mathrm{Sm}$ & $\mu \mathrm{g} / \mathrm{L}$ & 0 & 2.4 & 2.3 & 2.0 & $4.26 \%$ & $18.18 \%$ & $13.95 \%$ \\
\hline Selenium & $\mathrm{Se}$ & $\mu \mathrm{g} / \mathrm{L}$ & 1 & $<1.0$ & $<1.0$ & $<1.0$ & $0.00 \%$ & $0.00 \%$ & $0.00 \%$ \\
\hline Silver & $\mathrm{Ag}$ & $\mu \mathrm{g} / \mathrm{L}$ & 0 & $<0.1$ & $<0.1$ & $<0.1$ & $0.00 \%$ & $0.00 \%$ & $0.00 \%$ \\
\hline Sodium & $\mathrm{Na}$ & $\mu \mathrm{g} / \mathrm{L}$ & 200 & 66000 & 66000 & 68000 & $0.00 \%$ & $2.99 \%$ & $2.99 \%$ \\
\hline Strontium & $\mathrm{Sr}$ & $\mu \mathrm{g} / \mathrm{L}$ & 1 & 890 & 890 & 900 & $0.00 \%$ & $1.12 \%$ & $1.12 \%$ \\
\hline Sulfur & $\mathrm{S}$ & $\mu \mathrm{g} / \mathrm{L}$ & 1000 & 310000 & 330000 & 320000 & $6.25 \%$ & $3.17 \%$ & $3.08 \%$ \\
\hline Tantalum & Ta & $\mu \mathrm{g} / \mathrm{L}$ & 0 & $<0.05$ & $<0.05$ & $<0.05$ & $0.00 \%$ & $0.00 \%$ & $0.00 \%$ \\
\hline Terbium & $\mathrm{Tb}$ & $\mu \mathrm{g} / \mathrm{L}$ & 0 & 0.60 & 0.60 & 0.60 & $0.00 \%$ & $0.00 \%$ & $0.00 \%$ \\
\hline Tellurium & $\mathrm{Te}$ & $\mu \mathrm{g} / \mathrm{L}$ & 1 & $<0.5$ & $<0.5$ & $<0.5$ & $0.00 \%$ & $0.00 \%$ & $0.00 \%$ \\
\hline Thalium & $\mathrm{Tl}$ & $\mu \mathrm{g} / \mathrm{L}$ & 0 & 0.52 & 0.54 & 0.58 & $3.77 \%$ & $10.91 \%$ & $7.14 \%$ \\
\hline Thorium & Th & $\mu \mathrm{g} / \mathrm{L}$ & - & - & - & - & - & - & - \\
\hline Thulium & $\mathrm{Tm}$ & $\mu \mathrm{g} / \mathrm{L}$ & 0 & 0.21 & 0.19 & 0.19 & $10.00 \%$ & $10.00 \%$ & $0.00 \%$ \\
\hline $\operatorname{Tin} * *$ & Sn & $\mu \mathrm{g} / \mathrm{L}$ & 3 & $<3.0$ & $<3.0$ & $<3.0$ & $0.00 \%$ & $0.00 \%$ & $0.00 \%$ \\
\hline Titanium & $\mathrm{Ti}$ & $\mu \mathrm{g} / \mathrm{L}$ & 3 & $<3.0$ & $<3.0$ & $<3.0$ & $0.00 \%$ & $0.00 \%$ & $0.00 \%$ \\
\hline Tungsten & w & $\mu \mathrm{g} / \mathrm{L}$ & 1 & $<0.5$ & $<0.5$ & $<0.5$ & $0.00 \%$ & $0.00 \%$ & $0.00 \%$ \\
\hline Uranium & $u$ & $\mu \mathrm{g} / \mathrm{L}$ & 0 & 7.2 & 7.1 & 7.4 & $1.40 \%$ & $2.74 \%$ & $4.14 \%$ \\
\hline Vanadium & $\mathrm{v}$ & $\mu \mathrm{g} / \mathrm{L}$ & 0 & $<0.3$ & $<0.3$ & $<0.3$ & $0.00 \%$ & $0.00 \%$ & $0.00 \%$ \\
\hline Ytterbium & $\mathrm{Yb}$ & $\mu \mathrm{g} / \mathrm{L}$ & 0 & 1.2 & 1.2 & 1.1 & $0.00 \%$ & $8.70 \%$ & $8.70 \%$ \\
\hline Yttrium & $Y$ & $\mu \mathrm{g} / \mathrm{L}$ & 1 & 17 & 17 & 17 & $0.00 \%$ & $0.00 \%$ & $0.00 \%$ \\
\hline Zinc & $\mathrm{Zn}$ & $\mu \mathrm{g} / \mathrm{L}$ & 10 & 3700 & 3800 & 3800 & $2.67 \%$ & $2.67 \%$ & $0.00 \%$ \\
\hline Zirconium & $\mathrm{Zr}$ & $\mu \mathrm{g} / \mathrm{L}$ & 0 & 3.1 & 1.2 & 0.77 & $88.37 \%$ & $120.41 \%$ & $43.65 \%$ \\
\hline
\end{tabular}




\begin{tabular}{|c|c|c|c|c|c|c|c|c|c|}
\hline & Symbol & Units & $\begin{array}{l}\text { Sample name } \\
\text { Sample type } \\
\text { Sample number } \\
\text { Detection limit }\end{array}$ & $\begin{array}{c}\text { IN2-W } \\
\text { FA } \\
\text { No52 }\end{array}$ & $\begin{array}{c}\text { IN2-W } \\
\text { FA } \\
\text { No53 } \\
\text { Field Triplicate } \\
\end{array}$ & $\begin{array}{l}\text { IN2-W } \\
\text { FA } \\
\text { No54 }\end{array}$ & \%Diff 52-53 & \%Diff 54-52 & \%Diff 53-54 \\
\hline \multicolumn{10}{|l|}{ Sample description } \\
\hline \multicolumn{10}{|l|}{ Anions } \\
\hline Fluoride & $\mathrm{F}$ & $\mathrm{mg} / \mathrm{L}$ & $<0.05$ & 2.4 & 2.4 & 2.4 & - & - & - \\
\hline Chloride & $\mathrm{Cl}$ & $\mathrm{mg} / \mathrm{L}$ & $<0.05$ & 12.5 & 12.5 & 12.5 & - & - & - \\
\hline Nitrite & $\mathrm{NO}_{2}-$ & $\mathrm{mg} / \mathrm{L}$ & $<0.05$ & $<2.0$ & $<2.0$ & $<2.0$ & - & - & - \\
\hline Nitrate & $\mathrm{NO}_{3}-$ & $\mathrm{mg} / \mathrm{L}$ & $<0.05$ & $<2.0$ & $<2.0$ & $<2.0$ & - & - & - \\
\hline Sulphate & $\mathrm{SO}_{42}-$ & $\mathrm{mg} / \mathrm{L}$ & $<0.10$ & 1050.0 & 1050.0 & 1050.0 & - & - & - \\
\hline $\mathrm{pH}$ & & - & & 3.4 & 3.4 & 3.4 & - & - & - \\
\hline \multicolumn{10}{|l|}{ Metals } \\
\hline Aluminium & Al & $\mu \mathrm{g} / \mathrm{L}$ & 5 & 46000 & 48000 & 46000 & $4.26 \%$ & $0.00 \%$ & $4.26 \%$ \\
\hline Antimony & $\mathrm{Sb}$ & $\mu \mathrm{g} / \mathrm{L}$ & 2 & $<2.0$ & $<2.0$ & $<2.0$ & $0.00 \%$ & $0.00 \%$ & $0.00 \%$ \\
\hline Arsenic & As & $\mu \mathrm{g} / \mathrm{L}$ & 2 & 2.3 & 2.4 & 2.7 & $4.26 \%$ & $16.00 \%$ & $11.76 \%$ \\
\hline Barium & $\mathrm{Ba}$ & $\mu \mathrm{g} / \mathrm{L}$ & 0 & 8.0 & 8.0 & 8.7 & $0.00 \%$ & $8.38 \%$ & $8.38 \%$ \\
\hline Beryllium & $\mathrm{Be}$ & $\mu \mathrm{g} / \mathrm{L}$ & 0 & 3.1 & 3.1 & 3.4 & $0.00 \%$ & $9.23 \%$ & $9.23 \%$ \\
\hline Boron & B & $\mu \mathrm{g} / \mathrm{L}$ & 1000 & 1400 & 1500 & 1400 & $6.90 \%$ & $0.00 \%$ & $6.90 \%$ \\
\hline Cadmium & $\mathrm{Cd}$ & $\mu \mathrm{g} / \mathrm{L}$ & 0 & 19 & 19 & 21 & $0.00 \%$ & $10.00 \%$ & $10.00 \%$ \\
\hline Calcium & $\mathrm{Ca}$ & $\mu \mathrm{g} / \mathrm{L}$ & 300 & 200000 & 200000 & 220000 & $0.00 \%$ & $9.52 \%$ & $9.52 \%$ \\
\hline Cerium & $\mathrm{Ce}$ & $\mu \mathrm{g} / \mathrm{L}$ & 1 & 11 & 12 & 12 & $8.70 \%$ & $8.70 \%$ & $0.00 \%$ \\
\hline Cesium & Cs & $\mu \mathrm{g} / \mathrm{L}$ & - & - & - & - & - & - & - \\
\hline Chromium & $\mathrm{Cr}$ & $\mu \mathrm{g} / \mathrm{L}$ & 5 & $<5.0$ & $<5.0$ & $<5.0$ & $0.00 \%$ & $0.00 \%$ & $0.00 \%$ \\
\hline Cobalt & Co & $\mu \mathrm{g} / \mathrm{L}$ & 0 & 110 & 110 & 120 & $0.00 \%$ & $8.70 \%$ & $8.70 \%$ \\
\hline Copper & $\mathrm{Cu}$ & $\mu \mathrm{g} / \mathrm{L}$ & 5 & 16000 & 16000 & 17000 & $0.00 \%$ & $6.06 \%$ & $6.06 \%$ \\
\hline Dysprosium & Dy & $\mu \mathrm{g} / \mathrm{L}$ & 0 & 4.6 & 4.8 & 5.2 & $4.26 \%$ & $12.24 \%$ & $8.00 \%$ \\
\hline Erbium & $\mathrm{Er}$ & $\mu \mathrm{g} / \mathrm{L}$ & 0 & 2.4 & 2.4 & 2.7 & $0.00 \%$ & $11.76 \%$ & $11.76 \%$ \\
\hline Europium & $\mathrm{Eu}$ & $\mu \mathrm{g} / \mathrm{L}$ & 0 & 1.1 & 1.1 & 1.1 & $0.00 \%$ & $0.00 \%$ & $0.00 \%$ \\
\hline Gadolinium & $\mathrm{Gd}$ & $\mu \mathrm{g} / \mathrm{L}$ & 0 & 4.7 & 4.7 & 5.4 & $0.00 \%$ & $13.86 \%$ & $13.86 \%$ \\
\hline Gallium & $\mathrm{Ga}$ & $\mu \mathrm{g} / \mathrm{L}$ & 5 & $<5.0$ & $<5.0$ & $<5.0$ & $0.00 \%$ & $0.00 \%$ & $0.00 \%$ \\
\hline Germanium & $\mathrm{Ge}$ & $\mu \mathrm{g} / \mathrm{L}$ & 1 & 1.1 & $<1.0$ & $<1.0$ & $9.52 \%$ & $9.52 \%$ & $0.00 \%$ \\
\hline Hafnium & $\mathrm{Hf}$ & $\mu \mathrm{g} / \mathrm{L}$ & - & - & - & - & - & - & - \\
\hline Holonium & $\mathrm{Ho}$ & $\mu \mathrm{g} / \mathrm{L}$ & 0 & 0.93 & 0.95 & 0.98 & $2.13 \%$ & $5.24 \%$ & $3.11 \%$ \\
\hline Iridium & Ir & $\mu \mathrm{g} / \mathrm{L}$ & 1 & $<0.5$ & $<0.5$ & $<0.5$ & $0.00 \%$ & $0.00 \%$ & $0.00 \%$ \\
\hline Iron & $\mathrm{Fe}$ & $\mu \mathrm{g} / \mathrm{L}$ & 50 & 13000 & 13000 & 15000 & $0.00 \%$ & $14.29 \%$ & $14.29 \%$ \\
\hline Lanthanum & La & $\mu \mathrm{g} / \mathrm{L}$ & 0 & 3.5 & 3.6 & 3.9 & $2.82 \%$ & $10.81 \%$ & $8.00 \%$ \\
\hline Lead & $\mathrm{Pb}$ & $\mu \mathrm{g} / \mathrm{L}$ & 0 & 0.86 & 0.92 & 1.0 & $6.74 \%$ & $15.05 \%$ & $8.33 \%$ \\
\hline Lithium & $\mathrm{Li}$ & $\mu \mathrm{g} / \mathrm{L}$ & 2 & 410 & 420 & 460 & $2.41 \%$ & $11.49 \%$ & $9.09 \%$ \\
\hline Lutetium & Lu & $\mu \mathrm{g} / \mathrm{L}$ & 0 & 0.22 & 0.25 & 0.26 & $12.77 \%$ & $16.67 \%$ & $3.92 \%$ \\
\hline Magnesium & $\mathrm{Mg}$ & $\mu \mathrm{g} / \mathrm{L}$ & 30 & 51000 & 51000 & 56000 & $0.00 \%$ & $9.35 \%$ & $9.35 \%$ \\
\hline Manganese & $\mathrm{Mn}$ & $\mu \mathrm{g} / \mathrm{L}$ & 0 & 7500 & 7600 & 7400 & $1.32 \%$ & $1.34 \%$ & $2.67 \%$ \\
\hline Molybdenum & Mo & $\mu \mathrm{g} / \mathrm{L}$ & 10 & $<10$ & $<10$ & $<10$ & $0.00 \%$ & $0.00 \%$ & $0.00 \%$ \\
\hline Neodymium & $\mathrm{Nd}$ & $\mu \mathrm{g} / \mathrm{L}$ & 0 & 9.8 & 9.6 & 10 & $2.06 \%$ & $2.02 \%$ & $4.08 \%$ \\
\hline Nickel & $\mathrm{Ni}$ & $\mu \mathrm{g} / \mathrm{L}$ & 1 & 74 & 75 & 83 & $1.34 \%$ & $11.46 \%$ & $10.13 \%$ \\
\hline Niobium & $\mathrm{Nb}$ & $\mu \mathrm{g} / \mathrm{L}$ & 0 & $<0.05$ & $<0.05$ & $<0.05$ & $0.00 \%$ & $0.00 \%$ & $0.00 \%$ \\
\hline Palladium & $\mathrm{Pd}$ & $\mu \mathrm{g} / \mathrm{L}$ & - & - & - & - & - & - & - \\
\hline Phosphorus & $P$ & $\mu \mathrm{g} / \mathrm{L}$ & 1000 & $<1000$ & $<1000$ & $<1000$ & $0.00 \%$ & $0.00 \%$ & $0.00 \%$ \\
\hline Platinum & $\mathrm{Pt}$ & $\mu \mathrm{g} / \mathrm{L}$ & 0 & $<0.05$ & $<0.05$ & $<0.05$ & $0.00 \%$ & $0.00 \%$ & $0.00 \%$ \\
\hline Potassium & K & $\mu \mathrm{g} / \mathrm{L}$ & 200 & 10000 & 10000 & 11000 & $0.00 \%$ & $9.52 \%$ & $9.52 \%$ \\
\hline Praseodymium & $\operatorname{Pr}$ & $\mu \mathrm{g} / \mathrm{L}$ & 0 & 1.8 & 1.9 & 1.9 & $5.41 \%$ & $5.41 \%$ & $0.00 \%$ \\
\hline Rhenium & $\operatorname{Re}$ & $\mu \mathrm{g} / \mathrm{L}$ & 0 & 0.23 & $<0.2$ & $<0.2$ & $13.95 \%$ & $13.95 \%$ & $0.00 \%$ \\
\hline Rhodium & $\mathrm{Rh}$ & $\mu \mathrm{g} / \mathrm{L}$ & 0 & $<0.1$ & $<0.1$ & $<0.1$ & $0.00 \%$ & $0.00 \%$ & $0.00 \%$ \\
\hline Rubidium & $\mathrm{Rb}$ & $\mu \mathrm{g} / \mathrm{L}$ & 1 & 95 & 96 & 100 & $1.05 \%$ & $5.13 \%$ & $4.08 \%$ \\
\hline Ruthenium & $\mathrm{Ru}$ & $\mu \mathrm{g} / \mathrm{L}$ & 0 & $<0.1$ & $<0.1$ & $<0.1$ & $0.00 \%$ & $0.00 \%$ & $0.00 \%$ \\
\hline Samarium & $\mathrm{Sm}$ & $\mu \mathrm{g} / \mathrm{L}$ & 0 & 3.3 & 3.2 & 3.5 & $3.08 \%$ & $5.88 \%$ & $8.96 \%$ \\
\hline Selenium & $\mathrm{Se}$ & $\mu \mathrm{g} / \mathrm{L}$ & 1 & $<1.0$ & $<1.0$ & 1.2 & $0.00 \%$ & $18.18 \%$ & $18.18 \%$ \\
\hline Silver & $\mathrm{Ag}$ & $\mu \mathrm{g} / \mathrm{L}$ & 0 & $<0.1$ & $<0.1$ & $<0.1$ & $0.00 \%$ & $0.00 \%$ & $0.00 \%$ \\
\hline Sodium & $\mathrm{Na}$ & $\mu \mathrm{g} / \mathrm{L}$ & 200 & 62000 & 63000 & 69000 & $1.60 \%$ & $10.69 \%$ & $9.09 \%$ \\
\hline Strontium & $\mathrm{Sr}$ & $\mu \mathrm{g} / \mathrm{L}$ & 1 & 810 & 830 & 890 & $2.44 \%$ & $9.41 \%$ & $6.98 \%$ \\
\hline Sulfur & $\mathrm{s}$ & $\mu \mathrm{g} / \mathrm{L}$ & 1000 & 420000 & 370000 & 360000 & $12.66 \%$ & $15.38 \%$ & $2.74 \%$ \\
\hline Tantalum & $\mathrm{Ta}$ & $\mu \mathrm{g} / \mathrm{L}$ & 0 & $<0.05$ & $<0.05$ & $<0.05$ & $0.00 \%$ & $0.00 \%$ & $0.00 \%$ \\
\hline Terbium & $\mathrm{Tb}$ & $\mu \mathrm{g} / \mathrm{L}$ & 0 & 0.81 & 0.84 & 0.91 & $3.64 \%$ & $11.63 \%$ & $8.00 \%$ \\
\hline Tellurium & $\mathrm{Te}$ & $\mu \mathrm{g} / \mathrm{L}$ & 1 & $<0.5$ & $<0.5$ & $<0.5$ & $0.00 \%$ & $0.00 \%$ & $0.00 \%$ \\
\hline Thalium & $\mathrm{TI}$ & $\mu \mathrm{g} / \mathrm{L}$ & 0 & 0.43 & 0.49 & 0.51 & $13.04 \%$ & $17.02 \%$ & $4.00 \%$ \\
\hline Thorium & Th & $\mu \mathrm{g} / \mathrm{L}$ & - & - & - & - & - & - & - \\
\hline Thulium & $\mathrm{Tm}$ & $\mu \mathrm{g} / \mathrm{L}$ & 0 & 0.29 & 0.31 & 0.33 & $6.67 \%$ & $12.90 \%$ & $6.25 \%$ \\
\hline $\operatorname{Tin} * *$ & Sn & $\mu \mathrm{g} / \mathrm{L}$ & 3 & $<3.0$ & $<3.0$ & $<3.0$ & $0.00 \%$ & $0.00 \%$ & $0.00 \%$ \\
\hline Titanium & $\mathrm{Ti}$ & $\mu \mathrm{g} / \mathrm{L}$ & 3 & $<3.0$ & $<3.0$ & $<3.0$ & $0.00 \%$ & $0.00 \%$ & $0.00 \%$ \\
\hline Tungsten & w & $\mu \mathrm{g} / \mathrm{L}$ & 1 & $<0.5$ & $<0.5$ & $<0.5$ & $0.00 \%$ & $0.00 \%$ & $0.00 \%$ \\
\hline Uranium & U & $\mu \mathrm{g} / \mathrm{L}$ & 0 & 10 & 11 & 11 & $9.52 \%$ & $9.52 \%$ & $0.00 \%$ \\
\hline Vanadium & $\mathrm{v}$ & $\mu \mathrm{g} / \mathrm{L}$ & 0 & $<0.3$ & $<0.3$ & $<0.3$ & $0.00 \%$ & $0.00 \%$ & $0.00 \%$ \\
\hline Ytterbium & $\mathrm{Yb}$ & $\mu \mathrm{g} / \mathrm{L}$ & 0 & 1.8 & 1.8 & 2.1 & $0.00 \%$ & $15.38 \%$ & $15.38 \%$ \\
\hline Yttrium & $\mathrm{Y}$ & $\mu \mathrm{g} / \mathrm{L}$ & 1 & 25 & 25 & 28 & $0.00 \%$ & $11.32 \%$ & $11.32 \%$ \\
\hline Zinc & $\mathrm{Zn}$ & $\mu \mathrm{g} / \mathrm{L}$ & 10 & 4100 & 4200 & 4000 & $2.41 \%$ & $2.47 \%$ & $4.88 \%$ \\
\hline Zirconium & $\mathrm{Zr}$ & $\mu \mathrm{g} / \mathrm{L}$ & 0 & 0.54 & 0.42 & 0.37 & $25.00 \%$ & $37.36 \%$ & $12.66 \%$ \\
\hline
\end{tabular}




\begin{tabular}{|c|c|c|c|c|c|c|c|c|c|}
\hline & Symbol & Units & $\begin{array}{l}\text { Sample name } \\
\text { Sample type } \\
\text { Sample number } \\
\text { Detection limit }\end{array}$ & $\begin{array}{l}\text { IN13-W } \\
\text { FA } \\
\text { No55 }\end{array}$ & $\begin{array}{c}\text { IN13-W } \\
\text { FA } \\
\text { No56 } \\
\text { Field Triplicate } \\
\end{array}$ & $\begin{array}{l}\text { IN13-W } \\
\text { FA } \\
\text { No57 }\end{array}$ & \%Diff 55-57 & \%Diff 55-56 & \%Diff 56-57 \\
\hline \multicolumn{10}{|l|}{ Sample description } \\
\hline \multicolumn{10}{|l|}{ Anions } \\
\hline Fluoride & $\mathrm{F}$ & $\mathrm{mg} / \mathrm{L}$ & $<0.05$ & 2.2 & 2.2 & 2.2 & - & - & - \\
\hline Chloride & $\mathrm{Cl}$ & $\mathrm{mg} / \mathrm{L}$ & $<0.05$ & 140.0 & 140.0 & 140.0 & - & - & - \\
\hline Nitrite & $\mathrm{NO}_{2}-$ & $\mathrm{mg} / \mathrm{L}$ & $<0.05$ & $<2.0$ & $<2.0$ & $<2.0$ & - & - & - \\
\hline Nitrate & $\mathrm{NO}_{3}-$ & $\mathrm{mg} / \mathrm{L}$ & $<0.05$ & $<2.0$ & $<2.0$ & $<2.0$ & - & - & - \\
\hline Sulphate & $\mathrm{SO}_{42}-$ & $\mathrm{mg} / \mathrm{L}$ & $<0.10$ & 995.0 & 995.0 & 995.0 & - & - & - \\
\hline $\mathrm{pH}$ & & - & & 4.3 & 4.3 & 4.3 & - & - & - \\
\hline \multicolumn{10}{|l|}{ Metals } \\
\hline Aluminium & Al & $\mu \mathrm{g} / \mathrm{L}$ & 5 & 24000 & 23000 & 24000 & $0.00 \%$ & $4.26 \%$ & $4.26 \%$ \\
\hline Antimony & $\mathrm{Sb}$ & $\mu \mathrm{g} / \mathrm{L}$ & 2 & $<2.0$ & $<2.0$ & $<2.0$ & $0.00 \%$ & $0.00 \%$ & $0.00 \%$ \\
\hline Arsenic & As & $\mu \mathrm{g} / \mathrm{L}$ & 2 & 61 & 64 & 62 & $1.63 \%$ & $4.80 \%$ & $3.17 \%$ \\
\hline Barium & $\mathrm{Ba}$ & $\mu \mathrm{g} / \mathrm{L}$ & 0 & 14 & 13 & 13 & $7.41 \%$ & $7.41 \%$ & $0.00 \%$ \\
\hline Beryllium & $\mathrm{Be}$ & $\mu \mathrm{g} / \mathrm{L}$ & 0 & 1.9 & 1.9 & 1.9 & $0.00 \%$ & $0.00 \%$ & $0.00 \%$ \\
\hline Boron & B & $\mu \mathrm{g} / \mathrm{L}$ & 1000 & 5500 & 5400 & 5600 & $1.80 \%$ & $1.83 \%$ & $3.64 \%$ \\
\hline Cadmium & $\mathrm{Cd}$ & $\mu \mathrm{g} / \mathrm{L}$ & 0 & 11 & 11 & 11 & $0.00 \%$ & $0.00 \%$ & $0.00 \%$ \\
\hline Calcium & $\mathrm{Ca}$ & $\mu \mathrm{g} / \mathrm{L}$ & 300 & 250000 & 250000 & 250000 & $0.00 \%$ & $0.00 \%$ & $0.00 \%$ \\
\hline Cerium & $\mathrm{Ce}$ & $\mu \mathrm{g} / \mathrm{L}$ & 1 & 9.2 & 9.2 & 8.9 & $3.31 \%$ & $0.00 \%$ & $3.31 \%$ \\
\hline Cesium & Cs & $\mu \mathrm{g} / \mathrm{L}$ & - & - & - & - & - & - & - \\
\hline Chromium & $\mathrm{Cr}$ & $\mu \mathrm{g} / \mathrm{L}$ & 5 & $<5.0$ & $<5.0$ & $<5.0$ & $0.00 \%$ & $0.00 \%$ & $0.00 \%$ \\
\hline Cobalt & Co & $\mu \mathrm{g} / \mathrm{L}$ & 0 & 75 & 75 & 73 & $2.70 \%$ & $0.00 \%$ & $2.70 \%$ \\
\hline Copper & $\mathrm{Cu}$ & $\mu \mathrm{g} / \mathrm{L}$ & 5 & 8600 & 8500 & 8300 & $3.55 \%$ & $1.17 \%$ & $2.38 \%$ \\
\hline Dysprosium & Dy & $\mu \mathrm{g} / \mathrm{L}$ & 0 & 3.5 & 3.4 & 3.2 & $8.96 \%$ & $2.90 \%$ & $6.06 \%$ \\
\hline Erbium & $\mathrm{Er}$ & $\mu \mathrm{g} / \mathrm{L}$ & 0 & 1.7 & 1.7 & 1.6 & $6.06 \%$ & $0.00 \%$ & $6.06 \%$ \\
\hline Europium & $\mathrm{Eu}$ & $\mu \mathrm{g} / \mathrm{L}$ & 0 & 0.91 & 0.68 & 0.66 & $31.85 \%$ & $28.93 \%$ & $2.99 \%$ \\
\hline Gadolinium & $\mathrm{Gd}$ & $\mu \mathrm{g} / \mathrm{L}$ & 0 & 3.6 & 3.6 & 3.5 & $2.82 \%$ & $0.00 \%$ & $2.82 \%$ \\
\hline Gallium & $\mathrm{Ga}$ & $\mu \mathrm{g} / \mathrm{L}$ & 5 & $<5.0$ & $<5.0$ & $<5.0$ & $0.00 \%$ & $0.00 \%$ & $0.00 \%$ \\
\hline Germanium & $\mathrm{Ge}$ & $\mu \mathrm{g} / \mathrm{L}$ & 1 & 1.8 & 1.3 & 1.6 & $11.76 \%$ & $32.26 \%$ & $20.69 \%$ \\
\hline Hafnium & $\mathrm{Hf}$ & $\mu \mathrm{g} / \mathrm{L}$ & - & - & - & - & - & - & - \\
\hline Holonium & $\mathrm{Ho}$ & $\mu \mathrm{g} / \mathrm{L}$ & 0 & 0.67 & 0.64 & 0.63 & $6.15 \%$ & $4.58 \%$ & $1.57 \%$ \\
\hline Iridium & Ir & $\mu \mathrm{g} / \mathrm{L}$ & 1 & $<0.5$ & $<0.5$ & $<0.5$ & $0.00 \%$ & $0.00 \%$ & $0.00 \%$ \\
\hline Iron & $\mathrm{Fe}$ & $\mu \mathrm{g} / \mathrm{L}$ & 50 & 3600 & 3600 & 3500 & $2.82 \%$ & $0.00 \%$ & $2.82 \%$ \\
\hline Lanthanum & La & $\mu \mathrm{g} / \mathrm{L}$ & 0 & 3.2 & 3.2 & 3.2 & $0.00 \%$ & $0.00 \%$ & $0.00 \%$ \\
\hline Lead & $\mathrm{Pb}$ & $\mu \mathrm{g} / \mathrm{L}$ & 0 & 0.31 & 0.34 & 0.33 & $6.25 \%$ & $9.23 \%$ & $2.99 \%$ \\
\hline Lithium & $\mathrm{Li}$ & $\mu \mathrm{g} / \mathrm{L}$ & 2 & 1300 & 1300 & 1300 & $0.00 \%$ & $0.00 \%$ & $0.00 \%$ \\
\hline Lutetium & Lu & $\mu \mathrm{g} / \mathrm{L}$ & 0 & 0.16 & 0.17 & 0.17 & $6.06 \%$ & $6.06 \%$ & $0.00 \%$ \\
\hline Magnesium & $\mathrm{Mg}$ & $\mu \mathrm{g} / \mathrm{L}$ & 30 & 63000 & 62000 & 61000 & $3.23 \%$ & $1.60 \%$ & $1.63 \%$ \\
\hline Manganese & $\mathrm{Mn}$ & $\mu \mathrm{g} / \mathrm{L}$ & 0 & 5100 & 5000 & 5400 & $5.71 \%$ & $1.98 \%$ & $7.69 \%$ \\
\hline Molybdenum & Mo & $\mu \mathrm{g} / \mathrm{L}$ & 10 & $<10$ & $<10$ & $<10$ & $0.00 \%$ & $0.00 \%$ & $0.00 \%$ \\
\hline Neodymium & $\mathrm{Nd}$ & $\mu \mathrm{g} / \mathrm{L}$ & 0 & 7.7 & 7.7 & 7.4 & $3.97 \%$ & $0.00 \%$ & $3.97 \%$ \\
\hline Nickel & $\mathrm{Ni}$ & $\mu \mathrm{g} / \mathrm{L}$ & 1 & 51 & 50 & 50 & $1.98 \%$ & $1.98 \%$ & $0.00 \%$ \\
\hline Niobium & $\mathrm{Nb}$ & $\mu \mathrm{g} / \mathrm{L}$ & 0 & $<0.05$ & $<0.05$ & $<0.05$ & $0.00 \%$ & $0.00 \%$ & $0.00 \%$ \\
\hline Palladium & $\mathrm{Pd}$ & $\mu \mathrm{g} / \mathrm{L}$ & - & - & - & - & - & - & - \\
\hline Phosphorus & $P$ & $\mu \mathrm{g} / \mathrm{L}$ & 1000 & $<1000$ & $<1000$ & $<1000$ & $0.00 \%$ & $0.00 \%$ & $0.00 \%$ \\
\hline Platinum & $\mathrm{Pt}$ & $\mu \mathrm{g} / \mathrm{L}$ & 0 & $<0.05$ & $<0.05$ & $<0.05$ & $0.00 \%$ & $0.00 \%$ & $0.00 \%$ \\
\hline Potassium & K & $\mu \mathrm{g} / \mathrm{L}$ & 200 & 15000 & 15000 & 15000 & $0.00 \%$ & $0.00 \%$ & $0.00 \%$ \\
\hline Praseodymium & $\operatorname{Pr}$ & $\mu \mathrm{g} / \mathrm{L}$ & 0 & 1.5 & 1.5 & 1.4 & $6.90 \%$ & $0.00 \%$ & $6.90 \%$ \\
\hline Rhenium & $\operatorname{Re}$ & $\mu \mathrm{g} / \mathrm{L}$ & 0 & 0.21 & $<0.2$ & 0.24 & $13.33 \%$ & $4.88 \%$ & $18.18 \%$ \\
\hline Rhodium & $\mathrm{Rh}$ & $\mu \mathrm{g} / \mathrm{L}$ & 0 & $<0.1$ & $<0.1$ & $<0.1$ & $0.00 \%$ & $0.00 \%$ & $0.00 \%$ \\
\hline Rubidium & $\mathrm{Rb}$ & $\mu \mathrm{g} / \mathrm{L}$ & 1 & 140 & 140 & 140 & $0.00 \%$ & $0.00 \%$ & $0.00 \%$ \\
\hline Ruthenium & $\mathrm{Ru}$ & $\mu \mathrm{g} / \mathrm{L}$ & 0 & $<0.1$ & $<0.1$ & $<0.1$ & $0.00 \%$ & $0.00 \%$ & $0.00 \%$ \\
\hline Samarium & $\mathrm{Sm}$ & $\mu \mathrm{g} / \mathrm{L}$ & 0 & 2.4 & 2.4 & 2.5 & $4.08 \%$ & $0.00 \%$ & $4.08 \%$ \\
\hline Selenium & $\mathrm{Se}$ & $\mu \mathrm{g} / \mathrm{L}$ & 1 & 1.7 & 2.1 & 2.1 & $21.05 \%$ & $21.05 \%$ & $0.00 \%$ \\
\hline Silver & $\mathrm{Ag}$ & $\mu \mathrm{g} / \mathrm{L}$ & 0 & $<0.1$ & $<0.1$ & $<0.1$ & $0.00 \%$ & $0.00 \%$ & $0.00 \%$ \\
\hline Sodium & $\mathrm{Na}$ & $\mu \mathrm{g} / \mathrm{L}$ & 200 & 180000 & 180000 & 180000 & $0.00 \%$ & $0.00 \%$ & $0.00 \%$ \\
\hline Strontium & $\mathrm{Sr}$ & $\mu \mathrm{g} / \mathrm{L}$ & 1 & 1100 & 1100 & 1100 & $0.00 \%$ & $0.00 \%$ & $0.00 \%$ \\
\hline Sulfur & $\mathrm{S}$ & $\mu \mathrm{g} / \mathrm{L}$ & 1000 & 350000 & 350000 & 360000 & $2.82 \%$ & $0.00 \%$ & $2.82 \%$ \\
\hline Tantalum & $\mathrm{Ta}$ & $\mu \mathrm{g} / \mathrm{L}$ & 0 & $<0.05$ & $<0.05$ & $<0.05$ & $0.00 \%$ & $0.00 \%$ & $0.00 \%$ \\
\hline Terbium & Tb & $\mu \mathrm{g} / \mathrm{L}$ & 0 & 0.61 & 0.61 & 0.57 & $6.78 \%$ & $0.00 \%$ & $6.78 \%$ \\
\hline Tellurium & $\mathrm{Te}$ & $\mu \mathrm{g} / \mathrm{L}$ & 1 & $<0.5$ & $<0.5$ & $<0.5$ & $0.00 \%$ & $0.00 \%$ & $0.00 \%$ \\
\hline Thalium & $\mathrm{TI}$ & $\mu \mathrm{g} / \mathrm{L}$ & 0 & 0.48 & 0.44 & 0.45 & $6.45 \%$ & $8.70 \%$ & $2.25 \%$ \\
\hline Thorium & Th & $\mu \mathrm{g} / \mathrm{L}$ & - & - & - & - & - & - & - \\
\hline Thulium & $\mathrm{Tm}$ & $\mu \mathrm{g} / \mathrm{L}$ & 0 & 0.21 & 0.22 & 0.21 & $0.00 \%$ & $4.65 \%$ & $4.65 \%$ \\
\hline $\operatorname{Tin} * *$ & Sn & $\mu \mathrm{g} / \mathrm{L}$ & 3 & $<3.0$ & $<3.0$ & $<3.0$ & $0.00 \%$ & $0.00 \%$ & $0.00 \%$ \\
\hline Titanium & $\mathrm{Ti}$ & $\mu \mathrm{g} / \mathrm{L}$ & 3 & $<3.0$ & $<3.0$ & $<3.0$ & $0.00 \%$ & $0.00 \%$ & $0.00 \%$ \\
\hline Tungsten & w & $\mu \mathrm{g} / \mathrm{L}$ & 1 & $<0.5$ & $<0.5$ & $<0.5$ & $0.00 \%$ & $0.00 \%$ & $0.00 \%$ \\
\hline Uranium & U & $\mu \mathrm{g} / \mathrm{L}$ & 0 & 6.0 & 5.8 & 5.7 & $5.13 \%$ & $3.39 \%$ & $1.74 \%$ \\
\hline Vanadium & $\mathrm{v}$ & $\mu \mathrm{g} / \mathrm{L}$ & 0 & $<0.3$ & $<0.3$ & $<0.3$ & $0.00 \%$ & $0.00 \%$ & $0.00 \%$ \\
\hline Ytterbium & $\mathrm{Yb}$ & $\mu \mathrm{g} / \mathrm{L}$ & 0 & 1.4 & 1.2 & 1.1 & $24.00 \%$ & $15.38 \%$ & $8.70 \%$ \\
\hline Yttrium & $\mathrm{Y}$ & $\mu \mathrm{g} / \mathrm{L}$ & 1 & 19 & 19 & 19 & $0.00 \%$ & $0.00 \%$ & $0.00 \%$ \\
\hline Zinc & $\mathrm{Zn}$ & $\mu \mathrm{g} / \mathrm{L}$ & 10 & 2400 & 2300 & 2400 & $0.00 \%$ & $4.26 \%$ & $4.26 \%$ \\
\hline Zirconium & $\mathrm{Zr}$ & $\mu \mathrm{g} / \mathrm{L}$ & 0 & 0.33 & 0.28 & 0.27 & $20.00 \%$ & $16.39 \%$ & $3.64 \%$ \\
\hline
\end{tabular}




\begin{tabular}{|c|c|c|c|c|c|c|}
\hline & Symbol & Units & $\begin{array}{c}\text { Sample name } \\
\text { Sample type } \\
\text { Sample number } \\
\text { Detection limit }\end{array}$ & $\begin{array}{l}\text { P-ARD-17-W } \\
\text { FA } \\
\text { No73 } \\
\text { Field }\end{array}$ & $\begin{array}{l}\text { P-ARD-17-W } \\
\text { FA } \\
\text { No74 } \\
\text { icate }\end{array}$ & \%Diff 73-74 \\
\hline \multicolumn{7}{|l|}{ Sample description } \\
\hline \multicolumn{7}{|l|}{ Anions } \\
\hline Fluoride & $\mathrm{F}$ & $\mathrm{mg} / \mathrm{L}$ & $<0.05$ & $<0.10$ & $<0.10$ & - \\
\hline Chloride & $\mathrm{Cl}$ & $\mathrm{mg} / \mathrm{L}$ & $<0.05$ & 0.5 & 0.5 & - \\
\hline Nitrite & $\mathrm{NO}_{2}-$ & $\mathrm{mg} / \mathrm{L}$ & $<0.05$ & $<0.10$ & $<0.10$ & - \\
\hline Nitrate & $\mathrm{NO}_{3}-$ & $\mathrm{mg} / \mathrm{L}$ & $<0.05$ & $<0.10$ & $<0.10$ & - \\
\hline Sulphate & $\mathrm{SO}_{42-}-$ & $\mathrm{mg} / \mathrm{L}$ & $<0.10$ & 54.0 & 54.0 & - \\
\hline $\mathrm{pH}$ & & - & & 3.1 & 3.1 & - \\
\hline \multicolumn{7}{|l|}{ Metals } \\
\hline Aluminium & Al & $\mu \mathrm{g} / \mathrm{L}$ & 5 & 2300 & 2400 & $4 \%$ \\
\hline Antimony & $\mathrm{Sb}$ & $\mu \mathrm{g} / \mathrm{L}$ & 2 & 4.5 & 4.7 & $4 \%$ \\
\hline Arsenic & As & $\mu \mathrm{g} / \mathrm{L}$ & 2 & 33 & 33 & $0 \%$ \\
\hline Barium & $\mathrm{Ba}$ & $\mu \mathrm{g} / \mathrm{L}$ & 0 & 23 & 22 & $4 \%$ \\
\hline Beryllium & $\mathrm{Be}$ & $\mu \mathrm{g} / \mathrm{L}$ & 0 & $<0.2$ & $<0.2$ & $0 \%$ \\
\hline Boron & B & $\mu \mathrm{g} / \mathrm{L}$ & 1000 & $<1000$ & $<1000$ & $0 \%$ \\
\hline Cadmium & $\mathrm{Cd}$ & $\mu \mathrm{g} / \mathrm{L}$ & 0 & 2.2 & 1.9 & $15 \%$ \\
\hline Calcium & $\mathrm{Ca}$ & $\mu \mathrm{g} / \mathrm{L}$ & 300 & 2300 & 2600 & $12 \%$ \\
\hline Cerium & $\mathrm{Ce}$ & $\mu \mathrm{g} / \mathrm{L}$ & 1 & 1.0 & 0.96 & $4 \%$ \\
\hline Cesium & Cs & $\mu \mathrm{g} / \mathrm{L}$ & - & - & - & \\
\hline Chromium & $\mathrm{Cr}$ & $\mu \mathrm{g} / \mathrm{L}$ & 5 & $<5.0$ & $<5.0$ & $0 \%$ \\
\hline Cobalt & Co & $\mu \mathrm{g} / \mathrm{L}$ & 0 & 3.3 & 3.5 & $6 \%$ \\
\hline Copper & $\mathrm{Cu}$ & $\mu \mathrm{g} / \mathrm{L}$ & 5 & 600 & 620 & $3 \%$ \\
\hline Dysprosium & Dy & $\mu \mathrm{g} / \mathrm{L}$ & 0 & 0.25 & 0.22 & $13 \%$ \\
\hline Erbium & $\mathrm{Er}$ & $\mu \mathrm{g} / \mathrm{L}$ & 0 & 0.15 & 0.13 & $14 \%$ \\
\hline Europium & $\mathrm{Eu}$ & $\mu \mathrm{g} / \mathrm{L}$ & 0 & 0.033 & 0.082 & $85 \%$ \\
\hline Gadolinium & $\mathrm{Gd}$ & $\mu \mathrm{g} / \mathrm{L}$ & 0 & 0.25 & 0.21 & $17 \%$ \\
\hline Gallium & $\mathrm{Ga}$ & $\mu \mathrm{g} / \mathrm{L}$ & 5 & $<5.0$ & $<5.0$ & $0 \%$ \\
\hline Germanium & $\mathrm{Ge}$ & $\mu \mathrm{g} / \mathrm{L}$ & 1 & $<1.0$ & $<1.0$ & $0 \%$ \\
\hline Hafnium & $\mathrm{Hf}$ & $\mu \mathrm{g} / \mathrm{L}$ & - & - & - & \\
\hline Holonium & Ho & $\mu \mathrm{g} / \mathrm{L}$ & 0 & 0.052 & 0.050 & $4 \%$ \\
\hline Iridium & Ir & $\mu \mathrm{g} / \mathrm{L}$ & 1 & $<0.5$ & $<0.5$ & $0 \%$ \\
\hline Iron & $\mathrm{Fe}$ & $\mu \mathrm{g} / \mathrm{L}$ & 50 & 5000 & 5100 & $2 \%$ \\
\hline Lanthanum & La & $\mu \mathrm{g} / \mathrm{L}$ & 0 & 0.45 & 0.44 & $2 \%$ \\
\hline Lead & $\mathrm{Pb}$ & $\mu \mathrm{g} / \mathrm{L}$ & 0 & 5.2 & 4.7 & $10 \%$ \\
\hline Lithium & $\mathrm{Li}$ & $\mu \mathrm{g} / \mathrm{L}$ & 2 & $<2.0$ & $<2.0$ & $0 \%$ \\
\hline Lutetium & Lu & $\mu \mathrm{g} / \mathrm{L}$ & 0 & $<0.05$ & $<0.05$ & $0 \%$ \\
\hline Magnesium & $\mathrm{Mg}$ & $\mu \mathrm{g} / \mathrm{L}$ & 30 & 710 & 730 & $3 \%$ \\
\hline Manganese & $\mathrm{Mn}$ & $\mu \mathrm{g} / \mathrm{L}$ & 0 & 1600 & 1600 & $0 \%$ \\
\hline Molybdenum & Mo & $\mu \mathrm{g} / \mathrm{L}$ & 10 & $<10$ & $<10$ & $0 \%$ \\
\hline Neodymium & $\mathrm{Nd}$ & $\mu \mathrm{g} / \mathrm{L}$ & 0 & 0.70 & 0.68 & $3 \%$ \\
\hline Nickel & $\mathrm{Ni}$ & $\mu \mathrm{g} / \mathrm{L}$ & 1 & 2.4 & 2.4 & $0 \%$ \\
\hline Niobium & $\mathrm{Nb}$ & $\mu \mathrm{g} / \mathrm{L}$ & 0 & $<0.05$ & $<0.05$ & $0 \%$ \\
\hline Palladium & $\mathrm{Pd}$ & $\mu \mathrm{g} / \mathrm{L}$ & - & - & - & \\
\hline Phosphorus & $\mathrm{P}$ & $\mu \mathrm{g} / \mathrm{L}$ & 1000 & $<1000$ & $<1000$ & $0 \%$ \\
\hline Platinum & $\mathrm{Pt}$ & $\mu \mathrm{g} / \mathrm{L}$ & 0 & $<0.05$ & $<0.05$ & $0 \%$ \\
\hline Potassium & $\mathrm{K}$ & $\mu \mathrm{g} / \mathrm{L}$ & 200 & 1300 & 1300 & $0 \%$ \\
\hline Praseodymium & $\mathrm{Pr}$ & $\mu \mathrm{g} / \mathrm{L}$ & 0 & 0.15 & 0.15 & $0 \%$ \\
\hline Rhenium & $\operatorname{Re}$ & $\mu \mathrm{g} / \mathrm{L}$ & 0 & $<0.2$ & $<0.2$ & $0 \%$ \\
\hline Rhodium & $\mathrm{Rh}$ & $\mu \mathrm{g} / \mathrm{L}$ & 0 & $<0.1$ & $<0.1$ & $0 \%$ \\
\hline Rubidium & $\mathrm{Rb}$ & $\mu \mathrm{g} / \mathrm{L}$ & 1 & 6.6 & 6.2 & $6 \%$ \\
\hline Ruthenium & $\mathrm{Ru}$ & $\mu \mathrm{g} / \mathrm{L}$ & 0 & $<0.1$ & $<0.1$ & $0 \%$ \\
\hline Samarium & $\mathrm{Sm}$ & $\mu \mathrm{g} / \mathrm{L}$ & 0 & 0.21 & 0.19 & $10 \%$ \\
\hline Selenium & Se & $\mu \mathrm{g} / \mathrm{L}$ & 1 & $<1.0$ & 1.0 & $0 \%$ \\
\hline Silver & $\mathrm{Ag}$ & $\mu \mathrm{g} / \mathrm{L}$ & 0 & $<0.1$ & $<0.1$ & $0 \%$ \\
\hline Sodium & $\mathrm{Na}$ & $\mu \mathrm{g} / \mathrm{L}$ & 200 & 1100 & 1100 & $0 \%$ \\
\hline Strontium & $\mathrm{Sr}$ & $\mu \mathrm{g} / \mathrm{L}$ & 1 & 8.7 & 9.3 & $7 \%$ \\
\hline Sulfur & $\mathrm{S}$ & $\mu \mathrm{g} / \mathrm{L}$ & 1000 & 20000 & 20000 & $0 \%$ \\
\hline Tantalum & Ta & $\mu \mathrm{g} / \mathrm{L}$ & 0 & $<0.05$ & $<0.05$ & $0 \%$ \\
\hline Terbium & $\mathrm{Tb}$ & $\mu \mathrm{g} / \mathrm{L}$ & 0 & $<0.05$ & $<0.05$ & $0 \%$ \\
\hline Tellurium & $\mathrm{Te}$ & $\mu \mathrm{g} / \mathrm{L}$ & 1 & $<0.5$ & $<0.5$ & $0 \%$ \\
\hline Thalium & $\mathrm{Tl}$ & $\mu \mathrm{g} / \mathrm{L}$ & 0 & $<0.1$ & $<0.1$ & $0 \%$ \\
\hline Thorium & Th & $\mu \mathrm{g} / \mathrm{L}$ & - & - & - & \\
\hline Thulium & $\mathrm{Tm}$ & $\mu \mathrm{g} / \mathrm{L}$ & 0 & $<0.05$ & $<0.05$ & $0 \%$ \\
\hline $\operatorname{Tin} * *$ & Sn & $\mu \mathrm{g} / \mathrm{L}$ & 3 & $<3.0$ & $<3.0$ & $0 \%$ \\
\hline Titanium & $\mathrm{Ti}$ & $\mu \mathrm{g} / \mathrm{L}$ & 3 & $<3.0$ & $<3.0$ & $0 \%$ \\
\hline Tungsten & w & $\mu \mathrm{g} / \mathrm{L}$ & 1 & $<0.5$ & $<0.5$ & $0 \%$ \\
\hline Uranium & $U$ & $\mu \mathrm{g} / \mathrm{L}$ & 0 & 0.20 & 0.20 & $0 \%$ \\
\hline Vanadium & v & $\mu \mathrm{g} / \mathrm{L}$ & 0 & $<0.3$ & $<0.3$ & $0 \%$ \\
\hline Ytterbium & $\mathrm{Yb}$ & $\mu \mathrm{g} / \mathrm{L}$ & 0 & $<0.2$ & $<0.2$ & $0 \%$ \\
\hline Yttrium & $Y$ & $\mu \mathrm{g} / \mathrm{L}$ & 1 & 1.3 & 1.5 & $14 \%$ \\
\hline Zinc & $\mathrm{Zn}$ & $\mu \mathrm{g} / \mathrm{L}$ & 10 & 1800 & 1800 & $0 \%$ \\
\hline Zirconium & $\mathrm{Zr}$ & $\mu \mathrm{g} / \mathrm{L}$ & 0 & $<0.1$ & $<0.1$ & $0 \%$ \\
\hline
\end{tabular}




\begin{tabular}{|c|c|c|c|c|c|c|}
\hline & & & $\begin{array}{l}\text { Sample name } \\
\text { Sample type } \\
\text { Sample number }\end{array}$ & $\begin{array}{c}\text { P-ARD17-W } \\
\text { UA } \\
\text { No66 }\end{array}$ & $\begin{array}{c}\text { P-ARD17-W } \\
\text { UA } \\
\text { No65 * }\end{array}$ & \%Diff 65-66 \\
\hline & Symbol & Units & Detection limit & \multicolumn{2}{|c|}{ Field Duplicate } & \\
\hline \multicolumn{7}{|l|}{ Sample description } \\
\hline \multicolumn{7}{|l|}{ Anions } \\
\hline Fluoride & $\mathrm{F}$ & $\mathrm{mg} / \mathrm{L}$ & $<0.05$ & $<0.10$ & $<0.10$ & - \\
\hline Chloride & $\mathrm{Cl}$ & $\mathrm{mg} / \mathrm{L}$ & $<0.05$ & 0.5 & 0.5 & - \\
\hline Nitrite & $\mathrm{NO}_{2-}^{-}$ & $\mathrm{mg} / \mathrm{L}$ & $<0.05$ & $<0.10$ & $<0.10$ & - \\
\hline Nitrate & $\mathrm{NO}_{3-}^{-}$ & $\mathrm{mg} / \mathrm{L}$ & $<0.05$ & $<0.10$ & $<0.10$ & - \\
\hline Sulphate & $\mathrm{SO}_{42-}$ & $\mathrm{mg} / \mathrm{L}$ & $<0.10$ & 54.0 & 54.0 & - \\
\hline $\mathrm{pH}$ & & - & & 3.1 & 3.1 & - \\
\hline \multicolumn{7}{|l|}{ Metals } \\
\hline Aluminium & Al & $\mu g / L$ & 5 & 2200 & 2200 & $0 \%$ \\
\hline Antimony & $\mathrm{Sb}$ & $\mu \mathrm{g} / \mathrm{L}$ & 2 & 4.7 & 4.7 & $0 \%$ \\
\hline Arsenic & As & $\mu \mathrm{g} / \mathrm{L}$ & 2 & 35 & 34 & $3 \%$ \\
\hline Barium & $\mathrm{Ba}$ & $\mu \mathrm{g} / \mathrm{L}$ & 0 & 21 & 21 & $0 \%$ \\
\hline Beryllium & $\mathrm{Be}$ & $\mu \mathrm{g} / \mathrm{L}$ & 0 & $<0.2$ & $<0.2$ & $0 \%$ \\
\hline Boron & $\mathrm{B}$ & $\mu \mathrm{g} / \mathrm{L}$ & 1000 & $<1000$ & $<1000$ & $0 \%$ \\
\hline Cadmium & $\mathrm{Cd}$ & $\mu \mathrm{g} / \mathrm{L}$ & 0 & 2.0 & 2.0 & $0 \%$ \\
\hline Calcium & $\mathrm{Ca}$ & $\mu \mathrm{g} / \mathrm{L}$ & 300 & 2200 & 2400 & $9 \%$ \\
\hline Cerium & $\mathrm{Ce}$ & $\mu \mathrm{g} / \mathrm{L}$ & 1 & 0.94 & 0.96 & $2 \%$ \\
\hline Cesium & Cs & $\mu \mathrm{g} / \mathrm{L}$ & - & - & - & \\
\hline Chromium & $\mathrm{Cr}$ & $\mu \mathrm{g} / \mathrm{L}$ & 5 & $<5.0$ & $<5.0$ & $0 \%$ \\
\hline Cobalt & Co & $\mu \mathrm{g} / \mathrm{L}$ & 0 & 3.4 & 3.4 & $0 \%$ \\
\hline Copper & $\mathrm{Cu}$ & $\mu \mathrm{g} / \mathrm{L}$ & 5 & 600 & 600 & $0 \%$ \\
\hline Dysprosium & Dy & $\mu \mathrm{g} / \mathrm{L}$ & 0 & 0.23 & 0.22 & $4 \%$ \\
\hline Erbium & $\mathrm{Er}$ & $\mu \mathrm{g} / \mathrm{L}$ & 0 & 0.13 & 0.12 & $8 \%$ \\
\hline Europium & $\mathrm{Eu}$ & $\mu \mathrm{g} / \mathrm{L}$ & 0 & 0.084 & 0.057 & $38 \%$ \\
\hline Gadolinium & $\mathrm{Gd}$ & $\mu \mathrm{g} / \mathrm{L}$ & 0 & 0.23 & 0.21 & $9 \%$ \\
\hline Gallium & $\mathrm{Ga}$ & $\mu \mathrm{g} / \mathrm{L}$ & 5 & $<5.0$ & $<5.0$ & $0 \%$ \\
\hline Germanium & $\mathrm{Ge}$ & $\mu \mathrm{g} / \mathrm{L}$ & 1 & $<1.0$ & $<1.0$ & $0 \%$ \\
\hline Hafnium & $\mathrm{Hf}$ & $\mu \mathrm{g} / \mathrm{L}$ & - & - & - & \\
\hline Holonium & Ho & $\mu \mathrm{g} / \mathrm{L}$ & 0 & $<0.05$ & $<0.05$ & $0 \%$ \\
\hline Iridium & Ir & $\mu \mathrm{g} / \mathrm{L}$ & 1 & $<0.5$ & $<0.5$ & $0 \%$ \\
\hline Iron & $\mathrm{Fe}$ & $\mu \mathrm{g} / \mathrm{L}$ & 50 & 5000 & 5000 & $0 \%$ \\
\hline Lanthanum & La & $\mu \mathrm{g} / \mathrm{L}$ & 0 & $<0.4$ & 0.41 & $2 \%$ \\
\hline Lead & $\mathrm{Pb}$ & $\mu \mathrm{g} / \mathrm{L}$ & 0 & 4.8 & 4.9 & $2 \%$ \\
\hline Lithium & $\mathrm{Li}$ & $\mu \mathrm{g} / \mathrm{L}$ & 2 & $<2.0$ & $<2.0$ & $0 \%$ \\
\hline Lutetium & $\mathrm{Lu}$ & $\mu \mathrm{g} / \mathrm{L}$ & 0 & $<0.05$ & $<0.05$ & $0 \%$ \\
\hline Magnesium & $\mathrm{Mg}$ & $\mu \mathrm{g} / \mathrm{L}$ & 30 & 690 & 700 & $1 \%$ \\
\hline Manganese & $\mathrm{Mn}$ & $\mu \mathrm{g} / \mathrm{L}$ & 0 & 1500 & 1500 & $0 \%$ \\
\hline Molybdenum & Mo & $\mu \mathrm{g} / \mathrm{L}$ & 10 & $<10$ & $<10$ & $0 \%$ \\
\hline Neodymium & $\mathrm{Nd}$ & $\mu \mathrm{g} / \mathrm{L}$ & 0 & 0.71 & 0.68 & $4 \%$ \\
\hline Nickel & $\mathrm{Ni}$ & $\mu \mathrm{g} / \mathrm{L}$ & 1 & 3.5 & 3.6 & $3 \%$ \\
\hline Niobium & $\mathrm{Nb}$ & $\mu \mathrm{g} / \mathrm{L}$ & 0 & $<0.05$ & $<0.05$ & $0 \%$ \\
\hline Palladium & $\mathrm{Pd}$ & $\mu \mathrm{g} / \mathrm{L}$ & - & - & - & \\
\hline Phosphorus & $\mathrm{P}$ & $\mu \mathrm{g} / \mathrm{L}$ & 1000 & $<1000$ & $<1000$ & $0 \%$ \\
\hline Platinum & $\mathrm{Pt}$ & $\mu \mathrm{g} / \mathrm{L}$ & 0 & $<0.05$ & $<0.05$ & $0 \%$ \\
\hline Potassium & $\mathrm{K}$ & $\mu \mathrm{g} / \mathrm{L}$ & 200 & 1200 & 1200 & $0 \%$ \\
\hline Praseodymium & $\operatorname{Pr}$ & $\mu \mathrm{g} / \mathrm{L}$ & 0 & 0.14 & 0.14 & $0 \%$ \\
\hline Rhenium & $\mathrm{Re}$ & $\mu \mathrm{g} / \mathrm{L}$ & 0 & $<0.2$ & $<0.2$ & $0 \%$ \\
\hline Rhodium & $\mathrm{Rh}$ & $\mu \mathrm{g} / \mathrm{L}$ & 0 & $<0.1$ & $<0.1$ & $0 \%$ \\
\hline Rubidium & $\mathrm{Rb}$ & $\mu \mathrm{g} / \mathrm{L}$ & 1 & 6.0 & 6.2 & $3 \%$ \\
\hline Ruthenium & $\mathrm{Ru}$ & $\mu \mathrm{g} / \mathrm{L}$ & 0 & $<0.1$ & $<0.1$ & $0 \%$ \\
\hline Samarium & $\mathrm{Sm}$ & $\mu \mathrm{g} / \mathrm{L}$ & 0 & 0.20 & 0.18 & $11 \%$ \\
\hline Selenium & Se & $\mu \mathrm{g} / \mathrm{L}$ & 1 & 1.1 & 1.1 & $0 \%$ \\
\hline Silver & $\mathrm{Ag}$ & $\mu \mathrm{g} / \mathrm{L}$ & 0 & $<0.1$ & $<0.1$ & $0 \%$ \\
\hline Sodium & $\mathrm{Na}$ & $\mu \mathrm{g} / \mathrm{L}$ & 200 & 1100 & 1100 & $0 \%$ \\
\hline Strontium & $\mathrm{Sr}$ & $\mu \mathrm{g} / \mathrm{L}$ & 1 & 8.4 & 9.8 & $15 \%$ \\
\hline Sulfur & $\mathrm{S}$ & $\mu \mathrm{g} / \mathrm{L}$ & 1000 & 19000 & 19000 & $0 \%$ \\
\hline Tantalum & $\mathrm{Ta}$ & $\mu \mathrm{g} / \mathrm{L}$ & 0 & $<0.05$ & $<0.05$ & $0 \%$ \\
\hline Terbium & $\mathrm{Tb}$ & $\mu \mathrm{g} / \mathrm{L}$ & 0 & $<0.05$ & $<0.05$ & $0 \%$ \\
\hline Tellurium & $\mathrm{Te}$ & $\mu \mathrm{g} / \mathrm{L}$ & 1 & $<0.5$ & $<0.5$ & $0 \%$ \\
\hline Thalium & $\mathrm{TI}$ & $\mu \mathrm{g} / \mathrm{L}$ & 0 & $<0.1$ & $<0.1$ & $0 \%$ \\
\hline Thorium & Th & $\mu \mathrm{g} / \mathrm{L}$ & - & - & - & \\
\hline Thulium & $\mathrm{Tm}$ & $\mu \mathrm{g} / \mathrm{L}$ & 0 & $<0.05$ & $<0.05$ & $0 \%$ \\
\hline $\operatorname{Tin} * *$ & Sn & $\mu \mathrm{g} / \mathrm{L}$ & 3 & $<3.0$ & $<3.0$ & $0 \%$ \\
\hline Titanium & $\mathrm{Ti}$ & $\mu \mathrm{g} / \mathrm{L}$ & 3 & $<3.0$ & $<3.0$ & $0 \%$ \\
\hline Tungsten & w & $\mu \mathrm{g} / \mathrm{L}$ & 1 & $<0.5$ & $<0.5$ & $0 \%$ \\
\hline Uranium & U & $\mu \mathrm{g} / \mathrm{L}$ & 0 & 0.18 & 0.18 & $0 \%$ \\
\hline Vanadium & $\mathrm{V}$ & $\mu \mathrm{g} / \mathrm{L}$ & 0 & $<0.3$ & $<0.3$ & $0 \%$ \\
\hline Ytterbium & $\mathrm{Yb}$ & $\mu \mathrm{g} / \mathrm{L}$ & 0 & $<0.2$ & $<0.2$ & $0 \%$ \\
\hline Yttrium & Y & $\mu \mathrm{g} / \mathrm{L}$ & 1 & 1.4 & 1.4 & $0 \%$ \\
\hline Zinc & $\mathrm{Zn}$ & $\mu \mathrm{g} / \mathrm{L}$ & 10 & 1700 & 1700 & $0 \%$ \\
\hline Zirconium & $\mathrm{Zr}$ & $\mu \mathrm{g} / \mathrm{L}$ & 0 & $<0.1$ & 0.80 & $156 \%$ \\
\hline
\end{tabular}




\begin{tabular}{|c|c|c|c|c|c|c|c|c|c|}
\hline & Symbol & Units & $\begin{array}{l}\text { Sample name } \\
\text { Sample type } \\
\text { Sample number } \\
\text { Detection limit }\end{array}$ & $\begin{array}{c}\text { P-WRD-W } \\
\text { UA } \\
\text { No62 }\end{array}$ & $\begin{array}{c}\text { P-WRD-W } \\
\text { UA } \\
\text { No67 } \\
\text { Field Triplicate } \\
\end{array}$ & $\begin{array}{c}\text { P-WRD-W } \\
\text { UA } \\
\text { No68 }\end{array}$ & \%Diff 62-67 & $\%$ Diff 62-68 & \%Diff 67-68 \\
\hline \multicolumn{10}{|l|}{ Sample description } \\
\hline \multicolumn{10}{|l|}{ Anions } \\
\hline Fluoride & $\mathrm{F}$ & $\mathrm{mg} / \mathrm{L}$ & $<0.05$ & $<5.0$ & $<5.0$ & $<5.0$ & - & - & - \\
\hline Chloride & $\mathrm{Cl}$ & $\mathrm{mg} / \mathrm{L}$ & $<0.05$ & $<5.0$ & $<5.0$ & $<5.0$ & - & - & - \\
\hline Nitrite & $\mathrm{NO}_{2}-$ & $\mathrm{mg} / \mathrm{L}$ & $<0.05$ & $<5.0$ & $<5.0$ & $<5.0$ & - & - & - \\
\hline Nitrate & $\mathrm{NO}_{3}-$ & $\mathrm{mg} / \mathrm{L}$ & $<0.05$ & $<5.0$ & $<5.0$ & $<5.0$ & - & - & - \\
\hline Sulphate & $\mathrm{SO}_{42}-$. & $\mathrm{mg} / \mathrm{L}$ & $<0.10$ & 2750.0 & 2750.0 & 2750.0 & - & - & - \\
\hline $\mathrm{pH}$ & & - & & 2.6 & 2.6 & 2.6 & - & - & - \\
\hline \multicolumn{10}{|l|}{ Metals } \\
\hline Aluminium & $\mathrm{Al}$ & $\mu \mathrm{g} / \mathrm{L}$ & 5 & 100000 & 75000 & 76000 & $29 \%$ & $27 \%$ & $1 \%$ \\
\hline Antimony & $\mathrm{Sb}$ & $\mu \mathrm{g} / \mathrm{L}$ & 2 & $<2.0$ & $<2.0$ & $<2.0$ & $0 \%$ & $0 \%$ & $0 \%$ \\
\hline Arsenic & As & $\mu \mathrm{g} / \mathrm{L}$ & 2 & 850 & 630 & 630 & $30 \%$ & $30 \%$ & $0 \%$ \\
\hline Barium & $\mathrm{Ba}$ & $\mu \mathrm{g} / \mathrm{L}$ & 0 & 8.5 & 6.1 & 6.2 & $33 \%$ & $31 \%$ & $2 \%$ \\
\hline Beryllium & $\mathrm{Be}$ & $\mu \mathrm{g} / \mathrm{L}$ & 0 & 30 & 21 & 21 & $35 \%$ & $35 \%$ & $0 \%$ \\
\hline Boron & B & $\mu \mathrm{g} / \mathrm{L}$ & 1000 & $<1000$ & $<1000$ & $<1000$ & $0 \%$ & $0 \%$ & $0 \%$ \\
\hline Cadmium & $\mathrm{Cd}$ & $\mu \mathrm{g} / \mathrm{L}$ & 0 & 730 & 520 & 520 & $34 \%$ & $34 \%$ & $0 \%$ \\
\hline Calcium & $\mathrm{Ca}$ & $\mu \mathrm{g} / \mathrm{L}$ & 300 & 360000 & 260000 & 250000 & $32 \%$ & $36 \%$ & $4 \%$ \\
\hline Cerium & $\mathrm{Ce}$ & $\mu \mathrm{g} / \mathrm{L}$ & 1 & 280 & 200 & 200 & $33 \%$ & $33 \%$ & $0 \%$ \\
\hline Cesium & Cs & $\mu \mathrm{g} / \mathrm{L}$ & - & - & - & - & - & - & - \\
\hline Chromium & $\mathrm{Cr}$ & $\mu \mathrm{g} / \mathrm{L}$ & 5 & 17 & 12 & 11 & $34 \%$ & $43 \%$ & $9 \%$ \\
\hline Cobalt & Co & $\mu \mathrm{g} / \mathrm{L}$ & 0 & 720 & 510 & 500 & $34 \%$ & $36 \%$ & $2 \%$ \\
\hline Copper & $\mathrm{Cu}$ & $\mu \mathrm{g} / \mathrm{L}$ & 5 & 35000 & 25000 & 25000 & $33 \%$ & $33 \%$ & $0 \%$ \\
\hline Dysprosium & Dy & $\mu \mathrm{g} / \mathrm{L}$ & 0 & 37 & 26 & 25 & $35 \%$ & $39 \%$ & $4 \%$ \\
\hline Erbium & $\mathrm{Er}$ & $\mu \mathrm{g} / \mathrm{L}$ & 0 & 18 & 13 & 13 & $32 \%$ & $32 \%$ & $0 \%$ \\
\hline Europium & $\mathrm{Eu}$ & $\mu \mathrm{g} / \mathrm{L}$ & 0 & 15 & 10 & 10 & $40 \%$ & $40 \%$ & $0 \%$ \\
\hline Gadolinium & $\mathrm{Gd}$ & $\mu \mathrm{g} / \mathrm{L}$ & 0 & 49 & 33 & 33 & $39 \%$ & $39 \%$ & $0 \%$ \\
\hline Gallium & Ga & $\mu \mathrm{g} / \mathrm{L}$ & 5 & 30 & 19 & 20 & $45 \%$ & $40 \%$ & $5 \%$ \\
\hline Germanium & $\mathrm{Ge}$ & $\mu \mathrm{g} / \mathrm{L}$ & 1 & 16 & 10 & 11 & $46 \%$ & $37 \%$ & $10 \%$ \\
\hline Hafnium & $\mathrm{Hf}$ & $\mu \mathrm{g} / \mathrm{L}$ & - & - & - & - & - & - & - \\
\hline Holonium & Ho & $\mu \mathrm{g} / \mathrm{L}$ & 0 & 7.1 & 5.0 & 5.0 & $35 \%$ & $35 \%$ & $0 \%$ \\
\hline Iridium & Ir & $\mu \mathrm{g} / \mathrm{L}$ & 1 & $<0.5$ & $<0.5$ & $<0.5$ & $0 \%$ & $0 \%$ & $0 \%$ \\
\hline Iron & $\mathrm{Fe}$ & $\mu \mathrm{g} / \mathrm{L}$ & 50 & 450000 & 310000 & 310000 & $37 \%$ & $37 \%$ & $0 \%$ \\
\hline Lanthanum & La & $\mu \mathrm{g} / \mathrm{L}$ & 0 & 130 & 89 & 89 & $37 \%$ & $37 \%$ & $0 \%$ \\
\hline Lead & $\mathrm{Pb}$ & $\mu \mathrm{g} / \mathrm{L}$ & 0 & 16 & 12 & 11 & $29 \%$ & $37 \%$ & $9 \%$ \\
\hline Lithium & $\mathrm{Li}$ & $\mu \mathrm{g} / \mathrm{L}$ & 2 & 79 & 59 & 60 & $29 \%$ & $27 \%$ & $2 \%$ \\
\hline Lutetium & Lu & $\mu \mathrm{g} / \mathrm{L}$ & 0 & 1.9 & 1.3 & 1.3 & $38 \%$ & $38 \%$ & $0 \%$ \\
\hline Magnesium & $\mathrm{Mg}$ & $\mu \mathrm{g} / \mathrm{L}$ & 30 & 44000 & 31000 & 31000 & $35 \%$ & $35 \%$ & $0 \%$ \\
\hline Manganese & $\mathrm{Mn}$ & $\mu \mathrm{g} / \mathrm{L}$ & 0 & 110000 & 80000 & 79000 & $32 \%$ & $33 \%$ & $1 \%$ \\
\hline Molybdenum & Mo & $\mu \mathrm{g} / \mathrm{L}$ & 10 & $<10$ & $<10$ & $<10$ & $0 \%$ & $0 \%$ & $0 \%$ \\
\hline Neodymium & $\mathrm{Nd}$ & $\mu \mathrm{g} / \mathrm{L}$ & 0 & 170 & 110 & 120 & $43 \%$ & $34 \%$ & $9 \%$ \\
\hline Nickel & $\mathrm{Ni}$ & $\mu \mathrm{g} / \mathrm{L}$ & 1 & 200 & 140 & 140 & $35 \%$ & $35 \%$ & $0 \%$ \\
\hline Niobium & $\mathrm{Nb}$ & $\mu \mathrm{g} / \mathrm{L}$ & 0 & 0.076 & $<0.05$ & $<0.05$ & $41 \%$ & $41 \%$ & $0 \%$ \\
\hline Palladium & $\mathrm{Pd}$ & $\mu \mathrm{g} / \mathrm{L}$ & - & - & - & - & - & - & - \\
\hline Phosphorus & $P$ & $\mu \mathrm{g} / \mathrm{L}$ & 1000 & 3200 & 2500 & 2600 & $25 \%$ & $21 \%$ & $4 \%$ \\
\hline Platinum & $\mathrm{Pt}$ & $\mu \mathrm{g} / \mathrm{L}$ & 0 & $<0.05$ & $<0.05$ & $<0.05$ & $0 \%$ & $0 \%$ & $0 \%$ \\
\hline Potassium & K & $\mu \mathrm{g} / \mathrm{L}$ & 200 & 1300 & 900 & 910 & $36 \%$ & $35 \%$ & $1 \%$ \\
\hline Praseodymium & $\operatorname{Pr}$ & $\mu \mathrm{g} / \mathrm{L}$ & 0 & 38 & 26 & 26 & $38 \%$ & $38 \%$ & $0 \%$ \\
\hline Rhenium & $\operatorname{Re}$ & $\mu \mathrm{g} / \mathrm{L}$ & 0 & $<0.2$ & $<0.2$ & $<0.2$ & $0 \%$ & $0 \%$ & $0 \%$ \\
\hline Rhodium & $\mathrm{Rh}$ & $\mu \mathrm{g} / \mathrm{L}$ & 0 & $<0.1$ & $<0.1$ & $<0.1$ & $0 \%$ & $0 \%$ & $0 \%$ \\
\hline Rubidium & $\mathrm{Rb}$ & $\mu \mathrm{g} / \mathrm{L}$ & 1 & 7.2 & 5.6 & 5.5 & $25 \%$ & $27 \%$ & $2 \%$ \\
\hline Ruthenium & $\mathrm{Ru}$ & $\mu \mathrm{g} / \mathrm{L}$ & 0 & $<0.1$ & $<0.1$ & $<0.1$ & $0 \%$ & $0 \%$ & $0 \%$ \\
\hline Samarium & $\mathrm{Sm}$ & $\mu \mathrm{g} / \mathrm{L}$ & 0 & 41 & 28 & 29 & $38 \%$ & $34 \%$ & $4 \%$ \\
\hline Selenium & Se & $\mu \mathrm{g} / \mathrm{L}$ & 1 & 8.2 & 6.0 & 6.4 & $31 \%$ & $25 \%$ & $6 \%$ \\
\hline Silver & $\mathrm{Ag}$ & $\mu \mathrm{g} / \mathrm{L}$ & 0 & $<0.1$ & $<0.1$ & $<0.1$ & $0 \%$ & $0 \%$ & $0 \%$ \\
\hline Sodium & $\mathrm{Na}$ & $\mu \mathrm{g} / \mathrm{L}$ & 200 & 11000 & 9000 & 9000 & $20 \%$ & $20 \%$ & $0 \%$ \\
\hline Strontium & $\mathrm{Sr}$ & $\mu \mathrm{g} / \mathrm{L}$ & 1 & 1000 & 800 & 800 & $22 \%$ & $22 \%$ & $0 \%$ \\
\hline Sulfur & $\mathrm{s}$ & $\mu \mathrm{g} / \mathrm{L}$ & 1000 & 820000 & 630000 & 620000 & $26 \%$ & $28 \%$ & $2 \%$ \\
\hline Tantalum & $\mathrm{Ta}$ & $\mu \mathrm{g} / \mathrm{L}$ & 0 & $<0.05$ & $<0.05$ & $<0.05$ & $0 \%$ & $0 \%$ & $0 \%$ \\
\hline Terbium & $\mathrm{Tb}$ & $\mu \mathrm{g} / \mathrm{L}$ & 0 & 7.1 & 4.9 & 4.9 & $37 \%$ & $37 \%$ & $0 \%$ \\
\hline Tellurium & $\mathrm{Te}$ & $\mu \mathrm{g} / \mathrm{L}$ & 1 & 3.1 & 1.9 & 1.5 & $48 \%$ & $70 \%$ & $24 \%$ \\
\hline Thalium & $\mathrm{TI}$ & $\mu \mathrm{g} / \mathrm{L}$ & 0 & 1.6 & 0.95 & 0.94 & $51 \%$ & $52 \%$ & $1 \%$ \\
\hline Thorium & Th & $\mu \mathrm{g} / \mathrm{L}$ & - & - & - & - & - & - & - \\
\hline Thulium & $\mathrm{Tm}$ & $\mu \mathrm{g} / \mathrm{L}$ & 0 & 2.3 & 1.6 & 1.6 & $36 \%$ & $36 \%$ & $0 \%$ \\
\hline $\operatorname{Tin} * *$ & Sn & $\mu \mathrm{g} / \mathrm{L}$ & 3 & $<3.0$ & $<3.0$ & $<3.0$ & $0 \%$ & $0 \%$ & $0 \%$ \\
\hline Titanium & $\mathrm{Ti}$ & $\mu \mathrm{g} / \mathrm{L}$ & 3 & 5.2 & $<3.0$ & $<3.0$ & $54 \%$ & $54 \%$ & $0 \%$ \\
\hline Tungsten & w & $\mu \mathrm{g} / \mathrm{L}$ & 1 & $<0.5$ & $<0.5$ & $<0.5$ & $0 \%$ & $0 \%$ & $0 \%$ \\
\hline Uranium & U & $\mu \mathrm{g} / \mathrm{L}$ & 0 & 34 & 24 & 24 & $34 \%$ & $34 \%$ & $0 \%$ \\
\hline Vanadium & v & $\mu \mathrm{g} / \mathrm{L}$ & 0 & 11 & 8.3 & 7.9 & $28 \%$ & $33 \%$ & $5 \%$ \\
\hline Ytterbium & $\mathrm{Yb}$ & $\mu \mathrm{g} / \mathrm{L}$ & 0 & 14 & 9.8 & 9.7 & $35 \%$ & $36 \%$ & $1 \%$ \\
\hline Yttrium & Y & $\mu \mathrm{g} / \mathrm{L}$ & 1 & 220 & 150 & 150 & $38 \%$ & $38 \%$ & $0 \%$ \\
\hline Zinc & $\mathrm{Zn}$ & $\mu \mathrm{g} / \mathrm{L}$ & 10 & 28000 & 20000 & 19000 & $33 \%$ & $38 \%$ & $5 \%$ \\
\hline Zirconium & $\mathrm{Zr}$ & $\mu \mathrm{g} / \mathrm{L}$ & 0 & 0.25 & 0.56 & 0.32 & $77 \%$ & $25 \%$ & $55 \%$ \\
\hline
\end{tabular}




\begin{tabular}{|c|c|c|c|c|c|c|c|c|c|}
\hline & Symbol & Units & $\begin{array}{l}\text { Sample name } \\
\text { Sample type } \\
\text { Sample number } \\
\text { Detection limit }\end{array}$ & $\begin{array}{c}\text { P-WRD-W } \\
\text { FA } \\
\text { No76 }\end{array}$ & $\begin{array}{c}\text { P-WRD-W } \\
\text { FA } \\
\text { No77 } \\
\text { Field Triplicate } \\
\end{array}$ & $\begin{array}{c}\text { P-WRD-W } \\
\text { FA } \\
\text { No78 }\end{array}$ & \%Diff 76-77 & \%Diff 77-78 & \%Diff 76-78 \\
\hline \multicolumn{10}{|l|}{ Sample description } \\
\hline \multicolumn{10}{|c|}{ Anions } \\
\hline Fluoride & $\mathrm{F}$ & $\mathrm{mg} / \mathrm{L}$ & $<0.05$ & $<5.0$ & $<5.0$ & $<5.0$ & - & - & - \\
\hline Chloride & $\mathrm{Cl}$ & $\mathrm{mg} / \mathrm{L}$ & $<0.05$ & $<5.0$ & $<5.0$ & $<5.0$ & - & - & - \\
\hline Nitrite & $\mathrm{NO}_{2}-$ & $\mathrm{mg} / \mathrm{L}$ & $<0.05$ & $<5.0$ & $<5.0$ & $<5.0$ & - & - & - \\
\hline Nitrate & $\mathrm{NO}_{3}-$ & $\mathrm{mg} / \mathrm{L}$ & $<0.05$ & $<5.0$ & $<5.0$ & $<5.0$ & - & - & - \\
\hline Sulphate & $\mathrm{SO}_{42}-$. & $\mathrm{mg} / \mathrm{L}$ & $<0.10$ & 2750.0 & 2750.0 & 2750.0 & - & - & - \\
\hline $\mathrm{pH}$ & & - & & 2.6 & 2.6 & 2.6 & - & - & - \\
\hline \multicolumn{10}{|l|}{ Metals } \\
\hline Aluminium & $\mathrm{Al}$ & $\mu \mathrm{g} / \mathrm{L}$ & 5 & 120000 & 120000 & 110000 & $0 \%$ & $9 \%$ & $9 \%$ \\
\hline Antimony & $\mathrm{Sb}$ & $\mu \mathrm{g} / \mathrm{L}$ & 2 & $<2.0$ & $<2.0$ & $<2.0$ & $0 \%$ & $0 \%$ & $0 \%$ \\
\hline Arsenic & As & $\mu \mathrm{g} / \mathrm{L}$ & 2 & 910 & 890 & 890 & $2 \%$ & $0 \%$ & $2 \%$ \\
\hline Barium & $\mathrm{Ba}$ & $\mu \mathrm{g} / \mathrm{L}$ & 0 & 9.3 & 9.1 & 9.0 & $2 \%$ & $1 \%$ & $3 \%$ \\
\hline Beryllium & $\mathrm{Be}$ & $\mu \mathrm{g} / \mathrm{L}$ & 0 & 32 & 31 & 31 & $3 \%$ & $0 \%$ & $3 \%$ \\
\hline Boron & B & $\mu \mathrm{g} / \mathrm{L}$ & 1000 & $<1000$ & $<1000$ & $<1000$ & $0 \%$ & $0 \%$ & $0 \%$ \\
\hline Cadmium & $\mathrm{Cd}$ & $\mu \mathrm{g} / \mathrm{L}$ & 0 & 790 & 770 & 760 & $3 \%$ & $1 \%$ & $4 \%$ \\
\hline Calcium & $\mathrm{Ca}$ & $\mu \mathrm{g} / \mathrm{L}$ & 300 & 390000 & 380000 & 380000 & $3 \%$ & $0 \%$ & $3 \%$ \\
\hline Cerium & $\mathrm{Ce}$ & $\mu \mathrm{g} / \mathrm{L}$ & 1 & 310 & 310 & 300 & $0 \%$ & $3 \%$ & $3 \%$ \\
\hline Cesium & Cs & $\mu \mathrm{g} / \mathrm{L}$ & - & - & - & - & - & - & - \\
\hline Chromium & $\mathrm{Cr}$ & $\mu \mathrm{g} / \mathrm{L}$ & 5 & 18 & 17 & 18 & $6 \%$ & $6 \%$ & $0 \%$ \\
\hline Cobalt & Co & $\mu \mathrm{g} / \mathrm{L}$ & 0 & 770 & 760 & 760 & $1 \%$ & $0 \%$ & $1 \%$ \\
\hline Copper & $\mathrm{Cu}$ & $\mu \mathrm{g} / \mathrm{L}$ & 5 & 37000 & 37000 & 37000 & $0 \%$ & $0 \%$ & $0 \%$ \\
\hline Dysprosium & Dy & $\mu \mathrm{g} / \mathrm{L}$ & 0 & 41 & 40 & 39 & $2 \%$ & $3 \%$ & $5 \%$ \\
\hline Erbium & $\mathrm{Er}$ & $\mu \mathrm{g} / \mathrm{L}$ & 0 & 20 & 20 & 19 & $0 \%$ & $5 \%$ & $5 \%$ \\
\hline Europium & $\mathrm{Eu}$ & $\mu \mathrm{g} / \mathrm{L}$ & 0 & 16 & 16 & 16 & $0 \%$ & $0 \%$ & $0 \%$ \\
\hline Gadolinium & $\mathrm{Gd}$ & $\mu \mathrm{g} / \mathrm{L}$ & 0 & 52 & 51 & 50 & $2 \%$ & $2 \%$ & $4 \%$ \\
\hline Gallium & $\mathrm{Ga}$ & $\mu \mathrm{g} / \mathrm{L}$ & 5 & 30 & 31 & 30 & $3 \%$ & $3 \%$ & $0 \%$ \\
\hline Germanium & $\mathrm{Ge}$ & $\mu \mathrm{g} / \mathrm{L}$ & 1 & 18 & 16 & 16 & $12 \%$ & $0 \%$ & $12 \%$ \\
\hline Hafnium & $\mathrm{Hf}$ & $\mu \mathrm{g} / \mathrm{L}$ & - & - & - & - & - & - & - \\
\hline Holonium & Ho & $\mu \mathrm{g} / \mathrm{L}$ & 0 & 7.9 & 7.7 & 7.5 & $3 \%$ & $3 \%$ & $5 \%$ \\
\hline Iridium & Ir & $\mu \mathrm{g} / \mathrm{L}$ & 1 & $<0.5$ & $<0.5$ & $<0.5$ & $0 \%$ & $0 \%$ & $0 \%$ \\
\hline Iron & $\mathrm{Fe}$ & $\mu \mathrm{g} / \mathrm{L}$ & 50 & 480000 & 470000 & 470000 & $2 \%$ & $0 \%$ & $2 \%$ \\
\hline Lanthanum & La & $\mu \mathrm{g} / \mathrm{L}$ & 0 & 140 & 140 & 140 & $0 \%$ & $0 \%$ & $0 \%$ \\
\hline Lead & $\mathrm{Pb}$ & $\mu \mathrm{g} / \mathrm{L}$ & 0 & 16 & 16 & 16 & $0 \%$ & $0 \%$ & $0 \%$ \\
\hline Lithium & $\mathrm{Li}$ & $\mu \mathrm{g} / \mathrm{L}$ & 2 & 84 & 84 & 82 & $0 \%$ & $2 \%$ & $2 \%$ \\
\hline Lutetium & Lu & $\mu \mathrm{g} / \mathrm{L}$ & 0 & 2.0 & 2.0 & 2.0 & $0 \%$ & $0 \%$ & $0 \%$ \\
\hline Magnesium & $\mathrm{Mg}$ & $\mu \mathrm{g} / \mathrm{L}$ & 30 & 47000 & 47000 & 47000 & $0 \%$ & $0 \%$ & $0 \%$ \\
\hline Manganese & $\mathrm{Mn}$ & $\mu \mathrm{g} / \mathrm{L}$ & 0 & 140000 & 160000 & 140000 & $13 \%$ & $13 \%$ & $0 \%$ \\
\hline Molybdenum & Mo & $\mu \mathrm{g} / \mathrm{L}$ & 10 & $<10$ & $<10$ & $<10$ & $0 \%$ & $0 \%$ & $0 \%$ \\
\hline Neodymium & $\mathrm{Nd}$ & $\mu \mathrm{g} / \mathrm{L}$ & 0 & 180 & 180 & 170 & $0 \%$ & $6 \%$ & $6 \%$ \\
\hline Nickel & $\mathrm{Ni}$ & $\mu \mathrm{g} / \mathrm{L}$ & 1 & 210 & 200 & 200 & $5 \%$ & $0 \%$ & $5 \%$ \\
\hline Niobium & $\mathrm{Nb}$ & $\mu \mathrm{g} / \mathrm{L}$ & 0 & $<0.05$ & $<0.05$ & $<0.05$ & $0 \%$ & $0 \%$ & $0 \%$ \\
\hline Palladium & $\mathrm{Pd}$ & $\mu \mathrm{g} / \mathrm{L}$ & - & - & - & - & - & - & - \\
\hline Phosphorus & $P$ & $\mu \mathrm{g} / \mathrm{L}$ & 1000 & 3700 & 3700 & 3500 & $0 \%$ & $6 \%$ & $6 \%$ \\
\hline Platinum & $\mathrm{Pt}$ & $\mu \mathrm{g} / \mathrm{L}$ & 0 & $<0.05$ & $<0.05$ & $<0.05$ & $0 \%$ & $0 \%$ & $0 \%$ \\
\hline Potassium & K & $\mu \mathrm{g} / \mathrm{L}$ & 200 & 1200 & 1300 & 1300 & $8 \%$ & $0 \%$ & $8 \%$ \\
\hline Praseodymium & $\mathrm{Pr}$ & $\mu \mathrm{g} / \mathrm{L}$ & 0 & 41 & 40 & 40 & $2 \%$ & $0 \%$ & $2 \%$ \\
\hline Rhenium & $\operatorname{Re}$ & $\mu \mathrm{g} / \mathrm{L}$ & 0 & $<0.2$ & $<0.2$ & $<0.2$ & $0 \%$ & $0 \%$ & $0 \%$ \\
\hline Rhodium & $\mathrm{Rh}$ & $\mu \mathrm{g} / \mathrm{L}$ & 0 & $<0.1$ & $<0.1$ & $<0.1$ & $0 \%$ & $0 \%$ & $0 \%$ \\
\hline Rubidium & $\mathrm{Rb}$ & $\mu \mathrm{g} / \mathrm{L}$ & 1 & 7.5 & 7.6 & 7.2 & $1 \%$ & $5 \%$ & $4 \%$ \\
\hline Ruthenium & $\mathrm{Ru}$ & $\mu \mathrm{g} / \mathrm{L}$ & 0 & $<0.1$ & $<0.1$ & $<0.1$ & $0 \%$ & $0 \%$ & $0 \%$ \\
\hline Samarium & $\mathrm{Sm}$ & $\mu \mathrm{g} / \mathrm{L}$ & 0 & 46 & 44 & 44 & $4 \%$ & $0 \%$ & $4 \%$ \\
\hline Selenium & Se & $\mu \mathrm{g} / \mathrm{L}$ & 1 & 9.0 & 7.9 & 8.1 & $13 \%$ & $2 \%$ & $11 \%$ \\
\hline Silver & $\mathrm{Ag}$ & $\mu \mathrm{g} / \mathrm{L}$ & 0 & $<0.1$ & $<0.1$ & $<0.1$ & $0 \%$ & $0 \%$ & $0 \%$ \\
\hline Sodium & $\mathrm{Na}$ & $\mu \mathrm{g} / \mathrm{L}$ & 200 & 12000 & 12000 & 12000 & $0 \%$ & $0 \%$ & $0 \%$ \\
\hline Strontium & $\mathrm{Sr}$ & $\mu \mathrm{g} / \mathrm{L}$ & 1 & 1300 & 1300 & 1200 & $0 \%$ & $8 \%$ & $8 \%$ \\
\hline Sulfur & $\mathrm{S}$ & $\mu \mathrm{g} / \mathrm{L}$ & 1000 & 890000 & 1000000 & 900000 & $12 \%$ & $11 \%$ & $1 \%$ \\
\hline Tantalum & $\mathrm{Ta}$ & $\mu \mathrm{g} / \mathrm{L}$ & 0 & $<0.05$ & $<0.05$ & $<0.05$ & $0 \%$ & $0 \%$ & $0 \%$ \\
\hline Terbium & $\mathrm{Tb}$ & $\mu \mathrm{g} / \mathrm{L}$ & 0 & 7.6 & 7.5 & 7.5 & $1 \%$ & $0 \%$ & $1 \%$ \\
\hline Tellurium & $\mathrm{Te}$ & $\mu \mathrm{g} / \mathrm{L}$ & 1 & 2.4 & 2.2 & 2.7 & $9 \%$ & $20 \%$ & $12 \%$ \\
\hline Thalium & $\mathrm{Tl}$ & $\mu \mathrm{g} / \mathrm{L}$ & 0 & 1.4 & 1.4 & 1.4 & $0 \%$ & $0 \%$ & $0 \%$ \\
\hline Thorium & Th & $\mu \mathrm{g} / \mathrm{L}$ & - & - & - & - & - & - & - \\
\hline Thulium & $\mathrm{Tm}$ & $\mu \mathrm{g} / \mathrm{L}$ & 0 & 2.5 & 2.5 & 2.4 & $0 \%$ & $4 \%$ & $4 \%$ \\
\hline $\operatorname{Tin} * *$ & Sn & $\mu \mathrm{g} / \mathrm{L}$ & 3 & $<3.0$ & $<3.0$ & $<3.0$ & $0 \%$ & $0 \%$ & $0 \%$ \\
\hline Titanium & $\mathrm{Ti}$ & $\mu \mathrm{g} / \mathrm{L}$ & 3 & 3.2 & 5.2 & $<3.0$ & $48 \%$ & $54 \%$ & $6 \%$ \\
\hline Tungsten & w & $\mu \mathrm{g} / \mathrm{L}$ & 1 & $<0.5$ & $<0.5$ & $<0.5$ & $0 \%$ & $0 \%$ & $0 \%$ \\
\hline Uranium & U & $\mu \mathrm{g} / \mathrm{L}$ & 0 & 36 & 35 & 35 & $3 \%$ & $0 \%$ & $3 \%$ \\
\hline Vanadium & $\mathrm{v}$ & $\mu \mathrm{g} / \mathrm{L}$ & 0 & 12 & 11 & 11 & $9 \%$ & $0 \%$ & $9 \%$ \\
\hline Ytterbium & $\mathrm{Yb}$ & $\mu \mathrm{g} / \mathrm{L}$ & 0 & 15 & 15 & 15 & $0 \%$ & $0 \%$ & $0 \%$ \\
\hline Yttrium & $Y$ & $\mu \mathrm{g} / \mathrm{L}$ & 1 & 240 & 230 & 230 & $4 \%$ & $0 \%$ & $4 \%$ \\
\hline Zinc & $\mathrm{Zn}$ & $\mu \mathrm{g} / \mathrm{L}$ & 10 & 34000 & 41000 & 35000 & $19 \%$ & $16 \%$ & $3 \%$ \\
\hline Zirconium & $\mathrm{Zr}$ & $\mu \mathrm{g} / \mathrm{L}$ & 0 & 0.38 & 0.34 & 0.36 & $11 \%$ & $6 \%$ & $5 \%$ \\
\hline
\end{tabular}




\begin{tabular}{|c|c|c|c|c|c|c|c|c|c|}
\hline & Symbol & Units & $\begin{array}{l}\text { Sample name } \\
\text { Sample type } \\
\text { Sample number } \\
\text { Detection limit }\end{array}$ & $\begin{array}{l}\text { P-EC-W } \\
\text { UA } \\
\text { No61 }\end{array}$ & $\begin{array}{c}\text { P-EC-W } \\
\text { UA } \\
\text { No69 } \\
\text { Field Triplicate } \\
\end{array}$ & $\begin{array}{l}\text { P-EC-W } \\
\text { UA } \\
\text { No70 }\end{array}$ & \%Diff 61-69 & $\%$ Diff $61-70$ & \%Diff 69-70 \\
\hline \multicolumn{10}{|l|}{ Sample description } \\
\hline \multicolumn{10}{|l|}{ Anions } \\
\hline Fluoride & $\mathrm{F}$ & $\mathrm{mg} / \mathrm{L}$ & $<0.05$ & $<5.0$ & $<5.0$ & $<5.0$ & - & - & - \\
\hline Chloride & $\mathrm{Cl}$ & $\mathrm{mg} / \mathrm{L}$ & $<0.05$ & $<5.0$ & $<5.0$ & $<5.0$ & - & - & - \\
\hline Nitrite & $\mathrm{NO}_{2}-$ & $\mathrm{mg} / \mathrm{L}$ & $<0.05$ & $<5.0$ & $<5.0$ & $<5.0$ & - & - & - \\
\hline Nitrate & $\mathrm{NO}_{3}-$ & $\mathrm{mg} / \mathrm{L}$ & $<0.05$ & $<5.0$ & $<5.0$ & $<5.0$ & - & - & - \\
\hline Sulphate & $\mathrm{SO}_{42}-$. & $\mathrm{mg} / \mathrm{L}$ & $<0.10$ & 1200.0 & 1200.0 & 1200.0 & - & - & - \\
\hline $\mathrm{pH}$ & & - & & 2.8 & 2.8 & 2.8 & - & - & - \\
\hline \multicolumn{10}{|l|}{ Metals } \\
\hline Aluminium & $\mathrm{Al}$ & $\mu \mathrm{g} / \mathrm{L}$ & 5 & 38000 & 38000 & 39000 & $0 \%$ & $3 \%$ & $1 \%$ \\
\hline Antimony & $\mathrm{Sb}$ & $\mu \mathrm{g} / \mathrm{L}$ & 2 & $<2.0$ & $<2.0$ & $<2.0$ & $0 \%$ & $0 \%$ & $0 \%$ \\
\hline Arsenic & As & $\mu \mathrm{g} / \mathrm{L}$ & 2 & 25 & 8.1 & 8.0 & $102 \%$ & $103 \%$ & $0 \%$ \\
\hline Barium & $\mathrm{Ba}$ & $\mu \mathrm{g} / \mathrm{L}$ & 0 & 32 & 34 & 34 & $6 \%$ & $6 \%$ & $0 \%$ \\
\hline Beryllium & $\mathrm{Be}$ & $\mu \mathrm{g} / \mathrm{L}$ & 0 & 7.5 & 7.8 & 7.6 & $4 \%$ & $1 \%$ & $1 \%$ \\
\hline Boron & B & $\mu \mathrm{g} / \mathrm{L}$ & 1000 & $<1000$ & $<1000$ & $<1000$ & $0 \%$ & $0 \%$ & $0 \%$ \\
\hline Cadmium & $\mathrm{Cd}$ & $\mu \mathrm{g} / \mathrm{L}$ & 0 & 1000 & 1100 & 1100 & $10 \%$ & $10 \%$ & $0 \%$ \\
\hline Calcium & $\mathrm{Ca}$ & $\mu \mathrm{g} / \mathrm{L}$ & 300 & 360000 & 360000 & 370000 & $0 \%$ & $3 \%$ & $1 \%$ \\
\hline Cerium & $\mathrm{Ce}$ & $\mu \mathrm{g} / \mathrm{L}$ & 1 & 62 & 66 & 65 & $6 \%$ & $5 \%$ & $0 \%$ \\
\hline Cesium & Cs & $\mu \mathrm{g} / \mathrm{L}$ & - & - & - & - & & & \\
\hline Chromium & $\mathrm{Cr}$ & $\mu \mathrm{g} / \mathrm{L}$ & 5 & $<5.0$ & $<5.0$ & $<5.0$ & $0 \%$ & $0 \%$ & $0 \%$ \\
\hline Cobalt & Co & $\mu \mathrm{g} / \mathrm{L}$ & 0 & 350 & 360 & 370 & $3 \%$ & $6 \%$ & $1 \%$ \\
\hline Copper & $\mathrm{Cu}$ & $\mu \mathrm{g} / \mathrm{L}$ & 5 & 5100 & 5300 & 5400 & $4 \%$ & $6 \%$ & $0 \%$ \\
\hline Dysprosium & Dy & $\mu \mathrm{g} / \mathrm{L}$ & 0 & 11 & 11 & 11 & $0 \%$ & $0 \%$ & $0 \%$ \\
\hline Erbium & $\mathrm{Er}$ & $\mu \mathrm{g} / \mathrm{L}$ & 0 & 5.0 & 5.5 & 5.5 & $10 \%$ & $10 \%$ & $0 \%$ \\
\hline Europium & $\mathrm{Eu}$ & $\mu \mathrm{g} / \mathrm{L}$ & 0 & 3.9 & 3.9 & 3.8 & $0 \%$ & $3 \%$ & $1 \%$ \\
\hline Gadolinium & $\mathrm{Gd}$ & $\mu \mathrm{g} / \mathrm{L}$ & 0 & 13 & 14 & 13 & $7 \%$ & $0 \%$ & $2 \%$ \\
\hline Gallium & Ga & $\mu \mathrm{g} / \mathrm{L}$ & 5 & 8.8 & 8.9 & 8.8 & $1 \%$ & $0 \%$ & $0 \%$ \\
\hline Germanium & $\mathrm{Ge}$ & $\mu \mathrm{g} / \mathrm{L}$ & 1 & 3.1 & 3.0 & 3.3 & $3 \%$ & $6 \%$ & $2 \%$ \\
\hline Hafnium & $\mathrm{Hf}$ & $\mu \mathrm{g} / \mathrm{L}$ & - & - & - & - & & & \\
\hline Holonium & Ho & $\mu \mathrm{g} / \mathrm{L}$ & 0 & 1.9 & 2.1 & 2.1 & $10 \%$ & $10 \%$ & $0 \%$ \\
\hline Iridium & Ir & $\mu \mathrm{g} / \mathrm{L}$ & 1 & $<0.5$ & $<0.5$ & $<0.5$ & $0 \%$ & $0 \%$ & $0 \%$ \\
\hline Iron & $\mathrm{Fe}$ & $\mu \mathrm{g} / \mathrm{L}$ & 50 & 33000 & 36000 & 36000 & $9 \%$ & $9 \%$ & $0 \%$ \\
\hline Lanthanum & La & $\mu \mathrm{g} / \mathrm{L}$ & 0 & 30 & 31 & 31 & $3 \%$ & $3 \%$ & $0 \%$ \\
\hline Lead & $\mathrm{Pb}$ & $\mu \mathrm{g} / \mathrm{L}$ & 0 & 120 & 130 & 130 & $8 \%$ & $8 \%$ & $0 \%$ \\
\hline Lithium & $\mathrm{Li}$ & $\mu \mathrm{g} / \mathrm{L}$ & 2 & 32 & 34 & 33 & $6 \%$ & $3 \%$ & $1 \%$ \\
\hline Lutetium & Lu & $\mu \mathrm{g} / \mathrm{L}$ & 0 & 0.51 & 0.50 & 0.49 & $2 \%$ & $4 \%$ & $1 \%$ \\
\hline Magnesium & $\mathrm{Mg}$ & $\mu \mathrm{g} / \mathrm{L}$ & 30 & 16000 & 16000 & 16000 & $0 \%$ & $0 \%$ & $0 \%$ \\
\hline Manganese & $\mathrm{Mn}$ & $\mu \mathrm{g} / \mathrm{L}$ & 0 & 27000 & 28000 & 31000 & $4 \%$ & $14 \%$ & $3 \%$ \\
\hline Molybdenum & Mo & $\mu \mathrm{g} / \mathrm{L}$ & 10 & $<10$ & $<10$ & $<10$ & $0 \%$ & $0 \%$ & $0 \%$ \\
\hline Neodymium & $\mathrm{Nd}$ & $\mu \mathrm{g} / \mathrm{L}$ & 0 & 40 & 42 & 42 & $5 \%$ & $5 \%$ & $0 \%$ \\
\hline Nickel & $\mathrm{Ni}$ & $\mu \mathrm{g} / \mathrm{L}$ & 1 & 100 & 100 & 110 & $0 \%$ & $10 \%$ & $2 \%$ \\
\hline Niobium & $\mathrm{Nb}$ & $\mu \mathrm{g} / \mathrm{L}$ & 0 & $<0.05$ & $<0.05$ & $<0.05$ & $0 \%$ & $0 \%$ & $0 \%$ \\
\hline Palladium & $\mathrm{Pd}$ & $\mu \mathrm{g} / \mathrm{L}$ & - & - & - & - & & & \\
\hline Phosphorus & $P$ & $\mu \mathrm{g} / \mathrm{L}$ & 1000 & $<1000$ & $<1000$ & $<1000$ & $0 \%$ & $0 \%$ & $0 \%$ \\
\hline Platinum & $\mathrm{Pt}$ & $\mu \mathrm{g} / \mathrm{L}$ & 0 & $<0.05$ & $<0.05$ & $<0.05$ & $0 \%$ & $0 \%$ & $0 \%$ \\
\hline Potassium & K & $\mu \mathrm{g} / \mathrm{L}$ & 200 & 4700 & 4800 & 4800 & $2 \%$ & $2 \%$ & $0 \%$ \\
\hline Praseodymium & $\operatorname{Pr}$ & $\mu \mathrm{g} / \mathrm{L}$ & 0 & 8.9 & 9.4 & 9.3 & $5 \%$ & $4 \%$ & $0 \%$ \\
\hline Rhenium & $\operatorname{Re}$ & $\mu \mathrm{g} / \mathrm{L}$ & 0 & $<0.2$ & $<0.2$ & $<0.2$ & $0 \%$ & $0 \%$ & $0 \%$ \\
\hline Rhodium & $\mathrm{Rh}$ & $\mu \mathrm{g} / \mathrm{L}$ & 0 & $<0.1$ & $<0.1$ & $<0.1$ & $0 \%$ & $0 \%$ & $0 \%$ \\
\hline Rubidium & $\mathrm{Rb}$ & $\mu \mathrm{g} / \mathrm{L}$ & 1 & 13 & 14 & 14 & $7 \%$ & $7 \%$ & $0 \%$ \\
\hline Ruthenium & $\mathrm{Ru}$ & $\mu \mathrm{g} / \mathrm{L}$ & 0 & $<0.1$ & $<0.1$ & $<0.1$ & $0 \%$ & $0 \%$ & $0 \%$ \\
\hline Samarium & $\mathrm{Sm}$ & $\mu \mathrm{g} / \mathrm{L}$ & 0 & 10 & 11 & 11 & $10 \%$ & $10 \%$ & $0 \%$ \\
\hline Selenium & $\mathrm{Se}$ & $\mu \mathrm{g} / \mathrm{L}$ & 1 & 3.3 & 4.0 & 3.6 & $19 \%$ & $9 \%$ & $3 \%$ \\
\hline Silver & $\mathrm{Ag}$ & $\mu \mathrm{g} / \mathrm{L}$ & 0 & $<0.1$ & $<0.1$ & $<0.1$ & $0 \%$ & $0 \%$ & $0 \%$ \\
\hline Sodium & $\mathrm{Na}$ & $\mu \mathrm{g} / \mathrm{L}$ & 200 & 12000 & 12000 & 13000 & $0 \%$ & $8 \%$ & $2 \%$ \\
\hline Strontium & $\mathrm{Sr}$ & $\mu \mathrm{g} / \mathrm{L}$ & 1 & 860 & 880 & 880 & $2 \%$ & $2 \%$ & $0 \%$ \\
\hline Sulfur & $\mathrm{s}$ & $\mu \mathrm{g} / \mathrm{L}$ & 1000 & 310000 & 320000 & 350000 & $3 \%$ & $12 \%$ & $2 \%$ \\
\hline Tantalum & $\mathrm{Ta}$ & $\mu \mathrm{g} / \mathrm{L}$ & 0 & $<0.05$ & $<0.05$ & $<0.05$ & $0 \%$ & $0 \%$ & $0 \%$ \\
\hline Terbium & $\mathrm{Tb}$ & $\mu \mathrm{g} / \mathrm{L}$ & 0 & 1.9 & 2.0 & 2.1 & $5 \%$ & $10 \%$ & $1 \%$ \\
\hline Tellurium & $\mathrm{Te}$ & $\mu \mathrm{g} / \mathrm{L}$ & 1 & 0.84 & 0.78 & 0.75 & $7 \%$ & $11 \%$ & $1 \%$ \\
\hline Thalium & $\mathrm{TI}$ & $\mu \mathrm{g} / \mathrm{L}$ & 0 & 10 & 12 & 11 & $18 \%$ & $10 \%$ & $2 \%$ \\
\hline Thorium & Th & $\mu \mathrm{g} / \mathrm{L}$ & - & - & - & - & & & \\
\hline Thulium & $\mathrm{Tm}$ & $\mu \mathrm{g} / \mathrm{L}$ & 0 & 0.65 & 0.69 & 0.68 & $6 \%$ & $5 \%$ & $0 \%$ \\
\hline $\operatorname{Tin} * *$ & Sn & $\mu \mathrm{g} / \mathrm{L}$ & 3 & $<3.0$ & $<3.0$ & $<3.0$ & $0 \%$ & $0 \%$ & $0 \%$ \\
\hline Titanium & $\mathrm{Ti}$ & $\mu \mathrm{g} / \mathrm{L}$ & 3 & $<3.0$ & $<3.0$ & $<3.0$ & $0 \%$ & $0 \%$ & $0 \%$ \\
\hline Tungsten & w & $\mu \mathrm{g} / \mathrm{L}$ & 1 & $<0.5$ & $<0.5$ & $<0.5$ & $0 \%$ & $0 \%$ & $0 \%$ \\
\hline Uranium & U & $\mu \mathrm{g} / \mathrm{L}$ & 0 & 8.4 & 8.6 & 8.4 & $2 \%$ & $0 \%$ & $1 \%$ \\
\hline Vanadium & v & $\mu \mathrm{g} / \mathrm{L}$ & 0 & $<0.3$ & $<0.3$ & $<0.3$ & $0 \%$ & $0 \%$ & $0 \%$ \\
\hline Ytterbium & $\mathrm{Yb}$ & $\mu \mathrm{g} / \mathrm{L}$ & 0 & 4.0 & 4.0 & 4.0 & $0 \%$ & $0 \%$ & $0 \%$ \\
\hline Yttrium & Y & $\mu \mathrm{g} / \mathrm{L}$ & 1 & 63 & 64 & 65 & $2 \%$ & $3 \%$ & $0 \%$ \\
\hline Zinc & $\mathrm{Zn}$ & $\mu \mathrm{g} / \mathrm{L}$ & 10 & 18000 & 18000 & 20000 & $0 \%$ & $11 \%$ & $3 \%$ \\
\hline Zirconium & $\mathrm{Zr}$ & $\mu \mathrm{g} / \mathrm{L}$ & 0 & 0.12 & $<0.1$ & $<0.1$ & $18 \%$ & $18 \%$ & $0 \%$ \\
\hline
\end{tabular}




\begin{tabular}{|c|c|c|c|c|c|c|c|c|c|}
\hline & Symbol & Units & $\begin{array}{l}\text { Sample name } \\
\text { Sample type } \\
\text { Sample number } \\
\text { Detection limit }\end{array}$ & $\begin{array}{l}\text { P-EC-W } \\
\text { FA } \\
\text { No } 82\end{array}$ & $\begin{array}{c}\text { P-EC-W } \\
\text { FA } \\
\text { No } 83 \\
\text { Field Triplicate } \\
\end{array}$ & $\begin{array}{l}\text { P-EC-W } \\
\text { FA } \\
\text { No84* }\end{array}$ & \%Diff 82-83 & \%Diff 83-84 & \%Diff 82-84 \\
\hline \multicolumn{10}{|l|}{ Sample description } \\
\hline \multicolumn{10}{|c|}{ Anions } \\
\hline Fluoride & $\mathrm{F}$ & $\mathrm{mg} / \mathrm{L}$ & $<0.05$ & $<5.0$ & $<5.0$ & $<5.0$ & - & - & - \\
\hline Chloride & $\mathrm{Cl}$ & $\mathrm{mg} / \mathrm{L}$ & $<0.05$ & $<5.0$ & $<5.0$ & $<5.0$ & - & - & - \\
\hline Nitrite & $\mathrm{NO}_{2}-$ & $\mathrm{mg} / \mathrm{L}$ & $<0.05$ & $<5.0$ & $<5.0$ & $<5.0$ & - & - & - \\
\hline Nitrate & $\mathrm{NO}_{3}-$ & $\mathrm{mg} / \mathrm{L}$ & $<0.05$ & $<5.0$ & $<5.0$ & $<5.0$ & - & - & - \\
\hline Sulphate & $\mathrm{SO}_{42}-$. & $\mathrm{mg} / \mathrm{L}$ & $<0.10$ & 1200.0 & 1200.0 & 1200.0 & - & - & - \\
\hline $\mathrm{pH}$ & & - & & 2.8 & 2.8 & 2.8 & - & - & - \\
\hline \multicolumn{10}{|l|}{ Metals } \\
\hline Aluminium & $\mathrm{Al}$ & $\mu \mathrm{g} / \mathrm{L}$ & 5 & 42000 & 39000 & 38000 & $2 \%$ & $1 \%$ & $3 \%$ \\
\hline Antimony & $\mathrm{Sb}$ & $\mu \mathrm{g} / \mathrm{L}$ & 2 & $<2.0$ & $<2.0$ & $<2.0$ & $0 \%$ & $0 \%$ & $0 \%$ \\
\hline Arsenic & As & $\mu \mathrm{g} / \mathrm{L}$ & 2 & 5.2 & 4.9 & 4.3 & $1 \%$ & $3 \%$ & $5 \%$ \\
\hline Barium & $\mathrm{Ba}$ & $\mu \mathrm{g} / \mathrm{L}$ & 0 & 33 & 33 & 32 & $0 \%$ & $1 \%$ & $1 \%$ \\
\hline Beryllium & $\mathrm{Be}$ & $\mu \mathrm{g} / \mathrm{L}$ & 0 & 7.5 & 7.2 & 7.0 & $1 \%$ & $1 \%$ & $2 \%$ \\
\hline Boron & B & $\mu \mathrm{g} / \mathrm{L}$ & 1000 & $<1000$ & $<1000$ & $<1000$ & $0 \%$ & $0 \%$ & $0 \%$ \\
\hline Cadmium & $\mathrm{Cd}$ & $\mu \mathrm{g} / \mathrm{L}$ & 0 & 1200 & 1100 & 1100 & $2 \%$ & $0 \%$ & $2 \%$ \\
\hline Calcium & $\mathrm{Ca}$ & $\mu \mathrm{g} / \mathrm{L}$ & 300 & 360000 & 360000 & 360000 & $0 \%$ & $0 \%$ & $0 \%$ \\
\hline Cerium & $\mathrm{Ce}$ & $\mu \mathrm{g} / \mathrm{L}$ & 1 & 65 & 64 & 62 & $0 \%$ & $1 \%$ & $1 \%$ \\
\hline Cesium & Cs & $\mu \mathrm{g} / \mathrm{L}$ & - & - & - & - & - & - & - \\
\hline Chromium & $\mathrm{Cr}$ & $\mu \mathrm{g} / \mathrm{L}$ & 5 & $<5.0$ & $<5.0$ & 5.1 & $0 \%$ & $0 \%$ & $0 \%$ \\
\hline Cobalt & Co & $\mu \mathrm{g} / \mathrm{L}$ & 0 & 360 & 370 & 360 & $1 \%$ & $1 \%$ & $0 \%$ \\
\hline Copper & $\mathrm{Cu}$ & $\mu \mathrm{g} / \mathrm{L}$ & 5 & 5300 & 5400 & 5400 & $0 \%$ & $0 \%$ & $0 \%$ \\
\hline Dysprosium & Dy & $\mu \mathrm{g} / \mathrm{L}$ & 0 & 11 & 11 & 10 & $0 \%$ & $2 \%$ & $2 \%$ \\
\hline Erbium & $\mathrm{Er}$ & $\mu \mathrm{g} / \mathrm{L}$ & 0 & 5.3 & 5.2 & 5.1 & $0 \%$ & $0 \%$ & $1 \%$ \\
\hline Europium & $\mathrm{Eu}$ & $\mu \mathrm{g} / \mathrm{L}$ & 0 & 3.9 & 4.0 & 4.1 & $1 \%$ & $1 \%$ & $1 \%$ \\
\hline Gadolinium & $\mathrm{Gd}$ & $\mu \mathrm{g} / \mathrm{L}$ & 0 & 13 & 13 & 13 & $0 \%$ & $0 \%$ & $0 \%$ \\
\hline Gallium & Ga & $\mu \mathrm{g} / \mathrm{L}$ & 5 & 10 & 8.5 & 9.4 & $4 \%$ & $3 \%$ & $2 \%$ \\
\hline Germanium & $\mathrm{Ge}$ & $\mu \mathrm{g} / \mathrm{L}$ & 1 & 3.0 & 3.8 & 3.6 & $6 \%$ & $1 \%$ & $5 \%$ \\
\hline Hafnium & $\mathrm{Hf}$ & $\mu \mathrm{g} / \mathrm{L}$ & - & - & - & - & - & - & - \\
\hline Holonium & Ho & $\mu \mathrm{g} / \mathrm{L}$ & 0 & 2.1 & 2.0 & 2.0 & $1 \%$ & $0 \%$ & $1 \%$ \\
\hline Iridium & Ir & $\mu \mathrm{g} / \mathrm{L}$ & 1 & $<0.5$ & $<0.5$ & $<0.5$ & $0 \%$ & $0 \%$ & $0 \%$ \\
\hline Iron & $\mathrm{Fe}$ & $\mu \mathrm{g} / \mathrm{L}$ & 50 & 34000 & 35000 & 35000 & $1 \%$ & $0 \%$ & $1 \%$ \\
\hline Lanthanum & La & $\mu \mathrm{g} / \mathrm{L}$ & 0 & 31 & 30 & 30 & $1 \%$ & $0 \%$ & $1 \%$ \\
\hline Lead & $\mathrm{Pb}$ & $\mu \mathrm{g} / \mathrm{L}$ & 0 & 120 & 120 & 120 & $0 \%$ & $0 \%$ & $0 \%$ \\
\hline Lithium & $\mathrm{Li}$ & $\mu \mathrm{g} / \mathrm{L}$ & 2 & 33 & 32 & 32 & $1 \%$ & $0 \%$ & $1 \%$ \\
\hline Lutetium & Lu & $\mu \mathrm{g} / \mathrm{L}$ & 0 & 0.50 & 0.51 & 0.50 & $0 \%$ & $0 \%$ & $0 \%$ \\
\hline Magnesium & $\mathrm{Mg}$ & $\mu \mathrm{g} / \mathrm{L}$ & 30 & 16000 & 16000 & 16000 & $0 \%$ & $0 \%$ & $0 \%$ \\
\hline Manganese & $\mathrm{Mn}$ & $\mu \mathrm{g} / \mathrm{L}$ & 0 & 31000 & 35000 & 36000 & $3 \%$ & $1 \%$ & $4 \%$ \\
\hline Molybdenum & Mo & $\mu \mathrm{g} / \mathrm{L}$ & 10 & $<10$ & $<10$ & $<10$ & $0 \%$ & $0 \%$ & $0 \%$ \\
\hline Neodymium & $\mathrm{Nd}$ & $\mu \mathrm{g} / \mathrm{L}$ & 0 & 42 & 42 & 40 & $0 \%$ & $1 \%$ & $1 \%$ \\
\hline Nickel & $\mathrm{Ni}$ & $\mu \mathrm{g} / \mathrm{L}$ & 1 & 100 & 110 & 100 & $2 \%$ & $2 \%$ & $0 \%$ \\
\hline Niobium & $\mathrm{Nb}$ & $\mu \mathrm{g} / \mathrm{L}$ & 0 & $<0.05$ & $<0.05$ & $<0.05$ & $0 \%$ & $0 \%$ & $0 \%$ \\
\hline Palladium & $\mathrm{Pd}$ & $\mu \mathrm{g} / \mathrm{L}$ & - & - & - & - & - & - & - \\
\hline Phosphorus & $P$ & $\mu \mathrm{g} / \mathrm{L}$ & 1000 & $<1000$ & $<1000$ & $<1000$ & $0 \%$ & $0 \%$ & $0 \%$ \\
\hline Platinum & Pt & $\mu \mathrm{g} / \mathrm{L}$ & 0 & $<0.05$ & $<0.05$ & $<0.05$ & $0 \%$ & $0 \%$ & $0 \%$ \\
\hline Potassium & K & $\mu \mathrm{g} / \mathrm{L}$ & 200 & 4700 & 4900 & 4800 & $1 \%$ & $1 \%$ & $1 \%$ \\
\hline Praseodymium & $\operatorname{Pr}$ & $\mu \mathrm{g} / \mathrm{L}$ & 0 & 9.3 & 9.2 & 9.0 & $0 \%$ & $1 \%$ & $1 \%$ \\
\hline Rhenium & $\operatorname{Re}$ & $\mu \mathrm{g} / \mathrm{L}$ & 0 & $<0.2$ & $<0.2$ & $<0.2$ & $0 \%$ & $0 \%$ & $0 \%$ \\
\hline Rhodium & $\mathrm{Rh}$ & $\mu \mathrm{g} / \mathrm{L}$ & 0 & $<0.1$ & $<0.1$ & $<0.1$ & $0 \%$ & $0 \%$ & $0 \%$ \\
\hline Rubidium & $\mathrm{Rb}$ & $\mu \mathrm{g} / \mathrm{L}$ & 1 & 14 & 13 & 13 & $2 \%$ & $0 \%$ & $2 \%$ \\
\hline Ruthenium & $\mathrm{Ru}$ & $\mu \mathrm{g} / \mathrm{L}$ & 0 & $<0.1$ & $<0.1$ & $<0.1$ & $0 \%$ & $0 \%$ & $0 \%$ \\
\hline Samarium & $\mathrm{Sm}$ & $\mu \mathrm{g} / \mathrm{L}$ & 0 & 11 & 11 & 11 & $0 \%$ & $0 \%$ & $0 \%$ \\
\hline Selenium & Se & $\mu \mathrm{g} / \mathrm{L}$ & 1 & 3.5 & 3.9 & 3.6 & $3 \%$ & $2 \%$ & $1 \%$ \\
\hline Silver & $\mathrm{Ag}$ & $\mu \mathrm{g} / \mathrm{L}$ & 0 & $<0.1$ & $<0.1$ & $<0.1$ & $0 \%$ & $0 \%$ & $0 \%$ \\
\hline Sodium & $\mathrm{Na}$ & $\mu \mathrm{g} / \mathrm{L}$ & 200 & 13000 & 13000 & 13000 & $0 \%$ & $0 \%$ & $0 \%$ \\
\hline Strontium & $\mathrm{Sr}$ & $\mu \mathrm{g} / \mathrm{L}$ & 1 & 890 & 910 & 900 & $1 \%$ & $0 \%$ & $0 \%$ \\
\hline Sulfur & $\mathrm{S}$ & $\mu \mathrm{g} / \mathrm{L}$ & 1000 & 340000 & 380000 & 420000 & $3 \%$ & $3 \%$ & $5 \%$ \\
\hline Tantalum & $\mathrm{Ta}$ & $\mu \mathrm{g} / \mathrm{L}$ & 0 & $<0.05$ & $<0.05$ & $<0.05$ & $0 \%$ & $0 \%$ & $0 \%$ \\
\hline Terbium & $\mathrm{Tb}$ & $\mu \mathrm{g} / \mathrm{L}$ & 0 & 2.0 & 2.0 & 1.9 & $0 \%$ & $1 \%$ & $1 \%$ \\
\hline Tellurium & $\mathrm{Te}$ & $\mu \mathrm{g} / \mathrm{L}$ & 1 & 0.61 & 0.71 & 0.66 & $4 \%$ & $2 \%$ & $2 \%$ \\
\hline Thalium & $\mathrm{Tl}$ & $\mu \mathrm{g} / \mathrm{L}$ & 0 & 11 & 10 & 10 & $2 \%$ & $0 \%$ & $2 \%$ \\
\hline Thorium & Th & $\mu \mathrm{g} / \mathrm{L}$ & - & - & - & - & - & - & - \\
\hline Thulium & $\mathrm{Tm}$ & $\mu \mathrm{g} / \mathrm{L}$ & 0 & 0.66 & 0.66 & 0.66 & $0 \%$ & $0 \%$ & $0 \%$ \\
\hline $\operatorname{Tin} * *$ & Sn & $\mu \mathrm{g} / \mathrm{L}$ & 3 & $<3.0$ & $<3.0$ & $<3.0$ & $0 \%$ & $0 \%$ & $0 \%$ \\
\hline Titanium & $\mathrm{Ti}$ & $\mu \mathrm{g} / \mathrm{L}$ & 3 & $<3.0$ & $<3.0$ & $<3.0$ & $0 \%$ & $0 \%$ & $0 \%$ \\
\hline Tungsten & w & $\mu \mathrm{g} / \mathrm{L}$ & 1 & $<0.5$ & $<0.5$ & $<0.5$ & $0 \%$ & $0 \%$ & $0 \%$ \\
\hline Uranium & U & $\mu \mathrm{g} / \mathrm{L}$ & 0 & 8.3 & 8.3 & 8.1 & $0 \%$ & $1 \%$ & $1 \%$ \\
\hline Vanadium & $\mathrm{v}$ & $\mu \mathrm{g} / \mathrm{L}$ & 0 & $<0.3$ & $<0.3$ & $<0.3$ & $0 \%$ & $0 \%$ & $0 \%$ \\
\hline Ytterbium & $\mathrm{Yb}$ & $\mu \mathrm{g} / \mathrm{L}$ & 0 & 4.1 & 4.0 & 3.9 & $1 \%$ & $1 \%$ & $1 \%$ \\
\hline Yttrium & $Y$ & $\mu \mathrm{g} / \mathrm{L}$ & 1 & 65 & 66 & 66 & $0 \%$ & $0 \%$ & $0 \%$ \\
\hline Zinc & $\mathrm{Zn}$ & $\mu \mathrm{g} / \mathrm{L}$ & 10 & 21000 & 23000 & 24000 & $2 \%$ & $1 \%$ & $3 \%$ \\
\hline Zirconium & $\mathrm{Zr}$ & $\mu \mathrm{g} / \mathrm{L}$ & 0 & $<0.1$ & $<0.1$ & $<0.1$ & $0 \%$ & $0 \%$ & $0 \%$ \\
\hline
\end{tabular}




\begin{tabular}{|c|c|c|c|c|c|c|c|c|c|}
\hline & Symbol & Units & $\begin{array}{c}\text { Sample name } \\
\text { Sample type } \\
\text { Sample number } \\
\text { Detection limit }\end{array}$ & $\begin{array}{l}\text { P-PD-W } \\
\text { UA } \\
\text { No71 }\end{array}$ & $\begin{array}{c}\text { P-PD-W } \\
\text { UA } \\
\text { No72 } \\
\text { Field Triplicate } \\
\end{array}$ & $\begin{array}{l}\text { P-PD-W } \\
\text { UA } \\
\text { No63 }\end{array}$ & \%Diff 63-71 & $\%$ Diff 63-72 & \%Diff 71-72 \\
\hline \multicolumn{10}{|l|}{ Sample description } \\
\hline \multicolumn{10}{|l|}{ Anions } \\
\hline Fluoride & $\mathrm{F}$ & $\mathrm{mg} / \mathrm{L}$ & $<0.05$ & $<2.0$ & $<2.0$ & $<2.0$ & - & - & - \\
\hline Chloride & $\mathrm{Cl}$ & $\mathrm{mg} / \mathrm{L}$ & $<0.05$ & $<2.0$ & $<2.0$ & $<2.0$ & - & - & - \\
\hline Nitrite & $\mathrm{NO}_{2}-$ & $\mathrm{mg} / \mathrm{L}$ & $<0.05$ & $<2.0$ & $<2.0$ & $<2.0$ & - & - & - \\
\hline Nitrate & $\mathrm{NO}_{3}^{-}$ & $\mathrm{mg} / \mathrm{L}$ & $<0.05$ & 3.8 & 3.8 & 3.8 & - & - & - \\
\hline Sulphate & $\mathrm{SO}_{42-}-$ & $\mathrm{mg} / \mathrm{L}$ & $<0.10$ & 880.0 & 880.0 & 880.0 & - & - & - \\
\hline $\mathrm{pH}$ & & - & & 2.7 & 2.7 & 2.7 & - & - & - \\
\hline \multicolumn{10}{|l|}{ Metals } \\
\hline Aluminium & $\mathrm{Al}$ & $\mu \mathrm{g} / \mathrm{L}$ & 5 & 45000 & 44000 & 40000 & $12 \%$ & $10 \%$ & $2 \%$ \\
\hline Antimony & $\mathrm{Sb}$ & $\mu \mathrm{g} / \mathrm{L}$ & 2 & $<2.0$ & $<2.0$ & $<2.0$ & $0 \%$ & $0 \%$ & $0 \%$ \\
\hline Arsenic & As & $\mu \mathrm{g} / \mathrm{L}$ & 2 & 1800 & 1700 & 1400 & $25 \%$ & $19 \%$ & $6 \%$ \\
\hline Barium & $\mathrm{Ba}$ & $\mu \mathrm{g} / \mathrm{L}$ & 0 & 24 & 26 & 22 & $9 \%$ & $17 \%$ & $8 \%$ \\
\hline Beryllium & $\mathrm{Be}$ & $\mu \mathrm{g} / \mathrm{L}$ & 0 & 2.2 & 2.4 & 2.0 & $10 \%$ & $18 \%$ & $9 \%$ \\
\hline Boron & B & $\mu \mathrm{g} / \mathrm{L}$ & 1000 & $<1000$ & $<1000$ & $<1000$ & $0 \%$ & $0 \%$ & $0 \%$ \\
\hline Cadmium & $\mathrm{Cd}$ & $\mu \mathrm{g} / \mathrm{L}$ & 0 & 2100 & 2100 & 1900 & $10 \%$ & $10 \%$ & $0 \%$ \\
\hline Calcium & $\mathrm{Ca}$ & $\mu \mathrm{g} / \mathrm{L}$ & 300 & 33000 & 34000 & 32000 & $3 \%$ & $6 \%$ & $3 \%$ \\
\hline Cerium & $\mathrm{Ce}$ & $\mu \mathrm{g} / \mathrm{L}$ & 1 & 5.7 & 6.2 & 5.2 & $9 \%$ & $18 \%$ & $8 \%$ \\
\hline Cesium & Cs & $\mu \mathrm{g} / \mathrm{L}$ & - & - & - & - & - & - & - \\
\hline Chromium & $\mathrm{Cr}$ & $\mu \mathrm{g} / \mathrm{L}$ & 5 & 12 & 11 & 11 & $9 \%$ & $0 \%$ & $9 \%$ \\
\hline Cobalt & Co & $\mu \mathrm{g} / \mathrm{L}$ & 0 & 530 & 520 & 510 & $4 \%$ & $2 \%$ & $2 \%$ \\
\hline Copper & $\mathrm{Cu}$ & $\mu \mathrm{g} / \mathrm{L}$ & 5 & 24 & 23 & 26 & $8 \%$ & $12 \%$ & $4 \%$ \\
\hline Dysprosium & Dy & $\mu \mathrm{g} / \mathrm{L}$ & 0 & 2.5 & 2.7 & 2.3 & $8 \%$ & $16 \%$ & $8 \%$ \\
\hline Erbium & $\mathrm{Er}$ & $\mu \mathrm{g} / \mathrm{L}$ & 0 & 1.4 & 1.5 & 1.2 & $15 \%$ & $22 \%$ & $7 \%$ \\
\hline Europium & $\mathrm{Eu}$ & $\mu \mathrm{g} / \mathrm{L}$ & 0 & 0.70 & 0.66 & 0.61 & $14 \%$ & $8 \%$ & $6 \%$ \\
\hline Gadolinium & $\mathrm{Gd}$ & $\mu \mathrm{g} / \mathrm{L}$ & 0 & 2.7 & 2.8 & 2.4 & $12 \%$ & $15 \%$ & $4 \%$ \\
\hline Gallium & $\mathrm{Ga}$ & $\mu \mathrm{g} / \mathrm{L}$ & 5 & 40 & 39 & 37 & $8 \%$ & $5 \%$ & $3 \%$ \\
\hline Germanium & $\mathrm{Ge}$ & $\mu \mathrm{g} / \mathrm{L}$ & 1 & 3.9 & 5.0 & 4.1 & $5 \%$ & $20 \%$ & $25 \%$ \\
\hline Hafnium & $\mathrm{Hf}$ & $\mu \mathrm{g} / \mathrm{L}$ & - & - & - & - & - & - & - \\
\hline Holonium & Ho & $\mu \mathrm{g} / \mathrm{L}$ & 0 & 0.54 & 0.54 & 0.49 & $10 \%$ & $10 \%$ & $0 \%$ \\
\hline Iridium & Ir & $\mu \mathrm{g} / \mathrm{L}$ & 1 & $<0.5$ & $<0.5$ & $<0.5$ & $0 \%$ & $0 \%$ & $0 \%$ \\
\hline Iron & $\mathrm{Fe}$ & $\mu \mathrm{g} / \mathrm{L}$ & 50 & 230000 & 230000 & 220000 & $4 \%$ & $4 \%$ & $0 \%$ \\
\hline Lanthanum & La & $\mu \mathrm{g} / \mathrm{L}$ & 0 & 1.9 & 2.1 & 1.8 & $5 \%$ & $15 \%$ & $10 \%$ \\
\hline Lead & $\mathrm{Pb}$ & $\mu \mathrm{g} / \mathrm{L}$ & 0 & 720 & 770 & 640 & $12 \%$ & $18 \%$ & $7 \%$ \\
\hline Lithium & $\mathrm{Li}$ & $\mu \mathrm{g} / \mathrm{L}$ & 2 & 14 & 15 & 13 & $7 \%$ & $14 \%$ & $7 \%$ \\
\hline Lutetium & Lu & $\mu \mathrm{g} / \mathrm{L}$ & 0 & 0.12 & 0.12 & 0.10 & $18 \%$ & $18 \%$ & $0 \%$ \\
\hline Magnesium & $\mathrm{Mg}$ & $\mu \mathrm{g} / \mathrm{L}$ & 30 & 5300 & 5300 & 5200 & $2 \%$ & $2 \%$ & $0 \%$ \\
\hline Manganese & $\mathrm{Mn}$ & $\mu \mathrm{g} / \mathrm{L}$ & 0 & 15000 & 15000 & 13000 & $14 \%$ & $14 \%$ & $0 \%$ \\
\hline Molybdenum & Mo & $\mu \mathrm{g} / \mathrm{L}$ & 10 & $<10$ & $<10$ & $<10$ & $0 \%$ & $0 \%$ & $0 \%$ \\
\hline Neodymium & $\mathrm{Nd}$ & $\mu \mathrm{g} / \mathrm{L}$ & 0 & 6.0 & 6.2 & 5.4 & $11 \%$ & $14 \%$ & $3 \%$ \\
\hline Nickel & $\mathrm{Ni}$ & $\mu \mathrm{g} / \mathrm{L}$ & 1 & 170 & 170 & 160 & $6 \%$ & $6 \%$ & $0 \%$ \\
\hline Niobium & $\mathrm{Nb}$ & $\mu \mathrm{g} / \mathrm{L}$ & 0 & $<0.05$ & $<0.05$ & $<0.05$ & $0 \%$ & $0 \%$ & $0 \%$ \\
\hline Palladium & $\mathrm{Pd}$ & $\mu \mathrm{g} / \mathrm{L}$ & - & - & - & - & - & - & - \\
\hline Phosphorus & $P$ & $\mu \mathrm{g} / \mathrm{L}$ & 1000 & $<1000$ & $<1000$ & $<1000$ & $0 \%$ & $0 \%$ & $0 \%$ \\
\hline Platinum & $\mathrm{Pt}$ & $\mu \mathrm{g} / \mathrm{L}$ & 0 & $<0.05$ & $<0.05$ & $<0.05$ & $0 \%$ & $0 \%$ & $0 \%$ \\
\hline Potassium & $\mathrm{K}$ & $\mu \mathrm{g} / \mathrm{L}$ & 200 & 1300 & 1300 & 1300 & $0 \%$ & $0 \%$ & $0 \%$ \\
\hline Praseodymium & $\operatorname{Pr}$ & $\mu \mathrm{g} / \mathrm{L}$ & 0 & 1.1 & 1.1 & 0.96 & $14 \%$ & $14 \%$ & $0 \%$ \\
\hline Rhenium & $\operatorname{Re}$ & $\mu \mathrm{g} / \mathrm{L}$ & 0 & $<0.2$ & $<0.2$ & $<0.2$ & $0 \%$ & $0 \%$ & $0 \%$ \\
\hline Rhodium & $\mathrm{Rh}$ & $\mu \mathrm{g} / \mathrm{L}$ & 0 & $<0.1$ & $<0.1$ & $<0.1$ & $0 \%$ & $0 \%$ & $0 \%$ \\
\hline Rubidium & $\mathrm{Rb}$ & $\mu \mathrm{g} / \mathrm{L}$ & 1 & 4.6 & 4.9 & 4.0 & $14 \%$ & $20 \%$ & $6 \%$ \\
\hline Ruthenium & $\mathrm{Ru}$ & $\mu \mathrm{g} / \mathrm{L}$ & 0 & $<0.1$ & $<0.1$ & $<0.1$ & $0 \%$ & $0 \%$ & $0 \%$ \\
\hline Samarium & $\mathrm{Sm}$ & $\mu \mathrm{g} / \mathrm{L}$ & 0 & 1.8 & 1.8 & 1.7 & $6 \%$ & $6 \%$ & $0 \%$ \\
\hline Selenium & Se & $\mu \mathrm{g} / \mathrm{L}$ & 1 & 1.5 & 1.4 & 1.6 & $6 \%$ & $13 \%$ & $7 \%$ \\
\hline Silver & $\mathrm{Ag}$ & $\mu \mathrm{g} / \mathrm{L}$ & 0 & $<0.1$ & $<0.1$ & $<0.1$ & $0 \%$ & $0 \%$ & $0 \%$ \\
\hline Sodium & $\mathrm{Na}$ & $\mu \mathrm{g} / \mathrm{L}$ & 200 & 3300 & 3400 & 3200 & $3 \%$ & $6 \%$ & $3 \%$ \\
\hline Strontium & $\mathrm{Sr}$ & $\mu \mathrm{g} / \mathrm{L}$ & 1 & 37 & 38 & 35 & $6 \%$ & $8 \%$ & $3 \%$ \\
\hline Sulfur & $\mathrm{s}$ & $\mu \mathrm{g} / \mathrm{L}$ & 1000 & 200000 & 190000 & 190000 & $5 \%$ & $0 \%$ & $5 \%$ \\
\hline Tantalum & $\mathrm{Ta}$ & $\mu \mathrm{g} / \mathrm{L}$ & 0 & $<0.05$ & $<0.05$ & $<0.05$ & $0 \%$ & $0 \%$ & $0 \%$ \\
\hline Terbium & $\mathrm{Tb}$ & $\mu \mathrm{g} / \mathrm{L}$ & 0 & 0.43 & 0.47 & 0.40 & $7 \%$ & $16 \%$ & $9 \%$ \\
\hline Tellurium & $\mathrm{Te}$ & $\mu \mathrm{g} / \mathrm{L}$ & 1 & 0.66 & 0.94 & 0.90 & $31 \%$ & $4 \%$ & $35 \%$ \\
\hline Thalium & $\mathrm{Tl}$ & $\mu \mathrm{g} / \mathrm{L}$ & 0 & 65 & 69 & 58 & $11 \%$ & $17 \%$ & $6 \%$ \\
\hline Thorium & Th & $\mu \mathrm{g} / \mathrm{L}$ & - & - & - & - & - & - & - \\
\hline Thulium & $\mathrm{Tm}$ & $\mu \mathrm{g} / \mathrm{L}$ & 0 & 0.19 & 0.21 & 0.17 & $11 \%$ & $21 \%$ & $10 \%$ \\
\hline Tin $* *$ & Sn & $\mu \mathrm{g} / \mathrm{L}$ & 3 & $<3.0$ & $<3.0$ & $<3.0$ & $0 \%$ & $0 \%$ & $0 \%$ \\
\hline Titanium & $\mathrm{Ti}$ & $\mu \mathrm{g} / \mathrm{L}$ & 3 & $<3.0$ & $<3.0$ & $<3.0$ & $0 \%$ & $0 \%$ & $0 \%$ \\
\hline Tungsten & w & $\mu \mathrm{g} / \mathrm{L}$ & 1 & $<0.5$ & $<0.5$ & $<0.5$ & $0 \%$ & $0 \%$ & $0 \%$ \\
\hline Uranium & U & $\mu \mathrm{g} / \mathrm{L}$ & 0 & 4.5 & 4.8 & 4.0 & $12 \%$ & $18 \%$ & $6 \%$ \\
\hline Vanadium & V & $\mu \mathrm{g} / \mathrm{L}$ & 0 & 34 & 34 & 32 & $6 \%$ & $6 \%$ & $0 \%$ \\
\hline Ytterbium & $\mathrm{Yb}$ & $\mu \mathrm{g} / \mathrm{L}$ & 0 & 1.2 & 1.3 & 1.0 & $18 \%$ & $26 \%$ & $8 \%$ \\
\hline Yttrium & Y & $\mu \mathrm{g} / \mathrm{L}$ & 1 & 17 & 16 & 16 & $6 \%$ & $0 \%$ & $6 \%$ \\
\hline Zinc & $\mathrm{Zn}$ & $\mu \mathrm{g} / \mathrm{L}$ & 10 & 36000 & 35000 & 34000 & $6 \%$ & $3 \%$ & $3 \%$ \\
\hline Zirconium & $\mathrm{Zr}$ & $\mu \mathrm{g} / \mathrm{L}$ & 0 & $<0.1$ & $<0.1$ & $<0.1$ & $0 \%$ & $0 \%$ & $0 \%$ \\
\hline
\end{tabular}




\begin{tabular}{|c|c|c|c|c|c|c|c|c|c|}
\hline & Symbol & Units & $\begin{array}{l}\text { Sample type } \\
\text { Sample number } \\
\text { Detection limit }\end{array}$ & $\begin{array}{c}\text { FA } \\
\text { No79 }\end{array}$ & $\begin{array}{c}\text { FA } \\
\text { No } 80 \\
\text { Field Triplicate }\end{array}$ & $\begin{array}{c}\text { FA } \\
\text { No } 81\end{array}$ & \%Diff 79-80 & \%Diff 79-81 & \%Diff $80-81$ \\
\hline \multicolumn{10}{|l|}{ Sample description } \\
\hline \multicolumn{10}{|l|}{ Anions } \\
\hline Fluoride & $\mathrm{F}$ & $\mathrm{mg} / \mathrm{L}$ & $<0.05$ & $<2.0$ & $<2.0$ & $<2.0$ & - & - & - \\
\hline Chloride & $\mathrm{Cl}$ & $\mathrm{mg} / \mathrm{L}$ & $<0.05$ & $<2.0$ & $<2.0$ & $<2.0$ & - & - & - \\
\hline Nitrite & $\mathrm{NO}_{2}-$ & $\mathrm{mg} / \mathrm{L}$ & $<0.05$ & $<2.0$ & $<2.0$ & $<2.0$ & - & - & - \\
\hline Nitrate & $\mathrm{NO}_{3}-$ & $\mathrm{mg} / \mathrm{L}$ & $<0.05$ & 3.8 & 3.8 & 3.8 & - & - & - \\
\hline Sulphate & $\mathrm{SO}_{42-}$. & $\mathrm{mg} / \mathrm{L}$ & $<0.10$ & 880.0 & 880.0 & 880.0 & - & - & - \\
\hline $\mathrm{pH}$ & & - & & 2.7 & 2.7 & 2.7 & - & - & - \\
\hline \multicolumn{10}{|l|}{ Metals } \\
\hline Aluminium & $\mathrm{Al}$ & $\mu \mathrm{g} / \mathrm{L}$ & 5 & 42000 & 46000 & 45000 & $9 \%$ & $7 \%$ & $2 \%$ \\
\hline Antimony & $\mathrm{Sb}$ & $\mu \mathrm{g} / \mathrm{L}$ & 2 & $<2.0$ & $<2.0$ & $<2.0$ & $0 \%$ & $0 \%$ & $0 \%$ \\
\hline Arsenic & As & $\mu \mathrm{g} / \mathrm{L}$ & 2 & 1700 & 1900 & 1800 & $11 \%$ & $6 \%$ & $5 \%$ \\
\hline Barium & $\mathrm{Ba}$ & $\mu \mathrm{g} / \mathrm{L}$ & 0 & 24 & 24 & 24 & $0 \%$ & $0 \%$ & $0 \%$ \\
\hline Beryllium & $\mathrm{Be}$ & $\mu \mathrm{g} / \mathrm{L}$ & 0 & 2.2 & 2.2 & 2.1 & $0 \%$ & $5 \%$ & $5 \%$ \\
\hline Boron & B & $\mu \mathrm{g} / \mathrm{L}$ & 1000 & $<1000$ & $<1000$ & $<1000$ & $0 \%$ & $0 \%$ & $0 \%$ \\
\hline Cadmium & $\mathrm{Cd}$ & $\mu \mathrm{g} / \mathrm{L}$ & 0 & 2100 & 2300 & 2200 & $9 \%$ & $5 \%$ & $4 \%$ \\
\hline Calcium & $\mathrm{Ca}$ & $\mu \mathrm{g} / \mathrm{L}$ & 300 & 33000 & 34000 & 36000 & $3 \%$ & $9 \%$ & $6 \%$ \\
\hline Cerium & $\mathrm{Ce}$ & $\mu \mathrm{g} / \mathrm{L}$ & 1 & 5.8 & 5.6 & 5.8 & $4 \%$ & $0 \%$ & $4 \%$ \\
\hline Cesium & Cs & $\mu \mathrm{g} / \mathrm{L}$ & - & - & - & - & - & - & - \\
\hline Chromium & $\mathrm{Cr}$ & $\mu \mathrm{g} / \mathrm{L}$ & 5 & 12 & 12 & 12 & $0 \%$ & $0 \%$ & $0 \%$ \\
\hline Cobalt & Co & $\mu \mathrm{g} / \mathrm{L}$ & 0 & 530 & 530 & 540 & $0 \%$ & $2 \%$ & $2 \%$ \\
\hline Copper & $\mathrm{Cu}$ & $\mu \mathrm{g} / \mathrm{L}$ & 5 & 22 & 21 & 22 & $5 \%$ & $0 \%$ & $5 \%$ \\
\hline Dysprosium & Dy & $\mu \mathrm{g} / \mathrm{L}$ & 0 & 2.5 & 2.5 & 2.5 & $0 \%$ & $0 \%$ & $0 \%$ \\
\hline Erbium & $\mathrm{Er}$ & $\mu \mathrm{g} / \mathrm{L}$ & 0 & 1.4 & 1.4 & 1.4 & $0 \%$ & $0 \%$ & $0 \%$ \\
\hline Europium & $\mathrm{Eu}$ & $\mu \mathrm{g} / \mathrm{L}$ & 0 & 0.70 & 0.74 & 0.79 & $6 \%$ & $12 \%$ & $7 \%$ \\
\hline Gadolinium & $\mathrm{Gd}$ & $\mu \mathrm{g} / \mathrm{L}$ & 0 & 2.6 & 2.6 & 2.7 & $0 \%$ & $4 \%$ & $4 \%$ \\
\hline Gallium & $\mathrm{Ga}$ & $\mu \mathrm{g} / \mathrm{L}$ & 5 & 40 & 39 & 38 & $3 \%$ & $5 \%$ & $3 \%$ \\
\hline Germanium & $\mathrm{Ge}$ & $\mu \mathrm{g} / \mathrm{L}$ & 1 & 4.2 & 4.2 & 4.8 & $0 \%$ & $13 \%$ & $13 \%$ \\
\hline Hafnium & $\mathrm{Hf}$ & $\mu \mathrm{g} / \mathrm{L}$ & - & - & - & - & - & - & - \\
\hline Holonium & Ho & $\mu \mathrm{g} / \mathrm{L}$ & 0 & 0.54 & 0.52 & 0.52 & $4 \%$ & $4 \%$ & $0 \%$ \\
\hline Iridium & Ir & $\mu \mathrm{g} / \mathrm{L}$ & 1 & $<0.5$ & $<0.5$ & $<0.5$ & $0 \%$ & $0 \%$ & $0 \%$ \\
\hline Iron & $\mathrm{Fe}$ & $\mu \mathrm{g} / \mathrm{L}$ & 50 & 230000 & 230000 & 240000 & $0 \%$ & $4 \%$ & $4 \%$ \\
\hline Lanthanum & La & $\mu \mathrm{g} / \mathrm{L}$ & 0 & 1.9 & 1.9 & 2.0 & $0 \%$ & $5 \%$ & $5 \%$ \\
\hline Lead & $\mathrm{Pb}$ & $\mu \mathrm{g} / \mathrm{L}$ & 0 & 730 & 730 & 730 & $0 \%$ & $0 \%$ & $0 \%$ \\
\hline Lithium & $\mathrm{Li}$ & $\mu \mathrm{g} / \mathrm{L}$ & 2 & 14 & 14 & 14 & $0 \%$ & $0 \%$ & $0 \%$ \\
\hline Lutetium & Lu & $\mu \mathrm{g} / \mathrm{L}$ & 0 & 0.11 & 0.12 & 0.12 & $9 \%$ & $9 \%$ & $0 \%$ \\
\hline Magnesium & $\mathrm{Mg}$ & $\mu \mathrm{g} / \mathrm{L}$ & 30 & 5300 & 5300 & 5400 & $0 \%$ & $2 \%$ & $2 \%$ \\
\hline Manganese & $\mathrm{Mn}$ & $\mu \mathrm{g} / \mathrm{L}$ & 0 & 15000 & 16000 & 16000 & $6 \%$ & $6 \%$ & $0 \%$ \\
\hline Molybdenum & Mo & $\mu \mathrm{g} / \mathrm{L}$ & 10 & $<10$ & $<10$ & $<10$ & $0 \%$ & $0 \%$ & $0 \%$ \\
\hline Neodymium & $\mathrm{Nd}$ & $\mu \mathrm{g} / \mathrm{L}$ & 0 & 5.8 & 5.8 & 6.0 & $0 \%$ & $3 \%$ & $3 \%$ \\
\hline Nickel & $\mathrm{Ni}$ & $\mu \mathrm{g} / \mathrm{L}$ & 1 & 170 & 170 & 170 & $0 \%$ & $0 \%$ & $0 \%$ \\
\hline Niobium & $\mathrm{Nb}$ & $\mu \mathrm{g} / \mathrm{L}$ & 0 & $<0.05$ & $<0.05$ & $<0.05$ & $0 \%$ & $0 \%$ & $0 \%$ \\
\hline Palladium & $\mathrm{Pd}$ & $\mu \mathrm{g} / \mathrm{L}$ & - & - & - & - & - & - & - \\
\hline Phosphorus & $P$ & $\mu \mathrm{g} / \mathrm{L}$ & 1000 & $<1000$ & $<1000$ & $<1000$ & $0 \%$ & $0 \%$ & $0 \%$ \\
\hline Platinum & $\mathrm{Pt}$ & $\mu \mathrm{g} / \mathrm{L}$ & 0 & $<0.05$ & $<0.05$ & $<0.05$ & $0 \%$ & $0 \%$ & $0 \%$ \\
\hline Potassium & K & $\mu \mathrm{g} / \mathrm{L}$ & 200 & 1300 & 1400 & 1300 & $7 \%$ & $0 \%$ & $7 \%$ \\
\hline Praseodymium & $\mathrm{Pr}$ & $\mu \mathrm{g} / \mathrm{L}$ & 0 & 1.0 & 1.0 & 1.1 & $0 \%$ & $10 \%$ & $10 \%$ \\
\hline Rhenium & $\operatorname{Re}$ & $\mu \mathrm{g} / \mathrm{L}$ & 0 & $<0.2$ & $<0.2$ & $<0.2$ & $0 \%$ & $0 \%$ & $0 \%$ \\
\hline Rhodium & $\mathrm{Rh}$ & $\mu \mathrm{g} / \mathrm{L}$ & 0 & $<0.1$ & $<0.1$ & $<0.1$ & $0 \%$ & $0 \%$ & $0 \%$ \\
\hline Rubidium & $\mathrm{Rb}$ & $\mu \mathrm{g} / \mathrm{L}$ & 1 & 4.5 & 4.4 & 4.7 & $2 \%$ & $4 \%$ & $7 \%$ \\
\hline Ruthenium & $\mathrm{Ru}$ & $\mu \mathrm{g} / \mathrm{L}$ & 0 & $<0.1$ & $<0.1$ & $<0.1$ & $0 \%$ & $0 \%$ & $0 \%$ \\
\hline Samarium & $\mathrm{Sm}$ & $\mu \mathrm{g} / \mathrm{L}$ & 0 & 1.8 & 1.8 & 1.9 & $0 \%$ & $5 \%$ & $5 \%$ \\
\hline Selenium & $\mathrm{Se}$ & $\mu \mathrm{g} / \mathrm{L}$ & 1 & 1.3 & $<1.0$ & 1.4 & $26 \%$ & $7 \%$ & $33 \%$ \\
\hline Silver & $\mathrm{Ag}$ & $\mu \mathrm{g} / \mathrm{L}$ & 0 & $<0.1$ & $<0.1$ & $<0.1$ & $0 \%$ & $0 \%$ & $0 \%$ \\
\hline Sodium & $\mathrm{Na}$ & $\mu \mathrm{g} / \mathrm{L}$ & 200 & 3300 & 3300 & 3400 & $0 \%$ & $3 \%$ & $3 \%$ \\
\hline Strontium & $\mathrm{Sr}$ & $\mu \mathrm{g} / \mathrm{L}$ & 1 & 36 & 37 & 39 & $3 \%$ & $8 \%$ & $5 \%$ \\
\hline Sulfur & $\mathrm{s}$ & $\mu \mathrm{g} / \mathrm{L}$ & 1000 & 190000 & 190000 & 210000 & $0 \%$ & $10 \%$ & $10 \%$ \\
\hline Tantalum & $\mathrm{Ta}$ & $\mu \mathrm{g} / \mathrm{L}$ & 0 & $<0.05$ & $<0.05$ & $<0.05$ & $0 \%$ & $0 \%$ & $0 \%$ \\
\hline Terbium & $\mathrm{Tb}$ & $\mu \mathrm{g} / \mathrm{L}$ & 0 & 0.45 & 0.42 & 0.43 & $7 \%$ & $5 \%$ & $2 \%$ \\
\hline Tellurium & $\mathrm{Te}$ & $\mu \mathrm{g} / \mathrm{L}$ & 1 & 0.82 & 0.76 & 0.70 & $8 \%$ & $16 \%$ & $8 \%$ \\
\hline Thalium & $\mathrm{TI}$ & $\mu \mathrm{g} / \mathrm{L}$ & 0 & 65 & 64 & 64 & $2 \%$ & $2 \%$ & $0 \%$ \\
\hline Thorium & Th & $\mu \mathrm{g} / \mathrm{L}$ & - & - & - & - & - & - & - \\
\hline Thulium & $\mathrm{Tm}$ & $\mu \mathrm{g} / \mathrm{L}$ & 0 & 0.18 & 0.18 & 0.19 & $0 \%$ & $5 \%$ & $5 \%$ \\
\hline $\operatorname{Tin} * *$ & Sn & $\mu \mathrm{g} / \mathrm{L}$ & 3 & $<3.0$ & $<3.0$ & $<3.0$ & $0 \%$ & $0 \%$ & $0 \%$ \\
\hline Titanium & $\mathrm{Ti}$ & $\mu \mathrm{g} / \mathrm{L}$ & 3 & $<3.0$ & $<3.0$ & $<3.0$ & $0 \%$ & $0 \%$ & $0 \%$ \\
\hline Tungsten & w & $\mu \mathrm{g} / \mathrm{L}$ & 1 & $<0.5$ & $<0.5$ & $<0.5$ & $0 \%$ & $0 \%$ & $0 \%$ \\
\hline Uranium & U & $\mu \mathrm{g} / \mathrm{L}$ & 0 & 4.6 & 4.6 & 4.5 & $0 \%$ & $2 \%$ & $2 \%$ \\
\hline Vanadium & $\mathrm{v}$ & $\mu \mathrm{g} / \mathrm{L}$ & 0 & 34 & 34 & 36 & $0 \%$ & $6 \%$ & $6 \%$ \\
\hline Ytterbium & $\mathrm{Yb}$ & $\mu \mathrm{g} / \mathrm{L}$ & 0 & 1.1 & 1.1 & 1.1 & $0 \%$ & $0 \%$ & $0 \%$ \\
\hline Yttrium & $Y$ & $\mu \mathrm{g} / \mathrm{L}$ & 1 & 17 & 16 & 17 & $6 \%$ & $0 \%$ & $6 \%$ \\
\hline Zinc & $\mathrm{Zn}$ & $\mu \mathrm{g} / \mathrm{L}$ & 10 & 38000 & 37000 & 41000 & $3 \%$ & $8 \%$ & $10 \%$ \\
\hline Zirconium & $\mathrm{Zr}$ & $\mu \mathrm{g} / \mathrm{L}$ & 0 & $<0.1$ & $<0.1$ & $<0.1$ & $0 \%$ & $0 \%$ & $0 \%$ \\
\hline
\end{tabular}




\begin{tabular}{|c|c|c|c|c|c|c|}
\hline & Symbol & Units & $\begin{array}{c}\text { Sample name } \\
\text { Sample type } \\
\text { Sample number } \\
\text { Detection limit }\end{array}$ & $\begin{array}{l}\text { LN-BP-W } \\
\text { FA } \\
\text { No11 } \\
\text { Lab Du }\end{array}$ & $\begin{array}{l}\text { LN-BP-W } \\
\text { FA } \\
\text { No11 } \\
\text { plicate } \\
\end{array}$ & $\begin{array}{c}\text { LN-BP-W } \\
\text { FA } \\
\text { \% Diff No } 11\end{array}$ \\
\hline \multicolumn{7}{|l|}{ Metals } \\
\hline Aluminium & Al & $\mu \mathrm{g} / \mathrm{L}$ & 5 & 6300 & 6200 & $2 \%$ \\
\hline Antimony & $\mathrm{Sb}$ & $\mu \mathrm{g} / \mathrm{L}$ & 2 & 2 & 2 & $0 \%$ \\
\hline Arsenic & As & $\mu \mathrm{g} / \mathrm{L}$ & 2 & 4.0 & 3.3 & $19 \%$ \\
\hline Barium & $\mathrm{Ba}$ & $\mu \mathrm{g} / \mathrm{L}$ & 0 & 45 & 40 & $12 \%$ \\
\hline Beryllium & $\mathrm{Be}$ & $\mu \mathrm{g} / \mathrm{L}$ & 0 & 0.24 & 0.28 & $15 \%$ \\
\hline Boron & B & $\mu \mathrm{g} / \mathrm{L}$ & 1000 & 1000 & 1000 & $0 \%$ \\
\hline Cadmium & $\mathrm{Cd}$ & $\mu \mathrm{g} / \mathrm{L}$ & 0 & 7.8 & 6.9 & $12 \%$ \\
\hline Calcium & $\mathrm{Ca}$ & $\mu \mathrm{g} / \mathrm{L}$ & 300 & 36000 & 32000 & $12 \%$ \\
\hline Cerium & $\mathrm{Ce}$ & $\mu \mathrm{g} / \mathrm{L}$ & 1 & 12 & 11 & $9 \%$ \\
\hline Cesium & Cs & $\mu \mathrm{g} / \mathrm{L}$ & - & - & - & - \\
\hline Chromium & $\mathrm{Cr}$ & $\mu \mathrm{g} / \mathrm{L}$ & 5 & 5 & 5 & $0 \%$ \\
\hline Cobalt & Co & $\mu \mathrm{g} / \mathrm{L}$ & 0 & 100 & 89 & $12 \%$ \\
\hline Copper & $\mathrm{Cu}$ & $\mu \mathrm{g} / \mathrm{L}$ & 5 & 3900 & 3800 & $3 \%$ \\
\hline Dysprosium & Dy & $\mu \mathrm{g} / \mathrm{L}$ & 0 & 1.2 & 1.1 & $9 \%$ \\
\hline Erbium & $\mathrm{Er}$ & $\mu \mathrm{g} / \mathrm{L}$ & 0 & 0.64 & 0.58 & $10 \%$ \\
\hline Europium & $\mathrm{Eu}$ & $\mu \mathrm{g} / \mathrm{L}$ & 0 & 0.57 & 0.45 & $24 \%$ \\
\hline Gadolinium & $\mathrm{Gd}$ & $\mu \mathrm{g} / \mathrm{L}$ & 0 & 1.7 & 1.6 & $6 \%$ \\
\hline Gallium & $\mathrm{Ga}$ & $\mu \mathrm{g} / \mathrm{L}$ & 5 & 5 & 5 & $0 \%$ \\
\hline Germanium & $\mathrm{Ge}$ & $\mu \mathrm{g} / \mathrm{L}$ & 1 & 1 & 1 & $0 \%$ \\
\hline Hafnium & $\mathrm{Hf}$ & $\mu \mathrm{g} / \mathrm{L}$ & - & - & - & - \\
\hline Holonium & Ho & $\mu \mathrm{g} / \mathrm{L}$ & 0 & 0.22 & 0.21 & $5 \%$ \\
\hline Iridium & Ir & $\mu \mathrm{g} / \mathrm{L}$ & 1 & 1 & 1 & $0 \%$ \\
\hline Iron & $\mathrm{Fe}$ & $\mu \mathrm{g} / \mathrm{L}$ & 50 & 17000 & 15000 & $13 \%$ \\
\hline Lanthanum & La & $\mu \mathrm{g} / \mathrm{L}$ & 0 & 5.2 & 4.8 & $8 \%$ \\
\hline Lead & $\mathrm{Pb}$ & $\mu \mathrm{g} / \mathrm{L}$ & 0 & 53 & 48 & $10 \%$ \\
\hline Lithium & $\mathrm{Li}$ & $\mu \mathrm{g} / \mathrm{L}$ & 2 & 4.6 & 4.0 & $14 \%$ \\
\hline Lutetium & Lu & $\mu \mathrm{g} / \mathrm{L}$ & 0 & 0.061 & 0.059 & $3 \%$ \\
\hline Magnesium & $\mathrm{Mg}$ & $\mu \mathrm{g} / \mathrm{L}$ & 30 & 3300 & 2900 & $13 \%$ \\
\hline Manganese & $\mathrm{Mn}$ & $\mu \mathrm{g} / \mathrm{L}$ & 0 & 1000 & 1100 & $10 \%$ \\
\hline Molybdenum & Mo & $\mu \mathrm{g} / \mathrm{L}$ & 10 & 10 & 10 & $0 \%$ \\
\hline Neodymium & $\mathrm{Nd}$ & $\mu \mathrm{g} / \mathrm{L}$ & 0 & 7.4 & 6.6 & $11 \%$ \\
\hline Nickel & $\mathrm{Ni}$ & $\mu \mathrm{g} / \mathrm{L}$ & 1 & 91 & 81 & $12 \%$ \\
\hline Niobium & $\mathrm{Nb}$ & $\mu \mathrm{g} / \mathrm{L}$ & 0 & 0 & 0 & $0 \%$ \\
\hline Palladium & $\mathrm{Pd}$ & $\mu \mathrm{g} / \mathrm{L}$ & - & - & - & - \\
\hline Phosphorus & $P$ & $\mu \mathrm{g} / \mathrm{L}$ & 1000 & 1000 & 1000 & $0 \%$ \\
\hline Platinum & Pt & $\mu \mathrm{g} / \mathrm{L}$ & 0 & 0 & 0 & $0 \%$ \\
\hline Potassium & $\mathrm{K}$ & $\mu \mathrm{g} / \mathrm{L}$ & 200 & 2000 & 1800 & $11 \%$ \\
\hline Praseodymium & $\mathrm{Pr}$ & $\mu \mathrm{g} / \mathrm{L}$ & 0 & 1.7 & 1.6 & $6 \%$ \\
\hline Rhenium & $\operatorname{Re}$ & $\mu \mathrm{g} / \mathrm{L}$ & 0 & 0 & 0 & $0 \%$ \\
\hline Rhodium & $\mathrm{Rh}$ & $\mu \mathrm{g} / \mathrm{L}$ & 0 & 0 & 0 & $0 \%$ \\
\hline Rubidium & $\mathrm{Rb}$ & $\mu \mathrm{g} / \mathrm{L}$ & 1 & 5.0 & 4.5 & $11 \%$ \\
\hline Ruthenium & $\mathrm{Ru}$ & $\mu \mathrm{g} / \mathrm{L}$ & 0 & 0 & 0 & $0 \%$ \\
\hline Samarium & $\mathrm{Sm}$ & $\mu \mathrm{g} / \mathrm{L}$ & 0 & 1.4 & 1.3 & $7 \%$ \\
\hline Selenium & $\mathrm{Se}$ & $\mu \mathrm{g} / \mathrm{L}$ & 1 & 28 & 25 & $11 \%$ \\
\hline Silver & $\mathrm{Ag}$ & $\mu \mathrm{g} / \mathrm{L}$ & 0 & 2.1 & 1.8 & $15 \%$ \\
\hline Sodium & $\mathrm{Na}$ & $\mu \mathrm{g} / \mathrm{L}$ & 200 & 19000 & 16000 & $17 \%$ \\
\hline Strontium & $\mathrm{Sr}$ & $\mu \mathrm{g} / \mathrm{L}$ & 1 & 120 & 100 & $18 \%$ \\
\hline Sulfur & $S$ & $\mu \mathrm{g} / \mathrm{L}$ & 1000 & 4600000 & 4600000 & $0 \%$ \\
\hline Tantalum & $\mathrm{Ta}$ & $\mu \mathrm{g} / \mathrm{L}$ & 0 & 0 & 0 & $0 \%$ \\
\hline Terbium & $\mathrm{Tb}$ & $\mu \mathrm{g} / \mathrm{L}$ & 0 & 0.23 & 0.21 & $9 \%$ \\
\hline Tellurium & $\mathrm{Te}$ & $\mu \mathrm{g} / \mathrm{L}$ & 1 & 1 & 1 & $0 \%$ \\
\hline Thalium & $\mathrm{Tl}$ & $\mu \mathrm{g} / \mathrm{L}$ & 0 & 2.3 & 2.1 & $9 \%$ \\
\hline Thorium & Th & $\mu \mathrm{g} / \mathrm{L}$ & - & - & - & - \\
\hline Thulium & $\mathrm{Tm}$ & $\mu \mathrm{g} / \mathrm{L}$ & 0 & 0.080 & 0.078 & $3 \%$ \\
\hline $\operatorname{Tin} * *$ & Sn & $\mu \mathrm{g} / \mathrm{L}$ & 3 & 3.0 & 3.0 & $0 \%$ \\
\hline Titanium & $\mathrm{Ti}$ & $\mu \mathrm{g} / \mathrm{L}$ & 3 & 3 & 3 & $0 \%$ \\
\hline Tungsten & W & $\mu \mathrm{g} / \mathrm{L}$ & 1 & 1 & 1 & $0 \%$ \\
\hline Uranium & U & $\mu \mathrm{g} / \mathrm{L}$ & 0 & 0.43 & 0.39 & $10 \%$ \\
\hline Vanadium & V & $\mu \mathrm{g} / \mathrm{L}$ & 0 & 0 & 0 & $0 \%$ \\
\hline Ytterbium & $\mathrm{Yb}$ & $\mu \mathrm{g} / \mathrm{L}$ & 0 & 0.46 & 0.38 & $19 \%$ \\
\hline Yttrium & $Y$ & $\mu \mathrm{g} / \mathrm{L}$ & 1 & 7.7 & 6.4 & $18 \%$ \\
\hline Zinc & $\mathrm{Zn}$ & $\mu \mathrm{g} / \mathrm{L}$ & 10 & 120 & 110 & $9 \%$ \\
\hline Zirconium & $\mathrm{Zr}$ & $\mu \mathrm{g} / \mathrm{L}$ & 0 & 0.23 & 0 & $79 \%$ \\
\hline
\end{tabular}




\begin{tabular}{|c|c|c|c|c|c|c|}
\hline & & & $\begin{array}{l}\text { Sample name } \\
\text { Sample type } \\
\text { Sample number }\end{array}$ & $\begin{array}{l}\text { LN-VWD-W } \\
\text { FFA } \\
\text { No27 }\end{array}$ & $\begin{array}{l}\text { LN-VWD-W } \\
\text { FFA } \\
\text { No27 }\end{array}$ & $\begin{array}{l}\text { LN-VWD-W } \\
\text { FFA } \\
\text { \%Diff No } 27\end{array}$ \\
\hline & Symbol & Units & Detection limit & \multicolumn{2}{|c|}{ Lab Duplicate } & \\
\hline \multicolumn{7}{|l|}{ Metals } \\
\hline Aluminium & Al & $\mu \mathrm{g} / \mathrm{L}$ & 5 & 190000 & 190000 & $0 \%$ \\
\hline Antimony & $\mathrm{Sb}$ & $\mu \mathrm{g} / \mathrm{L}$ & 2 & 2 & 2 & $0 \%$ \\
\hline Arsenic & As & $\mu \mathrm{g} / \mathrm{L}$ & 2 & 320 & 320 & $0 \%$ \\
\hline Barium & $\mathrm{Ba}$ & $\mu \mathrm{g} / \mathrm{L}$ & 0 & 9.8 & 9.4 & $4 \%$ \\
\hline Beryllium & $\mathrm{Be}$ & $\mu \mathrm{g} / \mathrm{L}$ & 0 & 41 & 41 & $0 \%$ \\
\hline Boron & B & $\mu \mathrm{g} / \mathrm{L}$ & 1000 & 1000 & 1000 & $0 \%$ \\
\hline Cadmium & $\mathrm{Cd}$ & $\mu \mathrm{g} / \mathrm{L}$ & 0 & 110 & 110 & $0 \%$ \\
\hline Calcium & $\mathrm{Ca}$ & $\mu \mathrm{g} / \mathrm{L}$ & 300 & 460000 & 460000 & $0 \%$ \\
\hline Cerium & $\mathrm{Ce}$ & $\mu \mathrm{g} / \mathrm{L}$ & 1 & 290 & 290 & $0 \%$ \\
\hline Cesium & Cs & $\mu \mathrm{g} / \mathrm{L}$ & - & - & - & - \\
\hline Chromium & $\mathrm{Cr}$ & $\mu \mathrm{g} / \mathrm{L}$ & 5 & 110 & 110 & $0 \%$ \\
\hline Cobalt & Co & $\mu \mathrm{g} / \mathrm{L}$ & 0 & 820 & 830 & $1 \%$ \\
\hline Copper & $\mathrm{Cu}$ & $\mu \mathrm{g} / \mathrm{L}$ & 5 & 22000 & 21000 & $5 \%$ \\
\hline Dysprosium & Dy & $\mu \mathrm{g} / \mathrm{L}$ & 0 & 31 & 30 & $3 \%$ \\
\hline Erbium & $\mathrm{Er}$ & $\mu \mathrm{g} / \mathrm{L}$ & 0 & 16 & 16 & $0 \%$ \\
\hline Europium & $\mathrm{Eu}$ & $\mu \mathrm{g} / \mathrm{L}$ & 0 & 10 & 11 & $10 \%$ \\
\hline Gadolinium & $\mathrm{Gd}$ & $\mu \mathrm{g} / \mathrm{L}$ & 0 & 38 & 38 & $0 \%$ \\
\hline Gallium & $\mathrm{Ga}$ & $\mu \mathrm{g} / \mathrm{L}$ & 5 & 33 & 35 & $6 \%$ \\
\hline Germanium & $\mathrm{Ge}$ & $\mu \mathrm{g} / \mathrm{L}$ & 1 & 15 & 15 & $0 \%$ \\
\hline Hafnium & $\mathrm{Hf}$ & $\mu \mathrm{g} / \mathrm{L}$ & - & - & - & - \\
\hline Holonium & Ho & $\mu \mathrm{g} / \mathrm{L}$ & 0 & 6.0 & 6.0 & $0 \%$ \\
\hline Iridium & Ir & $\mu \mathrm{g} / \mathrm{L}$ & 1 & 1 & 1 & $0 \%$ \\
\hline Iron & $\mathrm{Fe}$ & $\mu \mathrm{g} / \mathrm{L}$ & 50 & 450000 & 450000 & $0 \%$ \\
\hline Lanthanum & La & $\mu \mathrm{g} / \mathrm{L}$ & 0 & 130 & 130 & $0 \%$ \\
\hline Lead & $\mathrm{Pb}$ & $\mu \mathrm{g} / \mathrm{L}$ & 0 & 7.1 & 6.8 & $4 \%$ \\
\hline Lithium & $\mathrm{Li}$ & $\mu \mathrm{g} / \mathrm{L}$ & 2 & 71 & 70 & $1 \%$ \\
\hline Lutetium & $\mathrm{Lu}$ & $\mu \mathrm{g} / \mathrm{L}$ & 0 & 1.8 & 1.8 & $0 \%$ \\
\hline Magnesium & $\mathrm{Mg}$ & $\mu \mathrm{g} / \mathrm{L}$ & 30 & 66000 & 67000 & $2 \%$ \\
\hline Manganese & $\mathrm{Mn}$ & $\mu \mathrm{g} / \mathrm{L}$ & 0 & 34000 & 32000 & $6 \%$ \\
\hline Molybdenum & Mo & $\mu \mathrm{g} / \mathrm{L}$ & 10 & 10 & 10 & $0 \%$ \\
\hline Neodymium & $\mathrm{Nd}$ & $\mu \mathrm{g} / \mathrm{L}$ & 0 & 150 & 150 & $0 \%$ \\
\hline Nickel & $\mathrm{Ni}$ & $\mu \mathrm{g} / \mathrm{L}$ & 1 & 890 & 900 & $1 \%$ \\
\hline Niobium & $\mathrm{Nb}$ & $\mu \mathrm{g} / \mathrm{L}$ & 0 & 0.11 & 0.12 & $9 \%$ \\
\hline Palladium & $\mathrm{Pd}$ & $\mu \mathrm{g} / \mathrm{L}$ & - & - & - & - \\
\hline Phosphorus & $\mathrm{P}$ & $\mu \mathrm{g} / \mathrm{L}$ & 1000 & 1600 & 1500 & $6 \%$ \\
\hline Platinum & $\mathrm{Pt}$ & $\mu \mathrm{g} / \mathrm{L}$ & 0 & 0 & 0 & $0 \%$ \\
\hline Potassium & $\mathrm{K}$ & $\mu \mathrm{g} / \mathrm{L}$ & 200 & 1000 & 970 & $3 \%$ \\
\hline Praseodymium & $\operatorname{Pr}$ & $\mu \mathrm{g} / \mathrm{L}$ & 0 & 36 & 35 & $3 \%$ \\
\hline Rhenium & $\mathrm{Re}$ & $\mu \mathrm{g} / \mathrm{L}$ & 0 & 0 & 0 & $0 \%$ \\
\hline Rhodium & $\mathrm{Rh}$ & $\mu \mathrm{g} / \mathrm{L}$ & 0 & 0 & 0 & $0 \%$ \\
\hline Rubidium & $\mathrm{Rb}$ & $\mu \mathrm{g} / \mathrm{L}$ & 1 & 11 & 11 & $0 \%$ \\
\hline Ruthenium & $\mathrm{Ru}$ & $\mu \mathrm{g} / \mathrm{L}$ & 0 & 0 & 0 & $0 \%$ \\
\hline Samarium & $\mathrm{Sm}$ & $\mu \mathrm{g} / \mathrm{L}$ & 0 & 35 & 34 & $3 \%$ \\
\hline Selenium & $\mathrm{Se}$ & $\mu \mathrm{g} / \mathrm{L}$ & 1 & 22 & 22 & $0 \%$ \\
\hline Silver & $\mathrm{Ag}$ & $\mu \mathrm{g} / \mathrm{L}$ & 0 & 0.85 & 0.91 & $7 \%$ \\
\hline Sodium & $\mathrm{Na}$ & $\mu \mathrm{g} / \mathrm{L}$ & 200 & 45000 & 45000 & $0 \%$ \\
\hline Strontium & $\mathrm{Sr}$ & $\mu \mathrm{g} / \mathrm{L}$ & 1 & 2800 & 2800 & $0 \%$ \\
\hline Sulfur & $S$ & $\mu \mathrm{g} / \mathrm{L}$ & 1000 & 5300000 & 5000000 & $6 \%$ \\
\hline Tantalum & $\mathrm{Ta}$ & $\mu \mathrm{g} / \mathrm{L}$ & 0 & 0 & 0 & $0 \%$ \\
\hline Terbium & $\mathrm{Tb}$ & $\mu \mathrm{g} / \mathrm{L}$ & 0 & 5.6 & 5.6 & $0 \%$ \\
\hline Tellurium & $\mathrm{Te}$ & $\mu \mathrm{g} / \mathrm{L}$ & 1 & 4.3 & 4.2 & $2 \%$ \\
\hline Thalium & $\mathrm{Tl}$ & $\mu \mathrm{g} / \mathrm{L}$ & 0 & 0.52 & 0.48 & $8 \%$ \\
\hline Thorium & Th & $\mu \mathrm{g} / \mathrm{L}$ & - & - & - & - \\
\hline Thulium & $\mathrm{Tm}$ & $\mu \mathrm{g} / \mathrm{L}$ & 0 & 2.1 & 2.0 & $5 \%$ \\
\hline $\operatorname{Tin} * *$ & Sn & $\mu \mathrm{g} / \mathrm{L}$ & 3 & 3.0 & 3.0 & $0 \%$ \\
\hline Titanium & $\mathrm{Ti}$ & $\mu \mathrm{g} / \mathrm{L}$ & 3 & 10 & 6.0 & $50 \%$ \\
\hline Tungsten & w & $\mu \mathrm{g} / \mathrm{L}$ & 1 & 1 & 1 & $0 \%$ \\
\hline Uranium & $U$ & $\mu \mathrm{g} / \mathrm{L}$ & 0 & 18 & 18 & $0 \%$ \\
\hline Vanadium & $\mathrm{V}$ & $\mu \mathrm{g} / \mathrm{L}$ & 0 & 23 & 22 & $4 \%$ \\
\hline Ytterbium & $\mathrm{Yb}$ & $\mu \mathrm{g} / \mathrm{L}$ & 0 & 13 & 13 & $0 \%$ \\
\hline Yttrium & $Y$ & $\mu \mathrm{g} / \mathrm{L}$ & 1 & 180 & 180 & $0 \%$ \\
\hline Zinc & $\mathrm{Zn}$ & $\mu \mathrm{g} / \mathrm{L}$ & 10 & 6500 & 6500 & $0 \%$ \\
\hline Zirconium & $\mathrm{Zr}$ & $\mu \mathrm{g} / \mathrm{L}$ & 0 & 2.2 & 1.9 & $15 \%$ \\
\hline
\end{tabular}




\begin{tabular}{|c|c|c|c|c|c|c|}
\hline & Symbol & Units & $\begin{array}{l}\text { Sample name } \\
\text { Sample type } \\
\text { Sample number } \\
\text { Detection limit }\end{array}$ & $\begin{array}{c}\text { DAR-1-W } \\
\text { UA } \\
\text { No29 } \\
\text { Lab Du }\end{array}$ & $\begin{array}{l}\text { DAR-1-W } \\
\text { UA } \\
\text { No29 } \\
\text { plicate }\end{array}$ & $\begin{array}{c}\text { DAR-1-W } \\
\text { UA } \\
\text { \%Diff } 29\end{array}$ \\
\hline \multicolumn{7}{|l|}{ Metals } \\
\hline Aluminium & $\mathrm{Al}$ & $\mu \mathrm{g} / \mathrm{L}$ & 5 & 360000 & 360000 & $0 \%$ \\
\hline Antimony & $\mathrm{Sb}$ & $\mu \mathrm{g} / \mathrm{L}$ & 2 & 3.3 & 3.7 & $11 \%$ \\
\hline Arsenic & As & $\mu \mathrm{g} / \mathrm{L}$ & 2 & 830 & 990 & $18 \%$ \\
\hline Barium & $\mathrm{Ba}$ & $\mu \mathrm{g} / \mathrm{L}$ & 0 & 9.7 & 9.6 & $1 \%$ \\
\hline Beryllium & $\mathrm{Be}$ & $\mu \mathrm{g} / \mathrm{L}$ & 0 & 53 & 53 & $0 \%$ \\
\hline Boron & B & $\mu \mathrm{g} / \mathrm{L}$ & 1000 & 1000 & 1000 & $0 \%$ \\
\hline Cadmium & $\mathrm{Cd}$ & $\mu \mathrm{g} / \mathrm{L}$ & 0 & 200 & 200 & $0 \%$ \\
\hline Calcium & $\mathrm{Ca}$ & $\mu \mathrm{g} / \mathrm{L}$ & 300 & 440000 & 430000 & $2 \%$ \\
\hline Cerium & $\mathrm{Ce}$ & $\mu \mathrm{g} / \mathrm{L}$ & 1 & 580 & 590 & $2 \%$ \\
\hline Cesium & Cs & $\mu \mathrm{g} / \mathrm{L}$ & - & - & - & - \\
\hline Chromium & $\mathrm{Cr}$ & $\mu \mathrm{g} / \mathrm{L}$ & 5 & 84 & 83 & $1 \%$ \\
\hline Cobalt & Co & $\mu \mathrm{g} / \mathrm{L}$ & 0 & 1000 & 1000 & $0 \%$ \\
\hline Copper & $\mathrm{Cu}$ & $\mu \mathrm{g} / \mathrm{L}$ & 5 & 20000 & 19000 & $5 \%$ \\
\hline Dysprosium & Dy & $\mu \mathrm{g} / \mathrm{L}$ & 0 & 74 & 74 & $0 \%$ \\
\hline Erbium & $\mathrm{Er}$ & $\mu \mathrm{g} / \mathrm{L}$ & 0 & 36 & 37 & $3 \%$ \\
\hline Europium & $\mathrm{Eu}$ & $\mu \mathrm{g} / \mathrm{L}$ & 0 & 26 & 25 & $4 \%$ \\
\hline Gadolinium & $\mathrm{Gd}$ & $\mu \mathrm{g} / \mathrm{L}$ & 0 & 92 & 92 & $0 \%$ \\
\hline Gallium & $\mathrm{Ga}$ & $\mu \mathrm{g} / \mathrm{L}$ & 5 & 76 & 69 & $10 \%$ \\
\hline Germanium & $\mathrm{Ge}$ & $\mu \mathrm{g} / \mathrm{L}$ & 1 & 29 & 28 & $4 \%$ \\
\hline Hafnium & $\mathrm{Hf}$ & $\mu \mathrm{g} / \mathrm{L}$ & - & - & - & - \\
\hline Holonium & $\mathrm{Ho}$ & $\mu \mathrm{g} / \mathrm{L}$ & 0 & 14 & 14 & $0 \%$ \\
\hline Iridium & Ir & $\mu \mathrm{g} / \mathrm{L}$ & 1 & 1 & 1 & $0 \%$ \\
\hline Iron & $\mathrm{Fe}$ & $\mu \mathrm{g} / \mathrm{L}$ & 50 & 660000 & 660000 & $0 \%$ \\
\hline Lanthanum & La & $\mu \mathrm{g} / \mathrm{L}$ & 0 & 270 & 270 & $0 \%$ \\
\hline Lead & $\mathrm{Pb}$ & $\mu \mathrm{g} / \mathrm{L}$ & 0 & 4.8 & 3.4 & $34 \%$ \\
\hline Lithium & $\mathrm{Li}$ & $\mu \mathrm{g} / \mathrm{L}$ & 2 & 130 & 130 & $0 \%$ \\
\hline Lutetium & $\mathrm{Lu}$ & $\mu \mathrm{g} / \mathrm{L}$ & 0 & 3.5 & 3.5 & $0 \%$ \\
\hline Magnesium & $\mathrm{Mg}$ & $\mu \mathrm{g} / \mathrm{L}$ & 30 & 140000 & 140000 & $0 \%$ \\
\hline Manganese & $\mathrm{Mn}$ & $\mu \mathrm{g} / \mathrm{L}$ & 0 & 47000 & 47000 & $0 \%$ \\
\hline Molybdenum & Mo & $\mu \mathrm{g} / \mathrm{L}$ & 10 & 10 & 10 & $0 \%$ \\
\hline Neodymium & $\mathrm{Nd}$ & $\mu \mathrm{g} / \mathrm{L}$ & 0 & 350 & 350 & $0 \%$ \\
\hline Nickel & $\mathrm{Ni}$ & $\mu \mathrm{g} / \mathrm{L}$ & 1 & 930 & 910 & $2 \%$ \\
\hline Niobium & $\mathrm{Nb}$ & $\mu \mathrm{g} / \mathrm{L}$ & 0 & 0.22 & 0.21 & $5 \%$ \\
\hline Palladium & $\mathrm{Pd}$ & $\mu \mathrm{g} / \mathrm{L}$ & - & - & - & - \\
\hline Phosphorus & $\mathrm{P}$ & $\mu \mathrm{g} / \mathrm{L}$ & 1000 & 6300 & 6300 & $0 \%$ \\
\hline Platinum & $\mathrm{Pt}$ & $\mu \mathrm{g} / \mathrm{L}$ & 0 & 0 & 0 & $0 \%$ \\
\hline Potassium & $\mathrm{K}$ & $\mu \mathrm{g} / \mathrm{L}$ & 200 & 1300 & 1400 & $7 \%$ \\
\hline Praseodymium & $\operatorname{Pr}$ & $\mu \mathrm{g} / \mathrm{L}$ & 0 & 80 & 81 & $1 \%$ \\
\hline Rhenium & $\operatorname{Re}$ & $\mu \mathrm{g} / \mathrm{L}$ & 0 & 0 & 0 & $0 \%$ \\
\hline Rhodium & $\mathrm{Rh}$ & $\mu \mathrm{g} / \mathrm{L}$ & 0 & 0 & 0 & $0 \%$ \\
\hline Rubidium & $\mathrm{Rb}$ & $\mu \mathrm{g} / \mathrm{L}$ & 1 & 9.8 & 9.6 & $2 \%$ \\
\hline Ruthenium & $\mathrm{Ru}$ & $\mu \mathrm{g} / \mathrm{L}$ & 0 & 0 & 0 & $0 \%$ \\
\hline Samarium & $\mathrm{Sm}$ & $\mu \mathrm{g} / \mathrm{L}$ & 0 & 82 & 83 & $1 \%$ \\
\hline Selenium & $\mathrm{Se}$ & $\mu \mathrm{g} / \mathrm{L}$ & 1 & 25 & 23 & $8 \%$ \\
\hline Silver & $\mathrm{Ag}$ & $\mu \mathrm{g} / \mathrm{L}$ & 0 & 0 & 0 & $0 \%$ \\
\hline Sodium & $\mathrm{Na}$ & $\mu \mathrm{g} / \mathrm{L}$ & 200 & 28000 & 28000 & $0 \%$ \\
\hline Strontium & $\mathrm{Sr}$ & $\mu \mathrm{g} / \mathrm{L}$ & 1 & 2000 & 2000 & $0 \%$ \\
\hline Sulfur & $\mathrm{s}$ & $\mu \mathrm{g} / \mathrm{L}$ & 1000 & 1800000 & 1800000 & $0 \%$ \\
\hline Tantalum & $\mathrm{Ta}$ & $\mu \mathrm{g} / \mathrm{L}$ & 0 & 0.067 & 0.070 & $4 \%$ \\
\hline Terbium & $\mathrm{Tb}$ & $\mu \mathrm{g} / \mathrm{L}$ & 0 & 14 & 14 & $0 \%$ \\
\hline Tellurium & $\mathrm{Te}$ & $\mu \mathrm{g} / \mathrm{L}$ & 1 & 2.2 & 2.2 & $0 \%$ \\
\hline Thalium & $\mathrm{Tl}$ & $\mu \mathrm{g} / \mathrm{L}$ & 0 & 0 & 0 & $0 \%$ \\
\hline Thorium & Th & $\mu \mathrm{g} / \mathrm{L}$ & - & - & - & - \\
\hline Thulium & $\mathrm{Tm}$ & $\mu \mathrm{g} / \mathrm{L}$ & 0 & 4.5 & 4.5 & $0 \%$ \\
\hline $\operatorname{Tin} * *$ & Sn & $\mu \mathrm{g} / \mathrm{L}$ & 3 & 3.00 & 3.00 & $0 \%$ \\
\hline Titanium & $\mathrm{Ti}$ & $\mu \mathrm{g} / \mathrm{L}$ & 3 & 24 & 26 & $8 \%$ \\
\hline Tungsten & w & $\mu \mathrm{g} / \mathrm{L}$ & 1 & 1 & 1 & $0 \%$ \\
\hline Uranium & U & $\mu \mathrm{g} / \mathrm{L}$ & 0 & 24 & 24 & $0 \%$ \\
\hline Vanadium & V & $\mu \mathrm{g} / \mathrm{L}$ & 0 & 26 & 26 & $0 \%$ \\
\hline Ytterbium & $\mathrm{Yb}$ & $\mu \mathrm{g} / \mathrm{L}$ & 0 & 26 & 27 & $4 \%$ \\
\hline Yttrium & $Y$ & $\mu \mathrm{g} / \mathrm{L}$ & 1 & 400 & 390 & $3 \%$ \\
\hline Zinc & $\mathrm{Zn}$ & $\mu \mathrm{g} / \mathrm{L}$ & 10 & 13000 & 13000 & $0 \%$ \\
\hline Zirconium & $\mathrm{Zr}$ & $\mu \mathrm{g} / \mathrm{L}$ & 0 & 2.3 & 2.4 & $4 \%$ \\
\hline
\end{tabular}




\begin{tabular}{|c|c|c|c|c|c|c|}
\hline & Symbol & Units & $\begin{array}{l}\text { Sample name } \\
\text { Sample type } \\
\text { Sample number } \\
\text { Detection limit }\end{array}$ & $\begin{array}{l}\text { LN-AB2 } \\
\text { UA } \\
\text { No42 } \\
\text { Lab Du }\end{array}$ & $\begin{array}{l}\text { LN-AB2 } \\
\text { UA } \\
\text { No42 } \\
\text { uplicate }\end{array}$ & $\begin{array}{c}\text { LN-AB2 } \\
\text { UA } \\
\text { \%Diff } 42\end{array}$ \\
\hline \multicolumn{7}{|c|}{ (1) } \\
\hline Aluminium & $\mathrm{Al}$ & $\mu \mathrm{g} / \mathrm{L}$ & 5 & 26 & 28 & $7 \%$ \\
\hline Antimony & $\mathrm{Sb}$ & $\mu \mathrm{g} / \mathrm{L}$ & 2 & 2 & 2 & $0 \%$ \\
\hline Arsenic & As & $\mu g / L$ & 2 & 2 & 2 & $0 \%$ \\
\hline Barium & $\mathrm{Ba}$ & $\mu \mathrm{g} / \mathrm{L}$ & 0 & 0 & 0 & $0 \%$ \\
\hline Beryllium & $\mathrm{Be}$ & $\mu g / L$ & 0 & 0 & 0 & $0 \%$ \\
\hline Boron & B & $\mu \mathrm{g} / \mathrm{L}$ & 1000 & 1000 & 1000 & $0 \%$ \\
\hline Cadmium & $\mathrm{Cd}$ & $\mu \mathrm{g} / \mathrm{L}$ & 0 & 0.058 & 0.097 & $50 \%$ \\
\hline Calcium & $\mathrm{Ca}$ & $\mu \mathrm{g} / \mathrm{L}$ & 300 & 300 & 300 & $0 \%$ \\
\hline Cerium & $\mathrm{Ce}$ & $\mu \mathrm{g} / \mathrm{L}$ & 1 & 1 & 1 & $0 \%$ \\
\hline Cesium & Cs & $\mu g / L$ & - & 1 & 1 & $0 \%$ \\
\hline Chromium & $\mathrm{Cr}$ & $\mu \mathrm{g} / \mathrm{L}$ & 5 & 5 & 5 & $0 \%$ \\
\hline Cobalt & Co & $\mu g / L$ & 0 & 42 & 42 & $0 \%$ \\
\hline Copper & $\mathrm{Cu}$ & $\mu g / L$ & 5 & 5 & 5 & $0 \%$ \\
\hline Dysprosium & Dy & $\mu \mathrm{g} / \mathrm{L}$ & 0 & 0 & 0 & $0 \%$ \\
\hline Erbium & $\mathrm{Er}$ & $\mu \mathrm{g} / \mathrm{L}$ & 0 & 0 & 0 & $0 \%$ \\
\hline Europium & Eu & $\mu \mathrm{g} / \mathrm{L}$ & 0 & 0 & 0 & $0 \%$ \\
\hline Gadolinium & $\mathrm{Gd}$ & $\mu \mathrm{g} / \mathrm{L}$ & 0 & 0 & 0 & $0 \%$ \\
\hline Gallium & Ga & $\mu g / L$ & 5 & 5 & 5 & $0 \%$ \\
\hline Germanium & Ge & $\mu \mathrm{g} / \mathrm{L}$ & 1 & 1 & 1 & $0 \%$ \\
\hline Hafnium & $\mathrm{Hf}$ & $\mu \mathrm{g} / \mathrm{L}$ & - & 1 & 1 & $0 \%$ \\
\hline Holonium & Ho & $\mu \mathrm{g} / \mathrm{L}$ & 0 & 0 & 0 & $0 \%$ \\
\hline Iridium & Ir & $\mu \mathrm{g} / \mathrm{L}$ & 1 & 1 & 1 & $0 \%$ \\
\hline Iron & $\mathrm{Fe}$ & $\mu \mathrm{g} / \mathrm{L}$ & 50 & 64 & 50 & $25 \%$ \\
\hline Lanthanum & La & $\mu g / L$ & 0 & 0 & 0 & $0 \%$ \\
\hline Lead & $\mathrm{Pb}$ & $\mu g / L$ & 0 & 15 & 15 & $0 \%$ \\
\hline Lithium & $\mathrm{Li}$ & $\mu \mathrm{g} / \mathrm{L}$ & 2 & 2 & 2 & $0 \%$ \\
\hline Lutetium & Lu & $\mu \mathrm{g} / \mathrm{L}$ & 0 & 0 & 0 & $0 \%$ \\
\hline Magnesium & $\mathrm{Mg}$ & $\mu g / L$ & 30 & 30 & 30 & $0 \%$ \\
\hline Manganese & $\mathrm{Mn}$ & $\mu \mathrm{g} / \mathrm{L}$ & 0 & 0 & 0 & $0 \%$ \\
\hline Molybdenum & Mo & $\mu \mathrm{g} / \mathrm{L}$ & 10 & 10 & 10 & $0 \%$ \\
\hline Neodymium & $\mathrm{Nd}$ & $\mu \mathrm{g} / \mathrm{L}$ & 0 & 0 & 0 & $0 \%$ \\
\hline Nickel & $\mathrm{Ni}$ & $\mu \mathrm{g} / \mathrm{L}$ & 1 & 1 & 1 & $0 \%$ \\
\hline Niobium & $\mathrm{Nb}$ & $\mu g / L$ & 0 & 0 & 0 & $0 \%$ \\
\hline Palladium & $\mathrm{Pd}$ & $\mu \mathrm{g} / \mathrm{L}$ & - & 0.23 & 0.19 & $19 \%$ \\
\hline Phosphorus & $\mathrm{P}$ & $\mu g / L$ & 1000 & 1000 & 1000 & $0 \%$ \\
\hline Platinum & $\mathrm{Pt}$ & $\mu \mathrm{g} / \mathrm{L}$ & 0 & 0 & 0 & $0 \%$ \\
\hline Potassium & $\mathrm{K}$ & $\mu \mathrm{g} / \mathrm{L}$ & 200 & 200 & 200 & $0 \%$ \\
\hline Praseodymium & $\mathrm{Pr}$ & $\mu \mathrm{g} / \mathrm{L}$ & 0 & 0 & 0 & $0 \%$ \\
\hline Rhenium & $\operatorname{Re}$ & $\mu g / L$ & 0 & 0 & 0 & $0 \%$ \\
\hline Rhodium & $\mathrm{Rh}$ & $\mu g / L$ & 0 & 0 & 0 & $0 \%$ \\
\hline Rubidium & $\mathrm{Rb}$ & $\mu g / L$ & 1 & 1 & 1 & $0 \%$ \\
\hline Ruthenium & $\mathrm{Ru}$ & $\mu \mathrm{g} / \mathrm{L}$ & 0 & 0 & 0 & $0 \%$ \\
\hline Samarium & $\mathrm{Sm}$ & $\mu \mathrm{g} / \mathrm{L}$ & 0 & 0 & 0 & $0 \%$ \\
\hline Selenium & $\mathrm{Se}$ & $\mu \mathrm{g} / \mathrm{L}$ & 1 & 1.7 & 1.4 & $19 \%$ \\
\hline Silver & $\mathrm{Ag}$ & $\mu \mathrm{g} / \mathrm{L}$ & 0 & 0.72 & 0.64 & $12 \%$ \\
\hline Sodium & $\mathrm{Na}$ & $\mu \mathrm{g} / \mathrm{L}$ & 200 & 200 & 200 & $0 \%$ \\
\hline Strontium & $\mathrm{Sr}$ & $\mu \mathrm{g} / \mathrm{L}$ & 1 & 1 & 1 & $0 \%$ \\
\hline Sulfur & $\mathrm{s}$ & $\mu g / L$ & 1000 & 5500000 & 5600000 & $2 \%$ \\
\hline Tantalum & $\mathrm{Ta}$ & $\mu \mathrm{g} / \mathrm{L}$ & 0 & 0 & 0 & $0 \%$ \\
\hline Terbium & $\mathrm{Tb}$ & $\mu g / L$ & 0 & 0 & 0 & $0 \%$ \\
\hline Tellurium & $\mathrm{Te}$ & $\mu g / L$ & 1 & 1 & 1 & $0 \%$ \\
\hline Thalium & $\mathrm{TI}$ & $\mu \mathrm{g} / \mathrm{L}$ & 0 & 0 & 0 & $0 \%$ \\
\hline Thorium & Th & $\mu \mathrm{g} / \mathrm{L}$ & - & 0 & 0 & $0 \%$ \\
\hline Thulium & Tm & $\mu \mathrm{g} / \mathrm{L}$ & 0 & 0 & 0 & $0 \%$ \\
\hline $\operatorname{Tin} * *$ & Sn & $\mu \mathrm{g} / \mathrm{L}$ & 3 & 0 & 0 & $0 \%$ \\
\hline Titanium & $\mathrm{Ti}$ & $\mu g / L$ & 3 & 3 & 3 & $0 \%$ \\
\hline Tungsten & w & $\mu \mathrm{g} / \mathrm{L}$ & 1 & 1 & 1 & $0 \%$ \\
\hline Uranium & U & $\mu \mathrm{g} / \mathrm{L}$ & 0 & 0 & 0 & $0 \%$ \\
\hline Vanadium & V & $\mu g / L$ & 0 & 0 & 0 & $0 \%$ \\
\hline Ytterbium & $\mathrm{Yb}$ & $\mu \mathrm{g} / \mathrm{L}$ & 0 & 0 & 0 & $0 \%$ \\
\hline Yttrium & $\mathrm{Y}$ & $\mu \mathrm{g} / \mathrm{L}$ & 1 & 1 & 1 & $0 \%$ \\
\hline Zinc & $\mathrm{Zn}$ & $\mu \mathrm{g} / \mathrm{L}$ & 10 & 10 & 10 & $0 \%$ \\
\hline Zirconium & $\mathrm{Zr}$ & $\mu \mathrm{g} / \mathrm{L}$ & 0 & 0.12 & 0 & $18 \%$ \\
\hline
\end{tabular}




\begin{tabular}{|c|c|c|c|c|c|c|}
\hline & Symbol & Units & $\begin{array}{l}\text { Sample name } \\
\text { Sample type } \\
\text { Sample number } \\
\text { Detection limit }\end{array}$ & $\begin{array}{l}\text { IN28-W } \\
\text { FA } \\
\text { No46 } \\
\text { Lab Dur }\end{array}$ & $\begin{array}{c}\text { IN28-W } \\
\text { FA } \\
\text { No46 } \\
\text { Iplicate }\end{array}$ & $\begin{array}{l}\text { IN28-W } \\
\text { FA } \\
\text { \%Diff } 46\end{array}$ \\
\hline \multicolumn{7}{|l|}{ Metals } \\
\hline Aluminium & Al & $\mu \mathrm{g} / \mathrm{L}$ & 5 & 15000 & 15000 & $0 \%$ \\
\hline Antimony & $\mathrm{Sb}$ & $\mu \mathrm{g} / \mathrm{L}$ & 2 & 2 & 2 & $0 \%$ \\
\hline Arsenic & As & $\mu \mathrm{g} / \mathrm{L}$ & 2 & 110 & 110 & $0 \%$ \\
\hline Barium & $\mathrm{Ba}$ & $\mu \mathrm{g} / \mathrm{L}$ & 0 & 8.6 & 8.2 & $5 \%$ \\
\hline Beryllium & $\mathrm{Be}$ & $\mu \mathrm{g} / \mathrm{L}$ & 0 & 1.7 & 1.8 & $6 \%$ \\
\hline Boron & B & $\mu \mathrm{g} / \mathrm{L}$ & 1000 & 1700 & 1800 & $6 \%$ \\
\hline Cadmium & $\mathrm{Cd}$ & $\mu \mathrm{g} / \mathrm{L}$ & 0 & 9.1 & 9.0 & $1 \%$ \\
\hline Calcium & $\mathrm{Ca}$ & $\mu \mathrm{g} / \mathrm{L}$ & 300 & 160000 & 160000 & $0 \%$ \\
\hline Cerium & $\mathrm{Ce}$ & $\mu \mathrm{g} / \mathrm{L}$ & 1 & 2.7 & 2.6 & $4 \%$ \\
\hline Cesium & Cs & $\mu \mathrm{g} / \mathrm{L}$ & - & - & - & - \\
\hline Chromium & $\mathrm{Cr}$ & $\mu \mathrm{g} / \mathrm{L}$ & 5 & 5 & 5 & $0 \%$ \\
\hline Cobalt & Co & $\mu \mathrm{g} / \mathrm{L}$ & 0 & 56 & 54 & $4 \%$ \\
\hline Copper & $\mathrm{Cu}$ & $\mu \mathrm{g} / \mathrm{L}$ & 5 & 28000 & 27000 & $4 \%$ \\
\hline Dysprosium & Dy & $\mu \mathrm{g} / \mathrm{L}$ & 0 & 1.6 & 1.6 & $0 \%$ \\
\hline Erbium & $\mathrm{Er}$ & $\mu \mathrm{g} / \mathrm{L}$ & 0 & 0.62 & 0.63 & $2 \%$ \\
\hline Europium & $\mathrm{Eu}$ & $\mu \mathrm{g} / \mathrm{L}$ & 0 & 0.46 & 0.38 & $19 \%$ \\
\hline Gadolinium & $\mathrm{Gd}$ & $\mu \mathrm{g} / \mathrm{L}$ & 0 & 2.1 & 2.0 & $5 \%$ \\
\hline Gallium & $\mathrm{Ga}$ & $\mu \mathrm{g} / \mathrm{L}$ & 5 & 5 & 5 & $0 \%$ \\
\hline Germanium & $\mathrm{Ge}$ & $\mu \mathrm{g} / \mathrm{L}$ & 1 & 1.4 & 1.4 & $0 \%$ \\
\hline Hafnium & $\mathrm{Hf}$ & $\mu \mathrm{g} / \mathrm{L}$ & - & - & - & - \\
\hline Holonium & Ho & $\mu \mathrm{g} / \mathrm{L}$ & 0 & 0.27 & 0.28 & $4 \%$ \\
\hline Iridium & Ir & $\mu \mathrm{g} / \mathrm{L}$ & 1 & 1 & 1 & $0 \%$ \\
\hline Iron & $\mathrm{Fe}$ & $\mu \mathrm{g} / \mathrm{L}$ & 50 & 23000 & 23000 & $0 \%$ \\
\hline Lanthanum & La & $\mu \mathrm{g} / \mathrm{L}$ & 0 & 0.88 & 0.92 & $4 \%$ \\
\hline Lead & $\mathrm{Pb}$ & $\mu \mathrm{g} / \mathrm{L}$ & 0 & 0.58 & 0.50 & $15 \%$ \\
\hline Lithium & $\mathrm{Li}$ & $\mu \mathrm{g} / \mathrm{L}$ & 2 & 450 & 440 & $2 \%$ \\
\hline Lutetium & Lu & $\mu \mathrm{g} / \mathrm{L}$ & 0 & 0.053 & 0.053 & $0 \%$ \\
\hline Magnesium & $\mathrm{Mg}$ & $\mu \mathrm{g} / \mathrm{L}$ & 30 & 28000 & 28000 & $0 \%$ \\
\hline Manganese & $\mathrm{Mn}$ & $\mu \mathrm{g} / \mathrm{L}$ & 0 & 3200 & 3300 & $3 \%$ \\
\hline Molybdenum & Mo & $\mu \mathrm{g} / \mathrm{L}$ & 10 & 10 & 10 & $0 \%$ \\
\hline Neodymium & $\mathrm{Nd}$ & $\mu \mathrm{g} / \mathrm{L}$ & 0 & 2.3 & 2.2 & $4 \%$ \\
\hline Nickel & $\mathrm{Ni}$ & $\mu \mathrm{g} / \mathrm{L}$ & 1 & 39 & 37 & $5 \%$ \\
\hline Niobium & $\mathrm{Nb}$ & $\mu \mathrm{g} / \mathrm{L}$ & 0 & 0 & 0 & $0 \%$ \\
\hline Palladium & $\mathrm{Pd}$ & $\mu \mathrm{g} / \mathrm{L}$ & - & - & - & - \\
\hline Phosphorus & $P$ & $\mu \mathrm{g} / \mathrm{L}$ & 1000 & 1000 & 1000 & $0 \%$ \\
\hline Platinum & $\mathrm{Pt}$ & $\mu \mathrm{g} / \mathrm{L}$ & 0 & 0 & 0 & $0 \%$ \\
\hline Potassium & $\mathrm{K}$ & $\mu \mathrm{g} / \mathrm{L}$ & 200 & 12000 & 12000 & $0 \%$ \\
\hline Praseodymium & $\operatorname{Pr}$ & $\mu \mathrm{g} / \mathrm{L}$ & 0 & 0.43 & 0.45 & $5 \%$ \\
\hline Rhenium & $\mathrm{Re}$ & $\mu \mathrm{g} / \mathrm{L}$ & 0 & 0 & 0 & $0 \%$ \\
\hline Rhodium & $\mathrm{Rh}$ & $\mu \mathrm{g} / \mathrm{L}$ & 0 & 0 & 0 & $0 \%$ \\
\hline Rubidium & $\mathrm{Rb}$ & $\mu \mathrm{g} / \mathrm{L}$ & 1 & 120 & 120 & $0 \%$ \\
\hline Ruthenium & $\mathrm{Ru}$ & $\mu \mathrm{g} / \mathrm{L}$ & 0 & 0 & 0 & $0 \%$ \\
\hline Samarium & $\mathrm{Sm}$ & $\mu \mathrm{g} / \mathrm{L}$ & 0 & 1.1 & 1.1 & $0 \%$ \\
\hline Selenium & $\mathrm{Se}$ & $\mu \mathrm{g} / \mathrm{L}$ & 1 & 1 & 1 & $0 \%$ \\
\hline Silver & $\mathrm{Ag}$ & $\mu \mathrm{g} / \mathrm{L}$ & 0 & 0 & 0 & $0 \%$ \\
\hline Sodium & $\mathrm{Na}$ & $\mu \mathrm{g} / \mathrm{L}$ & 200 & 68000 & 67000 & $1 \%$ \\
\hline Strontium & $\mathrm{Sr}$ & $\mu \mathrm{g} / \mathrm{L}$ & 1 & 990 & 1000 & $1 \%$ \\
\hline Sulfur & $S$ & $\mu \mathrm{g} / \mathrm{L}$ & 1000 & 270000 & 270000 & $0 \%$ \\
\hline Tantalum & $\mathrm{Ta}$ & $\mu \mathrm{g} / \mathrm{L}$ & 0 & 0 & 0 & $0 \%$ \\
\hline Terbium & $\mathrm{Tb}$ & $\mu \mathrm{g} / \mathrm{L}$ & 0 & 0.32 & 0.33 & $3 \%$ \\
\hline Tellurium & $\mathrm{Te}$ & $\mu \mathrm{g} / \mathrm{L}$ & 1 & 1 & 1 & $0 \%$ \\
\hline Thalium & $\mathrm{TI}$ & $\mu \mathrm{g} / \mathrm{L}$ & 0 & 0.29 & 0.28 & $4 \%$ \\
\hline Thorium & Th & $\mu \mathrm{g} / \mathrm{L}$ & - & - & - & - \\
\hline Thulium & $\mathrm{Tm}$ & $\mu \mathrm{g} / \mathrm{L}$ & 0 & 0.082 & 0.070 & $16 \%$ \\
\hline $\operatorname{Tin} * *$ & Sn & $\mu \mathrm{g} / \mathrm{L}$ & 3 & 3 & 3 & $0 \%$ \\
\hline Titanium & $\mathrm{Ti}$ & $\mu \mathrm{g} / \mathrm{L}$ & 3 & 3 & 3 & $0 \%$ \\
\hline Tungsten & w & $\mu \mathrm{g} / \mathrm{L}$ & 1 & 1 & 1 & $0 \%$ \\
\hline Uranium & $U$ & $\mu \mathrm{g} / \mathrm{L}$ & 0 & 3.0 & 2.8 & $7 \%$ \\
\hline Vanadium & $\mathrm{V}$ & $\mu \mathrm{g} / \mathrm{L}$ & 0 & 0 & 0 & $0 \%$ \\
\hline Ytterbium & $\mathrm{Yb}$ & $\mu \mathrm{g} / \mathrm{L}$ & 0 & 0.44 & 0.45 & $2 \%$ \\
\hline Yttrium & $Y$ & $\mu \mathrm{g} / \mathrm{L}$ & 1 & 6.9 & 7.2 & $4 \%$ \\
\hline Zinc & $\mathrm{Zn}$ & $\mu \mathrm{g} / \mathrm{L}$ & 10 & 2000 & 2100 & $5 \%$ \\
\hline Zirconium & $\mathrm{Zr}$ & $\mu \mathrm{g} / \mathrm{L}$ & 0 & 0 & 0 & $0 \%$ \\
\hline
\end{tabular}




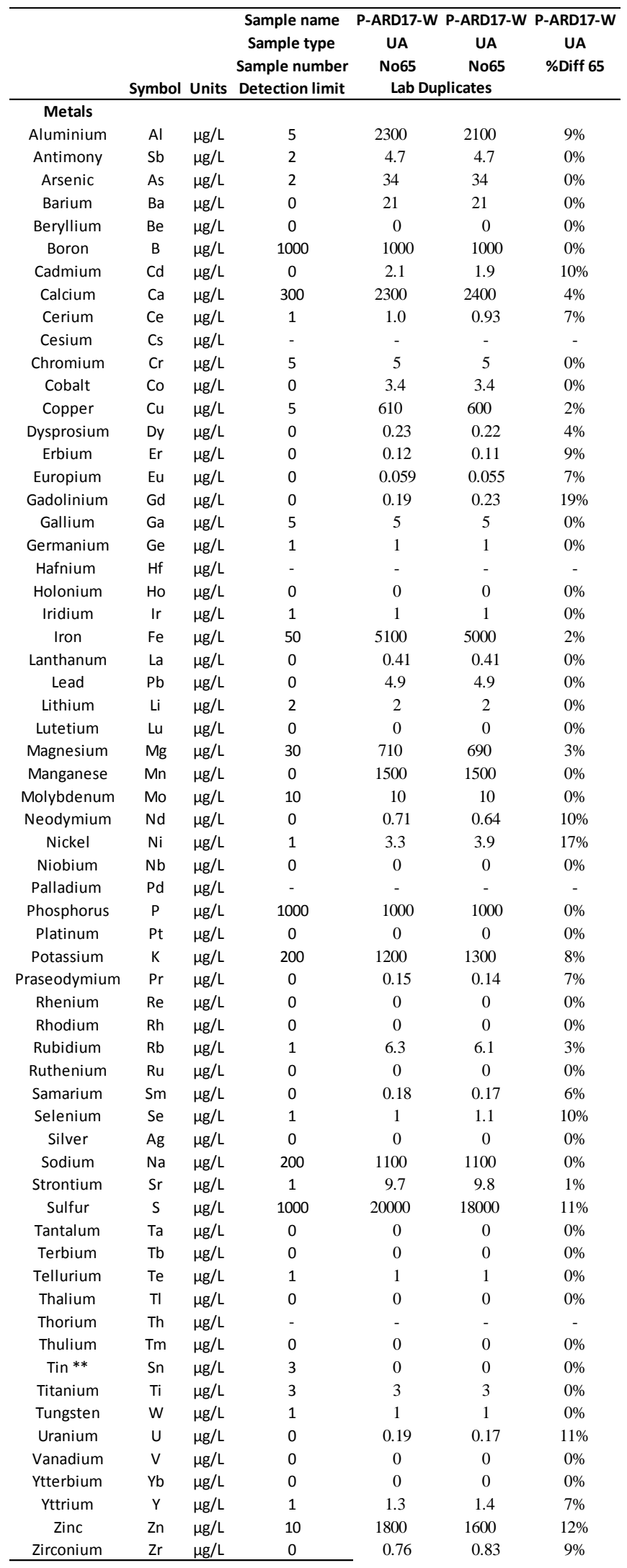




\begin{tabular}{|c|c|c|c|c|c|c|}
\hline & Symbol & Units & $\begin{array}{l}\text { Sample name } \\
\text { Sample type } \\
\text { Sample number } \\
\text { Detection limit }\end{array}$ & $\begin{array}{l}\text { P-EC-W } \\
\text { FA } \\
\text { No } 84 \\
\text { Lab Dur }\end{array}$ & $\begin{array}{c}\text { P-EC-W } \\
\text { FA } \\
\text { No } 84 \\
\text { plicates }\end{array}$ & $\begin{array}{c}\text { P-EC-W } \\
\text { FA } \\
\text { \%Diff } 84\end{array}$ \\
\hline \multicolumn{7}{|l|}{ Metals } \\
\hline Aluminium & Al & $\mu \mathrm{g} / \mathrm{L}$ & 5 & 39000 & 38000 & $3 \%$ \\
\hline Antimony & $\mathrm{Sb}$ & $\mu \mathrm{g} / \mathrm{L}$ & 2 & 2 & 2 & $0 \%$ \\
\hline Arsenic & As & $\mu \mathrm{g} / \mathrm{L}$ & 2 & 4.7 & 3.9 & $19 \%$ \\
\hline Barium & $\mathrm{Ba}$ & $\mu \mathrm{g} / \mathrm{L}$ & 0 & 32 & 32 & $0 \%$ \\
\hline Beryllium & $\mathrm{Be}$ & $\mu \mathrm{g} / \mathrm{L}$ & 0 & 7.0 & 7.1 & $1 \%$ \\
\hline Boron & $B$ & $\mu \mathrm{g} / \mathrm{L}$ & 1000 & 1000 & 1000 & $0 \%$ \\
\hline Cadmium & $\mathrm{Cd}$ & $\mu \mathrm{g} / \mathrm{L}$ & 0 & 1100 & 1100 & $0 \%$ \\
\hline Calcium & $\mathrm{Ca}$ & $\mu \mathrm{g} / \mathrm{L}$ & 300 & 370000 & 360000 & $3 \%$ \\
\hline Cerium & $\mathrm{Ce}$ & $\mu \mathrm{g} / \mathrm{L}$ & 1 & 62 & 63 & $2 \%$ \\
\hline Cesium & Cs & $\mu \mathrm{g} / \mathrm{L}$ & - & 1 & 1.2 & $18 \%$ \\
\hline Chromium & $\mathrm{Cr}$ & $\mu \mathrm{g} / \mathrm{L}$ & 5 & 5 & 5.1 & $2 \%$ \\
\hline Cobalt & Co & $\mu \mathrm{g} / \mathrm{L}$ & 0 & 370 & 360 & $3 \%$ \\
\hline Copper & $\mathrm{Cu}$ & $\mu \mathrm{g} / \mathrm{L}$ & 5 & 5500 & 5400 & $2 \%$ \\
\hline Dysprosium & Dy & $\mu \mathrm{g} / \mathrm{L}$ & 0 & 10 & 10 & $0 \%$ \\
\hline Erbium & $\mathrm{Er}$ & $\mu \mathrm{g} / \mathrm{L}$ & 0 & 5.1 & 5.1 & $0 \%$ \\
\hline Europium & $\mathrm{Eu}$ & $\mu \mathrm{g} / \mathrm{L}$ & 0 & 4.2 & 4.0 & $5 \%$ \\
\hline Gadolinium & $\mathrm{Gd}$ & $\mu \mathrm{g} / \mathrm{L}$ & 0 & 13 & 13 & $0 \%$ \\
\hline Gallium & $\mathrm{Ga}$ & $\mu \mathrm{g} / \mathrm{L}$ & 5 & 10 & 8.9 & $12 \%$ \\
\hline Germanium & $\mathrm{Ge}$ & $\mu \mathrm{g} / \mathrm{L}$ & 1 & 3.4 & 3.8 & $11 \%$ \\
\hline Hafnium & $\mathrm{Hf}$ & $\mu \mathrm{g} / \mathrm{L}$ & - & 1 & 1 & $0 \%$ \\
\hline Holonium & Ho & $\mu \mathrm{g} / \mathrm{L}$ & 0 & 2.0 & 2.0 & $0 \%$ \\
\hline Iridium & Ir & $\mu \mathrm{g} / \mathrm{L}$ & 1 & 1 & 1 & $0 \%$ \\
\hline Iron & $\mathrm{Fe}$ & $\mu \mathrm{g} / \mathrm{L}$ & 50 & 36000 & 34000 & $6 \%$ \\
\hline Lanthanum & La & $\mu \mathrm{g} / \mathrm{L}$ & 0 & 29 & 30 & $3 \%$ \\
\hline Lead & $\mathrm{Pb}$ & $\mu \mathrm{g} / \mathrm{L}$ & 0 & 120 & 120 & $0 \%$ \\
\hline Lithium & $\mathrm{Li}$ & $\mu \mathrm{g} / \mathrm{L}$ & 2 & 32 & 32 & $0 \%$ \\
\hline Lutetium & Lu & $\mu \mathrm{g} / \mathrm{L}$ & 0 & 0.49 & 0.52 & $6 \%$ \\
\hline Magnesium & $\mathrm{Mg}$ & $\mu \mathrm{g} / \mathrm{L}$ & 30 & 16000 & 16000 & $0 \%$ \\
\hline Manganese & $\mathrm{Mn}$ & $\mu \mathrm{g} / \mathrm{L}$ & 0 & 34000 & 38000 & $11 \%$ \\
\hline Molybdenum & Mo & $\mu \mathrm{g} / \mathrm{L}$ & 10 & 10 & 10 & $0 \%$ \\
\hline Neodymium & $\mathrm{Nd}$ & $\mu \mathrm{g} / \mathrm{L}$ & 0 & 40 & 41 & $2 \%$ \\
\hline Nickel & $\mathrm{Ni}$ & $\mu \mathrm{g} / \mathrm{L}$ & 1 & 110 & 100 & $10 \%$ \\
\hline Niobium & $\mathrm{Nb}$ & $\mu \mathrm{g} / \mathrm{L}$ & 0 & 0 & 0 & $0 \%$ \\
\hline Palladium & $\mathrm{Pd}$ & $\mu \mathrm{g} / \mathrm{L}$ & - & 1.8 & 1.8 & $0 \%$ \\
\hline Phosphorus & $P$ & $\mu \mathrm{g} / \mathrm{L}$ & 1000 & 1000 & 1000 & $0 \%$ \\
\hline Platinum & $\mathrm{Pt}$ & $\mu \mathrm{g} / \mathrm{L}$ & 0 & 0 & 0 & $0 \%$ \\
\hline Potassium & $\mathrm{K}$ & $\mu \mathrm{g} / \mathrm{L}$ & 200 & 5000 & 4700 & $6 \%$ \\
\hline Praseodymium & $\operatorname{Pr}$ & $\mu \mathrm{g} / \mathrm{L}$ & 0 & 8.9 & 9.1 & $2 \%$ \\
\hline Rhenium & $\operatorname{Re}$ & $\mu \mathrm{g} / \mathrm{L}$ & 0 & 0 & 0 & $0 \%$ \\
\hline Rhodium & $\mathrm{Rh}$ & $\mu \mathrm{g} / \mathrm{L}$ & 0 & 0 & 0 & $0 \%$ \\
\hline Rubidium & $\mathrm{Rb}$ & $\mu \mathrm{g} / \mathrm{L}$ & 1 & 13 & 13 & $0 \%$ \\
\hline Ruthenium & $\mathrm{Ru}$ & $\mu \mathrm{g} / \mathrm{L}$ & 0 & 0 & 0 & $0 \%$ \\
\hline Samarium & $\mathrm{Sm}$ & $\mu \mathrm{g} / \mathrm{L}$ & 0 & 11 & 11 & $0 \%$ \\
\hline Selenium & Se & $\mu \mathrm{g} / \mathrm{L}$ & 1 & 3.8 & 3.4 & $11 \%$ \\
\hline Silver & $\mathrm{Ag}$ & $\mu \mathrm{g} / \mathrm{L}$ & 0 & 0 & 0 & $0 \%$ \\
\hline Sodium & $\mathrm{Na}$ & $\mu \mathrm{g} / \mathrm{L}$ & 200 & 13000 & 13000 & $0 \%$ \\
\hline Strontium & $\mathrm{Sr}$ & $\mu \mathrm{g} / \mathrm{L}$ & 1 & 910 & 890 & $2 \%$ \\
\hline Sulfur & $\mathrm{S}$ & $\mu \mathrm{g} / \mathrm{L}$ & 1000 & 360000 & 480000 & $29 \%$ \\
\hline Tantalum & $\mathrm{Ta}$ & $\mu \mathrm{g} / \mathrm{L}$ & 0 & 0 & 0 & $0 \%$ \\
\hline Terbium & $\mathrm{Tb}$ & $\mu \mathrm{g} / \mathrm{L}$ & 0 & 1.9 & 1.9 & $0 \%$ \\
\hline Tellurium & $\mathrm{Te}$ & $\mu \mathrm{g} / \mathrm{L}$ & 1 & 0.73 & 0.60 & $20 \%$ \\
\hline Thalium & $\mathrm{TI}$ & $\mu \mathrm{g} / \mathrm{L}$ & 0 & 10 & 10 & $0 \%$ \\
\hline Thorium & Th & $\mu \mathrm{g} / \mathrm{L}$ & - & 0 & 0 & $0 \%$ \\
\hline Thulium & $\mathrm{Tm}$ & $\mu \mathrm{g} / \mathrm{L}$ & 0 & 0.66 & 0.65 & $2 \%$ \\
\hline $\operatorname{Tin} * *$ & Sn & $\mu \mathrm{g} / \mathrm{L}$ & 3 & 0 & 0 & $0 \%$ \\
\hline Titanium & $\mathrm{Ti}$ & $\mu \mathrm{g} / \mathrm{L}$ & 3 & 3 & 3 & $0 \%$ \\
\hline Tungsten & W & $\mu \mathrm{g} / \mathrm{L}$ & 1 & 1 & 1 & $0 \%$ \\
\hline Uranium & $U$ & $\mu \mathrm{g} / \mathrm{L}$ & 0 & 8.1 & 8.1 & $0 \%$ \\
\hline Vanadium & $\mathrm{V}$ & $\mu \mathrm{g} / \mathrm{L}$ & 0 & 0 & 0 & $0 \%$ \\
\hline Ytterbium & $\mathrm{Yb}$ & $\mu \mathrm{g} / \mathrm{L}$ & 0 & 3.9 & 3.9 & $0 \%$ \\
\hline Yttrium & $Y$ & $\mu \mathrm{g} / \mathrm{L}$ & 1 & 67 & 66 & $2 \%$ \\
\hline Zinc & $\mathrm{Zn}$ & $\mu \mathrm{g} / \mathrm{L}$ & 10 & 22000 & 25000 & $13 \%$ \\
\hline Zirconium & $\mathrm{Zr}$ & $\mu \mathrm{g} / \mathrm{L}$ & 0 & 0 & 0 & $0 \%$ \\
\hline
\end{tabular}




\begin{tabular}{ccccccr}
\hline \multicolumn{2}{c}{ Sample } & Symbol Units & Blank & $\begin{array}{c}\text { Certified Reference Material } \\
\text { QC }\end{array}$ & $\begin{array}{c}\text { QC } \\
\text { Target }\end{array}$ & \%Diff \\
\hline Fluoride & $\mathrm{F}$ & $\mathrm{mg} / \mathrm{L}$ & $<0.05$ & 2.4 & 2.5 & $6 \%$ \\
Chloride & $\mathrm{Cl}$ & $\mathrm{mg} / \mathrm{L}$ & $<0.05$ & 4.8 & 5.0 & $3 \%$ \\
Nitrite & $\mathrm{NO}_{2-}-$ & $\mathrm{mg} / \mathrm{L}$ & $<0.05$ & 2.3 & 2.5 & $10 \%$ \\
Nitrate & $\mathrm{NO}_{3}-$ & $\mathrm{mg} / \mathrm{L}$ & $<0.05$ & 2.2 & 2.5 & $13 \%$ \\
Sulphate & $\mathrm{SO}_{42}-$ & $\mathrm{mg} / \mathrm{L}$ & $<0.10$ & 4.5 & 5.0 & $10 \%$ \\
\hline
\end{tabular}

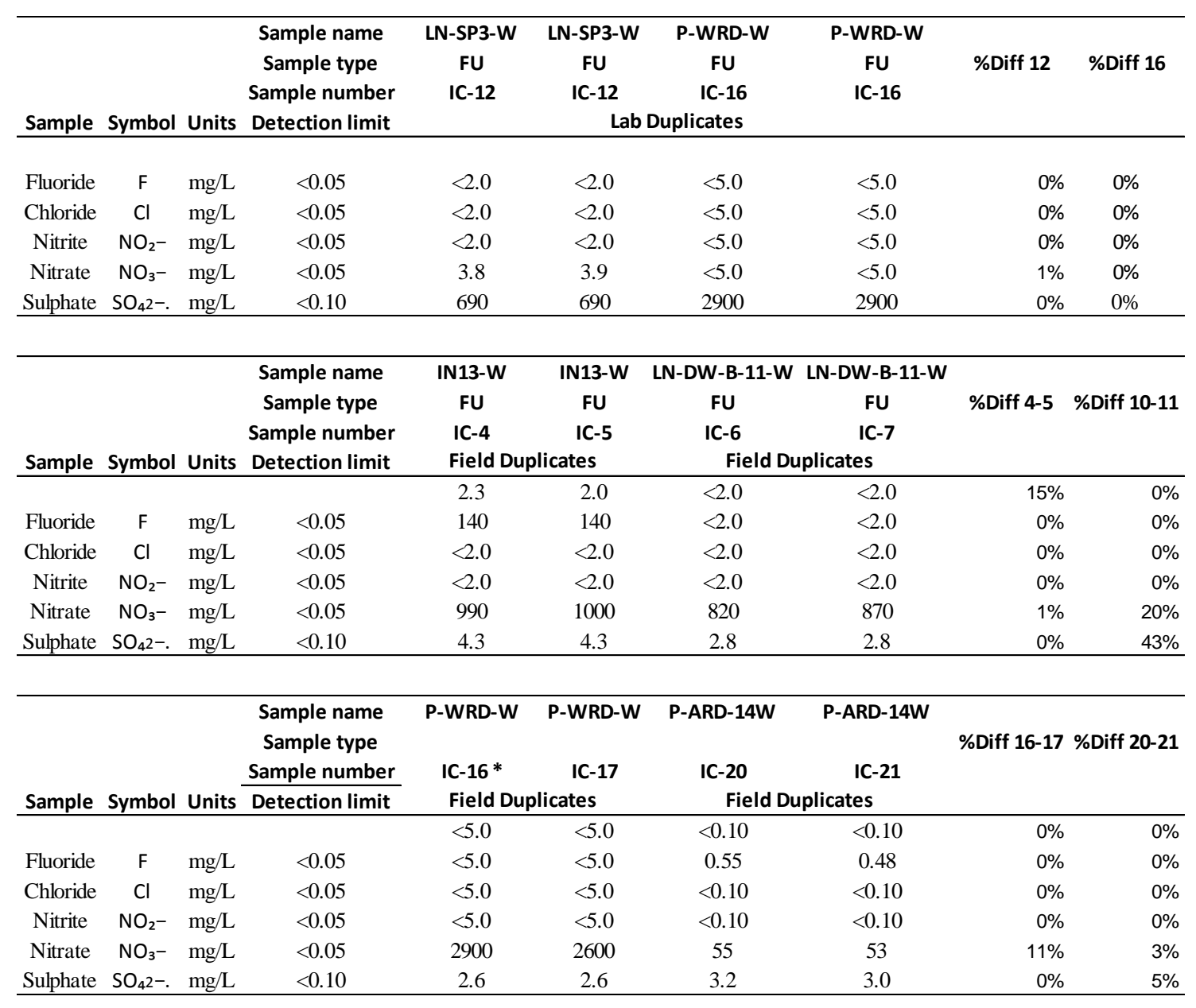


Appendix G: Field photographs
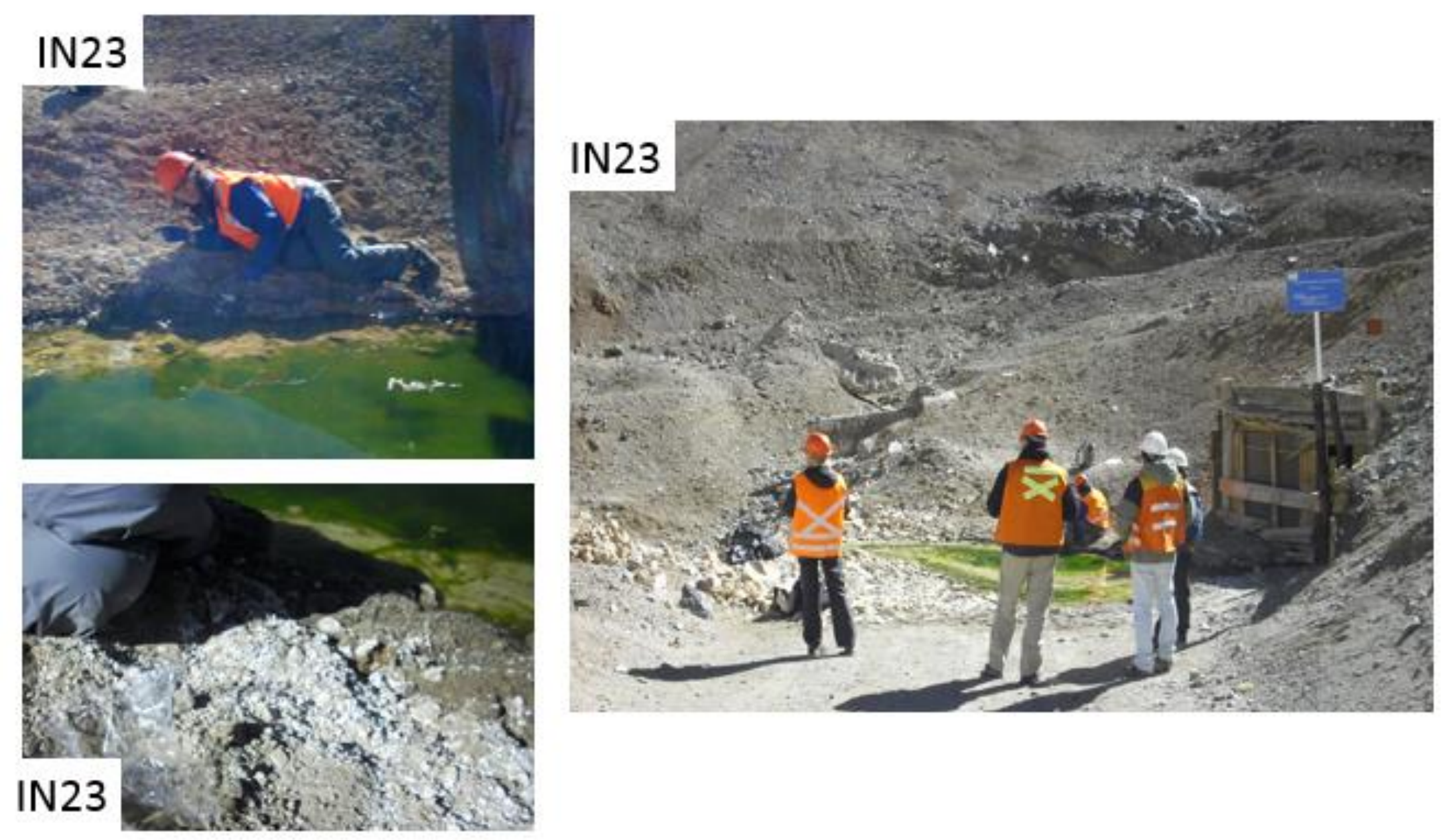

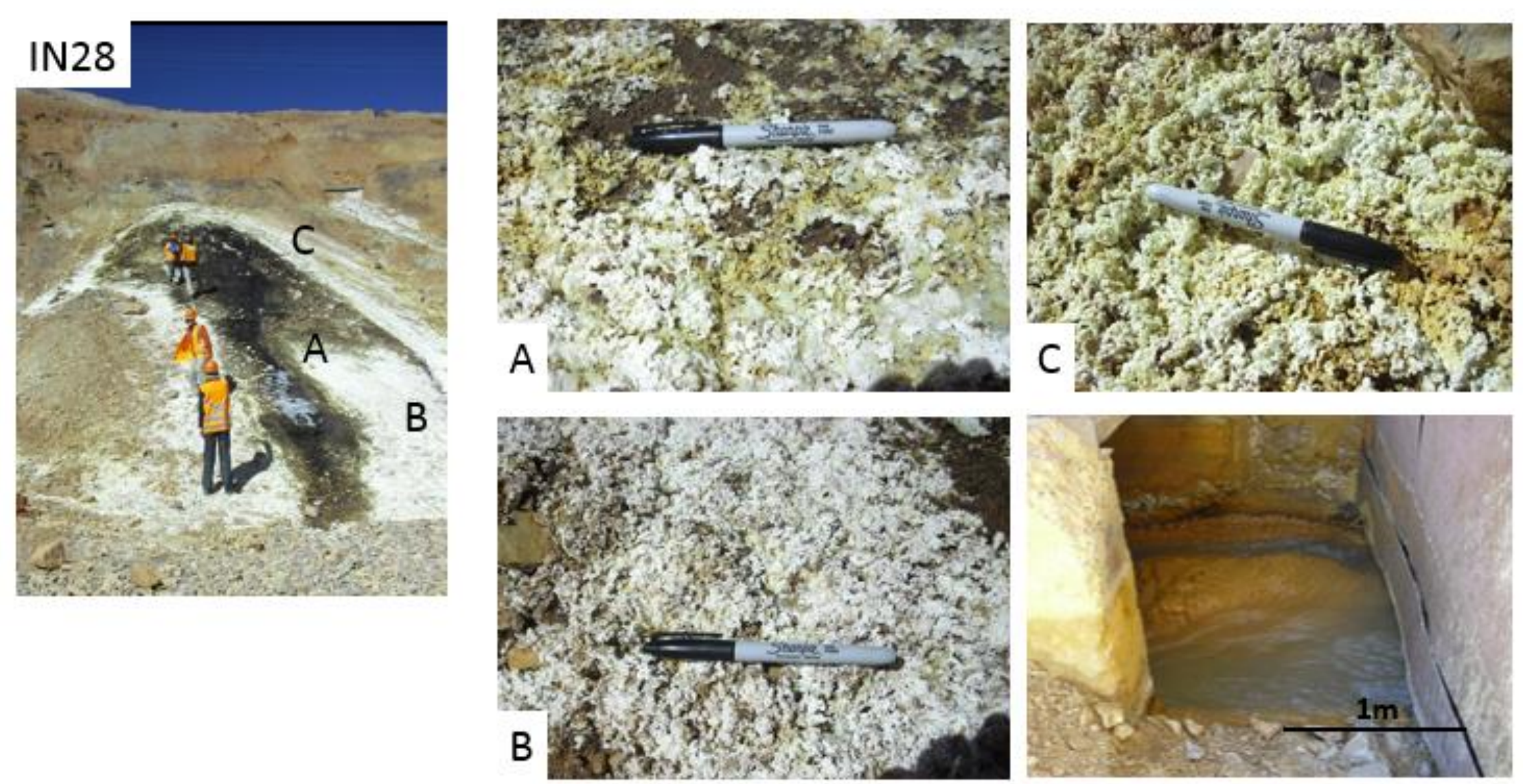

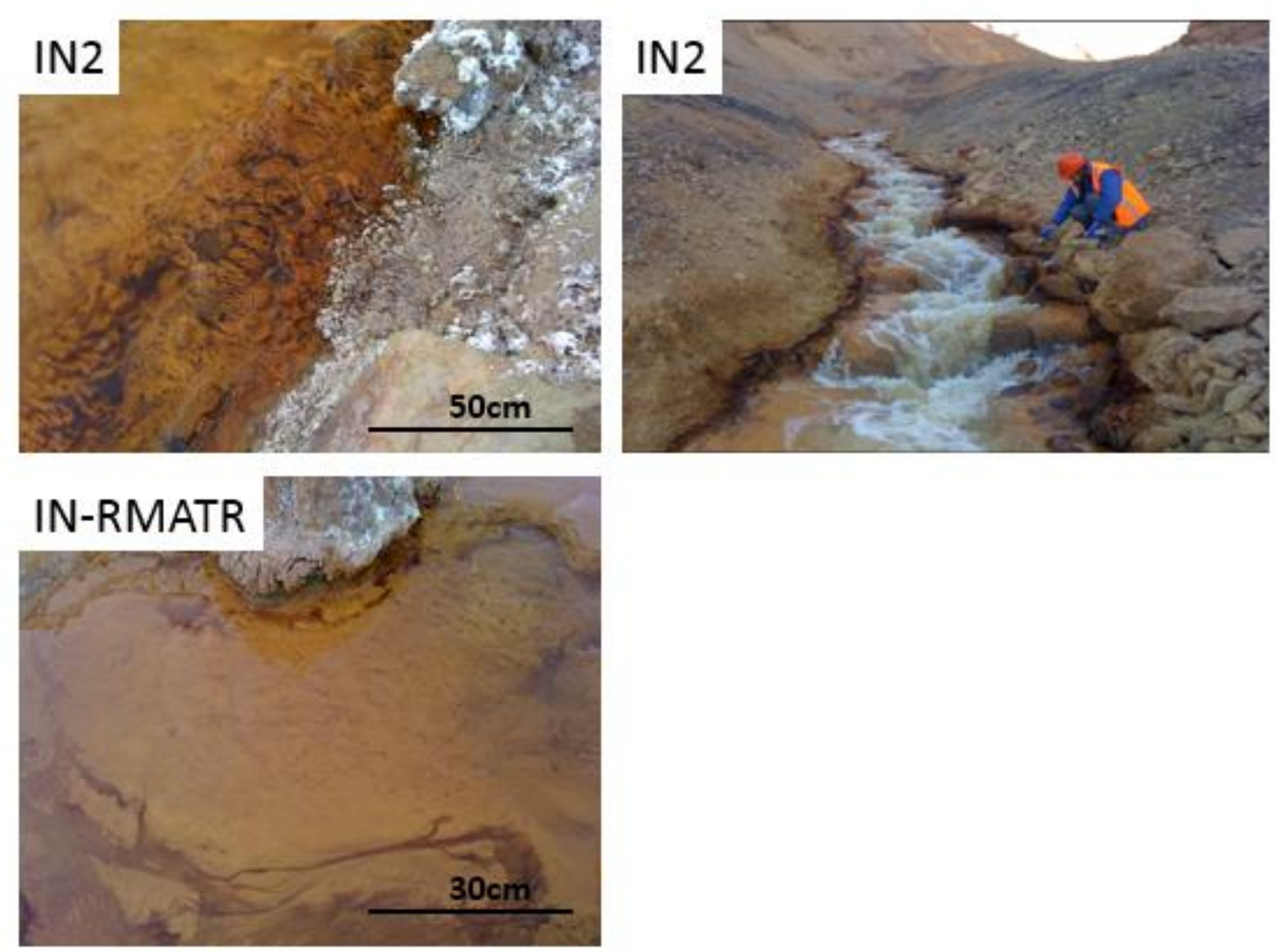

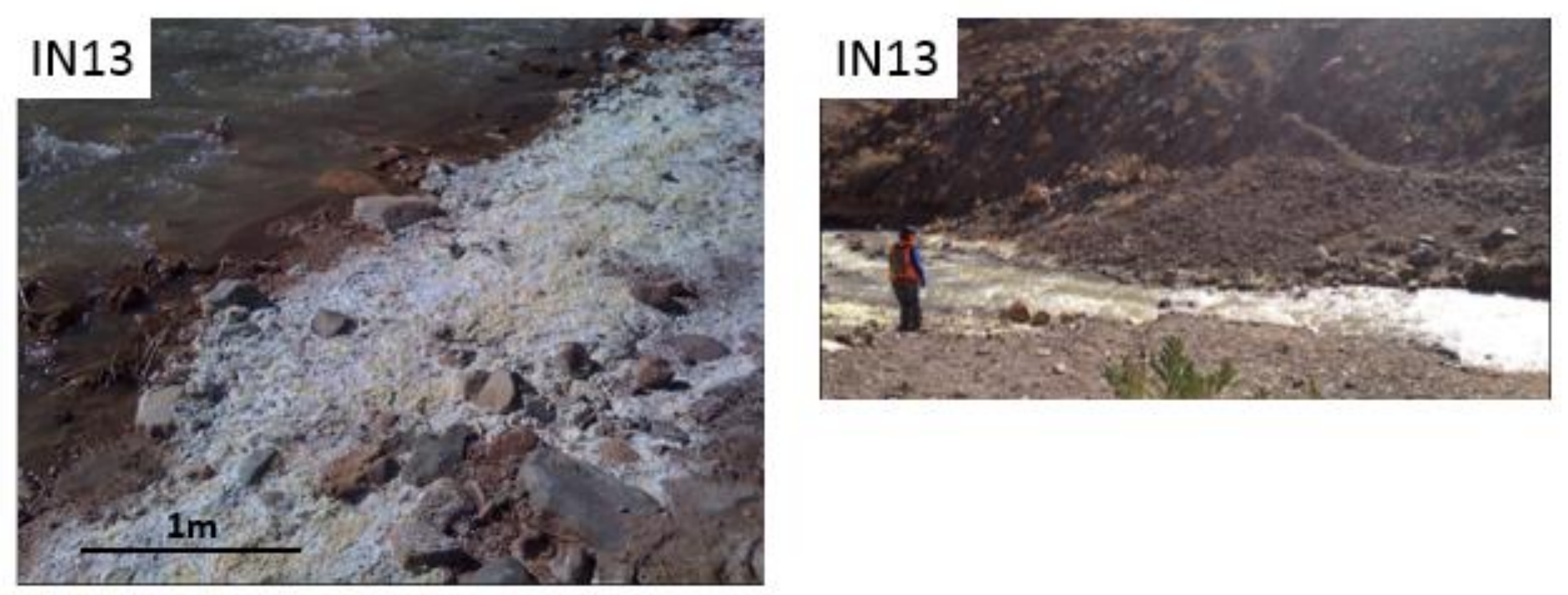

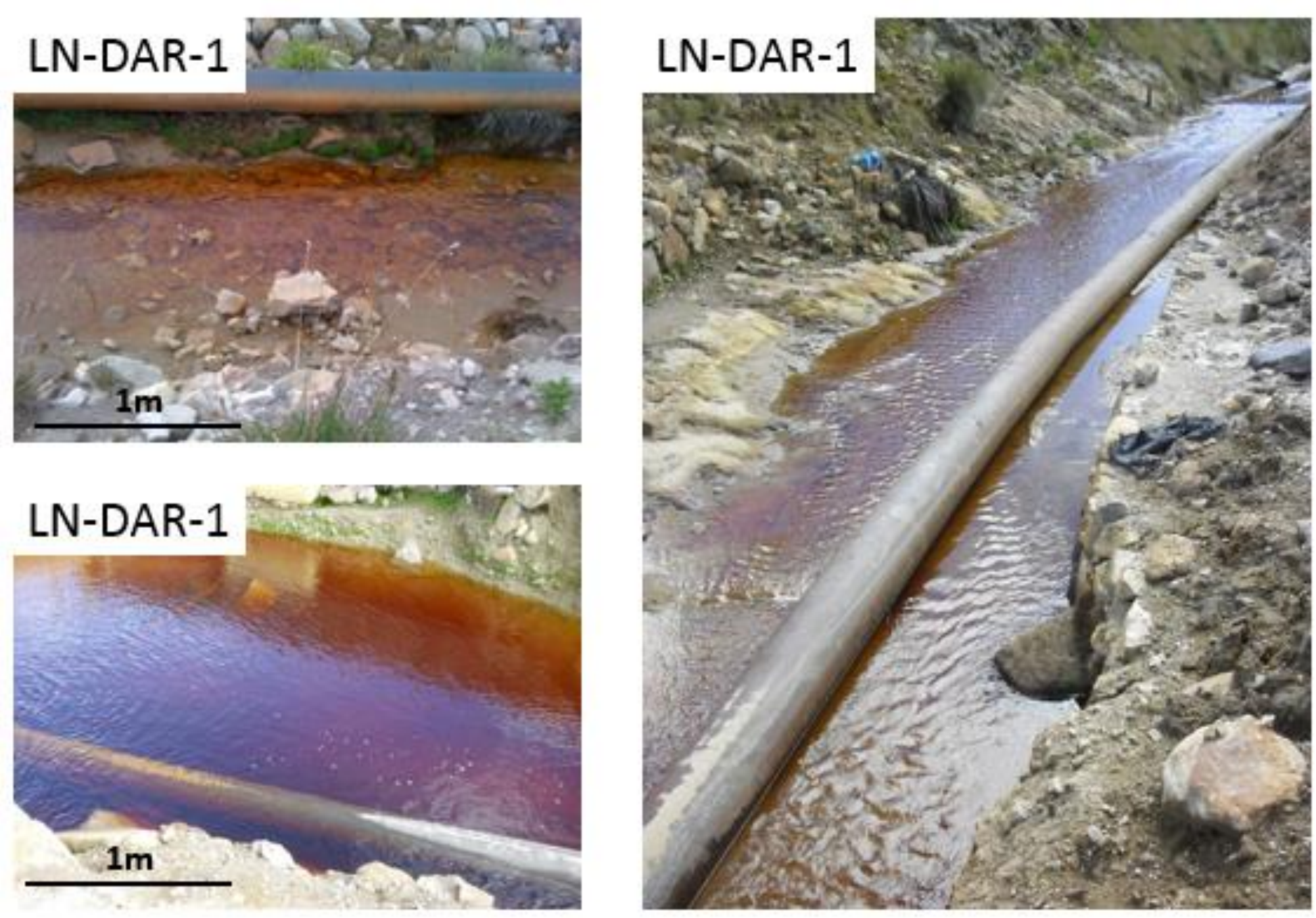

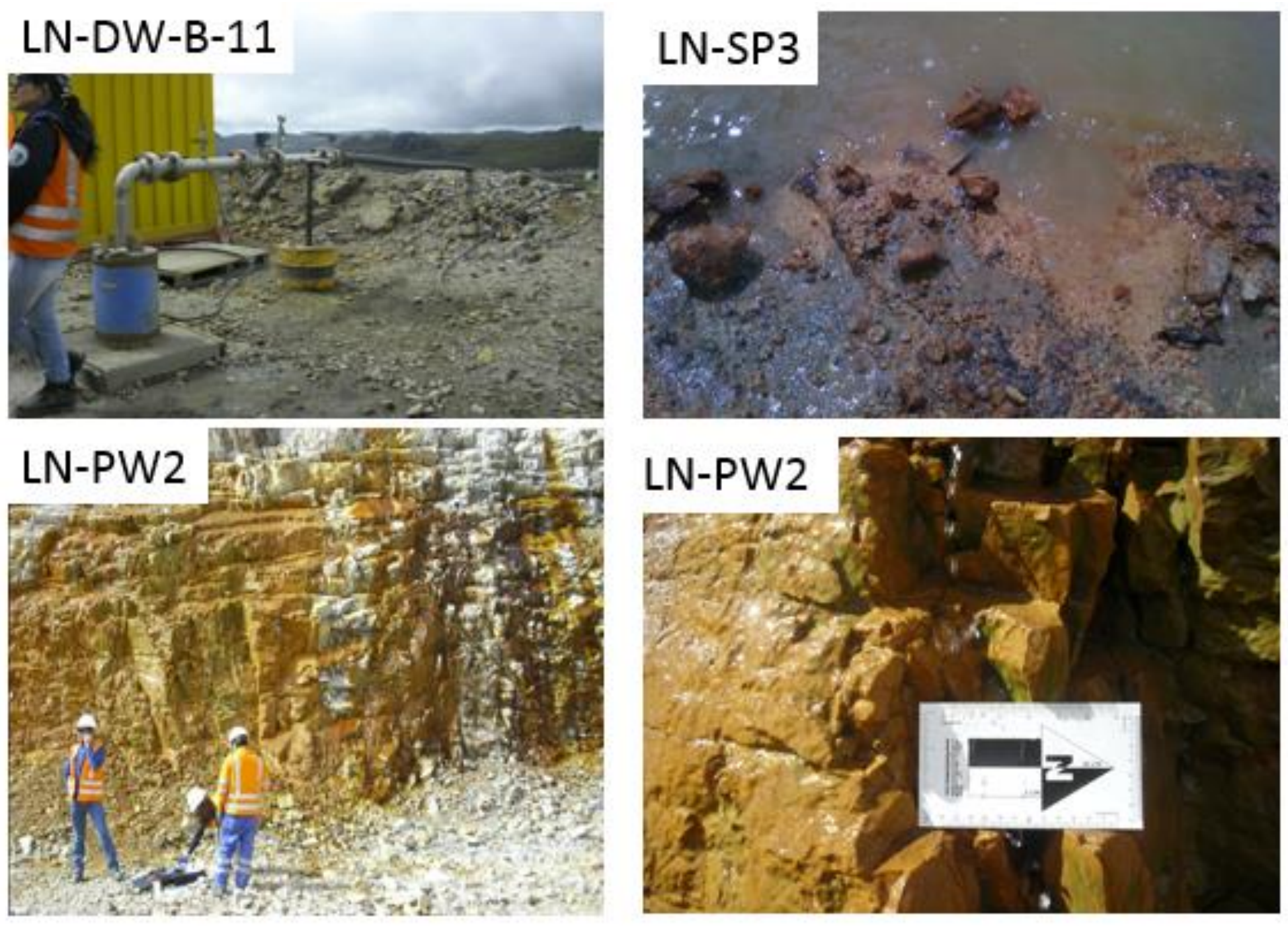


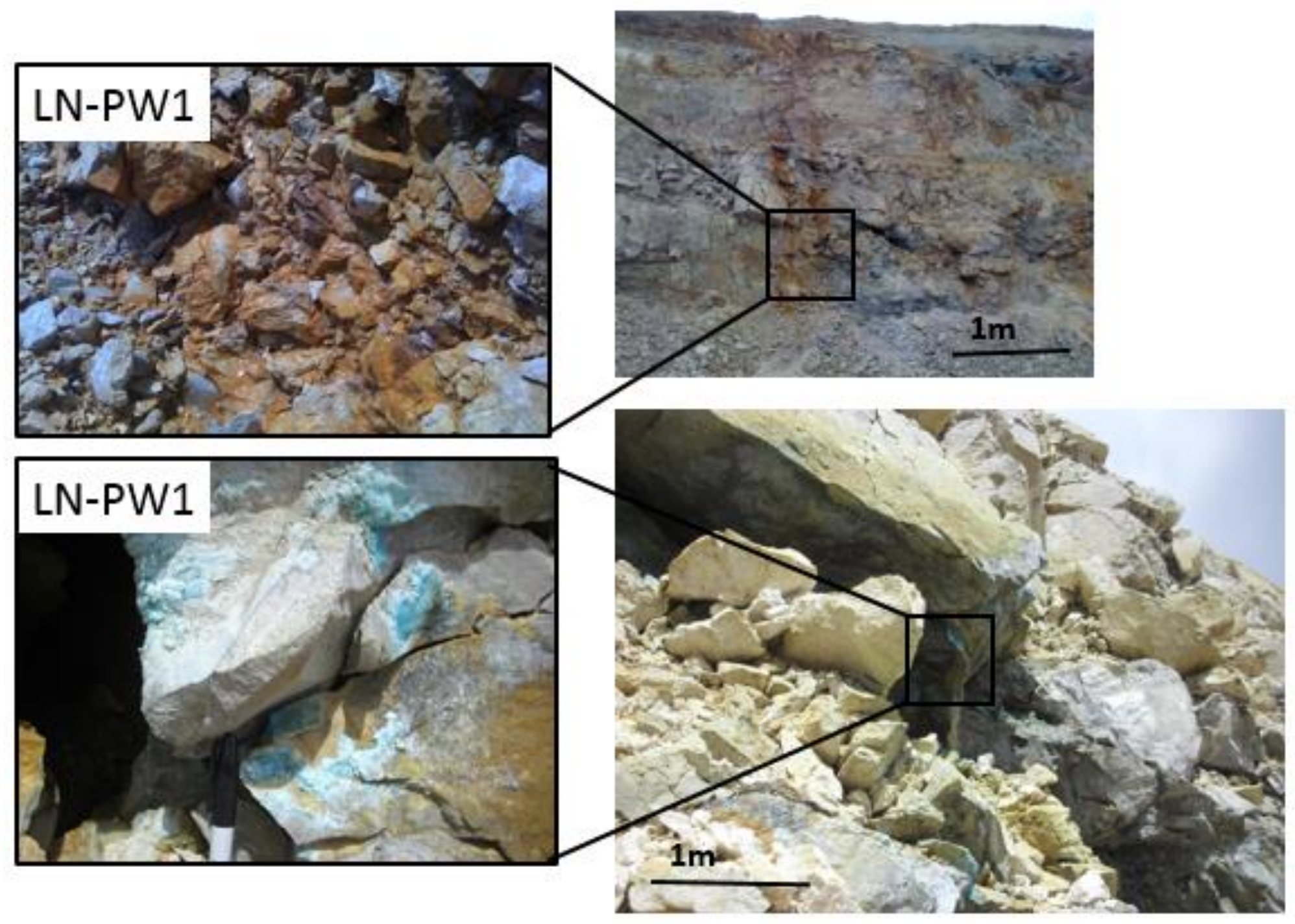



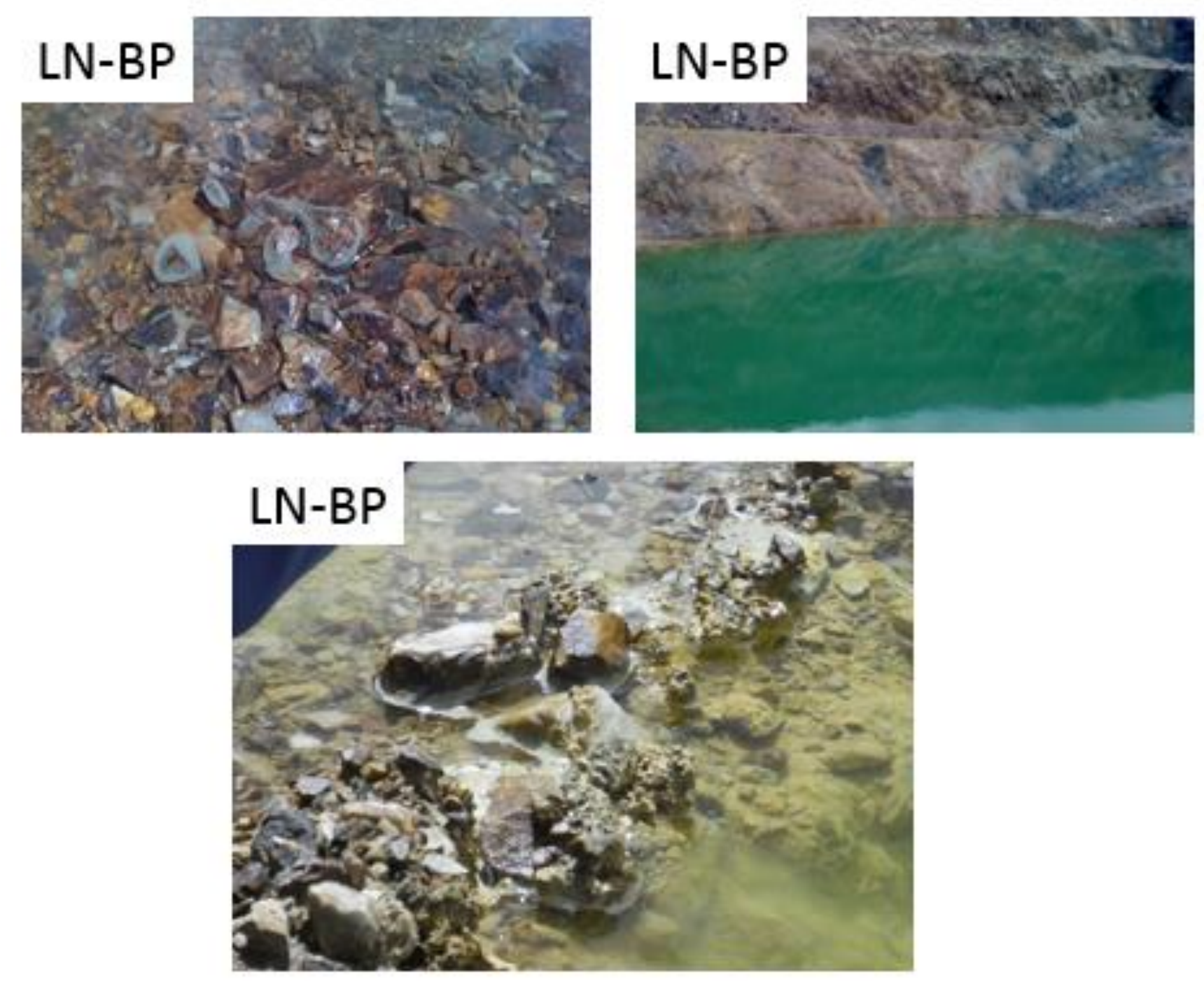

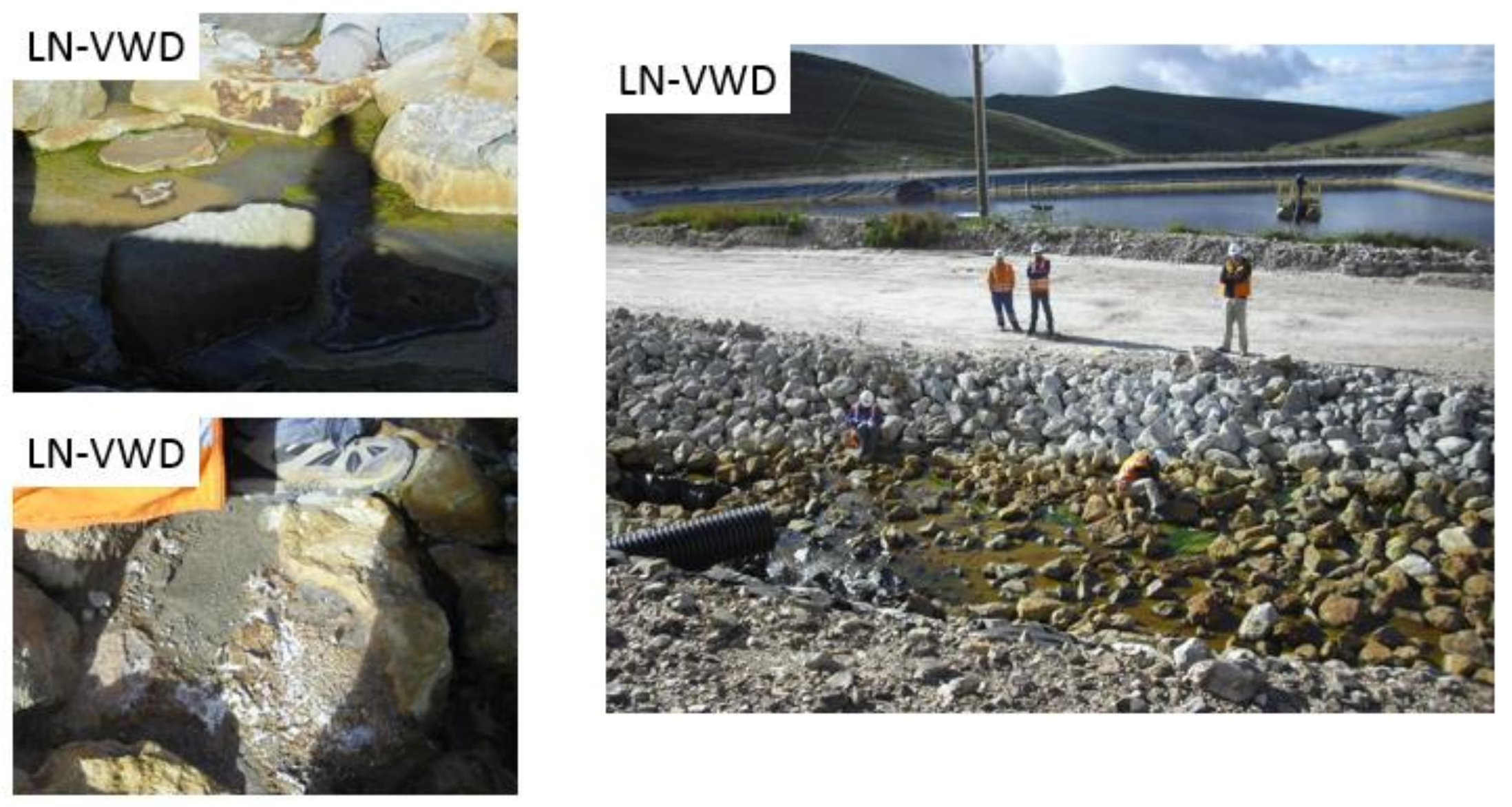

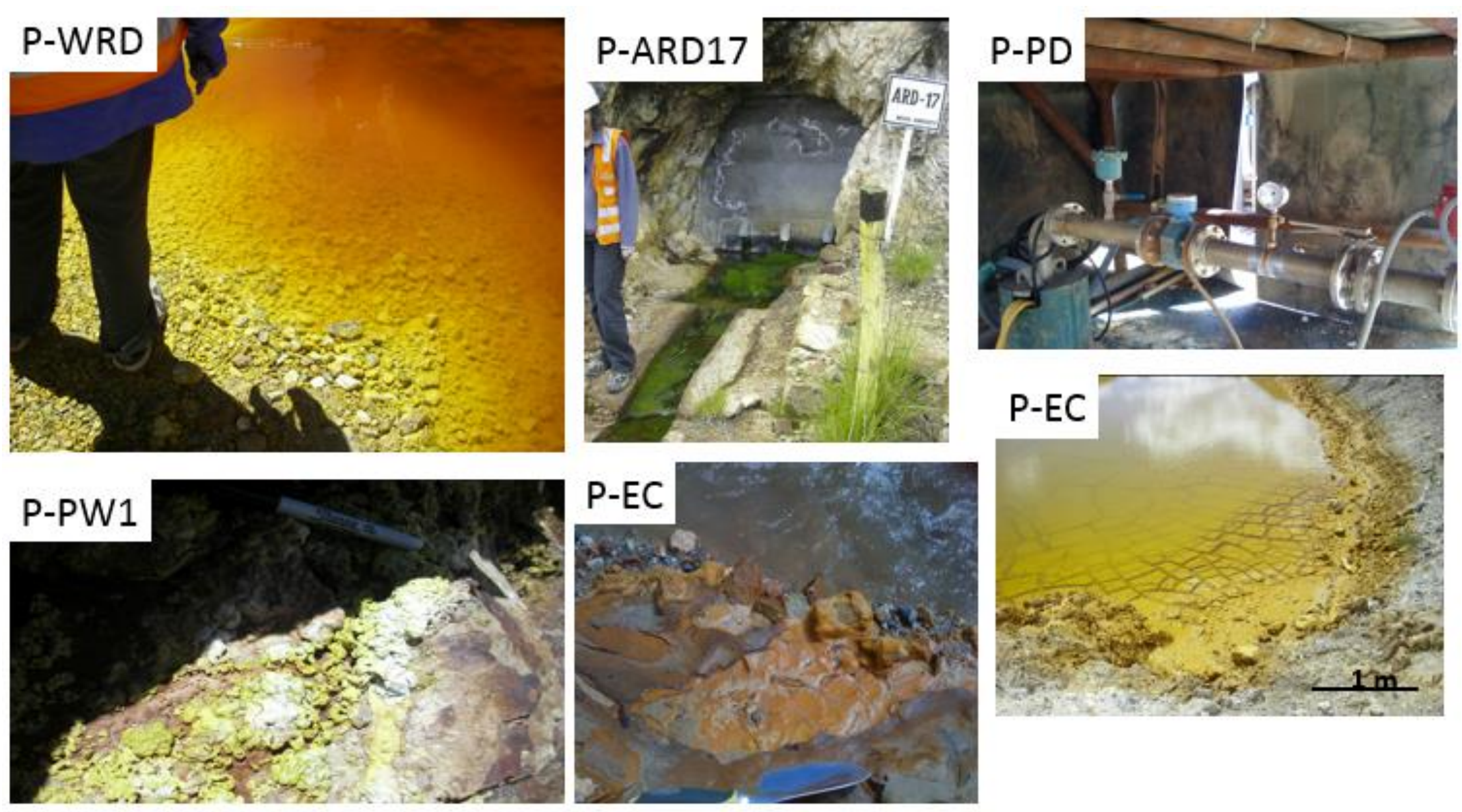